
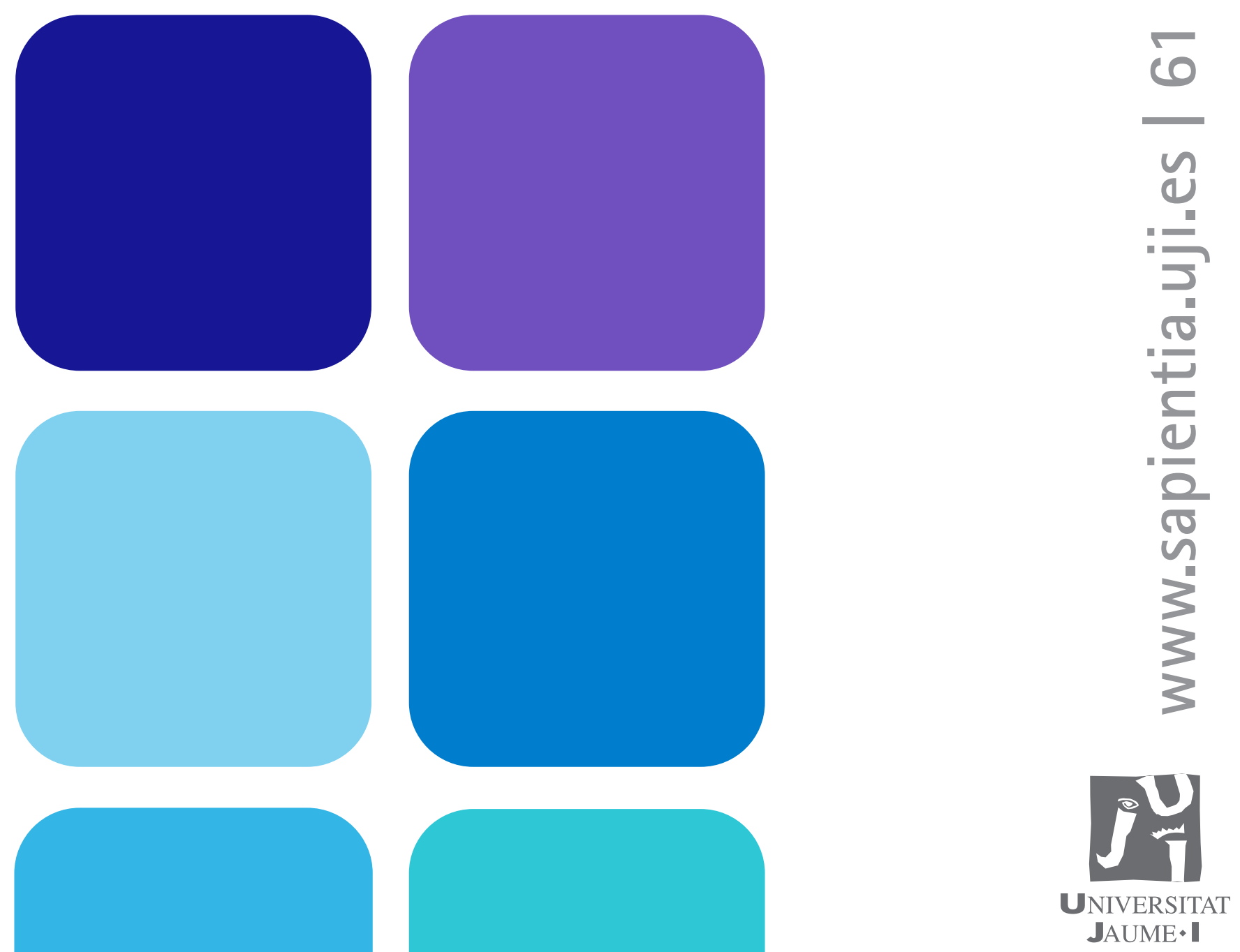

\title{
Català per als mitjans de comunicació
}

\author{
Joan Peraire
}

Enric Portalés 


\section{Català per als mitjans de comunicació}

Joan Peraire

Enric Portalés

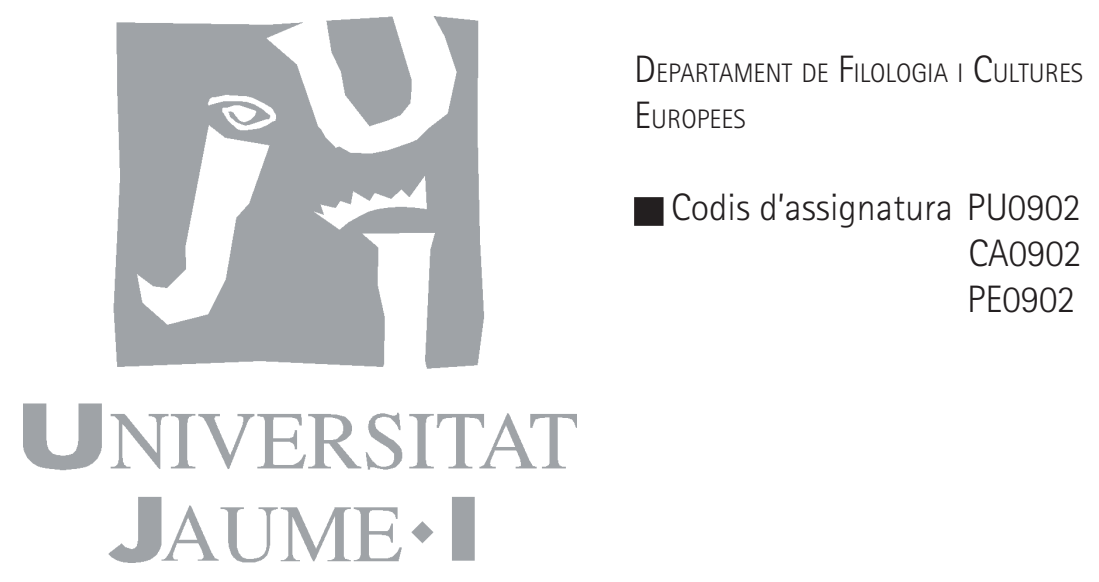


Edita: Publicacions de la Universitat Jaume I. Servei de Comunicació i Publicacions Campus del Riu Sec. Edifici Rectorat i Serveis Centrals. 12071 Castelló de la Plana http://www.tenda.uji.es e-mail: publicacions@uji.es

Col-lecció Sapientia, 61

www.sapientia.uji.es

Primera edició, 2012

ISBN: 978-84-695-3671-1

17 Publicacions de la Universitat Jaume I és una editorial membre de l'UNE, cosa que en garanteix la difusió de les obres en els àmbits nacional i interUnión de Eutrobalas
Universtrakas Españolas

\section{(c) (i) (9)(2)}

Aquest text està subjecte a una llicència Reconeixement-NoComercial-Compartirlgual de Creative Commons, que permet copiar, distribuir i comunicar públicament l'obra sempre que especifique l'autor i el nom de la publicació i sense objectius comercials, i també permet crear obres derivades, sempre que siguen distribuïdes amb aquesta mateixa llicència.

http://creativecommons.org/licenses/by-nc-sa/2.5/es/deed.ca 


\section{ÍNDEX}

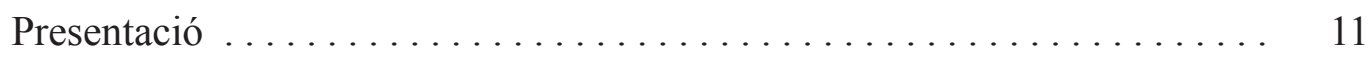

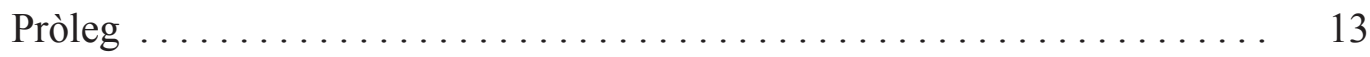

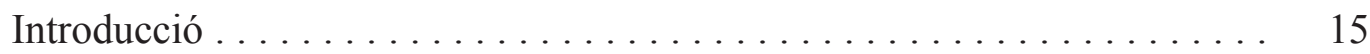

I. Comunicació i models de llengua $\ldots \ldots \ldots \ldots \ldots \ldots \ldots \ldots \ldots \ldots$

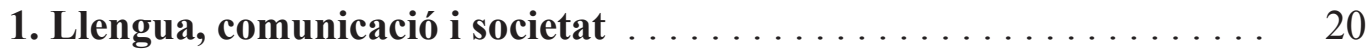

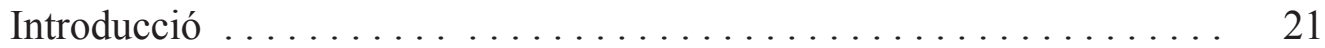

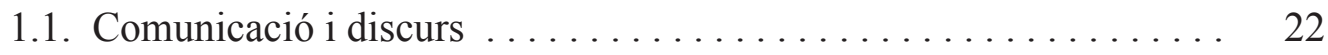

1.1.1. La societat de la informació ................ 22

1.1.2. Comunicació i cultura .................. 25

1.1.3. L'activitat discursiva: text, discurs i seqüències textuals . . . 27

1.1.4. Àmbits d'ús, registres i gèneres textuals . . . . . . . . . . . 30

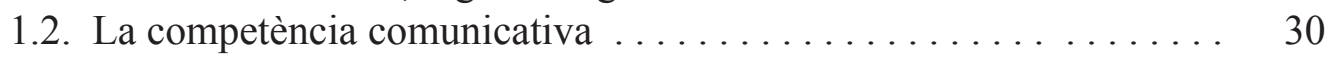

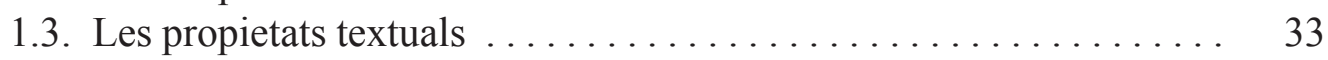

1.3.1. L'adequació ...................... 34

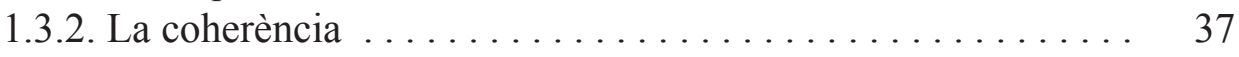

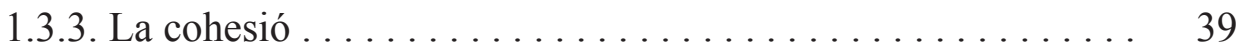

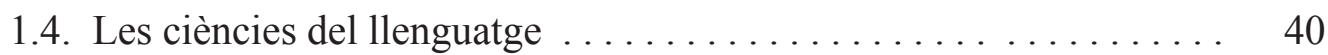

1.5. Llengua i societat: introducció a la sociolingüística . . . . . . . 44

1.5.1. Lingüística i sociolingüística: estructura i ús . . . . . . . . 44

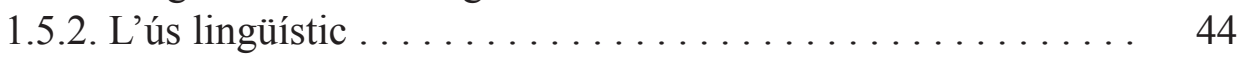

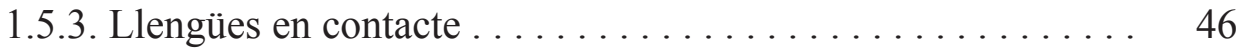

1.5.4. Normalització i substitució lingüística . . . . . . . . . . . 47

Lectures recomanades . . . . . . . . . . . . . . . . . . . 49

2. Models de llengua per als mitjans de comunicació $\ldots \ldots \ldots \ldots \ldots$. . . 51

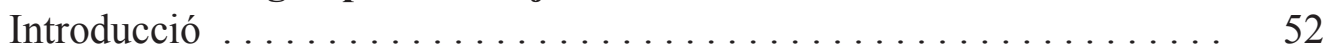

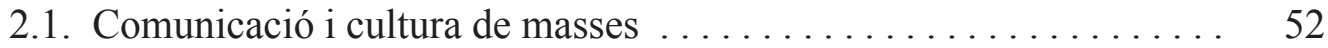

2.2. La variació lingüística $i$ el català estàndard $\ldots \ldots \ldots \ldots \ldots \ldots \ldots$

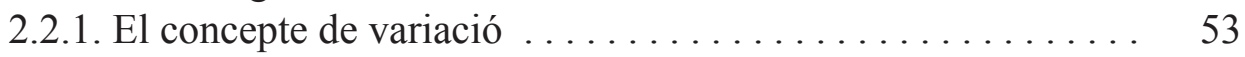

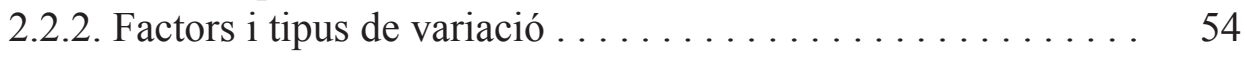

2.2.3. Les varietats geogràfiques del català ........... 56

2.2.4. Varietats diacròniques i socials . . . . . . . . . . 57

2.2.5. La variació diafàsica: varietats funcionals del català . . . . . 59

2.2.6. El català estàndard . . . . . . . . . . . . . 61 


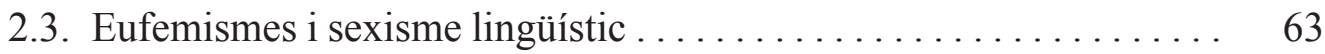

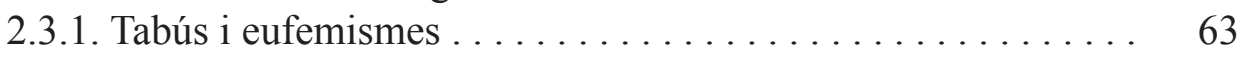

2.3.2. Els usos sexistes del llenguatge $\ldots \ldots \ldots \ldots \ldots \ldots \ldots \ldots 65$

2.4. Gèneres discursius i models de llengua . . . . . . . . . . . . . 67

2.4.1. El concepte de gènere . . . . . . . . . . . . . . . . . . . 67

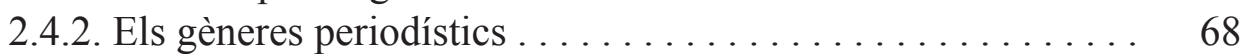

2.4.3. Els gèneres televisius . . . . . . . . . . . . . . . . . 69

2.4.4. Multimodalitat i gèneres audiovisuals . . . . . . . . 70

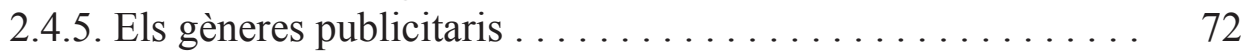

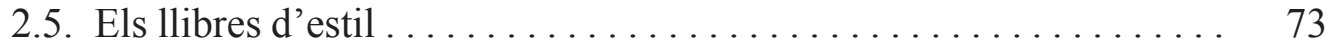

Lectures recomanades ...................... 75

II. Oralitat i escriptura en contextos comunicatius multimodals $\ldots$. . 77

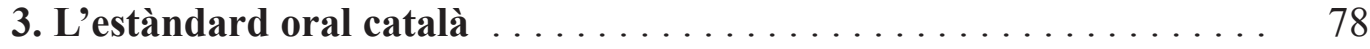

Introducció . . . . . . . . . . . . . . . . . . . . . . 79

3.1. Discurs oral i discurs escrit . . . . . . . . . . . . . . 79

3.1.1. Oralitat i escriptura . . . . . . . . . . . . . . . . . . 79

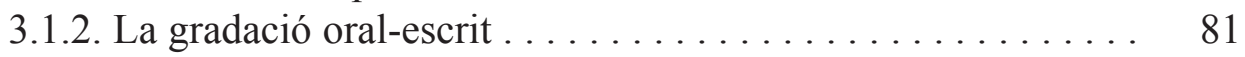

3.1.3. L'expansió de l'oralitat: els gèneres discursius secundaris . . 82

3.2. L'oral formal, entre l'oralitat i l'escriptura . . . . . . . . . 83

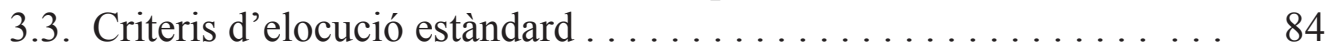

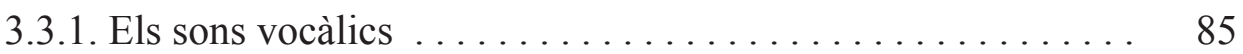

3.3.1.1. Les vocals tòniques $\ldots \ldots \ldots \ldots \ldots \ldots \ldots$

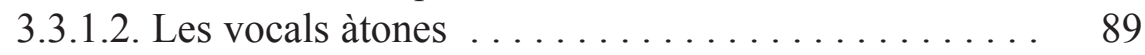

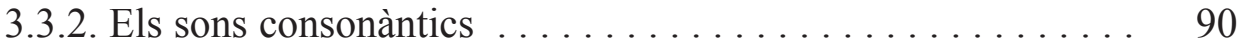

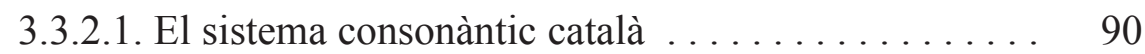

3.3.2.2. Les consonants sibilants ............. 93

3.3.3. Les propostes d'estàndard oral de l'IEC i l'AVL . . . . . . . . . 94

3.4. Qüestions de morfosintaxi per a l'estàndard oral . . . . . . . . . . 97

3.4.1. Criteris generals ..................... 97

3.4.2. L'ordenació dels elements de la frase . . . . . . . . . . . . . 97

3.4.2.1. L'ordre de mots a la ràdio i a la televisió . . . . . . . 98

3.4.2.2. Ordre neutre i canvis d'ordre de la frase ........ 98

3.4.3. Ús del pretèrit perfet $i$ del pretèrit indefinit . . . . . . . . . . 99

3.4.4. El participi concordat . . . . . . . . . . . . . . . . 100

3.4.5. La veu passiva . . . . . . . . . . . . . . . . . . 101

3.5. Estàndard oral i selecció lèxica . . . . . . . . . . . . . . . . . . 102

3.5.1. Recomanacions generals . . . . . . . . . . . . . 102

3.5.2. Criteris de selecció lèxica . . . . . . . . . . . . . 102

3.6. L'estàndard oral en els mitjans audiovisuals . . . . . . . . . . . 103

3.6.1. Models de llengua per als mitjans audiovisuals . . . . . . . . 103

3.6.2. Els perfils diversos de l'oral . . . . . . . . . . . . . . 103

Lectures recomanades . . . . . . . . . . . . . . . 105

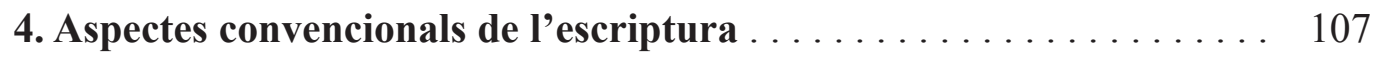

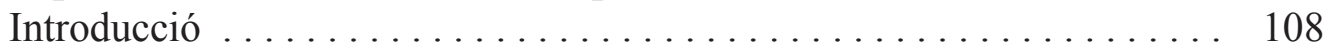

4.1. Les tecnologies de la paraula . . . . . . . . . . . . . . . . . . . 109

4.1.1. Evolució de les tecnologies de la paraula . . . . . . . . . . 109 


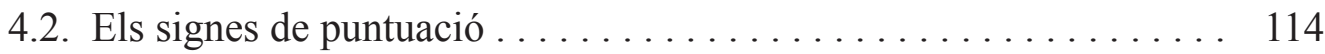

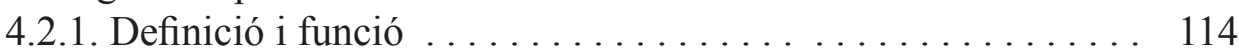

4.2.2. Normes d'ús dels signes de puntuació . . . . . . . . . 115

4.2.2.1. La coma ...................... 115

4.2.2.2. Punt, punt i coma, dos punts i punts suspensius . . . . 117

4.2.2.3. Els signes d'interrogació i d'exclamació ........ 120

4.2.2.4. Els guions i el guionet ............... 120

4.2.2.5. Parèntesis i claudàtors .............. 121

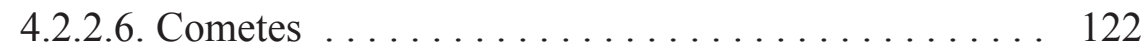

4.2.3. Aspectes gràfics . . . . . . . . . . . . . . . . . . 124

4.3. Elements paralingüístics de l'escriptura . . . . . . . . . . . 125

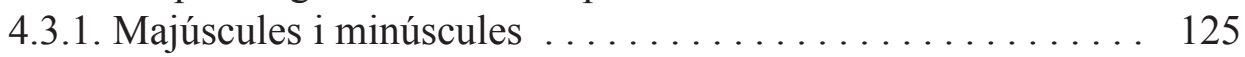

4.3.2. Escriptura dels nombres: xifres i lletres . . . . . . . . 128

4.3.3. Tipografia . . . . . . . . . . . . . . . . . . . . . . . 129

4.3.3.1. Qüestions de terminologia ............. 129

4.3.3.2. Els estils més habituals: rodona, cursiva i negreta . . 130

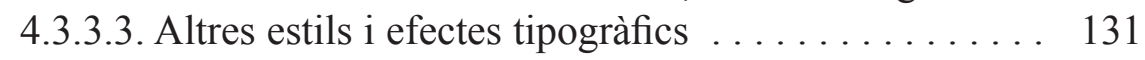

4.3.4. Presentació de l'escrit . . . . . . . . . . . . . . . . 133

4.3.4.1. Espais en blanc ................. 133

4.3.4.2. Disposició convencional del text . . . . . . . . 134

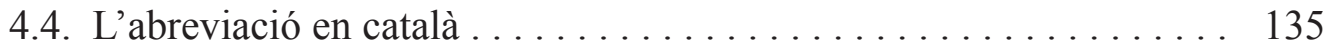

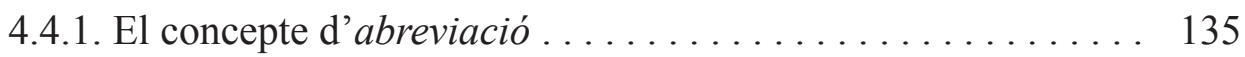

4.4.2. Abreviatures ........................ 136

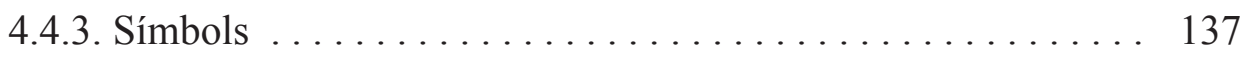

4.4.4. Sigles i acrònims . . . . . . . . . . . . . . . . . . 138

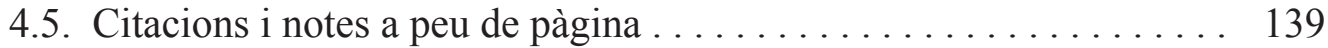

4.5.1. Referències i citacions textuals . . . . . . . . . . . . . 139

4.5.2. Notes a peu de pàgina . . . . . . . . . . . . . . . . . . . 141

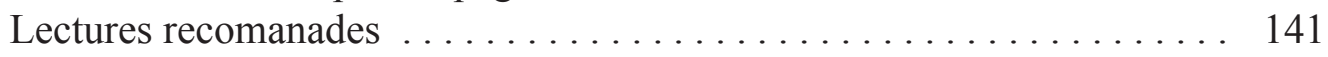

III. Coherència discursiva i estructura de la informació $\ldots \ldots \ldots$. . . . 142

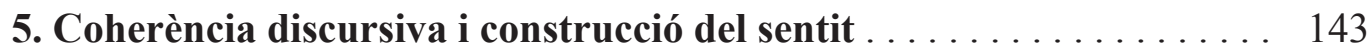

Introducció . . . . . . . . . . . . . . . . . . . . . . . . . . . . . . . . 144

5.1. Coherència discursiva i cohesió textual . . . . . . . . . . . 145

5.1.1. Significat, sentit i coherència . . . . . . . . . . . . 145

5.1.2. El concepte de coherència . . . . . . . . . . . . . . . 147

5.1.3. Coherència textual $\mathrm{i}$ escriptura . . . . . . . . . . . . . 148

5.1.4. Les regles de la coherència . . . . . . . . . . . . 150

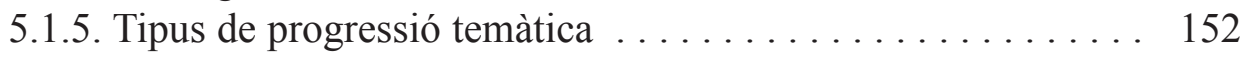

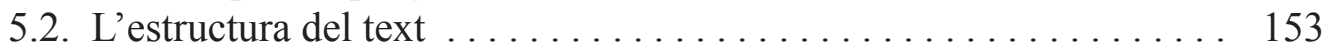

5.2.1. Factors determinants de l'estructura textual . . . . . . . . 153

5.2.2. Estructura dels gèneres expositius . . . . . . . . . . 154

5.2.3. Estructures narratives i argumentatives . . . . . . . . . 155

5.2.4. Superestructures o motlles genèrics . . . . . . . . . 156

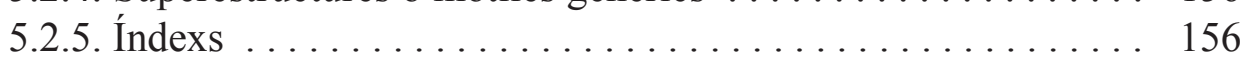

5.3. Organització de la informació en paràgrafs $\ldots \ldots \ldots \ldots \ldots \ldots 156$

5.3.1. El paràgraf: definició i funcions textuals . . . . . . . . . 156

5.3.2. Tipus de paràgrafs . . . . . . . . . . . . . 157 


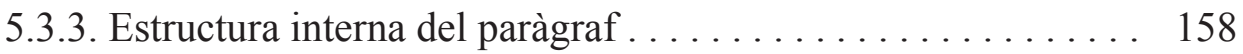

5.3.4. Algunes errades habituals . . . . . . . . . . . . . 158

5.3.5. Recomanacions . . . . . . . . . . . . . . . . . . 159

5.4. Procediments explicatius $\ldots \ldots \ldots \ldots \ldots \ldots \ldots \ldots \ldots \ldots \ldots \ldots$

5.4.1. Introduccions i conclusions . . . . . . . . . . . . . . . . . 161

5.4.2. La definició i la reformulació . . . . . . . . . . . . . . . 162

5.4.3. El resum . . . . . . . . . . . . . . . . . . . . . . . . . . . . . . 164

5.4.4. La nominalització . . . . . . . . . . . . . . . . . . 164

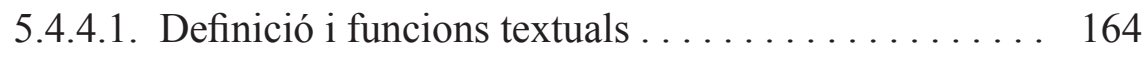

5.4.4.2. Les marques formals de la nominalització:

els sufixos . . . . . . . . . . . . . . . . . 165

5.4.5. Usos i funcions dels relatius . . . . . . . . . . . . . . 166

5.5. La informació implícita: pressuposicions i sobreentesos . . . . . . 169

5.5.1. Valor argumentatiu de l'implícit . . . . . . . . . . . . . 169

5.5.2. Tipus d'informació implícita . . . . . . . . . . . . 170

5.5.2.1. Els sobreentesos o implicatures conversacionals . . . 170

5.5.2.2. Les pressuposicions o formes convencionals

de l'implícit .................. 171

5.5.3. Mecanismes lingüístics de les pressuposicions . . . . . . . 172

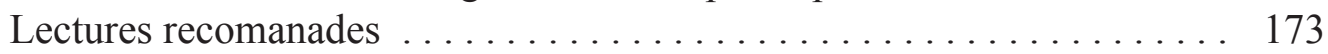

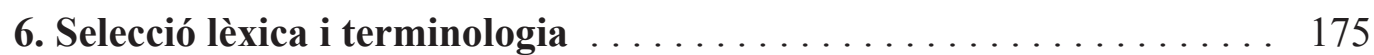

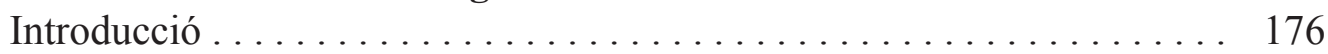

6.1. Criteris de selecció lèxica en el discurs dels mitjans . . . . . . . 176

6.1.1. Recomanacions generals . . . . . . . . . . . . . . 176

6.1.2. La interferència lingüística . . . . . . . . . . . . . . . . . 179

6.2. Precisió lèxica i neologia ... . . . . . . . . . . . . . . 181

6.2.1. La neologia . . . . . . . . . . . . . . . . . . . 181

6.2.2. Procediments de creació lèxica . . . . . . . . . . . . 182

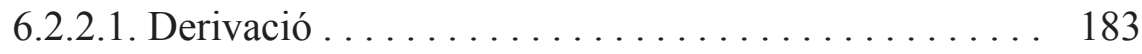

6.2.2.2. Composició ..................... 184

6.2.2.3. Truncació ....................... 186

6.2.2.4. El canvi semàntic . . . . . . . . . . . . . 186

6.2.2.5. Préstecs . . . . . . . . . . . . . . . . . . . . . 187

6.2.2.6. Altres procediments de formació de mots . . . . . . 188

6.3. El lèxic especialitzat: terminologia i estrangerismes . . . . . . . . 189

6.3.1. El Termcat . . . . . . . . . . . . . . . . . . . . . . . . . . . 189

6.3.2. L'Observatori de Neologia de la UPF . . . . . . . . . . . . . . . 190

6.3.3. Ús d'estrangerismes . . . . . . . . . . . . . . . . . . . . . . 192

6.3.3.1. Castellanismes . . . . . . . . . . . . . . . 192

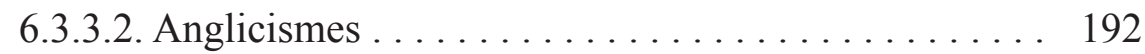

6.3.3.3. Llatinismes . . . . . . . . . . . . . . . . . . . . 193

6.4. Introducció a la fraseologia . . . . . . . . . . . . . . . . . . . . 194

6.4.1. Les unitats fraseològiques . . . . . . . . . . . . . . . . . . . 194

6.4.2. Propietats de les unitats fraseològiques . . . . . . . . . . . 195

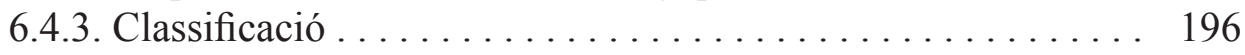

6.4.4. Pragmàtica de les expressions fraseològiques . . . . . . . . . . 197

6.4.5. La fraseologia en el discurs publicitari . . . . . . . . . . . . . 198

Lectures recomanades . . . . . . . . . . . . . . . . . . . . . . . . 199 


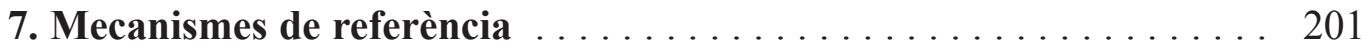

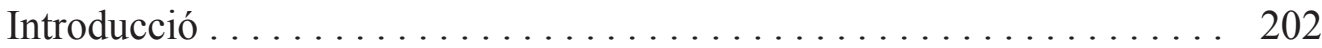

7.1. Coherència discursiva $i$ cohesió textual . . . . . . . . . . . . . 203

7.1.1. Els procediments de cohesió textual . . . . . . . . . . . 203

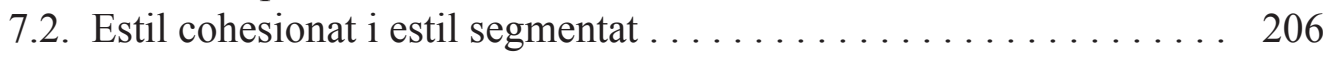

7.2.1. Estils comunicatius i redacció . . . . . . . . . . . . 206

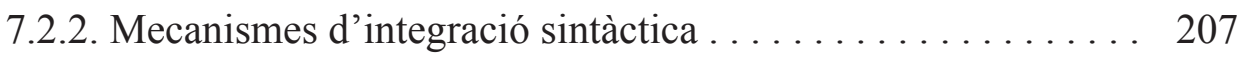

7.3. La referència discursiva . . . . . . . . . . . . . . . . . . . . . . 209

7.3.1. El concepte de referència . . . . . . . . . . . . . . . . . 209

7.3.2. Tipus de referència . . . . . . . . . . . . . 211

7.4. La referència gramatical . . . . . . . . . . . . . . 213

7.4.1. La pronominalització: pronoms febles i relatius . . . . . . . 215

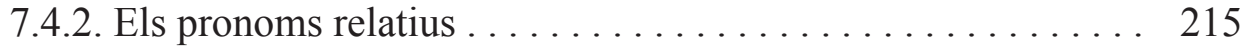

7.4.3. Els pronoms febles ..................... 216

7.4.4. Observacions sobre l'ús dels pronoms febles . . . . . . . 218

7.4.5. L'el-lipsi o anàfora zero . . . . . . . . . . . . . . 224

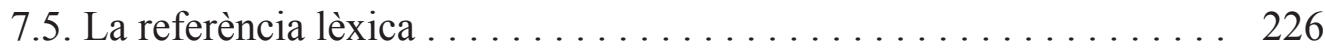

7.5.1. L'anàfora lèxica i les relacions de cohesió . . . . . . . . . 226

7.5.2. Repetició i reiteració . . . . . . . . . . . . . . . . . 227

7.5.3. Associació . . . . . . . . . . . . . . . . . . . . . . . . 229

Lectures recomanades . . . . . . . . . . . . . . . 232

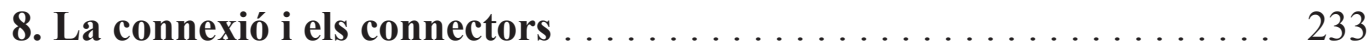

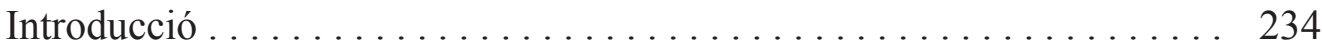

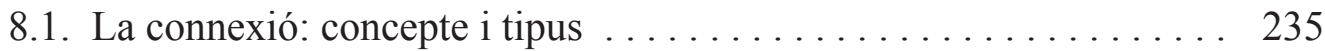

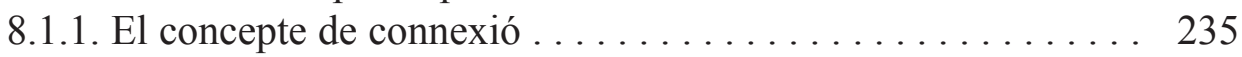

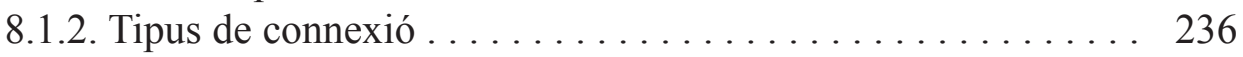

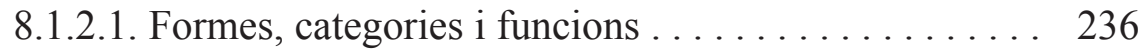

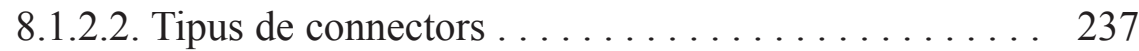

8.2. La connexió oracional i les conjuncions . . . . . . . . . . . . 240

8.2.1. La connexió oracional i l'oració composta . . . . . . . . . . 240

8.2.2. Tipus d'oracions compostes . . . . . . . . . . . . 241

8.2.3. Els connectors oracionals . . . . . . . . . . . . . . 244

8.2.4. Les relacions d'interordinació . . . . . . . . . . . . . . . . 244

8.2.5. Les construccions de subordinació . . . . . . . . . . . . . 245

8.3. La connexió textual . . . . . . . . . . . . . . . . . . . . 248

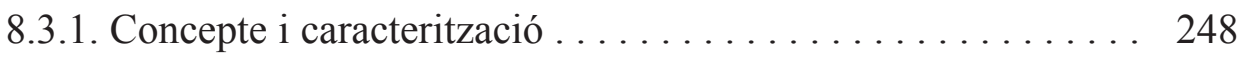

8.3.2. Els connectors parentètics . . . . . . . . . . . . . . 248

8.4. La connexió pragmàtica i els marcadors del discurs . . . . . . . . 250

8.5. Remarques sobre l'ús d'alguns connectors . . . . . . . . . . . 254

8.5.1. Connectors causals i consecutius . . . . . . . . . . . . 254

8.5.2. Connectors de contrast: adversatius i concessius . . . . . . . 255

8.5.3. Connectors comparatius i condicionals . . . . . . . . . 256

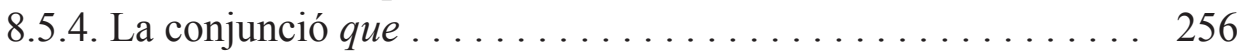

8.5.5. Usos de perquè, per què i per a què . . . . . . . . . . . . . . 257

8.6. Connexió textual, cohesió i escriptura . . . . . . . . . . . . . 257

8.6.1. Connexió textual i coherència discursiva . . . . . . . 257 
8.6.2. Cohesió textual i escriptura . . . . . . . . . . . . . . 259

8.6.2.1. Recomanacions generals ............. 260

8.6.2.2. L'estructura de la frase ............... 261

8.6.2.3. Alguns problemes de redacció ............ 262

Lectures recomanades . . . . . . . . . . . . . . . . . . . . 264

V. Aspectes pragmàtics i enunciatius del català $\ldots \ldots \ldots \ldots 265$

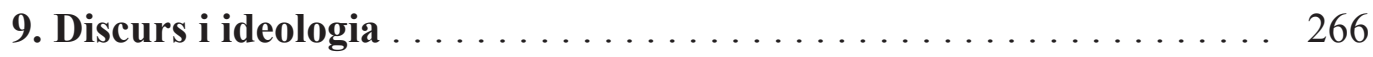

Introducció . . . . . . . . . . . . . . . . . . . . . . . . . . . . . 267

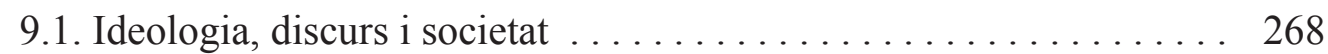

9.1.1. El concepte d'ideologia ................... 268

9.1.2. Ideologia i interacció social . . . . . . . . . . . . . 269

9.1.3. De la ideologia al discurs: actituds i marcs . . . . . . . . . 270

9.1.4. Llocs d'inserció de la ideologia en el discurs . . . . . . . . . 272

9.2. Text i context: la dixi i els díctics . . . . . . . . . . . . . . . 273

9.2.1. La dixi i els díctics . . . . . . . . . . . . . . . . . . . . . . . 274

9.2.1.1. La funció díctica . . . . . . . . . . . . . . . . . . . 274

9.2.1.2. Marques lingüístiques ................ 275

9.3. Acció i interacció: els actes de parla . . . . . . . . . . . 277

9.3.1. Els actes de parla . . . . . . . . . . . . . . . . . . 277

9.3.2. Classificació dels actes de parla .............. 278

9.4. Polifonia i discurs reportat . . . . . . . . . . . . . . . . 279

9.4.1. La noció de polifonia . . . . . . . . . . . . . . . . . 279

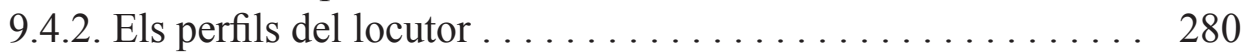

9.4.3. Les formes del discurs reportat . . . . . . . . . . . . . 281

9.4.4. Els verbs de locució . . . . . . . . . . . . . . . . . . . . . . 283

9.5. Procediments de modalització del discurs . . . . . . . . . 285

9.5.1. El concepte de modalització . . . . . . . . . . . . . . 285

9.5.2. Presència de l'emissor i del destinatari en el text . . . . . . . 286

9.5.3. Validació del contingut dels enunciats . . . . . . . . . . . 287

9.5.4. Atribució de diferents graus de certesa . . . . . . . . . . . 287

9.5.5. Transmissió de judicis de valor . . . . . . . . . . . . 288

9.5.6. La preservació de la pròpia imatge . . . . . . . . . . . . 289

9.5.7. Marcadors del discurs i figures retòriques . . . . . . . . . . 289

9.6. L'estratègia figurativa: metàfora i pensament . . . . . . . . . . . . 289

9.6.1. La metàfora i la metonímia . . . . . . . . . . . . . . . . . . 289

9.6.2. Tipus de metàfores . . . . . . . . . . . . . . . . . . . 293

9.7. Selecció lèxica i punt de vista . . . . . . . . . . . . . . . . 294

9.7.1. De l'argumentació en la llengua als blocs semàntics . . . . . . 294

9.7.2. Argumentació i topoi . . . . . . . . . . . . . . . . . . . . 296

9.7.3. Els blocs semàntics i l'estratègia argumentativa . . . . . . . . 298

Lectures recomanades . . . . . . . . . . . . . . . . . . . . . 302

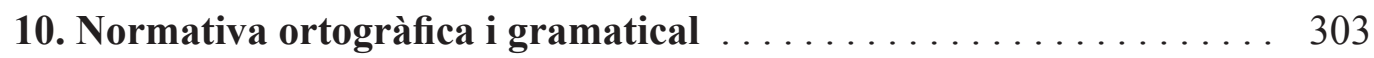

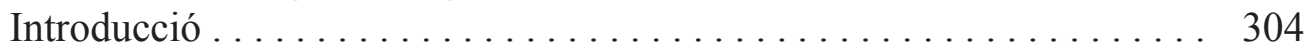

10.1. Aspectes avançats de normativa ortogràfica . . . . . . . . . . 304

10.1.1. L'escriptura de les vocals . . . . . . . . . . . . . . . . 304 
10.1.1.1. Confusions entre $a$ i $e$ àtones . . . . . . . 305

10.1.1.2. Confusions entre $o$ i $u \ldots \ldots \ldots \ldots$........ 305

10.1.1.3. Altres confusions . . . . . . . . . . . . 306

10.1.2. El hiat i els diftongs . . . . . . . . . . . . . . 306

10.1.3. L'accentuació . . . . . . . . . . . . . . . . . . . . 307

10.1.3.1. Les regles d'accentuació gràfica . . . . . . . . 307

10.1.3.2. L'accent diacrític . . . . . . . . . . . . . . 308

10.1.3.3. La qüestió de la $e$ tònica . . . . . . . . . . . 309

10.1.3.4. Ús i estalvi de la dièresi . . . . . . . . . . . . . . 309

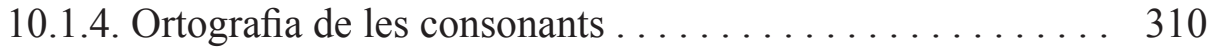

10.1.4.1. Els sons oclusius . . . . . . . . . . . . . . 310

10.1.4.2. Els sons fricatius . . . . . . . . . . . . 312

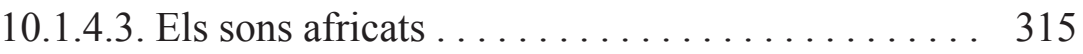

10.1.4.4. Els sons sonants .............. 316

10.1.4.5. Els sons laterals . . . . . . . . . . . . . . 317

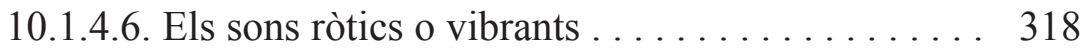

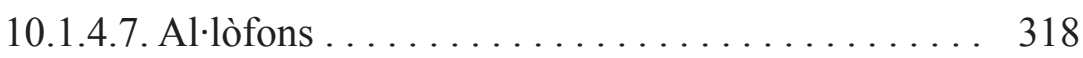

10.1.4.8. La lletra $h \ldots \ldots \ldots \ldots . . . \ldots \ldots . . . .319$

10.2. Formes i usos dels determinants . . . . . . . . . . . . 319

10.2.1. Determinants indefinits . . . . . . . . . . . . . 319

10.2.2. Determinants numerals . . . . . . . . . . . . 320

10.2.3. Quantificadors o determinants quantitatius ......... 322

10.2.4. Determinants demostratius . . . . . . . . . . . . . 323

10.2.5. Determinants possessius . . . . . . . . . . . 324

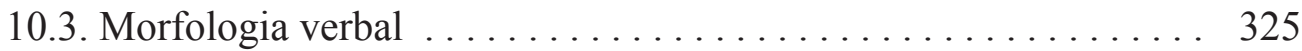

10.3.1. La flexió verbal . . . . . . . . . . . . . . . 325

10.3.2. Irregularitats verbals . . . . . . . . . . . . . . 325

10.3.2.1. Els verbs de la primera conjugació . . . . . . 325

10.3.2.2. Observacions sobre la segona conjugació . . . . . 326

10.3.2.3. Remarques sobre els verbs de la tercera conjugació ................... 327

10.3.3. Verbs transitius i pronominals . . . . . . . . . . 330

10.3.3.1. Verbs transitius i intransitius . . . . . . . 330

10.3.3.2. Verbs personals (o impersonals) i pronominals

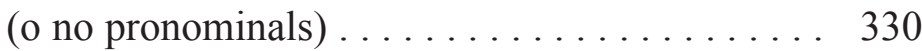

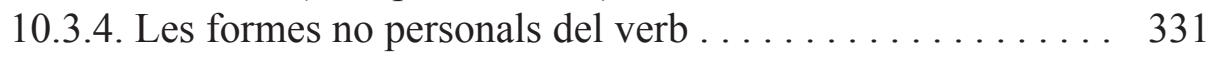

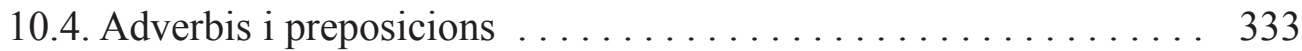

10.4.1. Aspectes generals . . . . . . . . . . . . . . . . 333

10.4.2. Remarques sobre l'ús de les preposicions $a$, amb, de i en ... 334

10.4.3. Canvi i caiguda de preposicions . . . . . . . . . 335

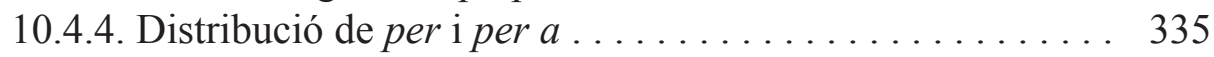

10.4.5. Adverbis i locucions adverbials . . . . . . . . . . 336

Lectures recomanades . . . . . . . . . . . . . . . . . . . . . . 337

Annexos .................................... 339

Annex I: Funcions textuals dels signes de puntuació . . . . . . . . . . 340

Annex II: Funcions convencionals dels signes de puntuació . . . . . . 341

Annex III: Tipografia . . . . . . . . . . . . . . . . . . . . . . . . . . . . 342 
Annex IV: Senyals per llegir 343

Annex v: Interferències lèxiques .................. 344

Annex vi: Ús de l'apòstrof $i$ el guionet . . . . . . . . . . . . . . . . 348

Annex VII: L'accent diacrític . . . . . . . . . . . . . . . . . . . . . 350

Annex viII: La conjugació verbal . . . . . . . . . . . . . . . . 351

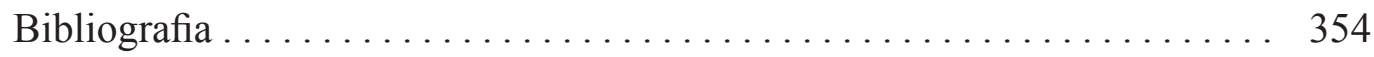

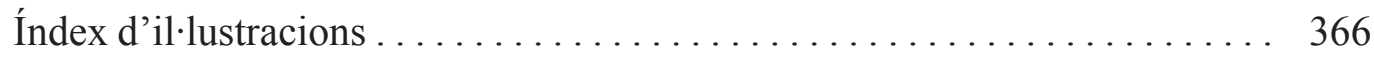

Índex temàtic . . . . . . . . . . . . . . . . . . . . . . . . . . . . . . . . . 369

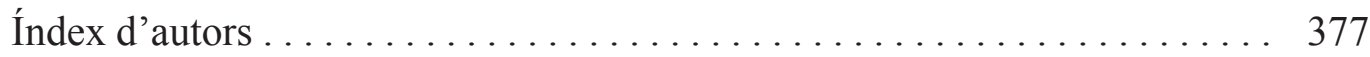




\section{Presentació}

\section{Una presentació d'amics}

En la comunicació quotidiana -si més no en el marc de la societat convencional- es fa sovint la presentació social d'individus que fins aquell moment no es coneixien. Per exemple, quan dues persones que no es coneixen coincideixen amb una tercera, un amic o amiga que ha tractat els dos, aquesta tercera persona facilita mitjançant el ritual de la presentació l'inici de la relació recíproca entre els desconeguts. Al capdavall aquest link, aquesta translació de familiaritat, és una versió incipient de la societat en xarxa, on el tercer en concòrdia fa de torsimany benèvol que vehicula la percepció mútua de les dues parts. És cert que aquesta mediació esmorteeix l'emoció de l'aproximació directa, la descoberta espontània de l'altre, la intriga del primer contacte, però des de sempre aquesta praxi ha palesat una intensa productivitat social, i és per això que s'ha convencionalitzat en la història de la nostra cultura. Vet ací quin és el meu paper com a prologuista ara mateix.

D'una banda, hi ha els autors d'aquest manual de llengua, dos professors competents i avesats a la tasca de l'ensenyament en diversos nivells educatius, entre els quals l'universitari és ara el que ens ocupa. L'Us té la sort de disposar, entre els seus contractats a temps parcial, d'alguns professionals com aquests que són una mà d'obra excepcionalment qualificada. En efecte, Joan Peraire i Enric Portalés han donat cos amb aquest llibre a una proposta de materials curriculars que tindrà sens dubte una utilitat envejable per als estudiants de periodisme, de publicitat, de comunicació audiovisual... El coneixement profund de la llengua i de les obres que l'estudien és un dels ingredients que han entrat en la preparació d'aquest menú. Un altre és la perspectiva actualitzadora que s'hi adopta quan la llengua es veu com una ferramenta per a la comunicació, més enllà de la mera descripció del sistema que hi subjau, de la langue com a producte estàtic i abstracte. No entraré en la discussió -bizantina i a vegades demagògica-de decidir si és primer l'ou o la gallina. Al capdavall, l'ús -els usos de la llengua en els diferents contextos socials al llarg del temps-es decanta com a conjunt d'estructures del sistema lingüístic, però també és cert que l'estudi de les estructures -lèxiques, gramaticals o discursives- fa més àgil l'adquisició i la potenciació de destreses verbals. Ser $i$ no ser alhora, amb perdó de Shakespeare. És a dir: 1'ou i la gallina, conjuntament. I, ultra tot això, la llarga experiència docent dels autors d'aquest llibre en garanteix la usabilitat per als alumnes, des del punt de vista d'una didàctica pròpia per a universitaris.

Ara bé, aquesta presentació dels autors del llibre no exhaureix la maniobra de terceria que el prologuista té encarregada. Caldria també efectuar el moviment invers: identificar, ni que siga temptativament, els lectors destinataris. Sens dubte, Enric i Joan, els autors, han imaginat llargament el perfil dels seus lectors ideals, per als qual ha estat escrita l'obra, però aquests lectors imaginats hauran de concretar-se en la jovenalla que, cada curs, poblarà les aules, un flux humà sempre jove, àvid de coneixements i aparentment igual cada any, però materialitzat en persones diferents. Vanessa o Aina, Joan Carles o Xavi, Àlex o Ivan o Samantha... Seran xics i 
xiques amb il·lusió d'esdevenir professionals de la comunicació social en les seues diverses branques, fascinats sovint per la imatge del comunicador mediàtic que es multiplica en visibilitat seductora, encuriosits pel ciberperiodisme, per la innovació tecnològica, pel màrqueting... Sens dubte, el treball sobre la comunicació no pot ignorar l'estructura empresarial, les característiques de la societat en xarxa, la dinàmica de Facebook o de Twitter, la multimodalitat semiòtica, els exercicis de màgia amb la tecnologia de les imatges.

No sé, tanmateix, si ells i elles són sempre prou conscients de la importància que el llenguatge conserva en aquest joc comunicatiu. A vegades els usos verbals, el lèxic, la gramàtica o la retòrica, poden semblar convidats de pedra coberts de pols en els recambrons de l'edifici mediàtic. A poc a poc comprendran, els nous estudiants, que això no és exactament així, i que avui la paraula té, com fa segles, una potència immensa a l'hora de configurar el concepte, de dissenyar l'argumentació o de mobilitzar les emocions dels altres. La paraula és, sens dubte, una energia renovable que ha de conviure amb els altres tipus d'energia -incloses les més avançades, a vegades no exemptes de riscs- i que ha de complementar-se amb aquestes, però que manté intacta la seua versatilitat fecunda.

Doncs bé, Enric i Joan, des d'aquest càlcul anticipatori fet des de la subjectivitat del prologuista, ací teniu un esbós de retrat dels que seran previsiblement els vostres lectors. Us els presente a la porta d'aquest llibre que està concebut per a ells $\mathrm{i}$ per a elles i que serà talment com una màquina que els ajudarà a pensar la llengua $\mathrm{i} a$ millorar-ne l'ús. Perquè, en el futur professional que els espera, aquesta destresa serà una condició exigible i una eina poderosa. Estic segur que després de treballar amb els continguts de la vostra obra ho tindran, tot això, molt més clar.

Vicent Salvador 


\section{Pròleg}

En la societat contemporània, la informació i la comunicació s'han convertit en un factor estratègic de desenvolupament i de modernitat. D'una banda, en el terreny de les grans corporacions multinacionals i dels estats poderosos i, de l'altra, en el de les petites empreses i de les corporacions locals, tant en l'àmbit públic com en la interacció personal de caràcter privat. Aquest esclat sense precedents s'ha produït gràcies a la confluència dels mitjans de massa i les noves tecnologies de la informació i la comunicació, que han afavorit el fenomen de la globalització i, alhora, han modificat d'una forma radical els estils de vida i les necessitats de formació de les noves generacions.

En aquesta nova societat, cal tenir especialment en compte el fenomen de la multiculturalitat i el plurilingüisme i, en el cas europeu, el procés de construcció d'una nova Europa sense fronteres, un fenomen històric sense precedents que exigeix, d'una banda, un canvi profund de les mentalitats per poder fer compatibles el manteniment de la diversitat lingüística i cultural amb la consolidació de la nova identitat europea i, de l'altra, una transformació radical de la formació superior en un marc més global i més interconnectat. És evident que, en aquest context sociocultural, sotmès a tensions noves $\mathrm{i}$ a una relativa inestabilitat, les professions lligades a la mediació i a la comunicació tenen un futur esplendorós i que la formació dels nous professionals de la comunicació presenta reptes i exigències apassionants.

Aquests perfils generals manifesten, en el cas de la cultura catalana, alguns matisos derivats de la situació de precarietat i de minorització de la llengua pròpia. Tot i els avenços que durant les últimes dècades s'han produït en el procés de normalització del català, especialment en alguns àmbits com l'educació i la comunicació de massa, la situació actual és encara d'una gran fragilitat. Per assolir una mínima normalitat és imprescindible el compromís de tota la societat -catalanoparlants i no-catalanoparlants, catalans (o valencians) d'origen i catalans (o valencians) d'adopció- a l'hora de garantir la presència de la llengua pròpia en els espais estratègics. Aquesta realitat és particularment dramàtica en el cas de la societat valenciana.

La consolidació del procés de normalització lingüística i cultural exigeix la implicació activa i compromesa dels poders públics i dels mitjans de comunicació de massa. Les classes populars han aconseguit mantenir la vitalitat del català i de la cultura catalana durant segles, lluitant contra el poder de l'estat i contra circumstàncies històriques i socials particularment adverses, en un exercici admirable de fidelitat i de compromís amb el futur. Però en la situació actual, qualsevol llengua de cultura moderna necessita la complicitat de les institucions públiques i el suport dels mitjans de comunicació. I aquesta idea indiscutible és especialment vàlida per als mitjans que operen en l'espai comunicatiu català, on el discurs dels mitjans en la llengua pròpia té un doble repte: d'una banda, competir en condicions difícils, des de la professionalitat i la qualitat, amb els mitjans d'àmbit estatal, públics i 
privats, que reforcen la situació de privilegi de la llengua i la cultura dominant, i, de l'altra, oferir productes d'una gran qualitat lingüística que reforcen la tasca formativa del sistema educatiu. I és evident que, per assumir aquest compromís amb la llengua i amb la cultura catalanes, els professionals dels mitjans han de tenir un bon domini de la llengua pròpia del territori on han de treballar.

Des d'aquesta perspectiva, el curs de llengua catalana per a comunicadors que presentem està pensat per facilitar als estudiants de Comunicació Audiovisual, Periodisme i Publicitat i Relacions Públiques els materials perquè puguen adquirir les estratègies i les habilitats comunicatives necessàries per exercir la professió en català, a fi de poder gestionar amb naturalitat els gèneres prototípics dels mitjans de comunicació de massa, tant els productes multimodals com els que formen part de l'àmbit de l'oralitat o de l'espai de l'escriptura.

Comunicar en català i des de l'espai comunicatiu català exigeix un esforç i un compromís de qualitat i de rigor, un compromís que per als joves professionals de la comunicació constitueix un suplement de formació. I en aquest sentit és important recordar que comunicar en català és alguna cosa més que oferir una traducció més o menys digna de productes pensats i fets en una altra llengua. La dignificació de la llengua i la cultura pròpies exigeix als professionals de la comunicació, i a les empreses del sector compromeses, l'esforç de pensar la realitat i oferir productes des d'una perspectiva pròpia, no supeditada als interessos ideològics dels grans grups mediàtics, dels partits polítics i dels sectors econòmics dominants. I els professionals valencians, en expressar un punt de vista propi de la realitat, personal i original, contribuiran a la pluralitat dels mitjans i, per tant, oferiran al conjunt de la societat mirades noves i diverses que permetran comprendre millor un món plural i complex. 


\section{Introducció}

Aquest materials constitueixen el temari de l'assignatura Llengua catalana per a comunicadors, que s'ofereix en el primer curs de les tres titulacions de l'àmbit de les ciències de la comunicació (Periodisme, Comunicació Audiovisual i Publicitat i Relacions Públiques). Es tracta d'una assignatura troncal, de sis crèdits, que s'ofereix com a alternativa a l'assignatura paral-lela de llengua espanyola. S'imparteix durant el primer semestre, amb quatre hores setmanals de docència, dues de teoria i dues de pràctica, i amb la voluntat d'oferir als estudiants una formació sòlida en llengua catalana des d'una perspectiva pragmàtica i discursiva.

Aquesta orientació general té unes implicacions teòriques i metodològiques que s'han tingut molt en compte, tant a l'hora de delimitar les competències bàsiques que han d'assolir els estudiants i d'articular la informació teòrica amb les activitats pràctiques, com a l'hora d'organitzar els continguts en temes i d'estructurar cada unitat temàtica.

Aquesta assignatura, a través dels continguts i les estratègies d'aprenentatge més adients, ha de permetre als estudiants l'adquisició de les competències que es descriuen a continuació.

1. Capacitat per a analitzar el discurs dels mitjans de comunicació i per aplicar a l'escriptura periodística els procediments de la lingüística textual i de l'anàlisi crítica del discurs.

2. Coneixement i estudi dels processos cognitius, emocionals i psicosocials implicats en la pràctica de la comunicació i de les formes d'expressió lingüística necessàries.

3. Desenvolupament de la capacitat per a analitzar els models de llengua utilitzats en els textos informatius i persuasius en llengua catalana i per a reconèixer l'especificitat del discurs oral i del discurs escrit en contextos comunicatius caracteritzats per la multimodalitat.

4. Capacitat per a analitzar els gèneres, les estructures, els continguts i els estils dels discursos periodístics, publicitaris i audiovisuals des del punt de vista de la variació lingüística i dels mecanismes de la llengua.

5. Desenvolupament de la capacitat per a reconèixer les principals dificultats de normativa lingüística en el registre dels mitjans de comunicació de massa i aplicar els recursos adequats a la producció de textos escrits propis del discurs periodístic, de la comunicació audiovisual i de l'àmbit publicitari.

6. Desenvolupament de les estratègies necessàries per produir i gestionar en català els gèneres orals més característics del periodisme radiofònic i televisiu, de la comunicació audiovisual i del discurs publicitari.

7. Formació en valors democràtics i en la no-discriminació lingüística a través de l'anàlisi dels llocs d'inserció de la ideologia en el discurs, particularment amb l'estudi del sexisme en el llenguatge, de la variació social vinculada a l'ús d'eufemismes, de l'ús de la informació implícita i de l'estratègia retòrica. 
8. Desenvolupament de les competències estratègiques necessàries per millorar la comunicació oral i escrita i la capacitat d'interacció social: el raonament crític, la capacitat d'anàlisi i síntesi, la capacitat d'organització i planificació, la capacitat de treballar en equip i la capacitat per a la resolució de problemes.

Per assolir aquestes competències, els continguts de l'assignatura s'organitzen al voltant de cinc blocs temàtics, cadascun dels quals comprèn dos mòduls o unitats, que es desenvolupen setmanalment, amb una dedicació de quatre hores de classe cadascun, dues hores teòriques i dues hores d'activitats pràctiques.

El pla d'estudis de la assignatura comprèn, per tant, deu mòduls temàtics en els quals alternen els continguts generals, comuns als tres graus, i els específics de cada grau. Entre els primers, cal destacar els aspectes genèrics de la descripció del català, com ara els conceptes de comunicació i discurs, la variació lingüística i la varietat d'estàndard (bloc 1); les relacions entre oralitat i escriptura en contextos comunicatius multimodals (bloc 2); l'estructuració de la informació i les estratègies de coherència textual (bloc 3); els procediments de cohesió textual, relacionats amb els connectors i amb els mecanismes lexicosemàntics (bloc 4), i els diversos aspectes pragmàtics $i$ enunciatius que permeten l'adequació dels textos als seus contextos de recepció i de producció (bloc 5).

Per poder desenvolupar les competències generals i els continguts esmentats, l'assignatura s'articula al voltant de diferents tipus d'activitats que han de permetre assolir capacitats de treball intel-lectual més específiques: classes teòriques ( 24 hores distribuïdes en 12 sessions de dues hores cadascuna), classes pràctiques ( 24 hores distribuïdes en 12 sessions de dues hores), seminaris i grups de discussió ( 2 sessions de 3 hores), tutories en grups reduïts (3 hores) i realització d'exàmens (3 hores).

L'assignatura es planteja amb la voluntat d'oferir un equilibri entre teoria i pràctica, entre la reflexió sobre la llengua i l'ús de la llengua. Aquesta perspectiva exigeix, d'una banda, l'adopció d'una orientació metodologica en què la interacció entre el professor i l'alumnat ocupa un lloc central i, de l'altra, una replantejament global dels continguts de la matèria en funció de les diferents dimensions de l'anàlisi del discurs i de les estratègies implicades en la lectura crítica i en la producció textual.

En aquest sentit, l'assignatura ofereix un tractament integrat dels mecanismes discursius relacionats amb la producció i la interpretació dels textos (com ara l'estructuració de la informació en paràgrafs, la selecció lèxica, la progressió temàtica, la connexió textual i la referència o els procediments relacionats amb la citació i amb el discurs reportat) amb els aspectes més interessants de normativa gramatical i ortogràfica del català (entre els quals, els pronoms febles i relatius, les preposicions, la morfologia verbal o la fraseologia). Els continguts i les pràctiques d'aquests dos nivells d'anàlisi de l'activitat lingüística, el discursiu i l'oracional, es presenten en el marc d'un enfocament discursiu i comunicatiu de la llengua catalana que prioritza el treball pràctic amb textos dels gèneres prototípics de l'àmbit 
periodístic, audiovisual i publicitari i fa compatibles la reflexió col·lectiva amb el treball individual, les activitats d'anàlisi i interpretació de materials amb els projectes de creació personal i la producció escrita amb la pràctica de l'oralitat.

Evidentment, aquesta perspectiva sobre la llengua i sobre els aprenentatges lingüístics té unes implicacions importants sobre la pràctica docent. D'una banda, el desenvolupament de l'assignatura exigeix l'assistència habitual dels estudiants a les sessions de classe i la participació activa en les discussions i en la interacció que es genere a l'aula; de l'altra, des del convenciment que els aprenentatges lingüístics són individuals i es produeixen des de les necessitats comunicatives de cada persona, és imprescindible oferir un ensenyament personalitzat, que pugui proporcionar a cada estudiant els recursos necessaris per millorar la seua competència comunicativa en català. Els exercicis d'aplicació de la teoria, les pràctiques, les lectures recomanades i els materials disponibles en l'Aula Virtual permeten d'atendre aquesta diversitat i afavoreixen l'aprenentatge individualitzat.

Pel que fa a l'estructura de la publicació, es pot observar que el text conté els continguts teòrics del programa de l'assignatura, organitzats en deu unitats temàtiques, amb la voluntat d'oferir als estudiants, d'una forma còmoda i senzilla, els coneixements de referència necessaris per poder realitzar els exercicis d'aplicació i les pràctiques previstes en el programa. El cos expositiu del dossier es completa amb una sèrie d'annexos, que complementen la informació essencial; la relació de les fonts utilitzades; dos índexs, un de temàtic i un d'autors, que faciliten d'una forma ràpida l'accés als conceptes desenvolupats $\mathrm{i}$ als autors citats en el text, $\mathrm{i}$ l'índex d'il·lustracions.

Totes les unitats presenten una estructura similar, que contribueix a la coherència del conjunt i en facilita l'ús i la consulta. El tema s'obri sempre amb un recordatori de l'índex de continguts i amb una breu introducció, que contextualitza la unitat, descriu els continguts seleccionats i recorda els objectius d'aprenentatge que es pretenen assolir. En el cos central de la unitat es presenten els continguts d'una forma jerarquitzada i seguint una ordenació lògica, amb textos il·lustratius, exemples i elements gràfics, que en faciliten la comprensió i l'assimilació. Finalment, el tema es tanca amb una breu relació de lectures recomanades, que presenten alguns textos fonamentals per ampliar els contiguts.

En el desenvolupament de cada unitat, a més dels elements gràfics, s'insereixen citacions breus, procedents de la bibliografia utilitzada, en què es recullen idees fonamentals expressades amb les paraules dels autors, i petits quadres de text en què se sintetitzen definicions i dades d'interès per completar la informació de referència. També es presenten, quan s'ha considerat necessari, notes breus al marge del text en què s'ofereixen adreces a llocs web essencials per completar la informació del cos expositiu. En qualsevol cas, cal remarcar que tots els elements gràfics (imatges, quadres, esquemes i taules) s'han identificat amb el mateix sistema -amb l'abreviatura fig., un número correlatiu que el situa en relació amb la resta de figures de la unitat i una breu descripció del contingut. No s'han numerat, però, 
les imatges que tenen una funció merament estètica, els textos complets que s'utilitzen per il·lustrar les idees exposades ni les taules de la unitat 10.

Finalment, convé remarcar el paper essencial que té, per al desenvolupament de l'assignatura, el complement de les activitats, que presenten una triple dimensió: els exercicis d'aplicació de la teoria proposats en cada unitat, les activitats interactives a les quals es pot accedir des de l'Aula Virtual i les pràctiques guiades d'anàlisi i producció de textos.

Pel que fa al model de llengua utilitzat en la redacció, observareu que s'ha donat preferència a les formes més generals sobre els particularismes exclusivament valencians. Així, s'han preferit els incoatius en -eix, els demostratius reforçats o les solucions lèxiques més formals (desenvolupament, servei...), tot i que no s'han defugit les variants valencianes quan tenen un prestigi en els registres formals i no distorsionen la naturalitat de l'estil expositiu, com ara els possessius meua-teuaseua, els presents de subjuntiu en -e o els imperfets en -ara. Hem optat, per tant, per aquella perspectiva que va utilitzar amb saviesa i amb rigor Joan Francesc Mira en la traducció de la Divina Comèdia; per un «català matisadament valencià», que va reivindicar també Vicent Alonso en la traducció dels Assaigs de Montaigne, amb la voluntat de deixar constància que aquesta llengua nostra és la llengua de tots i que les seues varietats l'enriqueixen i li confereixen una major vitalitat.

I finalment, només ens resta expressar el més sincer agraïment a totes les persones que, d'una forma o altra, han contribuït a fer possible aquest projecte docent. Als estudiants de les titulacions de l'àmbit de les ciències de la comunicació, que, des d'aquell llunyà 1999 fins ara, han estat protagonistes actius i víctimes propiciatòries de les nostres propostes didàctiques $i$ han contribuït, directament $o$ indirecta, a modificar els nostres punts de vista $i$ les nostres percepcions $i$, amb les seues aportacions, ens han ajudat a millorar els materials que oferim ara als estudiants que s'incorporen als nous graus. Als directors de les titulacions de Periodisme, Comunicació Audiovisual i Publicitat, que han acollit amb interès i han donat suport a aquesta iniciativa, i al professorat que imparteix docència en aquests graus, especialment a Margarita Porcar i a Javier Vellón, en el convenciment que seran necessàries moltes hores més de coordinació per continuar oferint als estudiants la docència de qualitat que es mereixen. I als companys de l'àrea de català, especialment a Joan-Ramon Monferrer i a Montserrat Ferrer, que comparteixen la fràgil estabilitat d'un petit despatx de la tercera planta de la Facultat de Ciències Humanes i Socials i algunes coses més, i a Adolf Piquer, company de viatge en tantes inquietuds intel-lectuals. I a Vicent Salvador, que ha estat una ajuda inestimable des de fa molts anys i continua sent un punt de referència indiscutible per a la pràctica docent i per a la nostra precària tasca investigadora. A tots ells, reiterem el nostre agraïment, tot i que, com se sol dir en aquests casos, assumim plenament la responsabilitat de les errades o inexactituds que, contra la nostra voluntat, es puguen haver comès en la redacció d'aquestes pàgines. 


\section{COMUNICACIÓ I MODELS \\ DE LLENGUA}




\section{TEMA 1}

\section{Llengua, comunicació i societat}

Introducció

1. Comunicació i discurs

2. La competència comunicativa

3. Les propietats textuals

4. L'estudi del discurs

5. Llengua i societat: introducció a la sociolingüística 


\section{Introducció}

Els últims anys ha fet fortuna, per referir-se a la societat actual, el concepte de societat de la comunicació. L'augment espectacular dels mitjans de comunicació, i especialment la generalització del fenomen d'Internet, ha afavorit que els ciutadans tinguen el privilegi de viure en l'època històrica amb més quantitat d'informació. De fet, la comunicació en la societat actual ha experimentat una mena d'explosió que ha comportat la saturació d'artefactes comunicatius en tots els espais de la vida pública i privada (informàtica, televisió, ràdio, cinema, telefonia mòbil, etc.). Tot i això, no deixa de resultar sorprenent que bona part dels problemes de convivència que hem d'afrontar actualment tenen a veure, més o menys directament, amb dèficits en la competència comunicativa.

No descobrirem res de nou si destaquem la incidència dels problemes relacionats amb la comunicació en el deteriorament de les relacions de parella, en les relacions entre pares i fills, en el fracàs escolar i en altres situacions de la vida diària. Sovint ens adonem que no ens comuniquem bé amb altres persones i observem com es generen $i$ es perpetuen malentesos que es converteixen en camps de mines que dificulten el trànsit de les persones pels camins de la comunicació.

La comunicació ocupa un lloc central en la mediació que estableix el discurs dels mitjans entre l'individu i la realitat i té també un paper fonamental en la construcció social de les identitats i en la difusió i transmissió de punts de vista i estils de vida, és a dir, en la consolidació de les ideologies.

Aquest tema presenta algunes reflexions que ens poden ajudar a entendre una mica millor el complex territori de la comunicació humana i aborda una sèrie de conceptes bàsics que han de permetre contextualitzar adequadament els continguts de la resta de temes de l'assignatura en l'àmbit de la comunicació audiovisual, del periodisme i del discurs publicitari. En primer lloc, es defineixen alguns conceptes bàsics relacionats amb la comunicació $i$ es plantegen alguns problemes que tenen a veure amb la comunicació i amb la societat de la informació. A continuació, es presenten els diferents components de la competència comunicativa i s'exposen, breument, els mecanismes lingüístics i discursius que constitueixen les propietats textuals. En l'última part d'aquest primer tema s'ofereix una visió panoràmica de les ciències del llenguatge, tot subratllant els centres d'interès de les disciplines que s'ocupen de l'estudi del discurs, particularment la pragmàtica, l'anàlisi del discurs i la sociolingüística. I, per completar aquest panorama introductori, la unitat es tanca amb una introducció a la sociolingüística, que inclou, a més de la presentació dels conceptes fonamentals per a l'estudi de les relacions entre llengua i societat, una breu aproximació a la història de la llengua catalana. 


\subsection{Comunicació i discurs}

\subsubsection{La societat de la informació}

Els últims anys hem assistit a un dels fets històrics més significatius i més transcendentals de l'era moderna, un fet impactant i d'unes dimensions espectaculars que a hores d'ara no ens deixen veure encara amb nitidesa els efectes socials i les repercussions sobre la psicologia $i$ els estils de vida de la humanitat contemporània. Es tracta de l'accés a la societat de la informació, la comunicació i el coneixement, un fenomen que s'ha produït de la mà de les noves tecnologies.

En aquest sentit, la societat de la comunicació es presenta com la forma actual de la societat de consum, que és, de fet, la darrera manifestació del capitalisme contemporani. Aquesta societat presenta una sèrie de trets que, sense pretensions d'exhaustivitat, ens poden ajudar a dibuixar-ne el perfil:

1. La societat contemporània obliga els individus a adaptar-se a un estil de vida líquida, és a dir, a una manera de viure en què les formes socials, les condicions d'actuació dels individus i les estratègies per adaptar-se a les innovacions canvien abans que les formes d'actuar es consoliden en uns hàbits $\mathrm{i}$ en unes rutines determinades. L'expressió vida líquida, un concepte desenvolupat pel filòsof Zygmunt Bauman, permet explicar algunes pautes de comportament i de pensament en la societat actual (Bauman, 2005).

La vida líquida és una vida precària i viscuda en condicions d'incertesa contínua, en la qual ocupen un lloc central la necessitat de modernització constant (que es concreta, per exemple, en el ritme incessant de la moda), la indústria d'eliminació de residus (en un sentit molt ample), la recerca permanent i obsessiva de la identitat en un món cada cop més global i la tendència a substituir la duració i la permanència per la velocitat. Des de les modernes trones mediàtiques, els nous centres de creació d'ideologia, ens recorden permanentment que l'important és córrer amb energia, córrer desesperadament per mantenir-nos en el mateix lloc. I hem d'assumir el risc de córrer sense saber en quina direcció correm ni per què. En la societat moderna líquida no hi ha lloc per a la pausa, ni per a la reflexió, ni per al pensament. Tot són desitjos, emocions, sensacions que cal viure intensament, al límit. I tot és breu i líquid, sense perfils precisos i definits, fins i tot les relacions amb les persones.

2. Aquest marc global permet entendre millor una segona característica de la societat actual: l'emergència de les noves tecnologies i l'aparició de les noves addiccions tecnològiques (als mòbils, als programes de missatgeria instantània, als reproductors d'MP3, a Internet o a les xarxes socials), que completen i matisen les altres addiccions, les antigues (a les festes, al sexe, a l'alcohol i al tabac o a les altres drogues). Les noves tecnologies de la informació i la comunicació han permès, per exemple, que actualment una 
persona en un sol dia puga estar en contacte amb tanta informació com la que tenia a l'abast durant tota la vida una persona a començament del segle XVIII. Si analitzem l'evolució que ha experimentat en cinquanta anys el ritme d'acumulació d'informació en les societats occidentals, observarem que cap al 1960 encara es necessitava més d'una generació perquè es doblara la quantitat d'informació emmagatzemada i acumulada; aquesta xifra s'havia reduït a deu anys el 1980, i a tres a finals del segle xx; el 2005, la informació es duplicava cada dos anys i en finalitzar la primera dècada del segle XXI, la xifra s'ha reduït a uns vuitanta dies. Les noves tecnologies han posat al nostre abast més informació que mai, però han introduït un nou problema, que hem d'afrontar d'una manera o d'una altra: la saturació informativa. La informació és un dret bàsic de l'ésser humà i cal exigir el dret a triar les fonts d'informació o a seleccionar les informacions que ens semblen pertinents. Ja sabem que informació és poder, que qui té la informació té el poder, però hem arribat a un moment en què l'excés d'informació, la saturació, es converteix en un problema que amenaça de crear noves formes de discriminació tecnològica. En la societat actual, sovint ofega l'excés, i es fa tan imprescindible com l'accés a la informació la clarificació dels criteris per seleccionar-la, per destriar els continguts rellevants d'allò que és perfectament prescindible.

3. El desenvolupament de les noves tecnologies de la informació i la comunicació ha comportat la introducció d'un nou paradigma digital que ha comportat la substitució de l'antic model analògic i ha permés integrar en dispositius i productes multimèdia un amplíssim ventall de manifestacions comunicatives molt diverses (veu, música, imatge estàtica, imatge en moviment o text escrit, entre algunes altres). La digitalització ha esdevingut sinònim de qualitat $\mathrm{i}$ símbol de modernitat $\mathrm{i}$ ha fet possible l'emergència amb força d'una nova cultura audiovisual, en què la imatge ocupa un lloc central.

4. La centralitat de la imatge en la societat actual té una ramificació molt productiva des del punt de vista ideològic en la potenciació de la superficialitat, del culte al cos i a la imatge física. En el fons, es tracta d'una estratègia de màrqueting l'objectiu de la qual és presentar als adolescents (i a les persones no tan adolescents) una sèrie de models ideals, d'estils i formes de vida associats a esportistes, cantants, actors i noies de passarel-la per posar en evidència allò que ens falta per ser com ells, com els herois i heroïnes contemporanis. I un cop s'ha aconseguit que els ciutadans interioritzen la mancança, el defecte, i s'ha creat un mercat de consumidors potencials, la indústria del cos s'encarrega d'oferir productes miraculosos per superar la tara i arribar a la perfecció (cremes miraculoses, protecció solar, liposuccions i tot tipus d'actuacions de cirurgia estètica). És evident que la manca d'autoestima i la incapacitat per adaptar-se a la vida líquida recorre la línia que separa el negoci del cos de la realitat dramàtica de l'anorèxia o dels trastorns psicològics. Es tracta, en definitiva, d'una manifestació de la incapacitat de veure més enllà dels valors promoguts pels nous amos del món. 
5. A més, l'accés a la societat de la comunicació ha comportat el desenvolupament d'un estil de vida caracteritzat pel culte a l'emoció, una manifestació de l'individualisme contemporani que sedueix l'ésser humà perquè legitima una manera de viure orgànica i bàsica, una manera de viure en què el cos ocupa un lloc central. El culte a l'emoció capgira l'escala de valors de la humanitat contemporània, ja que substitueix la racionalitat per la primitivitat dels sentits com a factor clau del desenvolupament humà. L'homo sapiens deixa pas, a poc a poc, a l'homo sentiens, i s'imposa progressivament la idea que traurem més profit de la vida si ens esforcem a sentir, més que no pas a pensar (Lacroix, 2001).

En aquest sentit, José Antonio Marina relaciona l'augment de les addiccions i la manca d'atenció de l'alumnat a les aules amb una contundència que ens ha de fer pensar: «La proliferació dels desitjos crea personalitats capricioses que suporten molt malament l'ajornament de la satisfacció i la frustració»» (Marina, 2007). La societat del coneixement és una societat capriciosa, una societat marcada per l'estil de vida del comandament a distància, pel fragmentarisme i per la fragilitat extrema.

6. Finalment, un dels trets que recorre tots els sectors i tots els espais de la societat contemporània és la tendència a la globalització, en l'àmbit de l'economia i la política, en el desenvolupament científic i tecnològic, en el món de la cultura - es fa, per exemple, especialment evident en la música, el cinema o l'esport de masses- $\mathrm{i}$ en el terreny de les relacions socials -els fenòmens migratoris o l'increment de les ONG en serien només alguns exemples. Aquest fenomen -que ha reforçat des de fa algunes dècades un imparable procés d'homogeneïtzació lingüística, cultural i ideològica- ha provocat també el desenvolupament d'un moviment de caràcter oposat, compensador del procés homogeneitzador, que tendeix a subratllar els valors del localisme i la diferència i les marques d'identitat, és a dir, de tot allò que ens identifica com a membres d'un grup social diferent i diferenciat -nacional, ideològic, estètic, tribal o de qualsevol altre tipus. I en aquest procés de redefinició de les identitats, i de recerca de l'equilibri entre globalitat i localisme, entre les tendències generals de l'anomenada civilització occidental contemporània $\mathrm{i}$ les particularitats específiques del grup humà de què formem part, els mitjans de comunicació de masses (la televisió i el cinema, la premsa, la ràdio i Internet) en són un factor determinant, un actor que representa un paper protagonista.

Aquestes característiques, que no pretenen ser exhaustives, ens permeten comprendre una mica millor el marc en què haurem de viure les properes dècades $\mathrm{i}$ ajuden a explicar la realitat de la societat actual des del punt de vista de la comunicació. La invasió imparable de la telefonia mòbil, la informatització de la vida pública i privada, l'expansió dels discursos audiovisuals i la digitalització de tots els discursos són algunes de les manifestacions més evidents de la cultura contemporània. La realitat és que vivim en un món on l'accés a la informació i a la comunicació s'ha convertit en un factor importantíssim per a l'exercici del poder 
i per a la consolidació de les desigualtats socials. I aquest fet sense precedents té importants repercussions sobre la psicologia de la humanitat contemporània, sobre els hàbits de consum $i$ sobre les relacions socials.

\subsubsection{Comunicació i cultura}

La comunicació és un procés d'interacció social que implica, en primer lloc, l'existència d'una relació entre persones i, en segon lloc, la transmissió d'informació. El mecanisme que permet establir i mantenir la comunicació entre éssers humans és extraordinàriament complex i implica el funcionament interrelacionat de diversos elements i de processos i accions també molt diversos.

Un esquema elemental de la comunicació contempla, com a elements imprescindibles del procés, els conceptes d'emissor i receptor, el missatge, el canal, el codi o sistema, el context i el referent. Ara bé, si entenem que la comunicació és un procés dinàmic que exigeix la participació activa dels individus que interaccionen, és imprescindible ampliar aquest model elemental per incloure, d'una banda, els processos de codificació i descodificació i les relacions entre els diversos elements que el configuren $i$, de l'altra, un component estratègic, que tinga en compte la intencionalitat de l'emissor, les estratègies de producció discursiva, un subcomponent inferencial i un conjunt d'estratègies d'assignació de sentit.

Segons la teoria clàssica de la comunicació, la comunicació és un procés d'intercanvi d'informació entre un element $\mathrm{A}$, anomenat tècnicament emissor, i un element B, anomenat receptor. D'acord amb aquesta visió, la informació circula entre els dos elements a través d'un determinat canal de comunicació, utilitzant un determinat sistema de signes o codi $\mathrm{i}$ empaquetada en una mena de càpsules (els textos o enunciats), que són desempaquetades en el punt de destinació per tal d'obtenir, després d'un procés de descodificació, la informació encriptada en el punt A. Aquesta teoria de la comunicació té el seu ancoratge en una visió racionalista i lògica del pensament, s'ha desenvolupat a partir de l'analogia entre el processament informàtic de la informació i el funcionament del cervell humà $(0$, per ser més exactes, de la part racional del cervell humà) i ha contribuït a provocar una espectacular eclosió del cognitivisme, especialment en l'àmbit dels estudis de psicologia i de les ciències del llenguatge.

Però quan parlem de comunicació humana, les coses no són tan senzilles, perquè sovint es produeixen interferències, malentesos, ironies, actes de parla indirectes i altres fenòmens que no poden explicar-se des d'una visió tan elemental del procés de comunicació.

Si la comunicació fóra un procés de transferència d'informació, quan, en un dinar formal, el nostre veí de taula ens pregunta si li podem passar la sal li contestaríem amb una resposta contundent («sí» o «no») i esperaríem una nova intervenció. Però tots sabem que si férem això el nostre comportament verbal seria considerat poc apropiat o francament descortès. 
Ja fa temps que els psicòlegs i els psicolingüistes insisteixen a recordar que el cervell racional és només la punta de l'iceberg de l'estructura mental: tot i que sovint els humans ens sentim orgullosos de la nostra racionalitat, el component racional no ocupa més de la vuitena part del volum global del cervell.

Per tal d'oferir un marc teòric del fet comunicatiu més ajustat a la realitat, durant les últimes dècades s'ha desenvolupat una perspectiva pragmàtica, segons la qual la comunicació és un procés d'assignació de sentit a la conducta verbal i no verbal de les persones. Aquest nou punt de vista, la comunicació inferencial, complementa la dimensió estrictament informativa. Així, tot i l'evidència que sovint en els processos de comunicació es produeix una transferència d'informació, no podem obviar que en molts casos, especialment en la interacció verbal cara a cara, l'assignació de sentit al comportament verbal dels interlocutors exigeix la formulació d'hipòtesis interpretatives o inferències a partir de la intencionaliat de l'emissor. Els actes de parla indirectes, la ironia, les pressuposicions, les metàfores, les implicatures conversacionals o les violacions intencionades de les màximes de la conversa en són alguns exemples molt evidents.

Quan l'expresident del govern espanyol José María Aznar, fa uns anys, donava lliçons als països de l'Amèrica Llatina sobre la importància de no deixar escapar «el tren de la modernitat», construïa el seu discurs polític sobre una imatge metafòrica de la modernitat - presentada com un tren, que s'allunya d'un passat modest i poc desitjable-i sobre l'ús del determinant demostratiu $e l$, que transmet la idea que de trens de la modernitat només n'hi ha un, el que passa en aquest moment gràcies a la política del seu partit. El mateix polític ens va deixar, utilitzant un format similar, algunes frases que han passat a la posteritat:

[1] No tenemos nada que hablar con quienes juegan a aprendices de brujos con la Constitución.

[2] Debe garantizar que España no se baja del autobús de la lucha contra el terrorismo.

La primera sentència activa una quantitat important d'inferències en posar en relació un concepte com la Constitución, objecte de veneració gairebé religiosa pels grups socials i polítics identificats amb aquest discurs, amb el significat del verb jugar -que transmet la idea de manca de maduresa, de poca seriositat i de poc compromís- i amb el sentit pejoratiu de l'expressió aprendices de brujos -que s'associa a pràctiques malèvoles, poc controlades i de dubtosos resultats.

La segona era una forma molt particular de demanar al futur president del govern que l'única manera d'acabar amb el terrorisme és continuar amb la política del govern que se'n va. La lluita contra el terrorisme és un autobús (només n'hi ha un) i, segons paraules literals de l'autor del discurs, el futur president baixaria de l'autobús «si se va de algún sitio» (és a dir, de l'Iraq).

Aquesta idea de comunicació té alguns punts de contacte amb el concepte de cultura, un concepte que cobreix una realitat molt extensa i, per tant, bastant difícil de definir. Des de la perspectiva adoptada en aquesta assignatura, és interessant de recordar tres aproximacions diferents, i en certa forma complementàries, al concepte de cultura: 
a) La cultura com el conjunt de totes les manifestacions humanes: «De fet, cultura ho és tot: la ciència, les lletres i les arts, però també la resta de les «formes de vida», des de l'estructura de la família fins als tipus de diversió, passant pels vestits, els menjars (i les begudes), les lleis, les creences o les malalties» (Fuster, 1972: 321).

b) La cultura com un espai de comunicació: "La nostra societat és el domini de la interacció i la comunicació [...]. La societat s'organitza com a espai de comunicació i per tant com a sistema de regles de comportament verbal i no verbal que el defineixen. Per a mi, un espai de comunicació tal és una cultura. La meva cultura és el meu espai de comunicació» (Serrano, 1980: 28).

c) La cultura com un sistema complex constituït per dos elements fonamentals, la consciència territorial i la llengua: «Des d'un punt de vista genèric, la cultura catalana -com les cultures d'altres pobles contemporanis- es pot entendre com un sistema cultural altament complex, que comprén i integra diversos subsistemes culturals, relatius almenys a tres nivells diferents: al simbòlic (llengua, creences, coneixements, valors i normes), al nivell de l'acció social (usos i costums, etc.), i al nivell material (patrimoni material propi)» (Gifreu, 1987: 25).

\subsubsection{L'activitat discursiva: text, discurs i seqüències textuals}

Per conèixer els mecanismes que regulen la interacció social és imprescindible saber què són els discursos i què són els textos, quin tipus de constituents menors els integren i com funcionen aquestes unitats en la interacció verbal humana. És imprescindible, en definitiva, conèixer quins mecanismes comunicatius es posen en marxa quan els éssers humans ens relacionem a través de l'activitat discursiva. L'anàlisi de la comunicació humana ha de tenir en compte, per tant, les pràctiques discursives (verbals i no verbals), però també les altres formes d'interacció que es produeixen en la vida social. En aquest sentit, cal prestar una atenció especial a les estratègies comunicatives utilitzades per representar i negociar els significats sobre els continguts i les tasques que es desenvolupen. De fet, convé destacar que l'activitat discursiva, és a dir, l'activitat comunicativa humana que es genera a partir de textos, conté tres components o dimensions complementàries: estructures lingüístiques, mecanismes paralingüístics i signes no verbals.

La dimensió lingüistica del discurs comprén tres nivells diferents: les estructures lingüístiques oracionals (oracions, paraules, morfemes, lexemes, sons i grafies), les unitats del nivell textual (textos, paràgrafs, connectors, modalització, variació lingüística...) i l'entonació (enunciativa, interrogativa, exclamativa).

La dimensió paralingüística comprén les qualitats primàries de la veu (volum, to, velocitat, modulació), els elements qualificadors o tipus de veu (tensa, relaxada, confusa, aspra, aguda, greu, etc.), els diferenciadors (veu amb plor, riure o sospir), els alternants o quasiparaules (veus d'animals i onomatopeies) $\mathrm{i}$ altres elements, com ara els silencis, les errades i els sorolls. 
Finalment, la comunicació no verbal comprèn dos àmbits complementaris: l'àmbit del cos humà (aspecte físic, moviments, gestualitat, somriures, mirades i contacte físic) i els factors comunicatius de l'entorn (espai i territorialitat, dimensió temporal i objectes associats).

Els estudiosos de la comunicació no verbal asseguren que en la comunicació en directe, en la interacció cara a cara, vora el 70\% dels significats es transmeten a través de la interpretació dels signes no verbals (gestos, somriures, postures, mirades) i paraverbals (silencis, tipus de veu, to, velocitat del discurs), i que només el 30\% es transmet a través dels signes lingüístics. I és també una constatació que quan s'observa algun tipus de contradicció entre el significat que es transmet amb les paraules i el sentit que comuniquen els signes no verbals associats al discurs verbal, sovint tendim a donar més credibilitat als signes no verbals que a les paraules. Segurament perquè resulta més difícil de mentir amb una mirada o amb un gest que amb una expressió.

El processament d'aquest $70 \%$ del sentit associat a recursos no verbals exigeix la posada en escena de les habilitats comunicatives relacionades amb l'emotivitat, amb la intuïció, amb els components no racionals del cervell humà, amb allò que s'anomena comunicació inferencial. Segurament és per això també que, sovint, s'atribueix a les dones una major capacitat comunicativa a l'hora d'interpretar els signes no verbals i, en general, una major capacitat de comunicació inferencial.

El text és la unitat lingüística comunicativa fonamental. Josep Maria Castellà (1992), que recull una definició anterior d’Enrique Bernárdez (1982), en destaca el caràcter social, l'articulació en tres nivells complementaris (pragmàtic, sintàctic i semàntic) i la capacitat d'integrar les dimensions cognitiva, ideològica, històrica i sociocultural de la interacció comunicativa.

El text és la unitat lingüística comunicativa, producte de l'activitat verbal humana, que posseeix un caràcter social; es caracteritza per l'adequació al context, la coherència informativa i la cohesió lineal. [...] La seua estructura reflecteix els procediments emprats per emissor i receptor en els processos d'elaboració i interpretació. Es construeix per mitjà de dos conjunts de capacitats $i$ coneixements: els propis del nivell textual i els del sistema de la llengua.

Castellà, 1992

Les dificultats terminològiques a l'hora de delimitar els territoris del text i del discurs tenen el seu origen en el caràcter polisèmic dels dos mots: text i discurs s'utilitzen en sentits diversos i contradictoris.

Una primera opció consisteix a identificar els dos conceptes i considerar-los a tots els efectes com a sinònims en tant que productes d'un procés comunicatiu. És la proposta de Gemma Rigau (1981), Enrique Bernárdez (1982) i Jorge Lozano (1982).

Des de la perspectiva adoptada en aquesta assignatura, i per tal de clarificar el panorama terminològic, reservarem el concepte de text per referir-nos a qualsevol 
producte comunicatiu de caràcter verbal, en un sentit molt proper al d'enunciat, i utilitzarem el terme discurs per fer referència a dues realitats diferents:

a) Un producte concret de l'activitat verbal humana considerat en tant que producte d'una pràctica social, de la qual forma part, a més del component estrictament textual (l'enunciat), un component enunciatiu que juga un paper determinant (l'enunciació). Aquesta accepció de discurs implica l'existència d'un text, efectivament produït, en una situació de comunicació concreta, en un determinat àmbit discursiu $\mathrm{i}$ amb una intencionalitat determinada. Tot $\mathrm{i}$ que es tracta d'una unitat essencialment verbal, el discurs, en aquest sentit, integra al voltant del component verbal tota una sèrie de mecanismes expressius paralingüístics i no lingüístics, conformant una mena de perifèria expressiva organitzada al voltant del nucli lingüístic. És possible l'existència de signes i de processos comunicatius sense la presència del llenguatge verbal, però en aquests casos no podem parlar ni de textos ni de discursos. El discurs és, per tant, el resultat d'inserir un text concret en un context comunicatiu específic. Aquesta idea es pot visualitzar perfectament amb aquesta senzilla fórmula:

\section{discurs $=$ text + context}

b) Un conjunt de discursos en el sentit $a$ ), produïts en situacions de comunicació específiques d'un àmbit d'ús determinat i caracteritzats per la posada en escena de mecanismes enunciatius ben diferenciats. Així, es pot parlar del discurs acadèmic, el discurs periodístic, el literari, el juridicoadministratiu, el quotidià, el científicotècnic, el televisiu, el publicitari o l'audiovisual.

Des de la nostra perspectiva, es tracta, per tant, d'estudiar el discurs en el sentit que proposa Teun A. Van Dijk per tal de conèixer les formes en què les elits que mantenen el poder construeixen el discurs públic:

Encara que hi ha moltes definicions de discurs, per exemple, com a esdeveniment comunicatiu, com a missatge, com a interacció verbal o com a forma d'interacció situada en societat, ací definirem el discurs com un text multimodal situat en el seu context social. Per tant, controlar el discurs és controlar el text i el context.

Van Dijk, 2010: 80

Malgrat el seu caràcter unitari, els textos no són productes homogenis, sinó entitats comunicatives complexes que s'adapten a formes genèriques predeterminades i estan constituïdes per seqüències textuals o estructures prototípiques elementals d'organització de la informació. Aquestes unitats - que estan determinades per criteris de caràcter pragmàtic, com ara la intencionalitat o el focus contextual- han estat reconegudes des de l'antiguitat clàssica, amb algunes variants i amb denominacions diverses, i constitueixen una de les formes més utilitzades de classificació de la diversitat discursiva. Actualment, tant en anàlisi del discurs com en didàctica de la llengua, s'acostuma a distingir cinc o sis seqüències elementals: diàleg, narració, descripció, explicació, argumentació i, en alguns casos, instrucció. 


\subsection{4. Àmbits d'ús, registres i gèneres textuals}

Els àmbits d'ús són els contextos o les situacions socials tipificades en què té lloc l'ús lingüístic. Aquests contextos estan bastant convencionalitzats socialment, són reconeguts de manera intuïtiva pels usuaris d'un idioma i-com que depenen de les relacions socials, de l'univers cultural i de les formacions ideològiques- tenen un caràcter variable, tant des del punt de vista històric com cultural. Així, es distingeix habitualment l'àmbit quotidià, l'acadèmic, el literari, el periodístic, l'administratiu, el comercial, el religiós, el científic, el jurídic, etc. L'existència d'aquests contextos socials tipificats determina, d'una banda, l'aparició de discursos especialitzats -en el sentit $b$ ) que apuntàvem més amunt- i, de l'altra, la consolidació de registres lingüístics especialitzats en els diversos àmbits i en els diversos ecosistemes discursius adscrits, així com la creació i adaptació de formes genèriques especialitzades a l'interior de cada formació discursiva.

Els registres són, per tant, seleccions operades sobre la superfície lingüística del discurs en funció de la situació de comunicació o l'àmbit d'ús. Per contra, els gèneres són formes relativament estables dels textos, una mena de matrius o siluetes textuals en les quals encaixen un conjunt més o menys extens de textos d'un àmbit d'ús determinat. Molt directament relacionats amb aquests conceptes es troben les nocions de macroestructura i superestructura. Les macroestructures són estructures globals del contingut dels textos i tenen, per tant, una naturalesa bàsicament semàntica. La macroestructura d'un text és «una representació abstracta de l'estructura global de significat del text» (Van Dijk, 1978: 55). Únicament les seqüències d'oracions que tenen una macroestructura poden anomenar-se pròpiament textos. Per contra, les superestructures són «les estructures globals que caracteritzen un determinat tipus de textos» (Van Dijk, 1978: 142). La superestructura és una noció més sintàctica que semàntica, una mena de forma del text, el tema o contingut del qual és la macroestructura. Es tracta, per tant, d'una espècie d'esquema al qual s'adapten tots els textos d'un gènere determinat (un relat, una instància, una carta o una notícia, per exemple).

\subsection{La competència comunicativa}

El concepte de competència lingüistica va ser introduït pel nord-americà Noam Chomsky per tal de definir el coneixement intern que un parlant té del model abstracte de la seva llengua i, en particular, de les possibilitats de produir i entendre totes les oracions gramaticals possibles. En unes altres paraules, la competència lingüística inclou les capacitats lingüístiques d'un parlant per expressar-se en la seua llengua i per entendre els missatges que els interlocutors li adrecen. Si és cert que necessitem uns coneixements lingüístics per produir missatges intel-ligibles, també ho és que aquests no són suficients perquè allò que diem tinga l'efecte desitjat en tots els casos. Així, en l'enunciat següent, el lector necessita actualitzar tota una sèrie de coneixements que no són lingüístics -que es tracta d'un titular d'un diari, que el Pp és un partit polític espanyol, que s'està fent una gestió de la grip A, etc.- sense els quals no pot entendre completament el missatge: 
Per incloure aquests coneixements, Dell Hymes introduí el concepte de competència comunicativa, que es defineix com la capacitat d'un individu de produir i entendre enunciats gramaticals de manera significativa en relació amb el context sociocultural i adequats a la situació en què es produeixen i als propòsits de la interacció.

Els coneixements lingüístics ens permeten rebutjar missatges que no segueixen les normes d'ordre sintàctic, com ara [4]. En canvi, necessitem recórrer a d'altres coneixements per elegir entre [5] i [6]:

[4] Atenes a sense control dos incendis segueixen encara.

[5] L'incendi va ser provocat per uns delinqüents a sou de la màfia del totxo.

[6] Tot sembla indicar que l'incendi va ser provocat amb la finalitat d'urbanitzar-hi els terrenys.

Gramaticalment, les oracions [5] i [6] són correctes, però, mentre que la primera seria inadequada en un àmbit periodístic, la segona ho seria en un intercanvi comunicatiu col·loquial o informal. Així doncs, la competència comunicativa inclou tota una sèrie de coneixements i d'estratègies, moltes apreses de manera natural $i$ inconscient, que permeten al parlant desenvolupar-se de manera eficaç en els contextos comunicatius en què intervé.

Tècnicament, la competència comunicativa inclou un conjunt de coneixements $i$ habilitats que es poden agrupar en quatre subcomponents: la competència gramatical, la sociolingüística, la discursiva i l'estratègica.

La competència gramatical es refereix al coneixement del funcionament dels elements lingüístics d'una determinada llengua (la pronúncia, la forma de les paraules, la construcció oracional, etc.).

La competència sociolingüística consisteix a adaptar el missatge a la situació de comunicació: a la intenció, a la relació entre els interlocutors, al lloc físic i al temps en què es produeix...

La competència discursiva té a veure amb les estratègies per construir un missatge que siga ordenat, intel-ligible i que s'adapte als models de textos que es defineixen segons la seua finalitat (informar, convèncer, descriure...).

La competència estratègica es refereix a l'ús de recursos verbals i no verbals per tal que la comunicació siga el més efectiva possible, compensant errades d'expressió o llacunes que puguen impedir la comunicació.

Vegem-ho amb un exemple. Hem de fer la publicitat impresa d'una empresa de creuers (Grimaldi Lines) que vol llençar un producte per a la tardor: viatges a Roma i Sardenya aprofitant el pont de l'11 de setembre i el de les festes de la Mercè a Barcelona. 
En primer lloc, si atenem a la competència gramatical, el nostre missatge s'haurà d'ajustar a les convencions lingüístiques del català (ortografia, morfologia, sintaxi) per crear un text que sigui correcte.

Seguidament, pel que fa a la competència sociolingüística, haurem de decidir a qui adrecem l'anunci. Si ho fem a gent gran (jubilats) seria convenient tractar-los de vostè i donar-los totes les facilitats pel que fa al transport, el menjar, etc. En canvi, si l'adrecem a gent jove o de mitjana edat, ens hi dirigirem amb oracions ben directes i, fins i tot, podem donar-hi un cert toc aventurer (direm que pot portar-hi el seu cotxe, per exemple). El lector s'ha de sentir còmode amb el tractament.

Finalment, pel que fa a la competència discursiva, haurem d'oferir tota la informació que considerem necessària perquè el lector no tinga cap dubte a l'hora d'elegir el nostre producte: les dates de l'oferta, les prestacions que inclou, el preu, les característiques del vaixell i dels hotels en els quals s'estarà... No hem d'oblidar que un anunci d'aquestes característiques és com un contracte que obliga l'empresa que s'anuncia a acomplir allò que ofereix.

L'empresa ha optat per l'anunci següent, aparegut al diari Avui, en el suplement Plaers del diumenge 23 d'agost del 2009.

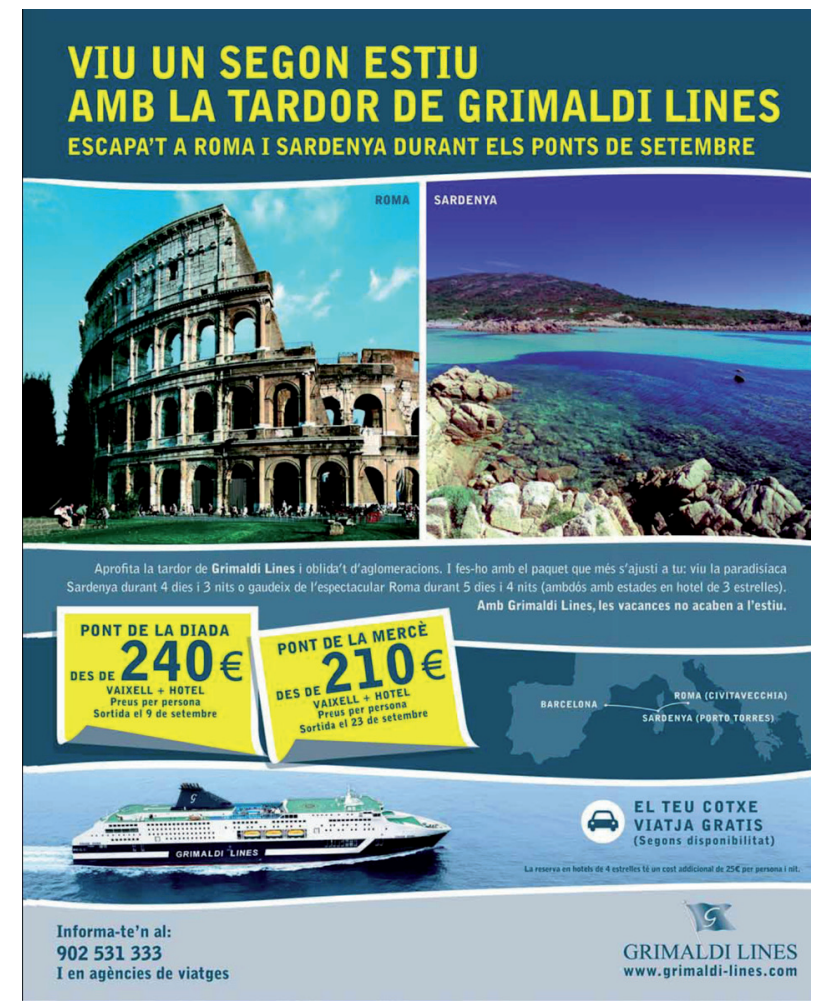

Fig. 1. Un full turístic 


\subsection{Les propietats textuals}

En la comunicació humana, el text (o discurs) és la unitat comunicativa fonamental. És una unitat de sentit que respon a una sèrie de regularitats marcades pel que anomenem propietats textuals. No és només un seguit d'oracions que es presenten successivament en la comunicació oral o escrita, sinó una unitat de caràcter social que aconsegueix que les persones es relacionen gràcies a la paraula. Els humans fem servir les llengües no sols per transmetre informació, sinó, sobretot, per establir relacions socials. Així doncs, els textos s'han d'adequar a les persones que intervenen en l'acte de comunicació.

Un text pot ser llarg (una novel·la o una pel·lícula) o curt (una simple salutació o un espot publicitari); es pot rebre pel canal auditiu o audiovisual; hi pot intervenir una sola persona o es pot construir amb la participació de molts individus... En definitiva, allò que el caracteritza, com ja hem dit, és que s'ajuste a les regles que marquen les propietats textuals, és a dir, als requisits que qualsevol manifestació verbal ha de posseir per tal de ser considerada un text. Vegem-ne uns exemples:

Tothom sap com ha de contar una història. De fet, ho fem cada dia diverses vegades. Històries senzilles i quotidianes, com aquesta:

- Has sentit allò del guàrdia civil d'Utiel?

- No, què ha passat?

- Doncs es veu que el civil ha tret la pistola reglamentària i li ha fotut uns quants trets a la dona i l'ha morta.

- Per què?

- No ho han dit. Es veu que estava de baixa, però igual tenia la pistola. No sé, segur que tenia depressió o alguna cosa aixi. És que tenir una pistola a l'abast... és molt perillós.

- I tant! Entres en qualsevol discussió i si la tens a mà, pum. Ja estàs ben fotut.

En canvi, els fets s'han de presentar amb un estil molt diferent si hem d'utilitzar la informació per a redactar una notícia periodística:

\section{Un guàrdia civil mata la seva dona a trets a València}

- L'agent, que va disparar diverses vegades l'arma reglamentària, ha estat detingut

- És la 40a víctima mortal per violència masclista a Espanya del 2009, i la tercera d'aquest mes

AGĖNCIES · VALĖNCIA

Una dona ha mort després que va rebre diversos trets efectuats pel seu marit, un agent de la Guàrdia Civil que resideix a la localitat valenciana d'Utiel, tal com han confirmat fonts de l'Institut Armat. Els fets es van produir ahir a la nit cap a les 22.00 hores al domicili de la parella. L'agent, que va fer servir la seva arma reglamentària per efectuar els trets, es troba detingut. 


\section{Sense denúncies anteriors}

El detingut, de 39 anys i sobre el qual no consten altres denúncies anteriors per violència de gènere, passarà durant les pròximes hores a disposició dels jutjats de Requena.

L'agent es trobava en actiu, però havia estat una temporada de baixa. El delegat del Govern a la Comunitat Valenciana, Ricardo Peralta, no ha concretat el motiu d'aquesta baixa mèdica, però apunta que no hi havia indicis que fessin preveure la possibilitat que es produis aquest crim.

\section{En actiu després d'una baixa}

Com que es trobava en actiu, aquest agent disposava de la seva arma reglamentària. Peralta ha condemnat aquest últim episodi de violència masclista i ha comentat que aquests actes tan «repudiables» únicament "serviran per reforçar l'esforç de les forces de seguretat» contra aquesta xacra.

La dona morta a Utiel és la víctima mortal número 40 de violència masclista a Espanya des de començament d'any i la tercera d'aquest mes, després de les morts de dues dones a Vélez-Rubio (Almeria) i Ondara (Alacant).

elPeriódico.cat, 8 de setembre de 2009

Òbviament, es tracta de la mateixa narració, tot i que ha estat contada de manera diferent perquè cadascun dels textos s'ha hagut d'ajustar a la situació comunicativa en què es troba. Tots dos textos segueixen unes regles oracionals i textuals, però no són les mateixes, ja que cada manifestació lingüística ha de tenir en compte l'auditori al qual s'adreça, les condicions de producció i recepció de l'àmbit d'ús social en què es produeix la comunicació i les convencions específiques del gènere utilitzat.

Així, el text, gràcies a les propietats textuals (l'adequació, la coherència i la cohesió), constitueix la major unitat significativa, té una funció social, s'estructura d'acord a unes regles oracionals i textuals i s'adapta a la situació comunicativa concreta, al context.

\subsubsection{L'adequació}

L'adequació és la propietat que permet relacionar el text amb el context, adaptar el seguit d'oracions a la situació comunicativa en què es troba. Té a veure amb els elements de la comunicació (emissor, receptor, canal, temps, lloc) que conformen el missatge d'acord amb el codi o llengua que s'empra.

Adequar el text al context té a veure amb la planificació. Segons J. M. Castellà, el parlant segueix unes normes socialment establertes per tal de produir un text adequat. En primer lloc, hem de tenir en compte la relació que s'estableix entre els interlocutors (si són coneguts, si n'és un de sol o diversos), i quina és la finalitat que es vol aconseguir mitjançant la producció del text (informar, convèncer, 
distreure); en segon lloc, hem de valorar com afectarà el canal (audiovisual, escrit, auditiu) en la recepció del missatge o quins elements farem servir per il·lustrar-lo o per donar-li suport (imatges, cançons), i, finalment, és important saber el temps i l'espai en què es produirà el text.

Així, per exemple, una notícia emesa per televisió no ha d'aprofundir tant en la quantitat d'informació com l'apareguda en un diari. Un espot televisiu ha de tenir molt en compte en quina franja horària s'emetrà i a qui va dirigit el producte que anuncia (és el que s'anomena públic objectiu o target). En definitiva, perquè el text siga eficaç s'ha d'adaptar a la situació en què es produeix la comunicació.

En l'anunci de la fig. 2, es poden identificar diverses marques discursives que remeten al receptor:

- El producte («cadira plegable»)

- La qualificació del producte («molt juvenil»)

- El tractament («en comprar la teva taula d'estudi», «estem per $t u »)$

- La fotografia (dos joves)

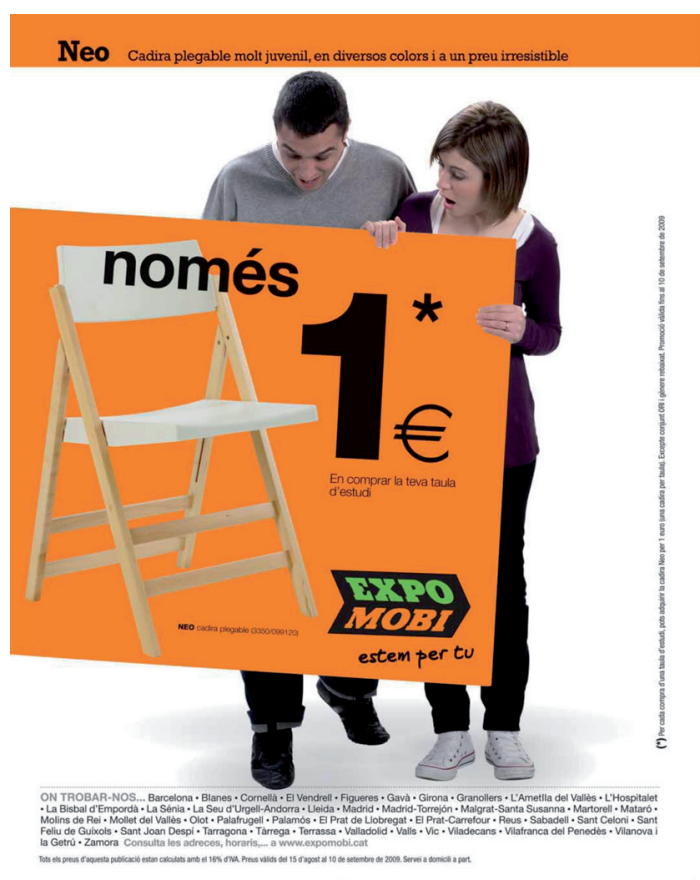

Fig. 2. Un anunci de premsa

Es pot deduir, per tant, que el text s'ha hagut d'adequar a un mitjà escrit (el periòdic) i utilitza un registre lingüístic escaient al receptor (joves estudiants). Es tracta d'un interlocutor tipus que se sent atret per un producte barat, senzill, que ocupa poc espai i a qui podem interessar fent-li veure que es tracta d'un objecte nou i juvenil.

Si ens fixem en l'anunci següent, veurem que l'objecte que s'ofereix (una llibreta d'estalvi amb el regal d'una planxa) no està adreçat a joves. Ben al contrari, el 
tractament (emporti's, passi, descobreixi...) es dirigeix a persones adultes, l'objecte mateix (una planxa hiperbòlica) no resulta gaire atractiu al jovent $i$ fins $i$ tot l'eslògan (A tot vapor, un crit que associem als antics vaixells), que pretén destacar un valor positiu en una planxa, resulta un mica anacrònic. El receptor d'aquest producte és algú que té estalvis (per tant, una persona gran), algú que farà servir l'electrodomèstic o que es veurà impel·lit a adquirir-lo.

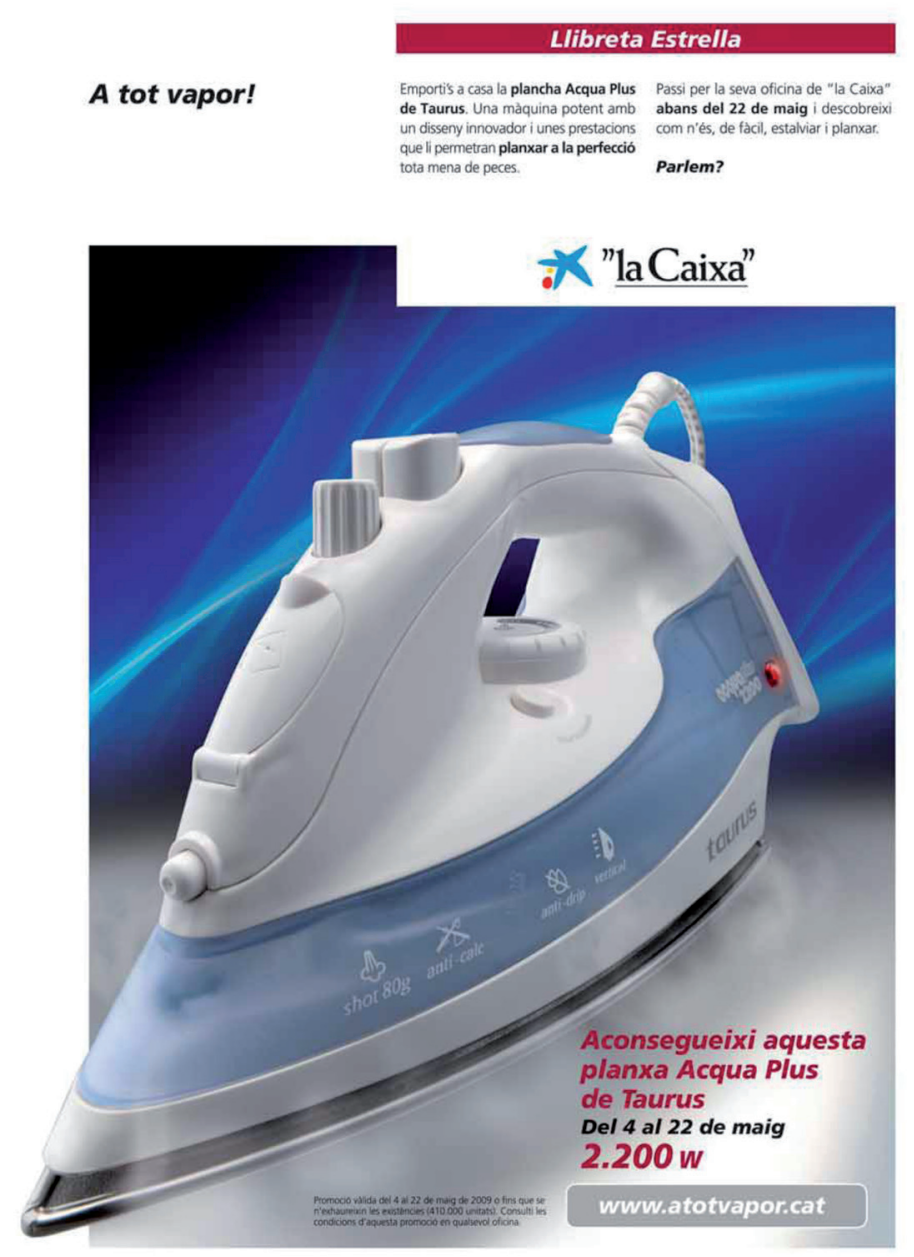

Fig. 3. A tot vapor!

L'adequació textual està relacionada, en definitiva, amb diversos mecanismes discursius, entre els quals cal remarcar la variació lingüística, la dixi, la modalització i la polifonia.

Un text és adequat si el missatge s'adapta al seu context, que implica una finalitat comunicativa, una situació enunciativa concreta (un emissor i un receptor, un temps i un espai) i un canal (oral, escrit, audiovisual) a través del qual s'emet. 


\subsubsection{La coherència}

La coherència és la propietat que dóna compte del significat global del text: de què parla (quin és el tema), quina informació dóna (de cada tema, se'n podrien dir moltes coses i necessàriament en fem una selecció) i com s'ha organitzat la informació seleccionada (Conca, 1998).

La coherència, doncs, ens remet a tres aspectes fonamentals: el tema del text, la selecció del contingut i l'organització de la informació.

1) El tema és la idea principal que recorre el text i dóna una idea de continuïtat, la síntesi del contingut, que sovint es veu reflectida en el títol. Veiem-ne un exemple en aquesta notícia:

\section{El Defensor del Poble diu que tutejar els professors és una falta de respecte}

EUROPA PRESS $\cdot$ MADRID

El Defensor del Poble, Enrique Múgica, ha manifestat avui que el "tuteig als professors és la introducció a una falta de respecte», i exigeix que s'imposi "disciplina i autoritat» a les aules del sistema educatiu espanyol.

Després d'haver presentat al Congrés dels Diputats l'informe sobre les activitats de la Institució el 2008, Múgica ha assenyalat que els alumnes haurien de tractar de vostè els professors en lloc de tutejar-los.

"Quan érem petits, els professors ens deien de vostè als que érem nens, i els nens, per descomptat, dèiem de vostè als professors. S'establia la necessària diferència que ha d'existir entre l'ensenyant i l'ensenyat. I això s'ha d'acceptar», ha asseverat.

Per Múgica, "afortunadament els vells temps de l'autoritarisme han desaparegut amb la Ilibertat», però "l'autoritat s'ha de mantenir» a la classe, i per fer-ho és necessari «imposar una disciplina», que, subratlla, ha d'estar "allunyada de l'autoritarisme».

elPeriódico.cat, 10 de setembre de 2009

Com veiem, el tema (les relacions entre professors i alumnes) es presenta ja en el titular de la notícia. De fet, els titulars de les notícies dels periòdics són un exemple clàssic de síntesi del contingut. Quan el llegim, ja sabem quina és la informació que es desenvoluparà. Per contra, els títols de novel·les, pel·lícules o exposicions no solen ser tan explícits.

2) Quan s'escriu sobre qualsevol tema, la informació disponible sol excedir la quantitat d'informació que haurem de fer servir en el text. Per tant, hem de ser capaços de decidir el grau d'aprofundiment, d'acord amb l'adequació, i de fer una bona selecció de la informació, cosa que ens permetrà rebutjar 
els continguts innecessaris, perquè l'abundància d'informació supèrflua fa perdre l'interès de l'interlocutor. Fixem-nos en la manipulació de la notícia anterior:

\section{El Defensor del Poble diu que tutejar els professors és una falta de respecte}

EUROPA PRESS · MADRID

El Defensor del Poble, Enrique Múgica, ha manifestat avui que el "tuteig als professors és la introducció a una falta de respecte», i exigeix que s'imposi "disciplina i autoritat» a les aules del sistema educatiu espanyol.

El Defensor del Poble és el funcionari de l'Estat o de govern regional encarregat de representar els interessos dels ciutadans i de defendre'ls dels abusos que puguin cometre els funcionaris d'un Estat o de govern. Aquest càrrec procedeix de la constitució sueca que en va establir un el 1809 per a solucionar els problemes dels abusos per la via burocràtica o judicial. Per tant, sovint es coneix amb el seu nom suec Ombudsman. La seva eficàcia és limitada, atès que no pot sancionar les actuacions de l'administració o les autoritats i, per tant, té un caràcter més polític que no pas judicial. En alguns països, el defensor del poble té la potestat de presentar accions davant un Tribunal Constitucional. A Espanya, el defensor del poble pot començar processos judicials a la Cort Constitucional.

Després d'haver presentat al Congrés dels Diputats l'informe sobre les activitats de la Institució el 2008, Múgica ha assenyalat que els alumnes haurien de tractar de vostè els professors en lloc de tutejar-los.

"Quan érem petits, els professors ens deien de vostè als que érem nens, i els nens, per descomptat, dèiem de vostè als professors. S'establia la necessària diferència que ha d'existir entre l'ensenyant i l'ensenyat. I això s'ha d'acceptarı, ha asseverat.

Per Múgica, «afortunadament els vells temps de l'autoritarisme han desaparegut amb la \|libertat», però "l'autoritat s'ha de mantenir» a la classe, i per fer-ho és necessari «imposar una disciplina", que, subratlla, ha d'estar "allunyada de l'autoritarisme».

elPeriódico.cat, 10 de setembre de 2009 http://ca.wikipedia.org/wiki/Defensor_del_poble

Òbviament, tota la informació marcada és innecessària en una notícia de premsa, ja que el lector del diari sap, encara que siga vagament, què és el defensor del poble o el Síndic de Greuges i, per tant, no és una informació pertinent.

3) L'organització de la informació fa referència a tres aspectes fonamentals: la superestructura, la macroestructura i la progressió temàtica.

La superestructura dels textos (Van Dijk) està relacionada amb els models textuals que segueixen alguns gèneres discursius en la distribució de la informació. Una part important dels gèneres discursius (per exemple, una instància, una notícia de 
premsa, un anunci o una crítica cinematogràfica) tenen unes característiques formals que ens permeten reconèixer-los fàcilment sense llegir-los. Així, en una notícia sempre trobarem l'autor (en el nostre cas, es tracta d'una agència de notícies) $\mathrm{i}$ el lloc on s'ha produit immediatament després del titular (o del lead, si n'hi ha), i no al final com podria passar en una carta o correu electrònic.

La macroestructura (Van Dijk) ordena la informació perquè sempre hi haja un equilibri entre allò que el receptor coneix (informació coneguda o temàtica) i allò que no coneix (informació nova o remàtica). Si tota la informació que oferim és nova, l'interlocutor es perdrà i no serà capaç de trobar-hi el fil; per contra, si tot el que diem és conegut, és ben probable que el lector se'n canse i abandone la lectura.

La forma com s'introdueix la informació nova a partir de la informació coneguda segueix una sèrie d'esquemes estereotipats de progressió temàtica que condicionen d'una forma decisiva la presentació de la informació al llarg del text. Aquests esquemes convencionals, que poden combinar-se i presenten sovint un important nivell de complexitat, estan directament relacionats amb la distribució de la informació en paràgrafs.

\subsubsection{La cohesió}

La cohesió és la propietat textual que es refereix als mecanismes lingüístics que s'usen per relacionar les diferents parts del text. Les oracions i els paràgrafs han d'estar connectats mitjançant elements gramaticals o lèxics que donen la sensació que tot el text està ben lligat i forma una unitat de contingut.

Hi ha dos tipus de mecanismes de cohesió, els procediments de referència i els connectors, que podem identificar en l'exemple següent:

[7] Sabem el que es porta $i$ a les nostres botigues ho tenim (Ribas Òptics).

D'una banda, la conjunció $i$ és un mecanisme de connexió perquè enganxa dues oracions, mentre que el pronom ho, d'altra banda, és un mecanisme de referència perquè repeteix el sintagma el que es porta.

En el text següent podem observar la confluència dels mecanismes de referència, que s'han assenyalat en negreta, i dels mecanismes de connexió, que apareixen subratllats: 
La píndola postcoital, també coneguda com 'la de l'endemà', es podrà comprar d'aquí a tres mesos a la farmàcia sense recepta mèdica. La podrà adquirir qualsevol persona de qualsevol edat sense la necessitat de cap autorització dels pares per un preu de 20 euros. Aixi ho va fer públic la ministra de Sanitat, Trinidad Jiménez, com a mesura per «evitar els embarassos no desitjats". Amb tot, des del ministeri s'ha remarcat que la intenció no és que aquests fàrmacs es converteixin en un mètode anticonceptiu més, sinó que només s'utilitzi "per a casos d'emergència». Aquests comprimits es fan servir fins a 48 hores després d'una relació sexual amb penetració en què s'hagi donat alguna situació que pugui implicar un embaràs.

Avui, 15 de maig de 2009

Dels tres connectors que hem assenyalat, n'hi ha dos (aixi i amb tot) que uneixen parts del text extenses - paràgrafs o fragments separats per punts- i un altre (sinó) que uneix dues clàusules per formar una oració composta a l'interior d'un paràgraf. Els primers s'anomenen connectors textuals i els segons, connectors oracionals.

Un senzill esquema ens pot servir per veure resumides les propietats textuals o nivells d'anàlisi del text de què hem parlat:

\begin{tabular}{|c|c|c|}
\hline \multicolumn{3}{|c|}{ PROPIETATS DEL TEXT } \\
\hline Adequació & Coherència & Cohesió \\
\hline $\begin{array}{l}\text { - Finalitat comunicativa } \\
\text { - Situació enunciativa: } \\
\text { emissor, receptor, temps } \\
\text { i espai } \\
\text { - Canal: oral, escrit o } \\
\text { audiovisual } \\
\text { - Varietats lingüístiques } \\
\text { - Polifonia i citació }\end{array}$ & $\begin{array}{l}\text { - Tema del text } \\
\text { - Selecció de la } \\
\text { informació } \\
\text { - Esquemes globals } \\
\text { - Progressió de la } \\
\text { informació } \\
\text { - Estructura en } \\
\text { paràgrafs }\end{array}$ & $\begin{array}{l}\text { - Mecanismes gramaticals } \\
\text { - Re referència } \\
\text { - Coferència lèxica } \\
\text { - compoxió intraoracional: } \\
\text { - Connexió textual } \\
\text { - Connexió pragmàtica: } \\
\text { la marcació discursiva }\end{array}$ \\
\hline
\end{tabular}

Fig. 4. Les propietats textuals

\subsection{Les ciències del llenguatge}

El llenguatge humà és un sistema de comunicació d'una gran complexitat. De fet, es pot afirmar que la llengua és un cos polièdric, constituït per una pluralitat de cares o subsistemes, que admet una gran diversitat de punts de vista o perspectives d'estudi. En aquest sentit, la història dels estudis sobre el llenguatge ha anat dibuixant dues grans tendències contradictòries: d'una banda, els intents d'establir una ciència autònoma (la lingüística), basats en la concepció de la llengua com a sistema o com a capacitat mental; de l'altra, la necessitat inevitable d'establir interseccions entre l'estudi del llenguatge i altres àrees contigües, com la dels estudis de caire comunicatiu i sociocultural (especialment la semiòtica, 
l'antropologia i la sociologia). En realitat, aquesta contradicció és conseqüència directa de l'essència de la llengua i és la responsable de la gran diversificació dels estudis del llenguatge.

Aquesta contradicció reflecteix en realitat una ambivalència essencial del llenguatge, que neix del seu paper com a capacitat cognitiva, per una banda, i com a eina comunicativa i consegüent fenomen cultural, per una altra. Aquesta ambivalència, al seu torn, és en part responsable de la gran diversificació del panorama que presenta la lingüística d'avui.

Payrató, 2003: 21

Per fer front a la nova realitat dels estudis lingüístics, i per referir-se al complex panorama d'estudis i investigacions actuals, molts especialistes prefereixen substituir la denominació clàssica de lingüistica pel terme ciències del llenguatge, menys marcat i menys desgastat que lingüística o filologia i alhora més associat a connotacions que suggereixen un caràcter més innovador, obert i plural de la disciplina. Entenem com a ciències del llenguatge el conjunt de totes les disciplines científiques que tenen com a objecte d'estudi el fenomen del llenguatge humà. En realitat, es tracta d'un conjunt obert de disciplines diverses que es van interrelacionant, fusionant $i$ dividint $i$, amb el temps, van perdent els perfils precisos que les diferencien d'altres disciplines properes. Aquesta situació es pot observar perfectament en l'evolució de les ciències del llenguatge interessades pels aspectes socioculturals i comunicatius -com ara la psicolingüística, la sociolingüística $o$ l'antropologia lingüística- $\mathrm{i}$ en les disciplines que estudien els aspectes més mentals -com ara la lingüística cognitiva, la lingüística computacional o la lingüística matemàtica. Aquesta diversitat del panorama actual de les ciències del llenguatge s'incrementa encara més si tenim en compte que les diverses aproximacions a l'estudi de la llengua, com passa en qualsevol altra ciència, poden adoptar orientacions diferents - de vegades, combinant-les o de forma alternativa-, entre les quals destaquen l'orientació teòrica, l'aplicada i la descriptiva.

En aquesta situació, per tal de clarificar una mica el panorama i assumint el risc de simplificar excessivament el territori, podem agrupar les ciències del llenguatge en dos grans grups, segons la perspectiva adoptada:

a) Les disciplines interessades en l'estudi del sistema lingüístic, de les formes $\mathrm{i}$ les estructures de la llengua al marge del context.

b) Les disciplines que adopten una perspectiva contextual, és a dir, un punt de vista que pren en consideració l'ús lingüístic.

Si a aquest primer criteri afegim l'abast o els límits dels fenòmens analitzats (oracional o supraoracional) i les unitats del llenguatge estudiades (oració, text, enunciat o discurs), obtenim, seguint la proposta de Payrató (2003: 135), un quadre de doble entrada que presenta el panorama general de les ciències del llenguatge: 


\begin{tabular}{lllll}
\hline Ciències & $\begin{array}{l}\text { Unitats } \\
\text { d'estudi }\end{array}$ & Abast & Perspectiva & Camps d'interès \\
\hline Gramàtica & Oració & Oracional & Estructura & Morfologia, sintaxi, fonètica... \\
\hline Lingüística textual & Text & Textual & Estructura & Estructura textual, cohesió... \\
\hline Pragmàtica & Enunciat & Oracional & Ús & Actes de parla, dixi, enunciació... \\
\hline Anàlisi del discurs & Discurs & Textual & Ús & Modalització, polifonia, ideologia... \\
\hline
\end{tabular}

Fig. 5. Les ciències del llenguatge 1

Aquest esquema, d'una gran simplicitat, permet fer-nos una idea molt clara de les relacions que s'estableixen entre les disciplines representades, que constitueixen, de fet, les dues cares d'una moneda: en una cara, la gramàtica i la lingüística del text; en l'altra, la pragmàtica i l'anàlisi del discurs. En una cara, l'estructura; en l'altra, l'ús.

La gramàtica s'ocupa de l'estudi de les oracions, com a entitats abstractes, i de les unitats que en formen part, des dels sintagmes als fonemes (i sons), passant per les paraules i les unitats constituents (lexemes i morfemes). En canvi, la lingüistica textual, anomenada també gramàtica del text, analitza els textos com a conjunt d'oracions, des d'un punt de vista teòric, i s'interessa, especialment, per l'estudi dels fenòmens que no poden explicar-se des d'una concepció oracional de la lingüística, com ara els mecanismes de cohesió textual o les estructures o seqüències textuals elementals (la narració, la descripció, l'argumentació...).

L'altra cara de la moneda està orientada a l'estudi de l'ús lingüístic i pren, per tant, en consideració totes les implicacions del context sobre el procés de comunicació. I aquí trobem dues disciplines complementàries: la pragmàtica i l'anàlisi del discurs. La pragmàtica, definida per Charles W. Morris com la branca de la semiòtica que s'ocupa de l'estudi de les relacions dels signes i de l'ús que se'n fa, ${ }^{1}$ és, en realitat, una perspectiva sobre el llenguatge, un punt de vista interessat a contemplar el llenguatge en ús, a analitzar-ne el funcionament en les situacions reals d'interacció social. Es tracta, per tant, d'una disciplina que s'ocupa de l'estudi de l'ús de la llengua en la comunicació i que ha mostrat un interès especial en l'anàlisi de les funcions del llenguatge, la dixi, les inferències, els actes de parla, la cortesia, la modalitat i l'estructura textual i conversacional. L'anàlisi del discurs, que s'ha desenvolupat d'una forma extraordinària durant les últimes dècades, presenta diverses tendències que tenen en comú la voluntat d'estudiar el text en el seu context de producció i de recepció i de posar, per tant, el focus d'atenció en els diversos aspectes del funcionament del discurs com a pràctica social. Entre la pluralitat d'enfocaments de l'anàlisi del discurs, cal destacar, en primer lloc, els estudis de caràcter sociolingüístic i antropològic (l'anàlisi de la conversa, la sociolingüística de la variació, la sociolingüística de la interacció i l'etnografia de la comunicació); en segon lloc, els estudis sobre l'enunciació,

1. La semiòtica és la ciència que s'ocupa de l'estudi dels sistemes de signes o dels fets comunicatius, i està constituïda per tres disciplines o perspectives fonamental: la sintaxi -o estudi de les relacions (de combinació) dels signes entre ells-, la semàntica -que estudia les relacions entre els signes i els significats- $\mathrm{i}$ la pragmàtica. 
que s'han ocupat, especialment, de la polifonia discursiva i de l'argumentació; i finalment, les investigacions, més recents, que han posat l'èmfasi en els aspectes ideològics del discurs (el corrent anomenat anàlisi crítica del discurs) i en l'estudi de l'argumentació en el discurs.

A aquestes disciplines fonamentals cal afegir encara un conjunt de disciplines interessades també en l'estudi del llenguatge des de la dimensió diacrònica (la història de la llengua i la gramàtica històrica), des del punt de vista psicològic (la psicolingüística i la lingüística cognitiva) i des de l'òptica social (la sociolingüística). I per acabar de completar aquest complex panorama teòric, no podem oblidar l'existència d'un conjunt de disciplines, que s'engloben en el marc global de les ciències de la comunicació i inclouen, per exemple, la semiòtica, la retòrica o la teoria de la comunicació.

La figura 6 presenta un esquema general de les ciències del llenguatge que permet situar cada disciplina en un marc global i observar-ne les relacions.

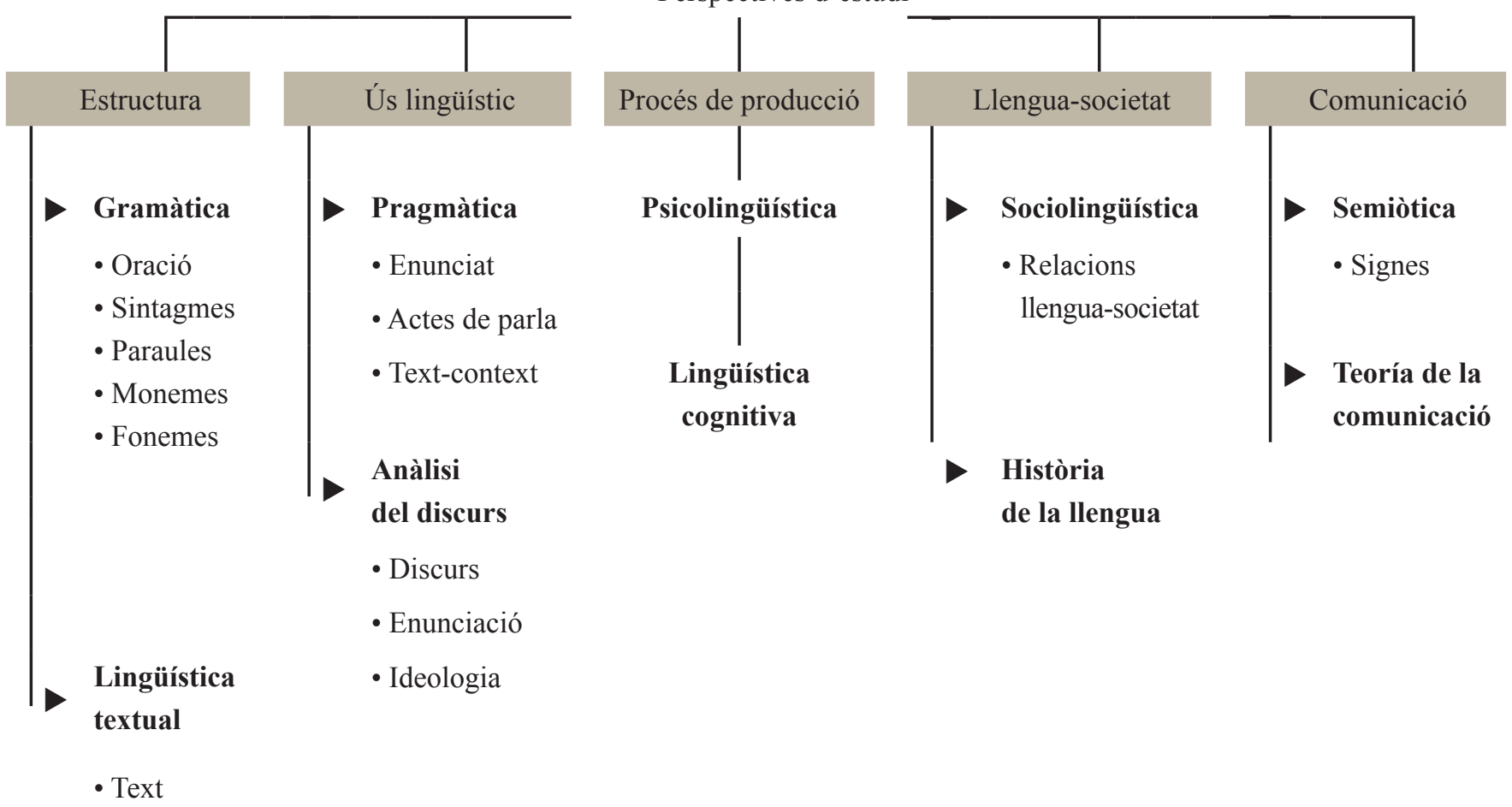

Fig. 6. Les ciències del llenguatge 2 


\subsection{Llengua i societat: introducció a la sociolingüística}

\subsubsection{Lingüística i sociolingüística: estructura i ús}

Tradicionalment, l'estudi de la llengua s'ha reduït a l'anàlisi dels mecanismes de l'estructura interna $i$ ha prestat una atenció especial a la llengua escrita. Les llengües són, però, sistemes de comunicació molt complexos que tenen una dimensió social indiscutible: les llengües són fets socials, sistemes convencionals de signes creats, mantinguts i suprimits per l'acció de l'ésser humà. Una determinada comunitat lingüística pot, voluntàriament, adoptar o abandonar una llengua, atorgar-li caràcter de llengua oficial i considerar-la llengua nacional o reduir-la exclusivament als àmbits privats i deixar-la desaparèixer. Des de la meitat del segle xx, s'ha desenvolupat una disciplina relativament nova, la sociolingüística, que s'ocupa d'estudiar els usos lingüístics, d'analitzar les formes en què les llengües (i les varietats lingüístiques) entren en relació amb els medis socioculturals en què funcionen, d'investigar les condicions d'existència i la interacció que s'estableix entre llengua i societat. Així, mentre la lingüística s'ocupa de l'estudi de l'estructura interna de la llengua, la sociolingüística analitza l'ús lingüístic (i el no-ús), la diversitat, la interacció llengua-societat i el paper dels usuaris de la llengua en els processos de canvi lingüístic.

El desenvolupament de la sociolingüística ha comportat la introducció d'una sèrie de conceptes teòrics per tal d'explicar satisfactòriament els fenòmens que constitueixen el centre d'interès d'aquesta nova disciplina. Aquí els presentarem agrupats en tres apartats ben diferenciats:

a) L'ús lingüístic: àmbits d'ús i àmbits de parla; prejudicis, actituds i normes d'ús lingüístic; ús convencional i ús intencional.

b) Llengües en contacte: contacte de llengües; llengües minoritàries i llengües minoritzades; conflicte lingüístic; bilingüisme i diglòssia.

c) Normalització i substitució: substitució lingüística; normalització; estandardització.

\subsubsection{L’ús lingüístic}

Saber una llengua no es redueix a conèixer llargues i inacabables llistes de paraules, fer transcripcions fonètiques acurades i elaborar magnífics i decoratius arbres d'anàlisi sintàctica. La competència lingüistica de les persones inclou, com hem vist, a més del component gramatical, un conjunt d'habilitats que conformen allò que s'anomena competència discursiva o textual $i$ un conjunt d'estratègies que formen part de la competència sociolingüística (fer servir l'idioma de la manera adequada en el moment adequat, segons l'interlocutor, el canal, el grau de formalitat $i$ altres circumstàncies que determinen el fet comunicatiu). En aquest sentit, les coordenades que configuren l'ús lingüistic, l'ús d'una varietat lingüística o una altra, estan determinades pels factors següents: 
- Qui parla a qui (en presència de qui): les persones o interlocutors.

- De què parla: el tema.

- On i quan (en quina situació): el lloc i el temps.

- Per quin mitjà (oral, escrit...): el canal o manera.

- Amb quina intencionalitat: el propòsit o intencionalitat comunicativa.

L'ús lingüistic està determinat directament per l'existència d'una sèrie de normes d'actuació lingüística, de caràcter social i fortament convencionalitzades, anomenades normes d'ús lingüístic. Aquestes normes consisteixen a aplicar determinades rutines de comportament lingüístic a marcs o models mentals més o menys convencionals, estan condicionades directament per les actituds lingüístiques $i$ sovint tenen l'origen en els prejudicis socialment més actius.

Els prejudicis són opinions no verificades o valoracions preconcebudes en virtut d'esquemes acceptats per la tradició compartida pels membres d'una comunitat, sense tenir un coneixement cert i raonat i que estan condicionats directament pels valors. Els prejudicis lingüístics són una classe particular d'aquest tipus d'esquemes convencionals de pensament que actuen sobre les llengües i els parlants, sobre els usos lingüístics i sobre la variació lingüística, i es manifesten d'una forma molt evident en els tòpics o llocs comuns (El mandarí és molt dificil; A València, parlen el valencià molt malament; La paraula servei no és valenciana...), en els refranys (Valencià i home de bé no pot ser; Als de Catí, el dimoni no els va poder seguir...) i en les expressions populars.

Les actituds lingüistiques són disposicions al manteniment, al canvi o a l'ocultació de la llengua pròpia, o posicionaments sobre els valors i la funcionalitat de les altres llengües o varietats. Entre l'ample ventall d'actituds lingüístiques, en les comunitats sotmeses a processos de minorització cultural i lingüística es poden identificar actituds favorables al procés de normalització (la lleialtat lingüística i la integració cultural) i actituds que afavoreixen el procés de minorització i, per tant, la substitució lingüística (l'autoodi i el rebuig). Les actituds lingüístiques es manifesten en normes d'ús específiques que condicionen i regulen els usos lingüístics de cada persona i, per tant, de cada grup social.

Si les actituds determinen el comportament social dels individus i la seua activitat discursiva, les actituds lingüístiques condicionen les normes d'ús lingüistic, que, de fet, suposen una regulació explícita o implícita del comportament lingüístic de les persones. Poden ser favorables o contràries a l'ús d'una determinada llengua $\mathrm{o}$ varietat lingüística. Habitualment, hom distingeix entre les normes d'ús convencional -les normes d'ús acceptades convencionalment i compartides per un grup social determinat, sovint contràries a la normalització lingüística de les llengües i varietats minoritzades- i les normes d'ús intencional -que comporten un ús lingüístic oposat a les normes convencionals i, per tant, favorable a la normalització lingüística (per exemple, canviar de llengua per adreçar-se a desconeguts, a la policia o a una tenda de la capital). 
Actituds i normes d'ús són dues dimensions complementàries - una psicològica i l'altra socialde l'actuació lingüística dels parlants d'una comunitat. Cal entendre per actituds els factors psicològics (concepcions, valors, prejudicis...) que determinen la visió de l'estatus i del prestigi de la llengua, del seu ús i de les interaccions que el determinen, de la seua evolució i de la necessitat mateixa de conèixer i dominar el codi. Les actituds configuren la predisposició a l'acció. És a dir, se'n deriven normes d'ús que es podrien definir com a normes socials i formes de comportament que es manifesten amb actuacions concretes d'ús de la llengua.

Sanz-Ruiz, 1990: 51

\subsubsection{Llengües en contacte}

En les societats contemporànies són molt poc habituals les situacions de monolingüisme i, per contra, són molt freqüents les societats que es caracteritzen per la multiculturalitat i el plurilingüisme, és a dir, per l'ús alternatiu de dues o més llengües. Els fenòmens de contacte lingüistic afecten probablement totes les llengües del món i provoquen dos tipus d'interferències: els préstecs i la convergència lingüística. Els préstecs o manlleus lèxics, presents en totes les llengües, no afecten la llengua receptora més enllà de l'expressió manllevada. En canvi, la convergència lingüística, provocada per un contacte massiu i permanent, comporta un procés de convergència gramatical que fa que el sistema d'una llengua s'assembli cada vegada més al d'una altra i pot tenir conseqüències decisives per al futur de la llengua.

Tanmateix, en l'estudi del contacte de llengües ocupa un lloc central el concepte de conflicte lingüístic, una expressió que s'utilitza per fer referència a una situació dinàmica i conflictiva en què una llengua (anomenada dominant) va desplaçant progressivament la llengua pròpia del territori (que esdevé minoritzada). La idea de conflicte lingüístic posa en relació, per tant, les nocions de llengua dominant i llengua minoritzada, que tenen un perfil marcadament sociolingüístic. Les cultures i llengües minoritzades són aquelles que estan sotmeses a un procés de substitució en el seu propi espai de comunicació o domini lingüístic. Per contra, les llengües dominants són aquelles que s'utilitzen fora del seu domini lingüístic original i provoquen un procés de retracció en els usos de les llengües minoritzades. Paral-lelament, cal distingir, des d'un punt de vista purament quantitatiu, entre llengües majoritàries, o llengües parlades per comunitats lingüístiques quantitativament importants, i llengües minoritàries, o llengües regionals, utilitzades per comunitats poc rellevats des del punt de vista quantitatiu.

Les situacions de contacte de llengües, que sovint es resolen en conflictes lingüístics, provoquen un ample ventall de relacions diverses entre les llengües que es poden encabir sota el paraigua dels termes bilingüisme i diglòssia.

La noció de bilingüisme fa referència a diverses situacions en què s'utilitzen dues llengües diferents; a l'ús alternatiu de dues llengües en un individu i, per extensió, en un grup social. D'entrada, cal distingir entre el bilingüisme individual i el bilingüisme social, tot i que existeixen altres formes de bilingüisme, entre les quals cal destacar el bilingüisme territorial i el bilingüisme oficial. 
El terme diglòssia s'utilitza per fer referència a una situació sociolingüística en què una llengua o una varietat lingüística alta (A) és emprada per a funcions formals i usos públics (educació, literatura, religió, etc.) i predominantment en l'ús escrit, mentre que la llengua o la varietat baixa (B) és emprada per a funcions informals i usos privats (interacció en l'àmbit familiar, comunicació íntima o espontània, etc.), generalment orals.
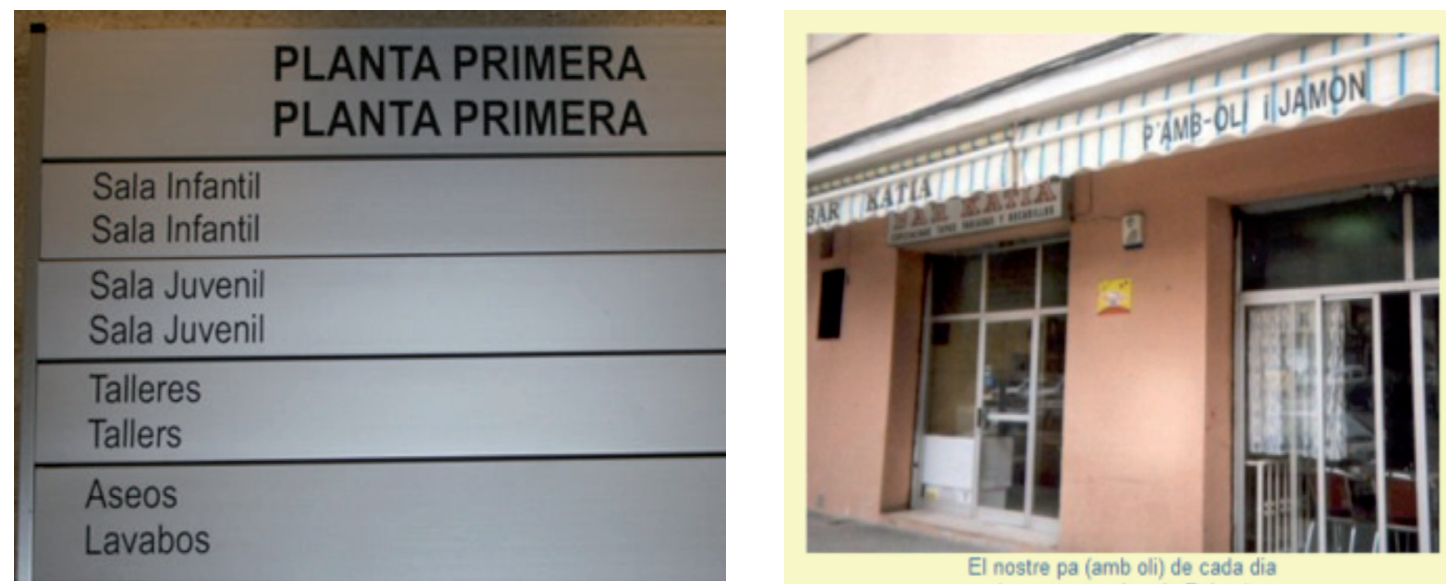

Fig. 7. El contacte de llengües en la retolació (font: http://bibiloni.cat/imatge/imatges.htm)

\subsubsection{Normalització i substitució lingüística}

La situació canviant del conflicte lingüístic sembla tenir només dos desenllaços possibles: la substitució -i, per tant, la desaparició- de la llengua minoritzada o recessiva, la que compleix menys funcions i la que finalment els parlants acaben abandonant -és el cas del còrnic o del dàlmata-, o bé la normalització -és el cas del txec o del polonès.

La llengua catalana viu, actualment, en una situació de conflicte lingüístic, i es troba sotmesa a dos processos contradictoris que actuen en dues direccions oposades:

a) un procés de substitució lingüistica, iniciat a començament del segle XVI, que comporta la pèrdua de parlants -és a dir, l'abandonament de la llengua, especialment en les àrees perifèriques del domini lingüístic $i$ en els grans nuclis urbans- $\mathrm{i}$ la pèrdua d'àmbits o situacions d'ús social de l'idioma, $\mathrm{i}$

b) un procés de normalització lingüistica, iniciat a començament del segle Xx, que comporta un procés de normativització o codificació -és a dir, la fixació de la normativa ortogràfica i gramatical de la llengua i la determinació de l'inventari lèxic-, un procés d'estandardització i un procés d'extensió social de l'idioma a partir d'un model determinat de planificació lingüística que inclou un major o menor grau d'oficialització. 
Des del punt de vista sociolingüístic, la història de la llengua catalana presenta quatre etapes ben diferenciades, que permeten explicar el pas d'una situació de plena normalitat a una altra de subordinació.

\section{El català, 1lengua nacional (1200-1516)}

El català era una llengua completa, parlada per tota la societat i utilitzada per l'aparell de l'estat. De fet, la Cancelleria, que representava les institucions polítiques, fou la responsable de la codificació i de la unificació idiomàtica, ja que serví d'exemple i de model lingüístic als escriptors. Aquesta codificació, que va ser molt prematura si la comparem amb la de la resta de les llengües romàniques, va ser possible gràcies a l'obra de Ramon Llull i d'altres escriptors de l'Edat Mitjana com Arnau de Vilanova.

El període de normalitat lingüística s'acaba amb la mort sense descendència de Martí l'Humà, el darrer rei del Casal de Barcelona, i la introducció de la dinastia dels Trastàmara amb Ferran d'Antequera (1412), com a conseqüència de l'acord del Compromís de Casp.

\section{Primer període d'interferència exògena (1516-1713)}

Amb l'entronització d'un rei de llengua castellana, la cort entra en contacte amb aquella llengua que comença a ser habitual entre les classes altes i els funcionaris pròxims al rei. Hi ha, per tant, un procés de substitució lingüística que afecta de manera selectiva a les classes dominants.

Després de les revoltes populars de les guerres de les Germanies (1519-1523), la participació de França en el manteniment del statu quo de la monarquia i l'aristocràcia rep com a contrapartida, amb el Tractat dels Pirineus (1659), l'annexió de la part septentrional del territori català.

A partir d'aleshores, parlem del període de decadència literària, perquè l'ús del català es redueix als àmbits populars i a la literatura de transmissió oral, i comença una etapa de repressió de l'ús social de la llengua catalana, que és el mitjà d'expressió de les classes populars que havien protagonitzat la revolta de les Germanies.

\section{La repressió exògena (1713-1975)}

A l'Estat Espanyol, el procés de persecució de la llengua catalana s'inicia després de la guerra de Successió i el tractat d'Utrecht (1713), amb la implantació dels Decrets de Nova Planta, que oficialitzen la prohibició de l'ús públic del català (ensenyament, administració...) i l'obligatorietat de l'ús del castellà. Comença així la castellanització de les classes populars. El conflicte lingüístic, que ja no afecta solament les classes dominants, sinó tota la població, s'estén verticalment. 
L'ús del castellà ja és una mostra d'ascens social, com es pot veure en el teatre d'Eduard Escalante, i anirà assimilant-se, per la via de la imposició, amb les dictadures de Primo de Rivera, primer, i de Francisco Franco, després.

Tot $\mathrm{i}$ això, les classes populars no es resignen a la pèrdua de la seua llengua, perquè, en definitiva, és un signe d'identitat individual i col-lectiva, i així, a finals del segle XVIII i principis del XIX, apareixerà el moviment de la Renaixença, que engega un procés de recuperació i codificació de la llengua que es completarà amb la intervenció de Pompeu Fabra.

\section{La situació actual (1975-2012)}

En l'actualitat ens trobem en una situació de cooficialitat de les dues llengües. Tanmateix, el bilingüisme consolida una situació de subordinació i marginalitat de la llengua catalana, sempre en inferioritat de condicions davant de l'aparell unificador dels estats espanyol i francès.

Tota la població catalanoparlant és bilingüe, però no ho és la castellanoparlant, de tal manera que s'estableix un bilingüisme unidireccional que només obliga, de fet, al coneixement de la llengua oficial de l'estat i deixa en segon terme el domini de la llengua pròpia del territori.

A més, cal tenir en compte les campanyes de disgregació interna-les polèmiques sobre el nom de l'idioma, l'existència d'una autoritat normativa qüestionada permanentment, els dèficits en l'ús públic, la manca de projecció exterior, l'existència d'àmbits d'ús deficitaris, el model de planificació lingüística dels estats espanyol i francès, els entrebancs a la construcció d'un espai de comunicació nacional...-i la persecució de l'ús normal de la llengua, això sí, de manera més subtil -reducció de fons per a l'ensenyament del català, supressió dels programes d'ensenyament en valencià, prohibició al País Valencià de les emissions de la Televisió de Catalunya; permissivitat a l'hora de concedir exempcions a l'ensenyament de la llengua en determinats territoris valencians de llengua castellana, reducció d'ajudes a la promoció de l'ús social de la llengua...

\section{Lectures recomanades}

BAssols, Margarida (2010): «La construcció de la identitat transnacional a través del discurs polític: la globalització»», en MARÍn, MARIA Josep i altres (ed.) (2010: 19-58).

Bauman, Zygmunt (2005): Vida de consum, Barcelona, Viena.

Fuster, Joan (2007): Diccionari per a ociosos, Barcelona, Edicions 62.

Gifreu, Josep (2006): La pell de la diferència, Barcelona, Pòrtic.

LaCroix, Michel (2005): El culte a l'emoció, Barcelona, La Campana. 
LakofF, George (2007): No pensis en un elefant, Barcelona, Ara.

Martí, Joan i Josep M. Mestres (ed.) (2002): Les llengües i les cultures en el procés de globalització de la societat de la informació, Barcelona, Institut d'Estudis Catalans.

Mollà, Toni (ed.) (2001): Ideologia i conflicte lingüístic, Alzira, Bromera.

PAYrató, Lluís (2003): Pragmàtica, discurs i llengua oral, Barcelona, Editorial UOC.

Puyal, Joaquim M. (2011): Aicnàlubma. Reflexions sobre la societat i els mitjans. Propostes per a la nova televisió, Barcelona, Columna.

SAngles, Ramon (2010): Comunicar-se, tot un art, Barcelona, Edicions SPD.

Serrano, Sebastià (2004): L'instint de la seducció, Barcelona, Ara. 


\section{TEMA 2}

\section{Models de llengua per als mitjans}

Introducció

1. Comunicació i cultura de masses

2. La variació lingüística i el català estàndard

3. Eufemismes i sexisme lingüístic

4. Gèneres discursius i models de llengua

5. Els llibres d'estil

Lectures recomanades 


\section{Introducció}

Al llarg de les últimes dècades, l'aparició de nous mitjans de comunicació en català, tant escrits com audiovisuals, ha tingut efectes molt clars sobre la percepció social de la llengua i la cultura catalana i ha provocat la necessitat de crear un model de llengua per a la comunicació pública, àgil, modern i adaptat a les exigències dels nous productes comunicatius. Aquesta nova realitat comunicativa s'ha produït en un marc en què els mitjans tradicionals han hagut d'adaptar-se a les noves tecnologies i als reptes de la globalització i en què els estudis de periodisme, publicitat i comunicació audiovisual han de formar els nous professionals per conviure en unes condicions de treball radicalment diferents a les que s'havien consolidat al llarg del segle xx. En aquesta realitat, complexa i canviant, és imprescindible que els professionals dels mitjans tinguen accés a un conjunt de recursos que els permeten utilitzar amb seguretat el model de llengua més adequat a cada situació comunicativa.

En aquest tema s'ofereix una reflexió sobre els models de llengua per a la comunicació pública i en català des de la perspectiva de la variació lingüística. Després d'una reflexió inicial sobre la cultura de masses, el tema presenta una visió panoràmica, necessàriament breu i parcial, del fenomen de la variació lingüística des de la perspectiva catalana, tot centrant l'atenció en la qüestió de l'estàndard i en els factors que condicionen la tria del registres lingüístics. Tot seguit, s'aprofundeix una mica més en la qüestió dels eufemismes i en el sexisme lingüístic, dos fenòmens relacionats directament amb la variació social que tenen una incidència directa en el llenguatge dels mitjans. I, finalment, es planteja una reflexió sobre la incidència de les convencions genèriques en l'elecció del model de llengua i es presenta una aproximació als llibres d'estil en català. El tema es tanca, com és habitual, amb una selecció de les lectures recomanades per completar la informació presentada.

\subsection{Comunicació i cultura de masses}

La cultura, entesa en un sentit ampli, té alguna cosa a veure amb la ideologia, però són dos conceptes que no es poden identificar. Les ideologies contribueixen a divulgar i generalitzar formes i usos culturals i, a més, alguns valors o principis ideològics constitueixen un element central de la cultura, però les ideologies $\mathrm{i}$ les cultures no són realitats equivalents. Les cultures solen tenir un fonament comú, i normes i valors compartits, però no una ideologia compartida a nivell global.

Des dels anys seixanta, quan es van generalitzar els mitjans de comunicació de massa, es van desenvolupar entre els estudiosos dues visions oposades que van donar lloc a dues actituds davant de l'ús de les noves tecnologies de la comunicació i la informació: l'actitud dels apocalíptics, que practiquen la crítica sistemàtica i el rebuig dels mitjans, i l'actitud dels integrats, que consumeixen acríticament i sense 
control els productes dels mitjans de comunicació de masses. Uns i altres, els crítics i els apologetes, «articulen discursos que aspiren a resultar convincents a partir només de mitges veritats, i redueixen sistemàticament la cultura a la seva dimensió d'objecte de consum» (Marín-Tresserras, 1994: 195). La realitat és, però, que en la societat de la comunicació i la informació la cultura de masses ocupa un lloc preeminent $\mathrm{i}$ que, més enllà de les discrepàncies, es poden identificar amb claredat algunes consideracions que constitueixen una mena de mínim comú denominador en el tractament de la cultura de masses.

El denominador comú en el tractament que la cultura de masses ha rebut per part de la majoria dels analistes $-\mathrm{i}$ de les més diverses tendències- es pot sintetitzar en aquests cinc punts o línies mestres:

1. La cultura de masses ha substituït la cultura tradicional popular preindustrial, i ha generat les seves pròpies tradicions.

2. La cultura de masses s'articula (és concebuda i es difon) des dels mitjans de comunicació de masses. La naturalesa dels mitjans electrònics de comunicació col-lectiva ha imposat nous llenguatges, noves relacions socials, nous usos, noves actituds («el mitjà és el missatge»).

3. La cultura de masses funciona ordinàriament com un gran mercat de consum, d'acord amb el que són les lleis econòmiques pròpies del capitalisme industrial i «postindustrial».

4. D'acord amb les pautes polítiques d'ús corrent i les lleis del mercat, la necessitat d'arribar a audiències que facin viable el càlcul polític o econòmic dels titulars dels mitjans imposa tendències d'homogeneïtzació i estandardització cultural.

5. La cultura de masses és una cultura transnacional.

Marín-Tresserras, 1994: 197-198

Els mateixos autors presenten $\mathrm{i}$ analitzen un decàleg de retrets o remarques crítiques que s'han fet, i es fan habitualment, a la cultura de masses, una mena de memorial de greuges. Segons aquest decàleg, la cultura de masses és una cultura tècnica, vulgar, cosmopolita, conservadora, depredadora, que genera confusió cultural, mercantil, mediocre, que fomenta la passivitat i immoral. Els autors insisteixen, però, que aquestes crítiques tenen sovint un contingut més moral que científic i que presenten una visió reduccionista de la realitat des de prejudicis que ja han etiquetat de perver$s a$ la tecnologia que fa possible la comunicació de masses i, per tant, també la cultura segregada per aquesta tecnologia.

\subsection{La variació lingüística i el català estàndard}

\subsubsection{El concepte de variació}

La realitat lingüística és un fenomen canviant, condicionat per una sèrie de factors històrics, polítics i sociològics, que permet realitzacions diverses en situacions diferents sense que això altere la seua finalitat bàsica, que és la intercomunicació. Per referir-se a aquesta realitat viva de la llengua, a les formes diverses d'ús del sistema lingüístic, els especialistes han introduït el concepte de variació lingüística, un concepte que inclou tres grans àmbits o espais conceptuals complementaris: les varietats dialectals, les varietats funcionals o registres lingüístics i la varietat estàndard $o$ varietat comuna. 
En el text següent de Ferran Torrent podem observar l'alternança de la varietat estàndard -que es manifesta en la narració, tot i que en les obres de Torrent la línia divisòria no és gaire clara- $\mathrm{i}$ del registre col-loquial -que apareix especialment en les expressions dialogades, on s'introdueixen habitualment les particularitats dialectals:

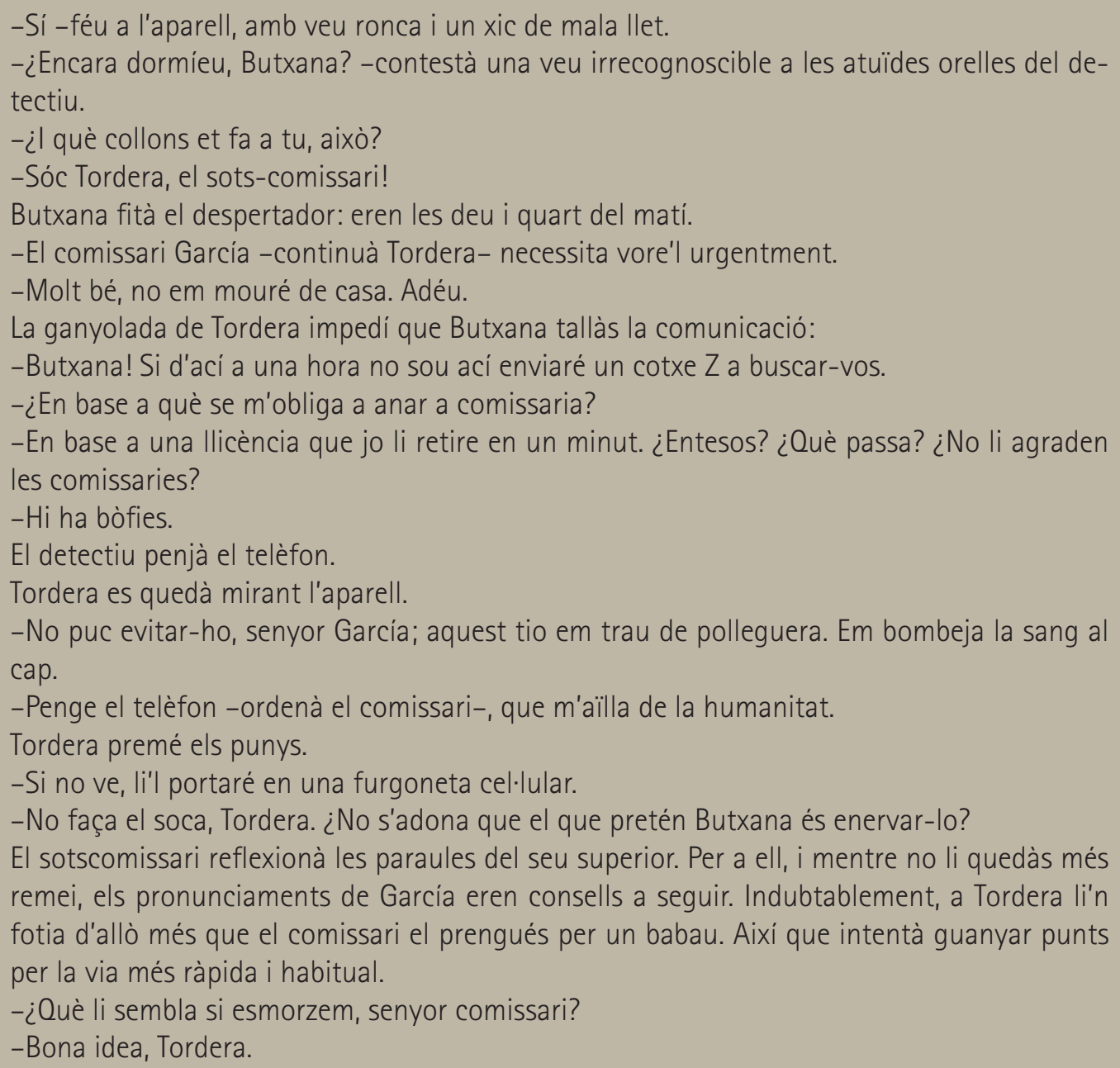

Ferran Torrent, Penja els guants, Butxana

\subsubsection{Factors i tipus de variació}

La variació lingüística està condicionada per quatre factors que determinen els quatre tipus de variació lingüística: l'espai, el temps, el grup social i la situació de comunicació.

Les varietats diatòpiques o dialectes geogràfics s'utilitzen en la relació entre persones que viuen en llocs pròxims; aquestes persones comparteixen unes característiques lingüístiques que els són pròpies i que els distingeixen d'altres grups que viuen en altres territoris. Un dialecte és la forma que presenta una llengua en un sector geogràfic determinat del seu domini lingüístic. En el cas del català, els 
lingüistes solen diferenciar dos grans blocs dialectals -el català oriental i el català occidental- i diversos dialectes, subdialectes i parlars propis d'àmbits geogràfics restringits (comarcal o local).

Llegint textos d'èpoques diferents ens adonem que, malgrat que en tots ells s'usa la mateixa llengua, les característiques del llenguatge varien: un text d'Ausiàs March és ben diferent d'un poema actual, però també d'un text de Ramon Llull. Es tracta de varietats històriques o cronolectes. En aquest apartat s'inclouen, a més de les varietats històriques pròpiament dites, les varietats generacionals, és a dir, les formes diverses de parlar de les generacions joves i de les generacions de més edat (el llenguatge juvenil, per exemple).

Les varietats socials o sociolectes són les diferents formes d'utilitzar la llengua pròpies dels diversos grups socials. En aquest tipus de variació hi trobem els argots dels grups marginals (llenguatge caló, llenguatge de la delinqüència...) i les varietats professionals o llenguatges específics de les diverses professions (estudiants, ensenyants, metges, polítics...).

Aquest primer tipus de variació està determinat pels usuaris de la llengua, és a dir, pels diferents grups humans que coexisteixen en una comunitat, definits i cohesionats per vincles generacionals, geogràfics i sociològics; en canvi, la variació funcional està condicionada per la situació de comunicació en què es produeix la interacció verbal; la diferència principal entre les varietats dialectals i els registres està, doncs, en el fet que les primeres sorgeixen de grups estables i nombrosos, que se solen excloure mútuament, mentre que els registres coexisteixen en un mateix parlant, que n'elegeix el més per a cada situació.

La fig. 8 ens pot ajudar a entendre millor com s'articula aquest complex territori de la variació.

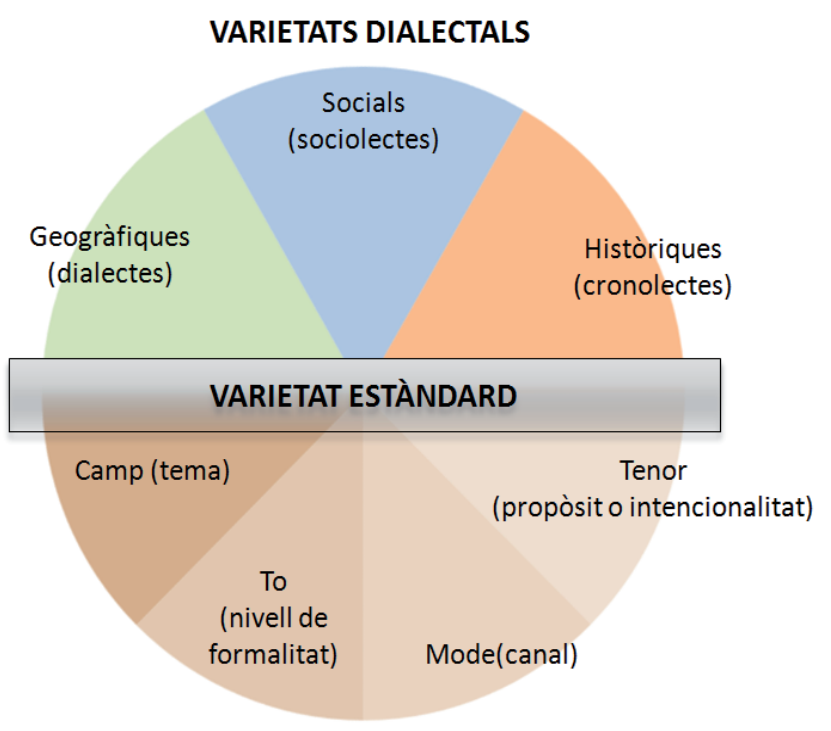

VARIETATS FUNCIONALS O REGISTRES

Fig. 8. Factors i tipus de variació lingüística 


\subsubsection{Les varietats geogràfiques del català}

El català és una llengua romànica que, com les altres nou (italià, romanès, sard, francès, francoprovençal, occità, castellà, portuguès i romanx), procedeix del llatí vulgar. Totes aquestes llengües, i les altres llengües del món, tenen diferents dialectes o varietats geogràfiques. En el cas del català, hom distingeix dos grans blocs dialectals, el català oriental i el català occidental, que es diferencien, entre d'altres, per les característiques següents:

\begin{tabular}{|c|c|}
\hline Català oriental & Català occidental \\
\hline $\begin{array}{l}\text { - Confusió de les vocals a i e àtones en [ə]: pare } \\
\text { [párə], para [párə]. }\end{array}$ & $\begin{array}{l}\text { - Distinció de les vocals a i e àtones: pare } \\
\text { [páre], para [pára]. }\end{array}$ \\
\hline $\begin{array}{l}\text { - Neutralització de les vocals o i } u \text { àtones en [u]: } \\
\text { posar [puzá], pujol [puzol]. }\end{array}$ & $\begin{array}{l}\text { - No neutralització de les vocals o i } u \text { àtones: } \\
\text { posar [pozá(r)], pujol [puzol]. }\end{array}$ \\
\hline $\begin{array}{l}\text { - Desinència de la la persona del present } \\
\text { d'indicatiu en }[-u,-i,-\varnothing] \text { : [párlu], [párli], [párl]. }\end{array}$ & $\begin{array}{l}\text { - Desinència de la 1a persona del present } \\
\text { d'indicatiu en }-O,-e \text { : [párlo], [párle] }\end{array}$ \\
\hline $\begin{array}{l}\left.\text { - Pronunciació [e } \int\right] \text { de l'increment-eix dels verbs } \\
\text { incoatius de la 3a conjugació: parteix [partéf], } \\
\text { parteixi [partéfi]. }\end{array}$ & $\begin{array}{l}\text { - Pronunciació [i]] de l'increment -eix dels } \\
\text { verbs incoatius de la 3a conjugació: parteix } \\
\text { [partí], partisca [partífka]. }\end{array}$ \\
\hline $\begin{array}{l}\text { - Caiguda de la } n \text { del plural de les antigues } \\
\text { esdrúixoles llatines acabades en -ns: HOMINES } \\
>\text { homes. }\end{array}$ & $\begin{array}{l}\text { - Manteniment de l'antic plural de les } \\
\text { esdrúixoles llatines acabades en -ns: } \\
\text { HOMINES > hòmens, JUVINES > jóvens. }\end{array}$ \\
\hline $\begin{array}{l}\text { - Lèxic específic: mirall, noi, xai, escombra, } \\
\text { sortir. }\end{array}$ & $\begin{array}{l}\text { - Lèxic específic: espill, xic, corder, granera, } \\
\text { eixir. }\end{array}$ \\
\hline
\end{tabular}

Taula 2.1. Català oriental i català occidental

Pertanyen al català oriental els dialectes rossellonès, català central, balear i alguerès, i al català occidental el nord-occidental i el valencià. Cadascun d'aquests sis dialectes no es parla de la mateixa manera en tota la seua àrea geogràfica, cosa que permet identificar-hi diferents subdialectes o modalitats pròpies d'espais regionals més o menys extensos i parlars o varietats territorials comarcals o locals. Així, en la zona on es parla el català central, es poden distingir cinc subdialectes: tarragoní, barceloní, salat, xipella i septentrional de transició. En l'àrea del rossellonès hi ha una comarca on es parla el subdialecte capcinès i una altra on es parla un subdialecte rossellonès de transició cap a l'occità. De la mateixa forma, el dialecte balear comprèn els subdialectes mallorquí, menorquí i eivissenc. Pel que fa als dialectes occidentals, mentre que en el domini del nord-occidental hom distingeix els subdialectes pallarès, ribagorçà i tortosí, el valencià es parla en les modalitats (o subdialectes) septentrional (o tortosí meridional), castellonenc, apitxat o central i valencià meridional o alacantí. A més, en l'àrea de l'alacantí hi ha dos illots lingüístics corresponents als pobles de Tàrbena i la Vall de Gallinera, que foren repoblats al segle XVIII per mallorquins i on es manté encara la parla mallorquina.

En el mapa representat en la fig. 9 es poden veure les varietats geogràfiques del català. S'hi pot observar que sovint la transició d'un dialecte a l'altre no es produeix 
d'una forma brusca, sinó amb extenses àrees de transició on es barregen les característiques d'un dialecte amb les de l'altre. Les línies imaginàries que uneixen els llocs on es parla d'una mateixa forma s'anomenen isoglosses i són molt importants per veure com es produeix la transició d'un dialecte (o una llengua) a un altre.

\subsubsection{Varietats diacròniques i socials}

Les varietats històriques o diacròniques comprenen, a més de les varietats històriques pròpiament dites (les formes diferents de parlar un idioma al llarg dels segles), les anomenades varietats generacionals, és a dir, les formes diverses d'emprar un idioma en funció de la generació a què pertanyen els usuaris. En l'àmbit de la variació generacional, cal distingir entre les varietats utilitzades per la gent gran, la parla infantil i l'argot juvenil.

Les varietats generacionals constitueixen una manifestació evident dels processos de canvi lingüístic i posen en evidència l'existència de factors extralingüístics que el provoquen (com ara les connotacions d'arcaisme o de ruralitat, el caràcter subversiu d'alguns usos lingüístics, el prestigi o el desprestigi d'algunes pronunciacions en alguns grups d'edat, l'originalitat...).

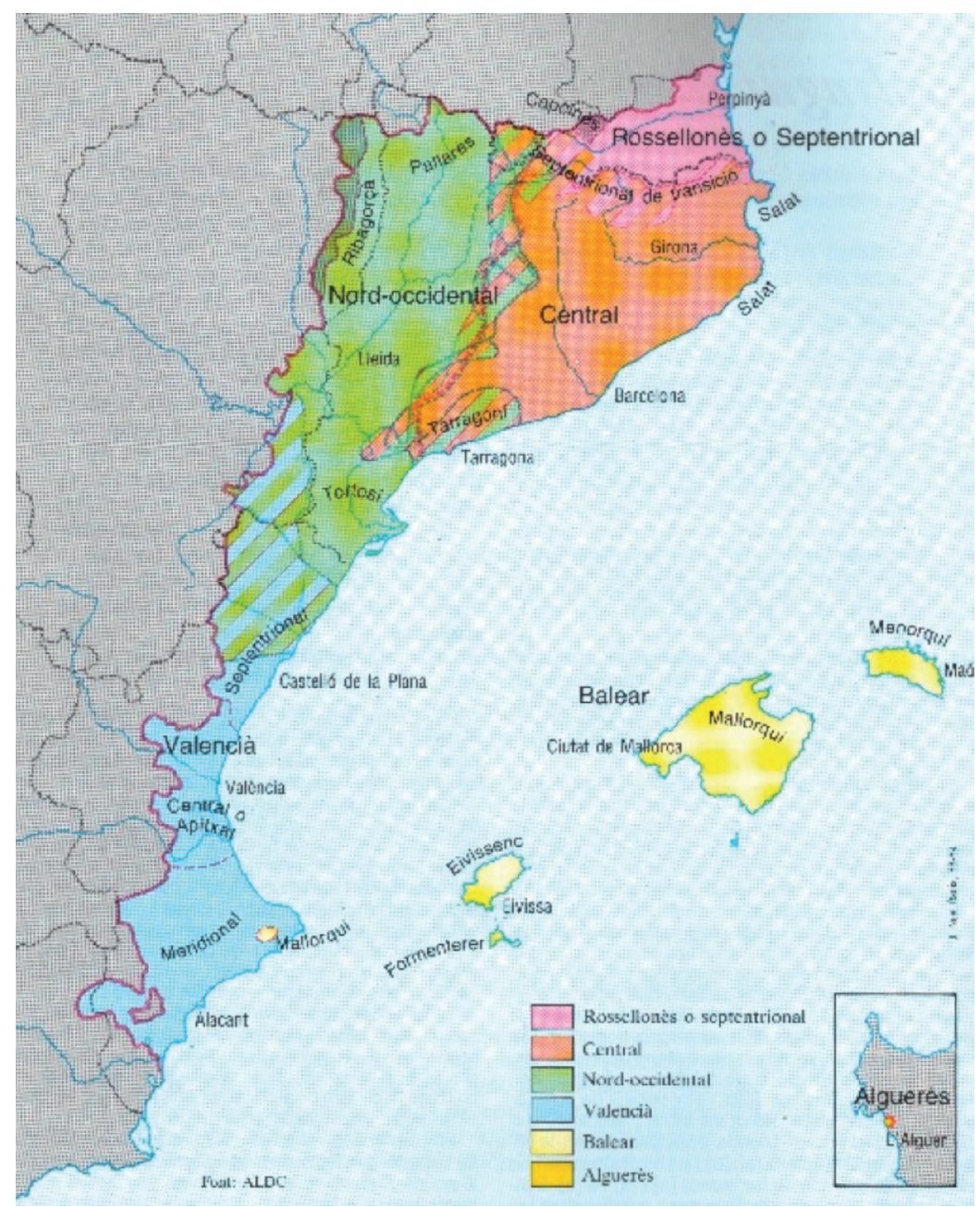

Fig. 9. Varietats geogràiques del català (font: Gimeno, 1989) 
Tot i que no podem parlar d'un llenguatge dels avis i un altre diferent del joves, és fàcil percebre una tendència dels joves a abandonar determinades expressions que consideren més pròpies de la gent major (com l'ús de l'article arcaic lo masculí: lo senyor rector, va venir amb lo cotxe...). Aquesta tendència provocarà, segurament, una pèrdua de la transmissió a les generacions següents.

L'interès dels joves d'apartar-se de la manera de parlar dels majors s'ha d'entendre com la intenció de crear una identificació pròpia i diferenciada, que els aparte no sols de les persones adultes, sinó també d'altres grups de joves amb els quals no s’identifiquen. Són els anomenats argots juvenils.

Els argots són fenòmens essencialment urbans, que sorgeixen de la necessitat de grups socials concrets de crear formes d'identificació enfront d'altres grups que habiten la ciutat. Típicament, els argots agafen un component contestatari contra l'autoritat i les formes culturals de les elits urbanes. Els seus parlants projecten la seva identitat a través del seu parlar. Per això trobem expressions susceptibles d'utilitzar-se de forma repetida dins la conversa. En el cas de l'argot juvenil, trobem vocatius com tio, expressions com guai, tope 'bé', 'perfectament' i conceptes d'ús habitual com queo 'a casa' o sobar 'dormir'. Per altra banda, hi ha tot el vocabulari referit al consum de droga, element molt important en la cultura juvenil actual: cavall 'heroïna', camell 'traficant', al-lucinar o flipar 'tenir sensacions o al-lucinacions', privar 'beure alcohol'. Tots aquests recursos expressius permeten parlar amb actitud positiva de comportaments socialment malvistos, tot creant entre els joves uns microespais socials on aparentment regeixen unes normes i uns valors diferents dels de la resta de la societat. És també per això que multitud d'expressions de l'argot juvenil acaben impregnant la parla d'altres sectors socials i són utilitzats quan es vol donar un to informal a la conversa, sobretot mitjançant petites agressions verbals, burles i comèdies efímeres.

Bibiloni, 1997: 143-145

Els usos lingüístics són senyals de poder i de distinció social que permeten comunicar i assenyalar molts aspectes de la identitat de les persones i dels grups socials a què pertanyen, $i$ també instruments poderosos de creació i manteniment d'aquestes mateixes identitats: «així com els parlants competents d'una llengua n'adquireixen el sistema fonològic o la sintaxi, també aprenen determinades valoracions o ideologies envers els seus usos i varietats» (Vallverdú, 2001: 182). Els usos lingüístics són, per tant, marcadors de les actituds lingüístiques i de les ideologies. És per això que les varietats socials constitueixen una de les dimensions més interessants de l'estudi de la variació.

En el cas del català, l'estudi de la variació social (o variació diastràtica) ha de prestar una atenció especial als fenòmens següents:

a) Les varietats territorials associades al registre col-loquial.

b) Les varietats vulgars associades a situacions de comunicació molt informals.

c) Les formes concretes de manifestació de la variació social: el català popular (el parlar de la e i el parlar de la baia alcoians, el parlar xava barceloní) i el català refinat (la varietat apijada o pija).

d) Les formes de parlar condicionades per les normes socials i el seu (in)compliment, que es manifesten en les formes de control lingüístic i reprodueixen, en definitiva, formes de control social, entre les quals cal tenir molt en compte: 
- els malapropismes -pronúncies i usos incorrectes de termes cultes i tècnics, com ara pendis, endicció, altobús o diarrera)-,

- els tabús i els disfemismes -formes lingüístiques transgressores de la norma social establerta, entre les quals cal destacar les blasfèmies, els insults, les paraulotes (com fotre o cagar) i el lèxic relacionat amb el sexe, amb l'escatologia i amb la mort-,

- els eufemismes -estratègies d'atenuació de les transgressions lingüístiques- $\mathrm{i}$

- els usos sexistes del llenguatge i les propostes per eliminar el sexisme lingüístic i construir un discurs políticament correcte.

\subsubsection{La variació diafàsica: varietats funcionals del català}

Les varietats funcionals o varietats diafàsiques, anomenades també registres lingüistics, són les formes diverses que adopta l'ús lingüístic condicionades pels factors que configuren el context o la situació de comunicació. Aquest tipus de variació està directament relacionada amb els àmbits d'ús social de l'idioma $\mathrm{i}$, per tant, amb les restriccions expressives imposades en cada àmbit per les convencions establertes i pels factors que regulen la comunicació. En aquest sentit, és evident que el lloc i el temps on es produeix la interacció, la relació i el grau de coneixement entre els interlocutors, el nivell de formalitat, la temàtica, el canal de comunicació i el grau de preparació del text, els gèneres i subgèneres que es poden utilitzar o la intenció comunicativa dominant, entre d'altres factors, condicionen d'una forma directa els recursos lingüístics i els mecanismes expressius que convé utilitzar en cada moment.

Els registres, com les altres formes de la variació, formen un espai continu on es poden identificar àrees diferents separades per gradacions i zones de transició.

La idea de continu de parla se sol aparellar molts cops amb la de variació, perquè sovint no podem aïllar amb facilitat les varietats o modalitats lingüístiques concretes que es presenten en una comunitat de parla: aquestes se solen presentar sense solució de continuïtat entre sí, per exemple en el cas de la variació històrica (que no es pot segmentar si no és mitjançant convencions més aviat arbitràries), de la social (amb la dificultat de delimitar amb precisió els grups socials) o, fins i tot, de la geogràfica (en el cas d'àrees de transició entre dialectes).

Payrató, 2003: 184-186

Segons la tradició anglosaxona, els factors determinants de la variació diafàsica són el camp, el mode, el tenor i el to.

El camp o tema determina l'essència d'ús de la llengua i separa els registres segons l'objecte del qual es parla, ja siga corrent o quotidià -en el cas del registre col-loquial-, o bé tècnic o especialitzat -en el cas dels llenguatges d'especialitat o tecnolectes. En general, es poden distingir fàcilment els dos registres (blau i hematoma), tot i que, de vegades, trobem àrees de confluència on es difícil distingir-los - per exemple, una conversa sobre la conveniència d'adquirir un cotxe o un altre. 
El mode es refereix bàsicament al canal-que ens permet distingir entre l'oral i l'escrit- i el grau de preparació del text -si es tracta d'un text planificat o espontani. Actualment, s'hi poden trobar moltes gradacions resultants de la combinació de les quatre variables (oral, escrit, preparat $i$ espontani), de tal manera que ens podem trobar usos lingüístics enganyosos, sobretot en els mitjans de comunicació audiovisuals, que semblen espontanis $i$, en canvi, estan absolutament planificats -per exemple, els diàlegs de les pel·lícules i les telesèries o alguns programes d'entreteniment.

El tenor es refereix al propòsit de l'ús lingüístic i, per tant, a les funcions del llenguatge, i permet diferenciar els textos amb una intenció informativa dels que pretenen mantenir una interacció amb una finalitat social. Podem relacionar el tenor amb les seqüències textuals o modalitats discursives -narrativa, descriptiva, expositiva, argumentativa, instructiva...- o, fins i tot, limitar-ne l'abast a la distinció entre textos subjectius i textos objectius.

El to es refereix a la relació personal que mantenen els interlocutors entre ells, que va de la més formal (o solemne) a la més pròxima (o familiar). S'ha d'entendre que entre les dues posicions hi ha una posició anomenada neutra que es caracteritza per no tenir cap tipus de marca lingüística.

L'aplicació dels factors esmentats a l'anàlisi de la variació funcional permet de distingir entre els registres formals i els registres informals:

a) Els registres formals (periodístic, literari, científic, tècnic, acadèmic, jurídicoadministratiu, etc.) es manifesten preferentment en la comunicació escrita, però és evident que tenen una presència molt important en els gèneres orals (conferències, classes magistrals, noticiaris de ràdio, etc.) i en els audiovisuals (documentals, reportatges televisius, etc.)

b) Per contra, és evident que els registres informals (col-loquial o familiar, vulgar, argots, etc.) es realitzen preferentment en els gèneres orals. El registre col·loquial — que tendeix a ser quotidià, oral, interactiu i poc controlat - es caracteritza per la relaxació articulatòria, l'ús d'un vocabulari bàsic restringit, l'estructuració sintàctica i discursiva i la presència d'elements gestuals $\mathrm{i}$ paralingüístics, com l'entonació i la intensitat.

En la societat actual, que es caracteritza per la tendència a la multiplicació dels àmbits o espais de comunicació, els registres tendeixen també a multiplicar-se i diversificar-se. Així, en les últimes dècades ha aparegut el registre audiovisual, que seria difícil encabir en alguns dels anteriors a causa de la diversa naturalesa dels textos que el conformen. 


\subsubsection{El català estàndard}

La varietat estàndard no forma part del catàleg de registres lingüístics ni és una varietat dialectal. De fet, l'estàndard és una varietat intermèdia entre les varietats dialectals i les varietats funcionals: d'una banda, és una varietat comuna que facilita la comunicació entre els usuaris de procedències geogràfiques o d'extraccions socials diferents, i de l'altra, constitueix una mena de nivell bàsic de referència compartit per tots els registres formals.

\footnotetext{
Mai com ara no havia estat tan necessari per servir aquestes necessitats, i de fet no havia funcionat amb tanta profusió, un registre comú: allò que hem acordat anomenar llengua estàndard. És un fet que tota llengua normalitzada ha arribat a comptar amb una norma funcional que comprèn aquelles situacions en què la comunicació pren un caràcter generalitzat i neutre, allunyada per un cantó d'elaboracions literàries o tècniques i, per un altre, d'aquell altre tipus d'especialitzacions que queden tancades en el clos familiar o altres grups reduïts.
}

Aquesta norma funcional comuna no és sinó la que ha sorgit i s'ha fixat en totes les llengües de cultura, les quals han desenvolupat aquest codi utilitari — que en certs pobles de gran diversificació dialectal ha exercit de lingua franca. Fóra la pròpia de la ràdio, la televisió, el cinema, les comunicacions verbals... (en llengua oral); la de la premsa, la publicitat, els escrits comercials, la correspondència en general... (en llengua escrita); i la de l'ensenyament en les situacions més formals (en llengua oral i escrita).

La característica principal d'aquesta norma comuna, o estàndard, és que actua amb un paper de directriu, punt de referència... que no vol pas dir uniformitat, tot i que implica el bandejament de formes que no s'hi ajusten, per una simple raó d'economia.

López del Castillo, 2001: 197-198

Per regular aquesta normativa, la societat actual ha anat imposant una pluralitat de protagonistes. En l'àmbit lingüístic i cultural català, la realitat política i social ha determinat que hi haja diferents entitats normatives que complementen el paper de l'Institut d'Estudis Catalans, particularment, pel que fa a l'àmbit valencià, l'Acadèmia Valenciana de la Llengua, però també altres institucions com el TERMCAT o els llibres d'estil dels diversos mitjans de comunicació, tant audiovisuals com escrits.

Actualment, la delimitació i l'ús habitual del català estàndard presenta encara aspectes problemàtics que plantegen debats permanents sobre aquesta varietat, especialment virulents en l'espai valencià, atiats sovint per interessos polítics partidistes que tenen molt poc a veure amb les necessitats de l'idioma i del procés de normalització de l'ús social. D'una forma sintètica, aquests debats tenen relació amb les qüestions següents:

1. La dialèctica entre estàndard i paraestàndards i entre l'estàndard general i les diferents modalitats territorials o subestàndards regionals.

2. La polèmica entre el català heavy -representat per les tendències de purisme lingüístic-i el català light-que recull les tendències que proposen el relaxament 
per tal d'aproximar l'estàndard als parlars populars, sovint amb un percentatge molt considerable d'interferències procedents del castellà.

3. Les dificultats derivades de la pronúncia estàndard, que necessita definir amb urgència un estàndard català únic, materialitzat en diversos accents regionals.

4. La problemàtica derivada de l'existència de morfologies verbals regionals, que han de conviure en les diverses submodalitats de l'estàndard sense provocar una regionalització excessiva que dificulte la comunicació interdialectal.

5. La presència massiva d'interferències lèxiques, procedents especialment de l'anglès i del castellà, que han de rebutjar-se (si es tracta de barbarismes) o adaptar-se al sistema lingüístic propi (en el cas dels neologismes).

6. La pervivència d'una situació social (i sociolingüística) que manté el català en una posició de minorització i provoca dificultats importants que, en alguns casos, amenacen la supervivència de l'idioma. Ens referim particularment als fets següents:

a) les dificultats per accedir a alguns àmbits d'ús socialment prestigiats -especialment el món de l'economia i els negocis, la justícia, el cinema, la publicitat, l'oci i l'etiquetatge-;

b) la consolidació d'una situació legal que discrimina la llengua catalana i provoca actituds lingüístiques i normes d'ús convencionals que bloquegen l'ús social de l'idioma;

c) la necessitat d'emprar en els usos públics un model de llengua no gaire allunyat de la varietat col-loquial, per tal d'aproximar-la als usuaris i fer que puguen sentir-la com a pròpia;

d) els dubtes dels usuaris sobre la identitat de l'idioma o sobre els elements que en formen part;

e) les tendències centrífugues, impulsades especialment per un sector de la societat valenciana, que condueixen inexorablement a la fragmentació i al secessionisme lingüístic, i, en definitiva, a la retracció de la llengua pròpia, $\mathrm{i}$

f) el paper i la funció social de l'Acadèmia Valenciana de la Llengua, que pot ajudar a consolidar un subestàndard valencià modern, integrat d'una forma natural en l'estàndard general, però pot també constituir una porta oberta a l'oficialització d'un model contradictori amb l'estàndard general i, per tant, una invitació a l'abandonament d'una llengua que es presenta sovint com un idioma que genera dubtes $\mathrm{i}$ incoherències als usuaris potencials.
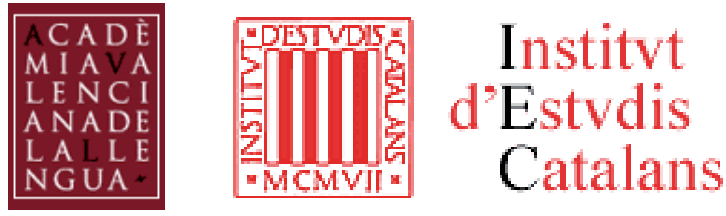

Fig. 10. Logotips de l'AVL i l'IEC, dues institucions normatives per a una mateixa llengua 
La inexistència d'una llengua catalana referencial completa determina al seu torn uns dèficits en la funció definidora i cohesionadora de la comunitat lingüística. Per això molts catalanoparlants són víctimes de nombrosos dubtes i d'espesses foscors sobre la identitat, els límits i les parts integrants de la seva llengua, igual que sobre la tradicionalment enverinada qüestió de noms. Un terreny sobre el qual és molt fàcil assentar estratègies d'esmicolament de la llengua i de substitució lingüística. Finalment, la suma dels dèficits esmentats i la consegüent manca d'un estàndard amb el grau de prestigi social propi dels estàndards en plenitud funcional són causa d'unes insuficiències en el nivell de lleialtat lingüística de molts catalanoparlants que, com se sap, és un ingredient essencial per al bon funcionament de les comunitats lingüístiques. En suma, plenitud funcional de l'estàndard i respostes positives dels usuaris (consciència i lleialtat lingüístiques) són realitats correlatives i inseparables. El projecte de normalització del català requereix que els dèficits en un ordre i l'altre siguin esmenats simultàniament.

Al País Valencià, l'adopció del nom de valencià a l'Estatut d'Autonomia, més que quelcom greu en si mateix, representa tenir la porta perillosament i contínuament oberta a la possibilitat d'una «galleguització», és a dir, la vehiculació - amb poder polític ho podrien fer els qui aspiren a ferho-d'una codificació alternativa incompatible amb la codificació del català comú; de la mateixa manera que el poder autonòmic gallec difon una codificació incompatible amb la portuguesa, amb finalitats clarament separadores de les dues comunitats. [...]

En síntesi, l'impediment principal per a la consolidació d'una llengua estàndard amb un equilibri complet d'usos i de funcions és l'existència d'un altre estàndard que s'apropia aquells usos i funcions. Dues llengües referencials és una contraditio in terminis: si dos punts de referència diferents pretenen coexistir, un d'ells anul·larà forçosament l'altre, per la mateixa noció de referència. $[\ldots]$

Repetim: una societat dependent no pot tenir una llengua independent.

Bibiloni, 1997: 143-145

\section{www}

Llocs web que ofereixen enregistraments audiovisuals dels diferents parlars catalans:

- http://www.museudelaparaula.com/web/home/

- http://prosodia.upf.edu/atlesentonacio/mapa.html

- http://www.ub.edu/sonscatala/

\subsection{Eufemismes i sexisme lingüístic}

\subsubsection{Tabús i eufemismes}

En totes les cultures existeixen conceptes i elements de la realitat que són considerats tabús, o idees que la ideologia dominant considera improcedents o inconvenients. Es tracta de conceptes i idees socialment o políticament rebutjables que convé reprimir. I una bona forma d'amagar la realitat és fer desaparèixer de la circulació les paraules que la representen. Sovint, els tabús afecten el lèxic relacionat $\mathrm{amb}$ el sexe, amb les funcions fisiològiques o amb la mort, però habitualment, en el discurs dels mitjans, els eufemismes s'estenen a tots els camps de la vida pública. Només cal recordar, a títol d'exemple, l'amplíssima diversitat de denominacions 
dels òrgans sexuals, les formes diverses de referir-se a la mort o les expressions utilitzades pels polítics els últims anys per no parlar de crisi econòmica o per referir-se als transvasaments.

Una estratègia per evitar l'ús de les paraules o expressions considerades tabú (per exemple cagar, morir-se o tenir relacions sexuals) és l'ús d'una terminologia científica o un lèxic culte, ideològicament menys marcats (per exemple, defecar, expirar o copular). Hi ha, però, altres possibilitats, com ara fer servir disfemismes, formes lingüístiques transgressores de la norma social establerta, que permeten orientar el discurs cap a un registre vulgar o contaminar-lo d'un to irònic amb el qual l'emissor pot distanciar-se del contingut de la interacció. Així, en els exemples anteriors, es podrien utilitzar respectivament les expressions femtar, criar malves o estirar la pota i follar, fotre un clau o fer-ho. Les blasfèmies, els insults, les paraulotes (hòstia, fill de puta) i el lèxic quotidià relacionat amb el sexe, i junt amb l'escatologia i amb la mort, formen part d'aquesta segona alternativa. I, finalment, existeix la possibilitat de cobrir els mots i les expressions considerats tabús amb eufemismes, és a dir, amb expressions que suavitzen, endolceixen i dissimulen els conceptes prohibits. En realitat, els eufemismes són estratègies d'atenuació de les transgressions lingüístiques. En els exemples anteriors, es podrien utilitzar expressions com ara fer de ventre (o anar a fer una feina o anar a fer una cosa que ningú no pot fer per mi), anar-se'n (o deixar-nos o estar assegut a la dreta del pare) ifer l'amor (o gitar-se junts).

Els eufemismes de la vida quotidiana, com els exemples que hem vist ara mateix, tenen simplement una funció de maquillatge del llenguatge corrent i s'utilitzen per tal d'atenuar les tensions en la interacció social i per respectar les convencions socials. Són, de fet, una manifestació de la cortesia lingüística. En canvi, en la comunicació pública, tot i que aquesta funció primària també està present, els eufemismes tenen una funció ideològica molt evident. Així, amb els anys, els ministeris de guerra s'han convertit en ministeris de defensa i els departaments d'espionatge en serveis d'intel-ligència; quan un país decideix ocupar-ne un altre, les operacions bèl-liques es bategen amb noms com ara llibertat duradora o tempesta del desert, i els combatents ocupants són identificats com l'exèrcit aliat o les forces democràtiques; les víctimes civils són danys col-laterals i els bombardejos sobre les tropes pròpies, provocats per accidents o per errors injustificables, són qualificats de $f o c$ amic.

Tots aquests exemples, i molts d'altres que podem trobar en el discurs polític i en l'àmbit periodístic, ens ajuden a comprendre la importància del llenguatge en la comunicació pública i ens permeten observar com el llenguatge no crea la realitat, que és un element preexistent, però pot transformar-la i pot canviar-ne els perfils. A través del llenguatge es poden transmetre percepcions radicalment diferents sobre els mateixos fets i, per tant, es poden crear, mantenir i divulgar determinats punts de vista sobre el món. I aquesta capacitat de mediació del llenguatge és especialment important per als professionals del periodisme, la publicitat i la comunicació audiovisual. 


\subsubsection{Els usos sexistes del llenguatge}

Un altre aspecte de la variació lingüística en el qual cal focalitzar l'atenció, especialment des de la perspectiva dels mitjans de comunicació, són els usos sexistes del llenguatge i les propostes per eliminar el sexisme lingüístic i construir un discurs políticament correcte. Ara bé, aquestes propostes no han de produir formes que resulten estranyes perquè es consideren sexistes determinades solucions que en realitat no ho són. L'abús de formes dobles (quan no han estat necessàries), la creació de parelles completament incorrectes (els/les treballadors/dores), l'atribució de sexisme a aquells mots que únicament expressen un gènere no marcat (la/ el pianista), han engegat una dura polèmica entre els gramàtics i els usuaris de la llengua que ha obligat determinats col-lectius -universitats, col·legis professionals i mitjans de comunicació- a manifestar oficialment quines són les regles que els membres han de seguir per tal d'evitar formes allunyades de l'ús correcte de la llengua.

Mostrem com a exemple la Declaració de la Universitat de les Illes Balears, que ha servit de model a altres manifestacions posteriors - la UPF o la Generalitat de Catalunya- o ha provocat modificacions d'alguns llibres d'estil -com el de la revista Llengua nacional.

Val a dir que a hores d'ara, i malgrat les indicacions de la major part dels lingüistes, les universitats valencianes encara no han introduït cap canvi en la norma de tractament del gènere en els seus textos.

\section{DECLARACIÓ SOBRE EL GĖNERE}

Algunes propostes formulades sobre el gènere gramatical, el denominat llenguatge no sexista, es basen en una encomiable voluntat de reflectir la igualtat entre homes i dones, però es formulen a partir d'un coneixement insuficient del funcionament de les estructures lingüistiques, per la qual cosa descansen sobre nocions cientifiques falses. En efecte, la ciència lingüística, basant-se en el concepte de marca, deixa ben establit que la llengua catalana i les altres llengües romàniques tenen un sistema gramatical en què la categoria del gènere constitueix una oposició en què un dels dos gèneres funciona regularment com a terme no marcat quant al sexe (l'anomenat masculi) i l'altre com a terme marcat ('anomenat femeni).

Les prevencions contra el gènere no marcat vénen del fet que aquest gènere ha estat anomenat tradicionalment masculí, una convenció terminològica que en el parlar corrent i en l'àmbit de la lingüistica es manté pel pes del costum, però que no lleva al gènere dit masculi la seva naturalesa de categoria comuna sempre que hom es refereixi a persones el sexe de les quals no es vulgui especificar. L'existència i l'ús de les formes no marcades de cap manera no pot ser considerat llenguatge sexista i llenguatge discriminatori, com podria ser implicit, per exemple, a l'acord normatiu de dia 10 de setembre de 2002 sobre l'ús a favor d'un llenguatge no sexista en la documentació universitària. Al contrari, les construccions que introdueixen artificiosament la segregació de gèneres en el discurs (per exemple, "els nins i les nines juguen plegats (i plegades)») atempten contra el bon ús de la llengua, consagrat no només en les gramàtiques, sinó també en la nostra tradició literària, fins i tot 
en les obres que més conspicuament han expressat la necessitat d'igualtat entre dones i homes. Per altra banda, són habituals les incoherències en documents que alteren l'ús normatiu i tradicional del gènere quan es pot referir a persones. Aquestes incoherències poden arribar, fins i tot, a crear dubtes d'aplicació de disposicions normatives si l'intèrpret suposa que la segregació de gèneres s'hi introdueix de manera voluntària i significativa (per exemple "Convocatòria d'ajuts per a families amb nins i nines menors de tres anys»).

Ateses aquestes consideracions, sol-licitam la modificació dels usos esmentats, que s'haurien de corregir d'acord amb els criteris que exposam a continuació i que haurien de ser els seguits sempre en la documentació de l'administració:

1. Sempre que un text es refereixi a una persona concreta cal usar el gènere corresponent al sexe d'aquesta persona.

2. Per a referir-se a qualsevol col·lectiu d'homes i dones cal utilitzar les formes no marcades de manera sistemàtica: els professors, els alumnes, els estudiants, els signants, els destinataris, etc. No s'han d'usar les formes dobles (els professors i les professores o els professors/les professores) ni paraules abstractes o noms d'institucions que poden dur a confusió. No és el mateix el Gerent o la Gerent i la Gerència, el Secretari o la Secretària i la Secretaria, etc.

3. Cal distingir els càrrecs referits a persones concretes i els càrrecs com a figura. En el primer cas s'ha d'usar el gènere pertinent ("la Rectora ha inaugurat...", "Cessament de la directora X»), mentre que en el segon s'ha d'usar la forma no marcada (per exemple, en els Estatuts, "el Rector és el màxim responsable...", "el Síndic de Greuges vetlarà per...»). Les referències a places o ocupacions s'han de fer amb la forma no marcada ("Es convoca una plaça de tècnic especialista....).

4. En tota la documentació oficial (per exemple en l'expedició de títols) s'ha de fer constar la forma no marcada: Titol de Graduat en Geografia, Titol de Doctor en Física. La raó és que es tracta de nocions fixades, independents del sexe del titulat, de manera semblant a la invariabilitat dels termes drets d'autor o tinent de batle.

5. En català les paraules professorat i alumnat són un calc de les corresponents castellanes, i el model de llengua de l'administració pública i de les instàncies educatives, que ha de ser genui, hauria de prescindir de la segona i reservar la primera per al significat que té en la majoria de llengües europees (l'exercici, la funció i el càrrec del professor). En qualsevol cas, aquestes paraules s'usen amb sentit de "col-lectiu», no de pluralitat, i no tenen el mateix significat que els plurals de professor i alumne. Aixi, per exemple, «En Miquel, na Maria i en Pere són professors que m'han marcat» no és substituïble per "En Miquel, na Maria i en Pere són professorat que m'ha marcat».

Els punts 1, 2, 3 i 4 són aplicables al català i a totes les Ilengües romàniques.

Palma, 26 de juny de 2009.

http://www.uib.es/depart/dfc/gresib/declaraciogenere.pdf 


\subsection{Gèneres discursius i models de llengua}

\subsubsection{El concepte de gènere}

Hem dit més amunt que els gèneres són formes relativament estables dels enunciats. Aquestes formes s'han anat adaptant al llarg dels segles a les necessitats comunicatives dels diversos àmbits discursius (literari, quotidià, jurídic, periodístic...) i a les exigències de cada moment històric. De fet, el primer intent d'establir una teoria dels gèneres es troba en la Poètica d'Aristòtil. Els gèneres són formes de distingir i classificar els textos d'un determinat àmbit d'ús lingüístic (el literari, per exemple, o el periodístic), però també són una forma de comprendre la diversitat discursiva i una espècie de manual d'ús que facilita els processos de comprensió i producció, oral i escrita. De fet, els gèneres constitueixen una mena de filtres o convencions comunicatives que contenen instruccions implícites imprescindibles a l'hora de redactar un text concret i, al mateix temps, comporten fórmules d'interpretació, un estil propi i una funció específica.

Segons Bakhtin, els gèneres estan determinats per tres dimensions complementàries: el contingut temàtic, la composició o estructura i l'estil (o els recursos expressius). L'ús de la llengua es du a terme en forma d'enunciats (orals i escrits) concrets i singulars que per-
tanyen als participants d'una o l'altra esfera de la praxis humana. Aquests enunciats reflecteixen
les condicions específiques i l'objecte de cadascuna de les esferes, no només pel seu contingut
(temàtic) i pel seu estil verbal, és a dir, per la selecció de recursos lèxics, fraseològics i grama-
ticals de la llengua, sinó, prioritàriament, per la composició o estructuració. Els tres moments
esmentats -el contingut temàtic, l'estil i la composició- estan vinculats indissolublement en la
totalitat de l'enunciat i es determinen, d'una forma semblant, per l'especificitat d'una esfera
concreta de la comunicació. Cada enunciat és, evidentment, individual, però cada esfera d'ús de
la llengua elabora els seus tipus relativament estables d'enunciats, que són anomenats gèneres
discursius.

Bakhtin, 1982: 248

Així, en el cas dels gèneres literaris, la funció social i les exigències de la poesia (formals, estructurals i temàtiques) són diferents de la funció i de les exigències de la narrativa, del teatre, de l'assaig o, del gènere epistolar o de la literatura de viatges. I, en el cas específic del teatre, també són radicalment diferents les convencions d'escriptura i les formes de recepció i de posada en escena de la comèdia, el drama, el sainet o l'acte sacramental, per posar alguns exemples. I el mateix podem dir del periodisme o del discurs acadèmic.

Els gèneres, per tant, «contribueixen a establir relacions més o menys fixes i determinades entre les formes i els continguts» (Gomis, 1989: 130) i ens ajuden a situar i a comparar i, per tant, a veure com està fet un text i a comprendre'l millor. Són formes que contenen estratègies comunicatives i artificis estètics que posen a disposició de l'escriptor o del periodista, que han anat evolucionant amb el temps i que permeten indagar les relacions entre temàtica i estructura del text, entre forma $\mathrm{i}$ història. 
Els gèneres periodístics tenen evidents punts de contacte amb els gèneres literaris, però presenten també algunes particularitats condicionades per les exigències del contracte enunciatiu que s'estableix entre els mitjans de comunicació i el públic i per la relació que manté el contingut de la comunicació de masses amb l'univers de referència.

\subsubsection{Els gèneres periodístics}

Els gèneres periodístics són també, com els gèneres literaris, principis d'ordre que permeten classificar els textos i determinen el tipus de relacions que s'estableixen entre la forma $\mathrm{i}$ el contingut, senyals al lector perquè sàpiga què trobarà, respostes formals a necessitats d'expressar un determinat tipus d'informació (un tipus de contingut específic). Constitueixen matrius formals que permeten, en definitiva, adaptar el discurs i el llenguatge a situacions de comunicació específiques. Ara bé, tot $i$ aquestes coincidències, entre els gèneres literaris $i$ els periodístics hi ha diferències evidents que fan encara més necessària l'existència dels gèneres periodístics.

D'aquestes diferències se'n deriven conseqüències i el resultat és que l'acord sobre gèneres periodístics és de bon tros més necessari que l'acord sobre els gèneres literaris. [...]

La literatura és avui, en termes generals, literatura d'autor. Un autor fa una obra amb una gran llibertat. Una altra cosa és que aquesta obra es publiqui o no, que es representi o es quedi al calaix. Ningú, però, discuteix que l'obra literària és en principi una creació personal, individual. Mentre que el text periodístic passa generalment per diferents mans i és sovint el resultat d'una negociació, d'un encàrrec, d'un acord sobre l'enfocament, l'extensió i, per descomptat, el gènere. Es redacta una notícia, s'escriu un reportatge, es fa una crònica, es prepara un editorial, etc. El treball de redacció pren com a referència constant i diària l'existència d'uns gèneres. Els gèneres permeten la comprensió i la col-laboració d'un equip de treball que fa un producte en ben poc temps: un diari, un noticiari radiat, un telenotícies o telediari.

Gomis, 1989: 132-133

A l'hora de classificar els gèneres periodístics, la funció o intencionalitat comunicativa és el criteri que permet una agrupació més interessant des del punt de vista pràctic. Així, tradicionalment es distingeix entre quatre funcions prioritàries: informar, clarificar, actuar i contactar. I per donar resposta a aquestes quatre funcions comunicatives elementals han sorgit i s'han desenvolupat quatre macrogèneres ben diferenciats: els gèneres informatius, els gèneres d'opinió, els gèneres d'entreteniment $\mathrm{i}$ els gèneres publicitaris. L'esquema següent presenta els diferents gèneres periodístics situats en els àmbits corresponents. Convé, però, tenir en compte l'existència d'alguns gèneres híbrids (com ara l'entrevista, la crònica o l'acudit gràfic) que ocupen una zona fronterera entre dues o més funcions i que, per tant, comparteixen algunes característiques discursives de diferents espais o macrogèneres. 


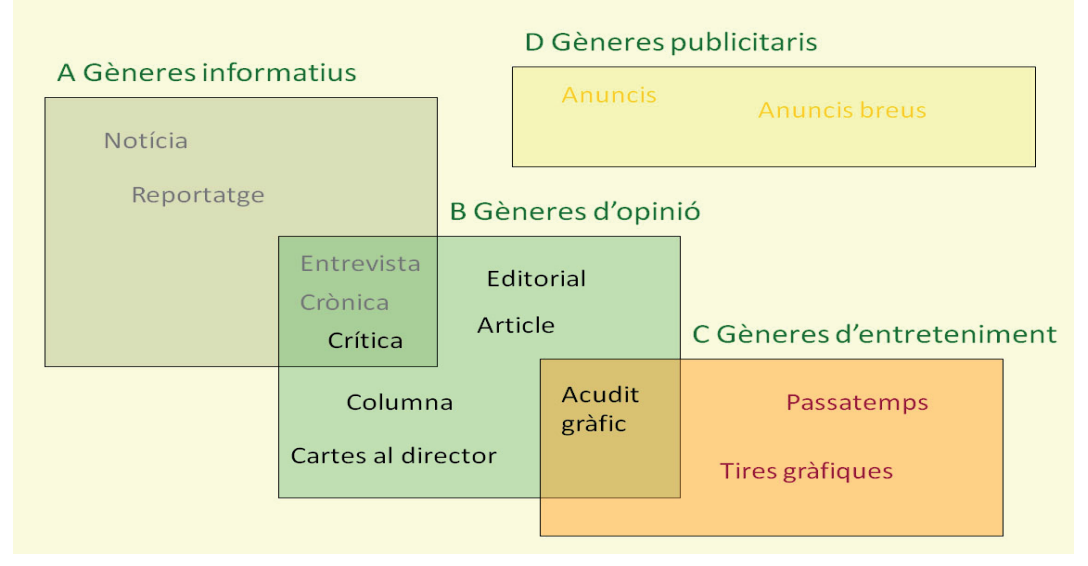

Fig. 11. Els gèneres periodístics

Els gèneres periodístics són fórmules per a la interpretació, una estratègia de producció que conté un seguit d'instruccions per al lector associades a cadascun dels gèneres i que, per tant, facilita la lectura del periòdic. Així, com diu Llorenç Gomis, el periodista fa el que fa i el lector sap el que llegeix. Cada gènere té una forma i tracta de produir uns efectes. I gràcies als diferents gèneres, el diari multiplica els seus recursos (Gomis, 1989: 140).

Finalment, cal insistir en la importància de la teoria dels gèneres en l'ensenyament del periodisme. De fet, els gèneres constitueixen la columna vertebral dels estudis de comunicació: estudiar com es fa una notícia, un reportatge, una entrevista, una crònica, una crítica, un article, un editorial «és més que seguir la disciplina d'unes normes» (Gomis, 1989: 140); és «comprendre la funció d'un text en un mitjà d'informació», imitar per aprendre com es redacta un determinat text i, alhora, analitzar i reflexionar sobre què passaria si no es fes així.

\subsubsection{Els gèneres televisius}

Els espais televisius, o textos televisius, són les unitats mínimes de programació, però sovint una sèrie de textos televisius comparteixen diverses característiques $\mathrm{i}$ donen lloc a un programa determinat. D'altra banda, és evident que hi ha programes molt similars entre si i que aquesta proximitat dóna lloc a diversos subgèneres i a conjunts més extensos que podem anomenar gèneres televisius i que posseeixen unes característiques comunes.

Més amunt hem vist que els gèneres són formes convencionals dels discursos a les quals s'ajusten tots els textos que comparteixen unes característiques comunicatives i discursives determinades. En el cas del discurs televisiu, els criteris essencials que permeten la identificació i caracterització dels diferents gèneres són els següents:

- la intencionalitat o funció comunicativa dominant,

- el mode discursiu (implicat o autònom, directe o diferit), 
- les seqüències textuals dominants (explicativa, narrativa, argumentativa, etc.) i els elements centrals de l'estructura textual,

- la relació amb el referent (imitació del món real, idealització, món de ficció, etc.),

- el tipus d'enunciació (plural, evident, oculta, figurada, sofisticada) i el grau de modalització (elevat, variable o baix), i

- el to o clau (emotiu, personal, optimista, humorístic, seriós, etc.).

L'aplicació d'aquests criteris a la programació televisiva permet identificar set grans macrogèneres, cadascun dels quals inclou diversos gèneres i programes:

\begin{tabular}{llll}
\hline Gèneres & Funció dominant & Seqüències & Programes inclosos \\
\hline Informatius & Informar & Narració, explicació & $\begin{array}{l}\text { Noticiaris, reportatges } \\
\text { i documentals... }\end{array}$ \\
\hline Gèneres d'opinió & Orientar l'opinió & Diàleg, argumentació & $\begin{array}{l}\text { Entrevistes, tertúlies, } \\
\text { debats... }\end{array}$ \\
\hline $\begin{array}{l}\text { Publicitat } \\
\text { Narrativa }\end{array}$ & Actuar & Argumentació & $\begin{array}{l}\text { Espots, } \\
\text { publireportatges, } \\
\text { bandes... }\end{array}$ \\
\hline $\begin{array}{l}\text { Retransmissions } \\
\text { en directe }\end{array}$ & Distreure & Narració & $\begin{array}{l}\text { Pel·lícules, telesèries, } \\
\text { dibuixos... }\end{array}$ \\
\hline $\begin{array}{l}\text { Programes } \\
\text { d'entreteniment }\end{array}$ & Distreure & Narració, descripció & $\begin{array}{l}\text { Retransmissions } \\
\text { esportives, actes } \\
\text { culturals... }\end{array}$ \\
\hline \begin{tabular}{l} 
Magazines \\
\hline
\end{tabular} & Distreure & Diàleg & $\begin{array}{l}\text { Reality shows, } \\
\text { concursos, acudits, } \\
\text { converses.. }\end{array}$ \\
\hline
\end{tabular}

Fig. 12. Els gèneres televisius

\subsubsection{Multimodalitat i gèneres audiovisuals}

El concepte de discurs multimodal o multimèdia sorgeix lligat a l'emergència de les noves tecnologies de la informació i la comunicació (Internet, CD-ROM, DVD...) i apareix associat al concepte d'informació digital. Per tant, quan parlem de multimèdia o multimodalitat fem referència a productes comunicatius que integren un conjunt molt heterogeni d'elements expressius (textuals, gràfics, musicals, figuratius, cinematogràfics...), amb el suport, sovint, de la tecnologia digital i integrats en una unitat superior, el producte multimèdia, que es caracteritza per la interactivitat -que permet la creació d'itineraris d'ús individualitzats-i la hipertextualitat -l'existència d'enllaços que permeten la navegació a la carta. D'aquesta forma, el discurs multimèdia és un discurs que integra, sobre un material de referència textual (una enciclopèdia electrònica, per exemple) o audiovisual (un joc d'ordinador o una pel·lícula en DVD), una amplíssima gamma de recursos d'àudio 
(veu, música, sorolls...), d'imatges estàtiques (fotografies, dibuixos, gràfics...) o d'elements gràfics en moviment.

Pel que fa als gèneres multimèdia, a hores d'ara encara resulta difícil d'oferir un panorama exhaustiu perquè es tracta d'un àmbit extraordinàriament dinàmic, de creació recent, que està sotmès a un continu procés de canvi i d'adaptació a l'aparició de noves tecnologies. Això no obstant, es poden distingir, provisionalment, quatre grans espais o àmbits genèrics:

a) el llibre electrònic i els altres productes de base textual, com ara les enciclopèdies, els diccionaris i les publicacions periòdiques (diaris, revistes de temàtica general i revistes especialitzades) i els llocs web;

b) la narrativa audiovisual comercialitzada en DVD (pel·lícules, telesèries, documentals...) o en línia;

c) els productes d'àudio (la música i els programes de ràdio digital) i els programes televisius, $\mathrm{i}$

d) els jocs multimèdia interactius.

La indústria multimèdia sorgeix de les possibilitats de digitalització i d'interactivitat de la informació i s'insereix dins les lògiques dels sectors culturals tradicionals. Per aquesta raó, és difícil parlar d'un sector multimèdia independent.

La principal transformació que es deriva de les tecnologies digitals és la possibilitat de versionar els productes. D'una banda, se simplifica el procés de creació, producció i difusió, però, de l'altra, es complica i encareix en multiplicar-se les opcions (diversos formats, accés a la carta, etc.), la qual cosa ha obligat a la creació dels grans grups multimèdia (el Grup Planeta amb Planeta Actimedia, Planeta-UOC, Estubroker; el Grup Enciclopèdia Catalana amb Interedi, Ensenyament Obert, o la Corporació Catalana de Ràdio i Televisió amb TVC Multimèdia, etc.).

A hores d'ara, els reptes que plantegen els nous gèneres creatius multimèdia a la cultura catalana són els següents:

- dotar el producte digital d'un valor afegit que permeta a les empreses afrontar el repte de la coexistència dels mateixos continguts en versió analògica i digital;

- adaptar-se a una nova organització del treball, atesos els perfils professionals emergents i les noves formes de treball;

- enfortir l'estructura institucional i empresarial del multimèdia, $\mathrm{i}$

- planificar polítiques públiques flexibles, amb pressupostos específics i instruments legals adequats per assumir el risc associat a l'elevat grau d'innovació d'aquest tipus de productes. 


\subsubsection{Els gèneres publicitaris}

La publicitat és, sens dubte, un dels fenòmens més emblemàtics de les societats contemporànies, una autèntica marca d'època. Quan parlem de publicitat ens referim a un conjunt molt heterogeni de pràctiques discursives la finalitat de les quals és estimular l'adquisició de productes comercials o modificar l'opinió o la conducta dels ciutadans. El discurs publicitari té, per tant, una dimensió essencialment argumentativa i persuasiva, i constitueix una estructura essencial de la societat de consum. Tot i que la importància del fenomen publicitari en la societat actual explica per ella mateixa l'interès per l'estudi científic de la comunicació publicitària, existeixen una sèrie d'arguments complementaris que justifiquen l'interès científic i social de la investigació sobre el funcionament del discurs publicitari.

En primer lloc, la ubiqüitat de les manifestacions publicitàries. La publicitat ha ocupat tots els àmbits de la vida social, des dels espais més diversos de la vida pública fins els racons més íntims de les relacions personals. Aquesta expansió s'ha produit amb el suport dels mass media $\mathrm{i}$ ha tingut repercussions importants en el seu desenvolupament.

D'altra banda, s'ha incrementat sensiblement el caràcter fagocitari i absorbent de tots els gèneres publicitaris i, per tant, s'han produït interessants fenòmens d'intertextualitat. Els textos publicitaris utilitzen prolíficament imatges, idees, paraules i ritmes procedents d'àmbits ben diversos (literatura, cinema, art, música, etc.) i han contribuït decisivament a contaminar tots els productes discursius contemporanis d'un ritme i d'un estil marcadament «publicitaris».

A més, el discurs publicitari té uns efectes psicosocials inevitables, i sovint imprevisibles, sobre les formes de pensament i sobre els estils de vida de la humanitat contemporània, particularment evidents en la creació i el manteniment de valors, tòpics, símbols i mites. L'ésser humà deixa de ser gradualment un animal que pensa $\mathrm{i}$ es converteix en un animal que mira i consumeix. I en aquest procés de transformació, el discurs publicitari té un paper determinant.

Finalment, el discurs publicitari constitueix un dels àmbits més dinàmics de la semiosfera contemporània, un dels més canviants. En aquest sentit, durant els últims vint anys s'han consolidat algunes tendències decisives que, sense pretensions d'exhaustivitat, apunten cap a tres direccions complementàries: $a$ ) potenciació de la dimensió argumentativa sobre la informativa, especialment a través de la seducció i la persuasió; $b$ ) predomini dels continguts implícits i les connotacions sobre la informació explícita i racional, i c) substitució de la força agressiva de l'imperatiu per estratègies discursives més subtils, lligades a l'ús dels actes de parla indirectes.

Pel que fa als gèneres publicitaris, els especialistes han presentat intents de classificació molt diversos, entre els quals ens interessa ara destacar dues perspectives complementàries: 
a) D'una banda, la classificació dels productes publicitaris utilitzant com a criteri el mitjà o suport de transmissió: la televisió, el cinema, la ràdio, el periòdic i els espais exteriors. Segurament, caldria afegir encara un dels suports més utilitzats actualment, la publicitat directa, a través del correu convencional, del correu electrònic o a través de la bústia i d'altres ubicacions sobre els objectes personals (cotxes, carpetes, roba, etc.).

b) De l'altra, la perspectiva dels models de creació, que permet distingir els anuncis descriptius i explicatius (amb el tipus problema-solució, les demostracions i la publicitat comparativa), els anuncis testimonials (que tenen un caràcter essencialment dialogat i inclouen la col-laboració de presentadors o testimonis, experts, persones famoses, persones corrents o personatges insòlits) i els anuncis narratius (que basen l'efecte en la dramatització d'una petita història).

\subsection{Els llibres d'estil}

Els llibres d'estil són una eina fonamental per al treball dels periodistes i, en general, de totes les persones que han de redactar documents per als mitjans de comunicació. Es tracta de reculls molt heterogenis de criteris de redacció i de producció textual, escrita i oral, l'objectiu dels quals és oferir suport $i$ assessorament als professionals $i$ alhora establir les condicions bàsiques perquè el discurs del mitjà que pretenen regular presente un grau remarcable d'homogeneïtat i de coherència formal, tant a nivell estrictament lingüístic com a nivell de presentació.

En general, aquests materials ofereixen un resum de la normativa ortogràfica $\mathrm{i}$ gramatical aplicada al mitjà específic a què s'adrecen, però també recullen habitualment les normes d'ús dels signes de puntuació, criteris per a l'ús de la tipografia o per a la selecció lèxica i un compendi d'aspectes diversos de caràcter estilístic.

En el cas català, els llibres d'estil sorgiren en l'àmbit del periodisme escrit durant els anys vuitanta i noranta (Avui, 1997; Coromina, 1991), però la consolidació del mitjà radiofònic i de la televisió va crear la necessitat de publicar materials adaptats als nous mitjans (Casals, 2003; Agulló-Camps, 2006) i, més recentment, l'aparició i el desenvolupament dels mitjans digitals en línia ha provocat la publicació de llibres d'estil per a mitjans com Vilaweb (2005), la Viquipèdia (2009) o l'Agència Catalana de Notícies (Ferré-Nogué, 2010), així com reflexions interessants sobre el periodisme electrònic (Micó, 2006). Tot i que el contingut i l'orientació dels llibres d'estil tradicionals i dels materials per als nous mitjans són ben diferents, en el fons tots mantenen una orientació similar i conserven l'objectiu central de garantir la coherència global de la comunicació, oral i escrita. 


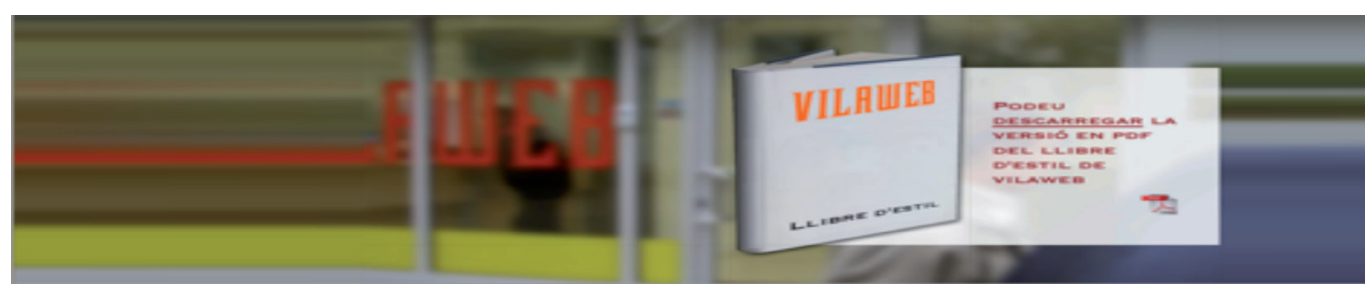

Fig. 13. Llibre d'estil de Vilaweb (http://10anys.vilaweb.com/llibreestil/)

Un exemple excel·lent de llibre d'estil és la pàgina web dels serveis lingüístics de la Corporació Catalana de Ràdio i Televisió, És a dir, que ofereix un ventall molt complet d'informació i recursos lingüístics pensats especialment per als professionals de la ràdio i la televisió en català, una actualització permanent $i$ una presentació senzilla i elegant.

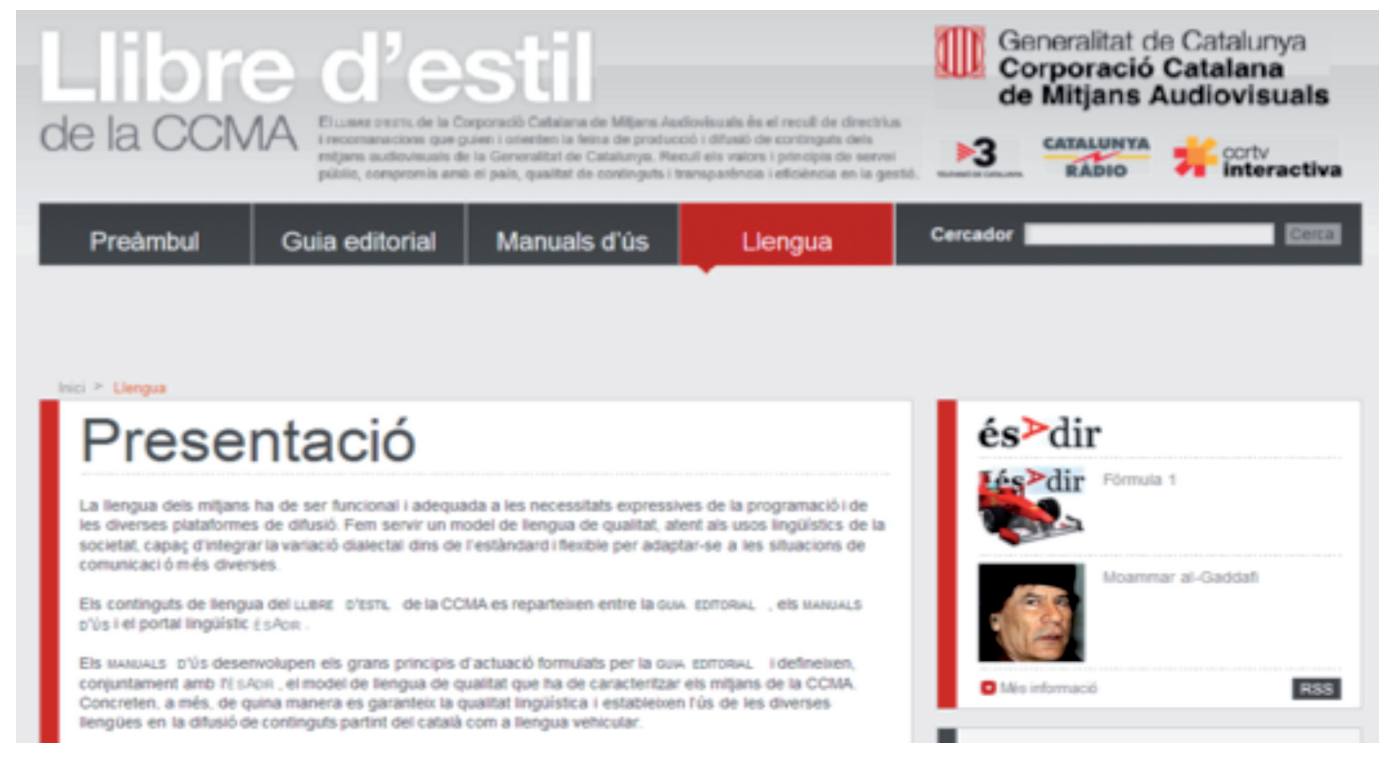

Fig. 14. Llibre d'estil de la CCMA (http://www.ccma.cat/llibredestil/llengua)

Un dels aspectes fonamentals d'aquesta web és l'apartat Model de llengua, que delimita, d'alguna forma, el marc de referència del discurs dels mitjans i presenta els criteris bàsics que n'han orientat l'estructura i el contingut. Amb la voluntat d'oferir un model adaptat a l'oralitat, la característica primera i essencial dels mitjans audiovisuals, es proposen un seguit de criteris, orientacions i continguts que no pretenen imposar una manera de parlar única, sinó establir un marc flexible en què l'expressió lingüística siga sempre la més adequada tenint en compte els diversos gèneres comunicatius amb què han de treballar els mitjans (informatius, magazines, humor, ficció, etc.).

Des del primer moment, tant a la ràdio com a la televisió, vam apostar decididament per un model de llengua que assegurés al màxim una comunicació eficaç amb la nostra audiència. Teníem molt clar que calia optar per un català correcte $\mathrm{i}$, alhora, clar, directe, àgil i genuí, amb preferència per les formes més naturals i espontànies de la llengua.

http://esadir.cat/modeldellengua 
Els criteris bàsics que orienten el model de llengua proposat per als mitjans de comunicació catalans asseguren un català funcional i comunicatiu, apte per resoldre amb èxit les necessitats expressives de la programació audiovisual:

1. Una llengua correcta, que pren com a punt de referència la normativa lingüística vigent $i$ té en compte les diverses obres descriptives que es van publicant sobre l'ús del català actual.

2. Una llengua adequada al mitjà, que ha de prioritzar les solucions lèxiques més properes a l'audiència, tot evitant l'ús de les paraules i construccions arcaïtzants o excessivament literàries.

3. Una llengua actual, que tinga en compte les necessitats comunicatives i els usos lingüístics habituals de la societat contemporània (neologismes, colloquialismes, paraules d'argot...), tot i que algunes expressions encara no apareguen recollides en els diccionaris normatius.

4. Una llengua comuna, basada en la varietat estàndard (sense barbarismes, ni dialectalismes d'àmbit reduït), que és la versió més neutra i la versió compartida per tota la comunitat lingüística, tot i que els mitjans han de reflectir també matisos i accents diferents d'acord amb l'origen dels locutors i presentadors.

5. Una llengua amb varietat de registres, amb capacitat per adaptar-se als diversos gèneres dels mitjans de comunicació (informatius, magazines, transmissions en directe i altres espais de divulgació), condicionats pel tema, el canal, el propòsit i el grau de formalitat.

\section{Lectures recomanades}

BiBILONI, Gabriel (1997): Llengua estàndard i variació lingüística, València, Eliseu Climent.

Carbonell, Jordi (1979): «Elements d'història social i política de la llengua catalana», Treballs de sociolingüistica catalana, 2, p. 87-102.

CAsals, Daniel (2003): El català en antena, Benicarló, Onada.

- i Neus Faura (2010): El català als mitjans de comunicació, Barcelona, Editorial UOC.

FERré, Carme (2008): Barcelona tv. Llibre d'estil, Barcelona, Editorial UOC.

- i Anna Nogué (2010): Llibre d'estil. Agència Catalana de Notícies, Barcelona, Editorial UOC.

Gomis, Llorenç (1989): Teoria dels gèneres periodistics, Barcelona, Generalitat de Catalunya.

Julià-Muné, Joan (2004): El llenguatge de la ràdio i de la televisió, Alzira, Bromera.

Martí, JoAn i Josep M. Mestres (ed.) (2003): «És espontània l'oralitat?», en MartíMestres (ed.) (2003: 197-211).

- (ed.) (2003): L'oralitat als mitjans de comunicació, Barcelona, Institut d'Estudis Catalans. 
— (ed.) (2004): Quin(s) model(s) de llengua escrita per als mitjans de comunicació?, Barcelona, Institut d'Estudis Catalans.

El Periódico (2002): Llibre d'estil. El Periódico de Catalunya, Barcelona, Primera Plana.

RuIz, Francesc (1996): Història social i política de la llengua catalana, València, Eliseu Climent.

SALVADOR, Vicent (2010): «L'eufemisme, entre la retòrica i la política», en MARÍN, Maria Josep i altres (ed.) (2010: 133-159).

SolÀ, Joan (1995): Llibre d'estil de l'Ajuntament de Barcelona, Barcelona, Consorci per a la Normalització Lingüística / Ajuntament de Barcelona.

Tuson, Jesús (1988): Mal de llengües, Barcelona, Empúries.

VAllverdú, Francesc (2000): El català estàndard i els mitjans audiovisuals, Barcelona, Edicions 62 / Televisió de Catalunya. 


\section{ORALITAT I ESCRIPTURA EN CONTEXTOS COMUNICATIUS MULTIMODALS}




\section{TEMA 3}

\section{L'estàndard oral català}

Introducció

1. Discurs oral i discurs escrit

2. L'oral formal, entre l'oralitat i l'escriptura

3. Criteris d'elocució estàndard

4. Qüestions de morfosintaxi per a l'estàndard oral

5. Estàndard oral i selecció lèxica

6. L'estàndard oral en els mitjans audiovisuals

Lectures recomanades 


\section{Introducció}

L'oralitat i l'escriptura constitueixen dues formes discursives prototípiques determinades, essencialment, pel canal de comunicació utilitzat, però entre l'una i l'altra existeix un inventari extens de gèneres discursius fronterers que comparteixen característiques d'aquests dos modes discursius bàsics. Si la conversa espontània constitueix el gènere més emblemàtic dels discursos orals informals, a l'altre extrem del mapa trobem el discurs escrit de caràcter expositiu i argumentatiu, que es caracteritza per un grau elevat de formalitat i per una altíssima gramaticalitat. I en la transició d'un àmbit a l'altre emergeix amb força un conjunt de formes discursives molt diverses que es caracteritzen per l'ús d'un model de llengua oral formal, és a dir, per un model de llengua que, tot i que utilitza el codi oral, s'apropa molt a les solucions gramaticals del codi escrit $i$, a nivell articulatori, s'allunya del relaxament de la fonètica pròpia dels usos espontanis del català col·loquial.

Aquest tema, dedicat a reflexionar sobre l'oralitat i l'escriptura, presenta algunes qüestions fonamentals que poden ajudar a entendre la importància de l'estàndard oral en l'àmbit dels mitjans de comunicació de masses. A partir de la ubicació de l'oral formal en l'àrea d'intersecció que es dibuixa entre els territoris complexos de l'oralitat i l'escriptura i la caracterització d'aquesta modalitat de la llengua oral, s'intenten delimitar els perfils de l'estàndard oral català.

Així, en la part central del tema, es presenten els criteris d'elocució estàndard des d'una triple perspectiva, que fa referència als aspectes fonètics, a les qüestions de morfosintaxi i a la problemàtica de la selecció lèxica. Finalment, hem cregut oportú d'oferir algunes reflexions sobre el tema de l'estàndard oral en els mitjans de comunicació, per tal de pensar en quines condicions i en quin tipus de programes cal emprar un model oral formal i en quines altres sembla més adient d'utilitzar un oral més proper al registre col-loquial. Es tracta, per tant, de plantejar la necessitat de definir dos models d'estàndard oral (un oral formal i un oral informal) i d'acordar quins criteris n'han de determinar l'ús d'un o de l'altre en la producció audiovisual en català, per tal de trobar el punt d'equilibri necessari entre la qualitat lingüística i la versemblança, entre la correcció i la credibilitat.

\subsection{Discurs oral i discurs escrit}

\subsubsection{Oralitat i escriptura}

La distinció entre els registres orals i els escrits, entre l'oralitat i l'escriptura, és una dicotomia que compta amb una llarga tradició en la història de la lingüística i en el camp de l'anàlisi del discurs. La llengua oral és la llengua per excel·lència -de fet, moltes llengües només tenen manifestació oral, i en el procés d'aprenentatge natural d'una llengua, el codi oral s'adquireix abans que l'escrit-, però, curiosament, és la modalitat menys estudiada. L'escriptura, en canvi, ha estat 
una modalitat més estudiada i és més ben coneguda, s'acosta més al model de correcció que defineix la normativa gramatical i ha tingut històricament un prestigi del qual no ha gaudit l'oralitat.

Actualment, sembla clar, però, que la dualitat entre oralitat i escriptura, allò que es concebia com una dicotomia oral/escrit, sense zones intermèdies, és en realitat una gradació, amb àrees d'intersecció i zones intermèdies d'adscripció dubtosa. Aquesta nova perspectiva sobre les relacions entre oralitat i escriptura exigeix la consideració, al costat del canal (oral/escrit), d'un altre factor fonamental: el grau de planificació o preparació del text.

Michael Gregory i Susanne Carroll (1978), seguint la línia dels estudis de Halliday, van presentar un interessant esquema, en forma d'arbre, que permet fer-se una idea bastant aproximada de les complexes relaciones entre l'oral i l'escrit:

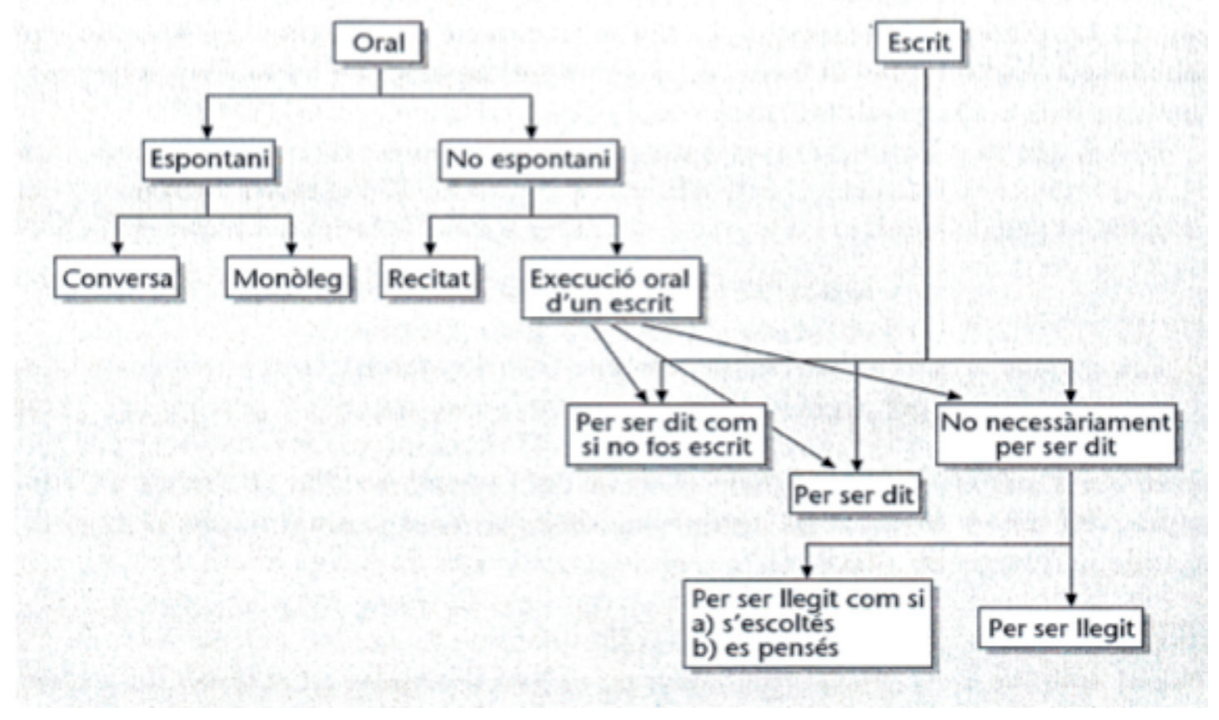

Fig. 15. Les relacions entre l'oral i l'escrit (font: Gregory-Carroll, 1978)

Aquesta estructura arbòria permet situar i relacionar entre si una amplíssima gamma de gèneres discursius, orals i escrits, i posa en evidència l'existència d'una zona intermèdia on apareixen productes discursius força interessants. Així, a l'esquerra trobem el text més prototípic de l'oralitat (la conversa espontània) i, a continuació, el monòleg espontani (no gaire freqüent) i els textos orals preparats (memoritzats o recitats).

En la zona intermèdia de l'arbre, on es produeix la confluència de les dues modalitats, apareixen els textos orals que són resultat de l'execució d'un text escrit previ, és a dir, produccions orals a partir de textos escrits que s'utilitzen com a base, com ara un text oral llegit, un monòleg oral a partir d'uns apunts previs o una intervenció oral que utilitza com a suport una presentació preparada amb l'ajut d'un programa informàtic.

En la part dreta del quadre trobem els textos escrits per ser dits com si no foren escrits (per exemple, els diàlegs d'una obra de teatre), els textos escrits per ser 
dits (com ara els sermons o les notícies de ràdio i televisió), els textos escrits per ser llegits com si s'escoltara o es pensara (com ara els diàlegs d'un conte o els monòlegs interiors) i, finalment, els textos escrits no necessàriament per ser dits, sinó per ser llegits (per exemple, una carta).

Aquest esquema, que s'hauria d'actualitzar per poder incorporar les modalitats més recents que s'han generat en l'ús dels mitjans de comunicació i de les noves tecnologies (com ara els xats, els correus electrònics o els missatges de mòbil), «té la virtut de fer-nos veure que quan parlem d'oral i escrit sense més adjectius o especificacions ho fem perquè tenim in mente unes situacions prototípiques gairebé antagòniques» (Payrató, 2003: 188). El mateix Payrató ho expressa amb claredat:

a) Pel que fa a l'oralitat, la immediatesa i la copresència, la contextualització (o el pes de la referència exofòrica), la retroalimentació instantània del receptor, el canal vocal-auditiu, el codi fònic, el paper de l'entonació, de molts marcadors discursius i dels codis paralingüístics vocals i gestuals.

b) Pel que fa a l'escriptura, el distanciament, la acontextualitat (o el predomini de la referència endofòrica), la retroalimentació diferida (en el millor dels casos!) del receptor, el canal visual, el codi gràfic, la (quasi total) absència del paper de l'entonació, de certs marcadors discursius i dels codis paralingüístics vocals i gestuals.

Payrató, 2003: 188

\subsubsection{La gradació oral-escrit}

Actualment, sembla clar que l'oposició entre l'oralitat i l'escriptura es presenta, més que com una relació dicotòmica, com una gradació entre dos modes comunicatius, $\mathrm{i}$ que entre el discurs escrit prototípic i el discurs genuïnament oral existeix una extensa nòmina de productes verbals que comparteixen característiques de l'un i de l'altre i que s'aproximen més o menys a un extrem i l'altre de l'eix oral-escrit.

En aquest sentit, sembla útil -per explicar la distinció entre oralitat i escriptura i per comprendre millor la idea de gradualitat entre els dos pols de la gradació- la consideració, almenys, de tres factors complementaris:

a) El canal físic de transmissió del discurs: gràfic/fònic.

b) El mode comunicatiu: oral/escrit.

c) Els paràmetres contextuals, que exigeixen la presa en consideració de les oposicions proximitat/distància (física i social) entre emissor i receptor, espontaneïtat/planificació o narració/persuasió.

Existeixen, doncs, «una sèrie de factors contextuals que incideixen significativament en la forma final dels textos, de manera que el fet de ser transmesos per un canal auditiu o gràfic no resulta totalment determinant» (Castellà-Vilà, 2002: 24). Així, la relació gradual entre oralitat i escriptura pot representar-se gràficament en un esquema a partir de la combinació del caràcter (monòleg/diàleg) i el mode (oral/escrit), o en un quadre d'entrada múltiple en què el mode oral i el mode escrit són el resultat d'una suma de components (fig. 16). 


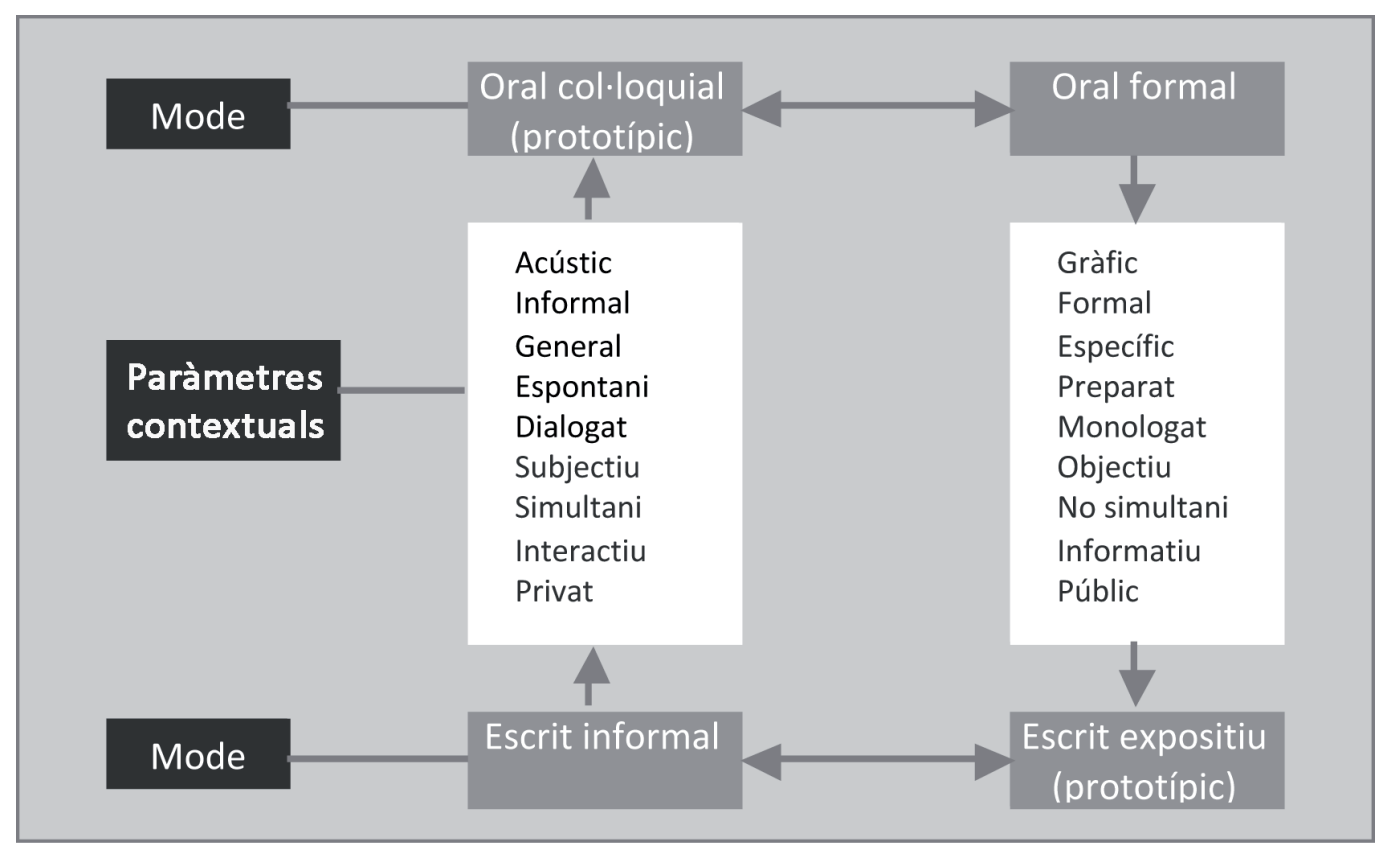

Fig. 16. La gradació oral/escrit i els paràmetres contextuals (font: Castellà-Vilà, 2002)

\subsubsection{L'expansió de l'oralitat: els gèneres discursius secundaris}

En l'escenari comunicatiu que es dibuixa en la societat actual conviuen una gran diversitat de gèneres discursius, orals i escrits, que reforcen la distinció que introduí Bakhtin entre gèneres discursius primaris i gèneres discursius secundaris. Mentre que els primers apareixen en la comunicació immediata, espontània i informal, els gèneres secundaris apareixen en situacions de comunicació més reflexives, més formals i més elaborades (sovint en forma escrita, tot i que també es produeixen en la comunicació oral).

Aquesta distinció es completa amb una visió complementària de la comunicació verbal humana, insinuada ja en la fig. 16, que permet distingir entre els anomenats gèneres prototipics (l'oral col-loquial i l'escrit expositiu), que concentren la major part de les característiques associades amb la llengua oral o amb la llengua escrita, i els gèneres intermedis (entre els quals se situa l'oral formal i l'escrit informal), que constitueixen un continuum entre els dos pols prototípics i que, de fet, «comparteixen en proporcions diverses característiques dels dos pols» (Castellà-Vilà, 2002: 26).

En l'àmbit de l'oralitat, aquesta distinció permet identificar un gènere prototípic, la conversa espontània, que representa d'una forma excel·lent l'oralitat quotidiana, natural, no planificada i de tema general, un gènere primigeni en l'ús del llenguatge i compartit per tota la humanitat i totes les civilitzacions. I, al seu costat, un ample ventall de gèneres orals, més o menys propers a l'escrit prototípic, que es poden agrupar en dos grans grups: 
a) Gèneres dialogats (de gestió compartida): entrevistes, reunions de treball, tertúlies, debats radiofònics o televisius, debats parlamentaris, taules redones, etc.

b) Gèneres monologats (de gestió unilateral): classes magistrals, exposicions orals de l'àmbit acadèmic, conferències, mítings electorals, sermons, discursos parlamentaris, intervencions dels advocats i dels fiscals en un judici, presentacions d'informes o projectes, exposicions dels temes d'una reunió, etc.

\subsection{L'oral formal, entre l'oralitat i l'escriptura}

La llengua oral formal ocupa, com acabem de veure, un lloc perifèric en l'àmbit de l'oralitat, que resulta intermedi entre l'oralitat i l'escriptura. D'acord amb aquesta posició, l'oral formal presenta una sèrie de característiques específiques, tant des del punt de vista contextual com des de la perspectiva textual i lingüística.

Josep M. Castellà i Montserrat Vilà ofereixen un quadre de síntesi, molt interessant, que presenta la relació entre la llengua oral formal i la llengua escrita a partir de tres columnes que permeten visualitzar d'una forma molt clara la proximitat de l'oral formal a l'oralitat o a l'escriptura.

Les característiques que es presenten en aquest quadre són molt generals $\mathrm{i}$, per tant, poden concretar-se de formes diferents en els diversos gèneres discursius en què s'utilitza la llengua oral formal. Així, per exemple, la distància respecte a l'auditori o el caràcter monologat o dialogat de la interacció no són els mateixos en la lectura d'una tesi doctoral (o en l'acte d'obertura d'una sessió parlamentària) que en una exposició oral a l'aula. I és evident, també, que el grau de reflexió i de preparació prèvia, el nivell de redundància, la llibertat en l'estructuració discursiva o les convencions que regeixen el procés de producció són molt diferents en els diversos gèneres orals.

Segons Josep M. Castellà, la llengua oral formal presenta una fesomia gramatical pròpia, que es concreta en unes característiques lèxiques, sintàctiques i cohesives específiques.

La llengua oral formal té una especificitat en la construcció gramatical, resultat de la producció monologada en temps real i, alhora, de la voluntat explícita d'aproximar-se a l'estructuració sintàctica de l'escriptura. El resultat és un estil discursiu intermedi entre les característiques de l'oralitat i de l'escriptura prototípiques, que presenta, però, un caràcter propi en alguns trets (per exemple, el nombre de construccions de subordinació). No té, doncs, de cap manera la simplicitat gramatical que erròniament s'ha assignat a les formes orals de llenguatge. Tampoc no és, però, tan similar com semblaria a la llengua escrita que pretén imitar, cosa que es percep amb molta més claredat en una transcripció que en la situació real d'audició, en què l'oient reconstrueix o repara de manera automàtica les vacilllacions i els canvis de rumb sintàctic.

D'acord amb aquests principis descriptius, l'aprenent d'orador ha de cercar en molts aspectes el punt mitjà entre l'oralitat i l'escriptura: ha de fer un esforç d'aproximació a l'escriptura, però sense arribar a la mera reproducció d'un text escrit; ha de ser més precís i elaborat que en el discurs col·loquial, però també ha resultar més esponjós i desimbolt que en la llengua escrita. La llengua oral formal consisteix en aquest equilibri, que és el que li dóna una fesomia pròpia. 
Aquesta fesomia pròpia de la llengua oral formal es concreta en les característiques generals i en els trets gramaticals que es presenten en la fig. 17.

\begin{tabular}{|c|c|}
\hline \multicolumn{2}{|c|}{ La llengua oral formal } \\
\hline Característiques generals & Trets gramaticals \\
\hline A. Trets contextuals & A. Característiques generals \\
\hline $\begin{array}{l}\text { 1. Caràcter no universal i aprenentatge escolar. } \\
\text { 2. Acústica, efímera i produïda en temps real. } \\
\text { 3. Context situacional compartit i comunicació } \\
\text { unidireccional. } \\
\text { B. Trets textuals }\end{array}$ & $\begin{array}{l}\text { 1. Té un estil gramatical propi, diferenciat de la } \\
\text { conversa informal i de l'escrit. } \\
\text { 2. Convé defugir la memorització literal i la lec- } \\
\text { tura en veu alta per trobar un estil oral formal } \\
\text { natural, desimbolt i plenament comunicatiu. }\end{array}$ \\
\hline 4. Formal i generalment monologada. & B. Característiques lèxiques \\
\hline $\begin{array}{l}\text { 5. Informativa, planificada i de tema sovint } \\
\text { especialitzat. } \\
\text { 6. Repetitiva i amb intervenció dels llenguatges } \\
\text { no verbals. }\end{array}$ & $\begin{array}{l}\text { 3. Té menys densitat lèxica que la llengua escrita } \\
\mathrm{i} \text { és més repetitiva. } \\
\text { 4. Presenta un nivell important i necessari de } \\
\text { redundància. }\end{array}$ \\
\hline C. Trets lingüístics & C. Característiques sintàctiques i cohesives \\
\hline $\begin{array}{l}\text { 7. Paper fonamental dels trets suprasegmentals. } \\
\text { 8. Ocurrència mitjana d'elements díctics, inter- } \\
\text { rogacions, exclamacions, interjeccions, ana } \\
\text { coluts, el·lipsis i canvis de direcció sintàctica. } \\
\text { 9. Correcció normativa i ús de la varietat } \\
\text { estàndard. }\end{array}$ & $\begin{array}{l}\text { 5. Ocupa un lloc intermedi entre l'estil nominal } \\
\text { i l'estil verbal. } \\
\text { 6. Té més construccions de subordinació que la } \\
\text { conversa informal i que l'escrit. } \\
\text { 7. Cohesió textual elevada: connectors, díctics } \\
\text { discursius, crides al receptor. } \\
\text { 8. Conté un cert nombre de trencaments sin- } \\
\text { tàctics que l'oient sol reparar d'una forma } \\
\text { automàtica. }\end{array}$ \\
\hline
\end{tabular}

Fig. 17. Característiques generals i trets gramaticals de la llengua oral formal

Malgrat la diversitat d'estils, «la major part dels gèneres orals formals comparteixen unes característiques comunes com ara la planificació del contingut, el valor del context, la importància de la prosòdia, una certa redundància informativa i una sintaxi particular» (Castellà-Vilà, 2002: 30).

\subsection{Criteris d'elocució estàndard}

A l'hora de descriure el sistema fonètic del català, cal distingir entre els sons vocàlics $i$ els consonàntics. Mentre que els primers poden ser nuclis sillàbics i, per tant, són unitats fonètiques imprescindibles per poder articular la tira fònica, els sons consonàntics no tenen autonomia prosòdica $\mathrm{i}$ conviuen obligatòriament en el context sil-làbic amb una $\mathrm{o}$ amb diverses vocals.

La distinció entre vocals i consonants exigeix criteris de caracterització específics per al sistema vocàlic i per al consonàntic. Això no obstant, abans de presentar els quadres generals del vocalisme i del consonantisme català, convé tenir en compte els criteris generals i els trets pertinents que se solen utilitzar a l'hora d'identificar i caracteritzar els fonemes i els sons d'un idioma. El quadre següent en presenta una síntesi. 


\begin{tabular}{l|l|l}
\hline \multicolumn{1}{c|}{ Criteri } & \multicolumn{1}{c}{ Sèries (trets pertinents) } \\
\hline Punt d'articulació & $\begin{array}{l}\text { Segons el lloc on es produeix l'acosta- } \\
\text { ment o el contacte dels òrgans actiu i } \\
\text { passiu en qualsevol articulació. }\end{array}$ & $\begin{array}{l}\text { Vocàlics: anteriors o prepalatals, centrals i posteriors } \\
\text { o velars. } \\
\text { Consonàntics: bilabials, labiodentals, dentals, alveo- } \\
\text { lars, prepalatals, palatals i velars. }\end{array}$ \\
\hline Mode d'articulació & $\begin{array}{l}\text { Modulació de l'aire segons l'obertura o o } \\
\text { el tancament del canal bucal. }\end{array}$ & $\begin{array}{l}\text { Vocàlics: quatre graus d'obertura (màxima, intermè- } \\
\text { dia grau 3, grau 2 i mínima). } \\
\text { Graduals o semivocàlics. } \\
\text { Consonàntics: continus (fricatius i aproximants), } \\
\text { oclusius, africats, laterals, vibrants i nasals. }\end{array}$ \\
\hline Sonoritat & Vibració o no de les cordes vocals. & $\begin{array}{l}\text { Són sonors els sons vocàlics i els graduals, nasals, } \\
\text { laterals, vibrants i aproximants. } \\
\text { Els sons oclusius, fricatius i africats es presenten en } \\
\text { forma de parelles sord-sonor. }\end{array}$ \\
\hline
\end{tabular}

Fig. 18. Criteris i trets pertinents

\subsubsection{Els sons vocàlics}

\subsubsection{Les vocals tòniques}

Les vocals són sons que es produeixen sense que la sortida de l'aire expirat trobe cap obstrucció. En català, totes les vocals són sonores; això és, es produeixen amb vibració de les cordes vocals. Generalment són orals, és a dir, s'articulen amb el vel del paladar en tensió, bloquejant el pas de l'aire cap a la cavitat nasal; però ocasionalment poden esdevenir nasals en contacte amb consonants nasals en la seqüència fònica.

Les vocals es poden classificar a partir del grau d'elevació i d'avançament de la llengua i a partir de la posició plana o arrodonida dels llavis. Tenint en compte el grau d'elevació de la llengua, les vocals es classifiquen en altes ([i] i [u]), mitjanes altes $([\mathrm{e}] \mathrm{i}[\mathrm{o}])$, mitjana $([ə])$, mitjanes baixes $([\varepsilon] \mathrm{i}[\mathrm{\jmath}])$ i baixa $([\mathrm{a}])$. Partint del grau d'avançament de la llengua, es classifiquen en anteriors ([i], [e] i $[\varepsilon]$ ), centrals $([\ni] \mathrm{i}[\mathrm{a}])$ i posteriors $([\mathrm{u}],[\mathrm{o}] \mathrm{i}[\mathrm{\jmath}])$. Les vocals posteriors, a més, es produeixen amb labialització o arrodoniment dels llavis. Aquesta caracterització de les vocals apareix esquematitzada en la fig. 19.

\begin{tabular}{|c|c|c|c|c|c|}
\hline \multirow{2}{*}{$\begin{array}{c}\text { Segons el grau } \\
\text { d'elevació lingual }\end{array}$} & \multicolumn{5}{|c|}{ Segons el grau d'avançament lingual } \\
\cline { 2 - 6 } & \multicolumn{2}{|c|}{ anteriors } & centrals & posteriors \\
\hline altes & i & & & & $\mathrm{u}$ \\
\hline mitjanes altes & & $\mathrm{e}$ & & & $\mathrm{o}$ \\
\hline mitjana & & & & ə & \\
\hline mitjanes baixes & & & $\varepsilon$ & & o \\
\hline baixa & & & & $\mathrm{a}$ & \\
\hline
\end{tabular}

Fig. 19. El vocalisme tònic 
La distribució de les vocals mitjanes no és del tot homogènia en el conjunt del domini lingüístic, i en certs casos es constaten vacil-lacions o pronúncies diferents, sobretot en les vocals de la sèrie anterior $([\mathrm{e}] \mathrm{i}[\varepsilon])$. Una part important d'aquestes divergències són motivades pels factors següents:

a) L'evolució de la vocal [e] del llatí vulgar en els dos grans blocs dialectals. A causa d'aquesta evolució, hi ha tota una sèrie de mots que es pronuncien $\mathrm{amb}[\mathrm{e}]$ en nord-occidental i en valencià, $\mathrm{amb}[\varepsilon]$ en central i en determinats parlars baleàrics, i amb [ə] en la resta del baleàric. Es tracta de mots com ara cadena, cera, francès o merèixer. Un nombre més reduït de mots, entre els quals es troben pèl i vel, tenen [ə] en parlars baleàrics $i[\varepsilon]$ en la resta del català. En tots aquests casos són igualment acceptables les diferents pronúncies tradicionals, independentment que queden reflectides o no a través de l'accentuació gràfica.

b) L'adaptació de certs mots cultes. En aquest tipus de mots és fàcil d'observar un predomini de les vocals mitjanes baixes $([\varepsilon] \mathrm{i}[\mathrm{\jmath}])$ en la pronúncia més genuïna. Aquest predomini, tanmateix, no és exempt de vacillacions o de diferències entre els parlars. Per exemple, els mots cultes en -ecte, -ecta, - epte i -epta (defecte, provecta, precepte, inepte/inepta) tenen $[\varepsilon]$ en valencià $\mathrm{i}$ en baleàric, però [e] en altres parlars. En canvi, els mots cultes acabats en -ema (morfema, problema, teorema) i en -ense (castrense, forense) tenen $[\varepsilon]$ en central i $[\mathrm{e}]$ en altres parlars. En aquests casos de vacillació, són igualment acceptables les diferents pronúncies. Amb tot, no és acceptable la tendència a generalitzar les vocals mitjanes altes ( $[\mathrm{e}] \mathrm{i}[\mathrm{o}])$ que es constata sobretot en determinats parlars de sectors urbans a causa, sens dubte, de la imitació de la pronúncia castellana.

c) La tendència a convertir la [o] en [0] en síl·laba inicial (o en monosíl·labs). A causa d'aquesta tendència, en la major part dels parlars, s'ha produit el canvi de [o] en [0] en mots com ara com, crosta, flor, hora, nom, olla, plor, roig, soca, sol i sostre, i presenten vacillació en la pronúncia uns quants mots amb el diftong ou (jou, pou, tou) i diversos mots cultes (corts, mot, vot, zona). En aquests casos, són acceptables les diferents pronúncies. No han seguit, però, aquesta tendència els parlars centrals de transició al septentrional, que mantenen la [o] en tots els casos, ni el septentrional, on tota [o] esdevingué $[\mathrm{u}]$ en l'antic. El septentrional, a més, presenta una altra peculiaritat, ja que la [o], que en certs parlars s'ha convertit en [o], ha esdevingut [u] en síl·laba travada amb nasal: font, pont. És recomanable d'evitar aquesta darrera pronúncia en els registres formals.

La distribució de les vocals mitjanes, $e$ i $o$ obertes i tancades, depèn de factors contextuals (el context fònic en què apareixen) $\mathrm{i}$ de factors purament lèxics. En el cas de la $o$ oberta, predominen els factors lèxics i, per tant, resulta difícil fer generalitzacions que no presenten excepcions. Tot $\mathrm{i}$ això, pot ser útil de recordar els contextos més usuals en què apareixen aquests dos sons. 
En la major part dels mots cultes, especialment en els mots esdrúixols, i en mots amb $i$ o $u$ en síl·laba posttònica.
Pètal, telègraf, anècdota, gènere, gènesi, rèmora, col-legi, exèrcit, èxit, incendi, inèdit, neci, obsequi, misteri, cèl·lula, fècula, ingenu, molècula, perpetu, pèrdua.
Mots acabats en -ència (en català oriental): ciència, innocència o paciència.

Mots com Dénia, sépia, séquia, sénia, llémena, témpores, cérvola, feréstega, llépola i sèmola presenten una certa vacil·lació.
Davant de $\boldsymbol{l}$, simple o geminada.
Arrel, cel, gel, melsa, tela, Feltre i, en valencià, delta i cel·la, novel la, parcel la. $\quad$ selva.

Davant de $r \boldsymbol{r}$.

Ferro, guerra, serra, ter-

ra.

Davant de $\boldsymbol{r}$ seguida d'una altra consonant.
Cert, gerd, perdre, hi- En fan excepció diversos mots vern, perla, verb, verd, en què la segona consonant vèrtex.

és labial: cérvol, herba, serp, terme; en valencià, $\mathrm{erm}$, ferm, tèrbol; Cercs i Berga en la pronúncia local, i, en parlars baleàrics, verd, pronunciada amb vocal neutra.

Hi ha una sèrie de mots que es pronuncien amb $e$ oberta en el central $i$ en certs parlars baleàrics, però amb $e$ neutra en la resta de parlars baleàrics i amb $e$ tancada en l'occidental. Aquesta triple pronúncia és tradicional.
En altres casos, com ara determinats mots amb el diftong $-\boldsymbol{e u}$, uns quants noms $\mathrm{i}$ adjectius amb el grup - $\boldsymbol{n d r}$ - $\mathrm{i}$ certs antropònims.
Deu, fideu, museu, peu, preu; cendra, divendres, gendre, tendre; Josep, Vicenç o Vicent. El diftong - $\boldsymbol{e} \boldsymbol{u}$ es pronuncia amb [e] si la $u$ alterna amb $v$ en una forma flexionada o en mots de la mateixa família: breu/brevetat, greu/gravissim, manlleu/ manllevadis, meu/meva, neu/nevada.

Fig. 20. Contextos en què apareix la vocal $e$ oberta (font: IEC, 2002)
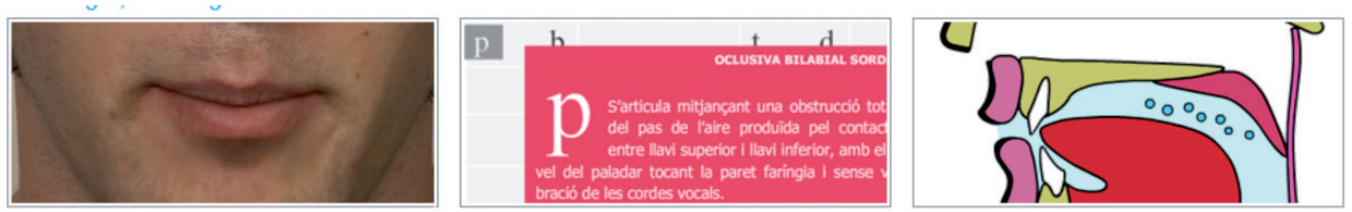

Fig. 21. Els sons del català (font: http://www.ub.edu/sonscatala/\#a_presentacio) 


\begin{tabular}{|c|c|c|}
\hline \multicolumn{3}{|c|}{ Contextos en què apareix la vocal $o$ oberta } \\
\hline context & exemples & excepcions \\
\hline $\begin{array}{l}\text { En la major part dels mots } \\
\text { cultes, especialment en mots } \\
\text { que contenen una } i \text { o una } u \text { en } \\
\text { síl·laba posttònica i en mots } \\
\text { esdrúixols. }\end{array}$ & $\begin{array}{l}\text { Anòmal, autònom, } \\
\text { hidrogen, pròleg; Antoni, } \\
\text { bibliòfil, custòdia, elogi, } \\
\text { lògica; còmput, cònjuge, } \\
\text { corpus, mòdul; cìmode, } \\
\text { nòmada, òrfena, pròr- } \\
\text { roga. }\end{array}$ & $\begin{array}{l}\text { Mots com fórmula, pólvora, } \\
\text { tómbola, tórtora, góndola; estó- } \\
\text { mac, furóncol, góndol; forma. }\end{array}$ \\
\hline $\begin{array}{l}\text { En diftong decreixent i en les } \\
\text { formes rizotòniques dels verbs } \\
\text { cloure, coure, moure i ploure. }\end{array}$ & $\begin{array}{l}\text { Alcoi, almoina, boira, } \\
\text { heroi; bou, dijous, nou, } \\
\text { ou, prou; cloure, coure, } \\
\text { moure i ploure. }\end{array}$ & $\begin{array}{l}\text { Les formes verbals fou i sou i, } \\
\text { amb vacil·lacions en diversos } \\
\text { parlars, en mots com ara jou, } \\
\text { pou, tou i Sant Boi ([o] en la } \\
\text { pronúncia local). }\end{array}$ \\
\hline $\begin{array}{l}\text { En els monosíllabs aguts aca- } \\
\text { bats en -o (llevat de la forma } \\
\text { verbal só i de l'adverbi no) i en } \\
\text { alguns demostratius, conjun- } \\
\text { cions i expressions. }\end{array}$ & 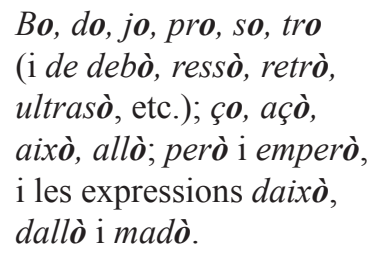 & \\
\hline $\begin{array}{l}\text { En uns quants mots acabats } \\
\text { en }-\boldsymbol{o s} \text {. }\end{array}$ & $\begin{array}{l}\text { Arròs, cos, espòs, gros, } \\
\text { os, repòs, terròs, tros. }\end{array}$ & $\begin{array}{l}\text { Nombrosos adjectius derivats } \\
\text { amb el sufix qualitatiu -ós: gro- } \\
\text { gós, aquós, generós. }\end{array}$ \\
\hline $\begin{array}{l}\text { En diversos mots acabats en } \\
\text {-osa. }\end{array}$ & $\begin{array}{l}\text { Cosa, llosa, nosa, rosa, } \\
\text { prosa. }\end{array}$ & \\
\hline $\begin{array}{l}\text { En alguns dels mots en què } \\
\text { la vocal és seguida dels grups } \\
\text { consonàntics -rt(a), - } \boldsymbol{l t}(\boldsymbol{a}) \text {, } \\
\text {-ldr- o - } \boldsymbol{n} \boldsymbol{d} \boldsymbol{r} \text {. }\end{array}$ & $\begin{array}{l}\text { Confort, conhort, con- } \\
\text { sort, fort, hort, import, } \\
\text { mort, sort, suport, tort, } \\
\text { horta, porta; giravolt, } \\
\text { revolt, revolta; absoldre, } \\
\text { doldre, moldre, resoldre; } \\
\text { compondre, correspon- } \\
\text { dre, pondre, tondre. }\end{array}$ & $\begin{array}{l}\text { Els mots cort; molt (quantifica- } \\
\text { dor), escolta; fondre. }\end{array}$ \\
\hline $\begin{array}{l}\text { En molts mots acabats en les } \\
\text { terminacions -oc/-oca, -of/-ofa, } \\
\text {-oig/-oja, ol/-ola, -ossa, -ost/- } \\
\text { osta i -ot/-ota. }\end{array}$ & $\begin{array}{l}\text { Albercoc, foc, groc, xoc; } \\
\text { lloca, oca, roca; carxofa, } \\
\text { estrofa; boig, roig; boja, } \\
\text { roja; bunyol, consol, dol, } \\
\text { vol; cassola, escarola, } \\
\text { escola, pistola, sola; } \\
\text { brossa, carrossa, crossa; } \\
\text { cost, impost, pressupost, } \\
\text { rebost; costa, crosta, } \\
\text { posta; clot, dot, got, } \\
\text { ninot; cabota, granota, } \\
\text { nota, pilota, pota. }\end{array}$ & $\begin{array}{l}\text { Els mots boc, boca; estoig; } \\
\text { gola, i, en valencià i baleàric, } \\
\text { bola, cola; bossa, gossa, óssa, } \\
\text { rossa; agost, congost, most, } \\
\text { llagosta; bot, brot, mot, nebot, } \\
\text { rot, tot. }\end{array}$ \\
\hline $\begin{array}{l}\text { En altres mots, molts dels } \\
\text { quals són monosíllabs o tenen } \\
\text { l'accent en la primera síl·laba, } \\
\text { i també en les formes rizotòni- } \\
\text { ques de verbs com ara constar, } \\
\text { llogar, robar, tocar i trobar. }\end{array}$ & $\begin{array}{l}\text { Cor, dona, flor, or, prova, } \\
\text { plor, roba, roda; consta, } \\
\text { lloga, roba, toca i troba. }\end{array}$ & \\
\hline
\end{tabular}

Fig. 22. Contextos en què apareix la vocal $o$ oberta (font: IEC, 2002) 


\subsubsection{Les vocals àtones}

En síl·laba àtona, tots els parlars presenten un sistema vocàlic reduït. Els més generals són el sistema de la major part dels parlars orientals, reduït a tres vocals ([i], [ə] i [u]), i el sistema dels parlars occidentals, reduït a cinc vocals ([i], [e], [a], [o] $\mathrm{i}[\mathrm{u}])$.

En els parlars orientals hi ha, a més, dos sistemes d'àmbit més restringit:

a) el sistema propi de la major part dels parlars mallorquins, que té quatre vocals, és a dir, les tres generals en els parlars orientals i la [o], i

b) el sistema de l'alguerès, reduït a les vocals [i], [a] i [u].

En tot cas, convé no confondre aquest darrer sistema amb la tendència a generalitzar la pronúncia [a] en substitució de [ə], que es constata en determinats sectors urbans de parlars orientals: c[a]ntral, $\cos [\mathrm{a}]$, [a]scolt $[\mathrm{a}]$. Aquesta tendència, motivada per factors externs a la llengua, no és acceptable.

Les diferències existents entre el vocalisme tònic i l'àton són degudes al fet que hi ha vocals que presenten un timbre diferent segons que apareguen en posició tònica o àtona en les diferents formes flexionades d'un mot o en mots de la mateixa família. Aquest procés, anomenat reducció vocàlica, consisteix en l'ascens o en la centralització de les vocals que s'hi veuen afectades. En la fig. 22 podem veure els diferents tipus de reducció sistemàtica que s'esdevenen en els dos grans blocs dialectals.

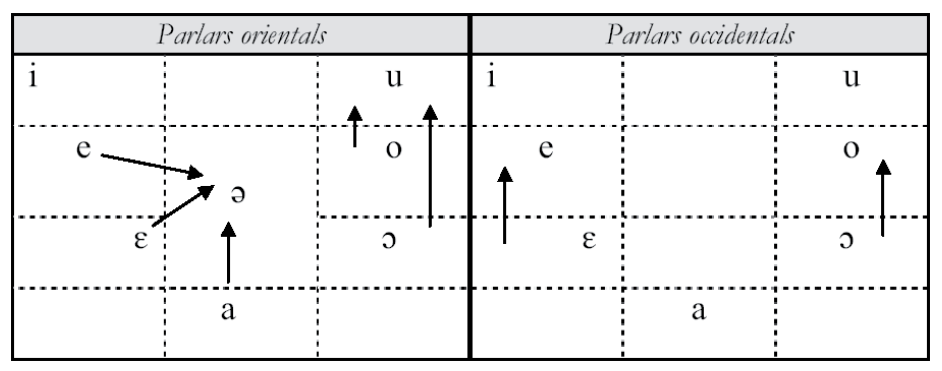

Fig. 23. El vocalisme àton i la reducció vocàlica (font: IEC, 2002) 


\subsubsection{Els sons consonàntics}

\subsubsection{El sistema consonàntic català}

Les consonants són sons que es produeixen amb una obstrucció o una constricció de l'aire expirat en algun punt del tracte vocal. Es classifiquen a partir de trets relacionats amb el lloc i amb el mode d'articulació.

1. El lloc d'articulació -o punt d'articulació- fa referència al punt on es produeix l'obstrucció o la constricció al pas de l'aire expirat i permet classificar les consonants en bilabials, labiodentals, dentals, alveolars, palatals i velars (fig. 23).

2. El mode d'articulació permet de classificar les consonants segons el tipus d'impediment que troba l'aire expirat i segons l'estat del passatge velofaringi i del passatge glotal. Fa referència, per tant, a tres criteris diferents $\mathrm{i}$ complementaris:

a) Atenent a l'estat del passatge velofaringi, les consonants poden ésser $n a$ sals o orals: les nasals es produeixen amb abaixament del vel del paladar, de manera que l'aire surt simultàniament tant per la cavitat nasal com per l'oral; les orals, en canvi, es produeixen amb el vel de paladar elevat i tocant la faringe, de manera que l'aire surt exclusivament per la cavitat oral.

b) Atenent a l'estat del passatge glotal, les consonants poden ésser sordes o sonores: en el primer cas, es produeixen sense vibració de les cordes vocals, i en el segon, amb vibració.

c) Atenent al tipus d'impediment efectuat en la cavitat oral, les consonants poden ésser oclusives, fricatives, africades, aproximants, bategants, vibrants $\mathrm{i}$ laterals. Les consonants oclusives, les fricatives i les africades poden ésser designades amb el terme genèric de consonants obstruents; les ròtiques (bategants i vibrants) i les laterals, amb el de consonants líquides.

- Les consonants oclusives presenten una fase implosiva, durant la qual s'interromp totalment la sortida de l'aire en algun punt de la cavitat oral, seguida immediatament d'una fase explosiva, que permet la sortida abrupta de l'aire. En el cas de les oclusives nasals, la sortida s'interromp en la cavitat oral, però no en la nasal.

- Les consonants fricatives presenten una constricció creada per l'acostament de dos òrgans articuladors que no interromp la sortida de l'aire, però que provoca una turbulència clarament audible.

- Les consonants africades són seqüències que combinen un moment oclusiu seguit d'un moment fricatiu produïts en la mateixa àrea articulatòria. 
- Les consonants aproximants presenten un acostament de dos òrgans articuladors, que crea una constricció menor que en el cas de les fricatives i que no provoca, per tant, turbulència. Les aproximants estan integrades per dues subclasses diferents: les graduals -[j] i [w], que són les variants consonàntiques de les vocals altes $[\mathrm{i}] \mathrm{i}[\mathrm{u}]$, respectivament- i les no graduals $-[\beta],[\delta] \mathrm{i}[\gamma]$, que són variants articulatòries de les oclusives orals sonores $[\mathrm{b}],[\mathrm{d}] \mathrm{i}[\mathrm{g}]$, respectivament.

- Les consonants ròtiques -que se subclassifiquen en bategant [r] i vibrant $[\mathrm{r}]$ - són alveolars i es diferencien pel nombre de contactes que l'àpex de la llengua estableix amb la regió alveolar: la bategant presenta un únic contacte i la vibrant, una successió de contactes molt breus (normalment, entre dos i quatre).

- Les consonants laterals presenten un contacte de la part central de la llengua amb la part superior de la cavitat oral. Aquest contacte crea un o dos canals laterals per on surt l'aire.

Podem veure el sistema consonàntic del català esquematitzat en la fig. 23 , on es representen els segments consonàntics distintius $i$, entre parèntesis, les variants combinatòries més significatives d'alguns d'aquests segments.

\begin{tabular}{|c|c|c|c|c|c|c|c|c|c|c|c|c|c|}
\hline \multirow{3}{*}{\multicolumn{2}{|c|}{$\begin{array}{l}\text { Segons el mode } \\
\text { d'articulació }\end{array}$}} & \multicolumn{12}{|c|}{ Segons el lloc d'articulació $i$ la sonoritat } \\
\hline & & \multicolumn{2}{|c|}{ Bilabials } & \multicolumn{2}{|c|}{ Labiodentals } & \multicolumn{2}{|c|}{ Dentals } & \multicolumn{2}{|c|}{ Alveolars } & \multicolumn{2}{|c|}{ Palatals } & \multicolumn{2}{|c|}{ Velars } \\
\hline & & sordes & sonores & sordes & sonores & sordes & sonore. & sordes & sonores & sordes & sonores & sordes & sonore. \\
\hline \multirow{2}{*}{ Oclusives } & orals & $\mathrm{p}$ & $\mathrm{b}$ & & & $\mathrm{t}$ & $\mathrm{d}$ & & & & & $\mathrm{k}$ & g \\
\hline & nasals & & $\mathrm{m}$ & & $(\mathrm{m})$ & & & & $\mathrm{n}$ & & $\mathrm{n}$ & & $(\mathrm{y})$ \\
\hline \multicolumn{2}{|l|}{ Fricatives } & & & $\mathrm{f}$ & $\mathrm{v}$ & & & $\mathrm{s}$ & $\mathrm{z}$ & $\int$ & 3 & & \\
\hline \multicolumn{2}{|l|}{ Africades } & & & & & & & $\widehat{\mathrm{ts}}$ & $\overline{d z}$ & t5 & $\overline{d z}$ & & \\
\hline \multirow{2}{*}{ Aproximants } & graduals & & & & & & & & & & $\mathrm{j}$ & & $\mathrm{w}$ \\
\hline & no graduals & & $(\beta)$ & & & & (ð) & & & & & & $(\mathrm{\gamma})$ \\
\hline \multirow{2}{*}{ Ròtiques } & bategants & & & & & & & & c & & & & \\
\hline & vibrants & & & & & & & & $\mathrm{r}$ & & & & \\
\hline \multicolumn{2}{|l|}{ Laterals } & & & & & & & & 1 & & $\kappa$ & & \\
\hline
\end{tabular}

Fig. 24. El sistema consonàntic del català (font: IEC, 2002)

Els elements distintius en una llengua són aquells que són capaços de discriminar mots d'aquesta mateixa llengua. Així, els elements [b] i [m] són distintius en català perquè permeten diferenciar mots com bou i mou o ball i mall. En cada un d'aquests parells de mots, l'element de la dreta es distingeix de l'element de l'esquerra tan sols per la consonant inicial, i aquestes es diferencien tan sols pel seu caràcter oral o nasal, respectivament. Així mateix, $[\mathrm{b}] \mathrm{i}[\mathrm{p}]$ són distintius en posició inicial absoluta de mot (per exemple, bany i pany), i és el caràcter sonor o sord del segment respectiu allò que els discrimina. No ho són, en canvi, en posició final absoluta de mot, ja que llavors desapareix la distinció entre les obstruents sonores i sordes: cap (substantiu, cf. caparró) i cap (forma verbal, cf. caber). En 
aquest cas concret, el fet no és reflectit per l'ortografia, però en altres casos sí (cf. cub 'hexaedre o potència aritmètica' i cup 'recipient on es trepitja el raïm').

Per contra, determinades consonants del quadre únicament es comporten com a variants combinatories d'una altra consonant. La consonant final de la forma verbal són, per exemple, és una nasal alveolar. Aquesta nasal, tanmateix, es pot assimilar al lloc d'articulació de la consonant següent i convertir-se, per exemple, en labial ([m]: Són portuguesos), en labiodental ([m]: Són francesos) o en velar ([ך]: Són guatemalencs). Es pot afirmar, per tant, que en determinats contextos, com ara en posició final de mot, aquests tres sons són variants articulatòries de [n].

En general, és acceptat que dos segments són variants combinatòries d'un mateix element invariant quan tots dos comparteixen una sèrie de trets articulatoris i quan l'alternança de l'un i l'altre en un determinat context fònic no és possible o no té valor contrastiu -és a dir, quan estan en distribució complementària o, en tot cas, la commutació de l'un per l'altre no provoca diferències de significat. Hi ha consonants, a més, que no tenen valor contrastiu en determinats parlars. La consonant labiodental sonora $[\mathrm{v}]$, per exemple, es manté amb valor contrastiu en baleàric, en la major part del valencià, en alguerès i, d'una manera recessiva, en el parlar del Camp de Tarragona: bena ([b]), vena ([v]). En els altres parlars, tanmateix, s'ha convertit en bilabial, i el so [v] únicament apareix com a variant combinatòria de [f] (afgà). D'una manera semblant, la consonant palatal fricativa [3] no té valor contrastiu en posició inicial en parlars nord-occidentals i valencians (jove) ni en posició intervocàlica en parlars valencians (pluja). En aquests parlars, la consonant fricativa es realitza com l'africada [đ3], i el so [3] únicament apareix com a variant sonoritzada de []] (peix i carn).

En el quadre següent podem veure alguns exemples de tots els sons consonàntics del català.

\begin{tabular}{|c|c|c|c|}
\hline $\begin{array}{c}\text { Conso- } \\
\text { nant }\end{array}$ & Exemples & $\begin{array}{c}\text { Conso- } \\
\text { nant }\end{array}$ & Exemples \\
\hline$[\mathrm{p}]$ & $\begin{array}{l}\text { pare, ceptre, Capçanes, dubte, } \\
\text { cap, cub }\end{array}$ & {$[\mathrm{y}]$} & $\begin{array}{l}\text { blancor, Francolí, llenca, congre, } \\
\text { ungla }\end{array}$ \\
\hline [b] & Biar, bou, ambició, combat & {$[1]$} & Linyola, literatura, lira, ala \\
\hline$[\beta]$ & abadia, esbart, voleibol & {$[\mathbf{r}]$} & rambla, enrabiar, Manresa, arrap \\
\hline$[\mathrm{f}]$ & $\begin{array}{l}\text { Falset, festa, cofre, diftong, } \\
\text { triomf }\end{array}$ & {$[\mathbf{c}]$} & mare, cremar, caire, roure, Montuiri \\
\hline$[\mathrm{v}]$ & valer, Valls, avisar, envà, afgà & {$[\mathrm{s}]$} & $\begin{array}{l}\text { son, cera, Guissona, Eivissa, tassa, } \\
\text { adreça, Corçà, Pollença, pas, jaç }\end{array}$ \\
\hline$[\mathrm{t}]$ & terra, Tous, atac, artèria, fet & {$[\mathrm{z}]$} & $\begin{array}{l}\text { ase, Osona, Gandesa, rosa, trànsit, } \\
\text { enze, Olzinelles, zinc }\end{array}$ \\
\hline [d] & dau, sandàlia, síndria & [S] & $\begin{array}{l}\text { xarop, xeringa, mixeta, Tuixén, } \\
\text { caixa, peix, guix, Flix }\end{array}$ \\
\hline [ð] & cada, esdeveniment, aidar & [3] & Jesús, Gelida, flagell, verge, caixmir \\
\hline$[\mathrm{k}]$ & $\begin{array}{l}\text { cor, quatre, què, kurd, Pacs, } \\
\text { Caldes d'Estrac, cuc, pròdig }\end{array}$ & {$[\mathrm{ts}]$} & potser, pots, adscripció \\
\hline$[\mathrm{g}]$ & $\begin{array}{l}\text { Gandia, gat, angoixa, acne, } \\
\text { maragda }\end{array}$ & {$[\overline{\mathrm{dz}}]$} & atzar, Atzeneta, setze, normalitzar \\
\hline$[\mathrm{\gamma}]$ & $\begin{array}{l}\text { figa, Figueres, esgotar, } \\
\text { amargor, aigua }\end{array}$ & {$\left[\mathrm{t} \int\right]$} & $\begin{array}{l}\text { txeca, cotxe, Garrotxa, Andratx, } \\
\text { despatx, Càlig, mig, Molig, Tírig, puig }\end{array}$ \\
\hline$[\mathrm{m}]$ & mare, estimar, plom & {$[\overline{\mathrm{d}} 3]$} & calitja, platja, fetge \\
\hline$[\mathrm{m}]$ & àmfora, infermer, confirmar & {$[\Lambda]$} & $\begin{array}{l}\text { Ilàntia, Ulldecona, cullera, Pallejà, } \\
\text { Esponellà, Palafrugell, ull, vell }\end{array}$ \\
\hline$[\mathrm{n}]$ & $\begin{array}{l}\text { nom, enemic, Peníscola, } \\
\text { ensabonar, ven }\end{array}$ & [j] & $\begin{array}{l}\text { Iàtova, iugoslau, Juià, maia, Alcoi, } \\
\text { heroi }\end{array}$ \\
\hline$[\mathrm{n}]$ & $\begin{array}{l}\text { nyora, penyora, Ontinyent, } \\
\text { Perpinyà, Fortaleny, guany }\end{array}$ & {$[\mathrm{w}]$} & uadi, guarda, quant, cauen, Güell, web \\
\hline
\end{tabular}

Fig. 25. Exemples de sons consonàntics (font: IEC, 2002) 


\subsubsection{Les consonants sibilants}

Amb el terme de sibilants designem les consonants articulades en l'àrea dentoalveolar o palatoalveolar que es caracteritzen per l'alt grau de turbulència produït durant la sortida de l'aire. Les sibilants poden ésser fricatives i africades. Són fricatives les consonants alveolars i les palatals i són africades les consonants articulades en l'àrea dentoalveolar i en l'àrea palatoalveolar. El quadre següent presenta un inventari sistemàtic d'aquests sons.

\begin{tabular}{|c|c|c|c|}
\hline $\begin{array}{c}\text { Consonant } \\
\text { sonda }\end{array}$ & Exemples & $\begin{array}{c}\text { Consonant } \\
\text { sanora }\end{array}$ & Eximples \\
\hline$[\mathbf{s}]$ & sopar, caça, Flaçà, cas & [z] & zero, Pilzà, casa, Isona \\
\hline$\left[\int\right]$ & xarop, Xile, Xilxes, caixa, Oix & [3] & gent, Algemesi, Juneda, pluja \\
\hline$[\mathrm{ts}]$ & potser, gots, els Guiamets & {$[\overline{d z}]$} & $\begin{array}{l}\text { dotze, normalitzar, Atzeneta, } \\
\text { I'Atzúvia }\end{array}$ \\
\hline$\left|\mathrm{t} \int\right|$ & $\begin{array}{l}\text { txec, Llutxent, metxa, } \\
\text { Felanitx, Urtx, mig, puig }\end{array}$ & 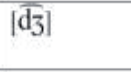 & Alcoletge, metge, Fatjó, mitja \\
\hline
\end{tabular}

Fig. 26. Les consonants sibilants (font: IEC, 2002)

Les consonants palatals presenten diferències considerables en els dos grans blocs dialectals. Simplificant una mica aquestes diferències, podem afirmar que en els parlars orientals predominen les consonants fricatives, mentre que en els parlars occidentals predominen les consonants africades.

En els parlars orientals, les consonants fricatives [C] i [3] no presenten restriccions en posició inicial de mot, però sí les africades [ $\mathrm{d} 3]$ i [ $[\mathrm{t}]$ : la consonant [ $\widetilde{d} 3]$ no apareix mai en aquesta posició, i la consonant [t] únicament es presenta en mots de procedència estrangera (Txèquia, txadià) i en pronúncies poc acurades de mots com

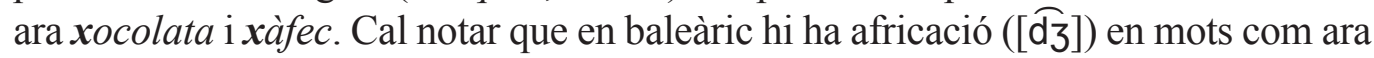
passejar, festejar, glopejar, plantejar i roja.

En els parlars occidentals, en canvi, no presenten restriccions les consonants africades, però sí les fricatives. La consonant fricativa [3] no té valor contrastiu en aquests parlars, i mots com ara jove i pluja s'hi pronuncien amb la consonant africada [ $\widehat{d} 3]$, tret del nord-occidental i del parlar del Camp de Tarragona, en què es realitza [3] en posició intervocàlica. La consonant [], d'altra banda, no apareix mai en posició postconsonàntica, i sols s'utilitza en posició inicial en un conjunt molt delimitat de mots, d'origen no llatí en molts casos (xaloc, xeringa, Xúquer); mots com ara anxova i xàfec es pronuncien, per tant, amb la consonant africada [t]. La consonant fricativa [ $]$ presenta encara una altra peculiaritat en aquests parlars, ja que, amb l'excepció del valencià meridional, es pronuncia precedida de la gradual [j] quan no és inicial de mot: caixa, peix, arruixar ([j]]).

En aquests contextos, són igualment acceptables tant les peculiaritats dels parlars orientals (on prevalen les pronúncies fricatives) com les dels parlars occidentals (on prevalen les africades i on la fricativa sorda intervocàlica o final es pronuncia precedida de [j]). 
Les consonants africades dentoalveolars no presenten diferències dialectals. En aquest cas, les restriccions posicionals són iguals en tots els parlars. Tenint en compte això, la consonant [ [ts] només apareix en posició inicial de mot en manlleus lèxics (tsar, tse-tse) i es troba rarament en posició interior de mot (potser, lletsó). La consonant [ $\mathrm{d} 3]$, en canvi, no apareix mai a principi de mot, i en posició interior de mot únicament es troba en un conjunt limitat de mots (dotze, tretze, setze, atzucac) i en el sufix causatiu-itzar (analitzar, formalitzar).

En el valencià apitxat, es va produir, ja des d'antic, l'ensordiment de totes les consonants sibilants sonores. En aquest parlar, per tant, es pronuncien amb [ts] mots com ara metge i pluja, amb [ts] mots com ara dotze i atzucac i amb [s] mots com ara casa i zero. Aquests tipus d'ensordiments, que també es constaten actualment en determinats parlars de grups urbans, no són recomanables.

\subsubsection{Les propostes d'estàndard oral de l'IEC i l'AVL}

El 1999, la Secció Filològica de l'Institut d'Estudis Catalans va publicar dos fascicles (1999a i 1999b) amb les propostes de la institució per a un estàndard oral. Més recentment (2006), l'Acadèmica Valenciana de la Llengua (AVL) ha presentat una adaptació dels criteris generals publicats per l'IEC a la realitat valenciana. Les dues propostes, tot i que divergeixen en alguns punts, comparteixen els objectius generals $\mathrm{i}$ els principis metodològics bàsics. Els dos documents parteixen de la necessitat de «sistematitzar unes pautes d'ús, generalment acceptades, que afavoreixin una pronunciació acurada de la nostra llengua», i pretenen establir un model lingüístic de referència adequat per als àmbits d'ús formals (l'administratiu, l'acadèmic i el periodístic, entre d'altres). I en tots dos casos es remarca la necessitat d'oferir un model no conflictiu amb les varietats dialectals, integrador, obert i flexible, amb el benentès que «primar la difusió d'uns trets lingüístics en les comunicacions formals d'abast general no hauria d'implicar de cap manera estigmatitzar qualsevol altra realització que no s'ajuste a uns determinats patrons estàndard», ja que «la llengua és un codi de comunicació molt complex, amb múltiples funcionalitats, que no es pot reduir a un model de referència uniforme i excloent» (AVL, 2006: LXIII).

Si cal descartar el procediment consistent a privilegiar una modalitat dialectal del català sobre les altres, no es tracta tampoc de crear una varietat supradialectal elaborada per especialistes d'una manera artificiosa, sinó més aviat de reforçar els trets que són comuns a les grans modalitats catalanes dialectals i evitar tot allò que pot dificultar la ràpida comprensió per part d'un auditori de procedència geogràfica diversa.

Aquest és el sentit de les propostes presentades: en efecte, la varietat funcional de l'estàndard que necessitem no pot entrar en conflicte amb cap de les manifestacions que la variació geolingüística enriquidora ha produït. L'estàndard no té una funció de suplència o de substitució de cap altra varietat en ús, sinó que més aviat ha de contribuir a obtenir un major rendiment del sistema. No és dubtós que la pràctica pot aconsellar alguns canvis; en realitat, l'estàndard que s'implanti ha d'ésser en definitiva, en gran part, creació de la dinàmica que la mateixa pràctica generarà; en aquest sentit, els professionals dels mitjans de comunicació tenen un paper decisiu. Molts pensen que res no es pot planificar pel que fa al llenguatge; això no és així, però evidentment l'èxit d'una planificació depèn de l'existència d'una voluntat col·lectiva. No ens hem de desanimar si les primeres temptatives no obtenen els resultats que voldríem.

IEC, 1999a: 10-11 
Tant la proposta de l'IEC com el model propugnat per l'AVL adopten, com a punt de partida, tres criteris generals: l'extensió territorial, el nivell de formalitat i el grau de correcció o admissibilitat.

Pel que fa a l'abast $\mathrm{o}$ extensió territorial dels fenòmens fonètics descrits, el document de l'IEC distingeix entre trets lingüístics d'àmbit general, si són propis de dos o més dels grans dialectes territorials, $i$ trets d'àmbit restringit, si són característics d'un determinat dialecte, però proveïts de prestigi en el seu àmbit territorial $i$, en conseqüència, recomanables quan la locució va dirigida a un auditori lingüísticament uniforme.

Així, són fenòmens d'àmbit general la pronunciació o l'emmudiment de la $-r$ etimològica final en mots com carrer ([karér] o [kəré]) o portar ([portár] o [purtá]), l'emmudiment de la $r$ de la primera síllaba del mot arbre o la pronunciació amb $r$ o sense $r$ de la primera síl-laba de les formes d'infinitiu, futur i condicional del verb prendre i els seus derivats (aprendre, comprendre, corprendre...). En canvi, són fenòmens d'àmbit restringit la pronunciació ea del sufix -esa en mots com malesa, bellesa o pobresa o la caiguda de la $-d$-intervocàlica en mots com cadira, vesprada o llaurador, trets característics d'alguns subdialectes valencians, o l'accentuació com a plans de certs mots esdrúixols, com música [muzíkə] o pràctica [prəktíkə], que es dóna en el català septentrional o rossellonès.

Quant al nivell de formalitat, les dues propostes (la de l'IEC i la de l'AVL) distingeixen entre registres formals -que es caracteritzen per un estil neutre, pel rigor expressiu i per la planificació prèvia- i registres informals -propis dels diàlegs $\mathrm{i}$ dels àmbits quotidians i col·loquials, és a dir, dels usos lingüístics caracteritzats per l'espontaneïtat i la flexibilitat.

És pròpia dels registres formals, per exemple, la pronunciació o l'emmudiment dels sons oclusius darrere nasal o l: font [font] / [fon], llamp [^ámp] / [^ám]... En canvi, són adequats només per als registres informals alguns fenòmens com ara l'emmudiment de la $l$ en els mots altre, nosaltres i vosaltres (que és d'àmbit general, compartit per tot el domini lingüístic), la pronunciació com a $i$ de la $l l$ en mots com cella [séia], ull [ui] o palla [páia] (pròpia del balear i d'alguns parlars orientals) i l'obertura en $a$ de la vocal inicial de mots començats per en-, em- o es-, com encetar [ansetár], embrutar [ambrutar], escoltar [askoltár] o enveja [amvédza]), que és un tret particular del català nord-occidental i del valencià.

Finalment, pel que fa al grau de correcció o d'acceptabilitat dels trets fonètics, les dues propostes distingeixen entre formes pròpies -si es tracta de fenòmens generals o prestigiosos en un àmbit determinat-, formes admissibles en alguns àmbits d'ús i en determinades condicions, i formes no recomanables o inadmissibles en tots els àmbits $\mathrm{i}$ en tots els registres.

Són, per exemple, formes pròpies la pronunciació fricativa del grup $t z$ del sufix -itz- en mots com protagonitzar [protayonizár], analitzar [analizár], localització [lokalizasió] i organitzador [oryanisaðór] o la pronunciació amb $i$ o sense $i$ de la 
sibilant palatal sorda després de vocal (feix, caixa, dibuixar,...). En canvi, són formes no recomanables o inadmissibles la palatalització de la $l$-inicial de mots cultes (*llogic, *lliberalisme, *lliterari,...), la pronunciació africada sorda del so sibilant

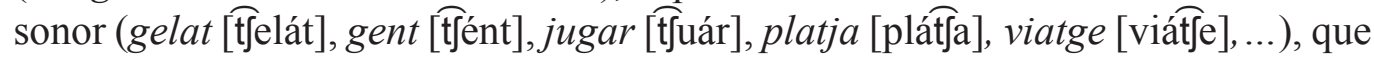
és general en valencià apitxat, o la reducció dels diftongs [kwa] i [je] a una sola vocal (quaranta [koránta], quasi [kázi], aigua [ajya], quallar [ko人ár], paciència [pasćnsja], etc.). Finalment, són formes admissibles, però només en alguns contextos i en certes condicions d'ús, la pronunciació unisil-làbica de $i$ seguida d'una altra vocal en mots com condició, ciència o història, o l'emmudiment de la $l$ en els mots altre, nosaltres i vosaltres.

Tot i aquesta aparent coincidència, com que els marcs de referència de les dues propostes són diferents -mentre que la proposta de l'IEC es refereix a tot el domini lingüístic, la de l'AVL es limita al territori valencià-, la perspectiva adoptada per l'AVL -sovint excessivament preocupada per remarcar i preservar fenòmens fonètics «genuïnament» valencians- provoca algunes contradiccions amb les recomanacions de la proposta de l'IEC. Així, una valoració general del document de l'AVL ha de tenir en compte que, tot i que es tracta d'una proposta molt rigorosa pel que fa a la presentació de les transcripcions fonètiques dels mots aportats com a exemples, introdueix algunes discrepàncies significatives:

a) D'una banda, el document de l'AVL té en compte algunes realitzacions fonètiques exclusivament valencianes que l'IEC no havia considerat i que són preses com a pròpies del valencià estàndard o acceptables (per exemple, la pronunciació com a [ej]] del grup ex-seguit de vocal en paraules com exem-

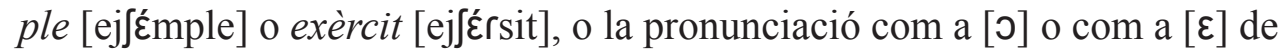
la vocal $a$ en posició final de paraula que es produeix per assimilació de la vocal oberta tònica de la síl·laba anterior: pilota [pilóto], vora [vóRo], tela

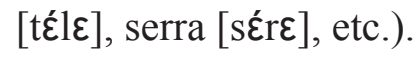

b) De l'altra, el model de valencià oral que propugna l'AVL considera pròpies del valencià estàndard diverses realitzacions fonètiques que la proposta de l'IEC considerava només admissibles en l'àmbit valencià i en registres informals (com ara la pronunciació com a $a$ de la vocal inicial de mots començats per en-, em-, es- o la pronunciació com a $e$ de la vocal $a$ de la 3a persona del singular del present d'indicatiu (ell cante, ell cantae, ell cantarie...).

\section{www}

Podeu consultar les propostes fonètiques de l'IEC i l'AVL en les adreces següents: http://publicacions.iec.cat/repository/pdf/00000062/00000072.pdf http://www.avl.gva.es/va/documents-normatius/minidestacado/00/document/0ral.pdf 


\subsection{Qüestions de morfosintaxi per a l'estàndard oral}

\subsubsection{Criteris generals}

En la llengua parlada col-loquial conviuen formes com saber i sapiguer, poder i poguer, veient i vegent, nosaltres i mosatros o natros i moltes altres variants morfològiques molt habituals en la llengua oral informal que no estan admeses per la normativa. Els mitjans de comunicació han d'optar per les solucions més generals, per les formes que constitueixen la varietat estàndard de la llengua.

En l'àmbit català, constitueix un punt de referència inevitable la proposta de la Secció Filològica de l'IEC (1999b), que inclou una descripció dels aspectes més problemàtics de la morfologia nominal (articles, substantius i adjectius, possessius, demostratius, quantificadors i indefinits, numerals i pronoms personals) i de la morfologia verbal des de la perspectiva de l'estàndard oral. Pel que fa a l'estàndard oral valencià, són molt clarificadores les aportacions de la Guia d'usos lingüístics, de Maria Josep Cuenca i Manel Pérez Saldanya (2002), editada per l'Institut Interuniversitari de Filologia Valenciana (IIFV).

Quant a la sintaxi, les coses són una mica més complexes. D'una banda perquè, com assenyala Francesc Vallverdú, «és en l'àmbit de la sintaxi on apareixen els trets gramaticals més particulars del llenguatge oral: inversions, repeticions, redundàncies, juxtaposicions, elisions, recursos específics (gestualitat), etc.» (2003: 52). De l'altra, perquè les errades sintàctiques són més difícils de detectar per l'usuari que no pas les fonètiques o les lèxiques, en part perquè sovint es tracta de construccions inacceptables que estan integrades per formes que individualment són gramaticals. Així, expressions com tenim que dur, hi ha que fer o anem a veure estan formades per paraules netament catalanes, que en un altre context són correctes, tot i que aquí donen lloc a expressions inadmissibles.

En les pàgines que segueixen, presentem algunes consideracions sobre l'ordenació dels elements de la frase, l'ús del pretèrit perfet i de l'indefinit, el participi concordat i l'ús de la veu passiva. El contingut procedeix gairebé íntegrament del web És a dir, que, a efectes pràctics, conté un recull d'orientacions força útils per a la construcció d'un estàndard oral modern en els mitjans de comunicació de massa.

\subsubsection{L'ordenació dels elements de la frase}

En català, la frase prototípica està formada per una constel-lació de grups nominals al voltant d'un verb. D'aquests grups nominals, un fa de subjecte i els altres fan de complements (directe, indirecte, preposicional), d'atributs i predicatius (del subjecte o del complement directe) i de complements circumstancials (de temps, de lloc, de manera, d'instrument, de finalitat...). El conjunt de la frase pot anar precedit d'un «marc» (un connector del tipus pel que fa a... o un complement de temps o de lloc). 
Els elements que caracteritzen la frase són la concordança, que relliga el verb amb el subjecte, $i$ el temps, que relaciona la frase amb el moment en què es pronuncia i amb el temps de les altres frases del discurs.

\subsubsection{L'ordre de mots a la ràdio i a la televisió}

El desplaçament del subjecte o dels complements és un recurs molt utilitzat en la llengua parlada espontània, cosa que el fa molt interessant per construir un llenguatge radiofònic o televisiu àgil. Però cal recordar que el desplaçament de complements és un recurs condicionat: per poder desplaçar un complement al començament de la frase, cal que ja estiga present anteriorment en el discurs. Això, en el curs d'una conversa espontània, es fa de moltes maneres; però en un context més formal, com en el cas dels informatius, s'ha d'evitar de començar un titular o una notícia amb un complement desplaçat, ja que li falta el context que faria possible el desplaçament al davant (tematització) i el marc formal de l'informatiu no permet els canvis d'entonació propis de la focalització, que sí que poden aparèixer en un programa espontani. Als titulars i al començament de la notícia cal fer servir frases en l'ordre neutre o amb el verb en passiva.

\subsubsection{Ordre neutre i canvis d'ordre de la frase}

L'ordre neutre de la frase -que presenta diferents possibilitats, determinades per l'estructura sintàctica de l'oració- es pot alterar per lligar bé el discurs, com quan posem en primer lloc de la frase un element ja conegut, per raons d'estil periodístic o per altres motius. L'oració [1] és un exemple d'ordre neutre:

[1] La policia (S) ha detingut (V) quatre adolescents (CD) avui (CC) a Barcelona (CC), quan calaven foc a un contenidor (CC).

Però si volem començar la notícia pel nombre de detinguts, hem de recórrer a la passiva:

[2] Quatre adolescents (S) han estat detinguts (V) per la policia (CAgent) avui (CC) a Barcelona (CC), quan calaven foc a un contenidor (CC).

També es pot desplaçar un complement al capdavant de la frase; però aquest recurs, anomenat tematització, està condicionat al fet que ja se n'hagi parlat anteriorment, i per tant, com a tema conegut, aquest complement es pugui encapçalar amb l'article definit. El desplaçament es pot aplicar a qualsevol complement fort (directe, indirecte, preposicional) que estigui en aquestes condicions.

[3] Els quatre adolescents (CD), els ha detinguts (V) avui (CC) la policia (S) a Barcelona (CC), quan calaven foc a un contenidor (CC) (però no: * Quatre adolescents (CD), els ha detinguts (V)...). 
En aquest cas, el que agafa importància són els elements que queden situats al final de la frase: qui els ha detingut (subjecte), en quines circumstàncies.

Quan desplacem un complement, al costat del verb hi apareix un pronom feble (en aquest cas, els). Altres exemples:

[4] De la seua situació a l'equip (CP), el jugador (S) n'ha parlat (V) avui al «Força Esports» (on agafa importància el programa).

[5] Els excursionistes que s'havien perdut (CD), l'equip de rescat (S) els ha trobats (V) sans i estalvis (CPred.).

[6] Contra aquesta resolució (CPrep.), el club (S) hi pensa recórrer (V) legalment.

[7] La mare (S) ha declarat (V) [(Oració CD) que a la seva filla (CI) li (CI) han trucat $(\mathrm{V})$ més d'una vegada $(\mathrm{CC})$ per proposar-li aquesta feina $(\mathrm{CC})]$.

També podem fer canvis d'ordre per poder «penjar» una frase explicativa de l'element que queda situat al final de la frase. En l'exemple següent, hi ha una anticipació del complement preposicional d'objecte i un desplaçament del subjecte al final de la frase:

[8] De la seva situació a l'equip (CP), n'ha parlat (V) avui (CC) el jugador holandès $(\mathrm{S})$, [(frase explicativa) que considera que a hores d'ara ja li haurien hagut de renovar el contracte].

El desplaçament de subjecte també es pot fer per destacar-lo:

[9] Els excursionistes que s'havien perdut (CD), els ha trobats (V) sans i estalvis (CPred.) un equip de rescat format per guies de muntanya (S).

Entre els canvis d'ordre de la frase, també cal tenir en compte les alteracions provocades per la focalització i per l'ús de la passiva pronominal.

\subsection{3. Ús del pretèrit perfet i del pretèrit indefinit}

En el relat d'accions passades dins un període de temps acabat s'utilitza el pretèrit perfet. Les marques temporals congruents són del tipus ahir, abans-d'ahir, una vegada, aquella vegada, aquell dia, l'altre dia, la setmana passada, el mes passat, aquell any, aquell segle...

La forma habitual del pretèrit perfet, en estàndard oral, és el perfet perifràstic.

Quan ens referim a fets emmarcats en un període que encara no ha acabat de transcórrer, cal utilitzar el pretèrit indefinit (ha portat). Les marques temporals congruents amb el pretèrit indefinit pertanyen a la sèrie següent: ara, avui, aquest matí, aquesta tarda, aquest vespre, aquesta nit, fa un moment, des de llavors, fins ara, (durant) aquesta setmana, (durant) aquest mes, enguany, aquest any, en el 
nostre segle, etc. Els adverbis i les locucions s'han de referir a un període de temps encara vigent, al període de temps en què ens trobem.

No s'ha de fer servir el perfet (va entrar, va fugir, van disparar), quan ens trobem encara en el mateix període de temps o quan allò que es relata ha passat fa poca estona, en comptes de les formes adequades en català (indefinit): ha entrat, ha fugit, han disparat.

Cal posar molta atenció en la distinció dels dos temps, una irregularitat que es comet sovint quan es tradueix de l'anglès o del castellà. Quan es narren fets esdevinguts durant el dia en què ens trobem, cal referir-s'hi usant sempre el pretèrit indefinit, encara que hagen transcorregut en una part del dia ja passada. En la traducció, si el traductor no coneix quan s'ha esdevingut exactament un fet perquè al text no hi cap marca temporal que ho indique, és preferible utilitzar el pretèrit indefinit si s'ha produït en un moment no allunyat del present.

\subsubsection{El participi concordat}

El participi pot indicar una noció temporal acabada, equivalent a la fórmula un cop tal cosa està feta, dita, duta a terme, vista, exposada, etc.

[10] Realitzades les obres, el consistori pot actuar amb una completa llibertat de decisió.

[11] Superades les dificultats, el president va dissoldre el Parlament.

[12] Dit això, fem una pausa per a la publicitat.

El participi permet la flexió de gènere i nombre. Exemples: cantat, cantada, cantats, cantades; perdut, perduda, perduts, perdudes; adormit, adormida, adormits, adormides; servit, servida, servits, servides.

Les formes del femení singular i plural (masculí i femení) del participi es poden utilitzar en els temps verbals compostos acompanyats dels pronoms la, els, les:

[13] La dona va desaparèixer fa dies, però aquesta setmana diversos testimonis asseguren que l'han vista voltant prop de la casa.

[14] Va treure diversos llibres i encara no els ha tornats.

[15] El marit assegura que estava dormint i assegura que no les havia sentides arribar.

Aquesta concordança avui dia ja no és habitual, exceptuant el cas del femení singular-l'han rebuda (la carta)-, com tampoc no és habitual la concordança en els casos del pronom en i dels verbs modals - per exemple, n'han trobada una o l'han poguda trobar. Tot i això, s'hauria de mantenir en el discurs dels mitjans de comunicació, especialment en els gèneres informatius. 


\subsubsection{La veu passiva}

La veu passiva, que només és possible en els verbs transitius, permet posar en el primer lloc de la frase l'element que en una frase activa hauria ocupat el lloc del complement directe, seguit del verb en participi, amb l'auxiliar ser. L'element que ocupava el lloc del subjecte, ara anomenat agent, pot aparèixer al darrere, precedit de la preposició per. Així, la frase activa [16] es pot transformar en [17] i fins i tot es pot prescindir de l'agent, afegint-hi o no un complement circumstancial, com es pot veure en [18] i [19]:

[16] El govern ha aprovat la llei.

[17] La llei ha estat aprovada pel govern.

[18] La llei ha estat aprovada.

[19] La llei ha estat aprovada per unanimitat.

En les traduccions per a la ràdio i la televisió, s'ha d'evitar calcar l'alta freqüència de la construcció verbal passiva en anglès i mantenir-la només quan hi ha una voluntat de ressaltar l'element de l'oració que fa de complement directe.

La veu passiva no és un recurs gaire habitual en el català parlat i per això en el llenguatge periodístic se'n fa un ús restrictiu -que en limita la presència als titulars, només si cal, a les primeres línies de la redacció de les notícies i a usos solemnes en què interessa marcar d'una forma clara el protagonisme del subjecte pacient- $\mathrm{i}$ se sol evitar com a recurs de redacció habitual:

[20] El Premi Sant Jordi de Novel·la ha estat concedit a l'escriptor gironí...

[21] L'artista santandreuenc ha estat nomenat fill predilecte de la ciutat.

La veu passiva és justificable en l'enunciat d'una notícia, però ja no ho és tant a mesura que avança el text, on és preferible la veu activa. Sempre que es puga, les frases han de seguir l'ordre neutre sense alteracions. Però quan és necessari, es poden utilitzar el desplaçament d'elements, les construccions amb el subjecte elidit i la passiva pronominal.

[22] El govern ha aprovat la llei [ordre neutre].

[23] La llei ha estat aprovada pel govern [veu passiva amb ésser].

[24] La llei, l'ha aprovada el govern [desplaçament de complement].

Cal recordar que aquest recurs només és possible quan el complement directe va precedit d'article determinatiu o demostratiu (el, aquest). Per tant, no podrem dir: Una llei, l'ha aprovada (aprovat) el govern.

[25] Han aprovat la llei per unanimitat [construcció amb el subjecte elidit].

[26] La llei s'ha aprovat per unanimitat [passiva reflexa o pronominal]. 


\subsection{Estàndard oral i selecció lèxica}

\subsubsection{Recomanacions generals}

El lèxic és un dels capítols més polèmics -perquè tothom té alguna opinió de la correcció o no de les paraules que utilitzem habitualment, sovint contradictòries $i$ no sempre amb una bona fonamentació lingüística-, però també un dels aspectes més emblemàtics, més vistosos diríem, del grau de correcció d'una intervenció oral. És, per tant, un dels àmbits on, des dels serveis d'assessorament lingüístic dels mitjans, es preconitzen més restriccions sobre els usos col-loquials propis de l'oralitat espontània.

Per tal de produir intervencions clares i precises, la selecció lèxica en els mitjans de comunicació audiovisuals ha de tenir molt en compte les recomanacions següents:

a) Tendència a la concisió i la claredat (expressions planeres, paraules d'ús corrent $\mathrm{i}$ exclusió de repeticions innecessàries, tòpics, crosses o falques): cal evitar usos abusius.

b) Exclusió d'arcaismes i d'expressions amb regust literari: cal evitar usos inadequats.

c) Precisió i genuïnitat a l'hora de triar les paraules, delimitant-ne els significats propis: cal evitar usos impropis.

d) Substitució dels verbs febles (estar, ser, fer, trobar, semblar, etc.) per verbs de predicació completa.

e) Utilització de les expressions fraseològiques genuïnes i rebuig dels calcs lingüístics d'estructures alienes (menys mal, ni molt menys o altres semblants).

\subsubsection{Criteris de selecció lèxica}

A l'hora de decidir si una paraula o una expressió d'ús habitual es pot utilitzar en la comunicació audiovisual convé tenir en compte les restriccions següents:

a) Evitar l'ús de dialectalismes, sobretot si es tracta de paraules i expressions d'abast molt local, especialment en els registres formals.

b) Evitar les interferències lèxiques innecessàries (barbarismes), que sovint tenen una presència important en el llenguatge col-loquial (per exemple, enfermetat, dolència, bueno, entonces, mouse, software...).

c) Fer un ús adequat dels tecnicismes, en funció del tipus de programa i dels destinataris. Per exemple, l'ús de cefalea o pneumònia en lloc de mal de cap o pulmonia no sembla la millor solució per construir un estàndard oral àgil amb el qual els destinataris se senten identificats.

d) Limitar l'ús de paraules i expressions considerades tabú, almenys en els registres formals, i fer un ús adequat dels eufemismes. Convé que els mitjans no abusen ni en un sentit ni en l'altre. 


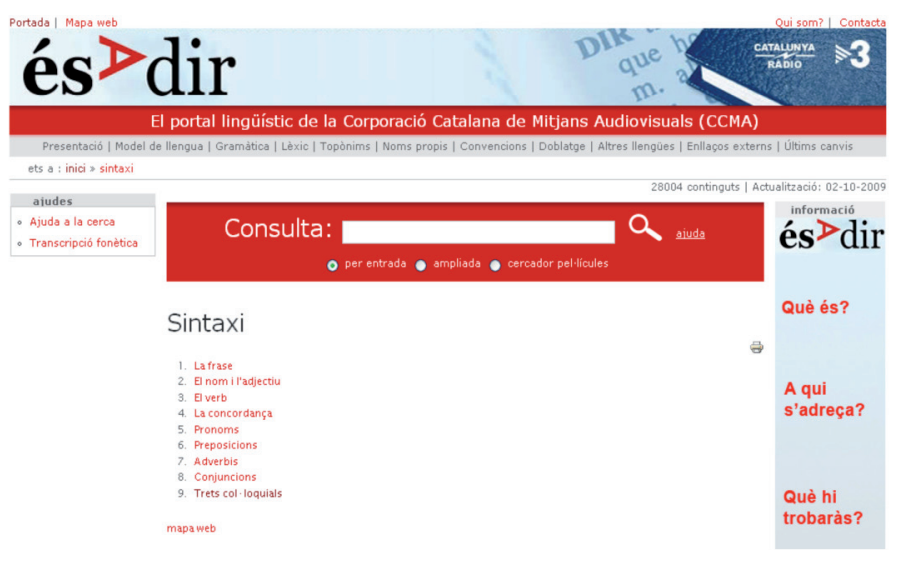

Fig. 27. Portal És a dir (http://esadir.cat/)

\subsection{L'estàndard oral en els mitjans audiovisuals}

\subsubsection{Models de llengua per als mitjans audiovisuals}

Els mitjans audiovisuals tenen una enorme responsabilitat en la difusió de l'estàndard oral. I encara més en el cas d'una societat com la valenciana, sotmesa durant segles a un ininterromput procés de minorització lingüística i cultural. Com deia Polanco, «en el cas valencià, però, la varietat estàndard, desconeguda per la majoria, ha de guanyar en gran mesura la legitimitat de la comunicació de masses, i ha de ser assegurant la comprensió (utilitat comunicativa) i l'adhesió (funció simbòlica) dels oients» (Polanco, 1990).

Aquest objectiu essencial només es podrà assolir si les emissions en català (en valencià) des dels mitjans audiovisuals tenen una cura especial per cercar l'equilibri entre l'ús de la varietat estàndard que les noves generacions de valencians ja han après a l'escola i la introducció de les paraules i expressions col-loquials genuïnes pròpies de l'oralitat espontània.

Es tracta, per tant, de construir un model oral amb perfils diversos per adaptar-se, amb naturalitat $i$ amb rigor, als diversos gèneres $i$ situacions comunicatives que conviuen en la producció audiovisual de qualsevol llengua de cultura moderna.

\subsubsection{Els perfils diversos de l'oral}

Un dels factors condicionants de la tria del model lingüístic en la producció audiovisual és el gènere. És evident, per exemple, que si volem construir productes que resulten creïbles no es pot emprar el mateix model de llengua en un noticiari de ràdio o de televisió que en una telesèrie o en una pel·lícula. En el primer cas, és recomanable utilitzar formes i expressions pròpies de l'estàndard oral formal, molt proper a l'estàndard escrit, mentre que en el segon és admissible un major relaxament articulatori i sembla més justificada la introducció de dialectalismes i expressions pròpies dels gèneres orals espontanis. 
Aquesta distinció entre registres formals i registres informals té molt a veure amb el nivell d'espontaneïtat del producte, però també amb la imatge que s'hagi de transmetre del programa o de les persones que hi intervenen. En realitat, parlar d'espontaneïtat en la producció audiovisual és bastant discutible (Martí, 2003), perquè l'ús de la paraula en la producció audiovisual mai no pot ser espontània. Es tracta, més aviat, de construir productes «que semblen espontanis», que transmeten un llenguatge natural i una sensació de frescor i d'agilitat que els facen similars a la interacció oral espontània.

Quan es parla dels perfils de l'estàndard oral en la comunicació audiovisual, de fet, es fa referència més a dos models complementaris que a dos estàndards diferents. En aquest sentit, Gifreu (2003) destaca el paper dels mitjans audiovisuals com a laboratoris de l'oralitat secundària, és a dir, d'aquestes noves formes de l'oralitat que han sorgit lligades al desenvolupament de les noves tecnologies de la paraula i que han transformat d'una forma radical els hàbits de consum i els estils comunicatius de la humanitat contemporània:

El problema urgent que planteja la cultura i la comunicació de la segona oralitat és l'elaboració i la negociació d'un estàndard oral composicional que puga ser ràpidament incorporat $\mathrm{i}$ usat arreu dels territoris com a registre formal estàndard de referència. Aquest registre tendiria a ser el propi dels gèneres informatius dels [mitjans audiovisuals]. A partir d'aquesta base de referència, caldria tenir en compte bàsicament tres contextos molt extrems d'actuació dels MA (lògicament, amb situacions intermèdies):

- l'ús d'un estàndard oral (fonètic i lèxic) per a les funcions predominantment informatives dels MA, equivalents en qualsevol tipus de MA (adreçat a un públic local, regional, nacional o al ciberespai);

- la incorporació en els altres gèneres de formes dialectals i de registres adients d'acord amb els propòsits del gènere, format $\mathrm{i} / \mathrm{o}$ programa, $\mathrm{i}$

- l'ús preferent de l'estàndard oral en les comunicacions destinades indiscriminadament al ciberespai.

Gifreu, 2003: 146

Aquesta idea, que sembla clara en l'àmbit teòric, presenta nombroses dificultats a l'hora de dur-la a la pràctica. D'una banda, l'oral formal, l'estàndard oral per parlar amb propietat, en una societat sotmesa a un procés de substitució lingüística ha de cercar sempre, com dèiem, l'equilibri entre el respecte estricte de la normativa gramatical i la incorporació de les formes i expressions més generals i més genuïnes de l'oral col-loquial. De l'altra, l'oral informal s'ha d'acostar tant com siga possible a l'oral col·loquial del carrer, que sovint està ple d'interferències que resulten molt difícils de substituir per les expressions pròpies (si n'hi ha). Albert Pla comenta aquestes dificultats a propòsit de la publicació del diccionari del Grup Flaix (2009) i apunta alguns exemples d'aquesta dificultat: agujetas, bicho raro, barri xino, xupar càmera, xivato, xollo, escaquejar-se... El problema és, com apunta Pla, que «la idea que un registre col-loquial es pot inventar contradiu la seva mateixa essència», ja que «el col-loquial és, per definició, el que es diu, i substituir-lo per el que caldria dir pot fàcilment convertir qui ho fa en un estrany, si no un pedant, entre els seus» (Pla, 2009). 
Òbviament, en el cas valencià, la situació és encara més complicada, ja que, d'entrada, és imprescindible superar aquella perillosa diglòssia practicada durant anys pels responsables de la ràdio i la televisió pública, que ha bandejat l'ús de la llengua pròpia del doblatge del cinema i les telesèries, o bé l'ha reduïda a la mínima expressió, i de vegades mostrant una llengua d'una qualitat discutible, en les sèries de producció pròpia. A més, és urgent, en els espais vehiculats en l'oral col·loquial, la recuperació de la fraseologia i la riquesa lèxica del valencià oral, molt empobrit a causa de la pressió de la llengua dominant, que ha desplaçat formes tradicionals $\mathrm{i}$ les ha envoltades d'unes connotacions que en dificulten l'ús normal en els mitjans de comunicació. I és imprescindible denunciar l'acció política a l'hora de marcar territoris de nefastes prohibicions, que contradiuen sovint les recomanacions de l'autoritat normativa $i$ han tingut uns efectes devastadors sobre la construcció d'un estàndard oral valencià modern. Per tant, caldria evitar expressions i paraules excessivament locals i reforçar la presència de construccions compartides amb altres àrees del domini lingüístic, com ara els demostratius reforçats o els incoatius en eix, per construir un estàndard comú sòlid i superar aquesta perillosa etapa de subestàndards regionals que no fan més que debilitar la fràgil salut de l'idioma compartit.

\section{Lectures recomanades}

Alturo, Núria i altres (ed.) (2002): Variació dialectal i estandardització, Barcelona, PPU.

Bassols, Margarida i Mila Segarra (ed.) (2009): El col-loquial dels mitjans de comunicació, Vic, Eumo.

Cros, Ana i altres (2000): Llengua oral i llengua escrita a la televisió, Barcelona, Publicacions de l'Abadia de Montserrat.

Julià-Muné, Joan (2004): El llenguatge de la ràdio i de la televisió, Alzira, Bromera.

- (2005): Fonètica aplicada catalana. Dels fonaments a les aplicacions de les ciències fonètiques, Barcelona, Ariel [inclou un $\mathrm{CD}$ ].

— i altres (2004): El català nord-occidental. Descripció i orientacions ortoèpiques, Lleida, Pagès Editors.

MARTí, Joan (2003): «És espontània l'oralitat?», dins MARTí-Mestres (ed.) (2003: 197-211).

Pla, Albert (2009): «El català col·loquial», Avui, 29 d'abril de 2009, p. $23<$ http:// paper.avui.cat/article/dialeg/162422/catala/col\%C2\%B7loquial.html> [consulta: 1 d'octubre de 2009].

Polanco, Lluís B. (1990a): «Reflexions sobre el model lingüístic dels mitjans de comunicació valencians», dins FerRANdo, Antoni (ed.) (1990: 25-30).

Torres, Marta (2001): «Els xats: entre l'oralitat i l'escriptura», Els Marges, 65 (desembre del 1999), p. 113-126.

Tubau, Ivan (1990a): Paraula viva contra llengua normativa, Barcelona, Laertes. 
Tubella, Imma (ed.) (2002): El català en els mitjans de comunicació, Barcelona, Institut d'Estudis Catalans.

VALLVERDÚ, Francesc (2000): El català estàndard i els mitjans audiovisuals, Barcelona, Edicions 62 / Televisió de Catalunya.

- (2002): «Els mitjans audiovisuals i la contaminació lingüística», Llengua i ús, 25, p. $4-10$. 
TEMA 4

\section{Aspectes convencionals de l'escriptura}

Introducció

1. Les tecnologies de la paraula

2. Els signes de puntuació

3. Elements paralingüístics de l'escriptura

4. L'abreviació en català

5. Citacions i notes a peu de pàgina

Lectures recomanades 


\section{Introducció}

L'escriptura és un codi lingüístic secundari que té, per definició, una naturalesa convencional. Tots els grups humans utilitzen per comunicar-se el llenguatge oral, però no totes les societats han desenvolupat la tecnologia necessària per traslladar la cadena fònica de la parla, que es desenvolupa, recordem-ho, en una dimensió temporal, sobre un suport material tangible (siga paper o qualsevol altra superfície), que presenta una orientació marcadament espacial. Mentre el llenguatge oral requereix el suport de l'oïda, l'escriptura utilitza el referent de la vista (i del tacte en alguns llenguatges especials). La introducció i el desenvolupament de les tecnologies de l'escriptura comporta, doncs, necessàriament la fixació d'una sèrie de criteris convencionals que permeten la comunicació d'una forma senzilla i natural. Aquests aspectes convencionals de l'escrit, lligats a la presentació formal dels documents, tenen una importància decisiva a l'hora de comunicar el contingut que volem transmetre. Algunes decisions relacionades amb la forma del text tenen a veure amb el tipus de text, particularment amb el gènere textual que s'està produïnt; així, per exemple, l'aspecte formal d'una instància és molt diferent de l'aspecte d'una notícia o d'una columna d'opinió; també són molt diferents, visualment, un conte, una obra de teatre o un sonet. D'altres qüestions tenen a veure amb una sèrie de convencions, acceptades socialment, que regulen l'ús dels tipus de lletra, els criteris de citació bibliogràfica o l'ús de les majúscules i les minúscules.

Aquestes convencions han anat evolucionant amb el temps i, de vegades, difereixen d'unes llengües a les altres i presenten algunes variants en funció del tipus de suport utilitzat, de l'àmbit on es produeix la comunicació i del gènere textual. Així, per exemple, s'accepta amb naturalitat la distribució de la informació periodística sobre el paper en columnes, que el contingut d'un poema es presente en forma de versos o que les intervencions dels personatges d'una novel·la vagen precedits per un guió. Totes les llengües tenen una sèrie més o menys estructurada de convencions que s'apliquen als usos escrits i que en el cas del català afecten, almenys, els aspectes següents:

a) Les regles d'ús dels signes de puntuació.

b) La distribució d'usos de les majúscules i minúscules i de números i lletres.

c) Els criteris que regulen els diferents tipus de lletra, aspectes i estils tipogràfics.

d) L'abreviació i els diferents tipus d'abreviatures.

e) La presentació de l'escrit (espais en blanc, interlineats...).

f) L'estabilitat del codi ortogràfic, que inclou, a més de les regles d'ús de les vocals i les consonants, les normes d'accentuació i les normes d'ús dels signes gràfics especials (punt volat, apòstrof, guionet...).

g) La inserció de citacions i notes a peu de pàgina i l'escriptura de llistats de bibliografia.

Es tracta, com es pot comprovar, de qüestions que tenen una incidència directa sobre la comprensió dels textos i que poden afavorir-ne la llegibilitat o dificultar-ne 
la lectura. És important, doncs, conèixer els criteris que regulen l'ús d'aquests aspectes i aplicar-los sistemàticament en la revisió de les pròpies produccions escrites. En les pàgines que segueixen presentarem alguns aspectes que cal tenir en compte durant el procés de revisió, un recull de les normes d'ús més habituals d'alguns aspectes convencionals de l'escrit $\mathrm{i}$ algunes recomanacions relacionades amb la presentació.

\subsection{Les tecnologies de la paraula}

\subsubsection{Evolució de les tecnologies de la paraula}

En les societats occidentals de la fi del segle xx, la comunicació i la informació han esdevingut, com hem vist, un dels primers béns de consum i un servei públic prioritari. De fet, s'han convertit en factors estratègics de primera importància, tant en l'àmbit polític i econòmic com en el social i en el cultural. Les institucions públiques i privades, les empreses i els ciutadans saben que el futur passa per l'accés i el control de la informació que circula pels cada vegada més poderosos circuits de la comunicació.

L'esclat espectacular de la comunicació ha estat conseqüència d'una sèrie de canvis decisius en les societats occidentals, que, alhora, ha actuat com a mecanisme accelerador de les transformacions. Entre aquests canvis, cal destacar els fets següents:

a) L'expansió dels discursos electrònics i audiovisuals s'ha produït vinculada al desenvolupament dels mitjans de comunicació de massa, que actuen de vehicles de transmissió.

b) El desenvolupament tecnològic - la confluència entre els mitjans de comunicació, les telecomunicacions i la informàtica- ha provocat transformacions decisives en el sistema de comunicacions i en el conjunt del sistema social i cultural, i ha estat un factor clau en el procés de globalització.

c) El consumisme i l'estètica de la moda han contribuït a generalitzar la cultura de la imatge, a l'espectacularització de totes les produccions dels mitjans de massa i a la uniformització cultural.

d) Finalment, la multiplicació de la interactivitat i el desenvolupament dels fenòmens multimèdia han transformat les formes d'ús dels mitjans de comunicació, la qual cosa ha provocat una transformació en profunditat de les pràctiques culturals i educatives, dels mecanismes de participació, de les formes de pensament, dels sistemes de valors i dels estils de vida.

Els tres elements més característics de les societats humanes -aquells que permeten de traçar més nítidament la línia de separació amb les societats formades per altres mamífers- són el desenvolupament del pensament racional, el llenguatge articulat i la possibilitat de crear i transmetre formes culturals. Evidentment, es tracta, més que de tres factors aïllats, dels tres eixos de coordenades d'un mateix 
espai tridimensional. En tot cas, la comunicació -la transmissió d'informació- és un element imprescindible per a la creació i la difusió de la cultura.

Des d'aquesta perspectiva, hom pot identificar tres formes bàsiques de transmissió de la cultura, lligades a tres etapes essencials en la història de les tecnologies de la comunicació: l'etapa de l'oralitat, l'etapa de l'escriptura i l'era dels discursos audiovisuals i de la tecnologia multimèdia. El descobriment $i$ el desenvolupament de l'escriptura, la invenció de la impremta i el desenvolupament de les modernes tecnologies electròniques $\mathrm{i}$ audiovisuals han suposat canvis transcendentals en la comunicació, en les formes de pensament i en les formes de viure i de percebre el món que s'han succeït al llarg de la història, en les relacions personals, en l'organització política i social i en les formes d'accés a la cultura. Així, l'evolució de les tecnologies de la comunicació ens permet identificar quatre grans etapes històriques, que coincideixen amb quatre períodes successius en les formes de transmissió cultural:

1) La logosfera o etapa de l'oralitat primària comprèn des dels inicis de la humanitat fins a l'aparició de les primeres formes d'escriptura en la civilització sumèria (cap al 3500 abans de Crist).

2) La grafosfera o edat de l'escriptura abasta una llarguíssima etapa que va des de les primeres escriptures ideogràfiques (sumèria i egípcia) i sil·làbiques a la invenció de la impremta (Gutenberg, 1450). En aquest període cal destacar dues innovacions tècniques que resultaren decisives per al desenvolupament de l'escriptura: la invenció de l'alfabet fenici -que va suposar el desenvolupament de la primera escriptura alfabètica- i la creació de l'escriptura alfabètica grega -la primera que va introduir signes gràfics per representar les vocals. És també el període en què es desenvolupa la retòrica com a art al servei de la persuasió.

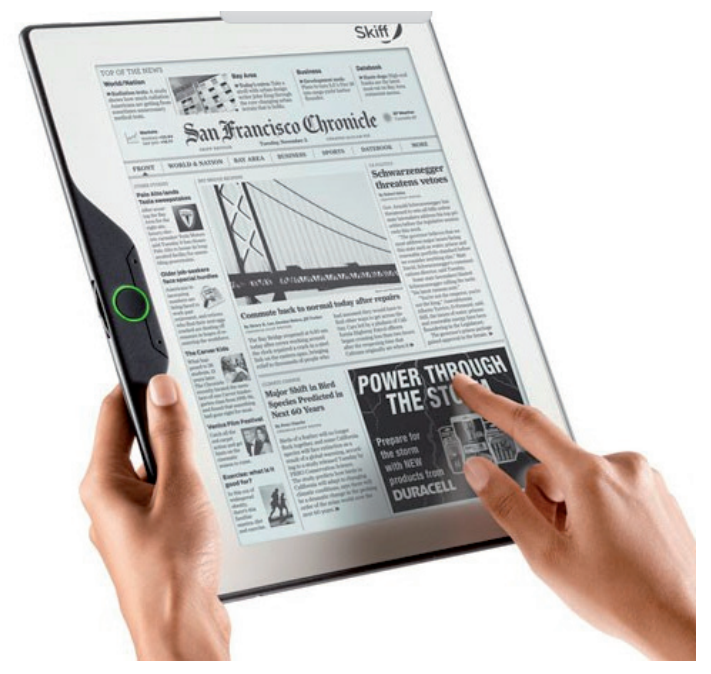

Fig. 28. Paper electrònic flexible

3) La galàxia Gutenberg o l'era de la impremta comprèn des de la invenció de la impremta fins al moment en què es generalitza l'ús de les modernes 
tecnologies de la paraula sobre suport electrònic i audiovisual. La circulació de les idees a través del llibre i l'aparició i desenvolupament de la premsa escrita són, sens dubte, les dues innovacions més decisives d'aquest període.

4) Finalment, la videosfera o constel-lació McLuhan ha convertit la imatge i la producció audiovisual en l'element central de les pràctiques comunicatives. Durant aquesta etapa -que s'inicia amb el descobriment de l'electricitats'han introduït i generalitzat noves tecnologies de l'oralitat (el telèfon i el telègraf, la ràdio, el magnetòfon, el casset, la ràdio digital) i s'han desenvolupat les modernes tecnologies de l'escriptura (la màquina d'escriure, el fax, els processadors de textos, el videotext i el correu electrònic). Es tracta de mitjans poderosos sense la presència dels quals ens resultaria actualment ben difícil de viure. Però el fet determinant en la història de la comunicació durant el segle xx ha estat la generalització a nivell planetari dels nous discursos audiovisuals, vinculats als mitjans de massa i associats a una cultura que sobrevalora el poder de la imatge com a mitjà autentificador de la realitat. Les columnes que sostenen l'edifici de la videosfera són, sens dubte, el desenvolupament del cinema (mut, sonor, color), de la televisió (blanc i negre, color, vídeo, televisió per cable, televisió digital), de la informàtica (invenció de l'ordinador, generalització dels ordinadors personals, expansió de les autopistes de la informació) i de les telecomunicacions (popularització de la telefonia mòbil). La nova realitat comunicativa ha comportat la consolidació de nous espais discursius vinculats a aquests mitjans, que s'han desenvolupat amb el suport i amb l'impuls de la publicitat, autèntica marca d'època que recorre transversalment tots els racons de la semiosfera contemporània.

El futur immediat sembla lligat, inevitablement, a les noves fronteres de la imatge. El desenvolupament de les tecnologies digitals - que han fet possible l'emmagatzematge i la difusió de grans quantitats d'informació- han permès ja la consolidació de la revolució multimèdia -que promet la integració de les diverses tecnologies existents-, l'expansió de la realitat virtual i la generalització de les xarxes de comunicació sobre els suports més diversos, des de les micropantalles dels telèfons mòbils d'última generació (els smartphones) a les macropantalles de la televisió d'alta definició del menjador de casa o les noves pantalles de projecció de les sales de cinema.

En la fig. 27 es pot observar gràficament el ritme d'acceleració progressiva amb què s'han introduït $\mathrm{i}$ desenvolupat les tecnologies de la paraula en la història de la humanitat. Aquesta representació ens permet visualitzar d'una forma molt clara que la concentració de noves tecnologies de la comunicació s'ha produït durant un període de temps pràcticament insignificant si ens situem en la perspectiva de l'evolució històrica de la humanitat. Fet i fet, com diu Tuson, «si reduïm tota la trajectòria humana, ben llarga, al temps còmode d'un dia de vint-i-quatre hores, l'escriptura va fer acte de presència cap a les onze de la nit, quan el dia ja se'ns estava escolant» (Tuson, 2006: 20). 


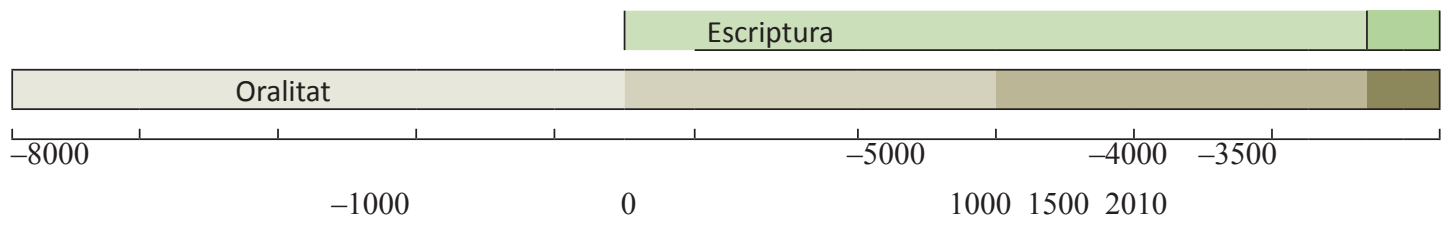

1. Logosfera o etapa de l'oralitat primària (.....- -3500)

2. Grafosfera o edat de l'escriptura (-3500 - 1450)

3. Galàxia Gutenberg o era de la impremta (1450-1895)

- Circulació de les idees a través del llibre

- Aparició i desenvolupament de la premsa i la publicitat

4. Videosfera o era de l'audiovisual (1850-2012)

Fig. 29. Evolució de les tecnologies de la comunicació

Des que s'han generalitzat els usos de la missatgeria instantània, les veus apocalíptiques pronostiquen la degradació de l'escriptura. Els textos escolars apareixen plens de símbols inintel-ligibles per a qui no els fa servir i els mestres s'escandalitzen perquè hi veuen un perill insalvable que amenaça la destrucció de la llengua escrita formal. És cert que missatges com aquest, que resulta gairebé indesxifrable, no són gaire tranquil·litzadors:

\section{n prll fnen mlt b i stc brt ls trs o $1 \mathrm{q}$ fe flt}

Tanmateix, la funció d'aquest text no és encapçalar el primer capítol d'una novella ni esdevenir un titular de premsa. Ben poques vegades sortirà de la pantalla d'un mòbil o d'un xat d'Internet. No s'ha d'oblidar que els egipcis transmetien els seus coneixements amb el suport tan sols de dibuixos i que fins a l'arribada dels grecs, l'escriptura prescindia de les vocals. Podem suposar, doncs, que aquest nou model d'escriptura -que és, en realitat, un codi de representació de la nova oralitat vinculada al desenvolupament dels nous mitjans tecnològics- conviurà de manera plàcida amb les pràctiques ordinàries convencionals.

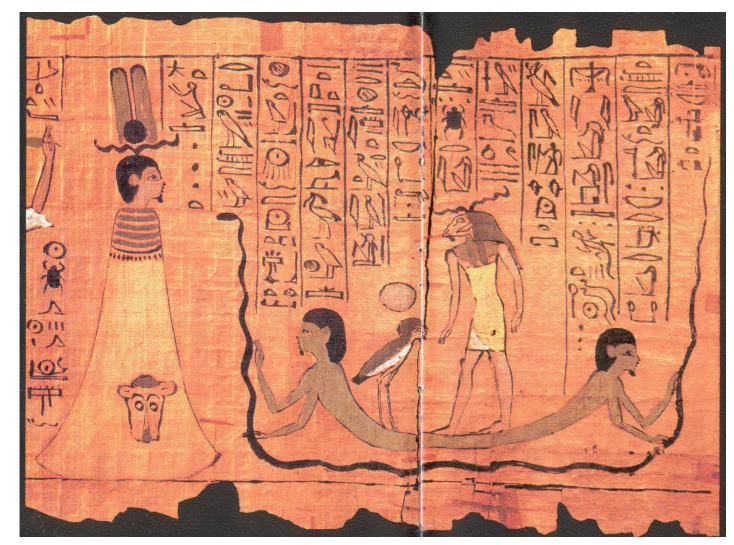

Fig. 30. L’escriptura jeroglífica egípcia

1. En parella funciono molt bé i estic obert als tres o al que faci falta. Es tracta de part d'una endevinalla apareguda al programa Bocamoll de Tv3 emès el 9 d'octubre de 2009; http://www.tv3.cat/bocamoll/ [consulta: 9 d'octubre de 2009]. 
L'aparició del cinema i de la televisió també va fer créixer les veus que anunciaven el final immediat d'altres formes d'oci, com el teatre o la literatura, $i$ ara, unes dècades després, es pot comprovar que no sols s'ha mantingut el gust per les arts escèniques i la lectura, sinó que s'han expandit de manera inimaginable. És veritat que només la meitat de la població llegeix algun llibre al llarg de tota la seva vida, però ningú no pot negar que l'altra meitat llig revistes, catàlegs, anuncis... Potser en un principi la imatge va representar una dura competició per a la lletra impresa, però, ara mateix, conviuen pacíficament sense molestar-se $\mathrm{o}$, fins i tot, col-laborant de manera harmoniosa. És el mateix futur que s'augura a la convivència de l'escriptura formal i la immediata, tramesa pels nous mitjans de comunicació.

De fet, la generalització de les eines informàtiques d'escriptura ha simplificat de manera evident la tasca feixuga de la mecanografia i ha subratllat la ridiculesa de les crítiques aparegudes a l'inici del procés. Els ordinadors han permès una escriptura més creativa $i$, sobretot, més ràpida, perquè tots el materials que hom necessitava tenir a l'abast en el procés de creació (diccionaris, gramàtiques, esborranys, esquemes) apareixen a la pantalla distribuïts en diverses finestres i preparats per a una consulta immediata a un sol clic de ratolí. De la mateixa manera que en disposar-se a escriure un text convencional, calia preparar tots els materials necessaris (llapis, retoladors, goma d'esborrar, fulls...), l'escriptor o escriptora actual ha d'amanir totes les eines informàtiques que li permetran que la seua tasca siga més lleugera.

En primer lloc, s'ha de disposar d'un programa d'edició de textos. Tot i que al mercat n'hi ha molts, durant els últims anys s'ha generalitzat l'ús de Microsoft Word, que inicialment funcionava en l'entorn Windows però ha acabat comercialitzant versions per a Mac, i de Writer, el processador de l'OpenOffice, un programari de codi obert, o de codi lliure, que pot funcionar en entorn Windows, Linux o Mac. Ambdós programes tenen la possibilitat de fer la correcció ortogràfica en moltes llengües (entre les quals es troba el català), la qual cosa ens permet escriure sense atendre de manera obsessiva la correcció. A més, els últims anys han començat a desenvolupar-se els correctors ortogràfics i gramaticals en català, que funcionen directament sobre qualsevol editor de textos, entre els quals destaquen WordCorrect, que ha presentat ja la versió 4.0.1, i Maxigramar Pro, que té versions per a Microsoft Word i per a OpenOffice. La realitat és que, com afirma Umberto Eco, la informàtica ha fet possible l'escriptura automàtica (una tècnica que inventaren els surrealistes a l'inici del segle $\mathrm{xx}$ ), ja que es pot mecanografiar al mateix ritme que brollen les idees (tot depèn, això sí, de la rapidesa dels dits) sense que l'ortografia siga un impediment per a la formulació ràpida dels pensaments. Aquests programes permeten, a més, comptar el nombre de paraules (si l'escrit ha de tenir un límit) o substituir-hi els mots que s'han repetit moltes vegades, buscar sinònims, crear còpies d'un mot que s'ha d'usar diverses vegades, etc. L'escriptura informatitzada ens permet també consultar el significat precís d'un mot gràcies als diccionaris en línia, entre els quals es troben el diccionari de l'IEC (http://dlc.iec.cat/), els diccionaris d'Enciclopèdia Catalana (http://www.enciclopedia.cat/ i http://www. multilingue.cat/), l'Alcover-Moll (http://dcvb.iecat.net/) i el diccionari ortogràfic i de pronunciació del valencià de l'AVL (http://www.avl.gva.es/lletres.asp). 
En definitiva, l'ofimàtica ha permès que l'escriptura resulte molt més fàcil i reeixida, perquè, a més, possibilita l'edició de textos com si es tractés de llibres o revistes. I ens ha ensenyat que, per aprofitar al màxim els recursos que ofereixen les tecnologies de la informació i la comunicació, hem de canviar radicalment les estratègies d'escriptura i hem de modificar profundament la concepció tradicional de la comunicació escrita.

\subsection{Els signes de puntuació}

\subsubsection{Definició i funció}

Els signes de puntuació són signes gràfics convencionals amb els quals es demarquen algunes unitats textuals per tal de facilitar-ne la interpretació per part del lector. La puntuació és un dels recursos més importants a l'hora d'organitzar l'estructura i el contingut del text escrit, ja que sense aquest mecanisme sovint resultaria difícil delimitar les diverses unitats significatives i interpretar-lo adequadament.

La concepció tradicional de la puntuació com una representació gràfica de les pauses de l'oral és inexacta i ha provocat molts malentesos, com ara la idea que la puntuació no té normes clares i que, en definitiva, depèn de l'estil i de la voluntat de l'escriptor. En aquest sentit, cal recordar que la llengua escrita no és una simple reproducció de l'oral, sinó un codi diferent que té les seues pròpies convencions. La puntuació no és, per tant, un conjunt de signes que representen l'entonació i les pauses de l'oral, sinó un sistema exclusiu de l'escriptura que s'utilitza en funció de criteris sintàctics i estructurals del text escrit.

La funció fonamental dels signes de puntuació és indicar els límits entre les unitats textuals (sintagmes, clàusules, oracions i paràgrafs), individualitzar-les i jerarquitzar-les per tal de guiar la interpretació del lector. Existeix, per tant, una relació molt estreta entre els signes de puntuació, les unitats textuals que delimiten i el seu significat.

A efectes pràctics, convé agrupar els usos dels signes de puntuació en dues grans funcions:

a) usos que tenen una funció textual, relacionats, per tant, amb l'entonació o amb la sintaxi, $\mathrm{i}$

b) usos associats a una funció convencional, alguns dels quals són específics de cada llengua i no són fàcils de generalitzar.

Habitualment, quan s'expliquen els usos dels signes de puntuació, se sol presentar un inventari més o menys minuciós de les funcions associades a cada signe (com es pot veure a continuació). Tanmateix, durant el procés d'escriptura, el problema que es presenta no és saber, per exemple, quines funcions fa la coma, sinó quin signe cal seleccionar en un context determinat. Per això, pot ser útil presentar en 
un quadre de doble entrada les funcions que pot realitzar cada signe de puntuació. Aquest sistema permet consultar, simultàniament, els usos de cada signe i els signes disponibles per a cada funció (vegeu els annexos I i II).

Els aspectes més conflictius de l'ús dels signes de puntuació estan relacionats amb la delimitació dels constituents de l'oració, la puntuació de numeracions i sèries, la puntuació a l'interior de les oracions compostes, el canvi d'ordre dels elements de l'oració i la marcació dels elements elidits.

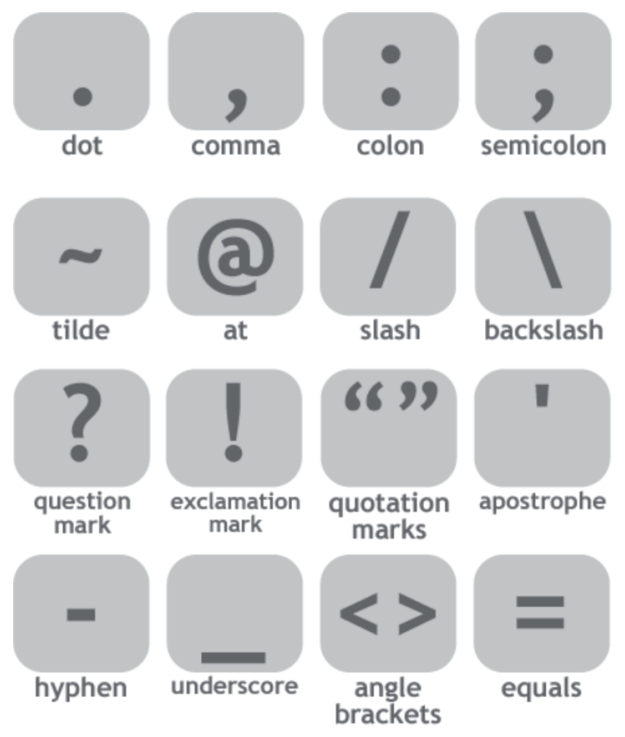

Fig. 31. Signes de puntuació

\subsubsection{Normes d'ús dels signes de puntuació}

La presentació detallada de tots els usos dels signes de puntuació és un objectiu que escapa a les possibilitats d'aquests materials. A més, ja hem apuntat que existeixen diversos llocs web que es poden consultar amb facilitat, on es poden trobar descripcions sistemàtiques amb exemples concrets. Per tant, aquí ens limitarem a exposar-ne els usos més habituals i els que presenten més dificultats des del punt de vista de la redacció periodística i publicitària. Per facilitar-ne la consulta, apareixen agrupats en diferents apartats, que presenten la normativa dels signes que tenen algun tipus d'afinitat o similitud. ${ }^{2}$

\subsubsection{La coma}

La coma indica una pausa menor en l'escriptura. Es posa en els casos següents:

1. Per a separar elements (mots, frases, etc.) d'una enumeració, fora dels casos en què hi ha les conjuncions $i, o$ o $n i$ o dels casos en què cal utilitzar un punt i coma (perquè les enumeracions ja contenen comes en alguna altra funció):

2. En els annexos I i II es presenten els quadres generals que resumeixen, respectivament, les funcions textuals i convencionals dels signes de puntuació. 
[1] Les grans firmes de moda s'han vist obligades a mirar enrere per bastir una moda portable, tranquil.la i intemporal, sense excentricitats.

[2] Les aules no disposen d'ordinadors, projectors ni pantalles.

[3] En la literatura catalana del segle d'or sobresurten els valencians Ausiàs March, que introdueix una veu personalíssima en la poesia i trenca amb la tradició de la poesia trobadoresca; Joanot Martorell, l'autor de Tirant lo Blanch, i Joan Roís de Corella, el representant més il·lustre de l'estil de la valenciana prosa.

2. Davant i darrere d'un incís o per separar un vocatiu de l'enunciat on s'inscriu:

[4] Segons la investigació, la suposada evasió fiscal s'hauria fet durant els anys 2003 i 2004 de la mà de Xarxes Televisives Italianes, una societat que en aquella època tenia la seu a la capital italiana i estava controlada per Mediaset, propietat de la família Berlusconi.

[5] El 3 de juny rebem, del regidor del districte, una resolució.

[6] Hola, Maria. No he pogut contestar abans el teu correu...

3. Per a indicar l'elisió d'un verb, tot i que es pot ometre en els casos en què l'ús provocaria una frase excessivament sincopada:

[7] A primer expliquen la prosa i a segon, la poesia.

[8] El percentatge d'estudiants aprovats el curs 2010-2011 va ser del 50\%, el següent del 55\% i l'altre del 60\%.

4. Quan es duplica un element que ha estat dit abans en forma de pronom.

[9] No ha dit quant li costarà, a l'usuari.

5. Quan es canvia de lloc un element de la frase, perquè passa a ser com un incís; per separar les oracions subordinades de la clàusula principal, i per marcar els anomenats connectors parentètics (com ara per tant, en canvi, és a dir, etc.):

[10] En l'actual conjuntura econòmica, les grans firmes de moda s'han vist obligades a mirar enrere.

[11] Villaronga ha intentat plasmar la seva personalitat a Pa negre, tot i que no és un projecte de creació pròpia.

[12] Els altres dos continuen ingressats en observació, però evolucionen positivament.

[13] Aquesta idea és, per tant, l'única conclusió que se'n pot treure.

6. Sempre que calga desfer alguna ambigüitat o facilitar la lectura del text (sense l'última coma de l'exemple següent no queda ben delimitat el nom de cada conselleria): 
[14] Assistiran a l'acte els consellers de Sanitat, Medi Ambient, Educació, i Cultura i Esport.

7. Entre la part entera i la part decimal en les xifres:

[15] L'assemblea va decidir ahir portar l'expresident i els membres de la seua junta als tribunals per reclamar-los els 48,7 milions d'euros en pèrdues acumulades durant els seus set anys de gestió.

8. Per separar l'autor de l'any de publicació de l'obra en el sistema estàndard de citació de fonts:

[16] En tot cas, el marge que separa un enfocament més o menys unitarista d'un altre més o menys secessionista és molt subtil (Pradilla, 2004: 132-133).

Per contra, cal recordar que no es posa coma entre el subjecte i el verb ni entre verb i complements, fora que hi haja un incís.

\subsubsection{Punt, punt i coma, dos punts i punts suspensius}

El punt indica una pausa major i, per tant, es posa al final d'una frase amb sentit complet i s'utilitza convencionalment en les indicacions horàries com a element demarcador entre les hores i els minuts, després de les abreviatures i per separar el número d'ordre d'un apartat del títol que introdueix.

[17] La policia ha detingut a l'aeroport del Prat una dona que intentava entrar al país amb 4,5 quilos de cocaïna amagada en peces de roba. Parallelament, s'ha desarticulat un grup de presumptes traficants en diverses poblacions del Vallès Occidental.

[18] Catalunya Vespre, l'informatiu dirigit per Kilian Sebrià, s'emet de dilluns a divendres, de $19.00 \mathrm{~h}$ a $20.00 \mathrm{~h}$.

[19] 2.1. Classificació dels connectors parentètics.

[20] En les p. 104 i 105, l'autora ofereix una taula general que presenta la classificació dels principals connectors parentètics.

En canvi, no s'escriu punt en els casos següents:

a) Per tancar les frases que formen els titulars de les notícies, els títols i subtítols de llibres o els eslògans publicitaris:

[21] Otegui demana a ETA un alto el foc unilateral

[22] Les fronteres del llenguatge

[23] Són pares, però són homes

[24] Vegeu l'apartat 2.3 del capítol 2 
b) Després dels signes d'exclamació i interrogació i al final de les datacions:

[25] S'ha de donar la notícia? Punts forts i punts febles.

[26] Castelló de la Plana, 15 d'octubre de 2012.

c) En les xifres que indiquen anys o ordre (per exemple en el DNI o en les pàgines d'un llibre):

[27] L'obra, que es va publicar el 2002 en tres volums, conté un capítol monogràfic, a càrrec de Joan Solà, dedicat a les oracions de relatiu (vol. 3, p. 2455-2565).

d) En els símbols i en les sigles (per separar les lletres que les formen):

[28] La Confederació Catalana d'ONG ha celebrat un acte aquest migdia a la plaça de Sant Jaume per reclamar més mesures i implicació a les administracions.

El punt $i$ coma indica una pausa més llarga que la de la coma i menys que la del punt. S'utilitza en els casos següents:

1. Quan hi ha comes i s'ha de fer una separació més important, però que no arriba a punt, o quan la relació entre una frase i una altra és més allunyada que la que expressaria una coma, però no tant com la que indicaria un punt.

[29] El programa té una enorme capacitat d'impacte social: d'una banda, perquè recull problemes i preocupacions que estan al carrer; de l'altra, perquè els planteja des d'una perspectiva original que sap...

2. Per a separar elements d'una enumeració - que habitualment se separen amb comes- quan ja hi ha comes dins de cada element. En aquest cas, abans de l'element final, precedit per les conjuncions $i, o$ o $n i$, s'hi sol posar una coma.

[30] El diari es va editar per primera vegada en forma de llibre a Argentina; a Anglaterra va ser publicat pel diari The Guardian; als Estats Units, pel Philadelphia Inquirer, i a Itàlia, per Panorama.

Els dos punts indiquen una subordinació del segon element al primer. Aquesta subordinació està relacionada amb tres usos fonamentals:

1. Per indicar la causa o la conseqüència d'un fet, per incorporar una demostració o una explicació i per introduir exemples o enumeracions.

[31] Uns 2000 periodistes han seguit el rescat des del campament Esperanza i es calcula que 1000 milions de persones l'han seguit en directe a tot el món. Des del punt de vista econòmic, el rescat també ofereix xifres: ha costat uns 14 milions d'euros. 
[32] La sèrie ha estat possible gràcies al treball d'un equip de grans professionals: guionistes, productors, actors i escenògrafs.

2. Per introduir citacions textuals o reproduccions en estil directe:

[33] Piñera: «Vam dir que no ens rendiríem i hem complert.»

[34] Johan: «En la meva vida he tingut dos grans vicis: fumar i jugar a futbol. El futbol m'ho ha donat tot en la vida; fumar quasi me la treu.»

3. Per separar la referència a la pàgina de l'any de publicació del text en el sistema estàndard de citació (vegeu els exemples 16 (p. 117) i 51 (p. 122)).

Tanmateix, els dos punts no es posen quan introdueixen una sèrie d'elements que formen un incís, si la frase continua després (en aquest cas s'han d'utilitzar guions o parèntesis davant i darrere de l'incís), o quan no són necessaris perquè no es trenca la continuïtat de la frase (per exemple, darrere són o de).

[35] *Aquestes variants temàtiques dibuixen un quadre de continguts habituals en el film policíac: gàngsters i bandits, màfia i drogues, racisme, intriga, violència, masclisme, herois fora de la llei, etc., que són els ingredients prototípics, juntament amb l'ambientació i el vestuari (i també l'acció, el ritme i la música) d'aquest gènere cinematogràfic.

[36] *Els aspectes essencials del rodatge són: la imatge i el so.

També cal recordar que en català, com en castellà o en anglès, abans dels dos punts no s'ha de deixar mai un espai en blanc, però aquest espai en blanc és normatiu, per exemple, en altres llengües com el francès:

[37] *Eduardo Mendoza : «M'agraden els antiherois».

[38] Essence : le gouvernement nie tout risque de pénurie.

Els punts suspensius (tres i prou, i sense espai entre la paraula i el punt que hi és més acostat) indiquen suspensió del pensament. Es posen per a indicar que una enumeració no queda tancada o per a assenyalar que una frase és inacabada perquè es vol donar a entendre alguna cosa, per reticència o per qualsevol altre motiu.

[39] Altres tipus de documentals poden ser el film enquesta, l'industrial, el científic, el submarí, l'antropològic i l'etnogràfic, el noticiari d'actualitat...

[40] Sí, vosaltres, molt de parlar, però a l’hora de la veritat... 


\subsubsection{Els signes d'interrogació i d'exclamació}

El signe d'interrogació és una marca de modalitat oracional i s'utilitza per indicar en l'escriptura la modalitat interrogativa directa. En català, habitualment, es posa només al final de l'oració, amb l'excepció d'alguns casos especials en què, per l'extensió de la frase i per l'absència d'indicadors d'interrogació, pot ser convenient escriure també el signe d'interrogació inicial.

[41] Fins a quin punt necessitem saber tot el que passa? És ètic que els mitjans divulguen tot el que saben o hi ha condicions i límits per a la informació?

El signe d'admiració indica admiració o exclamació i es posa també exclusivament al final de l'oració.

[42] «Som un grup de joves pirates en potència i tenim problemes per amotinar-nos en contra dels mestres. Ens encantaria que vingueres a ajudar-nos!».

[43] Home. Que sóc l'home dolent, collons! ( A Lorena.) Dis-li-ho. Sóc l'home dolent! El que no et deixa dormir! (Crida. Pausa. Desmunta el seu posat de monstre.) D'acord, sóc el monstre de l'anunci de la Valeriana! Ja ho he dit!

Tant el signe d'interrogació com el signe d'admiració són indicadors de final d'oració i, per tant, no s'han d'escriure mai seguits de punt. També va contra les convencions gràfiques l'ús d'un espai abans del signe i l'escriptura de diversos signes (??? o !!!) com a marca d'èmfasi de la pregunta o de l'exclamació.

\subsubsection{Els guions $i$ el guionet}

Els guions (-) s'utilitzen en els casos següents:

1. Per a inserir en el text un incís, un aclariment, un pensament o una informació accessòria (a vegades, en aquesta funció són intercanviables amb els parèntesis).

[44] Difícilment podria ser d'una altra manera, perquè el consumidor -i en això és completament diferent de les formes de vida anteriors- no associa la felicitat amb la satisfacció de les necessitats.

[45] Un altre dels projectes que s'han fet públics l'endemà del rescat és la docusèrie Coal -en anglès carbó- de la cadena nord-americana Spike TV.

[46] La societat de consumidors ha desenvolupat, fins a un grau sense precedents, la capacitat d'absorbir totes les formes de dissensió que inevitablement, igual que altres tipus de societat, genera -i de convertir-les, després, en un recurs fonamental per a la seua pròpia reproducció, reforçament i expansió. 
2. Per a indicar les intervencions dels locutors en els diàlegs $i$ introduir les acotacions del narrador o inserir les paraules del locutor principal a l'interior d'una citació en estil directe.

[47] -Escolteu, nois -va intervenir el sergent Recep-. Sabeu què és el que m'agrada més d'aquestes muntanyes?

[48] «Avui - ha dit Piñera- sento una profunda emoció, la mateixa que senten tots els xilens, però també sento una tremenda alegria, perquè els xilens vam dir que no ens rendiríem i complim.

Quan el tancament de l'incís coincideix amb la fi de l'oració, no s'ha d'escriure el guió final, especialment si és punt i a part, ja que el punt assumeix la funció de cloenda. En canvi, sí que es pot escriure guió i punt a l'interior d'un diàleg en un text narratiu.

El guionet (-) s'utilitza per a separar alguns mots compostos (Vila-real, penyasegat, comprar-ne...), per a separar períodes de temps i dates (curs 2010-2011) i per a unir mots i xifres (Barça-València, Castella - la Manxa). Quan els elements units consten d'un sol mot, no cal deixar espai abans i després del guionet, mentre que, quan uneix elements formats per més d'un mot, s'ha de deixar un espai davant $\mathrm{i}$ darrere del guionet. ${ }^{3}$

\subsubsection{Parèntesis i claudàtors}

Els parèntesis s'utilitzen per incloure una informació complementària, una intercalació o un incís. A vegades són intercanviables amb els guions o amb les comes, tot i que habitualment es prefereix o és prescriptiu l'ús dels parèntesis en els casos següents:

1. Quan la informació afegida és molt breu, quan cal fer un incís a l'interior d'un altre que s'ha marcat amb comes o amb guions o quan s'ha d'inserir en el text una enumeració exemplificadora.

2. En casos específics, com ara la indicació de les dates de naixement i de mort d'un personatge, les indicacions geogràtiques (països, comarques...) i l'any de publicació d'un llibre o del rodatge d'una pel·lícula.

[49] Orson Welles (1915-1985) havia nascut a Kenosha (Wisconsin) i es dedicà primerament al teatre, amb un notable èxit, $i$ també a la ràdio, mitjà en què es féu famós sobretot quan, arran de la seva adaptació (1938) de The War of the Worlds de H. G. Wells, difongué com una notícia una invasió d'extraterrestres, fet que desencadenà el pànic col·lectiu. La seua obra cinematogràfica mostra una visió molt particular del món i de la societat, exposada amb un llenguatge audaç i una renovació tècnica absoluta (nous tractaments de la il·luminació, moviments de la cambra,

3. En l'annex vi es presenta un quadre resum dels usos del guionet com a element de separació en els mots derivats i en els compostos. 
muntatges, etc.) [...]. Fou alhora actor i director, entre altres, del film Citizen Kane (1941), considerada una de les pel·lícules capitals de la història del cinema.

3. Per inserir les referències internes en un treball acadèmic o en un text periodístic i per marcar la procedència d'una citació en el sistema estàndard més utilitzat actualment (autor, any: data).

[50] Per tant, resultà una autèntica commoció per a Einstein que el 1949 Kurt Gödel, el del teorema de Gödel (vegeu el quadre adjunt), descobrira un espaitemps que corresponia a un univers ple de matèria en rotació, i que tenia bucles temporals en cada punt (fig. 5.4).

[51] Una de les idees essencials del cognitivisme és que les paraules evoquen marcs o «estructures mentals que donen forma a la manera com veiem el món» (Lakoff, 2004: 11).

Els claudàtors (també anomenats parèntesis quadrats o rectangulars) s'utilitzen per emmarcar els punts suspensius que indiquen que en una transcripció o una citació s'ha suprimit un fragment o per indicar, dins d'una citació, la intervenció de la persona que la reprodueix.

[52] Segons el president, «l'informe es presentarà a la premsa el 15 de giner [sic] de 2011».

\subsubsection{Cometes}

Les cometes simples s'utilitzen per a indicar el significat d'una paraula o d'una frase o per traduir, entre parèntesis, el títol d'una obra.

[53] L'steadicam, de l'anglés steady-cam 'estabilitzador de càmera', és un dispositiu que permet dur la càmara de cinema o televisió lligada al cos de l'operador i compensar els seus moviments, mostrant imatges similars al punt de vista subjectiu del personatge.

[54] Tony Curtis (1925-2010) va protagonitzar (1959), amb Marilyn Monroe i Jack Lemmon, Some Like It Hot ('Ningú no és perfecte', en castellà 'Con faldas i a lo loco'), dirigida per Billy Wilder, una de les millors pel·lícules de la història del cinema.

Les cometes dobles poden ser altes (“") o baixes («») i s'utilitzen en els casos següents:

1) Per reproduir una citació o paraules textuals d'una font externa, especialment en un treball acadèmic o en un text periodístic o publicitari.

[55] Segons Bassols: «La identitat no és un fet natural sinó una construcció cultural» (2010: 21$)$. 
[56] Vargas Llosa: «Escriuré fins a l’últim dia».

[57] L'extresorer Sala Martín qualifica Rosell de «covard».

[58] «La natura selecciona els que s'adapten millor al medi...». Charles Darwin (Nissan Terrano, 1999).

2) Per indicar un significat o un èmfasi especial, un matís irònic o personal, un doble sentit o una remarca.

[59] Hi ha moltes formes de patriotisme que no són sinó mera xenofòbia, perquè sovint els habitants d'una «pàtria» només arriben a sentir-se'n «patriotes» quan s'imaginen o es troben en fricció amb els veïns de la «pàtria» del costat (Joan Fuster, Diccionari per a ociosos).

3) Per fer pseudocitacions o «citacions de ningú en concret» i que no es poden considerar termes específics.

[60] La pel-lícula pertany, malgrat la seva indiscutible qualitat, a aquella categoria que s'ha anomenat «cinema comercial».

4) Per reproduir títols d'articles, capítols, poemes, cançons o altres unitats que formen part d'una obra (un llibre, una revista, un diari, un àlbum...) i per referir-se als títols de les exposicions quan el mot exposició no forma part del nom propi.

[61] «L'albatros» $\mathrm{i}$ «Correspondències» són dos dels poemes més emblemàtics de Les flors del mal, l'obra que inaugura la poesia contemporània.

En canvi, s'ha d'evitar l'ús de les cometes per a les funcions reservades a altres recursos gràfics, com la cursiva i la negreta -la paraula avió (no pas «avió»)-, o per marcar els noms propis d'empreses, institucions i altres entitats.

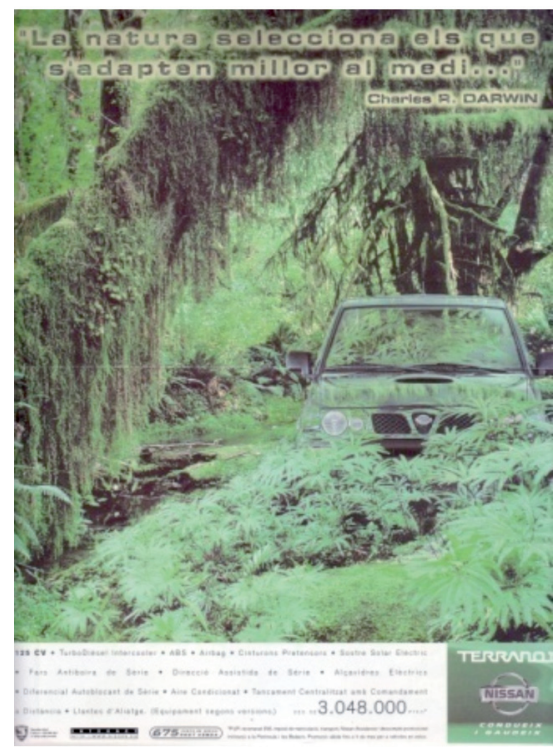

Fig. 32. Anunci de Nissan Terrano (2000) 


\subsubsection{Aspectes gràfics}

Algunes de les errades més habituals en l'ús dels signes de puntuació estan relacionades amb l'escriptura dels signes en contacte i amb l'ús dels espais en blanc. Tot seguit veurem quines són les indicacions generals pel que fa als usos dels espais i com es combinen amb els signes de puntuació.

Els signes de puntuació segueixen immediatament la paraula anterior i se separen amb un espai de la paraula següent:

[62] *Ara mateix , no estem en condicions d'oferir-los una opció més adequada.

[63] Ara mateix, no estem en condicions d'oferir-los una opció més adequada.

[64] *Tot programa que dirigeix Mikimoto aconsegueix èxit i elogis.I ben merescuts.

[65] Tot programa que dirigeix Mikimoto aconsegueix èxit i elogis. I ben merescuts.

[66] *Les fonts d'informació utilitzades habitualment pels periodistes són : agències de notícies, comunicats de premsa...

[67] Les fonts d'informació utilitzades habitualment pels periodistes són: agències de notícies, comunicats de premsa...

[68] *Informe-se'n !

[69] Informe-se'n!

Els guions, els parèntesis, els claudàtors i les cometes van units a la primera $\mathrm{i}$ l'última lletra de la paraula o del fragment que contenen. En el cas de les cometes, tampoc no cal deixar cap espai si van darrere d'un apòstrof.

[70] *La Unitat de Cures Intensives ( UCI ).

[71] La Unitat de Cures Intensives (UCI).

[72] *En l'acte - ha dit el magistrat - s'ha aconseguit evitar un mal a tercers.

[73] En l'acte - ha dit el magistrat-s'ha aconseguit evitar un mal a tercers.

[74] *La campanya « Coneixem el nostre entorn ».

[75] La campanya «Coneixem el nostre entorn».

[76] * Entenem per 1' «entorn» tot allò que ens envolta...

[77] Entenem per l'«entorn» tot allò que ens envolta...

Les xifres que serveixen per numerar capítols, apartats o elements d'una llista porten un punt al darrere de cada xifra seguit d'un espai en blanc. No cal afegir-hi cap altre signe.

[78]*1.- El discurs literari

[79] 1. El discurs literari

[80]*1.1La literatura d'idees

[81] 1.1. La literatura d'idees 


\subsection{Elements paralingüístics de l'escriptura}

Els elements paralingüístics de l'escriptura són un conjunt de recursos convencionals que afecten la presentació del text escrit sense modificar-ne aspectes essencials del contingut. L'ús de les majúscules i minúscules, l'escriptura dels nombres en xifres o en lletres, els aspectes tipogràfics i l'ús dels espais en blanc (i, en general, de tot allò que fa referència a la presentació de l'escrit) són alguns dels elements que convé tenir en compte a l'hora de presentar qualsevol text escrit.

\subsubsection{Majúscules i minúscules}

L'ús de les majúscules en l'escriptura respon a dues funcions: la funció demarcativa i la funció distintiva.

a) La funció demarcativa es refereix a la utilització de la majúscula segons la situació que té dins del text $\mathrm{i}$ està relacionada amb els signes de puntuació. És a dir, escriurem un mot en majúscula segons la posició que ocupa el mot dins del text: al principi, després d'un punt, després dels signes d'admiració i interrogació, dels punts suspensius o de l'inici de la majoria de les citacions.

b) La funció distintiva es refereix a la utilització de la majúscula per destacar alguns mots del text, segons la seua naturalesa, com en el cas del mots propis concrets (La Universitat de València té cinc segles).

Tot i que aquests principis generals, d'entrada, poden semblar senzills, en la pràctica la qüestió és força més complicada. Mentre que els usos de les majúscules relacionats amb la funció demarcativa no solen presentar dificultats, els usos distintius ofereixen nombroses vacil-lacions $i$ algunes contradiccions que en dificulten un ús coherent i senzill. Així, per exemple, és habitual que persones amb una bona competència gramatical en català tinguen dubtes a l'hora d'escriure el títol d'un treball, un nom de lloc, el nom d'una carrera o d'una assignatura, o bé determinats càrrecs i departaments d'una institució.

Com a criteri general, cal evitar l'ús de frases senceres o paraules completes en majúscula a l'interior del text per tal de destacar-les i limitar l'ús de les majúscules en els títols dels diversos apartats d'un text. Pel que fa a l'ús de la majúscula o la minúscula en la primera lletra de paraules o frases, habitualment se segueixen les convencions següents:

1. S'escriu amb majúscula la lletra inicial de frase, tant en posició inicial absoluta com després de punt o després dels signes d'interrogació i d'exclamació i dels punts suspensius que tanquen oració. S'escriu, però, en minúscula després de punt $\mathrm{i}$ coma $\mathrm{i}$ de dos punts. Tanmateix, quan els dos punts introdueixen una enumeració que s'inicia amb un nou paràgraf, es pot utilitzar indistintament la majúscula o la minúscula, tot i que se sol preferir l'ús de la minúscula si els elements de l'enumeració són mots o sintagmes nominals (i 
en aquest cas s'acostuma a ometre el punt al final de cada element o a substituir-lo per una coma) i es reserva la majúscula per a iniciar els elements de les enumeracions que són oracions (i en aquest cas se separen amb un punt).

2. S'escriuen amb majúscula els noms i cognoms de persones, divinitats, dinasties i llinatges, però es mantenen en minúscula els articles i les preposicions que formen part d'aquests noms: Miquel Martí i Pol, Zeus, Alfons el Magnànim, l'època dels Borja, etc.

3. S'escriuen amb minúscula els dies de la setmana, mesos, estacions de l'any, períodes històrics (excepte la Renaixença, el Renaixement i la Il·lustració) i els moviments culturals, literaris i pictòrics. Però s'escriuen amb majúscula els esdeveniments singulars de la història: la Revolució Francesa, la Segona Guerra Mundial, etc.

4. S'escriuen amb minúscula els càrrecs oficials i els títols nobiliaris, excepte si formen part d'un topònim: el president de la Generalitat, la regidora de Cultura, el comte Arnau, el carrer de Sant Nicolau, etc.

5. També s'escriuen amb minúscula els cicles educatius i les disciplines científiques, però amb majúscula els títols acadèmics i els noms de les assignatures: un estudi sobre informàtica; ciències com la física, la química i la biologia; llicenciat en Física i Química; doctorat en Dret Internacional; té un excel·lent en Teoria de la Comunicació.

6. S'empra la majúscula per escriure els noms propis d'institucions, organismes, entitats, empreses o establiments, però no els genèrics que es refereixen a un grup més o menys extens d'organismes: les universitats valencianes, els instituts de batxillerat, les comunitats autònomes de l'Estat espanyol, la Comunitat Valenciana, la Universitat Jaume I, tots els departaments de la Facultat de Ciències Humanes i Socials, les comarques del nord de Castelló, l'Institut Tirant lo Blanc, etc.

7. S'escriu amb majúscula la lletra inicial dels títols de llibres, articles, obres de teatre, pel-lícules o arts plàstiques i el nom de publicacions periòdiques (diaris i revistes) i de les col·leccions de llibres: El nom de la rosa, L'últim emperador, el setmanari 'El Temps', el diari 'Avui', la revista 'La Rella', l'article «Les llengües del nord d'Ałfrica», etc.

8. S'escriuen amb minúscula els noms genèrics d'accidents geogràfics, els noms de demarcacions i divisions territorials i la designació genèrica dels topònims urbans. Però s'han d'escriure amb majúscula els noms genèrics que ja formen part del topònim, és a dir, quan s'apliquen a un referent que no coincideix amb el significat del genèric. Exemples: la mar Negra, el riu Túria, la serra de Mariola, la vall del riu Ebre, la comarca de la Vall d'Albaida, la Vall d'Alba, la plaça del País Valencià, el carrer Major, l'avinguda del Rei en Jaume, etc. 
9. L'article dels topònims, en els noms catalans, s'escriu amb minúscula i, si cal, es contrau amb la preposició precedent. En els topònims d'una altra llengua, però, es manté la majúscula inicial i no es fan les contraccions (fora dels casos de topònims adaptats). Exemples: l'Alacantí, la Plana Baixa, l'Alt Maestrat i els Ports, la Safor, El Salvador, Las Palmas, Los Angeles, el Caire, el Japó, la Corunya, l'Havana, etc.

10. En informàtica, generalment s'escriuen amb majúscula inicial els noms de programes informàtics, llenguatges de programació i sistemes operatius (Word, Basic, Firefox...) i el nom d'un menú, d'una finestra o d'un quadre de diàleg (Obriu el menú Inserció i feu clic sobre el botó Imatge). En canvi, a diferència de la terminologia informàtica, en la terminologia física i química, les unitats de mesura s'escriuen en minúscula (clorur sòdic, polzada, megabit, gigabit, quilobit, etc.), però s'escriuen en majúscula els símbols de les unitats que provenen de noms propis ( $N$ de Newton). Igualment, en les designacions de lleis o teoremes, només s'escriuen en majúscula els noms propis que inclouen (les lleis de Kepler, la teoria de la probabilitat).

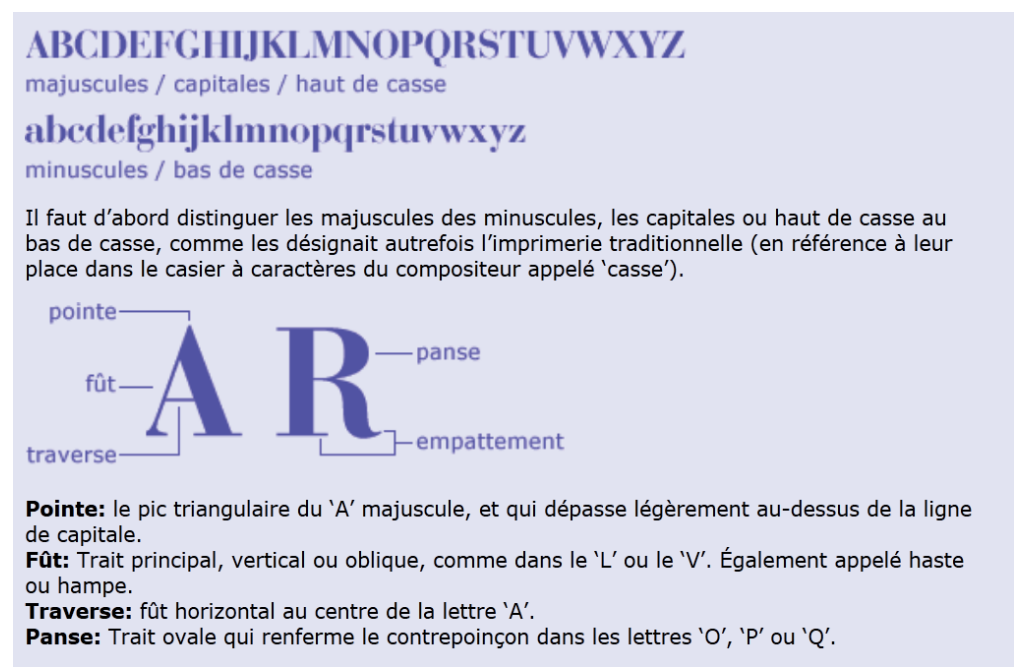

Fig. 33. Majúscules i minúscules

(font: http://www.planete-typographie.com/manuel/lexique.html)

Com podem comprovar, l'ús correcte de les majúscules i minúscules no és tan senzill com pot semblar en un principi. Per acabar, cal recordar que «molt sovint s'ha tendit a associar la majúscula amb el grau de respecte o amb la importància del concepte a què fa referència el mot» $i$, en conseqüència, «s'ha tendit a abusar-ne i a utilitzar-la de manera subjectiva». Avui dia, en canvi, els usos es decanten per altres criteris més estrictes i objectivables, malgrat les vacil-lacions i excepcions que es poden identificar (Nicolau-Cuenca, 2007: 21).

\section{www}

En cas de dubte, convé consultar la bibliografia més actualitzada i recórrer a la informació disponible en els llocs web següents:

http://www.uoc.edu/serveilinguistic/criteris/convencions/majuscules_minuscules.html http://www6.gencat.net/llengcat/publicacions/majus/index.htm http://esadir.cat/tipografia/majusminus 


\subsubsection{Escriptura dels nombres: xifres i lletres}

El fet d'escriure els numerals amb xifres o amb lletres depèn del tipus de text en què apareixen. En general, en treballs científics, econòmics o estadístics, és preferible utilitzar xifres, mentre que en obres literàries o de l'àmbit humanístic se solen utilitzar lletres. Això no obstant, es poden fer algunes recomanacions de caràcter general.

a) En principi, se solen escriure amb xifres els nombres que consten de més d'un mot i s'acostumen a escriure amb lletres els nombres formats per un sol mot.

b) S'escriuen amb xifres les quantitats exactes, els nombres que expressen decimals i els nombres que apareixen en quadres, llistes, gràfics o taules estadístiques (M’he gastat 859 euros en un disc dur; El problema dóna 6,4); els percentatges seguits de símbol i les quantitats en contacte amb una abreviació (14 \$; El 40\% de l'alumnat s'ha matriculat en una llicenciatura); els nombres que formen part d'una gradació, successió o sèrie (sense punt entre els milers i les centenes) (pàg. 1412; DNI: 37132 345); darrere de substantius (La pàgina 3; L'habitació 459); en les dates i expressions horàries exactes (Castelló de la Plana, 9 de desembre del 2011; Els magatzems obren a les 9.30); els números de capítols, apartats i pàgines i els números d'ordre ( $\mathrm{Al}$ capitol 5 è podeu consultar...; $1 r$; 6è), i les desenes, les centenes i els milers de milions (400 milions d'euros).

c) En canvi, s'escriuen amb lletres les quantitats aproximades (nombres trencats i partitius en sentit general, tants per cent expressats amb lletres, les hores en un sentit aproximat; S'ha begut, ell sol, un terç de l'ampolla; El quinze per cent dels usuaris demanen confidencialitat; Són dos quarts de dotze); en els textos redactats, les unitats de milions i de bilions i els mots milió, bilió i trilió per evitar nombres massa llargs en les quantitats rodones (Hi ha hagut un desfasament de més de dos milions d'euros), i l'edat i la durada (Aquest ordinador és una relíquia: té més de deu anys).

d) Malgrat aquestes indicacions, cal unificar l'ús de les xifres i lletres en una mateixa oració o en una sèrie, per raons de coherència. En aquest cas, tindran prioritat les xifres (El 1931, va obtenir el titol de pilot, a l'edat de 18 anys).

\footnotetext{
Solem escriure amb lletres els nombres d'un sol mot i amb xifres els de més d'un mot o quan volem expressar una quantitat exacta. Expressem amb xifres: els nombres precedits d'abreviacions o que segueixen un substantiu, les dates i les hores exactes, els apartats, les pàgines, els números d'ordre i les desenes, centenes i milers de milions. Escrivim amb lletres les quantitats aproximades (percentatges no expressats en símbols, les hores, els partitius i trencats en sentit general, les unitats de milió i els mots milió, bilió o trilió) i l'edat i la durada.
}

Nicolau-Cuenca, 2007: 25 


\subsubsection{Tipografia}

\subsubsection{Qüestions de terminologia}

Actualment, els processadors de textos permeten triar entre un amplíssim ventall de tipus de lletra, cadascuna de les quals és més o menys adequada per a un tipus de text o un altre: Arial, Courier, Times New Roman, Trebuchet, Script, etc. En general, convé triar una lletra clara i fàcilment intel-ligible i defugir (si no és per a la redacció de textos molt especials) les lletres sofisticades, manuscrites, molt petites o molt grans, i convé mantenir el mateix tipus de lletra durant tot el text. Pel que fa a la grandària, és aconsellable d'utilitzar per al cos del text una mida que pot oscil·lar entre 10 p. i 12 p. i per als títols, entre 14 p. i 20 p.

Els tipus de lletra més habituals permeten d'utilitzar, en moments puntuals de la redacció, efectes i estils per remarcar o destacar una paraula o expressió, un títol o un fragment del text. Els estils són formes d'emfasitzar el text i habitualment apareixen en algun lloc de la barra d'eines del processador de textos. Els més habituals són la lletra negreta, la cursiva i el subratllat. Els efectes, que es poden seleccionar des del menú Tipus de lletra, inclouen opcions com el subíndex i el superíndex, el ratllat i el doble ratllat, l'ombra, el contorn, el relleu, el gravat, la majúscula o la versaleta.

En general, per a tots els tipus de text, convé no emprar indiscriminadament els diferents estils $\mathrm{i}$ efectes especials del text $\mathrm{i}$ aplicar-los a fragments molt puntuals. Els diversos estils tenen assignades funcions específiques, les més habituals de les quals s'indiquen tot seguit.

tipografíaanatomía 0

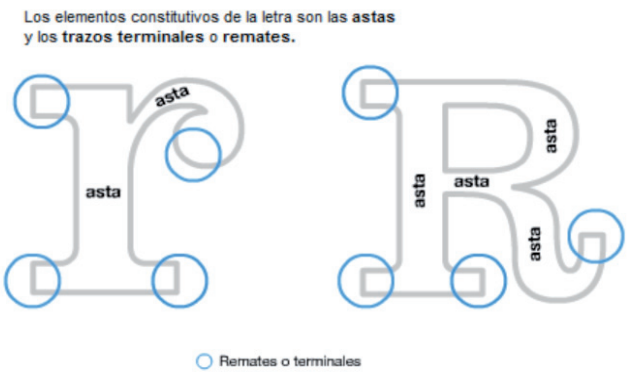

Fig. 34. Anatomia de la lletra (font: http://www.baber.biz/tipografia/html/anatomia.html) 


\subsubsection{Els estils més habituals: rodona, cursiva i negreta}

- La lletra rodona o normal

La lletra que es denomina rodona o normal és l'estil no marcat en el text. S'utilitza en la redacció del cos del text, és a dir, en el text que no es vol destacar o que no cal distingir de cap manera especial. És, per tant, l'estil tipogràfic que s'utilitza per no cridar l'atenció, per transmetre d'una forma neutra el contingut de les frases i dels paràgrafs. Convé recordar, però, que a més d'aquesta funció bàsica, també s'han d'escriure en lletra rodona o normal:

a) els noms de marques i establiments comercials o de lleure,

b) els noms propis de persona o de personatges de ficció, $\mathrm{i}$

c) els textos citats, en català o en una altra llengua.

\section{- Negreta}

La funció més comuna de la lletra anomenada negreta és permetre la localització immediata d'una paraula en un text. En els materials didàctics, també és admissible fer-la servir com a substitutiu del que s'anomena cursiva d'èmfasi, tot i que convé no abusar-ne (no és adequat utilitzar aquest recurs per a destacar frases senceres). Aquesta funció general es concreta en els usos següents:

a) Títols de capítols, apartats i subapartats d'un text.

b) Marcadors d'informació d'un text: paraules que es destaquen per facilitar la localització d'informació dins d'un paràgraf o dins d'un text llarg o complex. Exemple: «Respecte de la distribució d'alumnes per cicles, cal començar remarcant el predomini dels estudiants de primer cicle; en canvi, només una tercera part d'estudiants són de segon cicle».

c) Títols de taula o de figura. Exemple: «Figura 7.3. Instal·lació aïllada amb un transformador».

d) Encapçalaments de quadres i taules, tot i que també es pot emprar la lletra cursiva.

- Cursiva

La cursiva s'utilitza, fonamentalment, com a marca d'èmfasi -neutra semànticament, per destacar sense afegir connotació-, per escriure els títols d'obres i per reproduir mots i expressions d'altres llengües.

Com a element gràfic per destacar elements del text, s'utilitza en els casos següents:

a) Per marcar lletres, mots i frases objecte de consideració metalingüística: «El mot envers significa...», «En l'apartat $b . . . »$.

$b$ ) Per indicar paraules o fragments que es remarquen en el text perquè després se'n fa una explicació: «El fauvisme, moviment...». 
c) Per visualitzar mots clau i termes tècnics que convé destacar gràficament, en general quan apareixen per primer cop.

d) Per presentar els símbols de magnituds i termes algèbrics en els textos científics i les fórmules en què s'utilitzen (però les lletres gregues, els símbols dels elements químics i les unitats de mesura s'escriuen en rodona).

També s'escriuen en cursiva els títols de llibres, obres teatrals, peces musicals, pel-lícules, publicacions periòdiques i, en general, qualsevol obra de creació autònoma.

I, finalment, s'utilitza també la lletra cursiva per marcar paraules, locucions i expressions d'altres llengües (per exemple, s'escriuen sempre en cursiva les locucions llatines), tret de les que es troben al diccionari sense asterisc o sense indicació de procedència o han estat acceptades pel TERMCAT: fondue, single, striptease, a priori, a posteriori, grosso modo, attrezzo, western, mass media, soundtrack, raccord, brainstorming, etc.

No s'han d'escriure en cursiva els noms propis d'empreses o altres entitats (encara que siguen en una llengua estrangera): Instituto Libre de Enseñanza, Internet Interdisciplinary Institute.

\subsubsection{Altres estils $i$ efectes tipogràfics}

Els altres estils i efectes tipogràfics tenen usos molt específics i molt més restringits que els anteriors. Els més habituals són els següents:

a) La VERSALETA es fa servir en els numerals romans que expressen els segles -tret dels segles en un text en cursiva, que s'escriuen amb majúscula-i, de vegades, per marcar el cognom de l'autor en les relacions bibliogràfiques.

b) La MAJÚSCULA o VERSAL, tot i que és el tipus més antic, actualment s'utilitza només per introduir la inicial després d'alguns signes de puntuació (punt, punts suspensius, signes d'exclamació i interrogació) i en casos ben tipificats convencionalment (noms propis, noms d'empreses i institucions...). Cal evitar la inserció de frases senceres en majúscula a l'interior del text com a marcador d'èmfasi o com a recurs tipogràfic per destacar una paraula o una idea. En aquests casos, sempre és preferible emprar altres estils, com ara la negreta o, en casos molt especials, el subratllat. De fet, actualment, només s'accepta l'ús de frases senceres en majúscula en els casos següents:

- Eslògans publicitaris, lemes i rètols de carreteres.

- Títols de llibres (en la portada), en el llom i en la contraportada.

- Títols de capítols o parts de llibres i treballs, sempre que es tracte d'obres extenses.

- Textos molt breus en què es busca un impacte visual (eslògans, anuncis, avisos...) o es vol transmetre una idea de solemnitat (inscripcions, epitafis...). 
En qualsevol cas, convé no abusar d'aquest recurs, perquè precisament si se n'abusa pot arribar a perdre la seua eficàcia. La citació en un text de fragments que en el suport original estaven escrits en majúscules no justifiquen el manteniment d'aquest efecte tipogràfic en el text citat.

c) El subratllat és un efecte que s'ha d'emprar amb molta cura i amb molta precaució. Actualment, es tendeix a desaconsellar-ne l'ús per marcar una paraula o un fragment important del text (per a això s'utilitza la negreta o la cursiva) i en els títols i subtítols. Només es continua emprant com un mecanisme de selecció de paraules i idees importants durant el procés de lectura del text. És, per tant, més un recurs del lector per apropiar-se del contingut del text que no pas una estratègia de l'autor.

d) El superíndex s'utilitza per marcar en les fórmules matemàtiques l'operació de potenciació i per introduir, en el cos d'un text, els números corresponents a les notes a peu de pàgina. El mateix número (2, per exemple) es reprodueix davant del text de la nota, ara ja en l'estil normal i seguit d'un punt i un espai (2. Aquesta idea...) $\mathrm{El}_{\text {subíndex }}$ s'utilitza per indicar alguns matisos distintius en lletres i números.

e) A l'hora de redactar un text escrit, la selecció del tipus de lletra (o font) i dels efectes tipogràfics relacionats amb el color i grandària de la lletra depèn de factors molt diversos i no es poden donar recomanacions generals. Convé, però, no combinar indiscriminadament tipus de lletra, colors i grandàries diferents en un mateix text, perquè això en dificulta la lectura i pot crear confusions. En general, els canvis, que s'han de limitar al mínim imprescindible, han d'estar relacionats amb el contingut $\mathrm{i}$ han d'utilitzar-se per indicar alguna cosa al lector (la inserció d'un text complementari, la introducció d'una citació, una nota a peu de pàgina, els títols o subtítols, etc.). Així, per marcar el text d'una citació relativament extensa (més de tres o quatre línies) o per separar les notes a peu de pàgina del text principal, s'utilitza un cos de lletra inferior (amb un parell de punts n'hi ha prou) al cos del text matriu. L'ús del color per escriure el text o per marcar una paraula o una part del text és un element emfasitzador que resulta molt interessant a l'hora de revisar el text, especialment en documents que tenen més d'un autor. En aquests casos, el color pot associar-se amb una persona determinada i, per tant, pot indicar d'una forma molt visual les observacions o les modificacions que ha introduït en el text.

f) Finalment, la resta d'efectes tipogràfics que ofereixen actualment els processadors de textos (ratllat o doble ratllat, ombra, contorn, relleu o gravat) s'han d'emprar amb molta cura i molt esporàdicament. El ratllat o el doble ratllat, per exemple, s'utilitzen per marcar les paraules o les idees que proposem d'eliminar. Els altres efectes són recursos més o menys estètics que només s'han d'emprar en els títols de treballs o dossiers i en altres situacions excepcionals. 


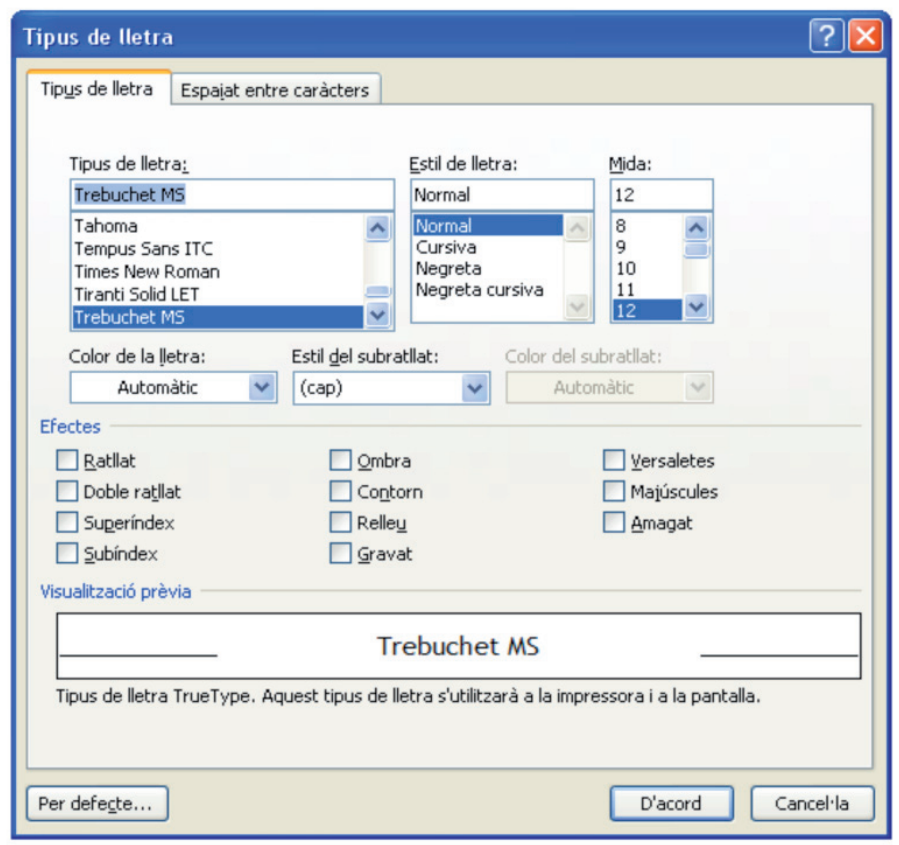

Fig. 35. Menú Tipus de lletra del Word

\subsubsection{Presentació de l'escrit}

La presentació del text és tan important com la redacció: d'una banda, perquè de la presentació en depèn la primera impressió que rep el lector i, de l'altra, perquè a través de la presentació de l'escrit, es comença a construir la imatge de l'autor i s'orienta el procés de lectura. És essencial, per tant, conèixer i emprar les convencions generals relacionades amb la distribució del text en la pàgina (marges, espais en blanc, paràgrafs, columnes...) i usar marques o senyals convencionals que faciliten la llegibilitat del text (títols, índexs, majúscules, negretes, cursives...). També és important conèixer les convencions específiques dels gèneres discursius més habituals (treball acadèmic, article d'opinió, notícia de premsa, etc.) i aplicar-les en la producció dels textos.

\subsubsection{Espais en blanc}

La distribució dels espais en blanc és un aspecte fonamental a l'hora de presentar qualsevol tipus de text: es tracta d'un recurs que facilita o dificulta la lectura i, per tant, la comprensió del text $i$, alhora, transmet al lector una sèrie d'indicis, més o menys precisos, sobre l'autor. És per això que convé dedicar-hi l'atenció necessària.

Quan es parla de l'ús dels espais en blanc en un text, habitualment es fa referència als aspectes següents: 
a) Ús de pàgines específiques per a la portada, l'índex o la introducció en els treballs i textos d'una certa extensió.

b) Marges del document (normalment, se solen utilitzar marges de $3 \mathrm{~cm}$ ).

c) Interlineat a l'interior del paràgraf, entre paràgrafs, i entre els títols i subtítols i el text.

d) Sagnies en la redacció dels paràgrafs: esquerra (primera línia, francesa) i dreta.

e) Espais en blanc al final d'una pàgina abans de començar un apartat nou.

Tot i que sobre aquests aspectes no hi ha solucions universals vàlides per a qualsevol tipus de text i per a qualsevol autor, és important de fer-ne un ús coherent al llarg de tot el text i de recordar que tots aquests recursos gràfics han de servir per fer més clar i més comprensible el text.

\subsubsection{Disposició convencional del text}

Alguns textos (cartes, instàncies, notícies...) tenen una disposició convencional (una superestructura) que els fa fàcilment recognoscibles. D'altres tenen, però, una forma més lliure. En els textos d'una certa extensió, especialment en els gèneres informatius i explicatius, els títols són un mecanisme important per estructurar i ordenar la informació. A través dels títols i subtítols, l'autor facilita una primera aproximació, d'una forma molt visual i molt ràpida, al contingut del text.

Els últims anys, els canvis tecnològics lligats al desenvolupament de la informàtica han provocat una autèntica revolució en la comunicació escrita. Els programes informàtics de processament i edició de textos han posat a l'abast de tothom un ampli ventall de possibilitats de presentació dels textos que abans només estaven a disposició de l'edició professional. A més, l'escriptura amb ordinador ha provocat un canvi radical en la forma d'escriure (especialment en el tractament dels esborranys i en les tècniques de correcció) i ha suposat la possibilitat de revisar automàticament l'ortografia i la gramàtica dels escrits i d'emprar els recursos electrònics disponibles a través d'Internet durant el procés de redacció i correcció.

Daniel Cassany, un dels especialistes que ha estudiat més i millor el procés de redacció, presenta un petit inventari de regles relacionades amb l'organització de la pàgina que permeten assolir una imatge de qualitat del text. El mateix autor presenta en un esquema una sèrie de recursos o marques lingüístiques i paralingüístiques que afavoreixen la llegibilitat del text. En l'annex Iv, elaborat a partir de la proposta de Cassany, els presenten agrupats en quatre tipus o funcions bàsiques. 
1. La pàgina és com una pintura emmarcada d'una exposició. L'escriptura és l'aquarel·la i el paper blanc fa de suport i marc. Els marges han de ser generosos, simètrics -que la pàgina no pengi cap a la dreta!- $\mathrm{i}$ rectes.

2. De l'equilibri entre la grandària de la lletra i del full i l'interlineat, en depèn la facilitat de visió. Val la pena tendir cap als espais amplis i la lletra grossa.

3. Els paràgrafs se solen marcar o bé amb un doble espai, anomenat línia blanca-com es fa en aquesta llista-, o bé amb una entradeta al començament -com la resta del llibre. No se solen barrejar els dos sistemes. [...]

4. Les PARAULES IMPORTANTS -títols, mots clau, tesis, etc.- poden anar marcats gràficament, tal com es fa en aquesta llista. Però cal ser CAUT: els abusos destorben més que no pas ajuden (tal com es veu en aquest punt).

5. S'ha d'identificar cada plana per motius de seguretat i comoditat: perquè no s'extraviï i perquè se sàpiga què es llegeix en tot moment. Els identificadors de pàgina es col-loquen als marges en punts estratègics. Els més corrents són el número de plana, el títol o referència del tema i l'autor. Un excés d'identificadors omple els marges de l'escrit i distorsiona la pàgina. Per això se solen concentrar tots en un únic marge.

6. Els títols i subtítols són les etiquetes del text. Se solen llegir moltes més vegades que cap altra part de l'escrit. Val la pena que siguin curts, clars i atractius: que informin del que trobarà el lector, que en continguin els mots claus i que serveixin per identificar cada part del text.

Cassany, 1993: 180-181 (adaptació)

\subsection{L'abreviació en català}

\subsubsection{El concepte d'abreviació}

Una abreviatura o abreviació és un procediment d'economia expressiva que consisteix a escurçar paraules o expressions d'ús habitual per estalviar espai en l'escriptura. Les abreviatures estan presents des dels manuscrits clàssics fins al llenguatge SMS d'Internet i són la base de la taquigrafia. La majoria d'abreviatures es formen amb la inicial del mot o les primeres lletres, com etc. per etcètera.

Quan es parla d'abreviació, es pot distingir entre abreviatures personals i convencionals. Les primeres s'usen per raons d'economia de temps, per exemple per prendre apunts o enviar missatges de mòbils; es basen en les normes d'ús habituals i, per tant, poden ser compreses per l'interlocutor amb ajuda del context. Moltes d'elles acaben sent convencionals, és a dir, d'ús general i fixat, com les usades en el llenguatge administratiu ( $C$ / per carrer, per exemple).

A efectes pràctics, hom acostuma a distingir, en el camp de l'abreviació, tres grans recursos o mecanismes d'abreujament: les abreviatures, els símbols i les sigles (i acrònims). 


\subsubsection{Abreviatures}

L'abreviatura és la representació d'un mot o dels mots d'una frase per alguna o algunes de les lletres que els formen, la primera de les quals ha de ser la inicial. Qualsevol paraula és susceptible de ser abreujada, però mentre que algunes tenen una abreviatura convencional, establerta i coneguda per tothom, d'altres admeten una major creativitat, ja que són els usuaris els encarregats de crear-la.

Normalment, solen portar, com a marca d'abreujament, un punt final, tot i que també hi ha algunes abreviatures que s'escriuen amb una barra (és incorrecte, però, escriure alhora el punt i la barra). Poden anar en minúscula o en majúscula, segons el context, i, si cal, han de dur accent. En alguns casos, a més, admeten la marca de plural.

Les abreviatures es poden formar per omissió, si se suprimeix la part final del mot (doc., bibl., p., av.), o per contracció, si se'n conserva la part inicial i la part final (sr., ctra.)

Des del punt de vista de l'escriptura és important tenir en compte els aspectes següents:

a) Abreviatures i espais en blanc. Les abreviatures s'escriuen amb un punt al final, i si es tracta d'una abreviatura composta de més d'un mot escurçat, cal deixar un espai entre mot i mot. Exemples: $c$. s. (centre de suport), A. M. Alcover (Antoni Maria Alcover).

b) Confluència amb els signes de puntuació. El punt abreviatiu s'omet en contacte amb el punt final de frase i els punts suspensius, però es manté, en canvi, davant qualsevol altre signe de puntuació.

c) Majúscules i minúscules. En general, les abreviatures s'escriuen amb minúscules o majúscules segons el tractament que tindrien les paraules que representen sense abreujar. Per això s'escriuen amb majúscules les inicials dels noms de persona i dels tractaments protocol-laris. Exemples: J. Martorell (Joanot Martorell), Excm. i Mgfc. Sr. (Excel·lentíssim i Magnífic Senyor). També s'escriu amb majúscula inicial l'abreviatura de senyor/senyora i doctor/doctora, per assimilació als tractaments protocol·laris.

d) Accentuació. Es mantenen els mateixos accents que tindrien les paraules sense abreujar. Exemples: pàg. (pàgina), núm. (número).

e) Ús de la cursiva. Les abreviatures d'expressions corresponents a altres llengües s'han d'escriure, preferiblement, en cursiva. Exemples: $n$. $b$. (nota bene).

f) Apostrofació. Els articles i preposicions, davant d'un mot abreujat, es comporten de la mateixa manera que si es tractés del mot sencer. Exemples: l'Excm. i Mgfc. Sr. Rector. 
g) Partició. Les abreviatures no s'han de partir a final de ratlla, ni s'han de separar del mot o la xifra que acompanyen. Exemples: Sra. Segura $\mid$ pàg. 3 |.

h) Noms de persona. Els noms de persona que comencen amb $L l$ es poden abreujar, optativament, amb $L$. o $L l$., ja que aquest dígraf representa un so diferent del que representa la lletra $l$. Exemples: $L l$. (Lluïsa) o bé $L$. (Lluïsa)

i) Ordinals. Els ordinals, tot i que són una abreviatura, convé escriure'ls sense punt final. Exemples: $1 r, 2 a, 5 e ̀, 4 t, 23 e ̀$, etc. Cal evitar, per tant, l'ús de les abreviatures $1^{a}, 5^{\circ}, 6 \dot{e} ., 7 n a ., 2 o n, 3 e r$ i similars.

\subsubsection{Símbols}

Els simbols són signes especials que es representen amb lletres, xifres, pictogrames, etc. Solen ser representacions de conceptes fixades per algun organisme oficial i, en la majoria de casos, tenen un reconeixement internacional. Si es componen de lletres, s'escriuen amb majúscules o minúscules, independentment de la tipografia general del text, segons s'haja fixat per a cada cas. No tenen mai marca de plural i s'escriuen sense punt. Pel que fa a l'ús dels símbols, cal tenir en compte les observacions següents:

a) Símbols i espais. Cal deixar un espai blanc entre el valor numèric i el símbol. Exemples: $13 \mathrm{~km}, 8 \mathrm{~min}, 100{ }^{\circ} \mathrm{C}$. Hi ha, però, algunes excepcions: $80 \%$, 4 ' (minuts geomètrics), $30^{\circ}$, etc.

b) Presència dins d'un text. No s'han de deixar símbols intercalats en el discurs. Exemples: quin percentatge (o tant per cent) s'obté... i no quin \% s'obté...

c) Coherència. No s'han de barrejar símbols i paraules senceres. Exemples: $\mathrm{km} / \mathrm{h}$ i no $\mathrm{km} / \mathrm{hora}$.

d) Símbols i magnituds. Els símbols referits a una magnitud només es poden fer servir quan aquesta magnitud s'expressa amb xifres. Exemples: $15 \mathrm{~km}$, 15 quilòmetres o quinze quilòmetres; però no quinze $\mathrm{km}$.

e) Partició. El símbol i la xifra a què es refereix formen un tot inseparable i, per tant, no es poden separar a final de ratlla.

f) El símbol de l'euro. Els símbols de l'euro $(€)$ i d'altres monedes s'utilitzen exclusivament, però no de manera obligatòria, en llistes i taules numèriques i, per tant, mai no es fan servir en un text continu. 


\subsubsection{Sigles i acrònims}

Les sigles són abreviatures formades per les lletres inicials d'una expressió constituïda per diverses paraules o per un grup d'inicials que s'utilitzen com un terme. La siglació és un recurs lingüístic cada vegada més productiu en la societat actual, tant per designar noms propis com per abreujar sintagmes procedents de llenguatges d'especialitat. Com a norma general, la primera vegada que aparega una sigla en un text s'ha d'escriure també el nom complet a què fa referència, i la resta de vegades que s'esmenta ja hi podrà aparèixer sola, sense desplegar. Hi ha algunes sigles, però, que són més conegudes que no pas el concepte a què es refereixen (com ara $K G B$ ) o són d'ús molt freqüent als mitjans de comunicació (com ara les sigles dels partits polítics o d'organitzacions internacionals) i no cal desplegar-les.

Les sigles s'escriuen sempre amb majúscules i sense punts ni espais entre les lletres (ESO i no E.S.O. ni E.S. O.), no tenen accents i són invariables gràficament-la forma de plural s'expressa amb l'article i no pas afegint una $-s$ al singular.

Pel que fa a l'apostrofació, els articles el i la i la preposició de s'apostrofen d'acord amb les regles generals davant les sigles començades en vocal -l'ICE, l'ONU, l'UCE (la $u$ és tònica), la UGT (la $u$ és àtona), la UNESCO, d'UNESCO- i davant de sigles començades en consonant que es llegeixen lletra per lletra, si el nom de la primera lletra comença en vocal ( $l$ ' $F B I, l^{\prime} N B A$ o d'NBA). En canvi, davant $s$ líquida, d'acord amb les normes generals, no apostrofem l'article la ni la preposició de: la SGAE. ${ }^{4}$

Els acrònims segueixen un procés de formació semblant a les sigles, però en aquest cas els formants del nou mot no han de ser necessàriament les inicials de paraula ni s'han de correspondre forçosament amb síl·labes d'aquestes paraules, ja que en els acrònims es busca que es puguen pronunciar sil-làbicament. Exemples: TERMCAT (Centre de Terminologia Catalana).

Tant les sigles com els acrònims poden lexicalitzar-se, cosa que comporta la incorporació a la llengua general com a paraules i, per tant, la representació d'acord amb regles d'escriptura generals (minúscules, formació de plural, accentuació...). Aquest procés es pot observar perfectament en mots com ara làser, ovni, sida, Renfe, Benelux, pimes, oenagé, etc.

\section{www}

Per consultar les abreviatures, símbols i sigles més habituals, es pot accedir a les pàgines web següents:

http://www.uoc.edu/serveilinguistic/criteris/convencions/abreviacions2.html http://esadir.cat/tipografia/abreviacions

4. Sobre l'ús de l'apòstrof en les sigles, podeu consultar l'annex VI. 


\subsection{Citacions i notes a peu de pàgina}

\subsubsection{Referències i citacions textuals}

En els treballs de recerca sovint hem de fer referència a les fonts externes, és a dir, als documents que hem consultat o que fins i tot hem reproduït parcialment. Hi ha, bàsicament, dos sistemes per referir-nos a aquests documents i per identificar-los: les notes a peu de pàgina i les notes a l'interior del text. En tots dos casos, però, és imprescindible facilitar, al final del treball, una relació detallada de les fonts consultades. Aquesta relació s'ha de presentar ordenada alfabèticament pels cognoms dels autors $i$ ha de facilitar les dades catalogràfiques precises dels materials utilitzats -autor i any d'edició, títol, lloc d'edició, editorial i, si es tracta d'un article, el títol de la revista on s'ha publicat, el número i les pàgines.

Les citacions de textos s'han d'incorporar al cos del discurs principal entre cometes angulars («»), i quan siguen extenses (més de tres línies), s’han de reproduir, sense cometes ni cursiva, en un paràgraf a part, amb el marge més entrat que el text. Si s'omet part del text de la citació, s'ha d'assenyalar amb punts d'elisió entre claudàtors: [...]. També s'haurà d'escriure entre claudàtors qualsevol incís de la persona que cita a l'interior del discurs citat.

En aquest sistema, la procedència de la citació s'indica immediatament després del discurs citat o, de vegades, abans de començar la citació, utilitzant la forma de referència bibliogràfica abreujada (autor, any: pàgines). D'aquesta forma se simplifica notablement el nombre de notes, es proporciona un aspecte més net al text i es facilita la lectura.

En les referències bibliogràfiques que apareixen dins el text només s'haurà de fer constar el cognom de l'autor -si no s'ha esmentat abans-, l'any d'edició de l'obra referida i, si escau, les pàgines que interessen, ja que les dades completes seran a la bibliografia. Si les pàgines són totes seguides, s'haurà de posar un guió entre ambdues xifres, i si no és el cas s'hi ha d'escriure una coma.

[82] Per tant, i tenint en compte les afirmacions de Mollà (1997: 109) [...].

[83] Ara bé, el nostre propòsit no és indagar en la tipologia de les formes de la comunicació científica, ni en la seua caracterització lingüística (Cabré, 1992: 115-153), sinó suggerir que les propietats amb què se'l sol caracteritzar habitualment [...].

[84] El cas és que l'oral i l'escrit són simples canals, que es poden expressar en diverses modalitats: formals, informals, etc. (Payrató, 1998: 9-20, 29, 31).

Quan l'obra té més d'un volum, s'haurà de fer constar el volum referit darrere dels dos punts, en números romans:

[85] Benveniste (1966: II, 254-257), en les precioses pàgines que dedica al tema, tracta l'eufemisme precisament en relació amb la blasfèmia. 
Per tant, cal prescindir en general de les abreviatures llatines: loc. cit., op. cit., ibídem...

A l'hora de citar idees procedents d'una font documental anterior (un 1libre, un article, un text inèdit o una web), disposem de tres possibilitats que requereixen tècniques de redacció diferents:

a) Si volem citar enunciats inferiors a l'oració o fragments textuals que ocupen dues o tres línies, se solen incorporar a l'interior del text, entre cometes $i$ integrats en la redacció, tot indicant-ne la procedència, abans o després de tancar la citació, amb el sistema autor-any-pàgina:

[86] Així, sense anar més lluny, quan s'analitzen els marcadors de caràcter adversatiu que tan freqüentment fa servir Fuster per marcar el contrast opositiu o matisador entre dues idees [...] trobem que els comentaris fets per Salvador a propòsit dels assaigs fusterians -com ara, quan afirma que sovint l'ús d'aquest tipus de marcadors es posa «al servei d'una estratègia discursiva molt concreta: la d'oferir, als ulls del lector, una autoimatge dialogant, negociadora» $(1994,239)$ - continuen sent perfectament vàlids per als textos acadèmics (Joan Borja: «Els discursos de la ciència», Saber i comunicar, p. 78).

b) Si hem de citar fragments textuals més extensos, convé redactar-los en un paràgraf a part, separats del text matriu per un interlineat superior al que s'utilitza habitualment, sagnats a l'esquerra i en un cos de lletra inferior a l'utilitzat en el text. En aquest cas, també se'n pot indicar la procedència abans o després de la citació.

[87] L'anàlisi dels gèneres discursius és un aspecte bàsic de la crítica cultural. L'autor que, des de la perspectiva assumida en aquest assaig, ha plantejat de manera més adequada i rigorosa l'anàlisi dels gèneres discursius és Mikhail Bakhtin. El seu punt de partida és el següent:

Les diverses esferes de l'activitat humana estan relacionades amb l'ús de la llengua. Per això és clar que el caràcter i les formes del seu ús són tan multiformes com les esferes de l'activitat humana [...]. Els tres moments mencionats -el contingut temàtic, l'estil i la composició- estan vinculats indissolublement en la totalitat de l'enunciat i es determinen, de manera semblant, per l'especificitat d'una determinada esfera de comunicació. Cada enunciat separat és, per descomptat, individual, però cada esfera d'ús de la llengua elabora els seus tipus relativament estables d'enunciats, els quals denominem gèneres discursius (1982: 248) [...].

El sorgiment de les llengües romàniques no fou el producte de la iniciativa cultural dels grups dominants (simbòlicament identificats amb una llengua morta). Fou més aviat el producte d'un període de crisi de poder i control social, quelcom semblant a un «instant de llibertat» (Pierre Bonnassie, 1978).

Enric Marín - J. M. Tresserras: Cultura de masses i postmodernitat 
c) Finalment, si volem esmentar la idea d'un autor o volem inserir en el text una paràfrasi del contingut d'un treball citat en la bibliografia, però no en fem una transcripció literal, podem indicar la procedència utilitzant el mateix sistema (autor, any i pàgina).

[88] Segons S. Levinson (1983: 12), la conversa és la manera prototípica d'usar el llenguatge. Hi ha qui, contràriament, sosté que la llengua escrita...

[89] Els incendis, que han augmentat al llarg del segle xx (Piñol, 1998), ja constitueixen ara una de les pertorbacions més importants en els ecosistemes mediterranis (Terradas, 1996) (Mètode, 34).

\subsubsection{Notes a peu de pàgina}

La inclusió d'una nota a peu de pàgina s'indica en el text mitjançant una crida -habitualment, un número aràbic en superíndex que s'ha de situar sempre darrere dels signes de puntuació, si n'hi ha-, que es reproduit, ja en format normal, a l'inici de la informació que conté la nota. El text de la nota es presenta al peu de la pàgina, separat del text on s'insereix per una línia contínua horitzontal i en un cos de lletra inferior al text matriu.

Actualment, s'observa una tendència, cada vegada més generalitzada, a reservar les notes a peu de pàgina exclusivament per introduir informació accessòria o per ampliar la informació que es dóna en el cos del text, i, per tant, a no utilitzar-les per indicar la procedència d'una citació.

\section{Lectures recomanades}

Martí, Joan I Josep M. Mestres (ed.) (2004): Quin(s) model(s) de llengua escrita per als mitjans de comunicació?, Barcelona, Institut d'Estudis Catalans.

Mestres, Josep M. (1995): Manual d'estil. La redacció i l'edició de textos, Vic, Eumo.

ONG, Walter J. (1982): Orality and Literacy. The Technologizing of the Word, Londres, Methuen \& Co. [Oralidad y escritura. Tecnologías de la palabra, Mèxic, Fondo de Cultura Económica, 1987].

Micó, Josep Lluís (2006): Periodisme en xarxa: llenguatge nou d'un ofici vell, Vic, Eumo.

Pujol, Josep M. i Joan Solà (2000): Ortotipografia. Manual de l'autor, l'autoeditor $i$ el dissenyador gràfic, Barcelona, Columna.

SERrano, Sebastià (1999): Comprendre la comunicació. El llibre del sexe, la poesia i l'empresa, Barcelona, Proa.

- (2003): El regal de la comunicació, Barcelona, Ara Llibres.

Tuson, Jesús (1996): L'escriptura. Una introducció a la cultura alfabètica, Barcelona, Empúries.

- (2006): Lletres sobre lletres, Barcelona, Empúries. 


\section{COHERÈNCIA DISCURSIVA I ESTRUCTURA DE LA INFORMACIÓ}




\section{TEMA 5}

\section{Coherència discursiva i construcció del sentit}

Introducció

1. Coherència discursiva i construcció textual

2. L'estructura del text

3. El paràgraf

4. Estratègies per sintetitzar la informació

5. Procediments per aclarir i ampliar la informació

6. La informació implícita

Lectures recomanades 


\section{Introducció}

La semiòtica estudia tots els processos culturals com a processos de comunicació, però cadascun d'aquests processos es produeix perquè al seu interior s'estableix un sistema de significació. De fet, el procés de comunicació es verifica només quan existeix un codi, un sistema de significació (Eco, 1977: 34-35). Segons Eco, «qualsevol procés de comunicació entre éssers humans pressuposa un sistema de significació com a condició pròpia necessària» (Eco, 1977: 35). Per tant, és impossible parlar de comunicació sense parlar de significació. Sovint ens referim a la significació, als continguts transmesos pels missatges, amb els termes significat i sentit. Cal, però, definir-los amb més exactitud en el marc del conjunt dels factors que intervenen en la interpretació lingüística.

D'acord amb la proposta de J. M. Castellà, «usarem significat per designar el potencial d'una expressió lingüística per representar el coneixement, mentre que el sentit serà el coneixement més les actituds, emocions, etc. que efectivament s'expressen i s'interpreten en un text i un context concrets. D'aquesta manera, el significat pertany més al terreny de la lingüística interna i el sentit correspon a la pragmàtica, la psicolingüística i la sociolingüística» (Castellà, 1992: 83). Des d'aquest punt de vista, «el sentit no és una secreció del cervell, totalment feta; és una cosa que es construeix en un locutor i es reconstrueix en un oient, en un context d'enunciació» (Bronckart, 1977, citat per Castellà, 1992: 84). Segons aquesta concepció, el sentit està constituït pel significat més el contingut aportat per la situació comunicativa (Castellà, 1992: 84) i, per tant, mentre que el significat és un aspecte fonamental del text, el sentit forma part del procés de construcció discursiva i del procés d'interpretació.

En treballar aquest tema, l'estudiant s'adonarà que en l'elaboració de qualsevol text, i també, per tant, en la redacció de textos de l'àmbit periodístic i publicitari i en la comunicació audiovisual, cal tenir en compte una sèrie d'aspectes relacionats amb la coherència textual i amb la construcció del sentit que resulten fonamentals per garantir l'eficàcia comunicativa. Es tracta, com es veurà a continuació, d'un conjunt de conceptes i tècniques de producció discursiva que permeten passar de la idea a la paraula i al text, del significat a la selecció lèxica i a l'ordenació dels elements de l'oració.

La unitat pretén que hom diferencie els mecanismes que tenen a veure amb l'articulació de les idees i amb l'estructura de la informació al llarg del text (el concepte de coherència, la progressió temàtica, l'estructura textual i l'organització de la informació en paràgrafs), per utilitzar els recursos lingüístics que permeten gestionar d'una forma eficaç la textualització d'aquestes idees (procediments per sintetitzar la informació, mecanismes per ampliar i aclarir la informació, pressuposicions i sobreentesos). 


\subsection{Coherència discursiva i cohesió textual}

\subsubsection{Significat, sentit i coherència}

Segons Brown i Yule, «un dels miratges més estesos i que més persisteixen en l'anàlisi del llenguatge és que el significat d'un missatge és entès només a partir de les paraules i l'estructura de les oracions utilitzades per expressar-lo» (BrownYule, 1983). Tot i que aquesta idea pot resultar còmoda perquè facilita extraordinàriament l'estudi de la significació, la consideració del funcionament real dels discursos introdueix prou elements per a la refutació d'una hipòtesi tan simplista com aquesta. Esmentarem només un parell de fets discursius que fan trontollar aquesta concepció del sentit i que exigeixen una ampliació dels punts de vista sobre la interpretació. Ens referim, en primer lloc, als nombrosos casos d'interpretacions divergents, de vegades, clarament oposades, d'un mateix enunciat lingüístic:

[1] Major pateix una derrota suau als comicis locals britànics.

[2] El president de la Generalitat té vocació d'equilibrista.

La interpretació de l'exemple [1] exigeix, en primer lloc, activar el marc 'eleccions', a l'interior del qual cal assignar sentits específics als complements verbals (comicis locals britànics i derrota suau) $\mathrm{i}$, tot seguit, activar el significat que en aquest context té el verb patir i assignar un referent al sintagma nominal que funciona com a subjecte, Major. També el sentit que s'assigne a l'adjectiu suau introdueix matisos diferents en la interpretació de l'enunciat. Pel que fa a l'exemple [2], les divergències en la interpretació tenen el seu origen, essencialment, en la dificultat per assignar un referent indiscutible al sintagma nominal que fa funció de subjecte (El president de la Generalitat) i, complementàriament, en l'ambigüitat semàntica del predicat verbal (té vocació d'equilibrista). En primer lloc, no sabem a quina institució es refereix l'enunciat (la Generalitat de Catalunya o la Generalitat Valenciana) i a quin president (un dels presidents actuals o un expresident) i, per tant, no podem recuperar la identitat del subjecte de l'oració -pot ser Alberto Fabra, Francisco Camps, Eduardo Zaplana o Joan Lerma, però també Artur Mas, José Montilla, Pasqual Maragall o Jordi Pujol. L'assignació d'un referent o l'altre determina, d'entrada, algunes hipòtesis interpretatives i n'elimina d'altres. Tanmateix, tant en un cas com en l'altre, el significat del subjecte sembla desaconsellar una interpretació literal del predicat i en suggereix una lectura en clau humorística, amb una tonalitat clarament irònica. Ara bé, què significa que un president de la màxima institució del país té vocació d'equilibrista? Sembla clar que només el context, lingüístic o extralingüístic, pot reduir la pluralitat d'interpretacions possibles. Per tant, el sentit de l'oració pot variar lleugerament en funció dels ajustaments que provoque cada interpretant, determinats pel seu coneixement del món i el seu coneixement de la realitat extralingüística i del context lingüístic.

En aquest sentit, ens sembla interessant de remarcar l'extraordinària facilitat que tenen els usuaris d'una llengua per assignar sentit, per interpretar amb coherència, un seguit de mots que no constitueixen una oració gramaticalment ben construïda o no contenen tota la informació necessària. Observem, si no, els casos següents: 
[3] Els rebels recuperen l'enclavament petrolier de Ras Lanouf.

[4] Entrebancs a la pista d'aterratge.

[5] Audi continua derrotant dracs.

[6] Hostessa TV. Bellesa insuperable. Rigorosa discreció. AP. 60 mil. Tel. 93/43030-97.

En l'exemple [3] necessitem saber de quins rebels parlem i on es troba l'enclavament petrolier de Ras Lanouf. En aquest cas, el subtítol de la notícia, el cotext, conté les dades necessàries per poder assignar el sentit adient a l'enunciat - «El suport de l'aviació aliada permet l'avanç de les tropes opositores a Gaddafi»- i per poder activar els coneixements enciclopèdics que en faciliten la interpretació -revolta a Líbia contra el coronel Gaddafi, març del 2011, actuació de l'aviació occidental per protegir la zona d'exclusió aèria decretada per l'onu, etc. El segon titular, que inicialment ens fa pensar en un problema indeterminat en qualsevol aeroport, va aparèixer en el titular d'un reportatge de la revista El Temps (núm. 1.388, 18 de gener del 2011, p. 30) dedicat a analitzar la situació a Euskadi després de l'anunci de la nova treva d'ETA. Ara són l'entradeta $\mathrm{i}$ el cos del text els que s'encarreguen de desfer l'ambigüitat: «L'anunci d'ETA del 10 de gener torna a remoure la política basca. Amb el tomb estratègic de l'esquerra independentista cap a vies només pacífiques i democràtiques, ara cal esperar el pas de la resta d'actors polítics, bascos i espanyols». L'exemple [5] és el titular d'un anunci de premsa aparegut el 23 d'abril de $2010 \mathrm{amb}$ motiu del dia de Sant Jordi. El text s'emmarca en un context figuratiu molt simple que, gràcies a la semblança entre la forma de la mànega de benzina i la forma del drac, evoca immediatament la llegenda tradicional (fig. 33). El contingut de la lletra petita de l'anunci completa la identificació i confirma la interpretació del text. Finalment, l'exemple [6] és un anunci breu procedent de la secció de contactes de la premsa escrita. Malgrat l'ús d'abreviatures i l'estil telegràfic, característic d'aquest subgènere publicitari, i malgrat que no s'hi expressa clarament el missatge, el sentit és inequívoc i transparent.

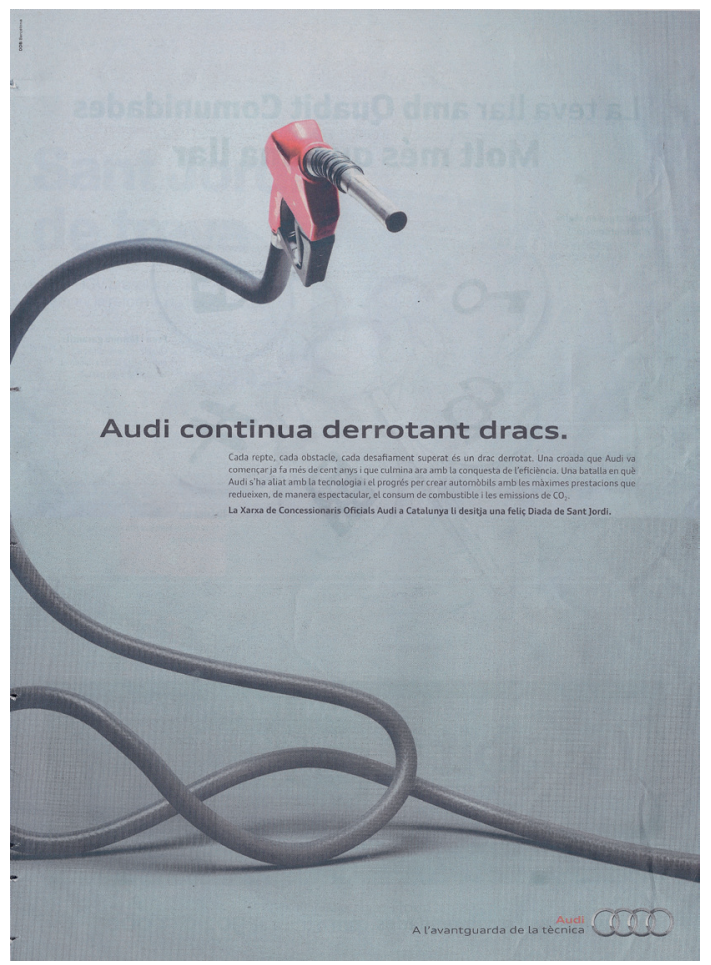

Fig. 36. Un anunci d'Audi (2010) 
Tots els casos comentats semblen apuntar la insuficiència d'una teoria semàntica centrada exclusivament en una concepció estricta de la significació i plantegen clarament la necessitat de tenir en compte els factors pragmàtics que remeten a la situació de comunicació com a element imprescindible per construir una teoria de la interpretació sòlida i ben fonamentada. En paraules de Widdowson, «el significat no existeix en el llenguatge per ell mateix: és elaborat pels interlocutors» (Widdowson, 1978). Són els usuaris els encarregats de donar coherència als textos, i només quan totes les hipòtesis interpretatives han fracassat i no és possible trobar-hi sentit, es pot reconèixer explícitament que un enunciat és incoherent, amb la qual cosa es reconeix, més que la manca de significat, la incapacitat del destinatari de trobar un missatge amb sentit en la cadena gràfica o fònica que intenta desxifrar. De fet, l'expressió no té sentit no s'utilitza mai davant d'un text escrit en una llengua que l'usuari no coneix -siga l'àrab, el xinès, l'anglès o qualsevol altre idioma.

\subsubsection{El concepte de coherència}

La coherència és la propietat per la qual un text s'organitza globalment per a la transmissió de sentit. Aquesta organització pot analitzar-se des de dues perspectives diferents i complementàries: el text com a producte i el text com a procés. Mentre que la primera es presenta com una perspectiva estàtica que es proposa l'estudi de l'objecte text, la segona pren com a punt de referència el punt de vista del subjecte (emissor i receptor) i té un caràcter essencialment dinàmic.

Tot i que la coherència és una propietat essencialment semàntica, en la construcció de la coherència dels textos intervenen elements pragmàtics (coherència pragmàtica) i sintàctics (mecanismes de cohesió o fenòmens de coherència superficial). En aquesta línia argumental, Michel Charolles (1978) formulava les consideracions següents sobre el concepte de coherència:

1) No es pot abordar l'estudi dels aspectes relacionats amb la coherència sense tenir en compte la linealitat textual, és a dir, sense considerar l'ordre d'aparició dels segments que conformen el text.

2) La coherència d'un enunciat s'articula a partir dels dos nivells d'organització textual i sorgeix, per tant, de la confluència de la coherència microestructural i la coherència macroestructural: «la coherència d'un enunciat ha de ser determinada conjuntament des d'un punt de vista local i global, perquè un text pot ben bé ser microestructuralment coherent sense ser coherent des d'una perspectiva macroestructural» (Charolles, 1978: 13). En conseqüència, «la possibilitat d'assignar a un text una seqüència de macroestructures microestructuralment coherent és una condició necessària per a la coherència global del text» (Charolles, 1978: 13).

3) Coherència i cohesió són dos fenòmens lligats estretament. En el marc de la gramàtica del text, és impossible tècnicament d'efectuar una separació rigorosa entre les regles de coherència -lligades íntimament a l'estructura 
profunda textual $\mathrm{i}$, per tant, de naturalesa essencialment logicosemàntica- i les regles de cohesió -relacionades amb l'estructura superficial dels textos, amb el discurs.

\subsubsection{Coherència textual i escriptura}

Un text no és simplement un conjunt d'oracions, sinó la unitat fonamental de la comunicació, una unitat que està constituïda per paraules, enunciats i oracions interrelacionats entre si i pels aspectes extralingüístics necessaris «per a produir i interpretar els enunciats com a conjunt significatiu en funció d'una intenció comunicativa i una interacció social» (Cuenca, 2008: 12).

Un dels aspectes fonamentals de la construcció textual és la coherència. Com és ben sabut, es tracta d'una propietat dels textos que fa referència al significat global del text i afecta directament aspectes com el tema i l'organització de la informació. De fet, un text ben construit s'orienta a desenvolupar un tema amb una estructura clara $\mathrm{i}$ combina la informació coneguda amb la informació nova que ha estat seleccionada adequadament, utilitzant els mecanismes de cohesió textual pertinents per tal que els receptors el puguen interpretar, li puguen donar sentit, d'acord amb la intenció comunicativa de l'emissor. I quan es produeix alguna errada en la construcció textual, per un ús incorrecte o per manca de connectors o per un ús deficient de la referència, aquesta errada afecta directament la coherència i la possibilitat de comprensió del text i, per tant, l'eficàcia de la comunicació. Vegem-ne un parell d'exemples:

[7] Bona nit i gràcies per haver vingut al Gran Teatre. Estem verdaderament contents de poder estrenar aquest espectacle a la Ribera Alta, i més en concret ací, a Alzira. Però, abans de començar, ens agradaria dir-vos tres coses. (Dubta). La segona és que tot el que ara us contarem està basat en fets reals apareguts a la premsa, només hem canviat els noms perquè ningú no s'hi puga sentir al·ludit. Els cognoms els hem deixats. La quarta cosa que volíem és fer-vos una pregunta: quantes vegades, al llarg de la vostra vida, trobant-vos malament, no heu sentit una cançó de Perales, Dyango, Camilo Sesto... i us heu trobat pitjor encara? (Carles Alberola - Roberto Garcia, Besos, Alzira, Bromera, p. 35).

[8] Esprémer el fenomen Larsson: les xifres de 'Millennium'. Les vendes dels llibres de Stieg Larsson són ja estratosfèriques. La quarta pel·lícula de la trilogia s'estrena divendres al cinema. Estocolm ha muntat una ruta turística de l'obra per promocionar la ciutat. A més, la parella de l'autor suec treballa en un llibre sobre què ha passat després de la mort de Stieg i en una pel·lícula biogràfica (Avui, 16 d'octubre de 2009, adaptació).

En el primer text es pot observar com la contradicció entre la primera expressió subratllada («ens agradaria dir-vos tres coses») i els marcadors d'ordre que s'utilitzen en la continuació («la segona» $\mathrm{i}$ «la quarta»), sense fer cap referència a la primera i a la tercera de les coses que ens prometia, obliga l'oient (o el lector) a 
fer determinades inferències per recuperar la coherència del text i és un element clau a l'hora d'assignar una interpretació humorística a la intervenció de l'actor. Aquesta proposta interpretativa, basada en el trencament de les inferències, es pot veure també en la part final del text que hem reproduit, quan la forma de fer referència a la música de Perales, Dyango i Camilo Sesto invita el públic a esperar una continuació oposada a la formulació amb què es tanca la intervenció («i us heu sentit pitjor encara»). En la intervenció d'un actor que interpreta un paper en una comèdia, aquestes «incoherències» tenen sentit i permeten orientar, d'entrada, el to de l'espectacle en clau humorística, però, per exemple, tindrien efectes radicalment oposats en un text acadèmic, com ara una conferència, o en un text periodístic, com una notícia o un reportatge. Observeu, per exemple, que en el text 8 una errada molt similar (la contradicció entre les expressions «quarta pel-lícula» i «trilogia») només pot interpretar-se com una errada de redacció.

També les errades de referència són sovint una manifestació superficial de problemes en l'estructura profunda dels textos que afecten, per tant, la coherència i el sentit i n'afecten directament el procés d'interpretació. Ho podem comprovar amb els dos textos següents:

[9] L'anunci està compost per vint-i-dos plans principals el ritme de canvi entre ells és vertiginós, donant així una sensació de rapidesa en la narració. Pel que fa a la illluminació podem distingir-ne de dos tipus: la illluminació

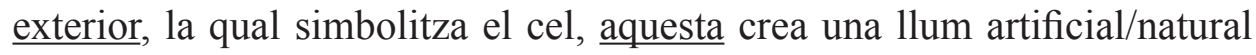
que envaeix la part interior de l'avió.

[10] La revolució francesa es va crear gracies a uns factors com van ser el lliberalisme, el capitalisme econòmic. Es va fer la revolució perque la gent tenia el proposit de conquerir nous mercats i fer-se mes rica portant els

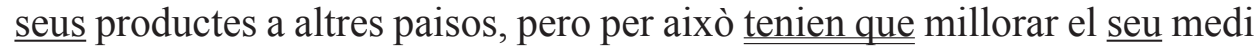
de transport, es va inventar el tren i es va perfeccionar el barco, per a que puguera arrivar aon ells volien.

Es tracta de textos d'estudiants que, com es pot comprovar, contenen diverses errades ortogràfiques i gramaticals, però, a més, presenten problemes importants relacionats amb la coherència, la qual cosa en dificulta la interpretació. En el text 9, deixant de banda l'estil excessivament segmentat de la primera oració i la introducció una mica forçada del connector pel que fa a, que és un introductor de tema utilitzat aquí en el sentit d'un connector d'addició, cal remarcar que les expectatives suggerides per l'expressió «dos tipus» es veuen defraudades per la construcció que pretén explicitar-los, ja que només se n'indica una de les dues (tot i que, és cert, se'n suggereix la segona). En tot cas, la forma d'organitzar la informació i l'articulació de la frase reflecteix, en aquest cas, problemes importants en l'organització de les idees.

Finalment, en el text 10, la successió de marques anafòriques que remeten a unitats poc clares o francament contradictòries constitueix una xarxa de referències caòtiques que en dificulten la lectura. Així, el substantiu col·lectiu «la gent», molt 
poc adequat en un text expositiu de l'àmbit acadèmic, és recuperat després en l'expressió «fer-se més rica» $\mathrm{i}$ en el determinant possessiu «seus» ('de la gent'), però l'aparició de la perífrasi d'obligació en plural («tenien que») contrària a la normativa, ens permet observar com s'ha perdut el subjecte de les idees precedents («la gent») i ha estat substituiit, segurament pel seu valor colllectiu, per un nou referent, no explícit ni formulat expressament, que es mantindrà fins al final del paràgraf («aon ells volien»). Aquell subjecte inicial («la gent»), s'ha transformat progressivament en alguna realitat diferent $\mathrm{i}$ indeterminada («les persones», «els ciutadans», «els homes»...) fins a esfumar-se misteriosament. La interpretació encara es complica una mica més amb l'aparició d'una forma verbal en tercera persona del singular («puguera») que remet a un referent anterior inexistent («la producció», «la revolució»).

La coherència es refereix, per tant, a la construcció del significat del text, es manifesta superficialment en la cohesió textual -en l'ús dels mecanismes de referència i en els connectors - i en la selecció de les estratègies d'adequació adients, i és un factor fonamental a l'hora d'assignar sentit a qualsevol producte verbal. Segons Maria Josep Cuenca, la coherència es manifesta en quatre conceptes bàsics, que enumera i explica sintèticament:

La coherència es refereix a la construcció del significat del text: quin tema desenvolupa i com ho fa. Així, els conceptes bàsics de la coherència són:

a) tema del text: és allò de què tracta el text, el seu contingut bàsic; pot explicitar-se amb paraules o frases temàtiques i pot inferir-se a vegades del títol o reinterpretar-se a partir d'aquest element paratextual;

b) estructura: organització de les informacions segons patrons formals i conceptuals; pot ajustar-se a models convencionals segons el tipus de text (un text narratiu sol tenir un plantejament, un desenvolupament de l'acció i un desenllaç) i el gènere (pensem en l'estructura d'una carta);

c) selecció de la informació: procés de focalització en certs aspectes temàtics en funció de la cerca de rellevància respecte al tema i la intenció comunicativa;

d) organització de la informació: procés d'ordenació jeràrquica d'informacions conegudes (repetició) i d'informacions noves (progressió).

Un text ben construït s'orienta a desenvolupar un tema amb una estructura clara i combina informació coneguda i informació nova que ha estat correctament seleccionada.

Cuenca, 2008: 139-140

\subsubsection{Les regles de la coherència}

Des de la perspectiva del text com a objecte o com a producte, l'anàlisi textual es planteja les condicions observables que fan que un text siga globalment coherent. Segons M. Charolles, perquè un text siga estructuralment coherent, a nivell macroestructural i a nivell microestructural, ha de seguir una sèrie de regles de coherència o condicions per a la bona formació dels textos.

Aquestes regles tenen una correspondència directa amb els elements de cohesió textual, però cal tenir en compte que els textos poden ser comunicatius encara que no respecten alguna de les regles. De fet, la coherència no és una propietat inherent 
a totes les produccions lingüístiques: sovint es produeixen errors que exigeixen ser reparats per l'emissor o, fins i tot, pel receptor. El quadre de la fig. 37 presenta, sintèticament, la formulació de les quatre regles de la coherència, i presenta alguns dels recursos expressius més directament relacionats amb cadascuna:

\begin{tabular}{lll}
\hline Regles & Definició & Recursos expressius \\
\hline Repetició & $\begin{array}{l}\text { La major part de les proposicions s'enca- } \\
\text { denen prenent com a suport la repetició } \\
\text { d'uns elements base. }\end{array}$ & $\begin{array}{l}\text { Pronominalitzacions, definitivització, } \\
\text { referències díctiques contextuals, substi- } \\
\text { tucions lèxiques, recobriments pressupo- } \\
\text { sicionals, represes d'inferències... }\end{array}$ \\
\hline Progressió & $\begin{array}{l}\text { El desenvolupament textual exigeix la } \\
\text { incorporació constant de nova informació. }\end{array}$ & Regles de progressió temàtica. \\
\hline No-contradicció & $\begin{array}{l}\text { El desenvolupament del text no ha d'intro- } \\
\text { duir cap element semàntic que contradiga } \\
\text { un contingut establert anteriorment (explí- } \\
\text { cit o implícit). }\end{array}$ & $\begin{array}{l}\text { Contradiccions enunciatives, contradic- } \\
\text { cions inferencials i pressuposicionals, } \\
\text { de representacions de mons. }\end{array}$ \\
\hline Regla de relació & $\begin{array}{l}\text { Els fets a què es refereix el text han d'estar } \\
\text { relacionats amb el món real o imaginari } \\
\text { representat. }\end{array}$ & $\begin{array}{l}\text { Mecanismes d'interrelació de fets i } \\
\text { esdeveniments. }\end{array}$ \\
\hline
\end{tabular}

Fig. 37. Les regles de coherència

Durant el procés de construcció del text, l'emissor elabora el seu discurs mitjançant l'expansió d'unes macroestructures prèvies més o menys conscients. El receptor, per poder descodificar i interpretar d'una forma coherent el text, ha de seguir el procés invers. Cal recordar que la macroestructura d'un text sovint no és compartida per tots els receptors i que les macroestructures que assignen els receptors a un text determinat no tenen per què coincidir amb la macroestructura que havia projectat o intentat projectar l'emissor.

Les macroestructures dels textos s'obtenen en aplicar una sèrie de macroregles al conjunt de les proposicions que constitueixen el text. Es tracta d'una sèrie d'operacions cognitives que permeten elaborar la macroestructura textual:

a) Omissió: tota informació de poca importància i no essencial pot $\mathrm{i}$ ha de ser suprimida.

b) Selecció: entre la informació essencial cal seleccionar els aspectes més rellevants per a cada marc concret.

c) Generalització: tota la informació essencial que puga incorporar-se a una proposició més general, més abstracta, ha de ser suprimida.

d) Construcció o integració: se substitueix per una nova informació integradora. 


\subsubsection{Tipus de progressió temàtica}

La progressió temàtica és un fenomen pont entre la coherència i la cohesió del text. És el mecanisme principal de dosificació de la informació que transmeten els textos i, alhora, un element essencial per a l'enllaç entre l'estructura global i la materialitat lineal del discurs.

Al costat dels factors que ens remeten a un nivell macroestructural de l'organització textual, a l'interior dels textos hi ha un conjunt de dispositius de tipus local sobre els quals se sosté la coherència textual, que contribueixen poderosament a la construcció del sentit. La continuïtat d'un text, la seua coherència, és el resultat de l'equilibri entre dues exigències fonamentals: una exigència de progressió i una exigència de repetició. D'una banda, el text ha de repetir informació ja donada, per mantenir la continuïtat temàtica, i de l'altra, ha d'aportar progressivament informació nova, per no donar voltes circularment a la mateixa idea.

La comprensió del dinamisme textual permet explicar com, a través de la coherència textual, es produeix una incessant transformació de les informacions noves en informacions donades, que hauran de servir de suport per a l'aportació d'elements nous. El concepte de progressió temàtica parteix dels treballs dels lingüistes de l'Escola de Praga, que investigaren com els diversos grups sintàctics de l'oració vehiculen dos tipus d'informacions: les que en un moment determinat del text són donades, adquirides, i les que són noves. L'oració es analitzada, per tant, no només «com una estructura sintacticosemàntica, sinó també com una estructura portadora d'informació a l'interior d'una determinada dinàmica textual» (Maingueneau, 1991: 219). En aquest sentit, introduïren la distinció entre tema, informació ja donada, i rema, informació nova. Segons les formes d'articulació de tema i rema a l'interior d'un text, es poden distingir, almenys, quatre tipus de progressió temàtica: progressió lineal, progressió de tema constant, progressió de tema derivat i progressió de tema i rema ramificats.

\section{Progressió lineal}

El rema (o element remàtic) (R) d'una frase (F) es converteix en el tema $(\mathrm{T})$ de la frase següent, i així successivament.

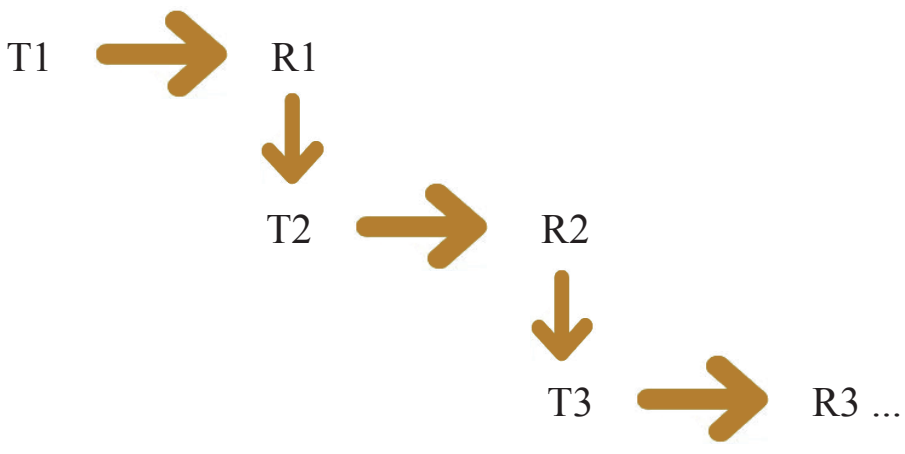

2. Progressió amb tema constant

Un mateix tema, encara que no necessàriament expressat amb les mateixes paraules, serveix de base per a successives aportacions de nova informació. Aquest 
esquema, en què a un mateix tema se li assignen diversos remes, és freqüent en els textos explicatius i en els relats.

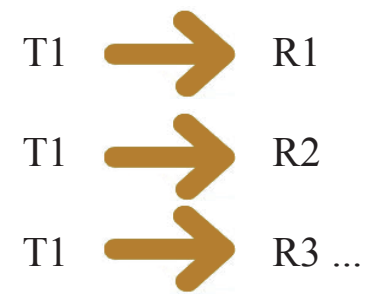

3. Progressió de tema derivat

El tema o el rema d'una frase, anomenat hipertema, es divideix analíticament en trets semàntics que esdevenen els temes de les frases següents. Es tracta d'un tipus de progressió que serveix per organitzar jeràrquicament un text $\mathrm{i}$, per tant, és típica dels textos argumentatius i de les exposicions.

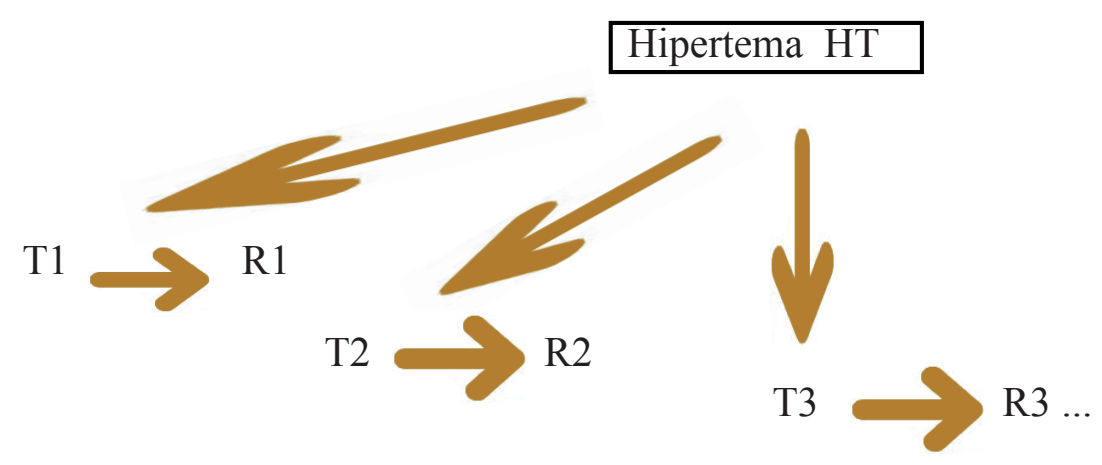

4. Progressió de tema i rema expandit o ramificat

El tema o el rema d'una frase s'expandeix o es ramifica en el text, on pot aparèixer tant en un tema com en un rema subjacent de les frases següents. Tant en aquest tipus de progressió com en l'anterior, sovint l'hipertema no és present explícitament en el text i poden presentar-se algunes dificultats d'interpretació. De vegades, els temes successius són complements circumstancials de lloc o de temps sense un antecedent explícit en el text i, aleshores, l'hipertema és «desenvolupament en el temps» o «distribució en l'espai».

\subsection{L'estructura del text}

\subsubsection{Factors determinants de l'estructura textual}

La selecció del contingut d'un text depèn, entre altres factors, de l'emissor, el destinatari, el missatge, el canal i, molt especialment, del gènere discursiu, que d'alguna forma és la cristal-lització dels condicionants derivats de la situació de comunicació, i de la seqüència textual predominant, que depèn essencialment de la finalitat o intenció comunicativa. 
El gènere condiciona la tria de la informació pertinent i en determina sovint l'organització i l'estructuració, ja que, en alguns casos, existeixen fortes restriccions formals, de caràcter convencional, determinades per la superestructura associada al gènere. Així, sabem que si hem d'escriure una notícia de premsa sobre un esdeveniment que acaba d'ocórrer necessitarem una informació determinada -què ha passat, qui n'és el protagonista, quan, on, com i per què ha passat-i l'haurem d'organitzar d'acord amb les regles del gènere -titular, avanttítol i subtítol, entradeta, cos del text, elements gràfics-, mentre que si hem de preparar un anunci per a una revista necessitarem un altre tipus d'informació i l'haurem d'organitzar d'una altra forma. Per tant, cada text exigeix, en funció del gènere a què pertany, un tipus d'esquema organitzatiu o un altre.

El segon factor que condiciona l'estructura de la informació és l'estructura textual o seqüència predominant. Ja sabem que no té les mateixes exigències una narració que una descripció i que no s'organitza de la mateixa forma la informació en un text expositiu o explicatiu que en un discurs argumentatiu. Sovint, cada seqüència té unes formes prototípiques d'organització de la informació, i aquest fet s'ha de tenir en compte a l'hora de redactar qualsevol text, encara que, de vegades, demane la combinació de diferents seqüències textuals.

\subsubsection{Estructura dels gèneres expositius}

En els gèneres de l'àmbit acadèmic -com ara els treballs d'investigació, les exposicions orals o les explicacions de classe- predominen les seqüències expositives, i aquest fet determina la selecció d'unes formes determinades d'organització de la informació, que, en resum, es poden concretar en cinc esquemes o estructures convencionals: descriptiva o enumerativa, comparativa, problema-solució, causaconseqüència, i seqüencial o temporal.

a) En l'estructura descriptiva o enumerativa, els continguts s'agrupen al voltant de determinats elements, que es presenten com a trets o atributs d'un tema principal, presentat en una posició jeràrquica superior als descriptors. Aquesta estructura presenta marques formals típiques, com ara l'ús de determinats índexs gràfics (lletres i números, guions, negreta, cursiva, espais en blanc...), els connectors additius (a més, també...) o els marcadors de canvi de tema (pel que fa a, quant a, en relació a...).

b) L'estructura comparativa s'utilitza quan es volen confrontar diversos fenòmens per mostrar-ne les semblances i les diferències. Pot presentar tres variants diferents (alternativa, adversativa $\mathrm{i}$ analògica) $\mathrm{i}$ en alguns casos apareix marcada per l'ús dels anomenats connectors de contrast (en canvi, mentre que, però...). Solen adoptar aquesta estructura els treballs que tenen com a objectiu comparar fenòmens, com per exemple la quantitat i la freqüència de la publicitat present en diversos mitjans audiovisuals, la llengua vehicular utilitzada o l'estructura dels informatius de diverses cadenes de televisió. 
c) En l'estructura problema-solució, la informació s'organitza al voltant de dues categories bàsiques (problema i solució), que poden mantenir entre si diverses relacions (temporal, parcial...). Tot i que no existeixen connectors específics que marquen aquest tipus d'estructura, sovint s'utilitzen determinades expressions que poden ajudar a detectar-la (un problema que s'ha de resoldre, les solucions, caldria prendre mesures com ara...). Adopten aquesta estructura els treballs que tenen com a objectiu exposar un problema, analitzar-ne les causes i proposar les possibles solucions. Un exemple podia ser investigar les causes de la castellanització dels mitjans audiovisuals valencians.

d) En l'estructura de causa-conseqüència, la informació s'organitza al voltant de dues categories (la causa i la conseqüència), que mantenen entre si una relació temporal (els antecedents es produeixen abans que l'efecte) i un vincle causal (els antecedents faciliten la conseqüència, o en són una condició). Els textos que adopten aquest esquema solen presentar marques formals que en faciliten la identificació, entre les quals cal destacar l'ús de connectors causals (ja que, perquè, car, per aquesta raó...) o consecutius (per tant, així doncs, en conseqüència...). Presenten aquesta estructura els treballs que tenen com a objectiu exposar un fet, analitzar-ne les causes i apuntar les conseqüències. Un exemple podria ser una crònica periodística sobre els orígens i les derivacions del cas Gürtel.

e) L'estructura seqüencial o temporal permet ordenar els continguts en una seqüència temporal amb l'ajut dels índexs gràfics (guions, números...) o dels connectors especialitzats en la marcació de la temporalitat o de l'ordre (en primer lloc, tot seguit, a continuació, després, per últim, finalment...). Adopten aquesta estructura els treballs que tenen com a objectiu explicar el curs temporal d'un fenomen, com ara presentar la successió dels fets en una notícia de premsa.

\subsubsection{Estructures narratives i argumentatives}

Els gèneres textuals que s'emmarquen en el model narratiu presenten, habitualment, una estructura de caràcter temporal, i es caracteritzen pel predomini dels marcadors d'integració lineal que assenyalen l'inici, la continuïtat o el tancament del relat i pel fet que l'acció ocupa un lloc rellevant en l'estructuració discursiva. De fet, les accions que conformen una història s'organitzen en seqüències i la seqüència narrativa prototípica consta d'una sèrie de fases o macroproposicions elementals ben identificades: situació inicial, desencadenant o complicació, accions i reaccions, desenllaç, situació final i moralitat. És evident, però, que en els relats d'una certa complexitat es desenvolupen històries complementàries que poden presentar diferents possibilitats combinatòries: l'encadenament, l'encastament o l'alternança.

També solen presentar una estructura bastant convencional els textos argumentatius. Habitualment, els diferents gèneres persuasius presenten una estructura seqüencial ben coneguda des de l'antiguitat clàssica: introducció o exordium, exposició dels 
fets o narratio, exposició dels arguments o argumentatio i conclusió. Tot i això, segons el lloc que ocupa la tesi defensada en el text, es parla d'estructura analitzant o deductiva -si la tesi apareix al principi i, a continuació, es presenten les conseqüències-, sintetitzant o inductiva -quan la tesi tanca l'exposició d'una sèrie d'idees que funcionen com a arguments-, enquadrada o circular.

\subsubsection{Superestructures o motlles genèrics}

A més de les estructures prototípiques de les seqüències explicatives, narratives i argumentatives i de les formes diverses de presentar la informació en cada cas, existeixen una sèrie de models textuals o superestructures específiques d'alguns tipus de textos que cal conèixer a l'hora d'escriure. Es tracta d'esquemes convencionals, reconeguts socialment, que tenen una tradició cultural més o menys consolidada, serveixen de plantilles o de motlles durant el procés d'escriptura i, alhora, faciliten el procés de lectura i guien el lector a l'hora d'assignar sentit al text. Així, per exemple, un sonet, una notícia de premsa, una instància, un telegrama, una crítica cinematogràfica o uns mots encreuats presenten una forma determinada d'organitzar la informació i, en alguns casos, un aspecte gràfic ben diferenciat que permet al lector, immediatament, de fer-se càrrec del tipus d'informació que trobarà en cada cas i de l'actitud que s'espera que adopte.

\subsection{5. Índexs}

En qualsevol cas, si es tracta de textos d'una certa complexitat, l'elaboració de l'índex o taula de continguts del document afavoreix la tasca de recerca i recollida d'informació i, al mateix temps, facilita un criteri molt clar per seleccionar les fonts d'informació i per ordenar les dades que anem recollint. L'índex de continguts és un concepte dinàmic, una mena de guia temàtica que es va gestant mentre es du a terme el procés de recull de dades, orienta el procés de treball i permet avançar. Com que es tracta d'un element obert, sempre s'hi poden introduir modificacions, suprimir apartats o afegir-ne de nous.

\subsection{El paràgraf}

\subsubsection{El paràgraf: definició i funcions textuals}

Al marge de l'estructura global que organitza els textos en funció dels factors que hem esmentat, la informació es distribueix en paràgrafs, cadascun dels quals pot estar construït segons una determinada forma d'organització interna. Els paràgrafs serveixen per estructurar el contingut de l'escrit i per mostrar formalment aquesta organització. És un recurs extraordinàriament visual que facilita la comprensió del text i constitueix una unitat significativa, ja que segmenta els apartats, temes i subtemes de l'escrit. 
El paràgraf acostuma a passar desapercebut en les produccions escrites, ja que sovint es pensa més en els continguts que s'han d'explicitar, en l'estructuració d'aquests continguts al llarg del text, que no pas en la gran rendibilitat que es pot traure d'aquesta unitat significativa supraoracional. El paràgraf arriba a assumir funcions específiques dins del text: es pot parlar de paràgrafs d'introducció, de cloenda final, de recapitulació, d'exposició, d'exemples o de resum. De fet, l'aspecte visual que ofereix un text ben estructurat en paràgrafs facilita la lectura $\mathrm{i}$ la comprensió de les idees. Així, podríem dir que cada idea té el seu paràgraf de referència, encara que per expressar idees més complexes se sol utilitzar més d'un paràgraf $\mathrm{o}$, a l'inrevés, un sol paràgraf pot presentar-nos més d'una idea. Mentre que una bona distribució de la informació en paràgrafs facilita la lectura del text, una organització inadequada en dificulta la comprensió i pot arribar a convertir-se en una barrera entre el text $\mathrm{i}$ els lectors.

\subsubsection{Tipus de paràgrafs}

D'acord amb la forma d'organitzar la informació a l'interior del paràgraf, podem distingir cinc tipus de paràgrafs diferents: d'enumeració, de comparació/contrast, de causa/conseqüència o efecte/causa, de desenvolupament d'un concepte $i$ de problema/solució.

El paràgraf d'enumeració és una de les formes més senzilles i més habituals d'organitzar la informació. Està constituït per una llista de propietats que descriuen un objecte, un fet o una idea, i una frase organitzadora, que se situa habitualment al començament del paràgraf i que pot especificar exactament el nombre d'elements que es presentaran, anticipar els continguts de la llista o només deixar entreveure que hi ha una relació d'elements, però sense especificar-ne el nombre ni enunciar-los.

El paràgraf de comparació/contrast esta construït per una frase marc, que presenta els objectes (dos o més) que seran sotmesos a comparació, i un text de presentació de les característiques dels objectes o idees confrontats. Aquesta presentació pot seguir un esquema de descripcions separades - cada objecte es analitzat per separat: primer l'un i després l'altre- o de descripcions contraposades -s'analitzen els elements que integren cada objecte de comparació i es contrasta cada element del primer objecte amb l'equivalent del segon.

El paràgraf d'efecte/causa o causa/conseqüència presenta un esdeveniment o una situació i, a continuació, analitza les raons o les causes que l'han provocat. La descripció de la causa pot aparèixer abans o després de l'efecte.

El paràgraf de desenvolupament d'un concepte presenta una idea principal, enunciada de forma explícita, que posteriorment es desenvolupa amb exemples, argumentacions, aclariments o detalls.

El paràgraf problema/solució està constituït per dues parts, una de les quals mostra el problema, mentre que l'altra exposa la solució o solucions possibles. Pot presentar 
diverses variants, com ara l'expressió explícita del problema seguit de la solució també explícita, l'expressió del problema seguit de diverses hipòtesis de solució, l'exposició del problema sense la formulació explícita de la solució (que es deixa sobreentesa) o l'exposició explícita de la solució, mentre el problema se sobreentén i queda implícit.

\subsubsection{Estructura interna del paràgraf}

A l'hora d'organitzar la informació a l'interior del paràgraf, existeixen diferents possibilitats alternatives, i els marcadors o connectors textuals tenen una importància decisiva. Tot i que, en qualsevol dels tipus que hem presentat, el contingut del paràgraf pot distribuir-se de formes diferents, habitualment els paràgrafs solen presentar una estructura interna en tres parts: l'entrada inicial o inici, el desenvolupament i la cloenda o tancament. La frase inicial té una importància decisiva perquè ocupa la posició més rellevant i, per tant, és el primer que es llegeix. Habitualment s'utilitza per introduir el tema o la idea central i per donar pistes sobre l'organització del contingut central del paràgraf. El desenvolupament sol estar format per diverses frases que presenten la informació relacionada amb el tema, i sovint conté connectors o marcadors textuals que en faciliten la lectura. Finalment, les últimes frases poden fer la funció de cloenda o tancament. Aquesta última fase, que no és normativa, pot incloure un comentari global o una frase de recapitulació que recupera alguna idea rellevant o formula explícitament la conclusió que es pot treure de la resta del paràgraf.

\subsubsection{Algunes errades habituals}

Prenent com a referències les idees que apunta Daniel Cassany (1993), les errades més habituals a l'hora d'organitzar la informació en paràgrafs es poden sistematitzar en el quadre següent:

a) Organització desequilibrada o barreja indiscriminada i anàrquica de paràgrafs llargs i curts, sense cap ordre i sense raó aparent.

b) Introducció de repeticions i desordres que trenquen la unitat significativa per causes diverses: separació en paràgrafs diferents d'idees que haurien d'anar juntes, repetició de la mateixa idea en dos o més paràgrafs, etc.

c) Organització de l'escrit en una sèrie interminable de paràgrafs-frase, sense punts i seguit, ja que cada paràgraf consta d'una sola frase, més o menys llarga, i el significat es descompon en una llista inconnexa d'idees, la qual cosa exigeix al lector l'esforç suplementari de relacionar-les i (re)construir unitats superiors.

d) Utilització de paràgrafs-totxo, unitats excessivament extenses que ocupen gairebé tota una pàgina, que, en el seu interior, solen incloure diverses subunitats que també han de ser identificades pel lector.

e) Distribució de les idees en paràgrafs amagats, de forma que, tot i que l'escrit està ben ordenat a un nivell profund, l'ordre resulta poc evident als ulls del lector, que ha de fixar-se molt per descobrir-ne l'estructura. En aquests casos, el text guanyaria claredat si és fera més evident l'ordre o si es fera explícit el principi d'ordenació.

f) Omissió de la frase generalitzadora (en els paràgrafs d'enumeració), introducció de contradiccions entre la frase organitzadora i la llista de propietats o elements que es presenten, repetició dels elements de la llista, ordenació sense criteri i ús d'estructures sintàctiques diferents en els elements enumerats (infinitius, formes verbals, nominalitzacions...).

g) Omissió o ús incorrecte dels connectors a l'interior del paràgraf.

(Cassany, 1993) 


\subsubsection{Recomanacions}

Tot i que no és fàcil sistematitzar en unes poques idees una sèrie de consells de caràcter general que siguen vàlids per a qualsevol tipus de text, podem atrevir-nos a proposar, amb totes les prevencions que calga, les recomanacions següents:

- Adaptar l'extensió del paràgraf al tipus de text i buscar una organització equilibrada, de forma que el paràgraf siga, efectivament, una unitat de sentit.

- Tenir molt en compte l'aspecte visual de la pàgina, per tal que la imatge de la pàgina $\mathrm{i}$ els paràgrafs conviden a llegir. Per això, s'aconsella que cada pàgina tinga entre tres $i$ vuit paràgrafs $i$ que cadascun continga entre tres $i$ quatre frases, malgrat que són acceptables, evidentment, les excepcions que calga.

- Pensar, abans de redactar el paràgraf, quina idea o idees ha de contenir, seleccionar el tipus de paràgraf adequat i utilitzar els connectors més adients.

- Per tal de comprovar si la distribució de la informació en paràgrafs és adequada, és molt interessant d'intentar sistematitzar la macroestructura del text, és a dir, posar un títol descriptiu molt breu (dues o tres paraules) per a cada paràgraf $i$ comprovar que els títols resultants no se superposen i que mantinguen una bona relació de veïnatge: «si no hi ha forats en el desenvolupament del tema, ni repeticions, ni desordres, això significa que els paràgrafs tenen unitat significativa i que estan ben construïts» (Cassany, 1993: 80).

\subsection{Procediments explicatius}

Molts textos, tant si tenen una estructura convencional com si no la tenen, solen presentar tres parts clarament diferenciades: introducció, desenvolupament i conclusió. Malgrat les diferències entre uns textos i uns altres, especialment en el contingut i l'estructura del desenvolupament, en els gèneres expositius de caràcter formal, la introducció i la conclusió són sovint constituents essencials que tenen funcions ben definides relacionades amb l'avançament d'informació i amb la síntesi dels aspectes fonamentals de l'exposició. En els textos expositius de l'àmbit acadèmic $-\mathrm{i}$ també en alguns gèneres de l'àmbit periodístic i publicitari i en la comunicació audiovisual, així com, en general, en tots els textos d'especialitat-, a més d'aquestes tècniques d'organització de la informació, s'utilitzen dues tècniques fonamentals per sintetitzar i estructurar el contingut essencial: les definicions i els resums.

A banda d'aquests procediments explicatius, els textos de l'àmbit acadèmic -i també els textos procedents dels gèneres periodístics i els textos científics i tècnics- utilitzen sistemàticament una sèrie de recursos per facilitar la comprensió a partir dels coneixements que se suposa que tenen els destinataris. Es tracta d'un conjunt de mecanismes discursius que serveixen per aclarir la informació, per ampliar-la o per condensar-la. Aquest esquema en presenta els més habituals. 


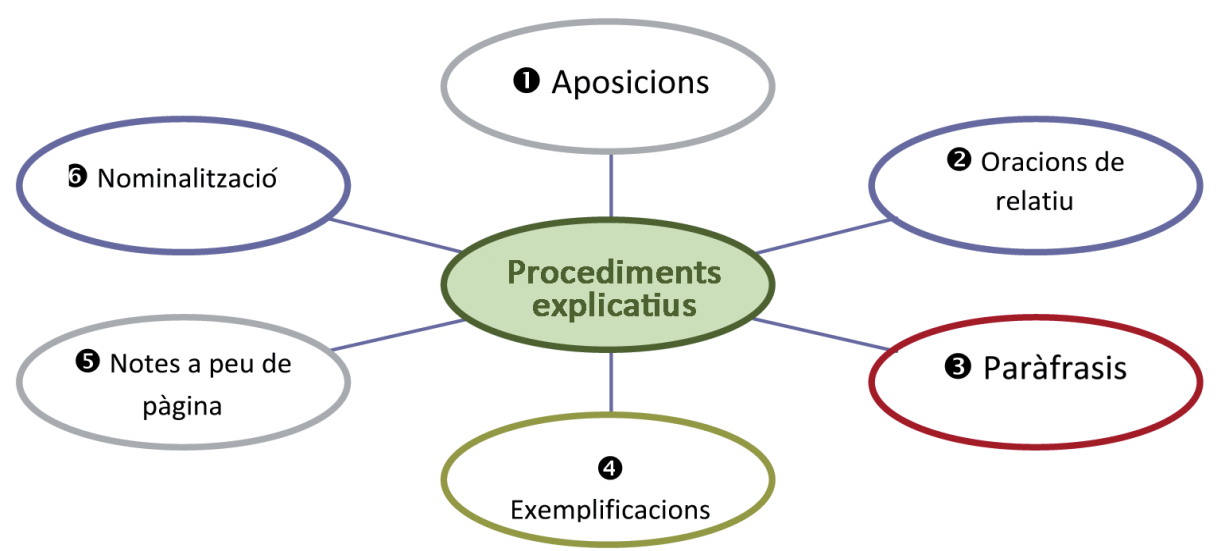

Fig. 38. Procediments per ampliar, aclarir i condensar la informació

L'aposició és un mecanisme d'ampliació de la informació que consisteix a inserir la informació complementària entre comes, parèntesis o guions. Per contra, les oracions de relatiu utilitzen com a elements d'enllaç els pronoms relatius. La paràfrasi és un procediment de reformulació del contingut d'un fragment del text amb paraules i expressions més entenedores. Aquesta funció també es pot realitzar mitjançant la introducció d'exemples (exemplificació). Les notes a peu de pàgina són un procediment específic dels textos acadèmics. Serveixen per introduir aclariments, observacions i ampliacions no essencials per a la lectura del text. Poden anar situades al final del treball o al peu de cada pagina, i s'introdueixen sempre amb un número que serveix de referència per inserir-les en el cos del text.

La nominalització, en canvi, és un procediment que s'utilitza per condensar la informació d'un text o d'un fragment textual. Consisteix a emprar substantius procedents d'accions verbals i, habitualment, suposa un trencament de l'estructura sintàctica per reduir la informació a un sol enunciat.

\subsubsection{Introduccions i conclusions}

La introducció d'un text, si en té, ocupa sempre una posició destacada i se sol situar a l'inici del text, però no tots els paràgrafs inicials de tots els textos fan una funció introductòria. Així, per exemple, no es pot considerar com a introducció l'inici d'un text si no conté algun tipus de presentació del contingut que s'hi abordarà. Per tant, l'essència de la introducció està més relacionada amb el contingut que no pas amb la localització.

Segons l'extensió del text, la introducció pot comprendre un sol paràgraf, un grup de paràgrafs, un apartat o un capítol complet. I si es tracta d'un text format per un únic paràgraf, la introducció es pot concentrar en una sola frase inicial.

En la introducció es contextualitza el text i s'avança la informació que s'exposarà a continuació. Habitualment, s'hi presenta el tema o se situa en un context més ample i se n'expliquen els antecedents, s'avança allò que es desenvoluparà en 
la resta del text i, en textos extensos, es pot exposar l'origen o la justificació del treball, els objectius, una síntesi dels continguts o de les hipòtesis de treball i les limitacions del text.

En canvi, en la conclusió, que se situa físicament al final del treball, se sol fer una síntesi, un resum o una recapitulació del que s'ha exposat, es destaca la idea principal, s'inclou una presa de posició sobre el tema o es presenten les noves perspectives obertes sobre el que s'ha tractat, les solucions o els resultats aportats pel treball.

En els textos expositius de caràcter formal, la introducció i la conclusió poden adoptar un to més subjectiu que el desenvolupament, ja que en aquestes parts, l'emissor hi és més present. Tot i això, convé defugir l'ús de la primera persona (Pense que; La meua opinió és que...) i utilitzar estructures sintàctiques més neutres per transmetre el punt de vista (Tot $i$ que es tracta d'un llibre interessant...; L'autor del text no sempre ha utilitzat els exemples més adients; És una pel-lícula innovadora, però...).

Pel que fa a les marques discursives, les introduccions i les conclusions, a més de situar-se en llocs estratègics (al començament $i$ al final del text), de vegades s'identifiquen amb els títols corresponents, ocupen la unitat textual d'un paràgraf (o de diversos paràgrafs) i en aquests casos es pot marcar la unitat amb un interlineat superior a l'habitual davant i/o darrere. A més, les conclusions poden anar introduïdes per connectors textuals especialitzats, com ara en conclusió, per tant, en resum, aixi doncs, en definitiva...

[11] En definitiva, en aquest llibre podem descobrir el potencial del vessant no verbal de la comunicació. L'autor posa el coneixement del meravellós món de la comunicació al servei de la felicitat humana.

[12] En resum, Tuson reivindica la pluralitat de llengües, les diferents maneres de dir el món, els sistemes de comunicació i d'expressió que els humans hem desenvolupat al llarg del temps, com a manifestacions i concrecions del nostre senyal més distintiu: el llenguatge, sense el qual no seríem humans. Patrimoni natural és un assaig molt recomanable per a estudiants i per a tot el públic interessat en qüestions de llengua i comunicació.

\subsubsection{La definició i la reformulació}

La definició és un mecanisme que consisteix a precisar el significat d'una paraula o expressió mitjançant procediments lingüístics. En lexicografia es considera que una definició, per ser considerada apta per entrar en un diccionari, ha de complir una sèrie de condicions mínimes: no contenir el terme definit ni un derivat -si no és que es defineix aquest al seu torn-, no ser circular - una definició no pot remetre a una altra que remeta a la primera- i ser suficient per entendre el sentit d'allò definit en condicions generals d'ús, de manera que es puga substituir el terme per la definició en un context ordinari sense que es perda informació. 
Segons Aristòtil, una bona definició consta de l'essència o gènere, que indica la classe o la categoria general a què pertany la paraula dins un conjunt, i de l'espècie, que indica els atributs pel qual el mot es diferencia d'altres iguals. En lingüística se sol identificar l'essència amb un hiperònim o mot general. En general, es pot afirmar que la definició delimita l'entitat descrita sobre la base dels coneixements existents prèviament, li adjudica uns atributs a través de la pertinença a una classe o conjunt i l'individualitza amb l'especificació dels trets característics. Es tracta, en definitiva, d'adscriure el concepte a una classe i d'especificar-ne les característiques essencials: «la definició té, doncs, la funció de descriure un concepte des dels aspectes més generals fins a les característiques particulars, $i$ ha de permetre diferenciar-lo d'altres conceptes» (Cuenca i altres, 2008: 163).

A l'interior d'un text, les definicions es poden introduir amb expressions verbals (és, es diu, s'anomena, es denomina, es defineix, està constituït, comprèn, etc.), poden presentar-se amb aposicions (entre comes o a l'interior d'un parèntesi) i, en posició final d'oració, poden anar precedides per dos punts. En canvi, en els diccionaris i en les relacions de vocabulari especialitzat que se solen incloure, en forma de glossaris, en els treballs d'investigació i en publicacions o en reportatges d'una certa especialització, se sol marcar el terme definit en negreta o en un color diferent.

Des del punt de vista lingüístic, a més del procediment clàssic de definició, un terme es pot definir per acumulació d'exemples, mitjançant l'ús d'un hiperònim, seguit o no d'una oració de relatiu especificativa, utilitzant la conjunció $o$ amb valor d'equivalència i situant aposicions després o abans d'un terme més col-loquial -marcades per pauses en l'oral i situades entre comes, parèntesis o guions explicatius, en els textos escrits. En els exemples següents es poden veure alguns d'aquests procediments:

[13] Per frenar la difusió del protestantisme es va reorganitzar la Inquisició, un tribunal eclesiàstic encarregat de perseguir i castigar els heretges.

[14] Pla emfàtic Contrapicat.

[15] El raccord, la continuïtat entre plans, és un element fonamental durant el procés de muntatge de la pel·lícula.

[16] Aquest conglomerat d'idees i circumstàncies aportava racionalitat a la noció mèdica de fascinació o encís com a forma patològica, atès que hi confluïen un cos amb capacitat d'enverinar, un objecte pacient predisposat (infants indefensos, adults en estat de debilitat, vells amb les defenses minvades...), proximitat física i semblança genèrica en tant que éssers humans, però diferència específica, perquè un dels cossos posseeix el verí, mentre que l'altre no.

[17] Taula $11 \mathrm{f}$. [LC] [IMF] Moble que consisteix en una peça llisa i plana sostinguda horitzontalment per peus o petges, que serveix per a menjar, escriure, treballar, jugar, etc. Una taula de noguera, de roure. Una taula de pedra. Una taula d'escriure. Una taula de ping-pong. Una tauleta de cosir. Una taula de cafè. Una taula rodona, quadrada. 
[18] La carn és teixit muscular constituït per un 75\% d'aigua, un $18 \%$ de proteïnes i un 3\% de greixos. Els teixits musculars estan integrats per les fibres musculars, constituïdes per proteïnes.

[19] L'steadicam (de l'anglès steady-cam) o estabilitzador de càmera és un dispositiu que permet dur la càmera lligada al cos de l'operador mitjançant un body o arnès, que atenua el moviment humà, i fa possible l'emissió o l'enregistrament d'imatges similars al punt de vista subjectiu del personatge.

En els gèneres expositius és molt habitual l'ús de parèntesis per introduir informació important per a la comprensió del text, bé perquè remet a coneixements anteriors essencials perquè el lector pugui comprendre'n el contingut (com ara en l'exemple [20]), bé perquè introdueix informació imprescindible per a la comprensió, encara que el lector no en tinga el record anterior (com ara en l'exemple [21]):

[20] El temps, que ajuda a determinar el tempo o ritme d'un film, està condicionat per dues tècniques fonamentals d'organització de l'acció: el flashforward (o el·lipsi narrativa que permet traslladar l'acció cap al futur) i el flash-back (o salt endarrere que la trasllada al passat).

[21] A més del tràveling clàssic (o moviment que es produeix quan la càmera es desplaça sobre uns rails o un suport que llisca), també cal destacar el tràveling òptic (que es produeix accionant l'òptica zoom) i els moviments combinats que es produeixen fent servir una dolly (una grua o petit vehicle amb rodes sobre el qual es desplaça la càmera i l'operador) o l'steadicam.

La reformulació pròpiament dita, amb l'ús d'un connector de reformulació, és també un recurs habitual per introduir un terme específic que cal utilitzar en lloc de l'explicació anterior, tot i que aquest procediment s'utilitza essencialment per aclarir una idea formulada amb paraules més opaques o per fer una paràfrasi del contingut d'un paràgraf o d'un conjunt d'oracions amb finalitat de síntesi o de recapitulació:

[22] En el discurs polític, i en el discurs políticament correcte, ocupa un lloc clau l'eufemisme, és a dir, l'expressió suau, atenuada i edulcorada de la realitat.

[23] Traduir és expressar en una llengua el que es diu o s'escriu en una altra, o en altres paraules, traslladar el sentit del text original al text terminal. Tanmateix, la traducció no és -o no hauria de ser- un simple intercanvi d'etiquetes, és a dir, la substitució dels mots d'una llengua per altres mots d'una altra llengua. 


\subsubsection{El resum}

El resum és un procediment de condensació de la informació d'un text. Cal recordar, però, que «no es tracta només de suprimir oracions o parts, sinó d'integrar la informació en una organització més general que incorpori la informació més detallada i que resulti més breu» (Cuenca i altres, 2008). Resumir un text o una seqüència implica una transformació d'una unitat de significat en una altra de nova, més breu quant a l'extensió i més sintètica quant a la forma d'expressió, però dotada d'una autonomia total respecte al text original, la qual cosa significa que ha de poder entendre's sense conèixer l'original. Saber resumir, i resumir bé, és una tècnica complexa que requereix la posada en escena de diferents habilitats, com ara la lectura comprensiva, la capacitat d'analitzar el text i de reconstruir-ne l'estructura que organitza les idees i el domini de les tècniques de redacció necessàries per presentar un text clar, coherent $\mathrm{i}$ ben cohesionat.

El resum és una estratègia molt utilitzada en la comunicació oral informal -es resumeixen fets, pel·lícules, novel·les...- i en gèneres més formals, com ara les sinopsis de llibres o crítiques de cinema, els gèneres acadèmics més habituals -exposicions orals, conferències, articles, informes, manuals...- o, en l'àmbit periodístic, els titulars i les entrades de les notícies i reportatges.

\subsubsection{La nominalització}

\subsubsection{Definició i funcions textuals}

La nominalització és un procediment que s'utilitza per condensar la informació. És un recurs lingüístic que permet de transformar les accions en conceptes mentals -per això es poden interpretar com a metàfores gramaticals- $i$ es pot utilitzar per introduir informació coneguda o nova en el text. Té, per tant, una gran importància en la construcció del text com a procediment anafòric per repetir els conceptes sense repetir les paraules i per introduir temes i remes nous. Observem l'exemple següent:

[24] Amb l'aparició dels canals autonòmics, i més tard amb la irrupció dels tres canals privats, el procés d'elecció de l'espectador es complica. En multiplicar-se l'oferta, l'espectador té la capacitat d'elecció; la «passivitat» total del televident canvia a una «certa activitat suggeridora» o un «actiu llibertari» (Ricardo Vaca Berdayes, Quién manda en el mando).

Del text anterior, les expressions l'aparició dels canals autonòmics i la irrupció dels tres canals provenen, respectivament, de les accions 'apareixen els canals autonòmics' i 'irrompen els tres canals privats'. En aquest procés, els verbs aparèixer i irrompre són substituïts pels substantius d'origen verbal aparició i irrupció, i el que era una frase queda reduït a un sintagma nominal. Si seguim llegint el text, observarem que el substantiu oferta resumeix tota la informació anterior. És una forma més d'economia lingüística, ja que oferta reprèn la informació coneguda i condensa en una paraula l'acció ('són nombrosos els canals que s'ofereixen'). 
La nominalització suposa, com es pot comprovar, la transformació d'una oració en un grup nominal. S'hi substitueix el verb per un substantiu postverbal abstracte que transforma l'acció en un fet ja realitzat, purament mental. Així, en una oració com L'arribada al poder de J. M. Aznar va estar condicionada pels casos de corrupció que afectaren el $P S O E$, la nominalització permet organitzar en un sol enunciat el que hauria estat objecte de dos enunciats successius (J. M. Aznar va arribar al poder i Els casos de corrupció afectaren el PSOE), i d'aquesta manera esdevé un recurs per a la condensació d'informació.

Les nominalitzacions poden realitzar diverses funcions en el procés de construcció textual: anafòrica, remàtica i temàtica.

La nominalització anafòrica funciona com a substitut d'un element anterior (conjunt d'oracions o paràgraf) per tal d'evitar-ne la repetició i facilitar-ne la comprensió. En aquesta funció, la nominalització pot reprendre el mateix radical del verb o substantiu anterior, pot utilitzar un demostratiu com a lligam o pot aparèixer en la posició inicial de la frase i presentar-se, per tant, com a element conegut.

La nominalització remàtica no funciona com a substitut i aporta informació nova. En canvi, la nominalització temàtica funciona com a element introductori de títols i subtítols dels apartats d'un treball.

\subsubsection{Les marques formals de la nominalització: els sufixos}

Habitualment les nominalitzacions es poden detectar per la presència de sufixos específics (com ara -ió, -ment o -nça), que comporten matisos significatius diferents. Tot i que, en termes generals es pot parlar de nominalització per referir-se a la creació d'un nom a partir d'un verb, un adjectiu o un altre nom, habitualment es reserva el terme per designar exclusivament els substantius procedents de verbs, és a dir, un procés que consisteix a transformar una acció en un efecte o en un estat.

A partir dels lexemes verbals es poden formar noms abstractes i noms concrets. Els abstractes posseeixen el valor de 'acció i efecte de l'acció verbal' i es formen amb els següents sufixos sinònims:

-ment (i no el castellà *-o): pagament, tractament.

-ció: avaluació, aprovació.

-nça: naixença, partença, defallença.

-or: escalfor, gelor, cremor.

-et: ronquet, xiulet.

-atge: embalatge, buidatge.

Amb el mateix valor, afegint-hi un tret addicional, tenim -dissa i -òria, que indiquen 'acció i efecte múltiple', i -im, que expressa 'acció empetitida': trencadissa, voladissa, cridòria o ruixim. Els sufixos que generen noms concrets poden tenir valors diferents i fins i tot oposats. Així, el sufix -dor té el significat de 'persona 
que fa l'acció verbal' i, juntament amb -tori, indica 'el lloc on es produeix l'acció'. El sufix -all, d'altra banda, pot referir-se, tant a 'l'objecte amb què es fa l'acció verbal' com al 'lloc on es fa' o al 'resultat que s'hi produeix'. Aquesta idea de resultat també es pot expressar, finalment, amb els sufixos -dura i -alla o -alles:

-dor: calculador, corredor, cobrador.

-dor: menjador, rebedor.

-tori: dormitori, vetlatori.

-all: fregall, amagatall, encetall.

-dura o -dures: feridura, serradures.

-alla o -alles: rialla, deixalles.

\subsubsection{Usos i funcions dels relatius}

Les oracions de relatiu fan una funció de complement nominal -la mateixa funció que fa habitualment l'adjectiu, i per això s'anomenen també oracions de relatiu adjectives-i que poden ser especificatives -si restringeixen l'abast del substantiu que modifiquen, com ara [25] i [26]- i explicatives -si no el restringeixen i es limiten a indicar una propietat o característica; és el cas de [27]. En l'escriptura, les oracions explicatives van marcades entre comes:

[25] La idea que s'amaga darrere d'aquests estudis (= amagada) era que en cas que algunes instal-lacions de comunicacions resulten malmeses com a conseqüència d'un atac nuclear, el sistema que quedarà en peu (= operatiu) continuarà proporcionant comunicació entre els ordinadors que funcionaren (= funcionals) per permetre una resposta a l'atac.

[26] En els anys següents s'estudien tècniques de comunicació entre ordinadors que no depenguen de punts de fallida únics.

[27] Gràcies al conjunt d'eines informàtiques i de comunicacions, que aprofita el www $i$ que hom ha anomenat «les tecnologies de la informació», aquests documents poden ser atractius i contenir, a més de text, gràfics, so, vídeos, etc.

Les oracions de relatiu apareixen encapçalades per un pronom relatiu, que pot ser àton (que), tònic (qui i què), compost (el qual i la resta de varietats), adverbial o locatiu (on), possessiu, neutre i adjectiu. El quadre següent presenta una visió de conjunt dels usos i funcions dels relatius. 


\begin{tabular}{|c|c|c|}
\hline Relatius & Característiques & Exemples \\
\hline que & $\begin{array}{l}\text { Relatiu àton. S'utilitza per substituir perso- } \\
\text { nes o coses. Fa funcions de subjecte, CI i CC } \\
\text { de temps. }\end{array}$ & No ha trobat els llibres que li havia demanat. \\
\hline qui & $\begin{array}{l}\text { Relatiu personal. És invariable i, per } \\
\text { tant, són incorrectes les formes el quin, la } \\
\text { quina, els quins, les quines... Si va precedit } \\
\text { de preposició, es pot substituir pel relatiu } \\
\text { compost. } \\
\text { No és recomanable l'ús de qui com a relatiu } \\
\text { àton en funció de subjecte, en oracions } \\
\text { explicatives en comptes de que en funció } \\
\text { de subjecte i en funció de cD precedit de } \\
\text { preposició. }\end{array}$ & $\begin{array}{l}\text { *Vaig saludar la dona qui m'havies presen- } \\
\text { tat. } \\
\text { Qui no vulga pols, que no vaja a l'era. } \\
\text { Sempre s'enamora de qui menys li convé. } \\
\text { Ha arribat la noia qui ha anat a avisar en } \\
\text { Pere (-r). } \\
\text { M'ho ha dit el senyor Pla, qui és la perso- } \\
\text { na... (-r). } \\
\text { La senyora Mateu, a qui tant apreciava l'En- } \\
\text { ric, era una professora excel-lent (-r). }\end{array}$ \\
\hline què & $\begin{array}{l}\text { Relatiu tònic. Fa funcions preposicionals. } \\
\text { Entre la preposició i el pronom no es pot } \\
\text { utilitzar mai l'article. }\end{array}$ & *El malalt amb el que parlàvem s'ha curat. \\
\hline $\begin{array}{l}\mathrm{El} / \mathrm{la} / \mathrm{el} / \mathrm{les} \\
\text { qual(s) }\end{array}$ & $\begin{array}{l}\text { Relatiu compost. Pot substituir els relatius } \\
\text { que (en les proposicions explicatives) i què } \\
\text {-qui (en tot tipus de proposicions). És d'ús } \\
\text { obligatori amb preposicions fortes i locuci- } \\
\text { ons prepositives. }\end{array}$ & $\begin{array}{l}\text { Necessitàvem una causa contra la qual } \\
\text { lluitar. } \\
\text { Es tracta d'un assumpte sobre el qual no vull } \\
\text { opinar. }\end{array}$ \\
\hline on & $\begin{array}{l}\text { Relatiu adverbial. Cal emprar amb cura el } \\
\text { relatiu on en les designacions de lloc figurat. } \\
\text { En els registres formals, no és recomanable } \\
\text { la forma } \boldsymbol{a} \text { on. }\end{array}$ & $\begin{array}{l}\text { El negoci on havien arriscat tants diners no } \\
\text { els va sortir bé (-r). }\end{array}$ \\
\hline $\begin{array}{l}\text { la qual cosa } \\
\text { / cosa que }\end{array}$ & $\begin{array}{l}\text { Neutre. S'usen en oracions explicatives } \\
\text { (sempre amb comes). No són correctes les } \\
\text { construccions amb el que, lo que, el qual o } \\
\text { lo qual. Es poden utilitzar formes equiva- } \\
\text { lents, com ara fet que o } \boldsymbol{i} \text { això. }\end{array}$ & $\begin{array}{l}\text { *No ens va fer bé la feina, el que ens va } \\
\text { disgustar molt. } \\
\text { No ens va fer bé la feina, cosa que ens va } \\
\text { disgustar molt. }\end{array}$ \\
\hline $\begin{array}{l}\text { art. }+\mathrm{N}+ \\
\text { prep. }+ \text { art. } \\
+ \text { qual }\end{array}$ & $\begin{array}{l}\text { Possessiu. Són incorrectes les expres- } \\
\text { sions amb que, procedents del llenguatge } \\
\text { col-loquial, i les expressions d'influència } \\
\text { castellana amb quin o qual. De vegades es } \\
\text { poden utilitzar formes alternatives amb el } \\
\text { relatiu i el verb tenir, que té. }\end{array}$ & $\begin{array}{l}\text { Era una masia a l'entrada de la qual hi } \\
\text { havia un escut. } \\
\text { *Aquell rellotge que el mecanisme / qual } \\
\text { mecanisme / qui mecanisme no funciona era } \\
\text { de l'avi. }\end{array}$ \\
\hline $\begin{array}{l}\mathrm{N}+\text { relatiu } \\
\text { compost }\end{array}$ & $\begin{array}{l}\text { Adjectiu. Sempre s'escriu separat per } \\
\text { comes del nom, i no és pot utilitzar amb } \\
\text { aquesta funció quin/quina. }\end{array}$ & $\begin{array}{l}\text { Li van donar } 200 \text { euros, la qual suma / suma } \\
\text { que havia de ser suficient per comprar el } \\
\text { regal. }\end{array}$ \\
\hline
\end{tabular}

Fig. 39. Usos i funcions dels relatius

Les oracions de relatiu explicatives poden utilitzar-se per realitzar funcions discursives diferents. Tot seguit se'n presenten les més habituals.

1. L'oració de relatiu pot introduir la definició del terme especific que funciona com a antecedent:

[28] El haiku, que és una de les formes de poesia tradicional japonesa més representatives, conté tres versos de cinc, tres i cinc síllabes sense rima. 
2. En segon lloc, l'oració de relatiu, a més d'explicar un terme específic, pot explicar un concepte, com a l'exemple següent:

[29] Hores més tard, el conseller de Benestar i Família va afirmar que el Govern no vol endurir les obligacions dels estrangers en matèria lingüística, sinó només fer complir la llei d'acollida, la qual especifica que el català és la llengua preferent en matèria d'integració.

3. Altres vegades no explica l'antecedent, sinó que s'utilitza per afegir informació tan o més rellevant que la de la proposició principal:

[30] L'arquitecte Oriol Bohigas, el qual es va proclamar president de l'Ateneu Barcelonès l'any 2003, va afegir que portant el timó d'una institució petita es poden materialitzar moltes més tasques que en grans càrrecs públics.

4. En ocasions, la proposició inserida, tot i que no explica el significat de l'antecedent, que ja és conegut, serveix per a explicar la informació que ve a continuació:

[31] Construir un sarcòfag, la funció del qual és protegir el nucli d'un reactor nuclear, impedirà l'alliberament de substàncies al medi exterior.

5. També pot afegir informació nova:

[32] Es tracta com a mínim d'un polític amb títol de doctor, cosa que no és freqüent, i encara menys a casa nostra.

6. En altres textos, es poden trobar exemples en què la clàusula de relatiu introdueix la conseqüència i explicita, per tant, una relació de causa/conseqüència que subratlla la informació continguda en la proposició inserida:

[33] A casa nostra hi ha pocs doctors a les empreses, cosa que pot reflectir el nostre baix nivell tecnològic.

7. De vegades, la proposició inserida presenta una informació considerada secundària, que no es pressuposa coneguda pel receptor i es presenta en un segon nivell informatiu.

[34] Zapatero i el Govern espanyol han actuat amb una celeritat encomiable, igual que el pP i cIU, que s'han apressat a donar suport a la resolució.

8. Finalment, en algun cas, es poden trobar en un mateix paràgraf dues proposicions de relatiu que vehiculen informacions de rellevància diferent.

[35] La llegenda dels amors de Ginebra i Lancelot, la qual es troba en la novel·la Lancelot o Le chevalier à la charrette, de Chrétien de Troyes, 
i que féu que Lancelot es convertís en un dels prototipus de l'amor cortès, va ser cèlebre durant tota l'edat mitjana.

Malgrat que aquesta tipologia sembla suggerir un inventari precís de funcions, cal remarcar que, sovint, en un mateix paràgraf es poden trobar oracions de relatiu amb funcions diferents: introduir informació nova, activar un coneixement previ o introduir una explicació que amplia la informació anterior.

[36] Pere, que havia esdevingut rei, s'afanyà a confiscar els béns del patrimoni reial, que la reina -la qual aleshores vivia refugiada a Castellahavia aconseguit per als seus fills, cosa que estigué a punt de provocar una guerra amb Castella, i a combatre Pere de Xèrica, el qual era partidari de la reina vídua.

\subsection{La informació implícita: pressuposicions i sobreentesos}

\subsubsection{Valor argumentatiu de l'implícit}

En la majoria dels intercanvis, el text lingüístic -oral o escrit- no recull de manera explícita tota la informació que l'emissor vol transmetre, sinó que és el receptor qui l'ha de deduir a partir dels coneixements que té de la llengua i del context. És aquest un mecanisme de «dir i no dir» que obeeix a diverses raons (Ducrot, 1972). A més del principi d'economia del llenguatge, l'ús de l'implícit en la comunicació permet:

a) construir actes de parla adequats a situacions comunicatives en què es presenten tabús que no poden explicitar-se perquè es consideren socialment punibles, com ara, per exemple, donar ordres a un superior sense que ho semble (Li importaria mostrar-me l'informe?);

b) fer afirmacions sense assumir la responsabilitat d'haver-les fetes i deixar que siga el receptor qui es responsabilitze de la interpretació (A: Què li sembla l'actuació arbitral, senyor Schuster? B: D'on és, l'arbitre? [en una roda de premsa postpartit, quan tothom sabia qui havia arbitrat $i$ que era un àrbitre del col-legi català]), i

c) presentar opinions o punts de vista que no es vol que siguen discutides, ja que tota informació explicitada es converteix en tema de possibles discussions (La mobilització de 30.000 soldats, que se centra en la regió tribal de Waziristan del Sud, permetrà al Pakistan assaltar per terra i aire el principal bastió dels talibans; La massiva assistència a la manifestació antiavortista constitueix un repte al govern. Els organitzadors presumeixen de reunir 2 milions de persones, tot $i$ que la policia n'estima unes 250.000). 


\subsubsection{Tipus d'informació implícita}

Cal diferenciar entre dos tipus d'implícits: els sobreentesos o implicatures conversacionals i les pressuposicions o implicatures convencionals. Els primers es troben relacionats amb la competència pragmàtica dels participants, que dedueixen la informació gràcies al coneixement de les màximes conversacionals. Per contra, en les pressuposicions, la informació implícita es pot inferir a partir de l'enunciat mateix i de les estructures lingüístiques emprades.

\subsubsection{Els sobreentesos o implicatures conversacionals}

Els sobreentesos o implicatures conversacionals són un tipus d'informació implícita que l'interlocutor pot deduir per a partir de l'aplicació del principi de cooperació $\mathrm{i}$ de les màximes conversacionals.

- Principi de cooperació. S'espera que la contribució dels parlants siga l'adequada al propòsit i a la direcció de l'intercanvi comunicatiu.

- Màxima de qualitat. S'espera que el parlant no afirme allò que és fals o el que desconeix.

- Màxima de quantitat. S'espera que la informació aportada pel parlant siga tota la necessària; que no hi falte ni en sobre res.

- Màxima de relació o de pertinència. S'espera que la informació aportada siga pertinent.

- Màxima de manera. S'espera que l'expressió emprada siga tan clara, ordenada i concisa com siga possible.

Fig. 40. El principi de cooperació i les màximes conversacionals

L'interlocutor espera que aquestes màximes es respecten. Això ens permet comunicar-nos amb una gran economia expressiva, però també manipular l'opinió dels receptors. Per exemple, en el discurs polític o periodístic és possible trobar la reiteració de falsedats que per a molts esdevenen increïbles, però que, tanmateix, arriben a convèncer molts ciutadans. Per què aconsegueixen ser acceptades com a certes? Perquè els ciutadans no experts o no previnguts en contra de l'emissor aplicaran la màxima de qualitat a la interpretació del discurs $i$, per tant, conclouran que «alguna cosa de veritat hi deu haver», o bé que l'informador ha accedit a alguna font informativa que els altres desconeixem. Un bon exemple d'aquesta estratègia manipuladora la vam tenir amb la suposada existència d'armes de destrucció massiva per justificar la invasió de l'Iraq o amb l'anomenada teoria de la conspiració sobre els atemptats de 1'11-M a Madrid.

A més, l'ús de l'implícit pot servir per carregar d'agressivitat una resposta, com es pot comprovar en el diàleg següent:

Alumne: La volta de creuer és característica de l'art romànic, veritat?

PROFESSOR: Sí, efectivament. I també ho són els gratacels!

La resposta del professor infringeix la màxima de qualitat («No afirmes allò que creus que és fals»). L'alumne sap que els gratacels no són característics de l'art 
romànic; també sap que el professor sap que no ho són i que, a més, el professor sap que l'alumne sap que no ho són. Llavors, per què no respon amb una simple negació? Doncs perquè a més de negar, el professor vol comunicar una altra idea: de la mateixa manera que seria imperdonable afirmar que en l'edat mitjana hi havia gratacels, també ho és afirmar que la tècnica constructora del romànic inclou la volta de creuer. Així, les paraules del professor no són només una resposta a la pregunta d'un estudiant, sinó, sobretot, una crítica a l'alumne que la formula. Es tracta d'un exemple de discurs agressiu, en aquest cas d'un professor, que caldria modalitzar mitjançant la cortesia lingüística per atenuar la desaprovació (Castellà i altres, 2007).

\subsubsection{Les pressuposicions o formes convencionals de l'implicit}

La pressuposició s'ha definit com una inferència inscrita en l'enunciat independentment dels contextos en què puga aparèixer. Açò implica fer una distinció entre dos nivells de contingut d'un enunciat: un primer pla, allò explícit en l'enunciat o allò exposat, i un segon pla, sobre el qual recolza el primer pla, allò pressuposat. Els continguts dels dos plans no tenen el mateix estatus. Els continguts pròpiament enunciats són aquells sobre els quals se centra l'enunciació i, per tant, poden ser objecte d'una resposta eventual. Per contra, les pressuposicions poden ser deixades de costat, ja que l'atenció no s'hi focalitzarà.

Hi ha un test clàssic per distingir la pressuposició: comprovar la seua resistència a la negació i a la interrogació. Si convertim en negativa o interrogativa una frase on hi ha una pressuposició, aquesta romandrà inalterable després de la transformació. Així, si neguem [37], obtenim [38], on es nega la informació exposada en primer pla, però es continua acceptant la informació implícita ('abans sí que ho feia').

[37] Enguany el senyor X ha continuat defraudant a Hisenda.

[38] No. Enguany el senyor X no ha continuat defraudant a Hisenda.

La possibilitat manipuladora en l'ús de pressuposicions rau en el fet que quan es contesta una pressuposició la conversa pren un caire polèmic. En principi, no s'espera que l'interlocutor continue el discurs fent referència als continguts pressuposats, sinó que es considera que ha de partir de la informació pròpiament exposada. En alguns casos, de fet, l'enunciat només és un recurs per vehicular la pressuposició. És el que passa en els interrogatoris policials. Així, l'enunciat [39] pressuposa que la persona, efectivament, va amagar un cadàver en algun lloc.

[39] On vau amagar el cadàver?

Els titulars periodístics sovint presenten pressuposicions. Són tan habituals en el discurs que passen desapercebudes, tret que la informació pressuposada entre en col-lisió directa amb el nostre coneixement del món o les nostres creences més arrelades. El fet és, però, que les pressuposicions no conflictives permeten transmetre molta informació que és acceptada sense qüestionar-la i, per tant, sense ésser 
sotmesa a un procés de verificació o de contrast amb altres fonts. En alguns casos, la pressuposició existencial vehiculada pel sintagma nominal definit permet introduir l'opinió dins del titular, perquè implica prendre partit a favor d'una determinada tesi o punt de vista i donar com a provats els fets objecte de discussió. Així, per exemple, l'enunciat [40] permet afirmar que els maltractaments es produïren, encara que els companys no els van denunciar.

[40] Els companys del soldat no denunciaren els maltractaments del caporal.
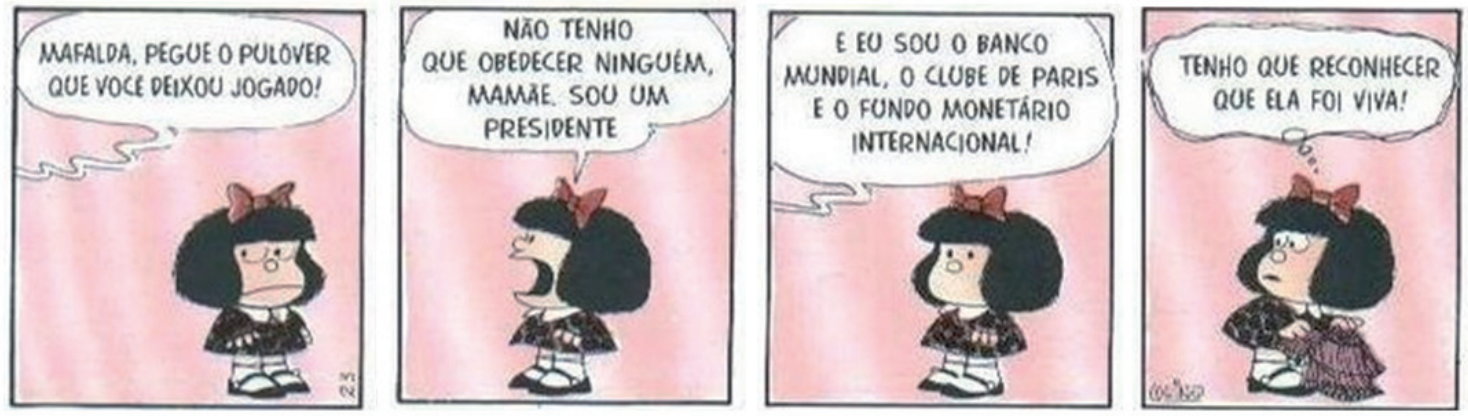

Fig. 41. Implicatures en Mafalda

Pressuposar és, en definitiva, donar una informació al marge del discurs, tot negant al destinatari el dret d'encadenar els enunciats a partir d'aquesta informació.

\subsubsection{Mecanismes lingüístics de les pressuposicions}

Les pressuposicions es transmeten amb l'ús de determinades expressions lingüístiques, de l'ordenació dels elements oracionals o d'altres estratègies discursives específiques. Els mecanismes lingüístics més habituals són els següents:

- Els verbs factius i contrafactius, que pressuposen la veritat o la falsedat de la completiva que introdueixen. Per exemple, la frase Maria sap que Joana és metgessa pressuposa la veritat de la professió de Joana; la frase Anna ignora la data de l'examen d'Història pressuposa que ja s'ha fixat una data per a l'examen esmentat.

- Els verbs subjectius, que impliquen un judici de valor sobre la completiva que introdueixen. Confessar, per exemple, implica el caràcter punible de l'acte expressat per l'expressió que segueix; reconèixer, en canvi, implica l'evidència d'haver d'acceptar el punt de vista de l'interlocutor o de l'adversari, i explicar transfereix una idea de racionalitat $i$ objectivitat, atès que implica una voluntat d'exposar les raons o les causes d'un fet determinat o d'una situació.

- Els verbs i els marcadors aspectuals. Deixar de pressuposa que abans hi havia un cert procés; de nou indica que el procés ha tingut lloc ja almenys una vegada; tornar a transmet una certa idea de recurrència... 
- Les nominalitzacions. El sintagma l'actuació de Lluís Llach pressuposa que Llach ha actuat.

- Els sintagmes nominals definits, que pressuposen l'existència del referent corresponent. En l'oració L'educació sexual dels joves ha fracassat, amb l'ús de l'article s'afirma de manera implícita que els joves han rebut algun tipus d'educació sexual.

- Els epítets no restrictius. En l'oració Les revistes del cor són plenes d'històries sobre els orgullosos membres de l'aristocràcia, la col·locació de l'adjectiu davant del nom pressuposa que els nobles són orgullosos; la frase En el programa es va fer una crítica molt dura de l'excel·lent novel·la d'IsabelClara Simó, pressuposa que la novel·la és excel·lent.

- Les interrogacions parcials. Per exemple, si formulem la pregunta Quan vas anar a París?, es dóna per pressuposat que el nostre interlocutor ha anat a París en algun moment anterior, o si preguntem Qui ve?, es pressuposa que ve algú.

- Les inversions de l'ordre habitual de la frase, que permeten centrar el focus d'atenció sobre l'element desplaçat i, per tant, permeten que no es done per pressuposada la informació de la resta de la frase. Així, la frase És Joan, qui ha arribat, pressuposa que algú ha arribat.

- Les aposicions mitjançant oracions de relatiu, que faciliten una informació lateral i no qüestionable sobre l'antecedent. Així, en l'oració El president, que semblava indignat, no va voler fer declaracions, l'aposició centra l'atenció en el fet que el president no va fer declaracions perquè no va voler, i pressuposa (ho deixa en segon terme) el fet que estava indignat.

\section{Lectures recomanades}

CASsany, Daniel (1993): La cuina de l'escriptura, Barcelona, Empúries.

- (2002): Rere les línies. Sobre la lectura contemporània, Barcelona, Empúries.

- (2007): Esmolar l'eina. Guia d'escriptura per a professionals, Barcelona, Empúries.

Cuenca, Maria Josep (2008): Gramàtica del text, Alzira, Bromera.

Ducrot, Oswald (1984): Le dire et le dit, París, Minuit [El decir y lo dicho, Barcelona, Paidós, 1986].

Duran, Xavier (2007): Les històries que les paraules amaguen, Barcelona, Mina. Espinal, Maria Teresa (1988): Significat i interpretació, Barcelona, Abadia de Montserrat.

LÓPEZ, Ángel (1996): Escritura e información. La estructura del lenguaje periodístico, Madrid, Cátedra. 
Millà, Ramon (2000): La 'realitat' en directe. Realització d'informatius diaris a televisió, Barcelona, Pòrtic.

NúÑEz Ladevéze, Luis (1991): La construcción del texto, Madrid, Eudema.

Tuson, Jesús (1999): ¿Com és que ens entenem? (si és que ens entenem), Barcelona, Empúries.

— (2008): Això és (i no és) Allò, Barcelona, Ara Llibres. 


\section{Selecció lèxica i terminologia}

Introducció

1. Criteris de selecció lèxica en el discurs dels mitjans

2. Precisió lèxica i neologia

3. El lèxic especialitzat: terminologia i estrangerismes

4. Introducció a la fraseologia

Lectures recomanades 


\section{Introducció}

Un dels objectius essencials de les lleis de normalització lingüística aprovades en els diversos territoris de parla catalana era la creació de mitjans de comunicació que usaren de manera prioritària la llengua pròpia, tot i que l'emissió de programes de contingut lingüístic en la ràdio i la televisió públiques en català ha estat molt irregular. ${ }^{1}$ Tots els llibres d'estil dels mitjans de comunicació reconeixen que un dels objectius és difondre la llengua pròpia, per incrementar-ne la vitalitat, afavorir la integració d'aquells que no l'usen de manera habitual i, així, facilitar la cohesió social. Sobretot, en un espai marcat per la subordinació cultural, per la influència decidida d'altres llengües d'abast majoritari i per la contínua introducció de masses de població que parlen idiomes diversos.

Quan aquesta finalitat ha estat reconeguda i forma part de les seues intencions de manera decidida, els mitjans es veuen obligats a plantejar-se'n una altra: la fixació de l'allau de neologismes i estrangerismes que la societat de la informació adopta d'una manera tan ràpida que resulta impossible consultar en les obres de referència. Els diccionaris normatius no poden incloure i fixar els mots que s'introdueixen gairebé cada dia a través dels mitjans. És per això que el personal encarregat de la correcció haurà d'emetre algunes hipòtesis que seran validades pel TERMCAT, en primer lloc, i posteriorment, si és el cas, pel diccionari normatiu.

En aquest tema ens centrarem en l'explicació dels criteris que han d'usar els mitjans en la selecció de mots, la introducció de neologismes, l'ús d'estrangerismes i l'adequació del que anomenem fraseologia o discurs prefabricat, ja que de l'adopció raonada de determinades solucions, en depèn l'acceptació i la difusió en els àmbits pertanyents a la vida quotidiana.

\subsection{Criteris de selecció lèxica en el discurs dels mitjans}

\subsubsection{Recomanacions generals}

El lèxic és un dels capítols més polèmics -perquè tothom té alguna opinió de la correcció o no de les paraules que utilitzem habitualment, sovint contradictòries i no sempre amb una bona fonamentació lingüística-, però també un dels aspectes més emblemàtics, més vistosos diríem, del grau de correcció d'una intervenció oral. És, per tant, un dels àmbits on, des dels serveis d'assessorament lingüístic dels mitjans, es preconitzen més restriccions sobre els usos col·loquials propis de l'oralitat espontània.

1. De fet, només Tv3 ha dedicat alguna atenció al debat sobre la situació de la llengua, ha emès alguns documentals sobre l'ús del català en sectors estratègics i diversos programes dedicats a difondre la varietat estàndard entre la població (Digui, digui, per exemple) o a divulgar el lèxic propi (Caçadors de paraules). 
Per tal de produir intervencions clares i precises, la selecció lèxica en els mitjans de comunicació audiovisuals ha de tenir molt en compte una sèrie de recomanacions bàsiques, reconegudes i especificades habitualment en els llibres d'estil. ${ }^{2}$ Aquestes recomanacions fan referència a la necessitat d'expressar-se amb concisió i claredat, d'emprar un lèxic precís i genuí, d'evitar els arcaismes i de substituir les interferències i els calcs lingüístics per expressions fraseològiques pròpies.

a) La tendència a la concisió i la claredat es concreta en la preferència per l'ús d'expressions planeres i paraules d'ús corrent i en l'exclusió de repeticions innecessàries, tòpics, crosses o falques. Cal evitar, per tant, els anomenats usos abusius.

Haurem de parar atenció, en aquest apartat, a la diferenciació que estableixen els llibres d'estil pel que fa a l'abast de difusió. Així, el periòdic Avui, el portal lingüístic del la Corporació Catalana de Mitjans Audiovisuals (És a dir) i el llibre d'estil de Vilaweb opten per un model de llengua aplicable a tot el domini lingüístic. Altres mitjans, com Andorra Televisió, El 9 Nou o els que pertanyen a les Illes Balears, prefereixen que el lèxic s'ajuste a la varietat nord-occidental en el primer cas, a l'oriental en el segon i a la balear en el darrer dels casos. Les paraules d'ús corrent són, per als mitjans territorials, paraules d'ús habitual als respectius territoris. Tanmateix, no es tracta de l'ús de les varietats dialectals en un sentit exclusiu. El Llibre d'estil per als mitjans de comunicació orals i escrits (2005) de les Illes Balears és, en aquest sentit, molt clar:

D'altra banda, és important que tinguem en compte que usar preferentment les variants lèxiques, morfològiques i sintàctiques de les Balears no vol dir que se n'hagi de fer sistemàticament un ús exclusiu. En determinades situacions comunicatives pot ser necessari recórrer als mots sinònims d'altres contrades per fer més variat i àgil el discurs, sobretot en casos en què es repeteixen molt els mateixos mots.

Universitat de les Illes Balears, 2005: 107-108

Són preferibles, doncs, les expressions [1], [2] i [3] en comptes de les expressions [4], [5] i [6]:

[1] Han aconseguit el primer lloc de la classificació.

[2] Hi anirà fins i tot el president.

[3] S'han creat una sèrie de tallers perquè els estudiants...

[4] Han assolit el primer lloc de la classificació.

[5] Hi anirà àdhuc el president.

[6] S'han creat una sèrie de tallers pràctics perquè els estudiants...

b) L'exclusió d'arcaismes i d'expressions amb regust més aviat literari està relacionada amb la recomanació d'evitar usos inadequats.

2. És ben significatiu que de tots els mitjans de comunicació que emeten, íntegrament o parcialment, en català, només la corporació RTVV no dispose d'un llibre d'estil públic i reconegut. 
La finalitat dels mitjans és fer-se entendre per un púbic de diversa formació i, per assolir aquest objectiu, han d'evitar l'ús de formes que no s'ajusten a la transmissió d'informació. L'arcaisme o el recurs literari resulta estrany en un mitjà que es caracteritza per la immediatesa i no per la lectura o l'escolta tranquil-la i reflexiva. Per tant, cal optar per les solucions dels exemples [7], [8] i [9] i rebutjar expressions com les dels exemples [10], [11] i [12], excessivament arcaiques, massa formals i poc adequades per als mitjans de comunicació de massa.

[7] Hi havia més de dues-centes persones.

[8] Van suspendre la representació perquè hi havia poc públic.

[9] Estava una mica nerviós.

[10] Hi havia dues-centes persones i escaig.

[11] Atès que hi havia poc públic, van suspendre la representació.

[12] Estava quelcom nerviós.

c) La precisió i la genuïnitat a l'hora de triar les paraules exigeix un coneixement exacte dels significats propis per tal d'evitar els usos impropis.

El fet de repetir mots sense saber-ne exactament el significat fa que, molt sovint, es considere que el sentit genuí d'una paraula és aquell que li han atorgat els mitjans i no el propi que apareix en el diccionari. Ho podem veure en alguns exemples que segueixen la mateixa distribució pel que fa a la correcció que els anteriors.

[13] En aquella hora hi havia poc *tràfic a l'autopista [el mot propi és trànsit]. [14] Van suspendre totes les * carreres de velocitat [curses].

[15] La festa començarà a la una * de la tarda [del migdia].

d) La substitució dels verbs febles (estar, ser, fer, trobar, semblar, etc.) per verbs de predicació completa, que són molt habituals en la llengua col·loquial, permet construir un discurs més precís, més dens conceptualment, i evitar l'ús de mots buits que allarguen les oracions de manera innecessària. Així, són preferibles les solucions dels exemples [16], [17] i [18] en lloc de les construccions [19], [20] i [21].

[16] L'edició de dijous publicava un reportatge sobre immigració.

[17] També hi participaran els membres del Consell d'Estudiants.

[18] Es podran consultar els resultats per Internet.

[19] En l'edició de dijous hi havia un reportatge sobre immigració.

[20] També hi seran els membres del Consell d'Estudiants.

[21] La consulta dels resultats es podrà fer per Internet.

e) La recomanació d'emprar expressions fraseologiques genü̈nes i d'evitar els calcs lingüístics d'estructures alienes (menys mal, ni molt menys o altres semblants), a la qual dedicarem el darrer apartat del tema, té molt a veure amb el caràcter intraduïble de la fraseologia, que constitueix un element 
essencial de la cultura d'un poble i és, per tant, un component cultural que cal preservar i protegir.

[22] *La retransmissió del concert d'any nou [de cap d'any].

[23] * La remodelació començarà en el casc antic [barri vell].

[24] *De totes formes, el president n'acceptà les observacions [de tota manera].
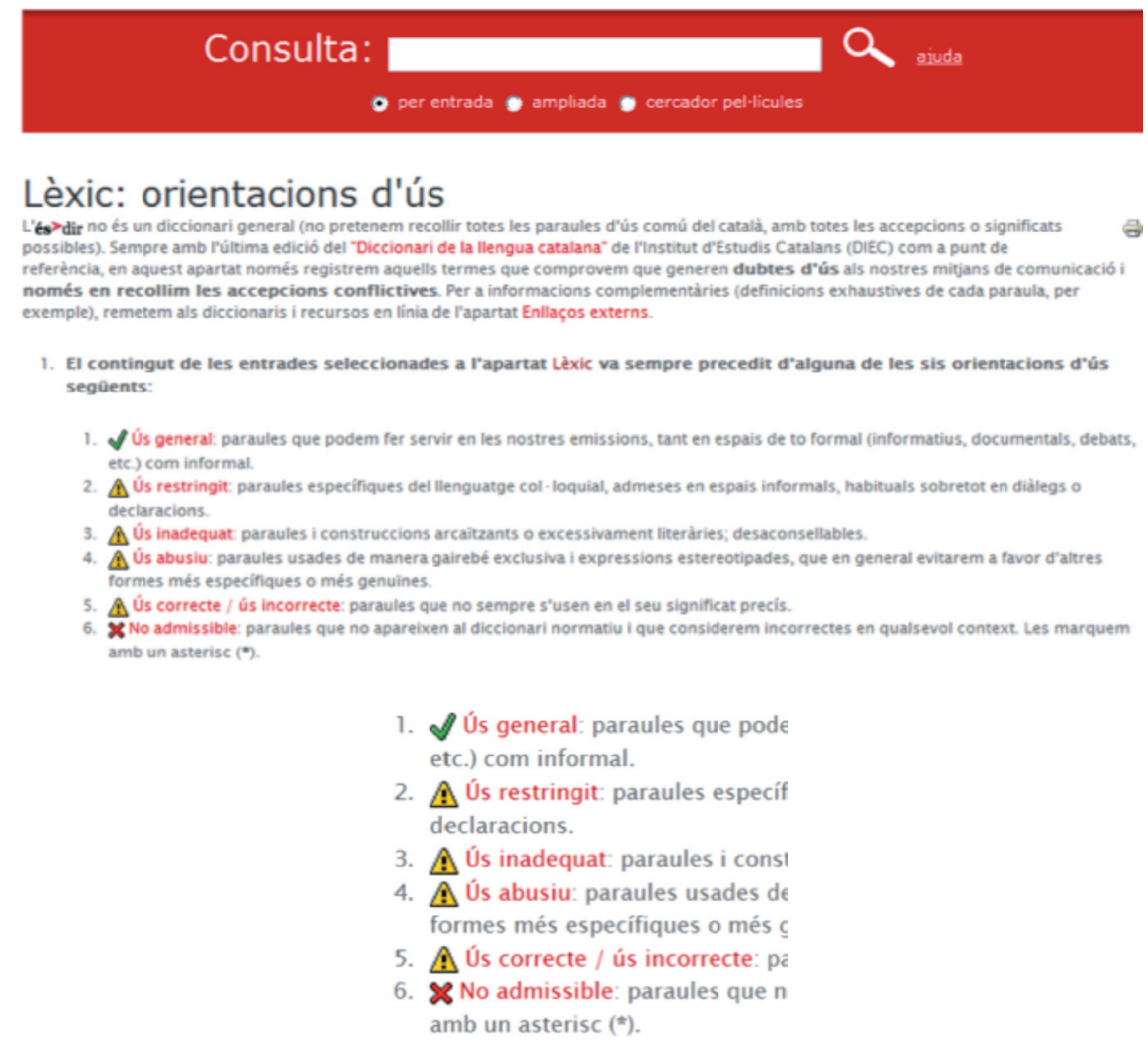

Fig. 42. Orientacions d'ús del lèxic del portal És a dir (font: http://esadir.cat/lexic/usgenrest)

\subsubsection{La interferència lingüística}

La història de les llengües en general, i de cada llengua en particular, ens ensenya un fet comú a totes: que no hi ha llengües «pures» i que una característica general és la «contaminació», la «mescla» de les unes amb les altres. Des d'una perspectiva històrica, es pot considerar l'exemple de les llengües romàniques: totes són filles del llatí, però els fenòmens de substrat (influència de llengües anteriors al llatí), de superstrat (influència de llengües assimilades i posteriors al llatí) i adstrat (influència de llengües veïnes) les han acabades de caracteritzar. Ara bé, aquesta «contaminació» no és proporcional. Hi ha llengües o varietats lingüístiques que són més «donants» i d'altres que són més «receptores». Precisament la interferència lingüística és un procés pel qual es produeix la transferència d'elements lingüístics procedents d'una llengua o varietat sobre una altra, la qual provoca 
processos de canvi lingüístic que es concreten en l'adopció d'elements aliens. Aquest fet, que es pot donar en tots els nivells del llenguatge (fonètic, morfològic, sintàctic, lèxic i semàntic), té especial rellevància en el repertori lèxic.

La interferència interlingüística es produeix amb la finalitat d'adaptar el repertori lexicogràfic d'una llengua a les noves necessitats comunicatives i es concreta en dos mecanismes oposats: els neologismes i els barbarismes.

a) Els neologismes són mots de nova creació que serveixen per designar objectes i conceptes nous (futbol, escàner, espot, ordinador, etc.). Un dels procediments més emprats a l'hora d'introduir neologismes són els préstecs o manlleus: expressions d'origen forà, però integrades completament en el nostre codi normatiu. Quan els préstecs procedeixen de les llengües clàssiques (llatí i grec) s'anomenen cultismes. En general, els préstecs s'introdueixen perquè la llengua no té prou recursos expressius per designar objectes o conceptes nous i, per tant, són útils i necessari.

b) Per contra, els barbarismes són elements procedents d'una altra llengua (en el nostre cas, normalment del castellà) que s'incorporen al sistema lingüístic per substituir expressions genuïnes i, per tant, sense cap necessitat objectiva (comedor, hasta, pues, entonces, de tal palo tal astilla, per lo menos, menos mal, etc.). Es tracta d'expressions parasitàries que cal evitar i substituir per les formes lingüístiques pròpies.

A més d'aquest tipus d'interferència, que podem anomenar externa o interlingüística, sovint es produeixen fenòmens d'interferència interna o intralingüística, que provoquen transferències de recursos lingüístics d'una varietat lingüística a una altra.

Des del punt de vista morfològic, les interferències es poden classificar en quatre categories: interferències no assimilades, quan la paraula originària no ha canviat: adiós, camión; interferències híbrides, quan la paraula originària s'ha adaptat parcialment a la llengua receptora des d'un punt de vista morfofonètic: vejés [vexés] pronunciat amb la $j$ castellana; interferències assimilades, quan la paraula originària s'ha adaptat completament a la llengua receptora des d'un punt de vista morfològic i fonètic: merluça, jusgat; i interferències de construcció, quan són còpies d'estructures de més d'una paraula: tenim que, per lo tant.

En l'annex v es presenten alguns dels castellanismes més freqüents i una relació d'expressions i frases fetes castellanes amb les equivalències corresponents en català. ${ }^{3}$

\section{www}

Existeixen diverses webs que ofereixen relacions més o menys exhaustives d'interferències lèxiques inacceptables en català. Són força interessants, a més del recull del Gripau, la web dels Serveis Lingüístics de la UOC i la secció de lèxic del portal És a dir:

http://www.uoc.edu/serveilinguistic/criteris/lexic/castellanismes.html http://esadir.cat/lexic

http://www.gripau.eu

3. La selecció, que procedeix del Gripau (Perujo, 2002), es pot consultar íntegrament en línia: http://www.ua.es/spv/gripau. pdf. També es poden consultar relacions d'interferències lèxiques en altres webs dels serveis lingüístics de les universitats de la Xarxa Vives. 


\subsection{Precisió lèxica i neologia}

\subsubsection{La neologia}

Els treballs de terminologia catalana en l'actualitat han de tenir molt en compte la incorporació constant de neologismes al corpus de lèxic disponible pels parlants de l'idioma. Segons el diccionari de l'IEC, un neologisme és una «unitat lèxica nova, formalment o semànticament, creada en una llengua per les pròpies regles de formació de mots o manllevada a una altra llengua» (DIEC, 2007: http://dlc.iec. cat/). El mateix diccionari defineix la neologia com el «conjunt de processos de formació de noves unitats lèxiques».

Una de les mostres del vigor intern i extern d'una llengua és la seva capacitat de crear noves paraules. Aquesta activitat és plenament funcional: en la mesura que es produeixen canvis socials, la llengua s'adapta a aquests canvis i genera unitats noves. I és un fet cert que com més consolidada està socialment i políticament una llengua, més àgil és la capacitat dels seus parlants de generar noves paraules sense que els preocupi si els nous usos estan o no inclosos en els diccionaris.

Cabré, 2004: 28

En l'actualitat, l'estudi dels neologismes s'ha obert cap a la investigació i el treball aplicat, ja que cada vegada és fa més evident la importància d'aquests treballs en relació amb la lexicografia, la creació de neologismes especialitzats i les polítiques de normalització. En totes les llengües es produeixen processos de creació lèxica, que formen part de la competència comunicativa dels parlants. La descripció dels neologismes permet observar que aquestes unitats lingüístiques no es creen mitjançant processos i recursos específics, sinó que fan servir els mateixos patrons i recursos que descriuen les paraules consolidades de la llengua. Aquesta observació justifica la hipòtesi que la competència del parlant descriu alhora l'estructura de les unitats conegudes i la formació de les unitats noves.

Els neologismes es poden classificar segons tres criteris complementaris: segons la manera com s'han format, segons la via de creació i penetració en la llengua i segons el seu àmbit d'ús.

a) Segons la manera de formació, els neologismes es poden classificar en tres grups: unitats noves 'exnihilo' (molt poc freqüents, fora del món publicitari), neologismes interns, formats d'acord amb els recursos propis de la llengua (morfològics, sintàctics, semàntics i fonològics), i préstecs (que inclouen els manlleus i els calcs).

b) La via de creació i penetració permet distingir entre els neologismes espontanis (resultat d'un acte de creació individual) i els neologismes planificats (preferentment de creació col·lectiva i institucional).

c) Finalment, el tercer criteri de classificació, l'àmbit d'ús, permet classificar les unitats lèxiques noves en dos grans grups, la neologia general -pròpia de la llengua comuna, dels usos de tots els parlants- i la neologia especialitzada -denominada també neonímia, que s'inscriu en els àmbits i usos especialitzats 
i és generada sovint per especialistes i per mediadors comunicatius de tema especialitzat. Tots dos tipus de neologia presenten diferències molt marcades. Així, la neologia general sol ser espontània, concisa i efímera, té un caràcter lúdic i expressiu, propicia la concurrència sinonímica, adquireix un valor estilístic específic, se sol utilitzar en les varietats informals, no interfereix sinó que reforça l'eficàcia comunicativa, prefereix el recurs al manlleu i al fons dialectal més que no pas al fons grecollatí i no sol transcendir el grup social que la produeix. En canvi, la neologia especialitzada sol ser planificada i molt més estable, és de caràcter referencial (perquè necessita denominar un concepte), tendeix a evitar la sinonímia (perquè pot interferir en l'eficàcia de la comunicació), s'inscriu en les varietats formals, sol rebutjar les connotacions, sol estar constituïda morfològicament i sintagmàticament, recorre sovint al fons grecollatí (que és el recurs que recomanen les normes iso per tal de consolidar denominacions estandarditzades) i tendeix a adaptar-se a les denominacions internacionals o a les d'altres llengües de cultura.

Una llengua que vulgui donar resposta de manera activa i eficaç al repte de la modernitat, en cas que no generi innovació tecnològica i científica i la difongui en llengua pròpia, ha de plantejar-se necessàriament com denominar les innovacions alienes. Si no, existeix el risc de perdre de mica en mica els registres de comunicació de prestigi o de desfigurar la seva fesomia lèxica en àmbits expressius determinants.

Els recursos que ofereixen tots els sistemes són suficients, per definició, per encunyar noves denominacions. El recurs al manlleu lèxic d'altres llengües, adaptat o literal, no s'hauria de rebutjar per principi, però en el cas de llengües com ara el gallec o el català cal ponderar amb atenció la magnitud de la transferència, ja que no es produeix bilateralment, sinó en una sola direcció. Confiar massa en el manlleu com a recurs d'actualització del lèxic d'una llengua minoritzada no seria un bon senyal de confiança per al futur.

Cabré, 2004: 41

\subsubsection{Procediments de creació lèxica}

El català -com les altres llengües del món- disposa d'un ample repertori de recursos de creació lèxica que permeten enriquir el corpus lexicogràfic de l'idioma amb mots i expressions per designar objectes i conceptes nous. L'esquema següent presenta una visió de conjunt d'aquests mecanismes, que tot seguit es descriuen i s'exemplifiquen adequadament.

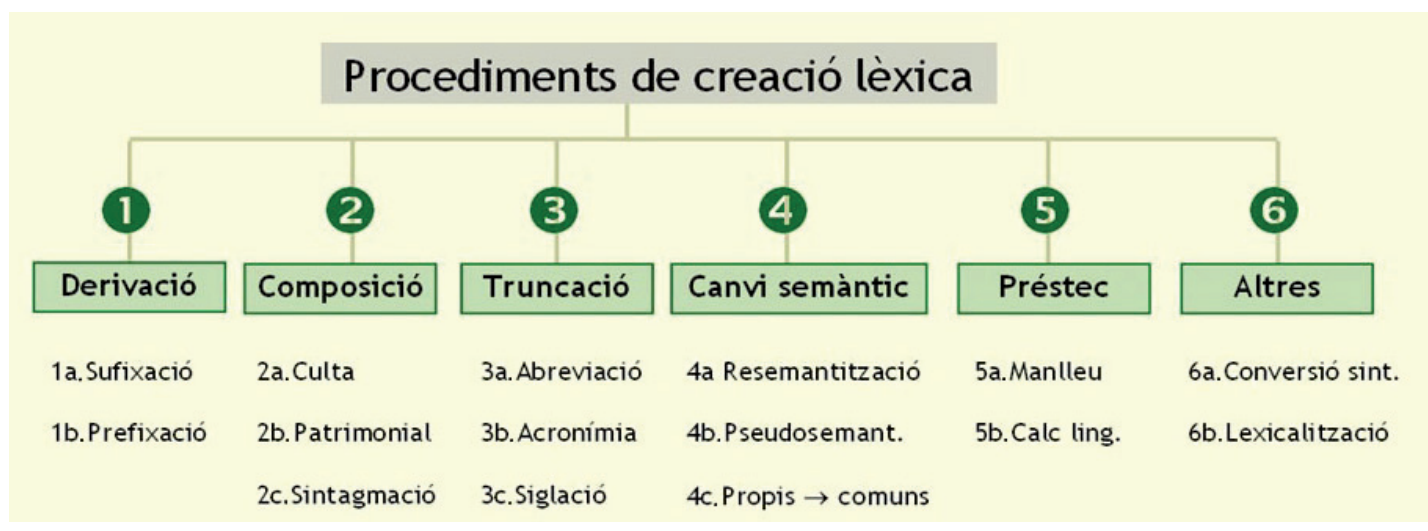

Fig. 43. Procediments de creació lèxica 


\subsubsection{Derivació}

El procés de derivació, que consisteix a afegir un sufix o un prefix al radical o a l'arrel d'un mot preexistent, és un dels mecanismes més habituals en la formació d'unitats lèxiques noves en català. Els dos procediments que té la llengua per construir neologismes per derivació són la sufixació i la prefixació.

a) La sufixació consisteix en l'adjunció d'un sufix (com ara-ment) a l'arrel o lexema de la paraula (com ara carregar). Amb aquest procediment es poden formar neologismes nominals (carregament, medicamentada, quietesa, gasoliner, carriler, radiofonista, maltractador, opinador, cimentera, tractorada, culerada, progressia, madridisme, fregall, rasclet, cendrer, climatitzador, embellidor, cacicada, aznarisme, murrieria, valencianitat, tutelatge, implantament, vessament, monitorització, equiparació, fidelització, deslocalització, desmantellament, enrocament, temporització, desmarcament, guionatge o entallatge), adjectivals (argumentable, postural, clientelar, planetari, capitalí, armamentístic, maquiavèlic, mediàtic, anorèxic, estratosfèric, tolstoià, tintinesc, espriuà, kafkià, dantesc, bolivarià, columnaire, castellanitzador, uniformitzador, globalitzador, argumentatiu, desaconsellable, ministrable o presidenciable) i verbals (parlotejar, editorialitzar, victimitzar, problematitzar, minoritzar, rebotejar o estatificar). La sufixació és un procediment molt productiu per a la creació de noms i adjectius, però no tant per a la creació de verbs. Alguns sufixos nominals i adjectivals són especialment productius -per exemple els que permeten designar doctrines i opcions ideològiques, partidaris o seguidors de, noms d'acció i efecte o adjectius de propensió a una qualitat-, mentre que d'altres tenen una vitalitat molt limitada. Pel que fa a la formació de verbs, destaca la productivitat dels sufixos -itzar i, amb una freqüència molt menor, -ejar; per contra, el sufix -ificar és gairebé testimonial.

b) Els neologismes formats per prefixació poden agrupar-se en diferents categories segons el significat del prefix. Així, el conjunt quantitativament més important d'aquestes unitats està format pels prefixos de negació (antiacord, antitot, anti-Messi, antisoroll, contraargumentació, no-esforç, deshomologar, deconstrucció, incivisme o insostenibilitat). La resta de neologismes formats per prefixació tenen un caràcter més o menys locatiu (probritànic, paramilitar, infrahistòria, transcontinental, ultrapirinenc, interculturalitat, coguionista, coresponsabilitat), expressen un matís marcadament temporal (prejubilació, postvacacional), introdueixen algun tipus de modificació relacionada amb la quantitat o la mesura (monotemàtic, multimodal, tripartit, plurilingüístic, multiusos, malinterpretar, pseudointel-lectual, neoconservador) o afegeixen al lexema un matís de gradació (ultranacionalista, hiperactiu, realimentar, reagrupar, sobreactuació, supersimpàtic, semiderruït, seminou, infravalorat). 


\subsubsection{Composició}

La composició és un procediment de creació lèxica que consisteix a obtenir una paraula nova a partir de la combinació de dues paraules preexistents. Sota aquesta denominació s'inclouen tres processos de creació neològica diferent: la composició culta, la composició patrimonial i la sintagmació.

a) Tradicionalment, la composició culta ha estat vinculada a la creació neològica en determinats àmbits d'especialitat (per exemple, la medicina) i no ha estat considerat un recurs morfològic rellevant en la formació de neologismes de la llengua general o d'àmplia difusió. No obstant això, segons les dades de l'Observatori de Neologia, actualment es tracta d'un procés de formació de paraules força productiu. Els neologismes formats per aquest procediment és poden classificar en tres grups diferents:

- Compostos formats per dos elements cultes procedents del llatí o del grec: cleptòcrata, lusofòbia o euròfils -i mots com frutícola, islamòleg, opiniatre, lliberticida, comicoteca o vinateca, que contenen falses formes prefixades cultes.

- Compostos híbrids, creats amb un formant culte (llatí o grec) i una paraula catalana: bioseguretat, aerolínia o humanoide. En aquest grup s'inclou el fenomen d'assignació de nous significats a formes prefixades ja existents o formants polisèmics (ecosistema, ecogestió, ecopacifista, eurobàsquet, europarlamentari, eurozona, narcosala, teleassistència, teleaddicte o telepredicador); la creació de nous formants assimilables, pel seu comportament, a formants cultes ja existents (ciberdelinqüència, cibercontractacions o ciberterrorisme), i el comportament neològic de determinats formants pel que fa a les condicions i restriccions imposades per la regla de formació aplicada (sentimentaloide o madriditis). Des d'un punt de vista semàntic, els compostos híbrids formen habitualment gentilicis (italoparlant, anglofrancès), quantitats (pentacampió, quadrilingüe), mots que remeten a la situació espacial (anteroextern, frontolateral), unitats de l'àmbit mèdic (cardiorespiratori, isquiotibial, dermocosmètica, vasocel-lular) i magnituds (macroprojecte, microcrèdits, maxiprocés, megaconcert).

- Compostos produïts a la manera culta, formats per la unió de dues paraules catalanes, en què al primer element s'afegeix la terminació -o, que confereix un cert matís culte a la unitat: ecologicosocial, albanokosovar, bascofrancès, mediaticojudicial, publicoprivada, musculoesquelètic o euskonazisme.

b) La composició patrimonial comprèn els fenòmens de formació de mots a partir de dues unitats preexistents, que s'escriuen juntes o amb guionet. Aquest criteri permet de distingir la composició patrimonial de la sintagmació, ja que en aquest cas es tracta d'unitats fraseològiques que s'escriuen habitualment separades i que no tenen una entrada pròpia en els diccionaris. 
Hi ha, però, alguns exemples d'unitats lèxiques formades per sintagmació que s'han normativitzat formalment aglutinades i que, per tant, tenen una entrada pròpia en els diccionaris (allioli, maldecap o ulldepoll). L'anàlisi dels mots compostos formats per composició patrimonial permet classificar-los en dues grans categories:

- Neologismes nominals: salvapantalla, sensepapers, portarotllos, aparcacotxes, portapreus, recolzacap, alçavidres, reposabraços, comte-rei o berenar-sopar.

- Neologismes d'altres categories gramaticals: agricolaramader, demòcrata-cristià, lúdic-esportiu o social-liberal.

c) La sintagmació consisteix a convertir tot un sintagma (format per dues o més paraules) en una entitat lèxica que té un significat unitari. Es tracta d'un tipus de composició situada en un terreny llindar entre la composició patrimonial i les unitats fraseològiques anomenades col-locacions. A efectes pràctics, les unitats generades amb aquest procediment, que en l'actualitat té un rendiment extraordinari, es poden classificar en dues categories:

- Neologismes nominals: banc electrònic, canal satèl·lit, tipus d'interès, tren d'alta velocitat, immigrant sense papers, pàgina web, cotxe bomba, tertúlia electrònica, televisió digital, revista del cor, virus informàtic, carril bici (o carril-bici), allioli o maldecap.

- Neologismes d'altres categories gramaticals: posar les banyes, anar com una moto, donar llum verda, caure en picat, de pedra picada o en clau de.

\subsubsection{Truncació}

La truncació és un procediment neològic, sovint oblidat per les gramàtiques tradicionals, que consisteix a crear mots nous escurçant, o truncant, d'una forma o altra, mots o unitats lèxiques preexistents. Aquest procediment inclou tres mecanismes diferents: l'abreviació, l'acronímia i la siglació.

a) L'abreviació és un procés de producció d'un neologisme a partir de la reducció o escurçament d'una unitat lèxica anterior. La unitat nova conserva el significat de la unitat original. Aquest recurs s'utilitza, especialment, en els àmbits informals, $\mathrm{i}$ això ha provocat una forta resistència a incorporar-los $\mathrm{a}$ la llengua estàndard i, per tant, als diccionaris (tot i que alguns s'hi poden trobar, com ara bus, curt o foto). La majoria de neologismes formats per abreviació són substantius: bici, boli, profe, depre, narco, pel·li, dire, melo, Toni, sudaca, híper, súper, ros (per tabac ros), metro o mòbil.

b) L'acronímia és un procediment que consisteix a formar una unitat lingüística nova a partir de la unió de més d'un mot o de seqüències de més d'un 
mot, amb la supressió d'una part dels mots preexistents: ofimàtica (oficina + informàtica), robòtica (robot + electrònica), aventurisme (turisme d'aventura), docudrama (documental dramàtic), infocultura (cultura informàtica), publireportatge (reportatge publicitari), infopistes (autopistes de la informació), papamòbil o aparthotel.

c) La siglació és un recurs de creació neològica molt viu en la llengua actual. Una sigla és el resultat de la unió de totes o la majoria de les inicials dels mots plens de què es compon una unitat sintàctica: ONG, IEC 0 TV3, per exemple. Ortogràficament, les sigles s'escriuen en versaletes, sense accents i sense punts entre les diferents lletres que les formen. Ara bé, algunes sigles s'han lexicalitzat $i$ han perdut les característiques que els són pròpies (les majúscules, per exemple) per incorporar-se al corpus lexicogràfic de la llengua (grapo, pimes, oenagé, Renfe, sida).

\subsubsection{El canvi semàntic}

El canvi semàntic és un procediment de creació neològica que permet obtenir un terme afegint un significat nou a una paraula ja documentada als repertoris lexicogràfics. Tot i que els neologismes semàntics són molt freqüents, sovint són difícils de detectar, perquè no presenten cap evidència formal del canvi de significat. Així, els mots cistella o ratolí, quan són utilitzats en el sentit que prenen en l'àmbit de l'esport o en el món de la informàtica, són neologismes semàntics. Aquests neologismes es poden agrupar en tres categories: neologismes semàntics pròpiament dits, neologismes pseudosemàntics i noms propis que es converteixen en noms comuns.

a) Els neologismes formats per l'adjunció d'un nou significat a una unitat lèxica ja documentada en els repertoris lexicogràfics es formen per homonímia o per polisèmia. L'homonímia provoca habitualment un canvi de significat (per exemple el mot carpa), mentre que la polisèmia pot provocar una restricció semàntica (tècnic, com a entrenador d'un equip; anímic, per referir-se a l'estat emocional d'un esportista), una ampliació del significat (personar-se o capital) o una extensió del significat (anell, pulmó, illa, lifting, vacunar-se, xip o visitar).

b) Els neologismes pseudosemàntics són unitats que presenten una certa ambigüitat a l'hora d'interpretar el procés de creació: poden explicar-se com a neologismes semàntics, però també com a unitats formades a partir d'altres processos: xoriço, quallar, mullar-se, subsistema, teledirigir, comunitari, aliats, popular (del PP) o convergent (de CIU).

c) La transformació de noms propis en noms comuns és un dels procediments de creació semàntica més utilitzats actualment. El fenomen afecta les marques comercials (fer un kit-kat, típex, wonderbra, mecano, danone, bollicao o viagra), els noms dels personatges de ficció (rambo, superman, barbie o pokémon), antropònims (verne, conde o jesulín) o topònims (un finisterre). 


\subsubsection{Préstecs}

El préstec lèxic o manlleu és un dels recursos de creació lèxica més productius. Es tracta d'un procediment que consisteix a incorporar a l'idioma unitats lingüístiques procedents d'una altra llengua. Els manlleus són termes generals que recobreixen els elements (no només lèxics) de procedència forana que han estat adaptats al sistema propi: debut, golf, míting, croissant, allegro, etc; els calcs són un tipus especial de manlleu que s'han produït a partir de la traducció literal d'un terme d'una altra llengua: per exemple, jardí d'infants, relacions públiques, any sabàtic o pedrera (a partir del castellà cantera, en un sentit esportiu).

\footnotetext{
Segons si la unitat manllevada conserva fidelment la grafia de la llengua d'origen o bé presenta alguna adaptació de la grafia a la llengua d'arribada, podem parlar, respectivament, de manlleus no adaptats (per exemple green, tour operator, quejio, cortijo, frottage, grappa, bewältigt, batzoki, canarinho, etc) o de manlleus adaptats (per exemple búmerang, xat, alimanya, triler, frapar, ga$z e t a$, etc.) El grau d'adaptació dels manlleus al sistema lingüístic del català, que pot dependre del grau d'especialització de la unitat, del sentiment d'estrangerisme que en té el parlant, etc., reflecteix aspectes com l'antiguitat de la introducció de cada unitat concreta en la llengua. A propòsit d'això, podem afirmar que una gran majoria de les unitats considerades en aquest capítol no estan adaptades a la grafia de la llengua catalana.
}

En la neologia per manlleu observem la presència d'unitats que ja apareixen repertoriades en els diccionaris de la llengua d'origen (com impeachment, paddock, cortijo, gafe, tablao, bambino o fauve) o que, fins i tot, trobem documentades en diccionaris catalans amb alguna marca (com western, folk, ikurriña, airbag, kibbutz, mozzarella o web). Aquests casos constitueixen el que podríem anomenar manlleus lexicogràfics. I dins d'aquests observem que hi ha unitats que coincideixen formalment amb l'entrada del diccionari de la llengua d'origen, però que el significat del seu context no coincideix (canvi de significat) o no coincideix exactament (ampliació o restricció del significat) amb la del diccionari. Són el que podem anomenar manlleus semàntics respecte a la llengua d'origen. Per exemple, cap de les accepcions de nutty que apareixen al diccionari anglès Collins Cobuild coincideixen amb el significat que podem documentar en usos actuals per al català i, per tant, podem afirmar que aquest manlleu que el català ha pres de l'anglès és un neologisme semàntic des del punt de vista de l'anglès, sempre que apliquem el criteri lexicogràfic. [...]

Al costat d'aquestes unitats també en trobem d'altres que ni tan sols apareixen en les principals obres de referència lexicogràfica de la llengua d'origen: beautiful people, data warehouse, key account manager, unit link, acoso y derribo, consociativismo, mediología, etc. Aquest altre tipus de manlleus conformen, al seu torn, neologismes en la llengua de partida, i des del nostre punt de vista podem considerar-los manlleus no lexicogràfics.

Freixa-Solé (coord.), 2004: 218-219

\subsubsection{Altres procediments de formació de mots}

A més dels mecanismes presentats en els apartats anteriors, la llengua disposa també d'una sèrie de recursos de caràcter sintàctic que permeten crear paraules noves a partir del canvi de categoria d'una unitat preexistent. En aquest apartat s'inclou l'anomenada conversió sintàctica, que consisteix a canviar de categoria una paraula amb tot el seu paradigma (per exemple, la creació del verb represaliar a partir del substantiu represàlia), i la lexicalització, que consisteix a transformar una forma flexiva en una categoria gramatical diferent (per exemple encertant, que passa de ser una forma flexiva del verb encertar a ser un substantiu). 
a) Els neologismes formats per conversió sintàctica es poden classificar en sis grups diferents:

- Verbs creats a partir de noms: opositar, clicar, represaliar, serigrafiar, pausar, voleiar, publicitar, niuar, mediar o diplomar-se.

- Noms creats a partir de verbs: sil·labeig, taloneig, fastigueig, remescla o vagabundeig.

- Adjectius que funcionen també com a noms: adjudicatària, clàssica, divisòria (per línia divisòria), elèctrica (per companyia elèctrica), municipals (per eleccions municipals) o indocumentats (per immigrants indocumentats).

- Noms que funcionen també com a adjectius: fantasmes (militants fantasmes), desmaquilladores (tovalloletes desmaquilladores), baixista (tendència baixista) o reina (jornada reina).

- Paraules de categories lèxiques menors que funcionen com a mots de categories majors: malgrat (malgrat tots els malgrats), però (tot eren peròs) o perquè (el perquè de les coses).

- Unitats morfològiques (formants cultes i afixos) que esdevenen adjectius i substantius: afro, crono, anti o isme.

b) La lexicalització permet obtenir substantius (i en alguns casos adjectius) a partir d'infinitius, gerundis i participis. La tendència dominant actualment és la lexicalització de participis de passat com a substantius (afectat, imputat, internada o processat) i de gerundis com a substantius o adjectius (firmant, recorrent, convocants, dopants, obstaculitzant o desafiant). Tot i això, cal recordar que es tracta d'un procediment poc productiu.

\subsection{El lèxic especialitzat: terminologia i estrangerismes}

Un dels trets més característics de la societat actual és la rapidesa amb què s'incorporen a l'activitat professional i a la vida quotidiana tota classe d'innovacions científiques, tècniques $i$, en un sentit general, culturals, que inevitablement, provoquen la introducció de termes nous per designar-los. En el cas del català, la procedència forana de bona part d'aquests innovacions tècniques provoca la incorporació d'una allau de terminologia estrangera, sovint sense una necessitat objectiva, atès que el sistema lingüístic disposa de recursos propis per a la creació de termes nous. És evident, per tant, la importància que té per a una llengua minoritzada com el català l'existència d'organismes encarregats d'analitzar els processos d'introducció de neologismes i de fixar els criteris per a la creació lèxica i per a l'adaptació terminològica. La incorporació del català als mitjans de comunicació i als altres àmbits comunicatius vinculats als registres formals -la ciència i la tècnica, l'ensenyament, la justícia o l'administració, per exemple- ha fet més evident que mai la importància del treball terminològic. 


\subsubsection{El TERMCAT}

El Centre de Terminologia TERMCAT és un organisme autònom creat el 1985, gràcies a un acord entre el Departament de Cultura de la Generalitat de Catalunya i l'Institut d'Estudis Catalans, amb la finalitat de promoure, coordinar i desenvolupar les activitats terminològiques en llengua catalana. La pàgina web del TERMCAT manifesta ben explícitament aquestes funcions:

El TERMCAT, com a centre de referència en el treball terminològic, es proposa garantir la qualitat i la disponibilitat de recursos i mètodes de treball als sectors públics i privats i impulsar la participació i la implicació de la societat en totes les seves activitats per a promoure, en un escenari multilingüe, el desenvolupament de la terminologia en llengua catalana i contribuir al progrés general d'aquesta llengua en tots els àmbits socials.

http://www.termcat.cat/centre/

El Centre de Terminologia ha publicat diversos dossiers de criteris terminològics i un ample ventall de diccionaris especialitzats, manté una relació actualitzada de bibliografia específica sobre terminologia per matèries i disposa d'una pàgina web molt interessant que ofereix, entre altres recursos, un servei de Neoloteca, amb una base de dades terminològica que inclou els termes normalitzats, i un servei anomenat Cercaterm, que permet fer consultes terminològiques en línia.

\section{wwW}

Des de les adreces següents es pot accedir als serveis Cercaterm, Neoloteca i Biblioteca del TerMCAT:

http://www.termcat.cat/ http://www.termcat.cat/ca/Neoloteca/ http://www.termcat.cat/ca/Biblioteca/

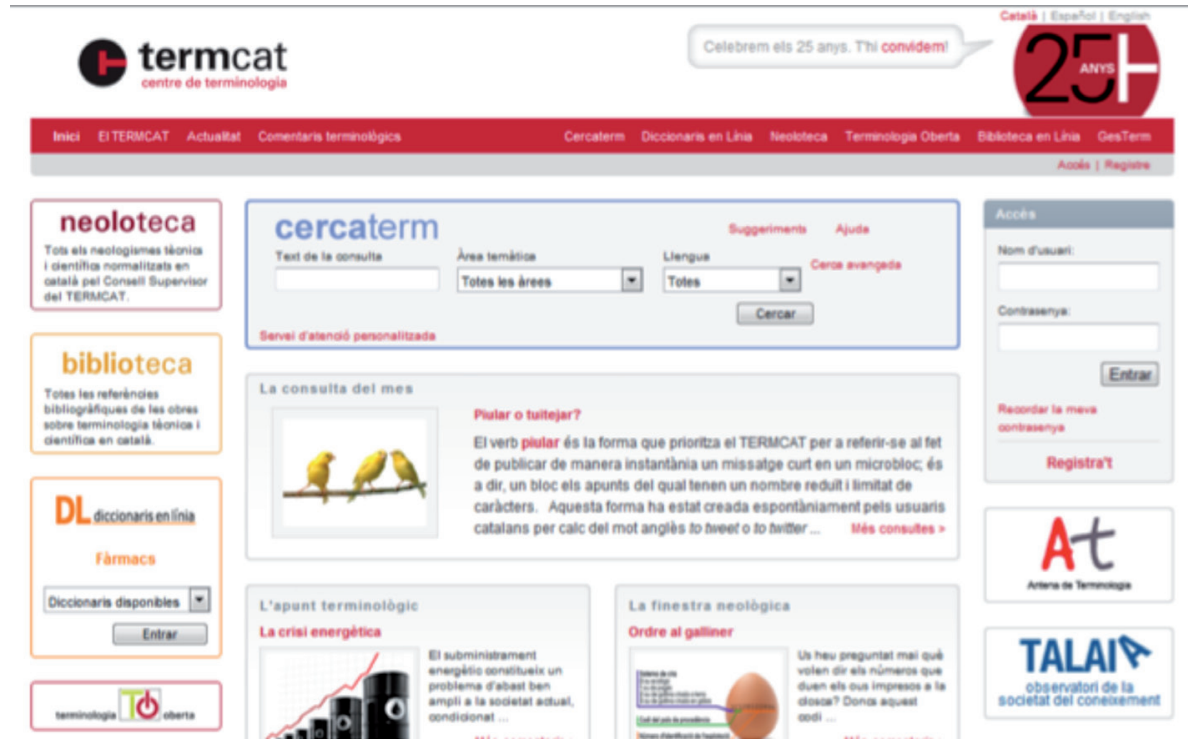

Fig. 44. Pàgina principal del TERMCAT (font: http://www.termcat.cat/) 


\subsubsection{L'Observatori de Neologia de la UPF}

L'Observatori de Neologia (OBNEO) és un grup de recerca de l'Institut Universitari de Lingüística Aplicada (IULA) de la Universitat Pompeu Fabra. Dirigit per la Dra. Teresa Cabré, neix com a grup de recerca el 1988 a la Universitat de Barcelona i, des del 1994, s'incorpora com a projecte de l'IULA de la Universitat Pompeu Fabra. L'Observatori de Neologia analitza el fenomen de l'aparició de paraules noves o neologismes en l'ús, tant pel que fa al català com al castellà.

Les activitats principals del grup estan relacionades amb els objectius següents:

a) Crear i mantenir un corpus de neologia de gran difusió en català i en castellà, corresponent al buidatge de textos escrits i textos orals.

b) Descriure i analitzar els recursos que fan servir el català i el castellà per actualitzar el seu lèxic, amb treballs que realitza el grup i que es donen a conèixer amb diverses publicacions i amb la participació en conferències, ponències i comunicacions.

c) Difondre periòdicament les noves creacions lèxiques, d'una banda, en forma de papers amb els neologismes documentats cada any en català i en castellà i, d'altra banda, en forma de diccionaris de neologismes.

d) Contribuir a l'actualització del lèxic contingut en diccionaris de llengua general.

e) Establir una plataforma que permeta l'intercanvi amb altres grups de neologia: amb observatoris de les diferents varietats geogràfiques del castellà a l'Amèrica Llatina, amb observatoris de les diferents llengües de l'Estat espanyol i amb observatoris d'altres llengües romàniques (italià, castellà i francès).

f) Promoure i organitzar activitats, reunions científiques i fòrums de reflexió a l'entorn de la neologia teòrica i descriptiva.

El grup ha organitzat diversos seminaris per divulgar la tasca que realitza, publica periòdicament llibres i articles d'investigació, realitza activitats de formació d'investigadors en recerca terminològica i manté una pàgina web (http://obneo.iula. upf.edu/) des de la qual es pot accedir a una sèrie de recursos vinculats al treball de recollida neològica que han dut a terme diversos organismes associats, entre els quals cal destacar un parell de cercadors molt pràctics (Obneo i Neorom), una Bústia Neològica, un diccionari de neologismes (en castellà) i un banc de neologismes, que conté termes en català i en espanyol. 


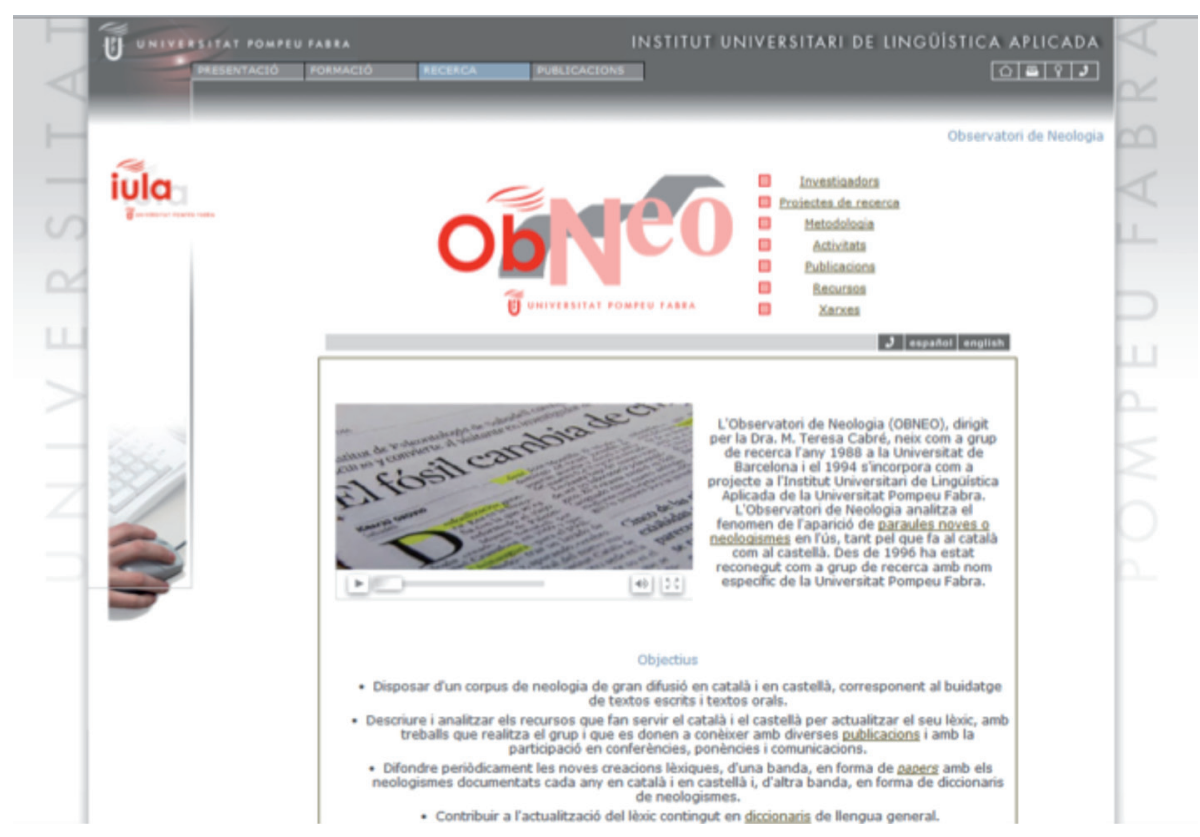

Fig. 45. L'Observatori de Neologia (oBneo) de la Universitat Pompeu Fabra (font: http://www.iula.upf.edu/obneo)

\subsection{3. Ús d'estrangerismes}

Hi ha una tendència generalitzada en els llibres d'estil consultats a considerar la introducció d'estrangerismes o manlleus com una riquesa que aporta la denominació de noves realitats a totes les llengües que els reben. Tanmateix, en una situació de minorització lingüística com la que pateix el català, s'ha de tenir molta cura amb la necessitat d'introduir aquests manlleus. En general, hom considera que no cal introduir noms estrangers per definir realitats que ja eren denominades en la llengua pròpia o que siguen fàcilment traduïbles. La tendència a incloure mots estrangers -que és molt habitual en els mitjans de comunicació i que és provocada per l'afany de modernització- $\mathrm{i}$ a adoptar ràpidament termes procedents de les llengües d'abast més general, com l'anglès o el castellà, ha d'estar limitada per la necessitat. En general, es tendirà a adaptar-los a l'ortografia i a la fonètica del català i, si això no és possible, s'hauran d'escriure en cursiva.

\subsubsection{Castellanismes}

En el cas dels castellanismes, cal distingir entre els termes que han adquirit caràcter normatiu i els no normatius que ja han estat objecte de definició en l'apartat dels barbarismes i que són totalment rebutjables.

Entre els castellanismes que han adquirit caràcter normatiu, és a dir, aquells que figuren en el Diccionari de la llengua catalana de l'Institut d'Estudis Catalans, cal distingir entre els que han substituït en un alt grau les paraules catalanes corresponents o que són de difícil substitució -com ara, per exemple, afició (afecció), clero 
(clergat, clerecia), convalidació (validació, homologació), curandero (remeier), monyo (trossa) o tensar (tesar) - i aquells altres que, tot $\mathrm{i}$ haver passat a formar part del corpus de la llengua i ser normatius a tots els efectes, coexisteixen amb els seus equivalents genuïns, que no solament no s'han de bandejar sinó que en molts casos fins i tot s'han de preferir en registres formals -com bell, bonic (guapo); natura morta (bodegó); brou (caldo); continuar (seguir); tenir cura (cuidar); destinació (desti); impedir, torbar (entorpir); lliurar, lliurament (entregar, entrega); quadre (quadro); rodet (carret fotogràfic) i vidu, vídua (viudo, viuda), entre d'altres.

\subsubsection{Anglicismes}

Dels nombrosos mots manllevats a l'anglès (anglicismes), cal distingir entre: $(a)$ els mots que tenen caràcter normatiu i que han substituït en un alt grau les paraules catalanes corresponents o que són de difícil substitució, $(b)$ els que, sense ser normatius ni haver estat adaptats, són de difícil substitució, i (c) els que tenen un equivalent viu en català o que són de fàcil substitució. En la taula següent es presenten alguns exemples de cada tipus:

\begin{tabular}{|c|c|c|}
\hline a) Mots normatius & b) Termes de subst... & c) Mots amb equivalent català \\
\hline $\begin{array}{l}\text { bar, bàsquet, beisbol, blues, bodi, } \\
\text { boicot, boom, bungalou, càme- } \\
\text { ra, càmping, campus, còctel, } \\
\text { copyright, disquet, escàner, } \\
\text { escúter, eslògan, esmòquing, } \\
\text { esport, espot, esprai, esprint, } \\
\text { esquaix, estand, estàndard, estoc, } \\
\text { estrès, ferri, futbol, gag, gàngster, } \\
\text { golf, iceberg, iot, jazz, làser, líder, } \\
\text { lísing, locaut, magazín, màna- } \\
\text { ger, màrqueting, màster, míting, } \\
\text { mòdem, òfset, pantis, pàrquing, } \\
\text { pedigrí, playback, playboy, plòter, } \\
\text { plum-cake, pòster, pub, puzle, } \\
\text { ràfting, ral·li, rànquing, rock, } \\
\text { sandvitx, surf, tàndem, tennis, } \\
\text { test, tiquet, tràiler, tramvia, tràve- } \\
\text { ling, vagó, videoclip, videoclub, } \\
\text { voleibol, waterpolo, whisky, } \\
\text { xarleston, xàrter, xip, xoc, zoom }\end{array}$ & $\begin{array}{l}\text { best-seller, establishment, } \\
\text { holding, music-hall, } \\
\text { remake, revival, royalty, } \\
\text { thriller, western }\end{array}$ & $\begin{array}{l}\text { abstract (resum), airbag (coixí } \\
\text { de seguretat), briefing (notes, } \\
\text { informe), background (historial, } \\
\text { antecedents, formació), compact } \\
\text { disc (disc compacte), container } \\
\text { (contenidor), fast food (restauració } \\
\text { ràpida, menjar ràpid), freelance } \\
\text { (independent), full-time (a jor- } \\
\text { nada completa), indoor (en pista } \\
\text { coberta), look (imatge), mailing } \\
\text { (tramesa, publitramesa), mass } \\
\text { media (mitjans de comunicació de } \\
\text { massa), mountain bike (bicicleta } \\
\text { tot terreny, bicicleta de muntanya), } \\
\text { night-club (sala de festes, discoteca), } \\
\text { overbooking (sobreocupació), } \\
\text { snowboard (surf de neu), workshop } \\
\text { (taller, sessió de treball) }\end{array}$ \\
\hline
\end{tabular}

Fig. 46. Anglicismes d'ús habitual

\subsubsection{Llatinismes}

Entre els mots o expressions manllevats al llatí, o llatinismes, n'hi ha de dos tipus: aquells que han esdevingut d'ús més o menys general i que han estat adaptats al català -i que per aquest motiu s'escriuen generalment en rodona-, i aquells altres que, pel fet de ser d'ús més restringit o especialitzat, conserven la grafia llatina 
-per la qual cosa s'escriuen, com a norma general, en cursiva.

Si bé la frontera entre tots dos supòsits no sempre és fàcil de traçar, tot seguit presentem, a tall d'exemple, alguns casos il-lustratius de llatinismes adaptats al català -que podríem considerar d'ús general i que, per tant, escriurem en rodona-i de llatinismes d'àmbit més restringit -propis dels llenguatges d'especialitat, que s'han d'escriure en cursiva:

\begin{tabular}{|c|c|}
\hline Llatinismes d'ús general & Llatinismes dels llenguatges d'especialitat \\
\hline $\begin{array}{l}\text { a posteriori, a priori, critèrium, currículum, } \\
\text { delírium trèmens, desideràtum, ego, estatus, } \\
\text { exequàtur, ex-libris, factòtum, fòrum, honoris } \\
\text { causa, ídem, in extremis, in fraganti, in vitro, } \\
\text { júnior, lapsus, oremus, pàssim, per càpita, } \\
\text { proforma, quòrum, sènior, ultimàtum, vade- } \\
\text { mècum, viacrucis }\end{array}$ & $\begin{array}{l}\text { ab absurdo, ab initio, ad hoc, ad hominem, } \\
\text { ad infinitum, a divinis, ad libitum, a fortiori, } \\
\text { bona fide, circa, cum laude, curriculum } \\
\text { vitae, de facto, de iure, de visu, ex aequo, } \\
\text { ex cathedra, in promptu, in situ, modus } \\
\text { operandi, modus vivendi, motu proprio, mu- } \\
\text { tatis mutandis, peccata minuta, per saecula } \\
\text { saeculorum, per se, quid pro quo, sine die, } \\
\text { sine qua non, statu quo, stricto sensu, sub } \\
\text { iudice, sui generis, urbi et orbi, versus, vox } \\
\text { populi }\end{array}$ \\
\hline
\end{tabular}

Fig. 47. Paraules i expressions d'origen llatí

\subsection{Introducció a la fraseologia}

\subsubsection{Les unitats fraseològiques}

Les unitats fraseològiques -anomenades també modismes i expressions idiomàtiques- són expressions lingüístiques formades sovint per dues o més paraules que funcionen unitàriament, amb un significat no predictible des del coneixement de les regles gramaticals convencionals. Així, l'expressió anar amb peus de plom s'utilitza per expressar la conveniència d'actuar amb delicadesa, de comportar-se amb cura, i no té res a veure amb la suma dels significats del verb anar i de l'expressió peus de plom. Normalment, el significat dels fraseologismes -que són peces fòssils o unitats gramaticalitzades- no és pot reconstruir des de la suma dels significats literals dels elements constituents. Aquestes unitats, que posseeixen una extraordinària capacitat expressiva, tenen sovint un origen metafòric i s'utilitzen també metafòricament en la interacció comunicativa.

Les unitats fraseològiques constitueixen un dels àmbits més específics, més peculiars, d'una llengua. Molt diferents d'unes llengües a les altres, són un dels reductes més resistents a la traducció i a l'aprenentatge i també, per això mateix, un camp especialment propici per a la interferència lingüística. La preservació de l'arxiu d'unitats fraseològiques pròpies és, per tant, una necessitat prioritària per a les llengües i les cultures minoritzades, com ara el català. 
[La fraseologia] precisament en la mesura en què és més baix el seu grau d'incardinació en les pautes regulars del sistema, constitueix un flanc vulnerable de la llengua, una porta oberta a la interferència lingüística.

Salvador, 1995: 14

Els trets característics d'aquest tipus d'unitats lingüístiques són els següents:

a) Són segments repetits, elements lingüístics prefabricats, que no obeeixen a un acte creatiu del llenguatge.

b) Són el resultat de processos de gramaticalització.

c) Poden presentar diverses alteracions del cos fònic.

d) Es tracta d'unitats fixades, de caràcter convencional, convertides en expressions rutinàries.

e) Tenen un caràcter idiomàtic: el significat global de la unitat no es pot deduir a partir de la suma dels significats dels diversos elements constituents.

f) Posseeixen un significat pragmàtic, molt lligat al context.

g) Solen presentar anomalies i poden incloure mots isolats que no s'utilitzen en el llenguatge general: a la babalà, acciamo, etc.

\subsubsection{Propietats de les unitats fraseològiques}

A més de les característiques esmentades en l'apartat anterior, les unitats fraseològiques presenten les propietats següents:

1. La fraseologia és un magatzem enciclopèdic de la cultura i la història del poble. Sovint hi ha referències a fets històrics i culturals passats que ja no s'entenen en la societat actual: Estic més fart que Mahoma de la cansala(d)a; Sempre va fet un «acciamo»; Quan el mal ve d'Almansa, a tots alcança, etc.

2. De vegades, no cal enunciar una unitat fraseològica completa, ja que només amb una part acompleix la funció comunicativa associada: Qui va amb un coix...; Qui amb xiquet es gita...; Qui no vullga pols..., etc.

3. Altres vegades, però, algunes unitats fraseològiques, i fins i tot altres expressions del llenguatge quotidià, són allargades amb apèndixs, normalment rimats o que guarden una relació amb la primera part, que, tot i que afegeixen un valor expressiu als segments originals, no hi aporten cap significat referencial: Està enamorat (i no troba casa); Açò és massa (p(er) a la carabassa), etc.

4. Alguns esquemes fraseològics permeten una certa variació i admeten, per tant, una certa creativitat i variabilitat: $d e$... a; de ... en; subjuntiu $+q u e / q u i$ + subjuntiu; més ... que; adjectiu + com + sN, etc.

5. Les unitats fraseològiques es caracteritzen per l'ús d'una sèrie de recursos retòrics de caràcter fònic -com ara l'al·literació, la rima o la paronomàsia-, que contribueixen a la cohesió, afavoreixen la difusió i, sobretot, en faciliten 
la memorització i transmeten un efecte lúdic i humorístic a la fraseologia: sense ric ni roc, sense trellat ni forrellat, sense solta ni volta, etc.

6. L'afebliment de l'ús de les expressions fraseològiques, especialment en les llengües $i$ en les cultures minoritzades, comporta una minva en l'autoimatge dels parlants com a comunitat i en la seua cohesió sociolingüística. En el cas valencià, els fenòmens d'interferència provocats per la fraseologia castellana (De tal palo tal astilla; A quien madruga, Dios le ayuda; Mala hierba nunca muere; menos mal; de repent), la baixa densitat de fraseologismes en el llenguatge dels mitjans de comunicació de massa i el desconeixement dels valors pragmàtics i discursius de les unitats fraseològiques per part de les generacions més joves han provocat que aquests sectors deixen d'emprar activament expressions que només coneixen d'una forma passiva. El domini de la fraseologia d'una segona llengua és, a més, un bon indicador del grau de domini pràctic d'aquest idioma.

\subsubsection{Classificació}

Tot i que aquesta categoria inclou unitats lingüístiques molt heterogènies, actualment sembla bastant acceptada pels estudiosos la distinció entre tres tipus d'unitats fraseològiques diferents: col-locacions o concurrències, locucions i enunciats. La fig. 48 desenvolupa aquesta classificació i presenta alguns exemples de cada tipus d'expressions.

Les concurrències i les locucions no són enunciats i no constitueixen, per tant, actes de parla complets, mentre que els enunciats fraseològics són actes de parla $\mathrm{i}$ tenen una major autonomia semàntica i pragmàtica.

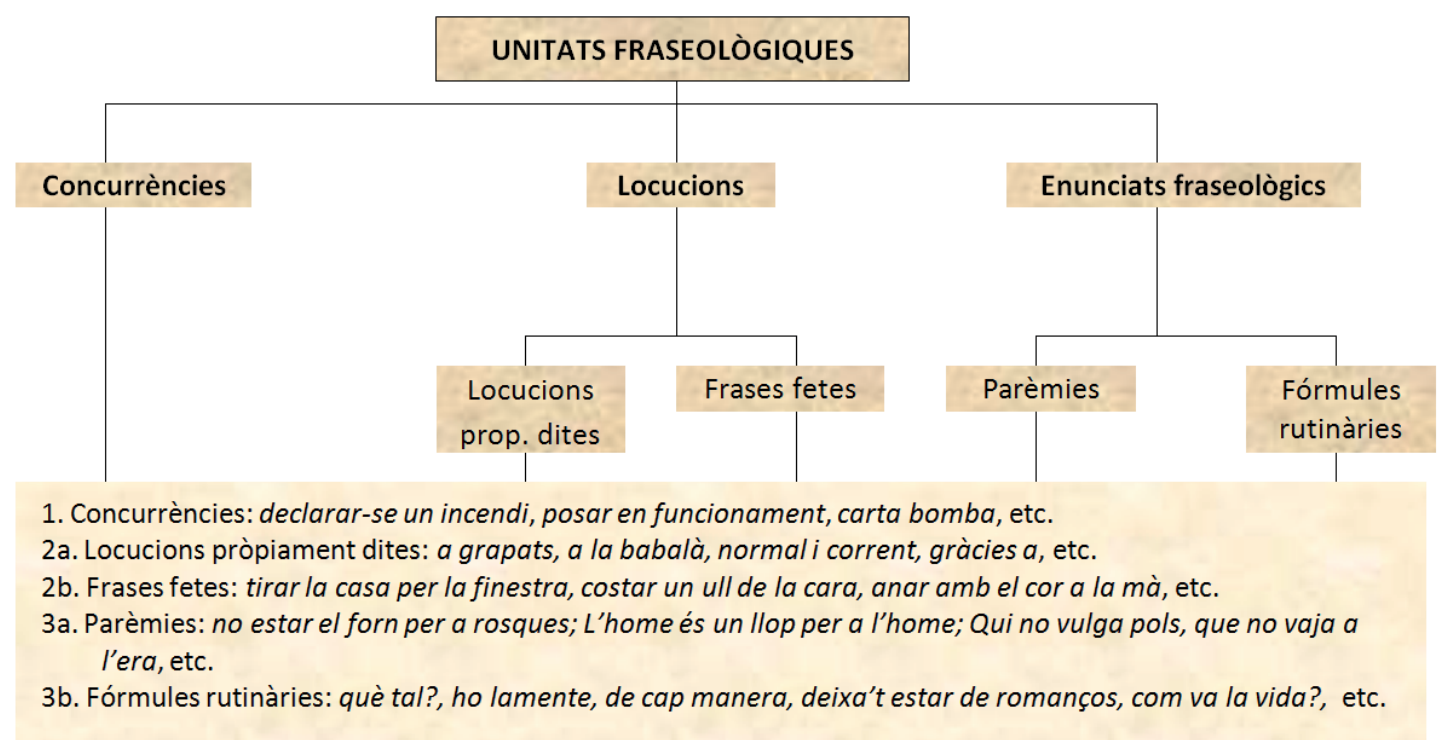

Fig. 48. Classificació de les unitats fraseològiques 
a) Les col-locacions o concurrències són unitats de naturalesa mixta, que no pertanyen al que s'anomena sintaxi lliure, però tampoc no poden equiparar-se a les expressions típicament lexicalitzades. En realitat, són compostos sintagmàtics, és a dir, expressions formades per dues paraules simples que designen una realitat que encara té alguna cosa a veure amb el significat de l'expressió. Així, una carta bomba és un tipus especial de bomba i, per tant, encara conserva el significat dels termes originals; també una eixida d'emergència és un tipus particular d'eixida d'un edifici.

b) Les locucions són unitats equivalents a un substantiu, un adjectiu o un adverbi: a la babalà, amb el cor a la mà, com un dimoni, la mar de, ni de bon tros, etc. Si el significat de les locucions és equivalent a un verb o a un sintagma verbal, s'anomenen frases fetes: posar pals a les rodes, estirar més el braç que la màniga, socarrar-se l'arròs, donar ales, etc.

c) Finalment, els enunciats fraseològics són expressions que equivalen a actes de parla complets i es poden classificar en parèmies i fórmules rutinàries. En la categoria de parèmies s'inclouen enunciats amb valors específics (com ara No estar el forn per a rosques, Haver-hi gat en sac o Els testos s'assemblen a les olles), citacions (L'home és un llop per a l'home o Pense, per tant sóc) i refranys o proverbis (Home roig i gos pelut, primer mort que conegut; Qui no vulga pols, que no vaja a l'era). Les fórmules rutinàries són expressions discursives que s'utilitzen per obrir o tancar el discurs (Què tal?, Fins després) o per marcar continuïtat (Què anava a dir-te), o bé fórmules rutinàries psicosocials que serveixen per establir i mantenir relacions i per expressar emocions, ordres o compromisos (per exemple, Deu n'hi do!).

\subsubsection{Pragmàtica de les expressions fraseològiques}

Els processos de gramaticalització tenen una gran importància a l'hora d'explicar la formació de les unitats fraseològiques. La gramaticalització és un procés complex que implica diverses transformacions en les unitats que l'experimenten: abstracció semàntica, increment del valor pragmàtic i informatiu i augment de la subjectivitat, alteració del cos fònic, etc. En aquest procés té sovint un paper determinant la metaforització i l'ús de procediments com la metonímia o la hipèrbole (Sancho, 1999: 57-79).

Un aspecte importantíssim de la fraseologia, tot i que ha rebut molt poca atenció, és el coneixement i l'estudi de les condicions pragmàtiques i socials en què s'han d'emprar les diverses unitats fraseològiques. Aquest fet és normal en una llengua que durant segles ha estat relegada al registre col-loquial i que, per tant, només coneixia l'ús de la fraseologia en aquest registre.

Com ha assenyalat Vicent Salvador, les unitats fraseològiques -que sovint no s'ajusten a les regles d'estructura sintagmàtica i incorporen informació pragmàtica- constitueixen un estadi intermedi dels processos de gramaticalització 
«que tendeixen a convencionalitzar i a fer emergir com a estructures en el nivell gramatical les estratègies discursives més reeixides en la praxi comunicativa» (2000: 21).

Aquesta és la segona direcció de què parlàvem suara: la indagació de la frontera entre fraseologia i discurs, mentre que la indagació del límit entre lèxic i gramàtica correspondria a la primera direcció. En aquest sentit, és útil la concepció de les unitats fraseològiques com a mostra d'estadis de transició entre el pla del discurs i el de la gramàtica, posició que permet copsar l'alt grau de gramaticalització de moltes unitats i, paral·lelament, les funcions de marcació i organització discursiva que tenen sovint tant les unitats més gramaticalitzades com les que mostren una simple recurrència més o menys generalitzada a partir d'estratègies de gestió del discurs.

Salvador, 2000: 22

Aquest procés de gramaticalització es pot observar en unitats com ara el connector concessiu encara que, que és la culminació d'un llarg procés en el qual «els usos lingüístics del català han anat especialitzant i convencionalitzant una rutina fraseològica» (Salvador, 2000: 22), i en els usos discursius actuals d'expressions com ara Déu n'hi do, si us plau, és clar, a veure o mira tu, que en el llenguatge colloquial ja han esdevingut, respectivament, deunidó, sisplau, esclar, aviam o ma tu i que, possiblement, s'aniran lexicalitzant fins a convertir-se en unitats gramaticals de ple dret.

\subsubsection{La fraseologia en el discurs publicitari}

El punt d'intersecció més evident entre la fraseologia i el discurs publicitari és, sens dubte, l'eslògan, un constituent clau de gairebé tots els anuncis. De fet, els eslògans, tot $\mathrm{i}$ que poden presentar una gamma molt diversa de possibilitats formals, sempre tenen una funció pragmàtica evident: ancorar l'anunci en la ment dels destinataris i crear les condicions que propicien l'adquisició del producte anunciat. Els eslògans publicitaris són unitats lèxiques dissenyades per transmetre, d'una forma sintètica, el missatge de l'empresa anunciant (Peraire, 2005). Es tracta d'enunciats que sovint presenten un caràcter sentenciós i un aspecte formal molt similar als proverbis o refranys: són productes verbals que es caracteritzen per la brevetat, el caràcter apodíctic i cadenciós i la voluntat de condensar, amb un estil concís i un aire rítmic, la visió de l'anunciant sobre el producte publicitat o sobre la mateixa empresa a través de la formulació d'una visió del món concreta que comporta sovint un determinat estil de vida. Constitueixen, en definitiva, una poderosa estratègia discursiva que facilita la difusió social de prejudicis, actituds i valors i, per tant, la divulgació de formes específiques de coneixement del món i de determinades orientacions ideològiques.

Tot i les coincidències de caràcter pragmàtic entre eslògans i refranys, és evident que els dos tipus d'unitats tenen un estatus molt diferent $i$ que existeixen diferències remarcables entre ambdues (Peraire, 2005), entre les quals cal destacar que «la unitat fraseològica té una marca de perennitat, de monument cultural, mentre que l'eslògan publicitari és essencialment efímer» (Sancho, 2005). 
L'eslògan és, en paraules de Grunig, «un encadenament verbal, sovint d'una extensió molt breu que es redueix a una o dues frases o intervencions, que ocupa una posició perceptivament remarcable en l'anunci» (2000: 75), i es caracteritza per l'ús d'una sèrie de mecanismes formals que en faciliten la circulació i la memorització, particularment la brevetat, el caràcter fragmentari, la repetició, la presència d'elements prefabricats i l'ús de procediments figuratius que remeten a imatges i models mentals predefinits.

Els eslògans, com els proverbis, constitueixen un poderós mecanisme de gestió de l'activitat mental humana, són reguladors del raonament i transmeten formes de pensament estereotipades. Es tracta d'enunciats prefabricats, llocs discursius on conflueixen una sèrie de mecanismes de caràcter sintàctic i pragmàtic, que propicien l'orientació argumentativa de l'anunci. Els eslògans, com els proverbis, són principis generals, frases genèriques, que tenen sovint un origen $\mathrm{i}$ un funcionament metafòric.

El discurs publicitari utilitza diferents tipus d'unitats lingüístiques prefabricades, concentrades habitualment en l'eslògan o en els titulars, amb una funció discursiva ritual o argumentativa, per tal de transmetre un cert aire dialògic i conversacional al text publicitari i, alhora, provocar un efecte d'ancoratge cognitiu de la marca i del producte anunciat en el destinatari.

Aquest efecte s'aconsegueix amb diferents possibilitats estratègiques:

a) l'ús d'expressions prefabricades que formen part de la memòria col·lectiva del poble (Que no et donen gat per llebre, Más buenos que el pan, Com una roca, Som en una altra ona...);

b) la introducció de modificacions que permeten cridar l'atenció sobre la unitat que trenca les expectatives creades (Menja i deixa menjar);

c) la introducció d'unitats de nova creació o la recontextualització d'unitats preexistents (Amb tarifa plana, Un sabor de cinc estrelles...), i

d) la proposta d'interpretació literal d'una frase feta o una locució preexistent (Deixa't portar).

La investigació sobre l'ús de les expressions fraseològiques en el discurs publicitari ens permet de conèixer millor el funcionament dels eslògans, tant des del punt de vista semàntic com des de la perspectiva sintàctica o pragmàtica. Les informacions que es vehiculen a través dels eslògans, les estructures sintàctiques preferides, l'ús de paral·lelismes, locucions i frases fetes i una sèrie de recursos de caràcter pragmàtic - entre els quals cal destacar la qüestió clàssica de la polifonia, la dixi, la modalitat oracional, les informacions implícites i les figures retòriquesfan evident la importància de la fraseologia en l'articulació discursiva d'aquestes petites i poderoses peces lingüístiques i en la construcció social de les ideologies. 
Llocs web sobre fraseologia:

http://proverbia.cat/default.asp

http://vpamies.blogspot.com/

http://refranys.wordpress.com/

http://vpamies.blogspot.com/p/top-ten-dels-refranys-catalans.html

http://refranyer.blogspot.com/2007/05/ndex-alfabtic-de-les-entrades-en-catal.html

http://www.polseguera.com/cgi-bin/phrases/catala/frasesca.cgi

\section{Lectures recomanades}

CABré, Maria Teresa (2004): «Introducció: la importància de la neologia per al desenvolupament sostenible de la llengua catalana», en Freixa-Solé (ed.) (2004: 17-45).

— i altres (2001): «Anàlisi contrastiva de la innovació lèxica en català i en castellà», Caplletra, 30, p. 192-212.

GinEBRA, Jordi (2003): «Fraseologia, concurrències lèxiques i llengua estàndard», en Pradilla, Miquel Àngel (ed.) (2003): Identitat lingüística i estandardització, Valls, Cossetània-URV.

Peraire, Joan (2005): «Unitats fraseològiques i ideologia en el discurs publicitari», en Articles de didàctica de la llengua i la literatura, 36, p. 43-55.

— (2006): «Sintaxi i pragmàtica de l'eslògan», en SALVAdoR-Climent (ed.) (2006: 109-138).

Salvador, Vicent i Adolf Piquer (ed.) (2006): El discurs prefabricat, 1. Estudis de fraseologia teòrica i aplicada, Castelló de la Plana, Universitat Jaume I.

SALVAdor, Vicent (1995): «De la fraseologia a la lingüística aplicada», Caplletra, 18, 11-30.

- (2000): «Idiomaticitat i discurs prefabricat», en SALVADOR-Piquer (ed.) (2000: 19-31).

Salvador, Vicent i Laia Climent (ed.) (2006): El discurs prefabricat, 2. Fraseologia i comunicació social, Castelló de la Plana, Universitat Jaume I.

SANCho, Pelegrí (1999): Introducció a la fraseologia. Aplicació al valencià colloquial, Paiporta, Denes. 


\section{PROCEDIMENTS DE COHESIÓ TEXTUAL}




\section{TEMA 7}

\section{Mecanismes de referència}

Introducció

1. Coherència discursiva i cohesió textual

2. Estil cohesionat i estil segmentat

3. La referència discursiva

4. L'anàfora gramatical

5. La referència lèxica

Lectures recomanades 


\section{Introducció}

La referència és un mecanisme discursiu essencial a l'hora de garantir la cohesió textual. Es tracta d'un procediment que permet la represa de tòpics o elements que ja han aparegut en el discurs per tal d'evitar la repetició constant de les mateixes formes. La referència endofòrica, diferent de la dixi o referència exofòrica, converteix el discurs en un complex entramat de relacions entre les diferents unitats textuals que garanteix, en definitiva, la coherència profunda dels textos.

La primera part del tema es dedica a presentar el concepte de coherència en relació a la cohesió textual i a analitzar les diferències entre l'estil cohesionat i l'estil segmentat, dos estils comunicatius que conviuen en el discurs dels media, de vegades amb alguna polèmica perquè la confrontació representa una certa oposició entre els gèneres periodístics, que mostren sovint una preferència per un estil cohesionat, i la comunicació publicitària, que habitualment tendeix a utilitzar un estil més segmentat. Tot i això, la vacil·lació entre un estil i l'altre també s'estén a l'àmbit del periodisme audiovisual i, en general, a tots els discursos multimodals, que, per definició, tendeixen a subordinar el codi lingüístic als altres codis expressius i, per tant, potencien un estil discursiu extremadament concís i contundent. Aquesta primera part es tanca amb una reflexió sobre els mecanismes d'integració sintàctica, que permeten el pas de la redacció segmentada a l'estil cohesionat. ${ }^{1}$

Tot seguit, es presenta una visió de conjunt del mecanisme de la referència i s'analitzen els dos grans procediments: l'anàfora gramatical i la referència lèxica. En primer lloc, després d'introduir el concepte i de presentar els diferents tipus de referència, es presenten els procediments de referència gramatical i s'estudia atentament la normativa que regula l'ús dels pronoms febles en català. De fet, la pronominalització és un dels mecanismes anafòrics per excel·lència i, en el cas català, una de les característiques identitàries de l'idioma és l'extraordinària riquesa pronominal i la varietat i complexitat de les combinacions de pronoms. La part final del tema es dedica a revisar, encara que d'una forma superficial, la problemàtica de la referència lèxica, tot incidint especialment en les diferències entre repetició, reiteració $i$ associació. Finalment, s'introdueix la noció de marc o frame, un concepte directament relacionat amb l'associació lèxica que és molt útil per explicar com es generen $i$ es transmeten determinats punts de vista mitjançant estructures cognitives que constitueixen una mena de rutines de programació dissenyades per orientar el pensament i la gestió de les idees.

Es tracta, en definitiva, d'oferir una visió de conjunt del fenomen de la referència, tot presentant-ne les idees fonamentals i proposant, de manera complementària, un conjunt variat d'activitats d'aplicació que han de permetre als estudiants ser capaços de valorar la importància dels elements lingüístics de referència en la construcció i en la interpretació textual.

1. El domini dels estils de redacció té una incidència fonamental sobre la capacitat per produir textos coherents, ben cohesionats i adequats a la situació comunicativa. Els exemples i les reflexions que es presenten en aquesta primera part del tema 7 tenen el complement lògic en l'última part del tema 8 , on s'ofereixen una sèrie de recomanacions, acompanyades també de nombrosos exemples, per millorar l'escriptura des de la cohesió textual. 


\subsection{Coherència discursiva i cohesió textual}

La coherència discursiva, un concepte semàntic que apareix als inicis de la gramàtica del discurs, fa referència a la percepció del significat d'un discurs a partir de la suma dels enunciats. Tal vegada resulte senzilla aquesta explicació, però hem de tenir en compte que la gramàtica anterior considerava el sostre significatiu en l'oració i no en el text. Així doncs, aquest significat complet que percebem com una unitat es conjuga de manera eficaç amb la correcta utilització dels mecanismes de cohesió textual. És per això que els errors de connexió esdevenen errors de coherència, ja que dificulten la comprensió de qualsevol text.

La cohesió relaciona i fa evidents els fenòmens d'adequació i coherència. D’una banda, els elements de connexió distribueixen i ordenen les idees del text, establint-hi concessions, negacions, explicacions...; de l'altra, permeten identificar els parlants, el lloc i el temps en què es produeix la comunicació mitjançant els procediments díctics, que remeten directament a l'adequació.

No ens podem referir a la cohesió textual des d'una perspectiva limitada que només tinga en compte els procediments típics de la connexió o la referència, ja que, en realitat, la cohesió inclou tots i cadascun dels elements lingüístics que apareixen en el text, des de la cohesió temporal, representada per la correcta utilització de les formes verbals, a l'ordenació de la frase, passant per tot tipus de qüestions relacionades amb l'estil discursiu.

La repetició d'un pronom no afecta solament la correcció gramatical o la saturació de referència, sinó el significat del període sencer; l'ús d'un article definit per un d'indefinit també ens situa en l'àrea de la incomprensió, de la no-referència... En definitiva, la cohesió és fonamental per a la construcció del text, sobretot des que sabem que no percebem els missatges de manera fragmentada, com un seguit d'oracions independents, i que només som capaços d'entendre oracions independents si estan inserides en un marc discursiu comprensible més extens.

\subsubsection{Els procediments de cohesió textual}

Els procediments de cohesió textual són un conjunt de mecanismes discursius que s'utilitzen per relacionar les diverses unitats textuals (paràgrafs, oracions, etc.); actuen sovint a nivell de l'estructura textual, per damunt de les estructures lingüístiques oracionals, i tenen una funció essencial en la construcció del text. Poden agrupar-se en tres grans categories: referència, connexió i altres procediments.

a) La referència és un fenomen pel qual un element lingüístic A (determinant, pronom, etc.) remet a un element $\mathrm{B}$, de manera que A només pot interpretar-se a partir del coneixement de B. L'element B ha de ser accessible al receptor perquè ja ha aparegut anteriorment en el text (anàfora) o apareixerà més endavant (catàfora), perquè és a l'entorn immediat (dixi) o perquè forma part del seu coneixement del món. 
b) La connexió és un procediment que consisteix a relacionar dues o més unitats contigües B i C (sintagmes, clàusules, oracions o esdeveniments contextuals) mitjançant un element lingüístic A (el connector), que adquireix sentit a partir de la relació entre les unitats connectades o entre aquestes i el coneixement del món dels interlocutors.

c) A més d'aquests dos grans grups de mecanismes hi ha altres procediments que, tot i que no tenen la funció prioritària de cohesionar el text o no són estrictament lingüístics, sovint resulten essencials en la conformació de l'arquitectura textual. En aquest grup s'inclouen la progressió temàtica, els temps verbals, els mecanismes paralingüístics i les isotopies audiovisuals.

Si analitzem, per exemple, el text [1], procedent d'una notícia de premsa, observarem com es combinen aquests tres mecanismes per produir un discurs coherent $\mathrm{i}$ ben cohesionat:

[1] Sarkozy i Cameron insten Gaddafi a deixar el poder «immediatament». Els dos dirigents adverteixen als fidels del líder libi que deixen les armes «abans que siga massa tard», mentre els rebels llancen una ofensiva sobre Sirte, la població natal del coronel, que segueix en mans del règim, tot i que la insurgència va assegurar que havia caigut.

Els presidents Sarkozy i Cameron, que apareixen com a subjecte del titular, apareixen represos en l'entradeta sota l'expressió els dos dirigents. L'altre subjecte discursiu, el president libi, apareix textualitzat en la primera aparició només amb el cognom (Gaddafi), però en l'inici de l'entradeta s'hi fa referència amb un sinònim que subratlla el seu paper com a polític (el líder libi) i més endavant amb un substantiu que en remarca la graduació militar (el coronel). També s'utilitza la referència per lligar textualment els opositors a Gaddafi -que de primer són anomenats els rebels i després s'amaguen sota una nominalització que els inclou (la insurgència) - i la ciutat objectiu de l'ofensiva -que és represa amb expressions sinònimes (Sirte, la població natal del coronel) i amb un pronom relatiu (que segueix), i es camufla sota l'el·lipsi o anàfora zero en l'última oració (va assegurar que havia caigut). En tots els casos, veiem que es tracta de reprendre un tòpic discursiu utilitzant diferents mecanismes expressius per evitar-ne la repetició literal. Així, es repeteix el concepte i es garanteix la continuïtat conceptual i la coherència del text i, alhora, es diversifica i s'enriqueix l'expressió. Finalment, cal remarcar la concentració d'elements lèxics que pertanyen al camp semàntic de la confrontació armada i dialèctica (deixar el poder, adverteixen, deixen les armes, rebels, una ofensiva, insurgència i havia caigut), amb la qual cosa es reforça la cohesió lèxica del text.

A més d'aquests procediments de referència, que estableixen una xarxa de relacions entre les unitats lèxiques del text, en la redacció de la notícia s'ha utilitzat el connector tot $i$ que, que permet relacionar dues idees entre les quals es vol subratllar el contrast o l'oposició existent ('Sirte segueix en mans del règim' i 'Els insurgents van assegurar que Sirte havia caigut'). Aquest connector estableix un 
vincle de concessivitat entre les dues clàusules lligades i, alhora, reforça la contradicció entre les accions militars dels rebels, que han llançat una ofensiva sobre la ciutat, i les declaracions de fonts de la insurgència, que havien assegurat que ja controlaven la població.

Finalment, com que es tracta del relat d'uns fets d'actualitat, el periodista que ha redactat el text ha decidit utilitzar el present d'indicatiu («insten», «adverteixen», «llancen» $\mathrm{i}$ «segueix»), tot $\mathrm{i}$ que la referència a la informació procedent dels rebels exigeix un desplaçament cap al passat («va assegurar») i, posteriorment, un nou moviment temporal, des d'aquest passat cap a un moment encara anterior en què s'hauria produït, segons les fonts de la insurgència, la caiguda de la ciutat («havia caigut»). Tot plegat, es tracta de construir una xarxa de relacions temporals coherents en què se situen els fets narrats d'una forma natural i lògica.

Com es pot comprovar, un dels problemes més habituals a l'hora de redactar un text escrit és la dificultat de trobar l'equilibri entre dues exigències aparentment oposades. D'una banda, cal assegurar al llarg del text la repetició dels tòpics o elements centrals del contingut del discurs, per tal d'evitar la caiguda en el buit i donar coherència a l'escrit. De l'altra, cal evitar la repetició constant de paraules i expressions per tal d'alleugerir la lectura del text. Es tracta, en definitiva, de trobar l'equilibri entre la repetició de conceptes i tòpics i la diversificació expressiva. En aquesta tasca juguen un paper essencial els procediments de referència, especialment l'anàfora.

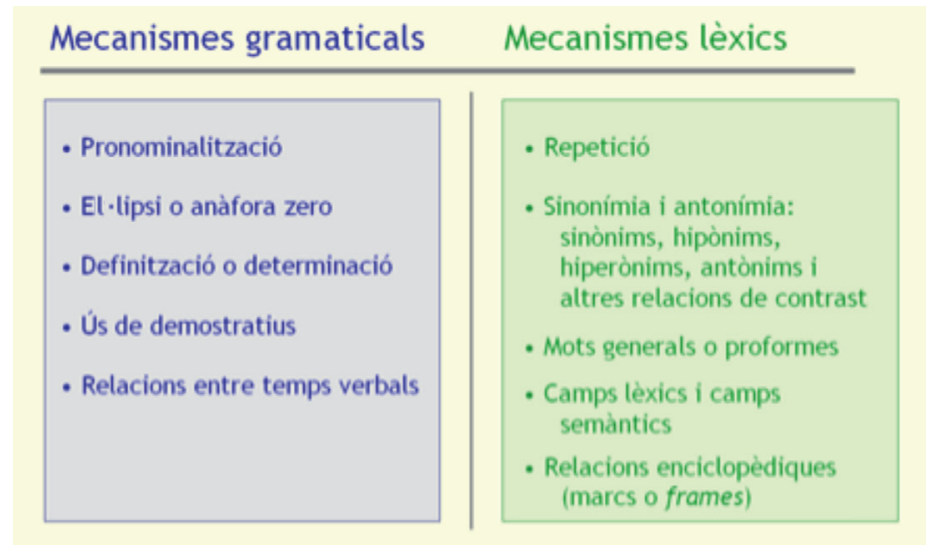

Fig. 49. Mecanismes de referència

L'anàfora opera amb classes de paraules diferents (noms i pronoms), tant amb els significats (anàfora lèxica) com amb els referents (anàfora gramatical). I també té una llarga tradició com a figura retòrica (la repetició). L'anàfora discursiva no és una mera substitució d'un antecedent que és reiterat al llarg del text amb pronoms o peces lèxiques. En realitat, l'anàfora representa molts altres mecanismes: inferències, delimitació de la memòria activa, efectes ideològics i valors argumentatius. Ho veurem més endavant de manera detallada.

Cal recordar que en la construcció textual funciona amb un rendiment excepcional el principi de manteniment de la referència, segons el qual, mentre no s'indique 
el contrari (mentre no aparega textualment un referent nou), s'entén que es manté el mateix referent, és a dir, que parlem de la mateixa persona, cosa o fet. Aquest principi, conegut i aplicat en qualsevol situació comunicativa per tots els usuaris i en tots els gèneres discursius, permet fer un ús racional de l'el-lipsi com a mecanisme de referència.

\subsection{Estil cohesionat i estil segmentat}

\subsubsection{Estils comunicatius i redacció}

L'estil segmentat i l'estil cohesionat són dos estils, dues maneres d'articular la producció lingüística, que es diferencien en la forma d'elaboració dels textos. L'estil segmentat és més habitual en els textos informals, que es produeixen de manera immediata i irreflexiva, mentre que l'estil cohesionat és més freqüent en els discursos dels àmbits formals, que es produeixen reflexivament.

L'estil segmentat té «períodes breus, una sintaxi senzilla, la presència d'una certa redundància, distints pronoms i molts punts» (Serafini, 1992: 173). En canvi, l'estil cohesionat «presenta períodes més llargs i una sintaxi més articulada» (Serafini, 1992: 173). D'altra banda, l'estil segmentat fa que el text siga més llarg i fragmentari, mentre que l'estil cohesionat resulta més curt i dens, ja que aporta molta informació en menys espai. Generalment es considera que un estil fragmentat és més senzill perquè la informació es dóna separadament, però pot resultar força monòton i el lector pot tenir la sensació que se'l tracta d'inexpert. En canvi, un text cohesionat fa una impressió contrària i, de vegades, s'ha de rellegir per entendre'l completament. Ho podem observar en aquests exemples alternatius. La primera redacció (d'estil segmentat) està formada a partir d'oracions simples unides amb punts. La segona canvia els punts per comes i insereix alguns elements amb oracions de relatiu i aposicions:

[2] Els corsos votaran diumenge el nou estatut. El resultat del referèndum resulta incert. L'estatut pot afectar l'organització territorial. Còrsega es divideix ara mateix en dos departaments.

[3] En un referèndum, de resultat incert, els corsos votaran diumenge un estatut que pot afectar l'organització territorial de Còrsega, ara dividida en dos departaments (Vilaweb, 2006).

Serafini distingeix les característiques dels dos estils a partir d'aquest quadre:

\begin{tabular}{lll}
\hline & Estil segmentat & Estil cohesionat \\
\hline Períodes & breus & llargs \\
\hline Sintaxi & senzilla, coordinació & complexa, subordinació \\
\hline Quantitat d'informació & més escassa & més abundant \\
\hline Textos & redundants, més llargs & concisos, més breus \\
\hline Pronoms & més nombrosos & menys nombrosos \\
\hline
\end{tabular}




\begin{tabular}{lll}
\hline & Estil segmentat & Estil cohesionat \\
\hline Substantius & més nombrosos & menys nombrosos \\
\hline Preposicions & més nombroses & menys nombroses \\
\hline Avantatges & claredat & varietat \\
\hline Inconvenients & monotonia & complexitat \\
\hline Típic & $\begin{array}{l}\text { llengua parlada, escrits de } \\
\text { divulgació }\end{array}$ & $\begin{array}{l}\text { llengua escrita; textos literaris, } \\
\text { històrics, filosòfics, jurídics }\end{array}$ \\
\hline
\end{tabular}

Fig. 50. Estil segmentat i estil cohesionat (Serafini, 1992: 174)

La mateixa autora considera que aquesta distribució respon a dos extrems, a dos casos límits. La influència dels mitjans de comunicació -sobretot en llengua anglesa- $\mathrm{i}$ alguns estudis sobre la funció pragmàtica i estilística d'aquests estils presenten una diferenciació més aviat funcional. Segons Serafini, «per tradició, l'ús de la hipotaxi es considera més culte $i$ adequat a la prosa argumentativa de tipus literari, filosòfic, històric, jurídic o artístic, mentre que l'ús de la parataxi es considera típic d'un estil ingenu o primitiu» (Serafini, 1992: 177).

Tanmateix, les diferències pel que fa a la puntuació (comes i punts i coma, en l'estil cohesionat, i punts en l'estil segmentat) no semblen identificar de manera clara a cadascun dels estils. Així, l'abundància de punts i les frases breus és una de les característiques de la redacció publicitària:

[4] Nou Peugeot 307 sw. Imagina el teu espai. Hem obert un nou camí. És més llarg que l'horitzó i més a prop que el punt de partida. I és el que et porta allà on vols estar. És ple de llum $\mathrm{i}$ de possibilitats. Les que tu vulgues inventar: fins a set seients i més de 50 formes de combinar-los. Peugeot.

D'altra banda, en el llenguatge dels mitjans de comunicació, especialment en llengua anglesa, «els periodistes moderns treballen sobre el principi que les oracions haurien de ser tan àgils com siga possible; per tant, usen poc els dos punts i el punt i coma» (Graves-Short, 1995: 160). La generalització de l'estil periodístic i la influència de l'anglès en els àmbits científics i de comunicació de massa poden incrementar la tendència a reduir l'extensió de les oracions (Cuenca, 2000).

En definitiva, l'ús d'un estil segmentat o cohesionat ha de tenir en compte el context, l'adaptació a les característiques pròpies de cada gènere i el canal de transmissió (oral, audiovisual o escrit).

\subsubsection{Mecanismes d'integració sintàctica}

Per tal d'evitar redaccions en què predominen els períodes curts i les frases simples, es poden usar diversos recursos lingüístics que ajuden a la construcció cohesionada de les oracions. Aquests recursos, segons la funció o finalitat amb què s'utilitzen, es poden agrupar en dues categories: composició oracional i integració 
sintàctica. En tots els exemples, de les parelles de solucions, sempre es considera més adequada o recomanable $(+\mathrm{r})$ la construcció marcada amb una $b$ que no pas la redacció identificada amb una $a$.

1) Els recursos de composició oracional uneixen oracions simples, estableixen una relació de subordinació en oracions que s'unien mitjançant la coordinació o la juxtaposició i faciliten la reducció dels períodes evitant l'abundància d'oracions subordinades, que són substituïdes per oracions de participi o de gerundi:

[5a] Nou dels onze ocupants de l'avió de la Força Aèria Brasilera (FAB) que havia desaparegut dijous a l'Amazònia van sobreviure a un aterratge forçós. Dels altres dos, un està desaparegut, i l'altre es troba entre les restes de l'avió. [-r]

[5b] Nou dels onze ocupants de l'avió de la Força Aèria Brasilera (FAB) que havia desaparegut dijous a l'Amazònia van sobreviure a un aterratge forçós; un està desaparegut i un altre està entre les restes de l'aeronau. $[+\mathrm{r}]$

[6a] Els delegats del president enderrocat, Manuel Zelaya, i del colpista, Roberto Micheletti, van firmar un acord per posar fi a la crisi, i això que el diàleg semblava esgotat. [-r]

[6b] Quan el diàleg semblava esgotat, els delegats del president enderrocat, Manuel Zelaya, i del colpista, Roberto Micheletti, van firmar ahir un acord per posar fi a la crisi. $[+r]$

[7a] La Unió Europea (UE) es va mostrar ahir avara en la lluita contra el canvi climàtic perquè està patint el càstig de la crisi econòmica i perquè considera que els Estats Units no s'hi han compromès. [-r]

[7b] Castigada per la crisi econòmica i decebuda per la falta de compromís dels Estats Units, la Unió Europea (UE) es va mostrar ahir avara en la lluita contra el canvi climàtic. $[+r]$

En el primer cas, es presentava un enunciat en què els darrers elements apareixien juxtaposats. En la transformació, mitjançant la conjunció $i$, s'han pogut unir els dos fragments finals. En el segon parell d'enunciats, s'ha construït una oració subordinada temporal per evitar la coordinació final. En canvi, en la tercera parella, s'ha evitat la proliferació d'oracions causals introduint dos participis.

2) Els procediments que permeten una major integració sintàctica de certs elements -entre els quals destaquen les nominalitzacions i les aposicions, que permeten evitar la introducció d'oracions atributives o d'altres enunciats independents- afavoreixen la fluïdesa i l'agilitat del discurs:

[8a] El president dels EUA, Barack Obama, va anunciar ahir la fi de la prohibició per als malalts de sida de viatjar al país. El veto, que estava vigent des del 1987, va ser imposat per Ronald Reagan. [-r]

[8b] El president dels EuA, Barack Obama, va anunciar ahir la fi de la prohibició per als malalts de sida de viatjar al país, un veto vigent des del 1987, imposat per Ronald Reagan. [+r] 
[9a] L'Ajuntament de Barcelona signa el decret perquè es desmunte l'antena que fa servir Jiménez Losantos per difondre les emissions d'esRadio a l'àrea barcelonina. [-r]

[9b] L'Ajuntament de Barcelona signa el decret de desmuntatge de l'antena que fa servir Jiménez Losantos per difondre les emissions d'esRadio a l'àrea barcelonina. $[+\mathrm{r}]$

En aquestes parelles d'enunciats, s'ha inclòs una aposició en l'exemple [8b] per evitar una oració subordinada adjectiva i una altra d'atributiva. En l'exemple [9b], s'ha introduït la nominalització del verb desmuntar per tal d'afavorir-ne la cohesió.

\subsection{Referència discursiva}

\subsubsection{El concepte de referència}

En la construcció de la coherència textual és fonamental l'equilibri entre la repetició de conceptes, tòpics o elements discursius i la incorporació d'elements nous per fer possible la progressió de la informació d'una forma natural. Aquest equilibri -i, per tant, la coherència discursiva- es basa en l'establiment de referents -els conceptes que introdueix el text- $\mathrm{i}$ en la represa d'alguns d'aquests tòpics al llarg del text, i és possible gràcies a l'aplicació dels principis d'analogia-les coses i els fets solen ser sempre semblants-, d'interpretació local -si es produeix algun canvi, aquest serà mínim- $\mathrm{i}$ de manteniment de la referència -si no es diu explícitament el contrari, una frase es refereix al mateix element que l'anterior. Aquests principis -que són fonamentals per construir el sentit del text i per poder, posteriorment, reconstruir-lo- permeten i exigeixen la utilització discursiva d'una sèrie de procediments de cohesió textual relacionats amb la referència.

La noció de referència s'utilitza per designar una propietat dels signes lingüístics $\mathrm{i}$ de les expressions que permet reenviar o remetre a un concepte o una realitat preexistent. Es tracta, per tant, d'un mecanisme discursiu que posa en relació dos elements: un antecedent (A), que posa el significat, i un element de referència (B), que només es pot interpretar totalment o parcialment a partir del coneixement d'A. L'element $\mathrm{A}$ ha de ser accessible al receptor perquè ja ha aparegut anteriorment en el text (anàfora) o apareixerà més endavant (catàfora), perquè és a l'entorn immediat (dixi) o perquè forma part del seu coneixement del món (marc o frame).
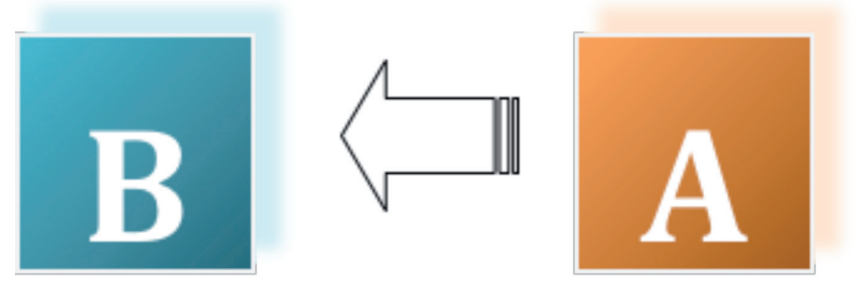

Fig. 51. El concepte de referència 
Així, per exemple, en l'anunci del RACC (fig. 52), podem observar que apareixen diferents tòpics (el RACC, el cotxe, les vacances, el destinatari) que són represos per diferents unitats lingüístiques (ell, et, nosaltres, te, les) i permeten l'assignació del sentit adient a l'enunciat.

L'anunci utilitza les imatges per representar textualment diferents elements de la situació de comunicació (l'emissor i el receptor) i diferents objectes d'aquesta realitat extratextual (el cotxe o el servei d'Autovacances). Aquesta estratègia permet l'ús de pronoms forts (ell, nosaltres) o febles (et, les) per reprendre els tòpics sense repetir les paraules i per construir un text coherent i ben cohesionat. A més, en el cos de l'anunci s'utilitzen altres unitats lingüístiques per no haver de repetir elements que ja havien aparegut anteriorment. Ens referim a l'expressió tot això, represa amb el pronom neutre ho, i a l'adverbi així, que fa referència a tot el contingut de les frases anteriors.

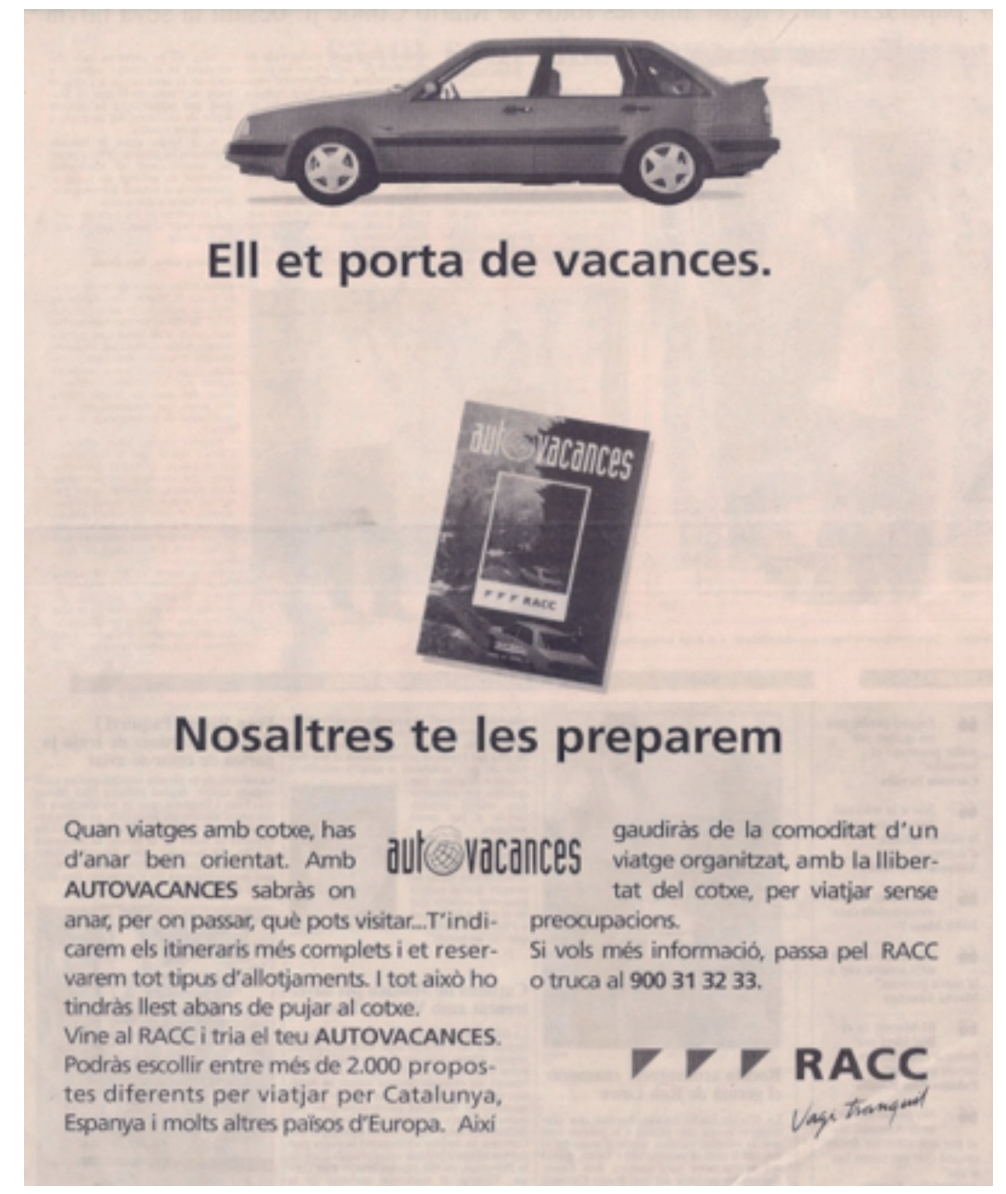

Fig. 52. Autovacances del RACC

Els mecanismes de referència són, doncs, un conjunt de procediments lingüístics -entre els quals es troben els pronoms (però també els determinants possessius, els demostratius o l'ús de sinònims, entre d'altres)- que realitzen en el text una funció anafòrica i, així, permeten la repetició de conceptes o tòpics discursius sense haver-ne de repetir forçosament les paraules i expressions. 


\subsubsection{Tipus de referència}

La relació d'un element lingüístic amb l'antecedent (la referència fòrica) es pot realitzar a través d'un element gramatical o a través d'un element lèxic. En el primer cas, la referència s'activa amb marques morfològiques (pronoms personals i relatius, possessius i morfemes verbals) o amb l'el-lipsi, que, de fet, es pot considerar com una mena de «pronom zero»; en el segon, la relació entre les dues unitats s'estableix mitjançant la repetició estricta, la reiteració a través del recurs a la sinonímia o l'associació. Tot i que l'anàfora gramatical i la lèxica alternen en el discurs, se sol preferir l'anàfora gramatical si l'antecedent és proper i fàcil d'identificar, mentre que l'anàfora lèxica sembla especialment indicada quan l'antecedent és menys accessible, perquè està més allunyat textualment o perquè la disponibilitat de diversos antecedents possibles pot crear ambigüitat interpretativa. En aquesta notícia es pot observar perfectament l'alternança dels dos tipus de referència.

Cultura | Espectacles

Beyoncé arrasa als premis MTV Europa

S'imposà en les categories de millor artista femenina, millor cançó i vídeo Agències | 06/11/2009 | Vistes: 69

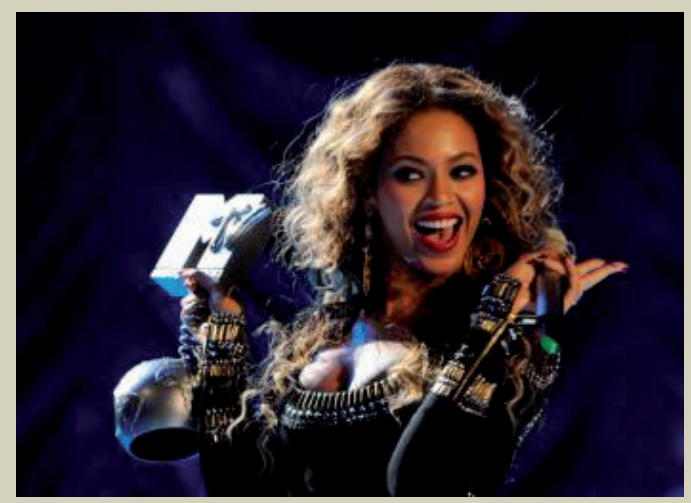

La cantant nord-americà Beyoncé ha arrasat avui a Berlin en els premis MTV Europe Music Awards 2009, en els quals n'ha recollit tres i ha deixat sense cap guardó a la colombiana Shakira, amb qui competia en dues categories.

Beyoncé va superar també una altra diva de la música, Lady Gaga, que malgrat les seves cinc nominacions, només va poder fer-se amb el premi d'Artista Revelació, ja que els premis a millor artista femenina, millor vídeo i millor cançó han Beyoncé, radiant, amb un dels seus guardons. Foto: Efe recaigut en l'exintegrant de Destiny's Child.

En recollir el seu guardó a la millor artista femenina, Beyoncé va dedicar el premi a les seves companyes de nominació -Kate Perry, Leona Lewis, Shakira i Lady Gaga- i especialment a la colombiana. «T'ador. Gràcies per inspirar-me. Ets meravellosa», li va dir Beyoncé a Shakira, amb qui ja va treballar en el tema "Beautiful Liar».

Després de guanyar en la categoria de millor cançó per «Halo» i en la de millor vídeo per "Single Ladiesı, la cantant va dedicar aquest últim premi al seu marit, el productor i raper Jay-Z, a qui ha agraït que li posàs un anell al dit» en al|lusió a la lletra del tema guanyador.

http://dbalears.cat/actualitat/Cultura/beyonce-arrasa-als-premis-mtv-europa.html 
La protagonista de la notícia, que apareix ja en el titular (Beyoncé), es manté com a referent en el subtítol (tot i que ara el redactor ha recorregut a l'el-lipsi o anàfora zero) $i$ en tots els paràgrafs del cos de la notícia. Per no haver de repetir el nom exactament en totes les oracions, s'utilitza l'anàfora lèxica (la cantant nord-americana, l'exintegrant de Destiny's Child o la cantant) o l'el-lipsi. També s'utilitza l'anàfora lèxica per referir-se als premis (premis мTV Europa, premis мTV Europe Music Awards 2009, guardons, premi i aquest últim premi) i als altres protagonistes de la notícia (Shakira, la colombiana; una altra diva de la música, Lady Gaga; el productor i raper Jay-Z, el seu marit).

El recurs a l'anàfora lèxica es completa amb la inserció de diferents procediments de referència de caràcter gramatical, entre els quals cal destacar els morfemes verbals (s'imposà, competia, va treballar, posàs), els possessius (seu, seves) i els pronoms febles ( $n$ ', -me, ets, li) i relatius (en els quals, amb qui, que).

Aquesta alternança discursiva, que es pot observar també en el text següent, és important des del punt de vista de la construcció textual, perquè els dos procediments són molt diferents.

[10] La primera guerra moderna. Un conflicte que va trasbalsar Europa durant tres dècades. La guerra dels Trenta Anys (1618-1648) es considera la primera guerra moderna a causa de l'ús massiu de l'artilleria, el nombre d'efectius mobilitzats, el sofriment de la població civil i la utilització de la propaganda impresa. Les seves causes són tan complexes que, encara avui en dia, els historiadors formulen hipòtesis per interpretar-ne la seva veritable naturalesa (Sapiens, 72: 22).

Mentre que l'anàfora gramatical es limita a reprendre el referent garantint el manteniment de marques gramaticals com la persona, el gènere o el nombre, però sense introduir informació lèxica, la referència lèxica aporta informació addicional sobre el referent, objectiva o subjectiva, que ens ajuda a caracteritzar els tòpics discursius i permet introduir determinats punts de vista.

En definitiva, la referència implica la presència de dos elements, A i B, relacionats d'acord amb les variables exposades en el quadre següent:

\begin{tabular}{|c|c|c|c|}
\hline Definició & & Tipus & Caràcter de la relació \\
\hline \multirow[t]{2}{*}{ A (antecedent) } & \multirow[t]{2}{*}{ A pot ser } & • Extralingüístic (dixi) & \multirow{3}{*}{$\begin{array}{l}\text { a) D'identitat referencial: } \\
\text { anàfora de referència, dixi, } \\
\text { cohesió lèxica per repetició } \\
\text { o reiteració. }\end{array}$} \\
\hline & & - Lingüístic (anàfora) & \\
\hline \multirow[t]{2}{*}{$\mathrm{B}$ (element de referència) } & \multirow[t]{2}{*}{ B pot ser } & $\begin{array}{l}\text { - Gramatical (anàfora, } \\
\text { dixi, el·lipsi) }\end{array}$ & \\
\hline & & - Lèxic (cohesió lèxica) & $\begin{array}{l}\text { b) De sentit: anàfora de sentit, } \\
\text { cohesió lèxica per asso- } \\
\text { ciació. }\end{array}$ \\
\hline
\end{tabular}

Fig. 53. La relació de referència 


\title{
7.4. La referència gramatical
}

L'anàfora és una categoria mixta, heterogènia, ja que pot situar-se en l'àmbit oracional o discursiu. En l'àmbit discursiu, presenta un doble paper, ja que, d'una banda, contribueix al manteniment de la referència entre les seqüències $i$, de l'altra, permet la progressió de la informació. Es tracta d'un mecanisme de cohesió que consisteix a utilitzar diversos mecanismes discursius per tal de referir-se als elements que apareixen en el text $\mathrm{i}$ evitar la repetició sistemàtica d'una mateixa forma. Els procediments de referència es poden classificar en dos grans grups: la referència exofòrica i la referència endofòrica. El primer inclou una sèrie de recursos que remeten al context extralingüístic, és a dir, a la situació de comunicació on té lloc el procés de producció i recepció del text. S'inclouen en aquest grup els díctics i l'alternança entre articles indefinits i definits. Per contra, la referència endofòrica consisteix a emprar diversos procediments per referir-se a elements discursius que han aparegut anteriorment en el text (anàfora) o que apareixeran més endavant (catàfora).

L'anàfora gramatical consisteix, com hem vist, en l'ús d'un element de caràcter morfològic per tal de reprendre un element textual anterior. Els procediments lingüístics que permeten activar aquest tipus de referència són la pronominalització, la definització o determinació, l'ús de demostratius i possessius, els morfemes verbals i l'el·lipsi o anàfora zero.

Com es pot comprovar en la notícia següent, l'ús d'aquest conjunt de procediments anafòrics al llarg del text permet de construir una sofisticada xarxa de relacions entre els tòpics o elements textuals, reforça la coherència discursiva $i$ és un indici inqüestionable de la solidesa de la redacció.

\section{7/11/2009 CINE|TROBALLA}

\section{Un internauta paga 3,6€ pel que resulta ser un inèdit de Chaplin}

\author{
EL PERIÓDICO
}

BARCELONA

L'internauta britànic Morace Park tafanejava a la pàgina de subhastes eBay quan va topar amb una oferta d'un venedor desconegut que oferia "una pel-lícula històrica» de set minuts, rodada en $35 \mathrm{~mm}$. Poc s'imaginava Park que quan va decidir pagar per la cinta 3,20 lliures, és a dir, gairebé 3,6 euros, rebria una antiga llauna per a cintes amb un regal insòlit a l'interior que podria arribar a taxar-se en 45.000 euros. Segons va revelar dijous passat el diari The Guardian, contenia un film de Charles Chaplin que ha resultat ser inèdit.

L'afortunat Park va buscar primer informació sobre la cinta a la xarxa. En no trobar res sobre la pel-lícula va començar a sospitar i va consultar el seu veí John Dyer, exempleat del Consell Britànic de Classificació Cinematogràfica. Van descobrir que cap expert no coneixia la seva existència. El títol de la filmació és Charles Chaplin in Zepped i el seu contingut urecorda Monty Python" perquè combina les burles de Chaplin amb seqüències d'animació. 
Les imatges mostren un bombardeig d'un dirigible zepeli sobre Anglaterra durant la Primera Guerra Mundial, del qual Chaplin es burla. «En aquella època el zepeli era un instrument de terror", assenyala Park, que opina que el film pertanyia a la propaganda bèl-lica destinada a treure als britànics la por a un atac aeri alemany. Una nota a la bobina indicava que es va projectar el 1916 a Egipte, aleshores protectorat britànic.

Park i Dyer ja preparen un documental sobre la troballa que es dirà The Lost Film Project i que el cineasta Hammad Khan ja està rodant a Los Angeles. Com va anar a parar la pel-lícula a eBay? Se li hauria de preguntar al misteriós venedor.

http://www.elperiodico.cat/default.asp?idpublicacio_PK=46\&tidioma=CAT\&tidnoticia PK=659633दtidseccio_PK=1013\&th $=$.

\begin{tabular}{|c|c|c|}
\hline Antecedent (A) & Element de referència (B) & Procediment utilitzat \\
\hline Un internauta & $\begin{array}{l}\text { L'internauta britànic Morace } \\
\text { Park }\end{array}$ & Definització o determinació \\
\hline L'internauta & Va topar & El·lipsi \\
\hline Un venedor desconegut & Que & Pronominalització \\
\hline Un regal insòlit & Que & Pronominalització \\
\hline La llauna & $\begin{array}{l}\text { Contenia un film de Charles } \\
\text { Chaplin }\end{array}$ & El·lipsi / Morfema verbal \\
\hline Un film de Charles Chaplin & Que & Pronominalització \\
\hline Morace Park & Va començar a sospitar & El·lipsi / Morfema verbal \\
\hline Morace Park & Va consultar el seu veí & Possessiu \\
\hline Morace Park i el seu veí & Van descobrir & El-lipsi / Morfema verbal \\
\hline La pel·lícula & $\begin{array}{l}\text { Cap expert no coneixia la } \\
\text { seva existència }\end{array}$ & Possessiu \\
\hline La filmació & El seu contingut & Possessiu \\
\hline Un bombardeig & Del qual Chaplin es burla & Pronominalització \\
\hline La Primera Guerra Mundial & En aquella època & Demostratiu \\
\hline El film & Es va projectar & El·lipsi \\
\hline El 1916 & Aleshores & Demostratiu \\
\hline Un documental & Que & Pronominalització \\
\hline Misteriós venedor & Se li hauria de preguntar & Pronominalització \\
\hline
\end{tabular}

Fig. 54. L'anàfora gramatical en una notícia de premsa 


\subsubsection{La pronominalització: pronoms febles i relatius}

La pronominalització consisteix a reprendre un element textual que ha aparegut en el text o que es pot identificar amb facilitat en el context comunicatiu amb un pronom fort (jo, tu, ell, nosaltres...), amb un pronom feble (el, la, ho, ens, hi, us...) o amb un relatiu (que, qui, el qual, la qual cosa, amb què...). Quan l'element de referència apunta a un element del context situacional es parla de referència extralingüística o exofòrica i aleshores es produeix el fenomen de la dixi. En canvi, quan el pronom fa referència a un element que ja ha aparegut en el text o que apareixerà més endavant es parla de referència endofòrica o textual i es produeixen els fenòmens de l'anàfora i la catàfora.

De vegades, l'ús d'un pronom fort pot resultar textualment improcedent perquè la redacció exigeix l'ús d'un pronom feble o perquè el principi de manteniment de la referència legitima l'ús inequívoc de l'el·lipsi, que permet una redacció més natural i més eficaç des del punt de vista comunicatiu (com ara en l'exemple [11]). En aquest cas, també seria possible l'ús d'una oració de relatiu: Castelló està dividida en sis districtes, en cadascun dels quals... En altres casos, l'aplicació d'aquest principi de manteniment de la referència afavoreix l'ús de l'el·lipsi en lloc de la reiteració d'un pronom feble (com en l'exemple [12]).

[11] La ciutat està creixent i, cada vegada més, les persones que en ella vivim necessitem millors serveis públics i atenció per part de la nostra administració, l'Ajuntament. Per això vull oferir-li tota la informació que necessite sobre les possibilitats i serveis que es troben en l'entorn del seu domicili. Castelló està dividida en sis districtes, i en cada un d'ells hi ha una delegació de l'Ajuntament en què podrà realitzar els mateixos tràmits i serveis que si acudira a les oficines centrals del consistori.

[12] El Circuit de Catalunya compta amb una situació privilegiada. Situat a tan sols $32 \mathrm{~km}$ de Barcelona i a $18 \mathrm{~km}$ de la costa del Maresme, el Circuit se situa entre dues grans vies de conducció. Una senyalització acurada als voltants del Circuit ajuda al visitant a arribar al seu destí sense problemes. En cotxe, s'hi pot arribar per l'autovia C-17 (sortida Montmeló) i l'AP-7. Si es decideix arribar per l'autopista de peatge AP-7, es disposa de diverses sortides per arribar al Circuit: 13, 14 i 15. D'altra banda, també s'hi pot accedir en tren, aturant-se a l'estació Montmeló de Rodalies RENFE (L2). Des de l'estació, i durant els Grans Premis, existeix un servei de bus llançadora fins a l'accés principal. També s'hi pot arribar a peu.

\subsubsection{Els pronoms relatius}

Els pronoms relatius permeten integrar en una sola unitat sintàctica dues oracions simples que presenten un element compartit. Com es pot observar en els exemples [13] i [14] es repeteix l'element en cursiva, cosa que permet substituir-lo en la primera clàusula per un relatiu (en aquest cas el relatiu neutre), que remet a l'antecedent subratllat: 
[13] Després d'unes quatre setmanes -encara que no es pot calcular exactament el temps a causa de la complexitat del procés-, els científics planegen portar a terme les primeres col-lisions de partícules a alta velocitat.

[14] S'espera que les primeres col-lisions de partícules a alta velocitat tindran lloc cap a mitjans de desembre o al gener.

[15] Després d'unes quatre setmanes -encara que no es pot calcular exactament el temps a causa de la complexitat del procés-, els científics planegen portar a terme les primeres col-lisions de partícules a alta velocitat, cosa que s'espera per a mitjans de desembre o al gener.

Així, l'expressió en cursiva de l'exemple [13], un sintagma nominal en funció de complement directe, apareix represa en l'exemple [15] pel relatiu neutre cosa que, que fa la mateixa funció sintàctica en l'oració inserida de relatiu-cosa que s'espera per a mitjans de desembre o al gener.

Sobre els usos i funcions dels relatius, podeu consultar l'apartat 5.4.5 del tema 5.

\subsubsection{Els pronoms febles}

Els noms substantius poden ésser designats sense esmentar-los. La llengua moderna evita certes repeticions de mots, per la qual cosa quan un nom ja ha estat esmentat abans, a fi d'evitar-ne la repetició, s'usen els pronoms, que són mots que substitueixen els noms, és a dir, que els designen sense esmentar-los. Són un procediment de referència clau en l'arquitectura textual. Així, no és normal de dir Han comprat la màquina però no saben fer anar la màquina, sinó Han comprat la màquina però no la saben fer anar, en què el pronom la substitueix el grup nominal la màquina.

És evident, però, que l'ús dels pronoms exigeix que es puga identificar clarament, pel context o pel cotext, el nom o grup nominal substituït pel pronom, tot i que els pronoms també poden substituir infinitius, adjectius, adverbis, altres pronoms i oracions senceres.

Els pronoms personals es divideixen en dos grups: els forts o tònics i els febles o àtons. Els pronoms personals forts són anomenats també díctics personals i s'utilitzen per inserir en el text les persones que intervenen en el procés de comunicació (emissor, receptor i tercera persona).

a) Els pronoms personals forts són jo, tu, ell, ella, nosaltres, vosaltres, ells, elles, nós, vós i vostè. Normalment s'usen en funció de subjecte, i quan fan la funció d'un complement van sempre precedits per una preposició.

b) Els pronoms personals febles són unes partícules àtones que se situen immediatament davant $\mathrm{o}$ darrere del verb. A diferència dels pronoms 
personals forts, només poden funcionar com a complement del verb, no admeten cap preposició i s'escriuen d'acord amb els criteris exposats en la fig. 55.

\section{Com s'escriuen els pronoms?}

- Un pronom feble s'escriu darrere del verb quan aquest és infinitiu, gerundi o imperatiu, i s'adjunta al verb amb l'apòstrof o amb el guionet: agafar-me, donant-hi, renta'l.

- Amb la resta dels temps verbals, els pronoms febles se situen davant, i van o bé sols o bé units al verb mitjançant l'apòstrof: Em telefona tots els dies, T'ha escrit una carta.

- Amb les formes verbals perifràstiques o compostes, podem col-locar el pronom davant 0 darrere el verb: la vaig portar, vaig portar-la; em va donar, va donar-me, l'estava mirant, estava mirant-lo.

- La repetició del mateix pronom, davant i darrere el verb, és innecessària i incorrecta: hi vaig anar-hi, ho vaig dir-ho, livaig dir-li.

Fig. 55. Criteris d'escriptura dels pronoms febles

Els pronoms febles presenten formes diferents per a cada persona gramatical segons la seua col-locació en relació al verb i segons el so inicial o final de la forma verbal amb què s'aglutinen. En el quadre següent es poden veure les formes que corresponen a cada funció oracional:

\begin{tabular}{|c|c|c|c|c|c|c|}
\hline \multirow{3}{*}{ Funcions } & \multicolumn{2}{|r|}{ Persona } & \multicolumn{4}{|c|}{ Formes } \\
\hline & & & \multicolumn{2}{|c|}{$\begin{array}{l}\text { Davant de verb } \\
\text { començat per }\end{array}$} & \multicolumn{2}{|c|}{$\begin{array}{c}\text { Davant de verb } \\
\text { acabat } a m b\end{array}$} \\
\hline & & & consonant & vocal & consonant & vocal \\
\hline & & & reforçades & elidides & plenes & reduïdes \\
\hline \multirow{3}{*}{$\begin{array}{l}\text { Complement } \\
\text { directe }\end{array}$} & \multirow{2}{*}{\multicolumn{2}{|c|}{ 1a }} & em & m' & - me & 'm \\
\hline & & & ens & ens & - nos & 'ns \\
\hline & \multirow{2}{*}{\multicolumn{2}{|c|}{$2 \mathrm{a}$}} & et & $t^{\prime}$ & -te & 't \\
\hline \multirow{2}{*}{ Indirecte } & & & us & us & -vos & -us \\
\hline & \multicolumn{2}{|c|}{ 3a reflexiu } & es & s' & -se & 's \\
\hline \multirow{5}{*}{ CD i atribut } & \multirow{5}{*}{$3 a$} & \multirow{2}{*}{ masculí } & el & l' & -10 & '1 \\
\hline & & & els & els & $-\operatorname{los}$ & '1s \\
\hline & & \multirow[t]{2}{*}{ femení } & la & ' & -la & -la \\
\hline & & & les & les & -les & -les \\
\hline & & neutre & ho & ho & -ho & -ho \\
\hline \multirow{2}{*}{$\begin{array}{l}\text { Complement } \\
\text { indirecte }\end{array}$} & \multirow{2}{*}{$3 a$} & \multirow{2}{*}{$\begin{array}{l}\text { masculí } \\
\text { i femení }\end{array}$} & li & li & $-1 i$ & - li \\
\hline & & & els & els & $-\operatorname{los}$ & '1s \\
\hline \multicolumn{3}{|c|}{ Atr, CC, CPred, CPrep } & hi & hi & -hi & -hi \\
\hline \multicolumn{3}{|c|}{$\mathrm{CD}$, CPrep, CC } & en & n' & - ne & ' $\mathrm{n}$ \\
\hline
\end{tabular}

Fig. 56. Formes i funcions dels pronoms febles 
Els pronoms realitzen diferents funcions sintàctiques que en determinen l'ús. En el quadre següent es pot distingir de manera clara quines són les funcions que poden desenvolupar els pronoms en les diverses circumstàncies en què poden aparèixer:

\begin{tabular}{|c|c|c|c|}
\hline & Funció & Pronoms & Condicions d'ús \\
\hline 1 & Complement directe & $\begin{array}{l}\text { el, la, els, les } \\
\text { es } \\
\text { em, ens / et, us } \\
\text { en } \\
\text { ho }\end{array}$ & $\begin{array}{l}\text { CD determinat de } 3 \text { a persona } \\
\text { CD reflexiu o recíproc ( } 3 \text { a persona) } \\
\text { CD de } 1 \text { a i } 2 \text { a persona } \\
\text { CD indeterminat o amb quantificador o indefinit } \\
\text { CD neutre }\end{array}$ \\
\hline 2 & Complement indirecte & $\begin{array}{l}\text { li (hi), els } \\
\text { es } \\
\text { em, ens, et, us }\end{array}$ & $\begin{array}{l}\text { CI de } 3 \text { a persona ( } h i \text { en contacte amb CD determinat) } \\
\text { CI reflexiu ( } 3 \text { a persona) } \\
\text { CI de } 1 \text { a i } 2 \text { a persona }\end{array}$ \\
\hline 3 & Atribut & $\begin{array}{l}\text { el, la, els, les } \\
\text { ho } \\
\text { en }\end{array}$ & $\begin{array}{l}\text { Atribut determinat (només amb el verb ser o ésser) } \\
\text { Atribut no determinat (o amb el verb semblar) } \\
\text { Atribut amb un matís d'intensitat o partitiu }\end{array}$ \\
\hline 4 & Complement predicatiu & en & $\begin{array}{l}\text { Amb verbs com dir-se, elegir, fer-se, nomenar o } \\
\text { amb un matís d'intensitat o partitiu } \\
\text { Amb altres verbs }\end{array}$ \\
\hline 5 & $\begin{array}{l}\text { Complement circumstan- } \\
\text { cial }\end{array}$ & $\begin{array}{l}\text { en } \\
h i\end{array}$ & $\begin{array}{l}\text { CC introduït amb la prep. de (llevat del CC de manera) } \\
\mathrm{CC} \text { introduït amb les altres preposicions }\end{array}$ \\
\hline 6 & Complement preposicional & $\begin{array}{l}\text { en } \\
h i\end{array}$ & $\begin{array}{l}\text { CPrep introduït amb la preposició de } \\
\text { CPrep introduït amb les altres preposicions }\end{array}$ \\
\hline 7 & Complement del nom & en & Introduït amb de (si el nom fa de CD o de PN) \\
\hline & Subjecte & en & Només si va posposat al verb \\
\hline
\end{tabular}

Fig. 57. Formes i funcions dels pronoms febles (quadre-resum)

Quan s'han d'utilitzar dues o més formes pronominals combinades, l'ordre de collocació dels pronoms segueix l'esquema següent:

\begin{tabular}{ccccc}
\hline Reflexiu & 2a persona & 1a persona & 3a persona & Adverbials \\
\hline$s e$ & te, us & me, ens & li, els, el, la, els, les, ho & $e n, h i$ \\
\hline
\end{tabular}

\subsubsection{Observacions sobre l'ús dels pronoms febles}

Una de les peculiaritats de la llengua catalana és l'extraordinària capacitat de pronominalització i la gran flexibilitat dels usos pronominals. L'ús adequat i correcte dels pronoms febles és, per tant, un aspecte clau de la competència idiomàtica dels parlants. Actualment, bé per la influència del castellà, bé per interferències produïdes pels registres col·loquials, s'observen usos discursius poc recomanats o francament incorrectes que cal evitar en tots els registres idiomàtics, però molt especialment en els àmbits formals. Alguns dels usos incorrectes més generalitzats són els següents: 
a) Confusió dels pronoms el (i variants) i ho.

El pronom el substitueix el complement directe masculí singular; en canvi, el pronom ho substitueix el complement directe neutre, que no és ni masculí ni femení, i equival, per tant, a això o allò.

[16] *Vam tornar el telèfon a la tenda i després vam anar a recollir-ho.

[17] Vam tornar el telèfon a la tenda i després vam anar a recollir-lo.

b) El plural de li és els, no pas *lis.

El plural del pronom $l i$, que representa el complement indirecte singular de tercera persona, és sempre els, tant si és masculí com si és femení. Per tant, la forma *lis no existeix i és totalment incorrecta. D'altra banda, també són incorrectes les combinacions els hi quan és refereix a un únic complement indirecte plural i els en hi per substituir un complement indirecte plural més el pronom adverbial en.

[18] *El president nord-americà va mantenir una reunió amb 18 congressistes per explicar-lis l'extensió i la implicació de l'operació.

[19] *El president nord-americà els hi va explicar, els límits de la intervenció als congressistes.

[20] *La comunitat internacional ha manifestat mostres de suport als libis; els n'hi han manifestades, fins i tot, els enemics més declarats.

[21] El president nord-americà va mantenir una reunió amb 18 congressistes per explicar-los l'extensió i la implicació de l'operació.

[22] El president nord-americà els els va explicar, els límits de la intervenció als congressistes.

[23] La comunitat internacional ha manifestat mostres de suport als libis; els n'han manifestades, fins i tot, els enemics més declarats.

c) Confusió entre el CD referit a persones (el, la, les) i el CI li.

Els pronoms de complement directe $e l$, la, les, quan es refereixen a persones, de vegades, es confonen amb els pronoms $l i$, els (complement indirecte). El problema es planteja amb alguns verbs en què hi ha vacil·lacions sobre el seu ús com a transitius -és a dir, amb un CD i, per tant, amb els pronoms el, la, les-o intransitius -això és, només amb CI i, per tant, amb els pronoms $l i$, els o amb altres complements.

[24] *El director no ha pogut telefonar al cap de redacció. L'haurà de telefonar el becari.

[25] El director no ha pogut telefonar al cap de redacció. Li haurà de telefonar el becari.

[26] *Si vols que elles t'escriguen, tu també les hauràs d'escriure.

[27] Si vols que elles t'escriguen, tu també els hauràs d'escriure.

[28] * La secretària li va ajudar amb el micròfon.

[29] La secretària el va ajudar amb el micròfon. 
d) Les combinacions se lo, se la, se los, se las són interferències del castellà que cal evitar.

En català, el pronom es és un pronom reflexiu -equivalent a a ell/a mateix/a o a ells/elles mateixos/eixes-o recíproc -equivalent a l'un a l'altre, els uns als altres, etc.- i no pot fer mai la funció de complement indirecte de tercera persona-equivalent a a ell o a ella- ni es pot combinar, per tant, amb els pronoms de complement indirecte el, la, els, les o ho.

[30] *El ministre de Turisme va presentar la dimissió al president del Iemen. Se la va presentar en el moment més crític de les revoltes populars.

[31] El ministre de Turisme va presentar la dimissió al president del Iemen. Li la va presentar en el moment més crític de les revoltes populars.

D'altra banda, cal recordar que les combinacions se'l, se la, se'ls, se les, s'ho només són correctes si la frase té un sentit reflexiu o recíproc o si el pronom es forma part d'un verb pronominal o usat pronominalment.

e) Els mots mateix, mateixa, mateixos i mateixes no són pronoms.

En català, els mots mateix, mateixa, mateixos i mateixes són determinants indefinits i no pas pronoms i, per tant, no poden substituir noms. Aquest ús és un calc del castellà, totalment incorrecte en català, que cal evitar. En lloc d'aquests indefinits, segons el context, cal emprar els pronoms adverbials en i hi o d'altres pronoms, o cal buscar una estructura sintàctica alternativa.

[32] *No em van oferir diners pel camp de golf, només m’oferiren fer-me soci del mateix.

[33] No em van oferir diners pel camp de golf, només m'oferiren fer-me'n soci.

[34] * La zona estava just al centre dels plànols per construir un camp de golf en la mateixa.

[35] La zona estava just al centre dels plànols per construir-hi un camp de golf.

[36] *El condemnat tindrà el permís aviat i la policia té por que no aprofite el mateix per fugir.

[37] El condemnat tindrà el permís aviat i la policia té por que no l'aprofite per fugir.

f) Omissió indeguda dels pronoms en o hi o substitució incorrecta per un altre pronom.

La influència del castellà, que no té aquests pronoms, fa que sovint apareguen omissions indegudes o substitucions incorrectes. Les errades més freqüents són les següents:

- Ús d'un pronom personal fort en lloc dels pronoms febles en o hi. Si bé és correcte usar el pronom fort en complements que es refereixen a persones, és millor usar els pronoms corresponents. En canvi, quan els pronoms forts 
no es refereixen a persones solen ser incorrectes i cal substituir-los pels pronoms febles corresponents.

[38] Un arquitecte no pot superar la mort de la seua dona. Un dia coneix unes persones que poden posar-lo en contacte amb ella.

[39] Un arquitecte no pot superar la mort de la seua dona. Un dia coneix unes persones que l'hi poden posar en contacte.

[40] La noia, maltractada i violada repetidament pel seu pare, acaba tenint un fill d'ell.

[41] La noia, maltractada i violada repetidament pel seu pare, acaba tenint-ne un fill.

[42] *El reportatge mostra la crisi del país asiàtic. En ell intervenen diversos experts que justifiquen per què no es va poder evitar l'accident.

[43] El reportatge mostra la crisi del país asiàtic. Hi intervenen diversos experts que justifiquen per què no es va poder evitar l'accident.

- Ús de $l i$ en comptes de $h i$ i ús de $e l$, la, els, les (CD determinat) en comptes de en. També, de vegades, s'utilitza erròniament $l i$ en lloc de en (amb el verb dir).

[44] *El mateix director del museu va recordar que durant l'any passat li van haver d'aportar més de 600.000 euros per mantenir-lo obert.

[45] El mateix director del museu va recordar que durant l'any passat hi van haver d'aportar més de 600.000 euros per mantenir-lo obert.

[46] *Bossa no portava monedes a les butxaques i, si les portava, era per fer algun joc de màgia.

[47] Brossa no portava monedes a les butxaques i, si en portava, era per fer algun joc de màgia.

[48] *Aquesta marató, monòleg, soliloqui, o com li vulgueu dir, és una absoluta bogeria.

[49] Aquesta marató, monòleg, soliloqui, o com en vulgueu dir, és una absoluta bogeria.

- Omissió del pronom adverbial hi quan substitueix complements preposicionals o circumstancials introduïts per les preposicions $a$, en, amb, per i sense, en el verb haver-hi, en els verbs de percepció i en altres verbs que matisen o canvien el significat.

[50] *Morfí Grei va oficiar un punk sinistre a Sidecar. En els bisos van desfilar els espectres de la Banda Trapera del Río.

[51] Morfí Grei va oficiar un punk sinistre a Sidecar. En els bisos hi van desfilar els espectres de la Banda Trapera del Río.

[52] *Abans havia gent que netejava les voreres de les carreteres.

[53] Abans hi havia gent que netejava les voreres de les carreteres.

- Omissió del pronom en quan substitueix el complement directe indeterminat (sentit partitiu), quan substitueix complements preposicionals o circumstancials introduïts per la preposició de, en el verb anar-se'n i amb altres verbs que van amb aquest pronom (saber-ne, tenir-ne prou, treure'n...). 
[54] *Quan hi havia més població, passava un tren cada hora. Ara només passen dos al dia.

[55] Quan hi havia més població, passava un tren cada hora. Ara només en passen dos al dia.

[56] *No volem dir que de les activitats programades, no es faça cap.

[57] No volem dir que de les activitats programades, no se'n faça cap.

[58] *De moment, girà vela i s'anà.

[59] De moment, girà vela i se n'anà.

g) Presència indeguda dels pronoms en i hi i ús del pronom en amb un valor possessiu.

Si els complements que poden representar els pronoms en i hi ja apareixen explícitament en la frase, els pronoms no són necessaris i, per tant, cal eliminar-los. Aquest error és molt freqüent amb el verb haver-hi.

[60] *N'hi ha molts escriptors en castellà que veuen el Ramon Llull com una amenaça.

[61] Hi ha molts escriptors en castellà que veuen el Ramon Llull com una amenaça. [62] *És un tema del qual se n'ha exagerat força.

[63] És un tema del qual s'ha exagerat força.

[64] *Parlava d'un lloc comú on hi tornaven moltes versions.

[65] Parlava d'un lloc comú on tornaven moltes versions.

D'altra banda, el pronom en pot tenir un sentit possessiu, quan significa pertinença o especificació. Per referir-se a un ésser inanimat que no és el subjecte de l'oració és més correcte usar en que no pas el possessiu, però hi ha casos en què l'ús d'en resulta molt forçat o és clarament incorrecte. Evidentment, és incorrecte usar alhora el pronom i el possessiu, com es pot comprovar en l'exemple [68].

[66] Han fet arribar el projecte al supervisor, que ara estudiarà el seu contingut. [67] Han fet arribar el projecte al supervisor, que ara n'estudiarà el contingut. [68] *Han fet arribar el projecte al supervisor, que ara n'estudiarà el seu contingut.

h) Repetició de pronoms.

De vegades, en una frase hi ha alhora un complement, explícit o representat per un pronom fort, i, a més, el pronom feble corresponent. En aquests casos, en general, són correctes les repeticions quan es tracta de pronoms de primera o de segona persona, però són poc recomanables, i sovint incorrectes, les repeticions dels pronoms de tercera persona. Malgrat això, alguns verbs admeten, o demanen, la repetició del pronom de CI ( $l i, e l s)$. Finalment, en alguns casos, la repetició pronominal pot ser deguda a una intenció emfàtica i, en aquestes ocasions, cal o es pot marcar amb els signes de puntuació.

[69] *El premi no els ha semblat oportunista als lectors de Murakami. [70] El premi no els ha semblat oportunista, als lectors de Murakami. 
[71] *Encara no sap com s'ho ha de prendre això.

[72] Encara no sap com s'ha de prendre això.

[73] Encara no sap com s'ho ha de prendre, això.

\subsubsection{L'el·lipsi o anàfora zero}

L'el-lipsi o anàfora zero és un procediment de cohesió que alterna amb la pronominalització. És possible gràcies a l'aplicació del principi de manteniment de la referència i és un recurs fonamental d'economia discursiva. Quan un element és conegut pel context lingüístic, pot pronominalitzar-se -mantenint així les característiques gramaticals per mitjà d'una forma més reduïda-o elidir-se -mantenint només el significat sense cap repetició formal. Com a afirma Maria Josep Cuenca, l'el·lipsi es pot entendre com una anàfora zero, és a dir, «com una pronominalització en què el pronom no té manifestació fonètica, més enllà d'una pausa en alguns casos» (Cuenca, 2008: 72-73) Tots dos procediments, com es pot veure en els exemples següents, eviten la repetició innecessària dels tòpics i fan els textos més llegibles i la redacció més natural.

\section{DIMARTS, 25/03/2008 - 06:00h \\ L'Asus eee, un ordinador d'un pam}

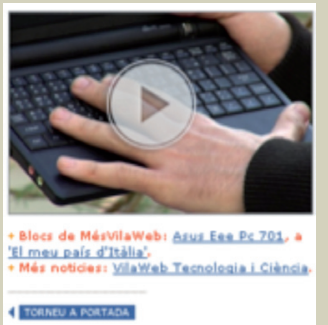

VilaWeb tv us ofereix un vídeo d'un dels ordinadors més petits i barats del mercat

Un dels ordinadors que ha causat més sensació últimament en l'àmbit de la informàtica és l'Asus eee PC:

Ono té el processador més avançat, ni un disc dur de gran capacitat, però, en canvi, si que és un dels més petits i més barats del mercat.

En aquest vídeo de VilaWeb tv podeu comprovar que $\emptyset$ tan solament fa un pam d'amplada, les caracteristiques principals que té i per què s'ha fet: per treballar o connectar-se a Internet des de qualsevol lloc.

L'Asus eee, que solament es pot comprar a la Catalunya del Nord o fora del país, ha aconseguit força ressò entre els blocaires. Els $\emptyset$ més barats costen uns 240 euros, però funcionen igual que la majoria de portàtils, malgrat el preu i les dimensions. De sèrie, $\emptyset$ porten instal·lada una distribució del sistema operatiu GNu/Linux Debian adaptada a aquest ordinador, però se $n$ 'hi poden instal·lar algunes altres de Linux, i fins i tot els sistemes Windows o MacOS X. La comunitat internacional d'usuaris d'aquest aparell, que ha crescut notablement, ha obert fòrums com eeeUser, en què s'intercanvien consells i guies de tota mena.

Una de les característiques principals d'aquest ordinador és que no va amb disc dur, sinó amb ssD ('Solid State Disc'), una memòria flaix similar a la de les càmeres de fotografia o a la uSB. L'ordinador perd capacitat d'emmagatzematge (no pot excedir els $8 \mathrm{~GB}$ ), però s'engega més ràpidament i gasta menys. El baix preu d'Asus també ha obligat a prescindir de components de tecnologia punta, més barats, però ben útils. $\emptyset$ És, doncs, una eina destinada als qui volen estar sempre connectats sense haver de traginar pes ni embalum.

http://www.vilaweb.cat/www/noticia?p_idcmp=2787480 
En el titular s'introdueix ja el tòpic de la notícia (l'Asus eee Pc 701), que es reprèn posteriorment amb expressions més o menys equivalents (un ordinador d'un pam, aquest ordinador, aquest aparell, l'ordinador o Asus), subratllades en el text, o amb algunes pronominalitzacions (que, n'hi). Però, com que el tòpic es manté al llarg del text, ja en el primer paràgraf comencen a introduir-se oracions amb l'el-lipsi d'aquest element, i el recurs es manté al llarg de tota la notícia. Així, com es pot observar, s'agilitza la lectura sense que se'n veja afectada la comprensió. Fins i tot en alguna oració com la següent, la redacció semblaria més natural sense la repetició lèxica:

[74] De sèrie, $\varnothing$ porten instal·lada una distribució del sistema operatiu GNU/ Linux Debian adaptada a aquest ordinador.

En les llengües de subjecte buit, com ara el català, l'elisió del subjecte és gairebé obligatòria quan es tracta d'un subjecte pronominal amb l'antecedent fàcilment accessible, clarament interpretable pel context lingüístic. Observeu aquests textos publicitaris:

[75] Quan parla el llop, callen els anyells. Als $80 \varnothing$ va ser l'ovella negra. Als $90 \varnothing$ és el llop. Un llop solitari. «El lobo estepario». Sent-lo. Ø Pensa com tu. Ø Abans era un llop que somiava canviar el món. Ara és un llop estepari que lluita perquè aquest món no el canviï a ell. Escolta'l cada nit. La seva veu farà callar els anyells.

[76] Si qui condueix no està en el que ha d'estar. Si Ø ha begut. Ø No s'hi veu de son. $\mathrm{O} \varnothing$ va passat... $\varnothing$ Lleva-li les claus. La gran majoria d'accidents de trànsit són fàcilment evitables, sobretot si qui condueix no va sol i hi ha una efectiva conscienciació del grup per a la prevenció d'aquells. Només s'ha de fer prevaler la seguretat de tots i llevar-li les claus a qui, per una causa o una altra, no haja de conduir o no es trobe en condicions de fer-ho. Evita els accidents de trànsit. Tu tens la clau.

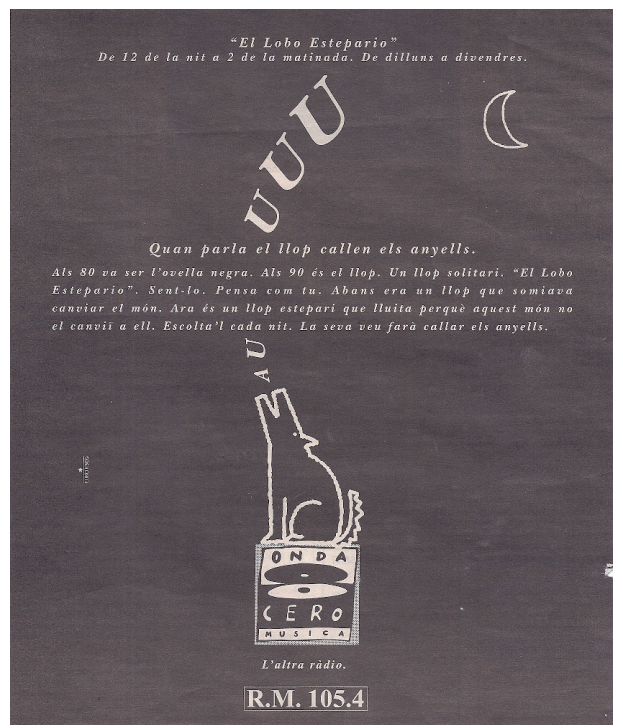

Fig. 58. Quan parla el llop... 


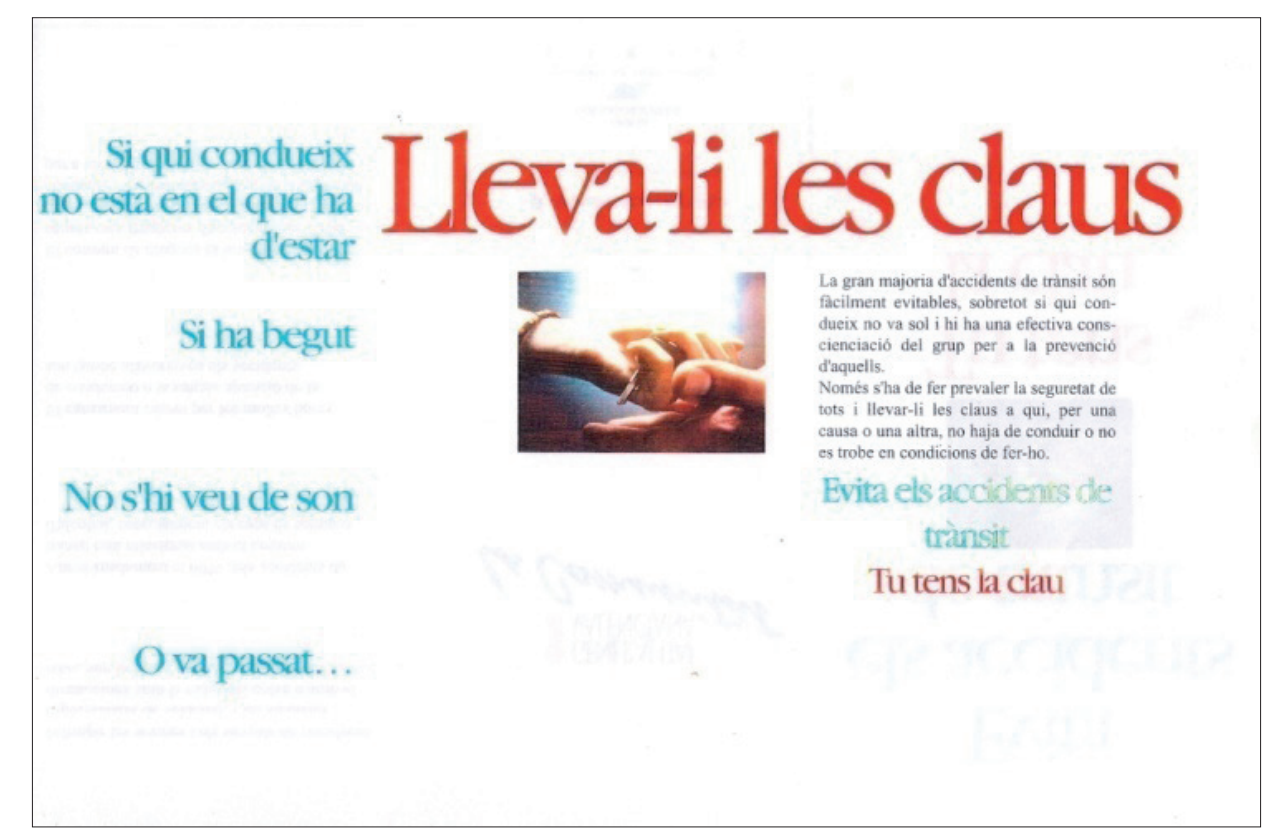

Fig. 59. Lleva-li les claus

En el primer cas, el referent és un conegut locutor de ràdio, i el títol del programa que presenta és identificat amb el nom de l'animal (el llop). Després d'un primer enunciat que té el caràcter sentenciós propi d'un aforisme, les dues primeres ellipsis tenen un referent extratextual (Jesús Quintero, el Loco de la Colina), però immediatament s'introdueix el títol del nou programa (El lobo estepario) i a partir d'aquí es complica la referència, perquè el pronom de la següent oració (Sent-lo) pot referir-se tant al presentador com al programa, ambigüitat que es manté en les el-lipsis i en les pronominalitzacions posteriors.

La primera part del text [76] té una estructura condicional, amb una sèrie de clàusules subordinades que introdueixen el tòpic (qui condueix) i preparen la segona part de la condicional, on el subjecte és el destinatari, que també apareix elidit $(t u)$. És interessant observar com es produeix l'el-lipsi del tòpic inicial en la segona frase (Si [qui condueix] ha begut) i com s'amplia l'abast de l'el-lipsi a la marca de condicionalitat en les següents ([Si qui condueix] no s'hi veu de son; O [si qui condueix] va passat...). També es pot observar l'errada de referència del pronom «aquells», que s'utilitza per evitar la repetició del sintagma «els accidents de trànsit» en lloc de la forma pròpia, el pronom feble «los», o de l'el·lipsi, que no resultaria gens forçada: «....sobretot si qui condueix no va sol o hi ha una efectiva conscienciació del grup per a la prevenció».

Aquesta extensió de l'el-lipsi a les formes verbals és molt freqüent en el discurs publicitari -i també en la redacció periodística-, com es pot observar en el text següent:

[77] LA TEUA TARGETA, Ø SEMPRE A LA CARTERA. Porta a la cartera la teua Targeta Sanitària. Perquè ja saps que has de presentar-la sempre per anar al metge... I ara també: Ø a la farmàcia. 
Observeu que en el titular, en majúscules, l'el·lisió del verb (ha d'anar / ha d'estar) s'ha marcat textualment amb l'ús de la coma, mentre que en la segona frase l'elisió del sintagma verbal (has de presentar-la sempre per anar) s'ha indicat amb un ús una mica atípic dels dos punts.

En definitiva, l'el-lipsi o anàfora zero és, en català, un recurs de cohesió fonamental que permet la represa de l'antecedent d'una forma natural, alternant amb els pronoms, sense haver de recórrer sistemàticament als mecanismes lèxics, entre els quals els més productius són, com veurem tot seguit, la repetició i la sinonímia.

\subsection{La referència lèxica}

\subsubsection{L'anàfora lèxica i les relacions de cohesió}

Com hem vist en els exemples anteriors, sovint la vinculació entre els diferents tòpics del discurs s'estableix mitjançant procediments de caràcter lèxic. Es tracta d'unitats lèxiques que funcionen d'una forma semblant als pronoms, ja que permeten establir relacions d'identitat referencial i de sentit o només relacions de sentit.

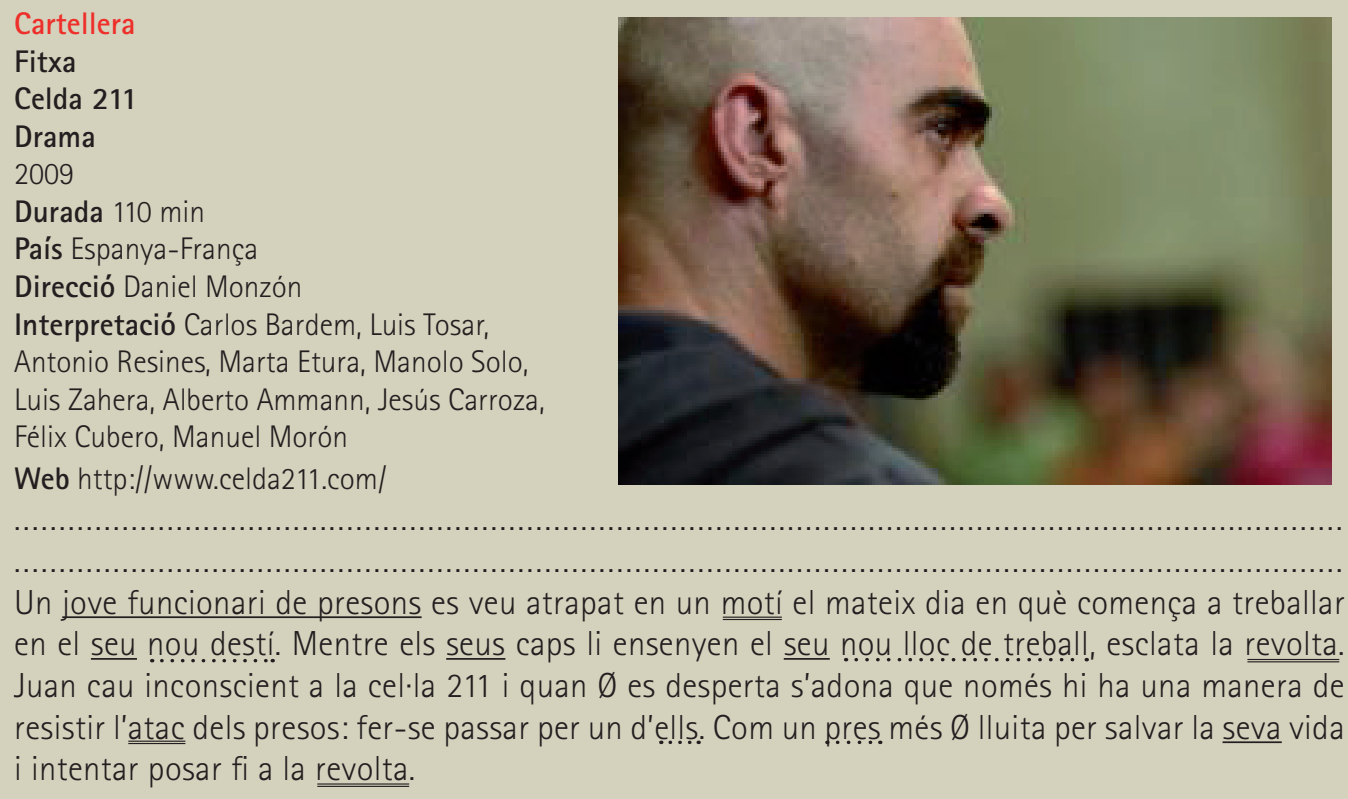

Un jove funcionari de presons es veu atrapat en un moti el mateix dia en què comença a treballar en el seu nou destí. Mentre els seus caps li ensenyen el seu nou lloc de trebal!! esclata la revolta. Juan cau inconscient a la cel·la 211 i quan $\emptyset$ es desperta s'adona que només hi ha una manera de resistir l'atac dels presos: fer-se passar per un d'ẹ!! S. Com un preș més $\emptyset$ Iluita per salvar la seva vida i intentar posar fi a la revolta.

L'argument de la pel-lícula està organitzat al voltant de dos nuclis temàtics o tòpics discursius fonamentals (el protagonista i la revolta), tot i que també emergeixen altres elements secundaris (el lloc de treball i els presos). El protagonista apareix textualitzat amb diferents anàfores gramaticals (el-lipsis i possessius) i amb una anàfora lèxica (un jove funcionari de presons, Juan), mentre que la represa de la sublevació es produeix utilitzant diferents mecanismes de cohesió lèxica: 
a) la repetició (revolta, presos),

b) la reiteració mitjançant la sinonímia (revolta, motí, atac dels presos), i

c) l'associació de paraules que mantenen una relació de caràcter enciclopèdic, ja que remeten a l'àmbit de la violència (atrapat, motí, esclata la revolta, cau inconscient, resistir, atac, lluita).

Maria Josep Cuenca (2008: 77) presenta un esquema de conjunt de les relacions de cohesió lèxica en què es poden observar les diferències entre els tres procediments essencials. En aquest esquema, que reproduïm amb alguna petita adaptació, l'element o elements en negreta són idèntics entre A (l'antecedent) i B (l'element de referència).
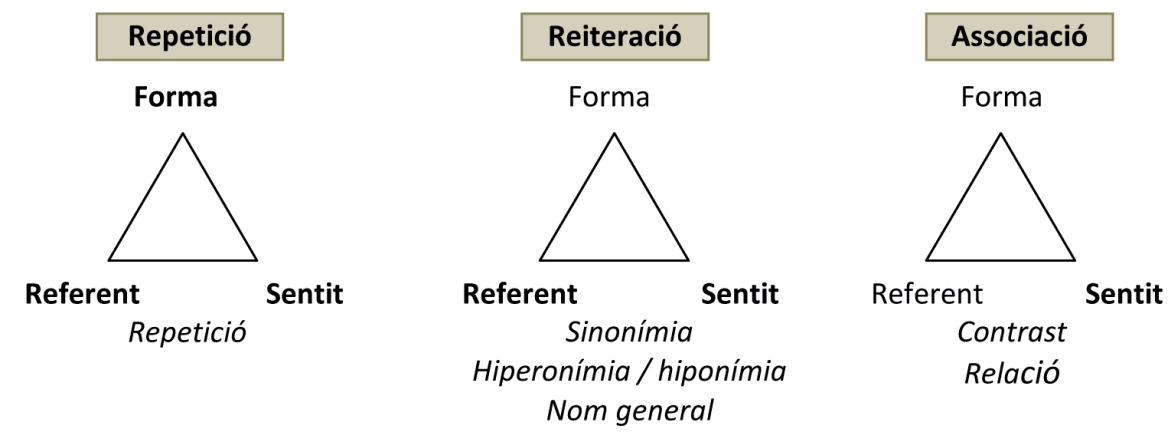

Fig. 60. Relacions de cohesió lèxica

\subsubsection{Repetició i reiteració}

La repetició implica una coincidència total de referent, sentit i forma entre l'antecedent i la marca de referència, com es pot observar en el text [78], tot i que, de vegades, per tal de diversificar l'expressivitat, s'utilitza la repetició parcial, que permet, per exemple, referir-se al protagonista d'una notícia amb el nom complet o només amb el cognom o amb el nom propi, com passa en el text [79]:

[78] L'Avui posa a l'abast dels seus lectors la càmera Mouvicam, dissenyada per a l'enregistrament d'activitats esportives amb so directe i imatge d'alta definició. Una càmera per a esportistes. L'Avui posa a l'abast dels seus lectors la càmera Mouvicam, pensada per als esportistes, que permet l'enregistrament de tota mena d'activitats amb so directe i imatge en alta definició. $L a$ càmera Mouvicam, que té un preu al mercat de 95 euros, arriba als lectors de l'Avui al preu de 55 euros, als quals cal adjuntar la corresponent cartilla omplerta amb el seguit de cupons que s'inclouran al diari. La cartilla es distribuirà diumenge vinent, 15 de novembre. La càmera Mouvicam, que es pot descriure com una videocàmera mòbil d'alta definició i que té un disseny que la fa apta per al seu ús mentre es duen a terme tota mena d'activitats dinàmiques, demostra la seva potencialitat i la seva versatilitat en aspectes com ara el seu pes, que es redueix a uns imperceptibles 98 grams (Avui, 8 de novembre de 2009). 
[79] Obama planta Merkel i no anirà als actes de celebració. Barack Obama ha declinat la invitació de Merkel i no serà demà a Berlín, contràriament a Gorbatxov i Medviédiev. El president dels EuA emprèn dimecres una gira per Àsia. (Avui, 8 de novembre de 2009).

Malgrat la potencialitat que ofereix la repetició parcial -que en el text [78] permet, per exemple referir-se a la càmera Mouvicam amb denominacions com ara la nova càmera o la Mouvicam-, la repetició estricta en oracions consecutives o molt properes no sol ser una bona solució, especialment en els gèneres formals. En aquests casos, és molt habitual reiterar el sentit i el referent utilitzant una forma diferent, és a dir, utilitzant un sinònim estricte, un hiperònim o un hipònim de l'antecedent.

La reiteració sinonímica permet, per exemple, diversificar la redacció i evitar la repetició del mot pel-lícula en el text que hem comentat en parlar de l'anàfora gramatical (vegeu l'apartat 7.4, ps. 213-214).

A l'hora de buscar una expressió equivalent del substantiu pel·lícula es pot recórrer, per tant, a sinònims estrictes (film, cinta), a hiperònims o mots d'abast més general que inclouen l'antecedent (obra, producció, treball), a hipònims o mots de significat més restringit (documental, melodrama, comèdia) i a expressions que s'hi identifiquen ocasionalment (bobina, troballa, filmació o regal insòlit). D'una forma similar, en l'exemple [80] es fa referència al llibre amb el títol, amb els sinònims volum i obra i amb l'expressió metonímica aquest títol.

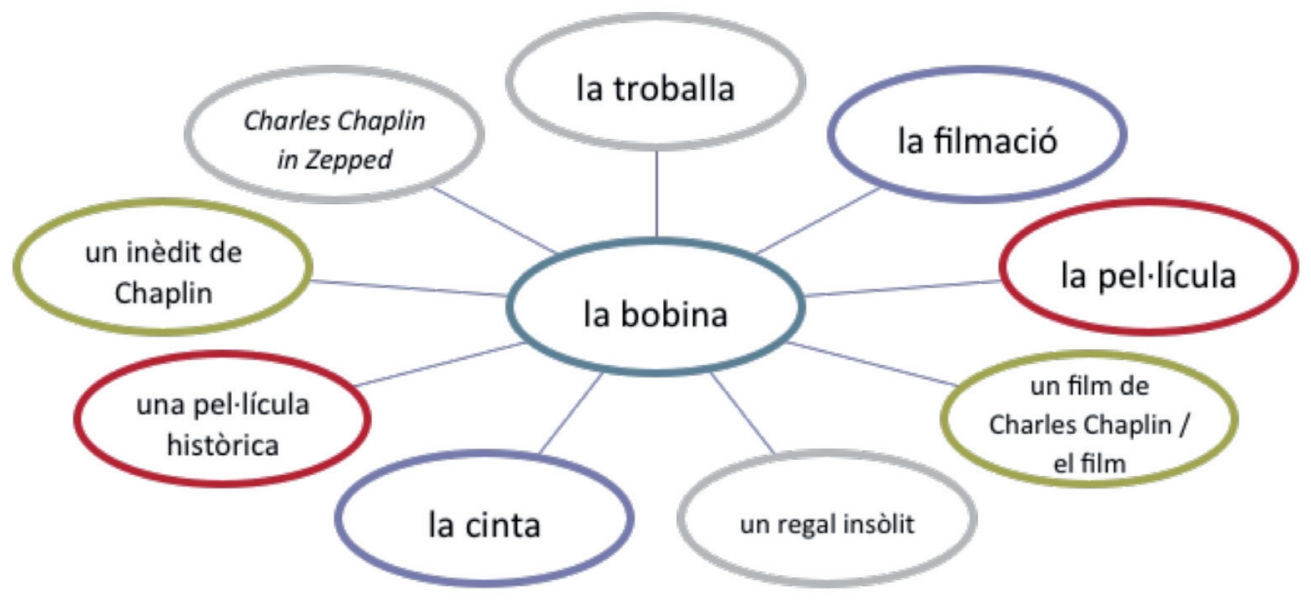

Fig. 61. La reiteració sinonímica en una notícia de premsa

[80] Joan Francesc Mira ha presentat a València Vida i final dels moriscos valencians, un volum de gran format en el qual ens convida a conéixer un fet clau en la nostra història, l'expulsió dels moriscos, ara que es compleixen quatre segles de la promulgació del decret. L'obra, que també s'ha publicat en castellà, s'ha presentat a la Sala de la Muralla del Col·legi Major Rector Peset, on es conserva un llenç de la muralla islàmica del 
segle XI, un dels escassos vestigis del passat àrab de València que encara perduren en la ciutat. Mira ha destacat que aquest títol «forma part del meu compromís cívic» per tal de posar a disposició del públic la perspectiva històrica d'un fet que la majoria de la societat desconeix (http:// www.bromera.com/).

\subsubsection{Associació}

Finalment, l'associació lèxica permet relacionar una sèrie de mots més enllà de la represa de referents. Es tracta de paraules que es relacionen pel seu significat, que formen part d'un mateix camp lèxic o d'un camp semàntic, encara que no identifiquen un referent unitari. Aquest tipus de referència, com subratlla Maria Josep Cuenca, «comporta únicament una relació de sentit, ja que la forma dels elements és diferent, i també els referents» (Cuenca, 2008: 82). En realitat, l'única relació que s'estableix es troba a nivell del significat lèxic i pragmàtic dels elements. En la notícia següent, per exemple, apareixen una sèrie d'unitats lèxiques de l'àmbit de la comunicació audiovisual que resulten ben familiars per a qualsevol lector contemporani.

\footnotetext{
lamalla.cat > Digitals

06/11/2009 06:00h | Actualitzat 05/11/2009 15:53h

\section{Apple estudia oferir televisió de pagament a través d'iTunes}

La companyia està negociant amb les cadenes per signar un conveni

ANAÏS LOPEZ

La popular companyia nord-americana Apple podria oferir televisió a través d'iTunes a un preu d'uns 30 dòlars mensuals. Ara per ara, l'empresa està sondejant les diferents cadenes de televisió per comprovar si estarien disposades a signar un acord. Per tal de no condicionar aquest servei a un hardware específic, la companyia de la poma oferiria aquest servei a través del seu software multimèdia iTunes, que actualment fan servir 100 milions d'usuaris.

Aquest servei seria un rival directe dels operadors de televisió per cable. No obstant, la materialització d'aquest projecte està condicionada als possibles acords que Apple pugui arribar a signar amb les televisions. Segons algunes dades, la companyia té la intenció de posar en marxa el servei a principis de 2010, tot i que de moment no s'ha signat cap acord amb les cadenes.
} 


\section{Disney, la més receptiva}

Bob Iger, director executiu de Disney, ha mostrat una gran predisposició per tancar acords amb Apple. L'any 2005, Disney va experimentar a iTunes venent pel-lícules a la carta a través del software.

Un punt problemàtic és el de les audiències. Tot i que els programes de les televisions estiguessin disponibles a iTunes després d'haver estat emesos en les cadenes d'origen, el número d'espectadors que ho veuen a través de la televisió convencional baixaria i això repercutiria en els ingressos publicitaris de les cadenes de televisió.

http://www.lamalla.cat/digitals/article?id=306028

Com es pot comprovar, en el text hi ha una gran densitat d'expressions que fan referència al món audiovisual: televisió de pagament, iTunes, cadenes de televisió, aquest servei, software multimèdia, operadors de televisió per cable, televisions, Disney, Apple, pel-lícules a la carta, programes, espectadors, ingressos publicitaris i cadenes de televisió. També s'hi poden detectar alguns substantius i diverses formes verbals que remeten a l'àmbit de l'empresa i les relacions comercials: oferir, companyia, signar un conveni, preu, l'empresa, rival directe, posar en marxa el servei, predisposició per tancar acords i ingressos publicitaris.

Es tracta de paraules que, si bé no mantenen entre si relacions d'identitat referencial, «es relacionen pel seu significat $i$ ens remeten a un àmbit que forma part de la nostra «enciclopèdia» col·lectiva, és a dir, els coneixements del món que compartim» (Cuenca, 2008: 82).

L'associació lèxica es manifesta en el discurs de formes molt diverses, una de les quals és el concepte de marc o frame, que ha desenvolupat la lingüística cognitiva a partir dels treballs inicials de Charles Fillmore. Una de les idees centrals del cognitivisme és que les paraules evoquen marcs o «estructures mentals que donen forma a la manera com veiem el món» (Lakoff, 2004: 11). Un marc és un conjunt d'associacions o estructures mentals integrades per conceptes, personatges, idees, relacions i valors que constitueixen punts de vista o visions del món més o menys estereotipades.

Un dels descobriments fonamentals de les ciències cognitives és que les persones pensen en termes de marcs i de metàfores, estructures conceptuals com les que hem descrites. Els marcs estan impresos en les sinapsis del nostre cervell, físicament presents en forma de circuits neuronals. Quan els fets no concorden amb els marcs, es conserven els marcs i s'ignoren els fets.

Lakoff, 2004: 99

Així, per exemple, la interpretació de l'eslògan reproduït en el text [81] exigeix l'activació d'un marc compartit per la cultura juvenil actual que està integrat, entre d'altres, pels elements següents: joventut, cap de setmana, festa, diversió, alcohol, alegria, hàbits de vida nocturns, cotxes, carretera, sales de festa, lligar, gitar-se molt tard, riure, passar-ho bé, etc. 
[81] Desperta. És de nit. Larios.

Els marcs tenen una gran importància en el discurs polític, perquè constitueixen una estratègia fonamental per a la transmissió de punts de vista sobre la realitat. Així, per exemple, per a la campanya de les eleccions europees del 2009, el PSOE, en el govern des del 2004, va emetre el famós vídeo dels brots verds per activar un marc que presentava la recuperació econòmica com una fràgil planteta que, malgrat la hostilitat del terreny, començava a créixer d'una forma ostensible. Paral·lelament, el discurs dels membres del govern va reforçar aquesta idea, que va arribar als titulars de la premsa:

[82] Salgado augura los primeros 'brotes verdes' «en unas semanas» (El País, 20 de maig de 2009).

Amb aquesta expressió s'activa un marc integrat per elements que transmeten vitalitat i recuperació: primavera, vegetació, color verd, retorn del cicle vital després de la duresa de l'hivern, sol, bon temps, preludi de l'estiu i de la tardor, creixement, vitalitat, optimisme... No cal dir que aquesta visió optimista va ser immediatament contestada per l'oposició, que va presentar un marc alternatiu, molt crític amb la situació econòmica, de la qual es feia directament responsable al govern:

[83] El secretario de Comunicación del pP de Madrid, Juan José Güemes, aseguró hoy que «da la impresión de que los brotes verdes» de la vicepresidenta económica, Elena Salgado, «son de marihuana y se los ha fumado el Gobierno» de José Luis Rodríguez Zapatero» (Europa Press, 2 de juny de 2009).

És evident que la rèplica del Conseller de Sanitat de la Comunitat de Madrid introdueix una perspectiva humorística sobre els brotets verds amb l'objectiu de deslegitimar la visió del govern i activar un marc cognitiu diferent, el marc de les drogues i els efectes en els consumidors. Unes setmanes abans el líder del PP, Mariano Rajoy, va referir-se en el debat parlamentari a la situació política i econòmica i a l'actuació del govern amb una expressió que posava l'èmfasi en un marc també ben transparent:

[84] Rajoy dice que «vamos hacia el abismo» y el FMI lo confirma (El Mundo, 23 d'abril de 2009).

Com es pot comprovar, mentre que el marc utilitzat pel partit del govern intenta transmetre la idea que l'evolució econòmica és un procés similar al cicle vital, un procés «natural»-i en aquest sentit, l'ús de la música de Vivaldi no és una elecció gratuïta-, el marc que proposa el partit de l'oposició activa una visió catastrofista de la situació, de la qual fa responsable al govern, i, amb l'ús de la primera persona del plural, subratlla la implicació col·lectiva en el desastre. 


\section{Lectures recomanades}

Cassany, Daniel (2007): Esmolar l'eina, Barcelona, Empúries.

Cuenca, Maria Josep (2008): Gramàtica del text, Alzira, Bromera.

FERrer, Montserrat (2004): Els pronoms febles, València, Tàndem (13a ed.).

LAKoff, George (2004): Don't Think of an Elephant! Know Your Values and Frame the Debate, Cambridge, Polity Press [No pensis en un elefant. Llenguatge $i$ debat politic, Barcelona, Viena, 2008].

MAciÀ, Jaume (1992): Faci'ls fàcils, els pronoms febles, Barcelona, Teide [el mètode inclou un programa informàtic, en disquet].

Peraire, Joan (2009): «Darwin i la teoria de l'evolució en la publicitat contemporània», Ribalta, 15 , p. 139-155.

— (2012): «L'argumentació publicitària: les paraules del desig», Articles, 58, ps. $57-70$. 


\section{TEMA 8}

\section{La connexió i els connectors}

Introducció

1. La connexió: concepte i tipus

2. La connexió oracional i les conjuncions

3. La connexió textual

4. Connexió pragmàtica i marcadors del discurs

5. Remarques sobre l'ús d'alguns connectors

6. Connexió textual i escriptura

Lectures recomanades 


\section{Introducció}

Els connectors són una de les categories més diverses i més conflictives de la lingüística textual i també una de les aportacions més interessants per a l'estudi del discurs. Entre les diverses disciplines que s'ocupen de l'estudi dels connectors no hi ha unanimitat ni en les denominacions ni en les classificacions proposades. Els conceptes de connectors, marcadors i organitzadors textuals (i alguns altres termes similars) cobreixen sovint realitats superposades i de fronteres boiroses. Sovint el terme connector s'utilitza per referir-se a aquest tipus d'unitats, altament gramaticalitzades, que són elements d'enllaç oracional i sovint es troben a la zona limítrof entre l'oració i el text. Tot i això, alguns estudiosos s'estimen més designar aquestes unitats amb el terme marcador i incloure-hi unitats molt poc gramaticalitzades i amb una funció modalitzadora, que marca la posició de l'enunciador, al marge de la connectiva: conjuncions, interjeccions, sintagmes preposicionals $i$ expressions diverses.

És evident que bona part del problema terminològic té les arrels en la diversitat de perspectives d'enfocament del tema (gramaticals o discursives) i de línies d'investigació (l'anàlisi de la conversa, la teoria de l'argumentació o la teoria de la rellevància) i en la mateixa diversitat textual (textos escrits, interaccions orals, gèneres textuals diversos). Ara bé, tot i aquesta complexitat, una de les fonts del problema ha estat i és la confusió entre les nocions de categoria gramatical i funció. Des d'una perspectiva cognitivista, s'imposa la necessitat de distingir, d'una banda, entre les diverses categories gramaticals que poden realitzar una funció connectiva (conjuncions, nexes, interjeccions...) i, de l'altra, entre els diversos tipus de connexió.

En aquest tema es presenta una visió de conjunt del fenomen de la connexió i els criteris per identificar i caracteritzar els diversos tipus de connectors. En primer lloc, s'analitza el concepte de connexió i es presenta una proposta de classificació d'aquest procediment de cohesió textual. En la part central de la unitat s'analitzen els diferents tipus de connexió (oracional, textual i pragmàtica) i es presenta una proposta de classificació de les unitats que realitzen aquestes funcions (conjuncions, connectors parentètics i marcadors discursius). Finalment, s'ofereixen una sèrie de remarques sobre els connectors que, en català, presenten algunes dificultats, i se'n clarifica la normativa que en regula l'ús. 


\subsection{La connexió: concepte i tipus}

\subsubsection{El concepte de connexió}

La connexió és un procediment que consisteix a relacionar dues o més unitats contigües A i B (sintagmes, clàusules, oracions o esdeveniments contextuals) mitjançant un element lingüístic $\mathrm{C}$ (el connector). Els connectors adquireixen sentit a partir d'aquesta relació entre les unitats connectades o per la relació entre aquestes i el coneixement del món dels interlocutors.

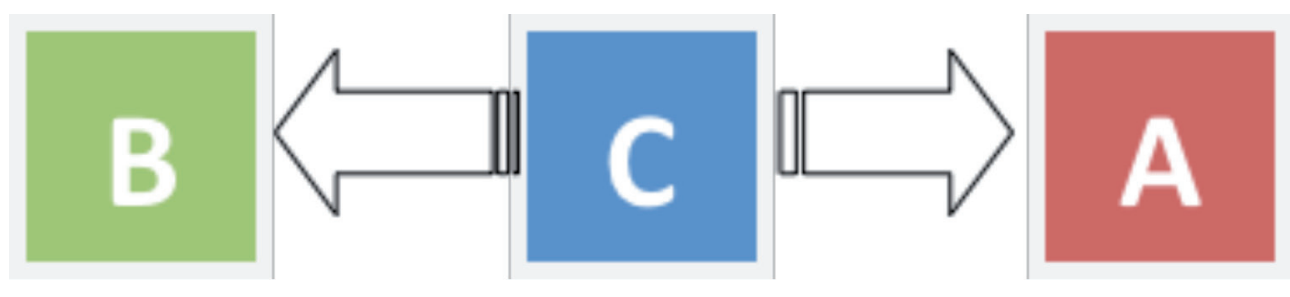

Fig. 62. El concepte de connexió

En els exemples següents es pot observar que les unitats en cursiva fan aquesta funció d'enllaç entre dues unitats. De vegades, les dues unitats connectades són clàusules, és a dir, unitats oracionals que en unir-se constitueixen una oració composta (com ara les quatre primeres). Com es pot comprovar, el connector es pot situar entre les dues unitats connectades -com ara en [1] i [2]- o en posició inicial -en [3] i [4]. Semànticament, les tres primeres oracions són equivalents $\mathrm{i}$ expressen la mateixa relació de causa-conseqüència. En canvi, l'oració [4] connecta dues idees entre les quals existeix una certa relació de contrast o d'oposició semàntica $i$, per tant, té un sentit oposat a les anteriors.

[1] La Maria aprovarà, perquè ha estudiat molt.

[2] La Maria ha estudiat molt i, per tant, aprovarà.

[3] Com que ha estudiat molt, la Maria aprovarà.

[4] Tot i que he estudiat de valent, no sé si podré aprovar.

En altres casos, però, els connectors se situen al començament d'una oració o presenten mobilitat oracional [5] i uneixen dues oracions més o menys autònomes. En aquests casos es parla de connexió textual [6] i de connexió pragmàtica [7].

[5] Així, el temps real coincideix amb el temps cinematogràfic, cosa que no passa en el muntatge, on es crea el temps cinematogràfic manipulant els temps reals i es crea, per tant, el temps del film. En definitiva, el pla seqüència és un pla sense muntar.

[6] A Gas Natural sabem que, quan acaba el dia, t'espera la llar. I és que milers de persones, a tot el món, treballem perquè tornar a casa siga el millor moment del dia.

[7] La força és encara un mitjà de persuasió. Ara, això sí: el més lent i el més fràgil dels coneguts (Joan Fuster). 
Els connectors tenen un paper fonamental en l'articulació del discurs oral i en la construcció de l'escrit, perquè permeten l'articulació de les idees i faciliten, per tant, el procés d'interpretació.

[8] [a] És un llibre amb molt de dinamisme. Ara bé, tot i que sí que [b] descriu l'entorn amb molta qualitat, [c] com a lector demanaria més temps per a la digestió, és a dir: [d] per estar ambientada en situacions reals, falta extensió. [e] Girona hi apareix com un lloc pintat amb pinzellades impressionistes, $i$ [f] els personatges, retratats amb una digital. De resultes d'això, [g] el llibre se'm fa curt. Joanet (Avui Cultura, 8 de maig de 2008, p. 2).

El text [8] és una breu ressenya de lectura, apareguda a la premsa, en què l'autor dóna el seu punt de vista sobre el llibre ('és un text que es llegeix molt bé') i aporta els arguments essencials per mantenir aquesta opinió ('té molt de dinamisme', 'bones descripcions', 'poca extensió', 'Girona es presenta com un lloc pintat' i 'els personatges semblen artificials'). Tot això, evidentment, d'una forma molt sintètica, ja que es tracta d'un text molt breu, i amb el suport d'una sèrie de connectors que il-lustren la successió de les idees, l'articulació del raonament i, per tant, el procés d'argumentació. Ens referim als marcadors de contrast ara bé, que indica una oposició entre la idea inicial $(a)$ i les idees que introdueix a continuació $(b, c$, $d$, e i f), i al consecutiu de resultes d'això, que tanca el text i presenta la idea final $(g)$ com una conseqüència lògica de totes les idees anteriors. El bloc central s'articula al voltant del connector concessiu tot $i$ que -que introdueix una restricció a la idea de contrast anunciada per ara bé (i, per tant, reforça d'una forma directa la idea inicial)-, de la reformulació que introdueix el connector és a dir i de la simple addició d'idees a través de l'ús de la conjunció $i$. I deixa en l'ambigüitat més o menys calculada la relació entre el bloc $b-c-d$ i el bloc $e-f$.

\subsubsection{Tipus de connexió}

\subsubsection{Formes, categories i funcions}

Des d'una perspectiva cognitiva, abans de parlar de tipus de connexió i de presentar una proposta de classificació dels connectors, és imprescindible de distingir entre tres conceptes que sovint es presten a confusions diverses: formes, categories i funcions. La relació entre aquestes tres variables, que sovint és complexa i depèn de factors diversos, s'ha simplificat d'una forma abusiva $i$ ha dut a considerar (almenys implícitament) que una forma determinada pertany a una categoria concreta i realitza una única funció.

És evident que una mateixa forma, per exemple ara, pot pertànyer a categories diferents (adverbi de temps, connector i marcador discursiu) i que pot realitzar funcions diverses (complement circumstancial de temps o connector pragmàtic), $\mathrm{o}$ que dues formes diferents, com ara que i sinó, que pertanyen a la mateixa categoria (conjuncions), realitzen una mateixa funció de connexió oracional. Per tant, és imprescindible distingir entre formes (o estructures), categories gramaticals (verb, 
conjunció, sintagma preposicional, interjecció, etc.) i funcions oracionals i textuals (complement del nom, complement del verb, connexió oracional, connexió textual, marcació discursiva, etc.).

\subsubsection{Tipus de connectors}

Entesa des d'una perspectiva funcional, la connexió és un mecanisme essencialment sintàctic que s'encarrega de relacionar dues unitats (clàusules, oracions o paràgrafs) a través d'un element que funciona com a nexe. Aquesta funció general es concreta en tres formes o tipus de connexió diferents: la connexió oracional (que origina les oracions compostes), la connexió textual (que relaciona les diferents parts del text entre elles) i la connexió pragmàtica (que relaciona el text amb el context situacional). Vegem-ho en paraules de Maria Josep Marín:

Així, considerem que la funció general de connexió conté tres subcomponents específics de funcions que es defineixen de la manera següent:

a) Funció connectiva intraoracional o connexió oracional, que es dóna dins de l'oració (relació estructural entre constituents oracionals).

b) Funció connectiva extraoracional no modalitzadora o connexió textual, que es dóna dins del text (relació text - context lingüístic).

c) Funció connectiva extraoracional modalitzadora o organització discursiva, que afecta el text i el context (relació text - context extralingüístic).

Marín, 1998: 222

Abans de presentar una classificació de les unitats que funcionen com a connectors és imprescindible tenir en compte que les tres funcions en què es concreta la connexió són exercides per un conjunt molt heterogeni de categories gramaticals i que sovint no hi ha una correspondència biunívoca entre formes, categories $\mathrm{i}$ funcions. Així, sovint una categoria pot realitzar més d'una funció, i una funció pot ser textualitzada amb diverses formes o categories. El quadre següent presenta un panorama global de la funció connectiva i relaciona les diverses subfuncions amb les categories gramaticals especialitzades en la funció de connexió. Per tal de facilitar-ne la lectura, en cada cas s'han marcat en cursiva els nexes prototípics.

\begin{tabular}{|c|c|c|c|c|c|}
\hline \multirow{2}{*}{$\begin{array}{l}\text { Tipus } \\
\text { de connexió }\end{array}$} & \multicolumn{2}{|c|}{ Característiques } & \multirow[b]{2}{*}{ Connectors } & \multicolumn{2}{|c|}{ Marques formals de la funció } \\
\hline & Abast & Modalització & & Gramaticals & $\begin{array}{l}\text { No gramaticals } \\
\text { Paralingüístiques }\end{array}$ \\
\hline Oracional & + intraor. & - modalitz. & $\begin{array}{l}\text { Connectors } \\
\text { dialèctics }\end{array}$ & $\begin{array}{l}\text { - conjuncions } \\
\text { - connectors parentètics }\end{array}$ & - connectors lèxics \\
\hline Textual & - intraor. & - modalitz. & $\begin{array}{l}\text { Connectors } \\
\text { textuals }\end{array}$ & $\begin{array}{l}\text { - connectors parentètics } \\
\text { - conjuncions }\end{array}$ & $\begin{array}{l}\text { - connectors lèxics } \\
\text { - signes gràfics }\end{array}$ \\
\hline Pragmàtica & - intraor. & + modalitz. & $\begin{array}{l}\text { Marcadors } \\
\text { discursius }\end{array}$ & $\begin{array}{l}\text { - interjeccions } \\
\text { - altres elements en procés } \\
\text { de gramaticalització }\end{array}$ & \\
\hline
\end{tabular}

Fig. 63. Tipus de connexió 
Les conjuncions o nexes primaris (que, ja que, però, $i$, o, perquè...) són els connectors per excel·lència de l'àmbit oracional, però algunes formes poden emprar-se també com a marcadors de connexió en el nivell textual. Són peces lèxiques morfològicament invariables que constitueixen una sèrie tancada i, semànticament, tenen un significat gramatical o lexicogramatical vinculat al valor connectiu. Es defineixen per la capacitat que tenen d'introduir clàusules i, per tant, per formar oracions compostes. Segons la relació estructural que introdueixen, les conjuncions o locucions conjuntives s'agrupen en tres grans classes: conjuncions de coordinació, conjuncions de subordinació i conjuncions d'interordinació.

Les conjuncions de coordinació «són paraules o locucions que marquen una relació d'equivalència entre els elements units» (Cuenca, 2006: 46), que són equivalents a un element simple de la mateixa naturalesa funcional (oració [9]). Les conjuncions pròpiament coordinants són les copulatives $(i, n i$, tant... com, etc.) i les disjuntives (o, o bé, ara... ara, etc.). Les conjuncions de subordinació, per contra, «manifesten una relació de dependència entre la clàusula que introdueixen i la resta de l'oració» (Cuenca, 2006: 47). Aquesta relació és igual a la que s'estableix entre un sintagma i el constituent del qual depèn, i es concreta en tres tipus diferents: la subordinació substantiva, l'adjectiva i l'adverbial (vegeu les oracions [10] i [11]). El nexe de subordinació bàsic és la conjunció que, tot i que també poden fer aquesta funció la interrogativa si, alguns nexes de temps, lloc i manera (segons, com, mentre, quan, on, etc.) i els pronoms relatius (que, què, el qual, la qual cosa...) i interrogatius (què, quins...). Finalment, les conjuncions d'interordinació indiquen una relació d'interdependència entre dues clàusules o dos sintagmes (exemples [12], [13] i [14]). Integren aquest grup les conjuncions adversatives (però, sinó, etc.) i les denominades tradicionalment adverbials no circumstancials: concessives, condicionals, finals, causals, consecutives i comparatives. Les conjuncions que poden funcionar com a connectors textuals ( $i, o$, però i, més rarament, perquè) solen situar-se en posició inicial de l'oració (vegeu l'exemple [15]).

[9] Poc temps després, Bac de Roda va ser traït per un conegut seu $i$ va ser penjat sense cap procés a Vic el dia 2 de novembre del 1713 (Sàpiens, 48: 56).

[10] Un equip del Clínic prova que Carles V patia de gota (Sàpiens, 48: 7).

[11] S'hi pot veure un audiovisual que fa una presentació de la ciutat a partir del relat de l'emperador Adrià quan aquest hi va viure un hivern del segle II $\mathrm{dC}$ (Sàpiens, 48: 61).

[12] Tenir un domicili propi, comprat o de lloguer, és condició necessària perquè hom sigui considerat ciutadà (Sàpiens, 48: 44).

[13] La cronologia d'Amarna no es pot establir amb exactitud perquè els seus successors van esborrar-la, literalment, de la memòria històrica (Sàpiens, 48: 25).

[14] Del final de Nefertiti, no en sabem res (ni la data, ni el lloc, ni les circumstàncies), però les possibilitats són realment extraordinàries (Sàpiens, 46: 25).

[15] L'existència d'aquesta gran ciutat, que va arribar a tenir més de vint mil habitants, va ser efímera. Mort el faraó, va ser sistemàticament desmantellada pels seus successors. Però en temps de Nefertiti sabem que allà la vida reial va arribar a gaudir d'un gran refinament (Sàpiens, 48: 24). 
Els connectors parentètics o nexes secundaris són resultat d'un procés de gramaticalització o fixació estructural de diferents sintagmes preposicionals o adverbials.

En conclusió, podem definir els connectors parentètics com les paraules o locucions invariables que indiquen enllaç connectiu i es caracteritzen pels trets sintàctics següents: caràcter parentètic des del punt de vista entonatiu i sintàctic, possibilitat de concurrència amb conjuncions, mobilitat posicional i capacitat generalitzada d'unir en el nivell oracional i en el textual.

Cuenca, 2006: 61

Des del punt de vista formal, els connectors parentètics són sintagmes preposicionals (a continuació, al capdavall, al contrari, d'entrada, de totes maneres, en canvi, en general, en tot cas, per començar, per cert, per tant, per exemple, amb tot...), adverbis (finalment, certament, ara bé, si més no, almenys, més aviat, així, llavors...), estructures que contenen formes verbals no personals (no obstant això, ben mirat, millor dit, fet $i$ fet...) o conjugades (és a dir, o siga, vaja, posem per cas...) i altres unitats complexes (a més, tot $i$ així, malgrat tot, així doncs, tanmateix, total, doncs, però...).

Les interjeccions són paraules i expressions que, de vegades, poden tenir una funció connectiva, especialment en la llengua oral, i, a més, una funció pragmàtica que permet establir lligams entre el text i el context situacional. Així, mots com eh?, oi?, home! (o dona!), bé, uf!, vaja! o mira! s'utilitzen per establir relacions de diversos tipus entre l'emissor i el receptor o entre l'emissor i el seu discurs.

Els connectors lèxics són elements lèxics plens (noms, adjectius, verbs, sintagmes o frases) que poden realitzar una funció connectiva entre les parts del text, però, alhora, poden realitzar també una funció sintàctica intraoracional (subjecte, complement...). Són elements que no s'han gramaticalitzat i que, per tant, poden experimentar modificacions formals (de gènere o de nombre): per acabar / per acabar us diré / acabaré dient que, en altres paraules / amb altres paraules / en altres termes / amb paraules més senzilles...

Finalment, els connectors gràfics són un conjunt de procediments no estrictament lingüístics que, des del punt de vista formal, es poden agrupar en tres grans blocs: signes de puntuació (punts, parèntesis, dos punts, punt i coma, etc.), signes gràfics (guions, lletres, nombres i altres signes) i elements paralingüístics (tipografia, espais en blanc, marges, tabulacions, sagnies, etc.). Es tracta d'elements ordenadors, que permeten assenyalar els títols i subtítols del text, separar els paràgrafs a l'interior d'un capítol o d'una part del text i fer més visible l'organització de la informació. En el llenguatge oral, aquesta funció de puntuació o d'organització discursiva recau essencialment sobre els elements paralingüístics i els signes no verbals (silencis, entonació, ritme, gestualitat, etc.).

Tot i la importància dels connectors no gramaticals (lèxics i gràfics) en l'organització del discurs, tant oral com escrit, convé restringir el concepte de connector a les marques formals estrictament gramaticals, és a dir, a les conjuncions, els connectors parentètics o nexes secundaris i les interjeccions (i els altres elements en procés de gramaticalització). Per tal de sistematitzar i classificar adequadament les unitats 
lingüístiques que funcionen com a connectors, considerem que en cadascun dels tres grans tipus de connexió (oracional, textual i pragmàtica) cal distingir, d'acord amb la proposta de M. J. Cuenca (2006), quatre significats bàsics o significats proposicionals (addició, disjunció, contrast i conseqüència), que, de fet, expliciten la relació semàntica i pragmàtica que existeix entre les dues unitats connectades. El gràfic de la fig. 64 presenta els tres tipus de connexió i els diferents significats específics vinculats als significats generals o proposicionals (addició, disjunció, contrast, conseqüència).

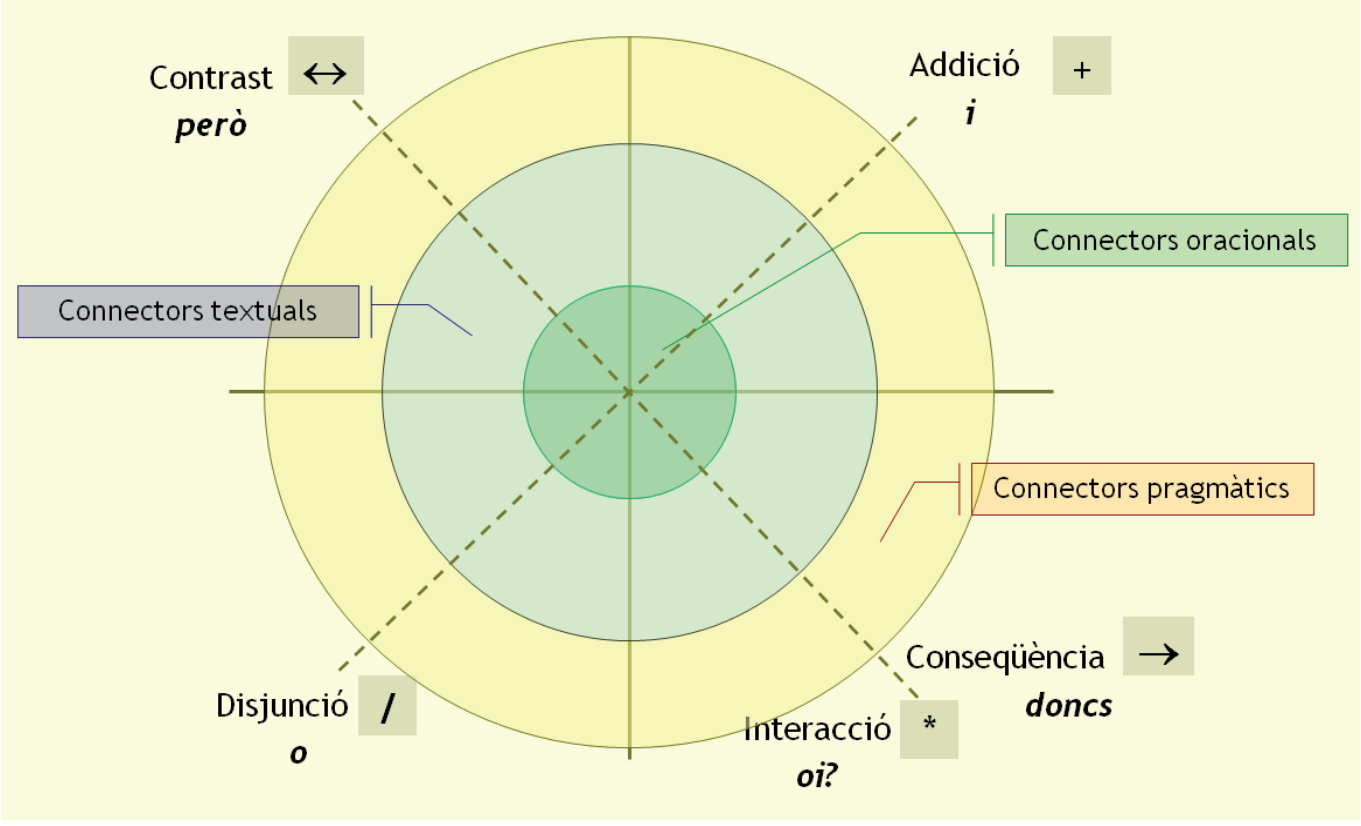

Fig. 64. Significats proposicionals bàsics i tipus de connectors

\subsection{La connexió oracional i les conjuncions}

\subsubsection{La connexió oracional i l'oració composta}

La funció de connexió oracional està molt vinculada al concepte d'oració composta i, per tant, convé tenir en compte, abans de presentar una classificació dels connectors oracionals prototípics, algunes reflexions sobre la composició oracional. De fet, a l'hora de caracteritzar i classificar els connectors oracionals, és imprescindible de situar el problema en un marc més global que prenga en consideració les aspectes següents:

a) Tot i que els connectors oracionals prototípics són, com hem vist més amunt, les conjuncions, també tenen una funció de nexe o element d'enllaç els connectors parentètics o nexes secundaris (en les construccions d'interordinació) i els pronoms relatius i alguns adverbis (en les construccions de subordinació). Es tracta, en definitiva, d'un conjunt de nexes que afecten fragments relativament breus del text (clàusules o sintagmes) i connecten les idees a l'interior d'una oració. 
b) La caracterització de l'oració composta i dels diversos tipus d'oracions compostes ens ha de permetre conèixer millor com funciona la composició oracional i, alhora, delimitar amb més precisió els nexes que tenen una funció clarament connectiva i els que no la tenen.

c) Sembla que només alguns tipus d'oracions compostes (i els connectors que les introdueixen) poden situar-se clarament en el marc de la connexió oracional (en el punt 8.2.4 veurem quines). La resta són construccions sintàctiques complexes que funcionen com un sintagma equivalent en l'oració simple.

\subsubsection{Tipus d'oracions compostes}

L'oració composta prototípica consta de dos verbs en forma personal i una conjunció, tot $\mathrm{i}$ que hi ha casos en què un dels verbs és una forma no personal (infinitiu, participi o gerundi) i casos en què actua com a nexe un connector parentètic (o una combinació de conjunció + connector parentètic), o casos que presenten una estructura sense cap mena de nexe. La identificació i la classificació de la composició oracional, com un procés de connexió que crea estructures complexes en el marc de l'oració, s'ha vinculat a la conjunció. Així, tradicionalment s'han diferenciat tres tipus d'oracions compostes (juxtaposades, coordinades i subordinades), que responen a tres tipus de relacions entre els membres constituents. Actualment, des de la perspectiva de la lingüística cognitiva, s'ha introduït el concepte d'interordinació, que explica d'una forma més satisfactòria el funcionament de les oracions adverbials no circumstancials i les adversatives, i es considera que la juxtaposició (la composició oracional sense nexes) és simplement una manifestació d'una estructura de subordinació, de coordinació o d'interordinació. Com apunta M. J. Cuenca, «la juxtaposició deixa al receptor la feina d'inferir la relació semàntica entre les clàusules» (2006: 116), una feina que, de vegades, és senzilla (com en els exemples [16] i [17]), però d'altres no ho és tant (com en [18] o en [19]).

[16] Ara et demano que decideixis, jo no puc fer-ho per tu (Riera, Primavera: 52). [17] Giovanni està massa begut, gairebé no s'aguanta (Riera, Primavera: 55).

[18] Vine aquí, al sofà: estaràs més còmoda (Riera, Primavera: 112).

[19] I de l'estranger, en fem un enemic: cada estranger és un enemic potencial (Fuster, Diccionari).

A l'hora de caracteritzar i diferenciar els tres tipus d'oracions compostes, Maria Josep Cuenca (2006: 98-103) proposa d'utilitzar quatre criteris: la relació estructural entre els constituents, la simetria, la reversibilitat i la recursivitat.

a) Segons la relació estructural entre els constituents de l'oració, es pot parlar de relació d'autonomia estructural (quan els elements units no tenen cap relació i poden funcionar amb independència), de dependència (quan una clàusula estableix una relació estructural igual a la relació que manté un sintagma respecte d'un element oracional jeràrquicament superior) o 
d'interdependència (quan el valor sintàctic i semàntic de la primera clàusula connectada està parcialment determinat per la segona $i$ viceversa, de forma que els dos elements units es troben al mateix nivell jeràrquic $i$ s'impliquen mútuament).

b) La simetria és la propietat que dóna compte de la possibilitat d'alterar l'ordre dels elements connectats mantenint el nexe en la mateixa posició. Segons aquesta propietat, una oració composta és simètrica si en invertir l'ordre dels elements constituents l'estructura resultant és gramatical i manté un significat idèntic (o molt semblant) al de l'estructura originària. Per contra, si no admet aquesta transformació, la construcció és asimètrica.

c) La reversibilitat es refereix a la possibilitat de traslladar el nexe i el segon element connectat a l'inici de l'oració. Es tracta, per tant, de comprovar si l'estructura «A nexe B» es pot transformar en «nexe B, $A$ » tot mantenint el significat originari.

d) Finalment, la recursivitat fa referència a la possibilitat d'afegir constituents nous a l'estructura de l'oració. La recursivitat, que és una propietat compartida per totes les oracions compostes, pot ser lineal (si l'element afegit se situa al mateix nivell que els anteriors i es relaciona de la mateixa forma) $i$ cíclica (si l'element nou se situa en una relació de dependència amb un dels elements originaris).

Tenint en compte aquests trets $i$, fonamentalment, la relació sintàctica establerta entre els elements que constitueixen una oració composta, es pot parlar de tres tipus d'oració composta:

a) coordinació (relació d'equivalència funcional i jeràrquica);

b) subordinació (relació de dependència sintàctica d'una clàusula, que realitza la funció d'un sintagma);

c) interordinació (relació de interdependència sintàctica i semàntica).

Cuenca, 2006: 103

La taula següent presenta una caracterització dels tres tipus d'acord amb els criteris exposats, amb alguns exemples de cadascun.

\begin{tabular}{llll}
\hline & \multicolumn{1}{c}{ Coordinació } & \multicolumn{1}{c}{ Subordinació } & \multicolumn{1}{c}{ Interordinació } \\
\hline $\begin{array}{l}\text { Relació } \\
\text { sintàctica }\end{array}$ & Autonomia estructural & Dependència A $\leftarrow$ B & Interdependència A $\leftrightarrow$ B \\
\hline Simetria & $\begin{array}{l}\text { Construcció simètrica: A } \\
\text { nexe B = B nexe A }\end{array}$ & $\begin{array}{l}\text { Construcció asimètrica: A } \\
\text { nexe B } \neq \mathrm{B} \text { nexe A }\end{array}$ & $\begin{array}{l}\text { Construcció asimètrica: A } \\
\text { nexe B } \neq \text { B nexe A }\end{array}$ \\
\hline Reversibilitat & $\begin{array}{l}\text { Construcció no reversible: } \\
\text { A nexe B } \rightarrow \text { nexe B, A }\end{array}$ & $\begin{array}{l}\text { No reversible (adj. i subst.) } \\
\text { o reversible (adv.) }\end{array}$ & $\begin{array}{l}\text { Construcció majoritària- } \\
\text { ment reversible }\end{array}$ \\
\hline Recursivitat & Recursivitat lineal & Recursivitat cíclica & Recursivitat cíclica \\
\hline
\end{tabular}




\begin{tabular}{llll}
\hline \multicolumn{1}{c}{ Coordinació } & \multicolumn{1}{c}{ Subordinació } & \multicolumn{1}{c}{ Interordinació } \\
\hline Exemples & Vindré o et telefonaré. & Una altra possibilitat & Els documents havien \\
A la fi de la dinastia XVIII & apunta que Nefertiti podia & quedat il.legibles per- \\
es van afanyar a restau- & ser filla del faraó Ay, quan & què s'hi havia escrit al \\
rar els antics cultes i a & aquest només era un alt & damunt. \\
perseguir la memòria dels & funcionari de la cort. & Es va convertir en el \\
reis d'Amarna. & La primera notícia que te- & pitjor maldecap de les \\
El PIB de l'eurozona creix & nim d'ella és un casament. & autoritats reials a Cata- \\
un 0,4\% i deixa enrere & & lunya, però mai no va ser \\
Espanya. & & condemnat. \\
\hline
\end{tabular}

Fig. 65. Tipus d'oracions compostes

Des del punt de vista de la connexió, que és el que ara ens interessa, ens ocuparem exclusivament de la coordinació i la interordinació, els dos tipus d'oracions compostes que s'estructuren sobre una relació pròpiament connectiva. En canvi, en les oracions subordinades, els nexes (conjuncions, pronoms o adverbis) són simplement elements d'enllaç que introdueixen una clàusula que fa la mateixa funció que un sintagma en l'oració simple (nominal, adjectiu o adverbial). Tot i això, més endavant presentarem una relació exhaustiva de les marques formals dels tres tipus de subordinació.

Podem parlar, doncs, de tres tipus de composició oracional, cadascun dels quals presenta unes característiques semàntiques i sintàctiques que en determinen la identitat i l'individualitzen per contrast amb els altres dos.

a) La coordinació és una relació serial, és a dir, una relació que «implica l'existència o la possibilitat d'una relació entre dos o més elements equivalents, que constitueixen una "sèrie" de conceptes relacionats» (Cuenca, 2008: 118). Des del punt de vista semàntic, es tracta d'un procediment que representa un concepte complex com una suma de conceptes més simples que s'hi integren per addició o disjunció.

b) La subordinació, en canvi, «es vincula al concepte de dependència sintàctica $\mathrm{i}$ es produeix quan una clàusula ocupa la posició d'un sintagma $\mathrm{i}$ fa, doncs, una funció oracional (subjecte, complement directe, complement preposicional o de règim verbal, complement de nom o d'adjectiu, atribut o complement circumstancial» (Cuenca, 2008: 119). D'acord amb la funció oracional que realitza la clàusula subordinada, les oracions subordinades es classifiquen en tres grans grups: substantives, adjectives i adverbials.

c) Finalment, la interordinació «es produeix entre clàusules o sintagmes que mantenen una relació semàntica de naturalesa binària» (Cuenca, 2008: 118), una relació d'interdependència entre les dues unitats connectades que es manifesta en les adversatives (tesi-antítesi), en les denominades adverbials no circumstancials (causals, consecutives, concessives, condicionals i finals), que concreten relacions de causa-efecte, i en les comparatives. 


\subsubsection{Els connectors oracionals}

Els connectors oracionals, anomenats també connectors dialèctics, són, essencialment, conjuncions i locucions conjuntives, que es poden classificar, atenent el significat i la funció que realitzen, en quatre grans blocs: addició, disjunció, contrast i conseqüència. El quadre següent conté les funcions i els significats específics que realitzen aquest tipus de connectors i els elements lèxics més representatius de cada significat:

\begin{tabular}{lll}
\hline \multicolumn{1}{c}{ Significats generals i específics } & \multicolumn{1}{c}{ Connectors principals } \\
\hline \multirow{2}{*}{ Addició } & additius & $i, n i$
\end{tabular}

Fig. 66. Els connectors dialèctics i la composició oracional

Els dos primers significats, l'addició i la disjunció, es manifesten, com hem vist, en les oracions coordinades, que no tractarem aquí perquè són sintàcticament molt elementals, mentre que les relacions de contrast i les relacions causals i consecutives s'expressen, respectivament, amb les oracions concessives i adversatives i amb les oracions causals, consecutives, condicionals i finals. Aquest dos tipus de relació sí que mereixen una mica més d'atenció.

\subsubsection{Les relacions d'interordinació}

Com assenyala Maria Josep Cuenca, les oracions coordinades i les subordinades «actuen directament en la síntesi d'estructures més complexes, eviten repeticions innecessàries i permeten un major grau d'especificitat conceptual» (Cuenca, 2008: 122). En canvi, les interordinades tenen un funcionament discursiu molt diferent, ja que no estalvien constituents i reflecteixen relacions binàries entre les dues clàusules connectades. Deixant de banda les comparatives, la resta expressen significats de caràcter contrastiu o causatiu i es relacionen de dos en dos, ja que manifesten relacions complementàries: 
a) el primer tipus (causals, condicionals i concessives) destaca l'origen de la relació, i el connector apareix precedint l'element que indica l'origen (la causa) de la relació;

$b)$ en canvi, el segon tipus (consecutives, finals i adversatives) destaca la fi de la relació, i el connector apareix precedint l'element que indica la conclusió o l'efecte.

\begin{tabular}{|c|c|c|}
\hline Tipus & Relació & Exemples \\
\hline Causals & $\underline{\text { Causa real }- \text { efecte real }}$ & $\begin{array}{l}\text { Aquest protocol és segur perquè qualsevol espia, di- } \\
\text { guem-li Eva, no pot interferir en el procés sense dei- } \\
\text { xar-hi rastre. }\end{array}$ \\
\hline Consecutives & Causa real - efecte real & $\begin{array}{l}\text { El món necessita herois } i \text {, per tant, val més que siguen } \\
\text { persones inofensives }\end{array}$ \\
\hline Condicionals & $\underline{\text { Causa possible }- \text { efecte }}$ & $\begin{array}{l}\text { Tanmateix, si ens quedem en la posada en escena } \\
\text { d'aquestes temátiques, la cosa deixa molt a desitjar }\end{array}$ \\
\hline Finals & Causa - efecte possible & $\begin{array}{l}\text { Els filòsofs naturals s'interessaren per la llanterna mà- } \\
\text { gica per tal de mostrar il-lustracions científiques. }\end{array}$ \\
\hline Concessives & $\frac{\text { Causa (tesi) }}{\text { contrari }}-$ efecte & $\begin{array}{l}\text { La majoria presenta certa base real, tot i que el nom- } \\
\text { bre d'errades i incongruències és tan aclaparador com } \\
\text { alarmant. }\end{array}$ \\
\hline Adversatives & $\begin{array}{l}\text { Tesi - antítesi (efecte } \\
\text { contrari) }\end{array}$ & $\begin{array}{l}\text { El cinema es manté de ficcions, però es nodreix també } \\
\text { de la realitat. }\end{array}$ \\
\hline
\end{tabular}

Fig. 67. Les relacions d'interordinació

\subsubsection{Les construccions de subordinació}

Ja hem vist que la subordinació es defineix com un tipus de relació de dependència estructural, sintàctica, d'una clàusula respecte d'un constituent jeràrquicament superior de l'oració on s'insereix. La clàusula subordinada ocupa la posició pròpia d'un sintagma en una oració simple (nominal, adjectival o verbal) i, per tant, depèn d'un constituent jeràrquicament superior (el verb o un nom en la major part dels casos), i es comporta com es comporten aquests sintagmes en l'oració simple. Segons l'equivalència categorial i funcional de la clàusula, es pot parlar de subordinació substantiva, adjectiva o adverbial.

Malgrat que la subordinació no és pròpiament un mecanisme de connexió i que els nexes que introdueixen les clàusules subordinades no es poden considerar connectors, en aquest moment pot resultar clarificador presentar una classificació d'aquest tipus d'oracions i una relació exhaustiva dels nexes i les construccions més utilitzades en català com a marques de la subordinació (fig. 68).

Les oracions subordinades substantives realitzen en l'oració composta les mateixes funcions que realitza el substantiu o el sintagma nominal en l'oració simple: subjecte, complement directe, complement indirecte, atribut... Des del punt de vista formal, la subordinació substantiva presenta dues possibilitats: 
a) Les oracions subordinades substantives d'infinitiu.

b) Les oracions subordinades introduïdes per un element d'enllaç.

Les oracions subordinades substantives d'infinitiu s'insereixen directament en l'oració principal, tot i que també poden anar introduïdes per les preposicions $a$ i de.

[20] La cup proposa acabar amb els vestigis franquistes en els carrers i places de Girona.

[21] L'entrenador vol conscienciar l'equip de la importància de l'eliminatòria.

Les oracions subordinades substantives introduïdes per un element d'enllaç poden presentar quatre estructures sintàctiques diferents:

\section{Conjunció que + oració}

[22] Albert II li va demanar que evités l'evaporació de Bèlgica.

En valencià, la conjunció que no s'ha d'ometre mai davant dels verbs de voluntat o desig. En canvi, no s'utilitza mai la conjunció que, sinó les preposicions a o per davant d'infinitius:

[23] Espere que tingueu la decència de reconéixer l'error (*Espere tingueu la decència de reconéixer l'error.)

[24] No tinc res a dir (*No tinc res que dir)

2. Conjunció si + oració

[25] Ella em va preguntar si podràs venir al sopar.

3. Pronom interrogatiu + oració

[26] El periodista va preguntar què diuen les estadístiques.

4. Pronom relatiu + oració

[27] Qui ho desitge podrà participar al xat i seguir-lo mitjançant la projecció en una pantalla gegant.

Les oracions subordinades adjectives, anomenades també oracions de relatiu, estan introduïdes per un pronom relatiu, que realitza una funció doble: d'una banda, actua com a nexe introductori de la clàusula subordinada, i de l'altra, realitza la mateixa funció sintàctica que el sintagma substituït.

Les oracions subordinades adverbials s'anomenen també oracions circumstancials perquè ocupen el lloc del complement circumstancial en l'oració simple. Es tracta d'oracions que tenen el valor d'adverbis o locucions adverbials i presenten una gran mobilitat oracional, ja que són les que tenen una major capacitat d'ocupar llocs diferents a l'interior de l'oració composta. 
Des del punt de vista semàntic, les subordinades adverbials es poden classificar en tres grans grups: de lloc, de temps i de manera. En aquestes subordinades, la clàusula inserida s'integra en la principal mitjançant dos procediments:

a) Amb un nexe o element d'enllaç, que és el relatiu on (en les adverbials de lloc) i les conjuncions i locucions adverbials de temps i mode (en les adverbials no locatives).

[28] Van accedir a la ciutat per on havien entrat les hosts del rei.

[29] Pagaré la multa abans que m'arribe amb recàrrec.

[30] Quan vaig mirar cap a la porta, en Gregori ja no hi era.

b) Amb l'ús d'un verb en forma no personal (infinitiu, gerundi i participi).

[31] En arribar a París, visitarem la catedral de Notre Dame.

[32] Vam veure l'actriu sortint del teatre.

[33] Caminava recolzat en un bastó.

\begin{tabular}{|c|c|c|}
\hline \multicolumn{2}{|c|}{ Tipus de subordinació } & Marques essencials \\
\hline \multicolumn{2}{|l|}{ Substantiva } & $\begin{array}{l}\text { que, verb en infinitiu, relatius que i qui, allò que, mots } \\
\text { interrogatius en construccions interrogatives indire- } \\
\text { tes }\end{array}$ \\
\hline \multicolumn{2}{|l|}{ Adjectiva } & $\begin{array}{l}\text { Pronoms relatius: que, prep. + què, prep. }+ \text { qui, prep. }+ \\
\text { art. + qual(s), on, la qual cosa, cosa que }\end{array}$ \\
\hline \multirow[t]{5}{*}{ Adverbial } & de lloc & on \\
\hline & de temps & $\begin{array}{l}\text { abans que, abans de }+ \text { inf., així que, alhora que, ara } \\
\text { que, cada vegada que, quan, d'ençà que, des que, de } \\
\text { seguida que, després que, després de }+ \text { inf., en }+ \text { inf., } \\
\text { mentre que, quan... }\end{array}$ \\
\hline & de manera & $\begin{array}{l}e n+\text { inf., bo } i+\text { ger., com }+ \text { gerundi, que }+ \text { participi, } \\
\text { segons que, sense }+ \text { inf., tot }+ \text { gerundi, tot } i+\text { gerundi... }\end{array}$ \\
\hline & comparatives causals & $\begin{array}{l}\text { Com més... més, de la mateixa manera que, igual que, } \\
\text { igualment que, major... que, menor... que, més... que, } \\
\text { menys... que, tal com, tant... com }\end{array}$ \\
\hline & consecutives discont. & Tal... que, tan que/tant/a/s/es... que. \\
\hline
\end{tabular}

Fig. 68. Marques de la subordinació

Llocs web sobre l'oració composta i les conjuncions:

http://cmapspublic2.ihmc.us/rid=1H9X26H3Q-25T2P34-K0K/L'oraci\%C3\%B3\%20composta.cmap http://www.ua.es/institutos/inst.filovalen/Guiausos.pdf

http://www.gripau.eu

http://www.ua.es/personal/robert.escolano/aprenentatge/exercicis/aprofundiment.htm 


\subsection{La connexió textual}

\subsubsection{Concepte i caracterització}

La connexió textual permet relacionar dues oracions o dues unitats superiors (grups d'oracions o paràgrafs). Es tracta d'un tipus de connexió que, com es pot veure en el quadre següent, presenta característiques ben diferents de la connexió oracional.

\begin{tabular}{|c|c|c|}
\hline Nivell & Connexió textual & Composició oracional \\
\hline Nivell & Extratextual & Intraoracional \\
\hline $\begin{array}{l}\text { Elements } \\
\text { units }\end{array}$ & $\begin{array}{l}\text { Dues oracions, conjunts d'ora- } \\
\text { cions o paràgrafs }\end{array}$ & $\begin{array}{l}\text { Dos o més constituents de l'oració (mots, sin- } \\
\text { tagmes o clàusules) }\end{array}$ \\
\hline Relació & Semàntica & Sintàctica i/o semàntica \\
\hline \multirow[t]{4}{*}{$\begin{array}{l}\text { Tipus de } \\
\text { relació }\end{array}$} & & $\begin{array}{l}\text { Cap relació (subordinació substantiva i adjecti- } \\
\text { va) }\end{array}$ \\
\hline & Addició i disjunció & Relacions serials: addició i disjunció \\
\hline & Contrast i conseqüència & $\begin{array}{l}\text { Relacions binàries: contrast, concessió, causa, } \\
\text { conseqüència, condició, finalitat, comparació }\end{array}$ \\
\hline & & Relacions circumstancials: temps, lloc i manera \\
\hline $\begin{array}{l}\text { Connectors } \\
\text { típics }\end{array}$ & Connectors parentètics & Conjuncions \\
\hline Funció & $\begin{array}{l}\text { Posar de manifest les relacions } \\
\text { de coherència entre parts del text } \\
\text { iguals o superiors a l'oració }\end{array}$ & Augmentar la complexitat sintàctica de l'oració \\
\hline
\end{tabular}

Fig. 69. Connexió textual i composició oracional

En general, aquest tipus de connectors són fàcils d'identificar i resulten essencials per a l'articulació de les idees a l'interior dels paràgrafs i per a la construcció de les xarxes de relació conceptual entre els diferents paràgrafs del text.

\subsubsection{Els connectors parentètics}

Els connectors prototípics de la connexió textual són els connectors parentètics, un conjunt de «mots o estructures diverses $i$ heterogènies formalment, que han modificat el seu significat i el seu comportament sintàctic a partir d'un procés de gramaticalització» (Cuenca, 2008: 99). Aquest procés de gramaticalització ha provocat en aquestes unitats lingüístiques una transformació essencial que afecta el seu significat, provoca una fixació estructural i determina un canvi de comportament sintàctic:

a) Els connectors parentètics perden el significat literal que tenen els mots o constituents integrants $\mathrm{i}$ assoleixen un significat general de tipus connectiu vinculat a una de les quatre relacions bàsiques (addició, disjunció, causalitat o contrast). Així, per exemple, el significat del connector ara bé no té res a 
veure amb el significat dels mots ara ('en aquest moment', 'en el moment de parla') i bé ('comportament adequat').

b) Aquest tipus de connectors queden fixats estructuralment i, per tant, no admeten addició d'elements o commutació, cosa que sí que és possible quan actuen com a elements solts (com a preposicions, adverbis o verbs). És possible, per exemple, inserir un determinant indefinit en la frase «La borsa sempre està en (un) canvi incessant», on la preposició en i el substantiu canvi tenen el seu significat original (preposicional i nominal), però no en l'oració «La química l'apassiona; la física, en (un) canvi, no la pot suportar».

c) Els connectors parentètics modifiquen el seu comportament sintàctic i exerceixen una pura funció connectiva, perifèrica respecte de l'oració on apareixen, que es manifesta en la seua posició (solen aparèixer encapçalant oracions o clàusules, tot i que tenen mobilitat posicional dins de l'oració) i en el seu caràcter parentètic (van entre pauses o inflexions tonals $i$ es reprodueixen en l'escriptura entre comes).

Es tracta, en definitiva, d'unitats de naturalesa híbrida, entre els elements d'origen i els connectors gramaticalitzats, que sintàcticament se situen en la perifèria de l'oració i solen considerar-se adverbis o locucions conjuntives, tot i que «tenen un ús i un significat diferent tant respecte als adverbis com respecte a les conjuncions» (Cuenca, 2008: 100).

Tot i que existeixen classificacions molt diverses dels connectors textuals, una de les propostes més útils ens permet d'agrupar-los d'acord amb els quatre significats proposicionals bàsics (addició, disjunció, contrast i conseqüència) i, posteriorment, a l'interior de cada grup, d'acord amb els significats concrets que realitzen.

\begin{tabular}{|c|c|c|}
\hline \multicolumn{2}{|c|}{ Significats generals i específics } & Principals connectors \\
\hline \multirow{10}{*}{$\begin{array}{l}\text { Addició } \\
\text { (additius o es- } \\
\text { tructuradors) }\end{array}$} & obertura & $\begin{array}{l}\text { respecte } a, \text { quant } a \text {, pel que fa a, en relació } a \text {, un altre punt és, } \\
\text { sobre, quant } a \text {, per començar... }\end{array}$ \\
\hline & continuïtat & $\begin{array}{l}\text { i, a més a més, a més, llavors/aleshores, endemés, tot seguit, des- } \\
\text { prés (no temporal), aixi mateix, així, aixi les coses, d'aquesta for- } \\
\text { ma, bé (continuatiu), doncs bé... }\end{array}$ \\
\hline & ordenació & $\begin{array}{l}\text { per començar, en primer lloc, en segon lloc, per últim, per acabar, per } \\
\text { fi, finalment... }\end{array}$ \\
\hline & distribució & $\begin{array}{l}\text { d'una banda, de l'altra, d'altra banda, al contrari, al seu torn, per } \\
\text { contra, per un costat, per l'altre, per una altra part... }\end{array}$ \\
\hline & intensificació & $i$, encara, encara més, més encara, a més, a més a més... \\
\hline & digressió & per cert, a propòsit \\
\hline & generalització & en general, generalment \\
\hline & especificació & $\begin{array}{l}\text { en concret, concretament, en particular, especialment, en especial, } \\
\text { especificament, fet i fet, de fet... }\end{array}$ \\
\hline & ampliació & en efecte, efectivament, per descomptat, certament... \\
\hline & equiparació & $\begin{array}{l}\text { de manera semblant, de la mateixa manera, de la mateixa forma, } \\
\text { igualment, aixi mateix, paral-lelament }\end{array}$ \\
\hline
\end{tabular}




\begin{tabular}{|c|c|c|}
\hline \multicolumn{2}{|c|}{ Significats generals i específics } & Principals connectors \\
\hline \multirow[t]{4}{*}{$\begin{array}{l}\text { Disjunció } \\
\text { (reformuladors) }\end{array}$} & explicació & $\begin{array}{l}\text { és a dir, o siga / o sia / o sigui, això és, (dit) en unes altres paraules } \\
\text { (i variants), dit d'una altra manera / forma, vull dir, vaja, total... }\end{array}$ \\
\hline & rectificació & $\begin{array}{l}\text { més ben dit, millor dit, vull dir, (o) millor, (o) encara millor, (o) si } \\
\text { voleu / (o) si preferiu (i variants), vaja, més aviat... }\end{array}$ \\
\hline & exemplificació & $\begin{array}{l}\text { per exemple, com ara, p. ex., cf., en particular, com a mostra, aixi, } \\
\text { a saber, en el cas de, posem per cas... }\end{array}$ \\
\hline & recapitulació & $\begin{array}{l}\text { en conclusió, en resum, en suma, per acabar, per concloure, fi- } \\
\text { nalment, aixi doncs, en definitiva, total, en fi, ras } i \text { curt, comptat } \\
i \text { debatut... }\end{array}$ \\
\hline \multirow[t]{5}{*}{$\begin{array}{l}\text { Contrast } \\
\text { (contrastius) }\end{array}$} & oposició & $\begin{array}{l}\text { tanmateix, si no, no obstant, en canvi, per contra, ara, ara bé, amb } \\
\text { tot, al contrari, en cas contrari, altrament... }\end{array}$ \\
\hline & concessió & $\begin{array}{l}\text { no obstant això, (amb) tot } i \text { amb això, tot } i \text { així, tot } i \text { això, tot amb } \\
\text { tot, malgrat tot, de tota manera / de totes maneres, en tot cas, en } \\
\text { qualsevol cas, siga com siga, però, per això, al capdavall, comptat } \\
i \text { debatut, fet i fet, total... }\end{array}$ \\
\hline & restricció & si més no, almenys \\
\hline & refutació & $\begin{array}{l}\text { al contrari (i variants com ans al contrari i ben al contrari), per } \\
\text { contra... }\end{array}$ \\
\hline & contraposició & en realitat, de fet, fet i fet, ben mirat, si bé es mira... \\
\hline \multirow{3}{*}{$\begin{array}{l}\text { Conseqüència } \\
\text { (conclusius) }\end{array}$} & causa & perquè, $i$ és que... \\
\hline & conseqüència & $\begin{array}{l}\text { per tant, així, així doncs, consegüentment, en conseqüència, com a } \\
\text { conseqüencia, per consegüent, llavors/aleshores... }\end{array}$ \\
\hline & conclusió & $\begin{array}{l}\text { al capdavall, al cap i a la fi, a fi de comptes, en conclusió, en defi- } \\
\text { nitiva, en fi, per tot plegat, total, tot plegat... }\end{array}$ \\
\hline
\end{tabular}

Fig. 70. Els connectors metadiscursius o connectors parentètics

\subsection{La connexió pragmàtica i els marcadors discursius}

Fins ara ens hem referit a la connexió oracional i a la connexió textual o discursiva, és a dir, dels procediments gramaticals que permeten relacionar, respectivament, dues clàusules a l'interior d'una oració o dues unitats textuals (oracions o paràgrafs) en el marc del text. La connexió pragmàtica permet relacionar el text amb els elements de la situació de comunicació (particularment el mateix text, l'emissor i el destinatari) i està vinculada a l'ús d'un tipus de connectors anomenats marcadors del discurs, un conjunt d'unitats lingüístiques molt heterogènies -especialment actives en el discurs oral, però presents també en l'escriptura- que s'han especialitzat en la realització de dues funcions discursives complementàries: d'una banda, funcionen com a connectors i, de l'altra, realitzen una funció pragmàtica relacionada amb l'expressió de la subjectivitat i el posicionament del parlant sobre el seu discurs. 
En aquest sentit, el terme marcadors discursos (Schiffrin, 1987) resulta mes comprehensiu que el de connectors argumentatius, tot incloent aquesta categoria. La noció es refereix als indicadors detectats en el text-sovint, però no exclusivament, com a elements que expliciten la connexió entre algunes de les parts del seu contingut-i que remeten al procés d'interacció discursiva que se serveix del text com a instrument. Els marcadors, doncs, senyalitzen una determinada organització del text que el lector haurà d'actualitzar per interpretar coherentment el conjunt; però, a més, indiquen una relació modalitzadora de l'autor amb els continguts tractats i una relació interpersonal, convenientment programada, amb el lector imaginat. Els marcadors anuncien $\mathrm{i}$ propicien, per tant, un to, una actitud envers la perspectiva adoptada i els mecanismes del diàleg amb el receptor. Són, en un mot, marques d'una estratègia que l'escriptor adopta en el procés de l'escriptura i que funcionen com a instruccions de lectura.

Maingueneau-Salvador, 1995: 185-186

La investigació sobre els marcadors del discurs es troba en una fase inicial i, per tant, no disposem encara d'estudis de conjunt sobre els marcadors en català, ni d'un inventari exhaustiu de tots els mots que funcionen com a marcadors en la pràctica comunicativa. Sovint, s'inclouen en aquesta categoria diversos mots i expressions que realitzen també funcions de connexió (marcadors d'integració lineal $\mathrm{i}$ alguns connectors parentètics o textuals) i algunes interjeccions.

Aquest tercer grup, format per interjeccions o elements molt propers a les interjeccions, és el que podem denominar connectors pragmàtics. Està constituït, fonamentalment, per interjeccions que poden indicar connexió textual en certs contextos, sobretot conversacionals, i sempre tenen un valor modalitzador més o menys marcat. Es pot dir que fan una funció connectiva en la mesura que encapçalen o acaben enunciats, i sobretot torns de parla, i contribueixen a l'organització del discurs. Si inicien enunciat, són més propers als connectors, lògicament. S'hi assemblen pel caràcter parentètic, però se'n diferencien pel fet que el valor modalitzador és força prominent. [...]

Podem dir, doncs, que els connectors pragmàtics són elements parentètics, amb posició generalment inicial, que marquen unió o transició dins de la conversa i tenen un valor modalitzador. Es tracta d'interjeccions o d'elements intermedis entre interjeccions i connectors parentètics, sovint amb un grau de gramaticalització poc elevat, que, pel fet que pressuposen la presència contigua d'una oració, es pot dir que funcionen com a connectors textuals. [...]

En resum, si ens situem en el nivell pragmàtic, el connector indica una relació que va més enllà de la unió de dos continguts i té com a funció principal organitzar l'estructura comunicativa (torns de parla, introducció o represa del tema, canvi de tema, etc.). Manifesta, igualment, les actituds del parlant respecte de la interacció comunicativa. Ens trobem en el límit entre la connexió i la modalització i, per això, hi ha problemes per dir si realment estem davant d'elements connectors pròpiament o de formes que fan de connector però que pròpiament no ho són.

Cuenca, 2006: 167-168 i 173

Els marcadors discursius, anomenats també operadors discursius, són, per tant, una mena d'instruccions de lectura imprescindibles a l'hora d'assignar significat als productes de la interacció comunicativa, tenen una funció clau en la construcció del discurs, com a marques de la interacció i del dialogisme, i permeten establir interessants jocs de complicitat entre la persona que parla o escriu i els seus destinataris. El quadre que presentem a continuació conté un inventari, encara provisional i incomplet, dels significats pragmàtics més rellevants vinculats a la marcació discursiva, i una relació de les unitats lingüístiques associades més 
emprades per expressar cadascun d'aquests significats. És evident que, d'acord amb el que hem dit, el quadre inclou algunes unitats que figuren també en alguna de les classificacions de connectors presentades anteriorment (connectors oracionals o connectors textuals). Es tracta de mots o expressions que tenen sentits diferents (de vegades, matisos subtils de significat) i que només es poden precisar amb exactitud si es té en compte el context en què apareixen, és a dir, les condicions pragmàtiques de l'enunciació.

Així, per exemple, mentre en [34] el mot vinga és una forma verbal, en [35] s'ha gramaticalitzat com a conjunció i té un significat de marcador discursiu. El mateix passa en els exemples [36] i [37] amb el mot home i en els exemples [38], [39] i [40] amb ara, que té, respectivament, el valor d'un adverbi de temps en [38] (que funciona com a complement circumstancial), d'un connector parentètic en [39] (que funciona com a connector textual de contrast) i d'una interjecció en [40] (que funciona com a marcador discursiu).

[34] Katsikaris: «Demane a l'afició que vinga al pavelló i que anime l'equip» (http://www.pamesabasket.com/val/noticias/fichanoticia.asp?ID=2877, 17-11-2006).

[35] Nasi: [...] Com que no has aconseguit trobar en què se t'imposa el català, has optat per dir que no ho has dit. Ara dius que no havies arribat a dir que t’imposen sinó que et volen imposar. És practicament el mateix. [...]

Pocasolta: Vinga, Nasi: qui és el mentider?

(http://forums.vilaweb.cat/www/forum/detall?idcmp=650000\&p_edi= General, 2003).

[36] L'home, ja ho hem dit, és el gran agent transformador de l'ecosfera: és qui ha canviat el paisatge de la Terra $i$ en condiciona el seu funcionament global (http://www.ub.es/ecologiaimediambient/, 23-11-2006).

[37] A: Beli...

$\mathrm{B}$ : què?

A: Per què no anem a Tossa aquesta nit?

B: Sí, home! Quasi res (Cuenca, 2006: 176; adaptació).

[38] Només la moderna expansió del turisme comença a derogar aquest principi de vella prosàpia sentimental: ara el foraster se'ns presenta com a client (Fuster, 1964).

[39] La intimitat que els famosos exposen a l'anomenada "premsa rosa» és una intimitat per exhibir. Ara, la intimitat que es fa pública com a denúncia és una intimitat per a protegir (Terricabras, 2006: 28).

[40] I ara! Et penses que no ho sabia, tot això? Em prens per idiota. 

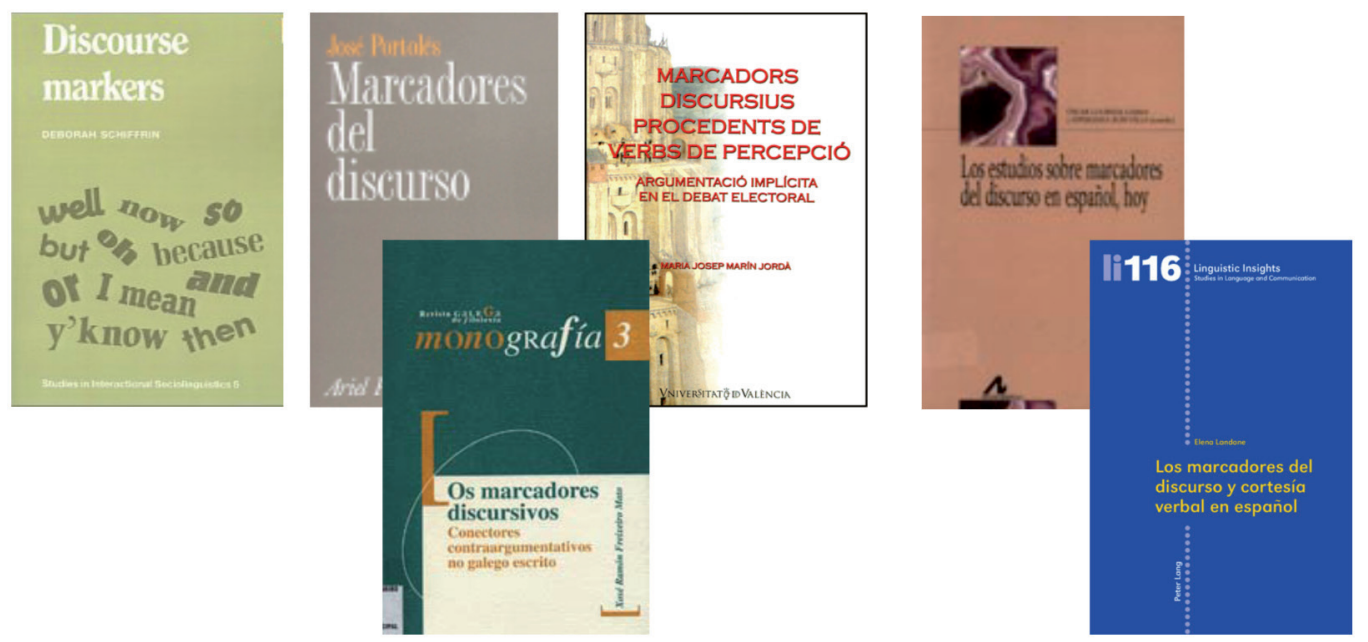

Fig. 71. Bibliografia sobre marcadors del discurs

Malgrat el caràcter dispers i poc sistemàtic de la investigació sobre els marcadors discursius, ens sembla interessant de presentar una proposta de classificació utilitzant els quatre significats proposicionals bàsics (addició, disjunció, contrast i conseqüència). Ens ha semblat imprescindible, això no obstant, d'ampliar la categoria del que hem anomenat marcadors de conseqüència amb els marcadors especialitzats a regular la interacció comunicativa, entre els quals ocupen un paper destacat els operadors escalars o marcadors de confirmació, els reguladors de la conversa, els focalitzadors i els evidenciadors. Convé remarcar que algunes d'aquestes unitats posseeixen diversos significats o diversos matisos semàntics lligats molt estretament als diferents usos discursius. Això significa que, de vegades, no és senzill distingir el matís exacte d'un marcador o que en una mateixa situació comunicativa una d'aquestes unitats puga ser interpretada de manera diferent pels interlocutors.

\begin{tabular}{|c|c|c|}
\hline \multicolumn{2}{|c|}{ Significats generals i específics } & \multirow{2}{*}{$\begin{array}{l}\text { Principals marcadors } \\
\text { Inici de torn de parla o d'explicació: a veure, mira/miri } \\
\text { (i variants), ah, un moment, escolta, eh; inici o canvi de } \\
\text { tema: ah, escoltalescolti, bé, molt bé, veuràs/veurà. }\end{array}$} \\
\hline \multirow[t]{7}{*}{ Addició } & additius & \\
\hline & emfasitzadors & $\begin{array}{l}\text { homeldona; ara, això sí, efectivament, en efecte, cal in- } \\
\text { sistir, convé destacar... }\end{array}$ \\
\hline & atenuadors & $\begin{array}{l}\text { homeldona, si de cas, d'alguna forma, fins a cert punt, } \\
\text { llavors, una miqueta... }\end{array}$ \\
\hline & comentadors & de fet, fet i fet, en realitat, ben mirat... \\
\hline & reorientadors & llavors... \\
\hline & $\begin{array}{l}\text { de reforç argu- } \\
\text { mentatiu }\end{array}$ & $\begin{array}{l}\text { en realitat, de fet, tot sembla indicar que, ben mirat, clar } \\
\text { que, és que... }\end{array}$ \\
\hline & de polaritat & home!; dona!; sí, homeldona; no, homeldona; clar, home... \\
\hline
\end{tabular}




\begin{tabular}{|c|c|c|}
\hline \multicolumn{2}{|c|}{ Significats generals i específics } & \multirow{2}{*}{$\begin{array}{l}\text { Principals marcadors } \\
\text { potser; sí, senyor; vés per on... }\end{array}$} \\
\hline Disjunció & de distanciament & \\
\hline & $\begin{array}{l}\text { matisadors o } \\
\text { puntualitzadors }\end{array}$ & $\begin{array}{l}\text { en tot cas, de totes formes, tot } i \text { això, ben mirat, si bé es } \\
\text { mira, ara, ara bé, això si, potser, en definitiva... }\end{array}$ \\
\hline & de formulació & bé... \\
\hline \multirow[t]{4}{*}{ Contrast } & contrastius & i ara!... \\
\hline & concessius & si, si... però; vés a saber... \\
\hline & de restricció & $\begin{array}{l}\text { Interrupció per incomprensió: eh?, com?, què...; interrup- } \\
\text { ció del torn de parla: a veure, aviam, veiam, vejam, viam } \\
\text { (i variants), escoltalescolti, mira/miri... }\end{array}$ \\
\hline & de refutació & sí, però; ni parlar-ne, en absolut, de cap manera... \\
\hline \multirow{6}{*}{$\begin{array}{l}\text { Conseqüència } \\
\text { i interacció }\end{array}$} & de tancament & total, en definitiva, al cap i a la fi, i punt, i ja està... \\
\hline & $\begin{array}{l}\text { de confirmació } \\
\text { (operadors esca- } \\
\text { lars) }\end{array}$ & $\begin{array}{l}\text { Petició d'acord: saps?, m'entens?, comprens?, d'acord?, } \\
\text { eh?, veus?, m'explico?, sí?...; petició de confirmació: eh?, } \\
\text { no?, oi?, veritat?, tat? (i variants) }\end{array}$ \\
\hline & expressius & $\begin{array}{l}\text { Dubte: eh, mmm, hum, ehem, bé; acord: bé, entesos, } \\
\text { homeldona (acord parcial); desacord: calla, de debò?, } \\
\text { de veres?, de veritat?, què dius (ara)?, sí, sí espera't; sí, } \\
\text { home!; negació: ah, no; d'això res, de cap manera, ni } \\
\text { parlar-ne, ni pensar-ho, oh; sorpresa: vés per on; assen- } \\
\text { timent: és clar que sí, està clar, i tant, oi tant, tu diràs, } \\
\text { veges, vet-ho aquí; disgust o distanciament negatiu: uf!; } \\
\text { lamentació: ai! }\end{array}$ \\
\hline & $\begin{array}{l}\text { reguladors de la } \\
\text { conversa }\end{array}$ & $\begin{array}{l}\text { Inici del torn de parla: ah, un moment, escolta, mira, eh, } \\
\text { a veure; pausa: a veure (i variants), eh... }\end{array}$ \\
\hline & focalitzadors & $\begin{array}{l}\text { generalment, especificament, intuïtivament, racional- } \\
\text { ment, cientificament, vulgarment, si fa no fa... }\end{array}$ \\
\hline & evidenciadors & $\begin{array}{l}\text { és clar, evidentment, és evident, ningú no ignora, sembla } \\
\text { clar que, està clar, òbviament, per descomptat, curiosament, } \\
\text { potser, tal vegada, sembla, conten (que), diuen (que)... }\end{array}$ \\
\hline
\end{tabular}

Fig. 72. Classificació dels marcadors discursius

\subsection{Remarques sobre l'ús d'alguns connectors}

\subsubsection{Connectors causals i consecutius}

La conjunció consecutiva doncs expressa sempre la conseqüència o conclusió de la idea precedent i, per tant, no pot introduir en cap cas l'expressió de la causa o el motiu. Si cal expressar algun d'aquests matisos, s'han d'usar perquè, com que, ja que o altres connectors causals:

[41] *En la cimera no es va arribar a cap acord, doncs els nord-americans no estan disposats a acceptar-ne les restriccions. 
[42] En la cimera no es va arribar a cap acord, ja que els nord-americans no estan disposats a acceptar-ne les restriccions.

[43] Com que els nord-americans no estaven disposats a acceptar-ne les restriccions, en la cimera no es va arribar a cap acord.

Les expressions *posat que, *donat que i *tota vegada que no tenen, en català, valor causal i, per tant, cal evitar-ne l'ús i substituir-les pels connectors causals adients. També cal evitar l'ús de les expressions *com i *degut a per expressar causalitat.

[44] * Donat que l'empresa ha fet fallida, els creditors es trobaran als tribunals.

[45] Ja que l'empresa ha fet fallida, els creditors es trobaran als tribunals.

[46] *Han decidit reunir un comitè de crisi, tota vegada que la situació sembla alarmant.

[47] Han decidit reunir un comitè de crisi, perquè la situació sembla alarmant.

[48] * Com no tenien prou temps de descans, ajornaran el partit.

[49] Com que no tenien prou temps de descans, ajornaran el partit.

[50] *Degut a les tensions polítiques, era necessari arribar a un acord.

[51] A causa de les tensions polítiques, era necessari arribar a un acord.

\subsubsection{Connectors de contrast: adversatius i concessius}

Tot i que, de vegades, la conjunció però té un valor intensiu, en aquest sentit no és correcte usar però que:

[52] *S'enfrontaven a una decisió complicada, però que molt complicada.

[53] S'enfrontaven a una decisió complicada, però molt complicada.

En l'expressió no obstant això (o això no obstant) no es pot prescindir del mot això:

[54] *El Barça va patir molt per mantenir el liderat a 1'ACB; no obstant, ahir es va desfer, de moment, del Panathinaikos.

[55] El Barça va patir molt per mantenir el liderat a l'ACB; no obstant això, ahir es va desfer, de moment, del Panathinaikos.

Finalment, són també calcs del castellà les construccions concessives *per molt que, *per $a+$ infinitiu, *així + subjuntiu. Cal, per tant, substituir-les per les expressions normatives: encara que, malgrat que, per bé que, tot i que, ni que, a pesar que i per més que, entre d'altres. 


\subsubsection{Connectors comparatius i condicionals}

Per expressar comparacions de proporcionalitat cal emprar les expressions com més... més, com més... menys, com menys... més i com menys... menys, perquè en català no són adequades les estructures del tipus *quan més... més, *quan menys... menys, *contra més... més o *mentre més... menys.

[56] *Quan més s'acosta la data, més nerviosos es mostren els protagonistes.

[57] Com més s'acosta la data, més nerviosos es mostren els protagonistes.

Les oracions condicionals, en català, utilitzen els connectors si, posat que, a condició que, sols que, amb què, en cas que, només que, si bé, mentre i llevat que. Cal recordar que:

a) Posat que és una locució condicional i no equival mai a la castellana puesto que, que en aquesta llengua té un valor causal.

b) En cas que, a diferència del castellà, no porta preposició de: *en cas de que.

c) Tot i que la conjunció mentre té un valor condicional, la locució mentre que, en català, té un valor adversatiu i s'utilitza, per tant, per indicar oposició o contrast entre dues idees.

d) Són calcs del castellà, i s'han d'evitar sempre, els connectors * cas que, *amb que, *sempre i quan $\mathrm{i} *$ a no ser que.

e) També són calcs del castellà les construccions *com + subjuntiu i *de + infinitiu amb valor condicional:

[58] *D'haver-ho sabut, no ens hi hauríem presentat.

[59] *Com tornes a fer-me això, tu i jo hem acabat.

[60] Si ho haguérem sabut, no ens hi hauríem presentat.

[61] Si tornes a fer-me això, tu i jo hem acabat.

\subsubsection{La conjunció que}

No es pot ometre la conjunció que quan introdueix certes oracions depenents d'un verb que expressa petició, propòsit o desig, ni darrere de l'adverbi d'afirmació sí:

[62] *Esperem ens informen dels resultats de les darreres investigacions.

[63] Esperem que ens informen dels resultats de les darreres investigacions.

[64] * Stoner no creu que siga el favorit del campionat, però Pedrosa sí ho creu.

[65] Stoner no creu que siga el favorit del campionat, però Pedrosa sí que ho creu. 


\subsubsection{Usos de perquè, per què i per a què}

La forma perquè pot ser conjunció causal (equivalent a ja que, atès que, com que, per tal com...), conjunció final (equivalent a a fi que, per tal que) i substantiu (precedint, doncs, d'article). No és correcte usar la forma per a què ni per a que per expressar finalitat:

[66] Hem avançat la reunió, perquè ja hi som tots.

[67] El temari de l'assignatura és a Internet perquè puga consultar-se amb comoditat (i no *per a que puga consultar-se...).

[68] I perquè conste, signe aquest certificat (i no *per a que conste...).

[69] No s'entén el perquè de la seua intervenció.

Per a què és una locució formada per la preposició composta per a més el pronom interrogatiu què. La trobem en frases interrogatives, directes o indirectes, i, per tant, el què equival a quina cosa, quina finalitat.

[70] Això que investigues, per a què serveix?

[71] Es pregunten per a què serveix el certificat digital.

Finalment, la forma per què pot ser la preposició per més el pronom interrogatiu què (equivalent, per tant, a per quina cosa o per quina raó) o la preposició per més el pronom relatiu tònic què (llavors equival a pel qual, per la qual, pels quals o per les quals).

[72] Convindria saber per què els jugadors estan disposats a fer vaga.

[73] Per què es va comunicar als clubs la fi del contracte d'emissió?

[74] Probablement mai no sabrem els motius per què Rajoy va decidir recolzar Camps.

\subsection{Connexió textual, cohesió i escriptura}

\subsubsection{Connexió textual i coherència discursiva}

La connexió textual és un mecanisme de relació cohesiva que s'estableix entre dues oracions o unitats textuals superiors i un connector que expressa la relació semàntica i pragmàtica que existeix entre les idees expressades en les unitats connectades. Es tracta, com hem vist, d'un fenomen que supera els límits de l'oració i permet articular les idees d'una forma coherent al llarg del text. En aquest sentit, podem afirmar que els connectors textuals, anomenats també organitzadors textuals i connectors metadiscursius, són el punt de confluència entre les exigències de coherència del discurs (oral o escrit) i la manifestació superficial de les relacions de cohesió entre les diverses unitats que integren el conjunt del text. 
Si analitzem, per exemple, els dos textos següents, podem observar perfectament, d'una banda, l'alternança d'aquest tipus de connectors amb els connectors oracionals i amb els connectors pragmàtics (sens dubte, en el fons i tal vegada) $\mathrm{i}$, de l'altra, la ubicació estratègica i la mobilitat posicional d'aquestes unitats.

La mecànica quàntica ha canviat la nostra economia, la nostra forma de comunicació, la nostra vida. Peró, sens dubte, ara presenciem la seua adolescència. És molt possible que el segle $x x$ no quede en la nostra memòria collectiva per una guerra (n'hi ha hagut massa) o per una catàstrofe, sinó per un fet científic. Podem enumerar tres candidats: la teoria de la relativitat, la mecànica quàntica $i$ el descobriment del DNA. És possible que la mecànica quàntica siga el fet que més transcendesca en la nostra història venidora. La relativitat és, en el fons, un canvi menor de paradigma, continuació de la cinemàtica de Galileu. El DNA serà entès, modificat i tal vegada substituït perquè tindrem control sobre les seues Ileis. Les Ileis de la mecànica quàntica, en canvi, semblen tenir un element de perpetuïtat absolut.

Mètode, 48 [en línia] http://hemeroteca.metode.cat//index. php?option=com_content\&task=view $=$ ¿tid $=451$ t $\mid$ temid $=$
La mort recent de López Vázquez també ha tret a la llum pública l'existència d'un telefilm dirigit per John Alaimo titulat Antoni Gaudi, una visió inacabada. Es va rodar el 1974, amb el popular actor interpretant el genial arquitecte a cavall entre el documental i la ficció, però el productor va fer fallida i el material va anar a parar a mans d'un banc. Un dels seus empleats, I'historiador i col-leccionista Carles Querol, n'ha conservat una còpia que dóna fe d'aquesta peça perduda en l'extensa filmografia del protagonista de Miquerida señorita. En cas de restaurar-se i estrenar-se, seria un altre film inèdit, mai no exhibit en públic. Hi ha projectes, en canvi, que no ho faran mai perquè no es van arribar a rodar. Amb ells es podria escriure una altra història del cine, paral·lela a l'oficial. D'exemples n'hi ha a cabassos i cada realitzador, per famós que sigui, podria fer-hi les seves aportacions.

Avui Espectacles, setmana del 14 al 20 de novembre de 2009, p. 9

Els connectors oracionals són conjuncions que connecten dues clàusules per constituir oracions coordinades $(i)$ o interordinades (sinó, perquè, però, en cas de). Per contra, els connectors parentètics (però, en canvi, també) realitzen una funció connectiva supraoracional, ja que connecten una oració amb la informació precedent en el paràgraf $\mathrm{o}$, fins $\mathrm{i}$ tot, amb el contingut del paràgraf precedent.

Aquest tipus de connectors tenen mobilitat oracional i sovint van entre comes per marcar, precisament, el seu caràcter parentètic i la seua mobilitat. Observeu, per exemple, com són de perfectament gramaticals les oracions següents, en què s'han desplaçat els connectors a un lloc diferent:

[75] Sens dubte, ara presenciem, però, la seua adolescència.

[76] En canvi, les lleis de la mecànica quàntica semblen tenir un element de perpetuitat absolut.

[77] També la mort recent de López Vázquez ha tret a la llum pública l'existència d'un telefilm...

[78] En canvi, hi ha projectes que no ho faran mai. 


\subsubsection{Cohesió textual i escriptura}

Quan parlem de l'escriptura dels mitjans de comunicació, hem de distingir els mitjans audiovisuals (ràdio i televisió) dels escrits (periòdics, revistes i setmanaris) i els mitjans multimèdia, que serien com una mena de combinació dels anteriors. Tot i que l'escriptura ha de tenir les mateixes característiques pel que fa a la claredat, simplicitat, coherència, concisió i concreció, hi ha algunes qüestions que diferencien la redacció de cada mitjà.

Els mitjans de comunicació escrits i els multimèdia (dirigits a un públic d'una formació mitjana) permeten al lector fer una lectura pausada i, si cal, una relectura. Això possibilita que els textos escrits per ser llegits puguen ser més extensos i no tinguen tanta urgència a l'hora de transmetre la informació. En canvi, els mitjans orals es caracteritzen per la gran incidència social, per la diversitat de receptors i per la impossibilitat de repetir els missatges, cosa que ha d'obligar els redactors a transmetre textos curts i fàcils d'entendre.

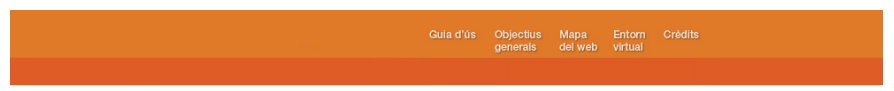

\section{argumenta}

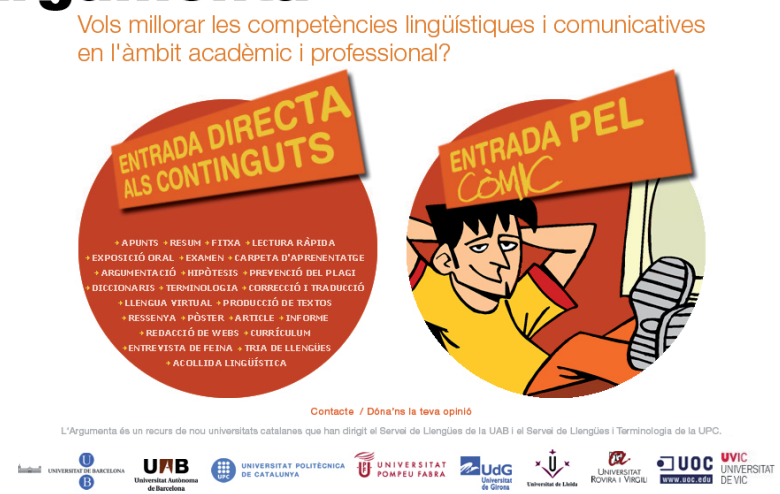

Fig. 73. Pantalla d'entrada del lloc web Argumenta

L'extensió del discurs (ja hem vist que tendeix a la reducció) presenta algunes dificultats de redacció. Tots els manuals recomanen brevetat (entre 20 i 30 paraules per oració) perquè es considera que les frases llargues costen més de llegir que no pas les curtes. La dificultat de comprensió dels períodes llargs té a veure amb el que s'anomena memòria a curt termini o memòria de treball, que ens permet emmagatzemar i manipular informació en un espai curt de temps (uns quants segons) i que es calcula que no sobrepassa els 58 mots. Els problemes que tendeixen a produir llargs períodes són, generalment, d'índole compositiva, és a dir, es relacionen amb el temps que s'ha dedicat a la preparació de la redacció. L'abundància d'idees en una mateixa oració, l'excés d'informació subsidiària o la construcció mitjançant subordinacions o incisos condueixen a una redacció que resulta difícil d'interpretar. Pel contrari, l'ordenació d'idees diferents en diverses oracions, la substitució de conjuncions, que allarguen els períodes per signes de puntuació forts, i la supressió o trasllat d'informacions addicionals, fan que la redacció siga més comprensible. Vegem-ho en un exemple ben diàfan extret de Cassany (2007): 


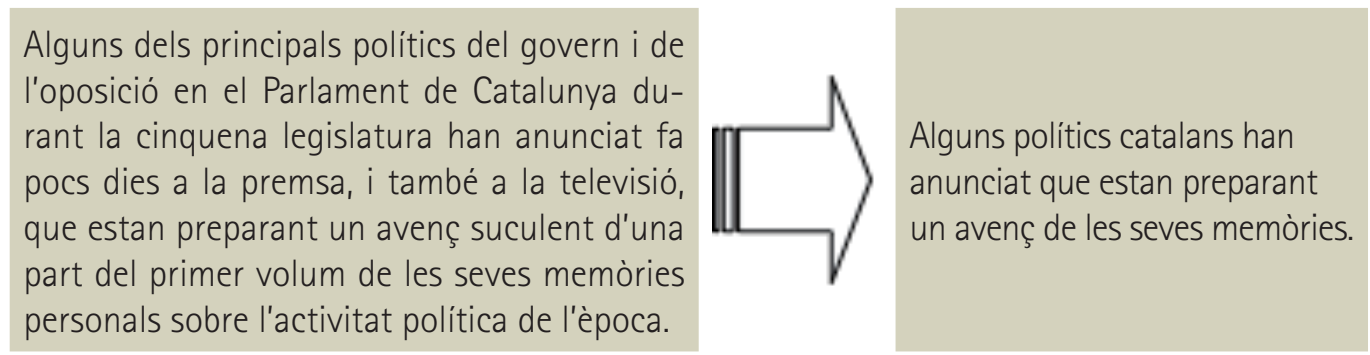

\subsubsection{Recomanacions generals}

El registre dels mitjans de comunicació s'ha de caracteritzar per la neutralitat: no es tracta d'una llengua pròxima a la familiar, però tampoc no comparteix les característiques dels registres científics o literaris. Es troba en un estadi intermedi entre els models formals i els informals.

En definitiva, l'estil dels mitjans de comunicació ha de ser clar, coherent, concís, concret i senzill, sobretot pel que fa als audiovisuals, per les característiques que hem esmentat més amunt.

a) Claredat. La funció principal de la llengua dels mitjans és transmetre informació; per tant, s'han d'evitar les frases complicades que podrien expressar-se de manera més senzilla, així com les perífrasis, l'abundància de mots i l'ús d'eufemismes.

[79] Dos mil manifestants han ocupat el centre de Barcelona avui al migdia. [80] *Prop d'uns dos mil manifestants, la majoria joves, han ocupat un centre de Barcelona ple de turistes avui al migdia, en una protesta contra la repressió marroquina del poble saharià.

b) Coherència. La coherència és fonamental per a l'enteniment de la redacció. Aquesta coherència no es refereix únicament al significat del text, sinó també a l'ordenació prosòdica i a les referències textuals en definitiva, a la cohesió.

[81] El conductor va fugir després d'atropellar un nin que va morir en l'accident.

[82] *El conductor va atropellar un nin que va morir en l'accident i va fugir.

c) Concisió. És molt recomanable la supressió de mots que no siguen necessaris per a la comprensió del text. Tampoc no s'ha d'abusar de clixés lingüístics que fan més llarga la redacció i no aporten cap contingut.

[83] Els implicats van declarar davant el jutge instructor.

[84] *Els implicats van prestar declaració davant el jutge que instrueix el cas.

d) Concreció. Convé evitar l'abús de mots abstractes i de nominalitzacions amb la intenció que el text siga més clar. 
[85] Si els adults s'automediquen continuadament per a l'insomni, pot ser útil que aprenguen les tècniques orientals per relaxar la ment i que coneguen les estadístiques que publica l'oms sobre els perjudicis que causa aquesta pràctica.

[86] *En el cas de l'automedicació continuada dels adults per a l'insomni, pot ser útil l'aprenentatge de les tècniques orientals de relaxació de la ment i la coneixença de les estadístiques publicades per l'oms sobre els perjudicis causats per aquesta pràctica.

e) Simplicitat. Cal evitar els períodes llargs, per a la qual cosa és convenient alternar frases mitjanes amb d'altres de curtes. D'altra banda, s'ha d'explicar aquells conceptes que siguen especialment complexos o poc comuns, de manera que tothom siga capaç d'entendre'ls.

[87] La dona, que tenia l'apèndix inflamat, va morir després de ser operada d'urgència.

[88] * La peritonitis aguda que patia la dona obligà els metges a practicar-li una intervenció d'urgència que acabà amb resultat de mort.

[89] El grup s'ha especialitzat en el hot jazz, varietat de jazz basada en un ritme més marcat $i$ en unes melodies menys cantables.

[90] *El grup s'ha especialitzat en el hot jazz.

\subsubsection{L'estructura de la frase}

La frase o l'oració és el fonament de l'estructura del text. Si l'oració està ben estructurada, el text també ho estarà. Un dels fonaments de la bona estructuració de l'oració és l'ordenació sintàctica. En català, l'ordre de la frase respon a l'estructura bàsica de subjecte, verb, complement directe $\mathrm{i}$ altres complements (indirecte, règim, circumstancials...); tanmateix, com la resta de llengües romàniques, el català presenta una certa flexibilitat pel que fa a la col·locació dels complements temporals, espacials o aspectuals.

\section{Vuit consells per escriure frases eficients}

1. Vigila les frases gaire llargues, de més de 30 mots! Comprova que es llegeixen fàcilment.

2. Esporga tots els mots i els incisos irrellevants. Queda't només amb els essencials.

3. Situa els incisos en el lloc més oportú: que no separin les paraules que estan relacionades.

4. Busca l'ordre dels mots més planer: subjecte, verb i complements. Evita les combinacions rebuscades.

5. Colloca la informació rellevant en el lloc més important de la frase: el principi.

6. No abusis de les construccions passives, de les negacions ni de l'estil nominal, que enfosqueixen la prosa.

7. Deixa actuar els actors: que els protagonistes de la frase facin de subjecte i objecte gramaticals.

8. No tinguis mandra de revisar les frases! Has d'elaborar la prosa, si vols que sigui enèrgica i entenedora.

Fig. 74. Consells per escriure frases eficients (font: Cassany, 1993) 


\section{REGLES PER MILLORAR LES FRASES}

Per aconseguir una prosa clara i eficaç cal tenir en compte l'estructura de les frases. En general, les frases llargues costen més de llegir que les curtes; per això els manuals d'estil solen recomanar la brevetat. Si hem de llegir frases massa llargues, la nostra memòria se sobrecarrega i no podem retenir totes les paraules. Aixi doncs, també cal evitar els incisos extensos, mantenir l'ordre lògic dels sintagmes i rebutjar estructures sintàctiques complicades, que dificulten la lectura.

1. Buscar un estil actiu

2. Evitar les negacions

3. Ajuntar els mots relacionats

4. Esporgar el que siga irrellevant

5. Limitar els incisos

6. Mantenir una ràtio baixa de noms i verbs

7. Limitar els gerundis

\section{REGLES PER ESCOLLIR PARAULES}

És molt important triar bé les paraules a l'hora d'escriure una frase; segons les seues caracteristiques, hi haurà paraules que fomentaran la llegibilitat del text i d'altres que l'obstaculitzaran (i, per tant, caldrà evitar-les).

OBSTACULITZEN LA LLEGIBILITAT
1. Paraules repetides
2. Crosses
3. Mots comodi
4. Verbs copulatius
5. Adverbis en -ment

\section{FOMENTEN LA LLEGIBILITAT}

\author{
1. Marcadors textuals \\ 2. Formes més populars \\ 3. Paraules planeres i curtes \\ 4. Mots concrets \\ 5. Perfet perifràstic
}

Fig. 75. Regles per millorar l'escriptura

\subsubsection{Alguns problemes de redacció}

En l'elaboració dels textos és fàcil d'adonar-se de problemes relacionats amb la sintaxi o amb el significat. En canvi, hi ha algunes mancances que tenen a veure amb la concordança que són més difícils de detectar i, per tant, més difícils d'evitar o de corregir. Alguns d'aquests errors habituals d'escriptura estan relacionats amb la concordança i amb els anacoluts.

a) Concordança dels subjectes col·lectius

És difícil d'esbrinar si amb un nom col·lectiu (grup, equip, la majoria de...) hem de concordar el verb amb el nom (en singular) o bé amb el significat (en plural). En els exemples següents es pot observar que la primera redacció (marcada amb l'asterisc) és incorrecta i la segona, correcta: 
[91] * La resta de participants van començar a protagonitzar la seua guerra particular.

[92] La resta de participants va començar a protagonitzar la seua guerra particular.

[93] *Faces el que faces, la gent sempre et criticaran.

[94] Faces el que faces, la gent sempre et criticarà.

[95] *La majoria dels taxistes van fer vaga.

[96] La majoria dels taxistes va fer vaga.

[97] *Tot i que la selecció del Marroc pensava pagar-se les seues despeses, la federació etíop els va fer saber que no era possible rebre'ls fins al pròxim dia 11.

[98] Tot i que la selecció del Marroc pensava pagar-se les seves despeses, la federació etíop $l i$ va fer saber que no era possible rebre-la fins al pròxim dia 11.

b) Anacolut

Es tracta d'un error molt freqüent de la prosa descuidada $i$ es refereix al trencament d'una frase perquè la segona part no té a veure amb la primera. Sol produir-se quan el primer període s'ha allargassat tant que ha perdut els elements de referència. Fixem-nos en aquest exemple manipulat del diari electrònic Vilaweb:

[99] * La plataforma En Moviment es visualitza per primera volta en aquesta mobilització, que acaba de començar a treballar des de l'àmbit de la societat civil valenciana per a un canvi i una regeneració democràtica de la política.

L'entradeta conté una part que no té res a veure amb l'enunciat de la primera part. Es tractaria d'intentar explicar quin tipus de plataforma és En Moviment, però ho faria d'una manera incorrecta. La redacció real és:

[100] La plataforma En Moviment es visualitza per primera volta en aquesta mobilització, que ha rebut el suport de nombroses entitats i partits. Durant la manifestació s'ha visualitzat per primera volta la plataforma En Moviment, que acaba de començar a treballar des de l'àmbit de la societat civil valenciana per a un canvi i una regeneració democràtica de la política.

c) Errors de concordança d'adjectius o verbs amb doble referència

Es tracta d'un error que fa coincidir un adjectiu amb un nom amb el qual es troba lligat i amb un altre que havia aparegut abans. També és el cas de verbs que es relacionen amb dos complements de règims diferents. Vegem-ne un exemple:

[101] *Pense que l'alcohol s'usa més que no pas s'abusa, exceptuant el cap de setmana que passa a la inversa. 
El subjecte de la primera oració passa a ser el complement en la segona, cosa que no es veu reflectida en l'ús dels verbs. Una possible solució seria:

[102] Pense que l'alcohol s'usa més que no pas se n'abusa...

Un altre exemple, ara amb un adjectiu que no concorda amb el nom amb què ho hauria de fer, sinó amb un altre amb el qual manté una certa relació de referència:

[103] *Un dels compositors més sol-licitat és Ennio Morricone.

[104] Un dels compositors més sol-licitats és Ennio Morricone.

\section{Lectures recomanades}

Cuenca, Maria Josep (2003): Sintaxi catalana, Barcelona, Editorial uoc.

- (2006): La connexió i els connectors. Perspectiva oracional i textual, Vic, Eumo.

- (2007): La sintaxi, Barcelona, Editorial Uoc.

- (2008): Gramàtica del text, Alzira, Bromera.

PorTALÉs, Enric (2012): «L'estratègia concessiva: un repte en l'ensenyament de l'argumentació», Articles, 58,ps. 36-48.

Portolés, José (2001): Marcadores del discurso, Barcelona, Ariel.

SCHIFFrIn, Deborah (1987): Discourse Markers, Cambridge, Cambridge University Press.

SolÀ, Joan (1994): Qüestions controvertides de sintaxi catalana, Barcelona, Edicions 62.

- (dir.) (2002): Gramàtica del català contemporani, Barcelona, Empúries, vol. 3. Vallverdú, Josep (dir.): Enciclopèdia de la llengua catalana, Barcelona, Edicions 62. 


\section{ASPECTES PRAGMÀTICS I ENUNCIATIUS DEL CATALÀ}




\section{TEMA 9}

\section{Discurs i ideologia}

Introducció

1. Ideologia, discurs i societat

2. Text i context: la dixi i els díctics

3. Acció i interacció: els actes de parla

4. Polifonia i discurs reportat

5. Procediments de modalització del discurs

6. L'estratègia figurativa: metàfora i pensament

7. Selecció lèxica i punt de vista

Lectures recomanades 


\section{Introducció}

Actualment s'accepta de forma unànime la influència dels mitjans de comunicació de massa en la formació i en el desenvolupament de les opinions que la societat adopta envers els fets que s'hi presenten. Sabem que la tendència política, esportiva o econòmica d'un mitjà afavoreix l'aparició del biaix informatiu que amaga els seus plantejaments ideològics. L'aparició d'una determinada notícia en un lloc de l'informatiu, la durada, les entrevistes amb els protagonistes, la introducció immediata d'una rèplica política a una notícia positiva d'un corrent determinat... ens faran identificar immediatament la tendència del mitjà. En unes altres paraules, si un canal de televisió és partidari del govern o si defensa els colors d'un equip de futbol, ho manifesta en el tractament de la informació i en l'ús d'estratègies lingüístiques que condueixen, de manera no sempre identificable pel gran públic, a l'acceptació dels plantejaments ideològics del mitjà.

No obstant això, el poder que s'atribueix als mitjans és, en realitat, relatiu. El vertader poder és el de les classes dominants que tenen l'accés a la informació i transmeten la seua visió del món a través dels altaveus de la ràdio, la televisió o la premsa. Teun A. van Dijk (1993 i 2004) considera que les classes dominants són aquelles que accedeixen a les diverses formes de discurs públic; en canvi, la gent corrent, que no té accés a aquest discurs ni coneixement del seu funcionament, no pot exercir cap influència directa sobre les informacions dels mitjans. I, encara més, mai no és la protagonista de les notícies que s'introdueixen a les cases mitjançant la televisió o, en menor mesura, la ràdio o la premsa. Els polítics, els empresaris, els intel·lectuals manifesten permanentment la perspectiva interessada de les notícies que el públic majoritari adoptarà de manera gairebé inconscient $\mathrm{i}$ defensarà com si fos seua.

En aquest tema analitzarem com es manifesta la ideologia a través dels mitjans i quines són les estratègies que s'utilitzen per tal que el pensament de les elits arrele en les classes populars. També veurem com la desviació informativa té un component clarament actitudinal, és a dir, en el fons, el que hom pretén és que el públic faça alguna cosa, que actue: que vote un partit, que rebutge els immigrants, que perdone els abusos de poder, etc.

La darrera part és la més interessant per tal com descobreix quines són les maneres de crear referents ideològics a través de l'adopció d'un determinat punt de vista en el discurs que es manifesta en l'aparició dels díctics (formes lingüístiques responsables de la creació d'un context determinat, d'uns models mentals). Uns referents que identifiquem amb l'ús interessat d'expressions que manifesten opinions i valoracions de la realitat i que coneixem com mecanismes de modalització del discurs. I, finalment, es presenta la construcció de mons conceptuals a través de l'assumpció d'idees que es fan presents a partir d'un procediment que impossibilita la confrontació dialèctica: les metàfores i els blocs semàntics. 


\subsection{Ideologia, discurs i societat}

\subsubsection{El concepte d'ideologia}

Les ideologies estan constituïdes per les creences fonamentals d'un grup, socialment compartides pels seus membres, i són el fonament de les pràctiques socials dels individus del grup, formes de representació social i de cognició que permeten organitzar i justificar prejudicis i actituds, integrar els valors d'una forma específica, en funció dels interessos del grup, $\mathrm{i}$ inferir opinions socials noves quan els membres d'un grup, i el grup mateix, s'enfronten a situacions noves.

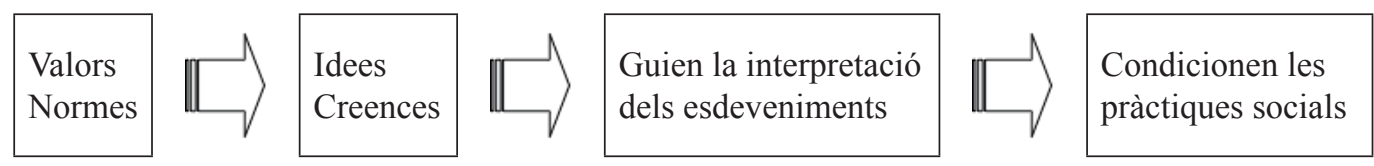

Fig. 72. Funció social de les ideologies: dels valors a les pràctiques socials

El racisme, el nacionalisme, el catolicisme, el comunisme, el masclisme o el feminisme són alguns exemples ben coneguts d'ideologies que tenen una presència important en la societat actual o en alguns grups socials.

Globalment, les ideologies són, per tant, «un tipus de cognició social i, més específicament, un conjunt de creences bàsiques que fonamenten les representacions socials d'un grup» (Van Dijk, 2003: 25). Segons Van Dijk, que ha publicat diversos treballs sobre les relacions entre ideologia i discurs, «una ideologia és una de les formes bàsiques de cognició social que defineixen la identitat d'un grup i, per tant, els sentiments subjectius de la identitat social (de la pertinença) dels seus membres» (Van Dijk, 2003). Des d'aquest punt de vista, les ideologies presenten una estructura integrada per tres constituents complementaris: creences, esquemes o models mentals i categories bàsiques.

a) Les creences ideològiques tenen un format proposicional: «Els homes i les dones han de tenir els mateixos drets», «Tots els ciutadans són iguals», «Les reivindicacions dels nacionalismes són un perill per a la unitat d'Espanya», etc.

b) Les ideologies s'organitzen en forma de «sistemes» de creences ideològiques que, segurament, tenen una naturalesa semblant als esquemes o models mentals.

c) L'esquema de la ideologia d'un grup està integrat per sis categories bàsiques: el criteri de pertinença (qui pertany $i$ qui no pertany al grup?), les activitats típiques (què fem i per què ho fem els membres del grup?), els objectius generals (què volem i per què?), les normes i valors (què és bo $i$ què és dolent per a nosaltres?), la posició en relació als altres grups (quines relacions mantenim amb els altres?) i els recursos (qui té accés als recursos del grup i qui n'està exclòs?). 
Les ideologies constitueixen, en definitiva, formes de cognició social de caràcter general i abstracte que serveixen de guia per a la interpretació dels esdeveniments (i dels discursos), condicionen les pràctiques socials dels individus i contribueixen decisivament a regular el procés de socialització.

\subsubsection{Ideologia i interacció social}

La ideologia condiciona els perfils de la interacció social en un grup humà. En aquest sentit, els aspectes socials de les ideologies es poden definir en dos nivells complementaris de descripció, que permeten visualitzar les formes de manifestació:

a) A nivell micro, que comprèn les formes de manifestació de les ideologies en les pràctiques socials quotidianes. En l'expressió i en la reproducció de les ideologies tenen un paper fonamental el discurs i moltes activitats paraverbals que acompanyen la parla (gesticulació, expressió facial, postura corporal, distància...).

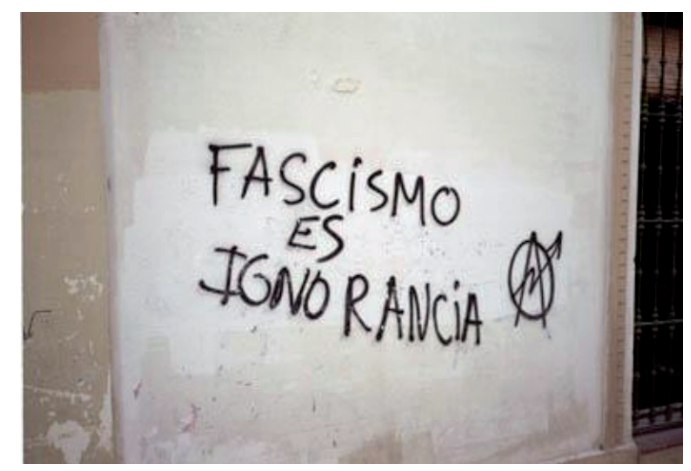

Fig. 77. Manifestació de la ideologia en un graffiti

b) A nivell macro, que fa referència a les propietats que utilitzen els membres d'un grup per identificar-se (criteris de pertinença, activitats típiques, objectius, normes, relacions i recursos). Així, la identificació amb el grup es manifesta en les pràctiques socials (activitats professionals, discriminació, resistència, manifestacions, etc.) i en les representacions socials conjuntes (creences, objectius i valors compartits). En la constitució i en el funcionament dels grups intervenen tres elements fonamentals:

- l'organització o estructuració, més o menys jerarquitzada, i el paper dels ideòlegs;

- la captació de nous membres a través dels diferents tipus de propaganda;

- la institucionalització i la difusió dels valors del grup a través de les institucions ideològiques, especialment del sistema educatiu i dels mitjans de comunicació.

Des d'un punt de vista global, la funció social de les ideologies cobreix dos objectius essencials: 
a) facilitar l'acció conjunta, la interacció i la cooperació entre els membres del grup, $\mathrm{i}$

b) crear i mantenir les relacions de poder (i de control) i legitimar el domini per part del grup o la classe social dominant.

És evident, per tant, que existeixen relacions molt estretes entre ideologia, societat i cultura; de fet, les ideologies constitueixen els fonaments compartits per les cultures, utilitzen com a mitjans de difusió institucions que formen part de la cultura d'un poble o d'un grup i s'expressen a través d'elements culturals amb una important càrrega simbòlica (els himnes, les banderes, la llengua, la forma de vestir, el pentinat, etc.).

\subsubsection{De la ideologia al discurs: actituds i marcs}

Les ideologies, com les altres formes de cognició social, són, per definició, generals $i$ abstractes -existeixen perquè s'apliquen a un gran ventall de situacions quotidianes-, i es manifesten en el llenguatge oral i escrit i en el comportament de les persones i dels grups socials. Els discursos són, per tant, el mitjà d'expressió i de transmissió de les ideologies, $\mathrm{i}$ en aquest procés de transmissió de valors i creences tenen una funció molt important la família, l'escola, els mitjans de comunicació de massa (la premsa, la ràdio i la televisió), la publicitat, el cinema i les noves tecnologies (entre les quals cal destacar, actualment, la telefonia mòbil i Internet). Els valors, els principis i les creences que configuren les ideologies determinen d'una forma natural i generalitzada l'existència d'una sèrie de prejudicis i actituds que regulen el discurs i el comportament social dels individus.

Els prejudicis són opinions no verificades o valoracions preconcebudes en virtut d'esquemes acceptats per la tradició comuna, sense tenir un coneixement cert i raonat. Estan condicionats directament pels valors.

Per contra, les actituds són les formes de reaccionar com a conseqüència dels valors i dels prejudicis, una mena de "“representacions" intermèdies entre les ideologies i el discurs [...], formes de cognició social que incorporen proposicions ideològiques aplicables a dominis socials específics» (Van Dijk, 2003: 29). Es tracta de predisposicions estables a valorar d'una manera determinada i actuar en conseqüència. Estan, doncs, condicionades pels valors, són adquirides i difícils de canviar (però es poden modificar amb el raonament), són precursores i determinants de les formes de comportament $\mathrm{i}$ tenen un component cognitiu (una de les causes per les quals les persones tenen actituds davant les coses és que pensen) $i$ un component afectiu i passional (que pot estar o no d'acord amb la raó).

L'esquema de la fig. 74 situa els conceptes que hem introduï en un mapa global i il-lustra d'una forma transparent el procés que condueix de la ideologia al discurs.

La transició de la ideologia al discurs es produeix amb el suport de les representacions mentals dels episodis que generen les experiències viscudes. Aquestes representacions mentals es presenten en forma de marcs (frames), ${ }^{1}$ anomenats també

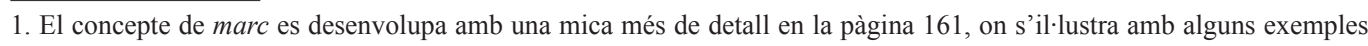
procedents del discurs polític. 
models mentals, uns esquemes que simplifiquen de forma extraordinària el processament de la informació i l'activitat cognitiva.

Els models mentals són subjectius i personals, relativament simples (és a dir, amb poques categories fixes), prou flexibles per poder aplicar-se a les situacions poc freqüents que hem d'afrontar en la vida diària, i contenen elements heterogenis, com escenaris (espacials i temporals), participants (persones i objectes, relacions, usos...), esdeveniments i afirmacions (especificacions, exemples) de creences generals i abstractes.

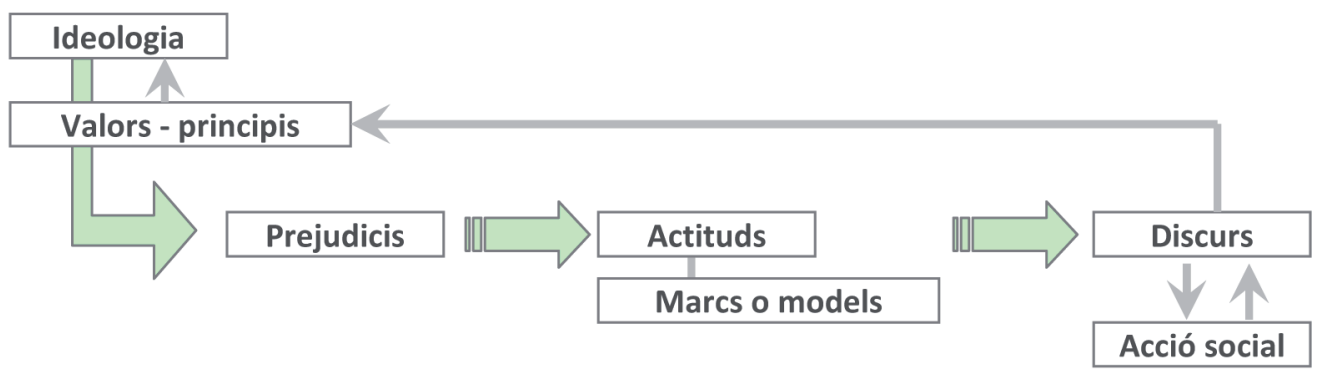

Fig. 78. De la ideologia al discurs

Els discursos són el mitjà d'expressió i de transmissió de les ideologies, i sovint en el procés de transmissió i reproducció de les ideologies intervenen, com hem apuntat més apunt, les institucions especialitzades (l'Església, les ONG, els partits polítics, els sindicats, l'escola, els mitjans de comunicació...). De fet, l'organització del grup i la institucionalització constitueixen dos elements fonamentals per garantir una reproducció eficient de les ideologies dominants (el nacionalisme o el consumisme) i per fer emergir amb força les ideologies alternatives (l'ecologisme o el feminisme, per exemple).

Des del punt de vista cognitiu, les ideologies es desenvolupen perquè organitzen representacions socials i s'utilitzen per controlar les pràctiques socials dels individus. En realitat, la funció social de les ideologies consisteix a facilitar l'acció conjunta, la interacció i la cooperació dels membres de dins i de fora del grup. En el nivell macro, les ideologies defineixen les relacions de poder i de domini entre els membres d'un grup i s'utilitzen per legitimar el domini per part de la classe dominant o els grups i organitzacions d'elit. El poder es pot definir en termes de control social i, habitualment, això significa control de l'acció, de la ment i del discurs i de les seues propietats (el context, els tòpics, l'estil...). Com que el discurs influeix sobre la ment dels receptors, els grups poderosos poden controlar indirectament el pensament de les persones a través del discurs dels mitjans de comunicació, que presenta formes diverses de manipulació, persuasió i seducció. El discurs dominant (el discurs dels poderosos) influeix decisivament sobre les formes de definir o de percebre la realitat (els esdeveniments, les situacions i les paraules) en els nostres models mentals i sobre les formes de representació de la societat en el nostre coneixement, en les actituds i en les ideologies: 
Un dels recursos socials més importants de bona part del poder contemporani és l'accés al discurs públic. Qui controla el discurs públic controla indirectament la ment (inclosa la ideologia) de les persones i, per tant, també les seues pràctiques socials. És freqüent trobar aquesta relació entre poder social, discurs, ment i control. En un enfocament més crític del poder, ens interessen especialment l'abús de poder o la dominació i de quina forma les ideologies poden utilitzar-se per legitimar aquest domini.

Van Dijk, 2003: 31

\subsubsection{Llocs d'inserció de la ideologia en el discurs}

De vegades, les ideologies s'expressen explícitament i, en aquests casos, són molt fàcils de detectar (per exemple, en una campanya electoral, en un debat, en la publicitat corporativa d'una empresa o en la publicitat institucional), però també apareixen de forma indirecta, implícita, en estructures discursives que no manifesten d'una manera tan òbvia l'orientació ideològica. Sovint, una entonació determinada de l'oració, un matís de dubte o de sorpresa, una expressió irònica, una metàfora o un pronom constitueixen marques d'ideologia en el discurs. De fet, la ideologia pot aparèixer potencialment en qualsevol estructura del llenguatge oral o escrit.

Com que el discurs és tan complex i les estructures ideològiques es poden manifestar de formes tan diferents, Teun $\mathrm{A}$. van Dijk proposa una estratègia pràctica general per a l'anàlisi ideològica del discurs que parteix del fet que les ideologies organitzen les persones, els grups humans i la societat en general en termes polaritzats. Aquesta estratègia es concreta en un quadre conceptual que anomena «quadrat ideològic» i que és aplicable a l'anàlisi de totes les estructures del discurs:

- Posar èmfasi en els nostres aspectes positius.

- Maximitzar els aspectes negatius dels altres.

- Minimitzar els nostres aspectes negatius.

- Minimitzar els aspectes positius dels altres.

El discurs disposa d'un ample ventall de recursos per maximitzar o minimitzar els significats $i$, per tant, reforçar la pertinença o l'exclusió d'un grup determinat i evidenciar les formes de distinció dels altres mitjançant les accions, els objectius, les normes i els recursos propis.

Segons Van Dijk, els recursos expressius a través dels quals es manifesta l'orientació ideològica dels discursos es poden agrupar en les categories incloses en el quadre següent: 


\begin{tabular}{|c|c|c|c|}
\hline \multirow{2}{*}{$\begin{array}{c}\text { Nivells } \\
\text { Semàntic }\end{array}$} & \multirow{2}{*}{$\begin{array}{l}\text { Categories } \\
\text { El significat } \\
\text { del discurs }\end{array}$} & \multicolumn{2}{|c|}{ Estructures (recursos) } \\
\hline & & $\begin{array}{l}\text { - Selecció de temes } \\
\text { - Nivell de descripció o grau } \\
\text { de detall } \\
\text { - Implicacions i pressuposicions }\end{array}$ & $\begin{array}{l}\text { - Coherència local } \\
\text { - Sinonímia i paràfrasis } \\
\text { - Contrast o polarització } \\
\text { - Exemples i il·lustracions } \\
\text { - Negacions }\end{array}$ \\
\hline & $\begin{array}{l}\text { Les estructures } \\
\text { proposicionals }\end{array}$ & $\begin{array}{l}\text { - Presentació dels actors } \\
\text { - Modalitat i modalització } \\
\text { - Evidenciadors }\end{array}$ & $\begin{array}{l}\text { - Ambigüitat, mitigació } \\
\text { i eufemismes } \\
\text { - Topoi }\end{array}$ \\
\hline \multirow[t]{2}{*}{ Sintàctic } & $\begin{array}{l}\text { Estructures } \\
\text { formals: les formes } \\
\text { del discurs }\end{array}$ & $\begin{array}{l}\text { - Estructures textuals globals } \\
\text { (superestructures) } \\
\text { - Tipografia }\end{array}$ & $\begin{array}{l}\text { - La sintaxi de l'oració } \\
\text { - Ordenació del discurs }\end{array}$ \\
\hline & L'argumentació & $\begin{array}{l}\text { - Tesi i arguments } \\
\text { - Estructura de l'argumentació } \\
\text { - Les fal-làcies }\end{array}$ & $\begin{array}{l}\text { - Estratègies retòriques: } \\
\text { metàfora, antítesis, } \\
\text { eufemismes, hipèrboles... }\end{array}$ \\
\hline Pragmàtic & Acció i interacció & $\begin{array}{l}\text { - Actes de parla. Actes de parla } \\
\text { indirectes } \\
\text { - Expressió de l'actitud: ironia, } \\
\text { dramatisme, complicitat... }\end{array}$ & $\begin{array}{l}\text { - Estratègies de la interacció } \\
\text { conversacional: silencis, torns } \\
\text { de parla, llocs pertinents de } \\
\text { transició, cortesia, màximes } \\
\text { conversacionals... }\end{array}$ \\
\hline
\end{tabular}

Fig. 79. Llocs d'inserció de la ideologia en el discurs

En aquest tema es presenten algunes de les estratègies que tenen un paper fonamental en la inserció de biaixos ideològics en el discurs dels mitjans de comunicació: la dixi exofòrica i els mecanismes dialògics del discurs, els actes de parla, la polifonia discursiva, la selecció lèxica (que permet activar topoi i blocs semàntics), l'estratègia figurativa i els mecanismes de modalització del discurs.

\subsection{Text i context: la dixi i els díctics}

Gràcies a les aportacions dels filòsofs del llenguatge, durant les últimes dècades $s$ 'ha desenvolupat extraordinàriament una visió pragmàtica del llenguatge que situa l'ús lingüístic com a centre d'atenció de la investigació i parteix de la constatació que utilitzar la llengua és actuar, que parlar és fer. Aquest nou punt de vista sobre el discurs ha comportat el desenvolupament de la pragmàtica i ha situat el focus d'atenció en aspectes lingüístics que fins fa poques dècades no havien rebut gaire atenció per part dels estudiosos del llenguatge.

Aquesta perspectiva pragmàtica del discurs i de la comunicació ha centrat l'interès, per exemple, en la teoria dels actes de parla, en l'estudi del dialogisme, que es fa evident a través dels díctics i de les manifestacions diverses del dialogisme, però també en l'anàlisi de les formes diverses d'expressar l'actitud de l'emissor en el discurs (ironia, dramatisme, complicitat...), de les estratègies específiques de la interacció conversacional (silencis, torns de parla, llocs pertinents de transició, màximes conversacionals, regles de cortesia...) i de les diverses manifestacions d'inserció d'informació implícita en el discurs (pressuposicions i sobreentesos o 
implicatures). Alguns d'aquests conceptes ja s'han presentat en temes anteriors i ara només es reprendran per completar l'anàlisi del discurs des d'aquesta perspectiva pragmàtica, però d'altres es desenvoluparan en aquest apartat i en els següents.

\subsubsection{La dixi i els díctics}

\subsubsection{La funció díctica}

Els textos són unitats comunicatives que estan íntimament relacionades amb la situació de comunicació en què s'insereixen. Sempre fan referència, per tant, a la realitat circumdant: a les coordenades temporals, espacials i personals de l'enunciació (referència exofòrica) o a diversos elements del mateix enunciat (referència endofòrica). Les unitats lingüístiques que expliciten les relacions del text amb el context en què es produeix o amb altres parts del mateix text s'anomenen dictics.

A grans trets, es pot afirmar que la dixi és una funció lingüística que permet establir una connexió directa entre l'enunciat, d'una banda, i els participants o les circumstàncies en què es produeix l'enunciació (o l'acte de parla), de l'altra, de tal manera que la interpretació d'un element díctic depèn precisament dels participants i de les circumstàncies de l'acte de parla. En la llengua, a més de les unitats que tenen un valor bàsic conceptual, n'hi ha d'altres que hi actuen fonamentalment com a indicadors o mostradors, això és, en funció díctica. Les categories díctiques, des d'aquesta perspectiva, expressen distincions relacionades amb els participants en l'acte de parla, això és, amb l'emissor, que codifica i emet l'enunciat, i amb el receptor, que el rep i el descodifica (dixi de persona); amb l'estatus social amb què es presenten o es designen els interlocutors (dixi social); amb el moment en què es produeix l'acte de parla (dixi temporal), i amb l'espai en què se situen els interlocutors (dixi espacial).

IEC, 2006

Tradicionalment s'han distingit tres classes de díctics, que es poden entendre com les tres dimensions de l'espai comunicatiu en què se situen els enunciats: els interlocutors o persones participants, l'espai i el temps en què es produeix l'intercanvi comunicatiu. Es tracta, per tant, de les tres dimensions sobre les quals es planifiquen i s'interpreten els enunciats, d'una sèrie de recursos de caràcter pragmàtic que permeten l'articulació o l'ancoratge del text en el context o situació comunicativa en què es produeix. A aquestes tres categories díctiques bàsiques cal afegir una sèrie de mecanismes lingüístics relacionats amb la dixi social i amb la dixi discursiva o textual.

La dixi es materialitza en els textos en una sèrie de mecanismes gramaticals ben coneguts, però té una funció clarament pragmàtica, ja que aquestes categories no s'omplen de contingut si no és en una situació comunicativa concreta, és a dir, en el procés d'enunciació. Així, mentre la frase [1] no pot interpretar-se sense conèixer a quins elements del context situacional remeten els elements en cursiva, la frase [2] es pot interpretar perfectament sense una dependència estricta del context.

[1] Ara, agafeu els exàmens i deixeu-los ací.

[2] A les 10.30, els alumnes deixaran els exàmens a la taula. 
És evident que la densitat lèxica d'un text està directament condicionada pel grau de dependència contextual dels enunciats. És per això que les interaccions conversacionals presenten sovint un nombre de díctics molt elevat i que a l'hora d'estudiar el funcionament d'aquestes unitats és particularment interessant de fixar-se en les produccions dialogades, especialment si es tracta de textos espontanis.

\subsubsection{Marques lingüistiques}

El gràfic de la fig. 80 representa, d'una forma clara, els diversos tipus de díctics en relació amb els constituents elementals de la situació de comunicació.

\section{Enunciació}

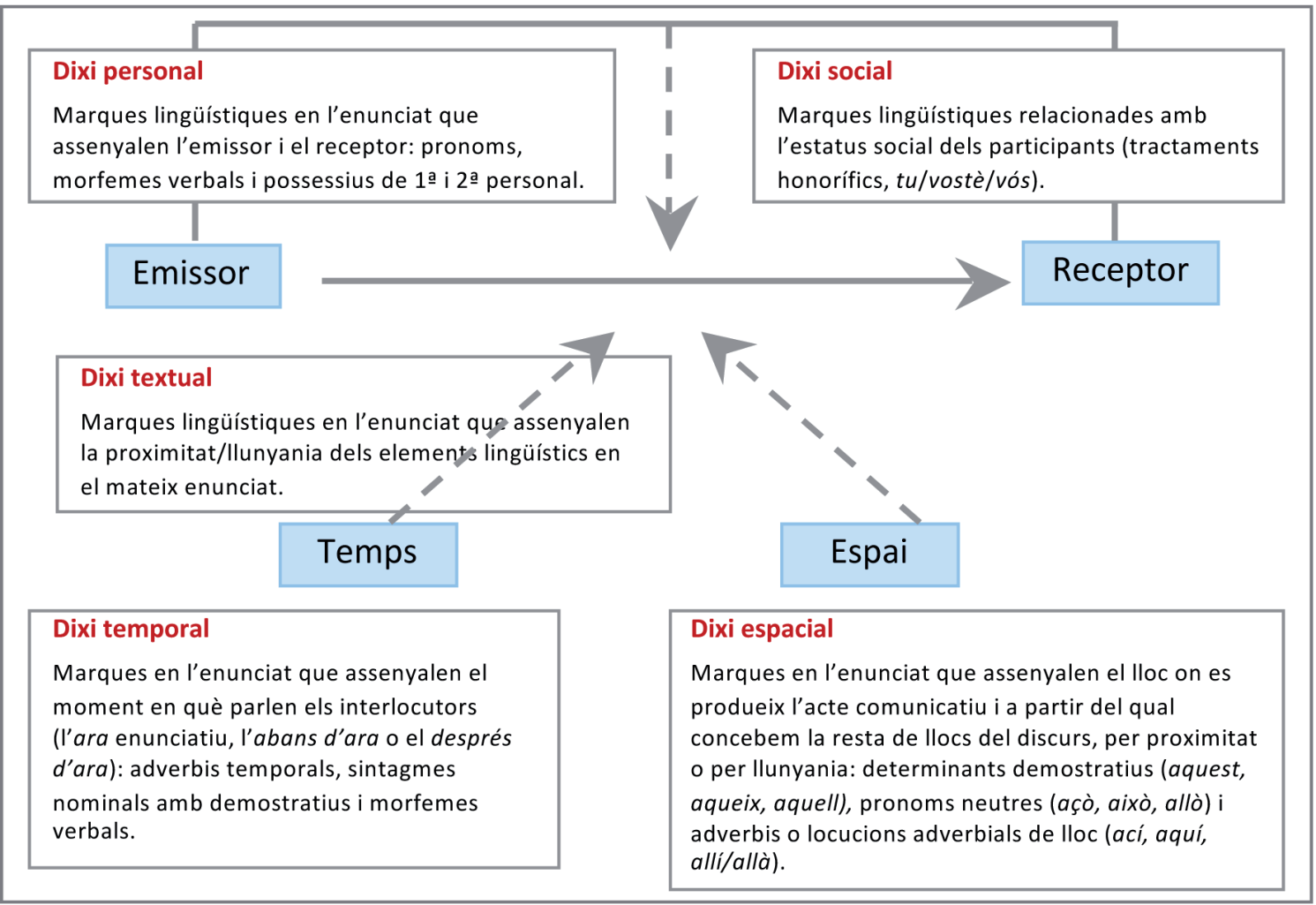

Fig. 80. Tipus de dixi

La dixi personal relaciona els enunciats amb els participants en l'acte comunicatiu, amb la distinció de tres categories: la persona que parla (jo), el receptor $(t u)$ i tot allò que no remet directament a les anteriors (ell/a), i que és l'objecte de l'enunciat. La primera i la segona poden reflectir diversos tipus d'associacions:

- Plural de modèstia: nosaltres, tot referint-se a un jo que no vol implicar-se en l'enunciat per aconseguir un major distanciament del receptor i una major objectivitat en el seu enunciat.

- Plural majestàtic: nosaltres o nós com a fórmules d'autoreferència utilitzades per reis i papes. 
- Inclusiva: nosaltres $(j o+t u+t u+\ldots)$ i vosaltres $(t u+t u+t u+\ldots)$, per implicar el destinatari.

- Exclusiva: nosaltres $(j o+$ ell $[a]+$ ell $[a]+\ldots)$ i vosaltres $(t u+$ ell $/ a+$ ell $/ a$ $+\ldots)$, que reflecteixen la inclusió de l'emissor o el receptor en un col-lectiu específic del qual no forma part el destinatari.

- Generalitzadora: nosaltres (jo + tu (o vosaltres) + ell/a o ells/es), en què l'emissor i el receptor formen part d'un plural col·lectiu general que inclou més persones.

De fet, la tercera persona no es troba en el mateix nivell que les altres dues, el jo emissor i el $t u$ receptor: no forma part de la interlocució i, per tant, no és una forma díctica.

La dixi temporal relaciona els enunciats amb un temps determinat. Si no s'especifica el contrari, el temps implícit és l'ara de l'enunciació, en funció del qual té sentit un abans i un després. Les tres categories verbals de present, passat i futur reflecteixen evidentment aquests tres moments, però és prou sabut que el present, per exemple, pot recobrir parcel·les del futur (Torne ara mateix) i del passat (el present «històric» de qualsevol narració: Llavors vaig anar-hi, i li dic: Animal, que ets un animal!). Aquest ús és molt freqüent en la modalitat col·loquial, on trobem autèntiques fòrmules fixes de transició del tipus I li va dir, diu...; I deia, diu...; etc.

La dixi espacial, relaciona els enunciats amb el lloc en què es produeixen. El català antic feia una distinció de tres graus, que es conserva en el valencià actual: a) ací, açò, est; b) aquí/ahí, això, eix, i c) allí/allà, allò, aquell. Aquests tres graus de distància (immediat/mediat/llunyà) s'associen respectivament a les tres persones gramaticals (jo/tu/ell), i es redueixen a dos en la resta del català: aquí/allí(-à), aquest/aquell, etc.

Aquestes tres modalitats díctiques constitueixen els eixos respecte als quals es construeix el missatge. Aquest, implícitament, sempre quedarà referit als tres punts centrals de les que alguna vegada han estat anomenades coordenades díctiques: el jo, l'ara i l'ací.

La dixi social té a veure amb els estatus socials dels parlants, i determina el tractament que reben en el context. A banda de tractaments honorífics, el català utilitza en aquest sentit un sistema amb dues opcions (tu/vostè), que es trien en funció de la menor o major formalitat, respectivament, que els parlants atorguen a la situació de parla. Una tercera opció (vós) ha quedat relegada -en gran part segurament per la influència del castellà- a usos molt restringits, i es troba en camí de desaparèixer totalment.

Finalment, la dixi textual o dixi discursiva engloba les referències intertextuals (o endofòriques) que contribueixen d'una manera decisiva a la cohesió del text. Aquest tipus de dixi inclou una sèrie d'elements lingüístics que s'utilitzen per fer referència a altres elements del text. Les formes prototípiques de la dixi textual són el demostratiu neutre això (que pot contrastar amb açò i allò) i la resta de demostratius (aquest, aquesta, aquelles, etc.). 
Tot i que la dixi textual és una funció lingüística molt propera a l'anàfora, cal distingir els dos procediments. Mentre que la funció díctica assenyala elements del text d'acord amb la seua proximitat o llunyania respecte al punt on apareix inserit el díctic -com ara en els exemples [3] i [4], on el pronom neutre això i el demostratiu aquesta reprenen el contingut de la frase anterior i, al mateix temps, indiquen proximitat en el text-, l'anàfora és un procediment de referència que es limita a repetir el contingut del seu antecedent — com es pot veure en l'exemple [5], on el pronom ho només repeteix el contingut de l'expressió «que la situació a l'Iraq ha millorat».

[3] Diuen que atacaran l'Iraq. Això ja se sabia.

[4] Els Estats Units són els guardians del planeta i aquesta funció se 1'han apropiada.

[5] Diuen que la situació a l'Iraq ha millorat i ho continuaran dient.

Per parlar amb propietat, cal limitar el concepte de dixi textual als fenòmens lingüístics similars a les oracions [3] i [4] i mantenir dins del camp de la referència anafòrica els fenòmens de pronominalització.

\subsection{Acció i interacció: els actes de parla}

\subsubsection{Els actes de parla}

Els actes de parla són, com la resta d'accions humanes, una manifestació de l'activitat social humana, una activitat que realitzem amb uns recursos verbals i no verbals específics (dimensió locutiva de l'acte de parla), amb unes determinades intencions (dimensió il-locutiva) i que provoca uns efectes socials pràctics en els interlocutors (dimensió perlocutiva). De l'estudi de la dimensió locutiva dels actes de parla (del contingut i la forma dels enunciats descontextualitzats), se n'ocupen la lògica i la gramàtica, mentre que de l'estudi de la dimensió il·locutiva, que es basa en el context $i$ en la intencionalitat, se n'ocupa la pragmàtica.

Per tant, els actes de parla són els enunciats lingüístics considerats des d'una perspectiva pragmàtica, és a dir, com a discursos que tenen una forma determinada, són produits amb una intencionalitat concreta i provoquen determinats efectes socials. Els actes de parla tenen tres components complementaris:

- Acte locutiu: la forma de l'enunciat lingüístic que s'emet.

- Acte il-locutiu: força comunicativa de l'emissor que expressa la seua intencionalitat.

- Acte perlocutiu: efecte que es pretén aconseguir en el receptor. 


\subsubsection{Classificació dels actes de parla}

Per tal d'investigar com funciona el llenguatge quan és utilitzat pels parlants, els investigadors han proposat diverses classificacions dels actes de parla. Una de les més conegudes consisteix a distingir-ne cinc tipus diferents:

\begin{tabular}{lll}
\hline Tipus d'actes & \multicolumn{1}{c}{ Intencionalitat } & \multicolumn{1}{c}{ Exemples } \\
\hline Assertius & Afirmar alguna cosa sobre la realitat. & $\begin{array}{l}\text { Asseverar, proposar, definir, expli- } \\
\text { car, insistir... }\end{array}$ \\
\hline Directius & $\begin{array}{l}\text { Influir en els altres o cridar la seua } \\
\text { atenció. }\end{array}$ & $\begin{array}{l}\text { Demanar, preguntar, ordenar, } \\
\text { manar, recomanar, prohibir, donar } \\
\text { instruccions... }\end{array}$ \\
\hline Compromisius & $\begin{array}{l}\text { Posar-se obligacions per decisió } \\
\text { pròpia. }\end{array}$ & $\begin{array}{l}\text { Prometre, jurar, oferir, apostar, } \\
\text { comprometre's, amenaçar... }\end{array}$ \\
\hline Expressius & $\begin{array}{l}\text { Mostrar actituds emocionals o } \\
\text { afectives envers els altres o envers la la } \\
\text { realitat. }\end{array}$ & $\begin{array}{l}\text { Felicitar, demanar disculpes, agra- } \\
\text { ir, saludar.. }\end{array}$ \\
\hline Declaratius & Canviar l'estat de coses. & $\begin{array}{l}\text { Sentenciar, acomiadar, inaugurar, } \\
\text { batejar, declarar la guerra, aixecar } \\
\text { una sessió, casar-se... }\end{array}$ \\
\hline
\end{tabular}

Fig. 81. Tipus d'actes de parla

Directament relacionat amb el concepte i la classificació dels actes de parla es troba la noció de modalitat oracional. De fet, la modalitat és la manifestació prosòdica i sintàctica de la força illlocutiva d'un enunciat.

La tipologia de la modalitat oracional parteix de la distinció entre modalitats primàries, que són obligatòries en tant que constituents oracionals bàsics, i secundàries o opcionals. L'esquema següent en presenta la classificació completa:

Modalitats oracionals $\left\{\begin{array}{l}\text { Primàries }\left\{\begin{array}{l}\text { Asseverativa: dir } \\ \text { Interrogativa: preguntar } \\ \text { Exhortativa: ordenar }\end{array}\left\{\begin{array}{l}\text { Directa / indirecta } \\ \text { Total / parcial }\end{array}\right.\right. \\ \text { Secundàries }\left\{\begin{array}{l}\text { Exclamativa: exclamar } \\ \text { Dubitativa: dubtar } \\ \text { Desiderativa: desig }\end{array}\right.\end{array}\right.$

Fig. 82. Modalitat oracional

Els actes de parla indirectes són aquells, molt habituals en el llenguatge col·loquial, però també en el llenguatge dels mitjans de comunicació, en què es produeix una oposició entre l'acte locutiu i la seua força il-locutiva. No existeix coincidència entre allò que expressa la locució i el que s'espera que faça el receptor. Per exemple: 
[6] Pots passar-me la sal?

[7] M'agradaria que em passares la sal.

[8] Series tan amable de passar-me la sal?

En aquests casos el locutor demana una acció per part del receptor sense expressar-ho de manera directa. De vegades, algunes manifestacions demanen un coneixement intens del significat pragmàtic, sobretot quan s'usa la ironia o altres figures retòriques. Sovint aquest tipus d'actes de parla estan relacionats amb les regles de la cortesia i constitueixen estratègies discursives per esmorteir la força i l'agressivitat de les modalitats exhortatives.

\subsection{Polifonia i discurs reportat}

\subsubsection{La noció de polifonia}

El discurs periodístic, com l'acadèmic i el científic, té una constitució essencialment polifònica, com a mínim en dos sentits diferents: d'una banda, perquè sovint els textos d'aquest àmbit, tot $\mathrm{i}$ que tenen una autoria evident -de fet l'autor signa sempre els treballs que produeix i assumeix la responsabilitat de les idees exposades-, utilitzen amb profusió altres veus discursives que són utilitzades com a estratègia de legitimació ideològica o com a suport argumentatiu; de l'altra, perquè en la investigació científica i periodística és una pràctica habitual el treball en equip i, per tant, la redacció i publicació de textos diversos d'autoria collectiva. Per tant, a l'hora d'abordar l'estudi del discurs periodístic i publicitari és imprescindible de prestar una atenció especial a les formes de citació i a les convencions utilitzades en els gèneres d'aquests àmbits per indicar la procedència de les idees o les paraules citades.

Un text no és un mecanisme homogeni i uniforme: d'una banda, els gèneres i les unitats discursives estan constituïts, sovint, per una combinació de diferents seqüències textuals (narratives, argumentatives, explicatives, descriptives i dialogades) i, de l'altra, els textos, tot i que tenen un únic subjecte de l'enunciació, un únic emissor, solen estar integrats per elements relacionats amb diferents fonts d'enunciació, amb diferents veus.

La noció de polifonia està relacionada amb la superposició de diverses veus en un únic enunciat, posa en qüestió la idea que un enunciat té un sol origen -anomenat indistintament emissor, subjecte parlant, enunciador o locutor-, és a dir, una font única de producció, i permet analitzar com es desdobla aquest subjecte en el discurs (Ducrot, 1980). Per a l'estudi de la polifonia és interessant de distingir entre tres nivells de producció discursiva diferent: autor, locutor i enunciador.

a) L'autor és el subjecte parlant o productor material del text.

b) El locutor o emissor és el responsable de l'enunciat. Així, l'estil directe o l'estil indirecte es poden interpretar a partir de la distinció entre dos locutors diferents en un mateix enunciat, dels quals només un s'identifica amb 
l'autor o subjecte parlant. En l'enunciat [9], per exemple, existeix un primer locutor, que és el responsable de l'enunciació del text (En Joan m'ha dit...), i un segon locutor, que emergeix del discurs del primer locutor per assumir la responsabilitat de venir l'endemà del moment en què es produeix l'enunciació (Hi aniré demà).

[9] En Joan m'ha dit: hi aniré demà.

c) Els enunciadors són entitats que es fan presents en l'enunciat, més que amb les seues veus, amb el seu punt de vista. Es tracta d'una possibilitat que de vegades utilitzen els locutors per introduir en el seu propi discurs posicions diferents de la seua. La ironia, per exemple, es pot explicar com un fenomen en què un locutor deixa escoltar una veu diferent a la pròpia, la veu d'un enunciador que expressa un punt de vista insostenible. En aquests casos, el locutor assumeix les paraules de l'enunciador, però no assumeix el seu punt de vista. L'ús d'enunciadors és una estratègia argumentativa molt utilitzada en el discurs publicitari que permet la inserció d'afirmacions que no són assumides pel locutor ni per l'autor, però poden utilitzar-se per orientar el missatge en un sentit o en un altre. En l'eslògan [10], el locutor, que apareix identificat amb el nom de l'empresa i amb el col·lectiu nosaltres, utilitza un punt de vista extern, compartit per bona part dels destinataris potencials del missatge, segons el qual fer entrepans és una cosa molt senzilla. En aquest cas, el contrast entre aquest missatge i la informació pressuposada per la segona part de l'eslògan ('els nostres entrepans són els millors') s'utilitza per iniciar un doble moviment argumentatiu que, d'una banda, qüestiona la veracitat del punt de vista recollit $i$, de l'altra, subratlla la qualitat del producte anunciat:

[10] Si és tan fàcil fer entrepans, per què ningú no els fa com nosaltres? Bocatta.

De vegades, aquestes tres entitats coincideixen en la veu del subjecte parlant, però sovint es manifesten clarament a l'interior d'un text.

\subsubsection{Els perfils del locutor}

La veu discursiva del locutor -que representa el jo discursiu, el subjecte responsable de l'enunciat- es fa present en l'enunciat a través de diverses marques lingüístiques (pronoms personals de 1a persona, singular o plural; formes verbals de 1a persona, singular o plural; determinants possessius de 1a persona) i provoca determinats efectes pragmàtics en el receptor. El locutor s'implica totalment en l'enunciat i representa les opinions personals. Per contra, el plural pot tenir diverses funcions pragmàtiques. D'una banda, podem distingir el plural majestàtic amb una funció clarament retòrica, que només és usat pels reis o papes (Nós, Jaume I), i el plural de modèstia, que té un efecte impersonalitzador ( $D$ 'acord amb les dades, proposem...). D'altra banda, podem diferenciar entre el plural inclusiu $(\mathrm{jo}+\mathrm{tu})$ que manifesta el desig del locutor d'implicar l'al·locutari en el discurs ( $\mathrm{Si}$ 
pensem en les conseqüències del conflicte...) el plural exclusiu (jo + ell), que no compta amb l'al-locutari i, en canvi, es recolza en terceres persones que comparteixen el discurs amb el locutor (Nosaltres els professors i professores d'aquesta Universitat volem oferir-vos una primícia...) i, finalment, el plural generalitzador $($ jo + tu + ell), que pretén incloure en el discurs un al·locutari molt extens amb el qual hom comparteix alguna característica (Nosaltres els humans...).

Paral·lelament, també el destinatari de l'enunciat del locutor (anomenat tècnicament al·locutari) emergeix en el discurs sota marques lingüístiques diferents (pronoms personals de 2 a persona, singular o plural; formes verbals de 2 a persona, singular o plural; determinants possessius de 2 a persona) i provoca diversos efectes pragmàtics. La forma prototípica del vosaltres $(\mathrm{tu}+\mathrm{tu}+\mathrm{tu})$ remet contextualment a l'al·locutari múltiple (Vosaltres que m'escolteu...), però també pot tenir una interpretació que inclou la tercera persona (tu + ell) de tal manera que només es refereix a una part de l'auditori (Vosaltres, les dones, esteu ja cansades...).

\subsubsection{Les formes del discurs reportat}

La pluralitat de veus en el discurs es manifesta a través del discurs reportat, fenomen que es produeix quan dins d'una enunciació se n'integra una altra, el discurs citat, que presenta marques de subjectivitat i de dixi pròpies. Existeixen diverses formes de manifestació textual del discurs citat: el discurs narrativitzat, el discurs directe, el discurs directe lliure, el discurs indirecte i el discurs indirecte lliure.

a) El discurs narrativitzat constitueix un report narratiu d'un acte de parla i, de fet, no intenta capturar ni reproduir les paraules usades originàriament:

[11] En el seu últim llibre, Stephen Hawking expressa amb claredat i agudesa les seues brillants idees científiques.

b) El discurs directe emergeix quan un locutor (L1) reprodueix literalment el text d'una altra veu, d'un altre locutor (L2), que, de fet, és qui assumeix la responsabilitat d'allò que es diu. Aquesta forma de representació del discurs citat comporta una repetició exacta d'un altre enunciat o enunciats, de manera que coexisteixen dos sistemes enunciatius (dos jo-ara-aqui). El pas d'un nivell enunciatiu (E1) a l'altre (E2) es fa evident per l'ús, opcional, d'un verb de locució (que introdueix el text citat), de vegades amb el suport de dos punts o d'elements paralingüístics com els espais en blanc o els salts de línia, l'ús de les cometes o altres sistemes (com ara la tipografia o l'interliniat) que emmarquen el text reportat i l'ús d'un sistema de temps verbal que remeten a una situació enunciativa pròpia (E2):

[12] El viatge en el Beagle fou, en paraules de Darwin, «l'esdeveniment més important de la meua vida $\mathrm{i}$ ha decidit tota la meua carrera» (Domínguez: 2000, 34). 
c) Amb el discurs indirecte, el locutor reprodueix un enunciat d'una altra persona, però mantenint-ne només el significat i modificant-ne la forma per tal d'integrar-la dins del seu propi sistema enunciatiu. Això comporta un major control de l'autor-locutor (L1) sobre tot l'enunciat, una atenuació de la subjectivitat de l'enunciador i modificacions substancials en els temps verbals i en el sistema díctic (pronoms personals, demostratius, possessius, etc.), que s'han d'adaptar al nivell enunciatiu en què és troba L1.

[14] Darwin va manifestar que el viatge del Beagle fou l'esdeveniment més important de la seua vida i que havia decidit tota la seua carrera

En aquest cas, el discurs citat ha de dependre necessàriament d'un verb de locució (al nostre exemple, va manifestar).

d) El discurs directe lliure constitueix una variant del discurs directe, utilitzada sovint en la interacció oral espontània i en el discurs literari, sovint amb la intenció de transmetre un matís irònic a l'enunciat. En aquest cas s'observa un intent d'eludir la responsabilitat de l'enunciació; es complica una miqueta el sistema pronominal, que passa del tu/ell al jo, un jo que assenyala indirecció.

[13] Fou l'esdeveniment més important de la meua vida $i$ ha decidit tota la meua carrera, va manifestar Darwin.

e) Finalment, el discurs indirecte lliure és una variant de discurs reportat en què les intervencions del segon locutor (L2) s'insereixen en el discurs del primer (L1) sense les marques típiques del discurs directe (verbs i díctics personals de primera persona, adverbis de proximitat...) i sense les marques d'introducció del discurs indirecte (verbs de dicció i conjunció que). Aquesta tècnica es detecta perquè en el discurs del locutor L1 apareixen interferències de la veu del locutor L2 -variacions en els temps verbals, formes de parlar, que senyalen el personatge o reproducció de pensaments, creences o inquietuds que només poden atribuir-se a L2-i transmet al lector una sensació de fusió de les dues veus.

[15] Per a Darwin, el viatge del Beagle va ser l'esdeveniment més important de la seua vida.

[16] La va mirar. On aniria sense ella.

Les característiques del discurs periodístic i publicitari determinen la preferència per les formes de citació més ben delimitades i més transparents (el discurs directe i l'indirecte, però també el discurs narrativitzat) i el rebuig sistemàtic de l'ús de les formes més «literàries» (com ara el discurs directe lliure o l'indirecte lliure).

El discurs reportat en estil directe posa en contacte dues situacions d'enunciació (E1 i E2), la primera de les quals (E1) inclou un locutor que s'identifica amb l'autor o autors del text (L1), que cedeix la veu a un altre locutor (L2) i activa així una situació d'enunciació anterior (E2). En els textos de l'àmbit cientificotècnic, com 
en els textos acadèmics, l'ús de fragments de text citats en estil directe està regulat per una sèrie de convencions que convé conèixer i utilitzar amb precisió:

a) El discurs directe es introduït per un verb de locució (dir, declarar, expressar, exposar, explicar...) o per una expressió equivalent (segons A, com assenyala $A$, en paraules $d$ 'A...).

b) Va emmarcat entre cometes baixes («...»), si ocupa un màxim de dues o tres línies, o se situa en un paràgraf independent, en un cos de lletra més reduït que el text matriu, sagnat a l'esquerra i separat del discurs matriu per un interlineat doble, si la citació és més extensa.

c) Exigeix l'expressió precisa de la font de procedència del discurs citat, habitualment utilitzant el sistema (autor: any, pàgines).

Per contra, el discurs reportat en estil indirecte reprèn les idees expressades en E2 des de la perspectiva d'E1 i demana, per tant, l'ús d'uns temps verbals referits a la situació d'enunciació citant (E1) i la introducció del discurs citat amb una oració completiva (verb de locució $+q u e$ ). Òbviament, en aquest cas no hi ha marques tipogràfiques que evidencien la separació del text citat del discurs en què s'insereix, ja que aquesta forma de citació permet la integració natural del text citat en el text matriu.

\subsubsection{Els verbs de locució}

Tant en el discurs directe com en l'indirecte, convé prestar una atenció especial a la selecció del verb de locució introductori del discurs reportat, ja que sovint la tria d'una forma verbal o una altra comporta la inserció de matisos significatius diferents (que solen passar desapercebuts), però que modalitzen d'una forma molt evident el discurs. Tot $\mathrm{i}$ que un reduït grup de verbs tenen un caràcter neutre $\mathrm{i}$, en principi, no comporten una modalització marcada (diu que, ha declarat que, va manifestar que, afirma que...), amb la selecció del verb de locució l'autor del text pot assignar al discurs citat un matís de 'dubte, inseguretat' (creu que), 'contundència' (assegura que, defensa que), 'insistència' (remarca que, recorda que, subratlla que, insisteix que), 'racionalitat' (explica que, argumenta que, pensa que), 'exhaustivitat' (exposa que) o 'matisació' (matisa que, puntualitza que).

En els exemples següents s'observa nítidament l'efecte que provoca el canvi del verb introductori de la locució:

[17] Kenneth Roeder, un dels pioners en l'estudi de les bases neurals del comportament, afirmava que l'objectiu últim de qualsevol investigació sobre el sistema nerviós és la comprensió del comportament.

[18] Kenneth Roeder [...] creia que l'objectiu últim de qualsevol investigació sobre el sistema nerviós és la comprensió del comportament. 
[19] Kenneth Roeder [...] explica que l'objectiu últim de qualsevol investigació sobre el sistema nerviós és la comprensió del comportament.

El quadre següent presenta alguns dels matisos semàntics associats als verbs de locució més habituals. Observeu com es manifesta aquesta pluralitat de matisos en la notícia que es reprodueix a continuació:

\begin{tabular}{lll}
\hline Significats addicionals transmesos & Verbs fonamentals & \multicolumn{1}{c}{ Altres verbs } \\
\hline $\begin{array}{l}\text { Introduir el discurs citat d'una forma } \\
\text { neutra }\end{array}$ & diu que, assenyala que & $\begin{array}{l}\text { manifestar, declarar, } \\
\text { exposar }\end{array}$ \\
\hline Afegir comentaris o matisacions & $\begin{array}{l}\text { vol deixar clar que, matisa } \\
\text { que, comenta que, explica } \\
\text { que }\end{array}$ & $\begin{array}{l}\text { observar, puntualitzar, } \\
\text { aclarir }\end{array}$ \\
\hline $\begin{array}{l}\text { Insistir sobre algun aspecte conegut o } \\
\text { destacar una idea }\end{array}$ & $\begin{array}{l}\text { recorda que, explica que, } \\
\text { comenta que, concreta }\end{array}$ & $\begin{array}{l}\text { destacar, insistir, } \\
\text { subratllar, remarcar }\end{array}$ \\
\hline Mostrar acord o coincidència & coincideixen que, per als dos & $\begin{array}{l}\text { compartir, estar } \\
\text { d'acord, concordar, } \\
\text { convergir }\end{array}$ \\
\hline Mostrar disconformitat & assenteix & $\begin{array}{l}\text { discrepar, dissentir, } \\
\text { divergir }\end{array}$ \\
\hline Afirmar amb reserves & creu que & $\begin{array}{l}\text { pensar, confiar, } \\
\text { suposar, sospitar, } \\
\text { opinar, etc. }\end{array}$ \\
\hline $\begin{array}{l}\text { Indicar amb contundència i seguretat } \\
\text { una opinió }\end{array}$ & defensa que, assegura & amollar, concloure \\
\hline Advertir, amenaçar & advertir & amenaçar \\
\hline
\end{tabular}

Fig. 82. Verbs de locució

26.04.2006

Lliga de Campions

\section{Ancelotti creu que al seu equip no se li pot reprotxar res}

L'entrenador del Milan, Carlo Ancelotti, s'ha resignat avui a veure's fora de la final de la Lliga de Campions contra el Barcelona, després d'empatar sense gols al Camp Nou en la tornada de les semifinals, encara que ha destacat l'uesforç i compromis" dels seus jugadors i ha assegurat que al seu equip "no se li pot reprotxar res». L'italià, que ha tornat a rebutjar de ple les preguntes sobre el seu possible futur com a entrenador del Reial Madrid («tinc contracte amb el Milan fins al 2008»), ha reconegut que torna a Milà "amb desil-lusió per haver perdut l'eliminatòria, però amb la satisfacció d'haver arribat aquí i caure contra un gran equip».

Ancelotti ha apuntat que el Milan s'ha mantingut "al mateix nivell» en els dos partits i ha afegit que «la sort ha estat favorable al Barcelona. El Barcelona ha jugat amb força i coratge i mereix ser a la final, encara que també el Milan ho hauria merescut», ha afegit l'entrenador de l'equip italià. A més, Ancelotti ha lamentat que el col-legiat del partit, l'alemany Markus Merk, anul·lés un gol legal a Xevtxenko després d'un salt amb Puyol. «No sé què ha vist, perquè Xevtxenko salta de manera normalı, ha adduït.

http://www.324.cat/noticia/120081 
A més dels verbs que introdueixen discurs narrativitzat, que apareixen en el text subratllats, es pot observar perfectament que el periodista ha utilitzat una ampla gamma de matisos semàntics que oscil·len entre l'expressió de dubte i inseguretat (creu que) a la contundència més absoluta (ha assegurat que), passant per la simple idea de continuïtat (ha afegit) o la focalització d'un aspecte concret (ha apuntat que) i per altres verbs que posen l'accent en l'actitud de la persona que constitueix la font del discurs citat i que oscil·la entre la lamentació (ha lamentat que), la confessió (ha reconegut que) i la voluntat de justificació (ha adduït).

\subsection{Procediments de modalització del discurs}

\subsubsection{El concepte de modalització}

Els gèneres argumentatius inclouen un ample ventall de textos que tenen com a intenció comunicativa dominant orientar l'opinió o la conducta dels destinataris i, sovint, regular la vida social. Es tracta de textos que sovint presenten un grau elevat de subjectivitat i que manifesten marques constants, més o menys explícites, de la presència de l'emissor i de l'orientació ideològica del discurs.

El concepte de modalització fa referència al «conjunt de marques que l'emissor deixa en el missatge, marques que funcionen com a indicadors de la seua presència i que es manifesten amb procediments gramaticals, lèxics, discursius, gràfics...» (Grau, 2002: 84). La presència d'aquestes petjades de l'emissor en l'enunciat comunica d'una forma més o menys explícita apreciacions, creences, opinions o actituds del subjecte parlant.

La modalització es pot fer explícita en el text a través de recursos molt diversos. Així, per exemple, l'emissor pot fer judicis de valor i presentar-los com a propis, però també pot recórrer a la introducció d'altres veus a les quals «fa dir» allò que li interessa introduir en el seu discurs. La introducció d'altres veus en el discurs permet «construir exposicions que contenen judicis de valor o opinions dels quals el parlant no es fa necessàriament responsable» (Grau, 2002: 84). De fet, la citació de paraules d'altres persones permet matisar o disminuir la responsabilitat de l'emissor sobre el contingut del discurs citat, reforçar la tesi continguda en el discurs amb un argument d'autoritat, mostrar uns coneixements determinats o utilitzar les paraules citades per desmarcar-se del contingut i iniciar la contraargumentació. En qualsevol cas, la noció de modalització no es pot separar de la noció de polifonia enunciativa, introduïda per Oswald Ducrot, que hem tractat en l'apartat anterior.

La manifestació discursiva de la modalització està lligada a una sèrie de procediments que, esquemàticament, estan relacionats amb els recursos següents:

1. Presència de l'emissor i el destinatari en el text

2. Validació del contingut dels enunciats mitjançant fonts i citacions

3. Atribució de diferents graus de certesa

4. Transmissió de judicis de valor 
5. Preservació de la imatge (màximes de cortesia)

6. Marcadors del discurs

7. Figures retòriques

\subsubsection{Presència de l'emissor i del destinatari en el text}

L'autor d'un text disposa d'una sèrie de recursos lingüístics per tal de construir un discurs declaratiu i despersonalitzat o per donar-hi un to càlid i intimista, per presentar les opinions com a punts de vista compartits per un col-lectiu més o menys extens o per donar al text un to distanciat i objectiu. En cada cas, disposem d'un ventall ample de formes lingüístiques que remeten a la presència de l'emissor en el text i, per tant, constitueixen marques directes de la inscripció del punt de vista de l'emissor en el discurs:

a) Discurs molt personalitzat: pronoms forts de 1a persona (Jo ho veig així, A mi no m'agrada), altres formes gramaticals de 1a persona (pronoms i adjectius possessius, pronoms febles, terminacions verbals) o fórmules introductòries específiques (personalment, al meu entendre, segons el meu parer, etc.).

b) Discurs impersonal: emmascarament de l'emissor darrere d'una 3a persona (Això és un despropòsit), ús col-loquial de la 2a persona del singular en lloc de la 3 a (Si t'exigeixen molt i no reps res a canvi, potser penses que no val la pena dedicar-hi tants esforços), frases amb subjecte inconcret (La gent prefereix veure resultats immediats), ús de les diferents formes de la veu passiva (En aquest documental es presenten els resultats d'una investigació...), etc.

c) Discurs amb emissor col·lectiu: introducció de l'emissor en un plural d'autor o plural de modèstia (El tema que avui tractarem...), ús del plural com a procediment d'apropament al receptor (A continuació, recordarem un parell d'exemples ben coneguts) o ús del plural de 1a persona generalitzador, sovint en verbs de dicció, d'enteniment i de percepció (Els europeus sabem bé que...).

Quant a la presència del receptor, existeixen també una sèrie de marques lingüístiques que remeten directament i d'una forma explícita al destinatari del text i que alhora estableixen una distància determinada entre emissor i destinatari:

a) Les formes de tractament personal (tu,vosaltres, vostè, vós), les fórmules de tractament solemne (senyor/a, il-lustríssima, molt honorable...) i les expressions de tractament de relació utilitzant el nom del càrrec (professor, senyor alcalde, senyora consellera...) o el nom propi precedit de mots com senyor, senyora, doctor, doctora, president...

b) La utilització del nom propi (Josep, Mireia), un hipocorístic (Pep, Tòfol, Tina, Beth...) o un adjectiu (bonica, simpàtic...). 
c) Substitució de la segona persona per la tercera: «Voldria agrair la presència de totes les persones que han vingut aquí aquest vespre» (en lloc de «les persones que heu vingut»).

d) Ús del plural de la primera persona com a fórmula d'aproximació: Com estem?

\subsubsection{Validació del contingut dels enunciats}

L'emissor pot utilitzar com a estratègia de modalització el recurs a l'explicitació de les fonts d'informació. Cal recordar que una citació mai no és neutra, és a dir, tot i que pot semblar que els enunciats citats literalment conserven la seua independència, la realitat és que l'actitud de qui fa la citació resulta determinant. Així, l'autor d'un text selecciona unes determinades paraules i no unes altres per citar, i decideix d'utilitzar un verb de locució no marcat (dir o declarar) o selecciona un verb marcat i, per tant, amb adherències significatives més o menys evidents (acusar, defensar, criticar, lamentar, denunciar, desmentir, confessar, etc.).

\subsubsection{Atribució de diferents graus de certesa}

Tant en els discursos orals en què predomina la funció referencial, és a dir, la transmissió d'una informació, com en els que comuniquen opinions o maneres de veure, el modus pot adoptar diferents formes que fan que el missatge arribe al receptor amb un grau de certesa molt alt, que s'apunte només com a probable o possible o que s'acoste a la incertesa o a la improbabilitat. A més, l'emissor pot assumir la responsabilitat de l'enunciat i mostrar-se com a avalador directe del seu contingut, o se'n pot desvincular i atribuir la procedència a altres veus que en són les directament responsables, actuant, en aquest cas, com a simple agent de transmissió que garanteix, això sí, l'autenticitat de les paraules dites.

El grau de certesa d'un enunciat es mou, per tant, en un eix que va de la certesa absoluta a la improbabilitat. Així, d'una manera general, podem considerar que les actituds de l'emissor es poden classificar en tres grans grups que afecten tres possibilitats diferents:

1. El contingut del missatge (el dictum) es presenta com a absolutament cert.

2. El contingut del missatge es presenta com a cert, però sense subratllar aquesta certesa.

3. El contingut es presenta com a possible o probable, amb tots els matisos intermedis que es troben en l'eix que va de la certesa absoluta a la incertesa.

El quadre reproduït en la fig. 80 presenta un inventari dels recursos lingüístics disponibles per expressar els diferents graus de certesa. 


\begin{tabular}{|c|c|c|}
\hline \multirow{2}{*}{ Recursos lingüístics } & \multicolumn{2}{|c|}{ Per presentar el contingut } \\
\hline & com a absolutament cert & com a possible o probable \\
\hline $\begin{array}{l}\text { 1. Frases introductòries i verbs } \\
\text { modals que afecten la validesa } \\
\text { de l'enunciat. }\end{array}$ & $\begin{array}{l}\text { 1. És evident que el nombre } \\
\text { d'alumnes disminuirà a } \\
\text { partir d'ara. }\end{array}$ & $\begin{array}{l}\text { 1. Sembla que el nombre d'alum- } \\
\text { nes disminuirà a partir d'ara. }\end{array}$ \\
\hline $\begin{array}{l}\text { 2. Adverbis o expressions amb } \\
\text { funció adverbial. }\end{array}$ & $\begin{array}{l}\text { 2. Òbviament, li costarà trobar } \\
\text { feina. }\end{array}$ & $\begin{array}{l}\text { 2. Probablement, li costarà trobar } \\
\text { feina. }\end{array}$ \\
\hline $\begin{array}{l}\text { 3. Lèxic marcat que comporta un } \\
\text { tret avaluatiu del tipus veritat/ } \\
\text { fals o cert/incert. }\end{array}$ & $\begin{array}{l}\text { 3. L'estudi ha confirmat amb } \\
\text { precisió el nivell de com- } \\
\text { prensió lectora. }\end{array}$ & $\begin{array}{l}\text { 3. Hi ha la possibilitat que les } \\
\text { pràctiques faciliten també la } \\
\text { comprensió. }\end{array}$ \\
\hline $\begin{array}{l}\text { 4. Mots que comporten una } \\
\text { restricció o una generalització } \\
\text { absolutes. }\end{array}$ & $\begin{array}{l}\text { 4. No hi ha cap necessitat de } \\
\text { realitzar activitats que van } \\
\text { contra la llei. }\end{array}$ & 4. Ø \\
\hline $\begin{array}{l}\text { 5. Expressions, locucions i frases } \\
\text { fetes. }\end{array}$ & $\begin{array}{l}\text { 5. No faré cap hora extra: } h i \\
\text { podeu pujar de peus! }\end{array}$ & $\begin{array}{l}\text { 5.Vés a saber si farà alguna cosa } \\
\text { del que ha promès! }\end{array}$ \\
\hline 6. Modes verbals que situen l'ora- & 6. Ø & 6. Al migdia podrien aparèixer \\
\hline $\begin{array}{l}\text { 7. Dinàmica discursiva que contri- } \\
\text { bueix a produir una impressió de } \\
\text { veritable/fals o de cert/incert. }\end{array}$ & $\begin{array}{l}\text { 7. Proces argumentatiu sólid } 1 \\
\text { coherent. }\end{array}$ & $\begin{array}{l}\text { alguns nuvols. } \\
\text { 7. Procés argumentatiu feble. }\end{array}$ \\
\hline $\begin{array}{l}\text { 8. Trets relacionats amb l'emissió } \\
\text { de la veu. }\end{array}$ & 8. Èmfasi expressiva. & 8. Entonació dubitativa o vacil·lant. \\
\hline
\end{tabular}

Fig. 84. Recursos per expressar els diferents graus de certesa (font: Grau, 2002)

\subsubsection{Transmissió de judicis de valor}

La transmissió de judicis de valor a través de marques lingüístiques específiques constitueix, sens dubte, un dels mecanismes modalitzadors més utilitzats i més ben estudiats. En general, els procediments utilitzats per transmetre judicis de valor es poden agrupar en cinc blocs ben diferenciats:

a) Unitats lèxiques i expressions amb valor axiològic (adjectius, substantius, verbs, perífrasis verbals, connectors i articles amb implicació, quantitatius, interjeccions, locucions i frases fetes).

b) Procediments morfosintàctics: ús de modalitats oracionals no assertives, priorització d'elements significatius dins l'oració i ús de morfemes valoratius (diminutius, augmentatius, pejoratius, sufixos i prefixos de superlatiu).

c) Recursos prosòdics: fenòmens d'èmfasi tonal, volum, to, ritme i pauses.

d) Procediments discursius: avaluació per selecció (tria d'uns temes i silenci sobre uns altres), avaluació per jerarquització (establiment d'un ordre d'importància, tematització).

e) Recursos sociolingüístics: alternança de codis i ús d'expressions que connoten valors culturals, polítics i religiosos. 


\subsubsection{La preservació de la pròpia imatge}

Especialment en l'argumentació oral, però també en l'escrita, l'emissor disposa d'una sèrie d'estratègies vinculades al manteniment de les màximes de cortesia que funcionen també com a elements modalitzadors. D'acord amb la classificació que proposa Leech (1983), aquestes màximes es presenten de la forma següent:

1. Màxima de tacte: suposa que tu ets l'autoritat i que el teu interlocutor t'ha d'autoritzar.

2. Màxima de generositat: minimitza el teu propi benefici i maximitza el benefici del teu interlocutor.

3. Màxima d'aprovació: minimitza el menyspreu cap a l'altre i maximitza l'estimació.

4. Màxima de modèstia: minimitza la valoració de tu mateix i maximitza la valoració de l'altre.

5. Màxima d'acord: minimitza el desacord i maximitza els punts d'acord.

6. Màxima de simpatia: minimitza l'antipatia i maximitza la simpatia.

\subsubsection{Marcadors del discurs i figures retòriques}

Finalment, també tenen una funció modalitzadora molt evident els marcadors del discurs (vegeu el tema 8) i les figures retòriques (que es presentaran a continuació). En el primer cas, es tracta de mecanismes que comporten un posicionament clar de l'emissor en relació al contingut del seu discurs o als seus interlocutors. En el segon, d'un conjunt de procediments que, com veurem tot seguit, tenen una gran importància en l'articulació del pensament i en la gestió de les idees i, per tant, una funció cognitiva de primer ordre. La metàfora i la resta de figures retòriques -la metonímia, la hipèrbole o la ironia- permeten introduir en el discurs una determinada visió del món i, per tant, una determinada orientació argumentativa. Els dos procediments, els marcadors i la metaforització, tenen una presència important en el discurs periodístic, tant en els gèneres d'opinió com en els gèneres informatius.

\subsection{L'estratègia figurativa: metàfora i pensament}

\subsubsection{La metàfora i la metonímia}

La metàfora és un dels pilars centrals de l'edifici retòric des de fa més de dos mil anys. Tradicionalment, s'ha considerat que es tractava d'un fenomen exclusivament lingüístic, que tenia el seu ecosistema propi en el territori del discurs literari -especialment en el domini de la poesia-i que era, essencialment, un recurs d'embelliment del discurs i, per tant, un mecanisme perfectament inútil i suprimible en altres tipus de discursos. Les teories clàssiques del llenguatge havien assumit que «la metàfora és un assumpte del llenguatge, no del pensament», i que les expressions metafòriques constituïen un fenomen aliè al territori del llenguatge quotidià. 
Les investigacions realitzades durant els darrers vint anys han destacat, però, la presència de la metàfora en tots els àmbits discursius -la literatura i el cinema, evidentment, però també el discurs acadèmic, la publicitat, el llenguatge dels mitjans de comunicació i els articles científics de divulgació, per esmentar-ne alguns-i han confirmat que es tracta d'un fenomen absolutament central en la construcció dels discursos de la vida quotidiana.

Des de la perspectiva de la lingüística cognitiva, la metàfora no és exclusivament un recurs expressiu de caràcter lingüístic, sinó un poderós mecanisme de construcció del pensament i de gestió de les idees. Es tracta, per tant, d'una de les estratègies essencials d'estructuració del pensament. Les metàfores són mecanismes de comprensió d'un domini cognitiu -anomenat tècnicament domini de destinacióen termes d'un altre domini cognitiu -anomenat domini d'origen. Es tracta d'un mecanisme essencialment analògic, mitjançant el qual projectem els coneixements que tenim de dominis ben coneguts i propers a la nostra experiència vital sobre àmbits més abstractes i més desconeguts. Per tant, entenem un domini de l'experiència humana en termes d'un altre domini experiencial, sovint més concret o dotat d'una materialitat o un poder plàstic més intens. Així, un esdeveniment esportiu és conceptualitzat sovint com una proesa èpica o com una guerra; la comunicació és un procés d'enviament d'idees o significats (que són objectes), empaquetats en expressions lingüístiques (que són recipients), a través d'un canal; el temps és or; la vida és un viatge; la ment humana és una màquina, i les idees són aliments o persones.

La metàfora consisteix, per tant, a utilitzar una paraula o una idea en el lloc d'una altra paraula o idea amb la qual manté una relació d'analogia, és a dir, una determinada semblança. Així, per exemple, si en un titular de premsa llegim que «El Castelló ix de l'UCI i ofereix símptomes de recuperació», ja sabem que no es tracta del Sr. Castelló que ha tingut un accident de cotxe i està molt greu a la unitat de cures intensives d'un hospital, sinó d'un equip de futbol que havia perdut alguns partits i es trobava mal classificat. De fet, la metàfora suposa una identitat entre dos termes i idees i presenta la forma «A és $\mathrm{B} » \mathrm{O}$ « $\mathrm{A}=\mathrm{B}$ », on $\mathrm{A}$ és el domini de destinació i B, el domini d'origen. En el cas que comentem, A és l'equip de futbol $\mathrm{i} \mathrm{B}$, un malalt greu. Perquè una metàfora funcione $\mathrm{i}$ es puga interpretar en el sentit adequat s'han de donar dues condicions:

a) L'existència d'un element o un conjunt d'elements compartits pels dos termes o dominis (en aquest cas la gravetat, una situació perillosa).

b) Una projecció o equivalència d'elements d'una idea sobre l'altra (aquí, l'equip de futbol és un malalt, les derrotes són els problemes de salut, la mala classificació és la UCI, les victòries són la recuperació, etc.).

Sovint, les metàfores (especialment, les anomenades metàfores estructurals) impliquen una sèrie de projeccions o correspondències entre elements del domini de destinació i elements del domini d'origen (a1 $\rightarrow$ b1, a $\rightarrow$ b2, a3 $\rightarrow$ b3...). Així, l'eslògan «La vida és un esport molt dur», acompanyat de les imatges de l'espot (fig. 9) i del text verbal que les acompanya ([19]), activa les projeccions 
següents: A (la vida) = B (un esport de competició); a1 (anar a treballar) $\rightarrow$ b1 (els cent metres lliures); a2 (un embús) $\rightarrow$ b2 (una cursa d'obstacles); a3 (anar a comprar) $\rightarrow$ b3 (una competició de gimnàstica); a4 (l'estrès de la vida quotidana) $\rightarrow$ b4 (una cursa contrarellotge). Aquest mecanisme de correspondències permeten entrar en acció el producte anunciat, una beguda isotònica destinada inicialment a la recuperació dels esportistes d'elit, i projectar el seu ús cap a les activitats de la vida quotidiana.

[19] Per a tu què és més dur, l'esport o la vida? Els cent metres lliures o anar a treballar? Els 3000 obstacles o un embús? El gimnàs o anar a comprar? Una contrarellotge o anar tot el dia contra el rellotge? Aquarius t'ajuda a recuperar els fluids essencials i minerals que perds en l'esport i en la vida. Aquarius: la vida és un esport molt dur.
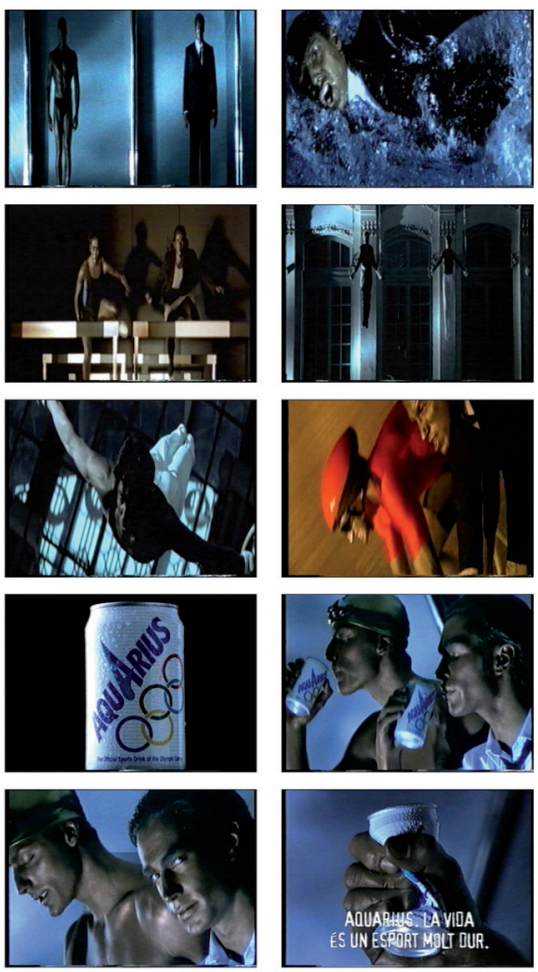

Fig. 85. Espot d'Aquarius

Alguns esquemes metafòrics són universals, però la major part de les metàfores tenen un caràcter cultural $i$, per tant, un àmbit d'ús restringit a un domini geogràfic i social determinat. Així la metàfora la vida és una cursa de braus i les expressions que en formen part-agafar el bou per les banyes, mirar els bous des de la barrera, patir una rebolcada, entrar a matar o capejar el temporal- tenen sentit en una cultura mediterrània on les festes dels bous ocupen un lloc central, però no serien enteses en altres àmbits geogràfics sense aquest rerefons cultural.

La metonímia, en canvi, és un mecanisme una mica diferent, ja que en aquest cas la projecció no es realitza entre dos dominis diferents, sinó entre dos elements d'un mateix domini cognitiu, anomenats respectivament punt de referència i zona 
activa. La metonímia permet utilizar el continent en lloc del contingut (prendre's un got de vi), el nom de la ciutat o de l'edifici on resideix una institució en lloc de la institució (Pequín no ha volgut fer declaracions; la Casa Blanca ha emès un duríssim comunicat), el símbol per referir-se a la institució representada (el paper de la Corona) o la part pel tot (el motor de la teua vida, per referir-se a un cotxe). En tots els casos, com es pot observar, entre la zona activa (o terme substitut) i el punt de referencia (o element substituiit) existeix una relació de proximitat o de contigüitat evident que permet fer la substitució.

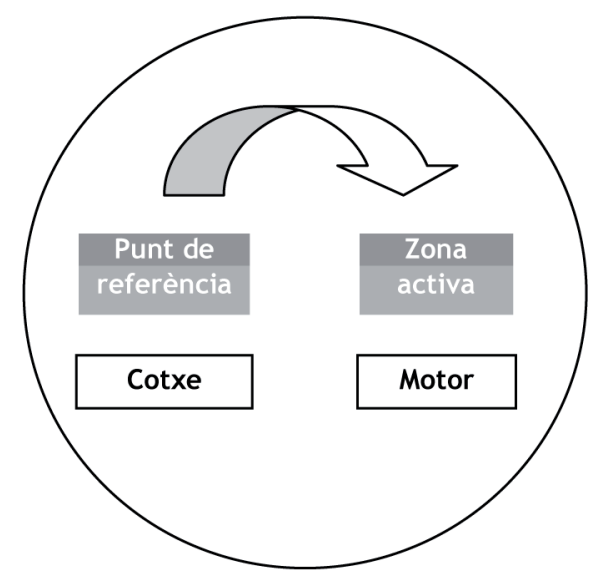

Fig. 86. Funcionament de la metonímia

Tant la metáfora com la metonímia són dos procediments fonamentals de creació lèxica, ja que permeten introduir noves accepcions a termes que formen part del corpus de l'idioma. Aquestes noves accepcions, que els repertoris lexicogràfics acostumen a marcar com a sentit figurat (fig. 10), permeten ampliar les possibilitats expressives de l'idioma sense haver de recórrer sistemàticament al préstec $i$, alhora, permeten introduir matisos significatius que fan possible un ús més precís del llenguatge. És evident, per exemple, que les dues oracions següents, malgrat ser molt similars, no transmeten exactament la mateixa informació:

[20] El seu govern, senyor president, és un problema per a la societat.

[21] El seu govern, senyor president, és un càncer per a la societat.

La paraula problema conté la idea de 'dificultat o qüestió que s'ha de resoldre', que es pot resoldre o aclarir, i du associada d'una forma gairebé automàtica la paraula solució. En canvi, el mot càncer en el mateix cotext transmet una major gravetat, ja que transfereix a l'expressió el seu govern la idea de 'creixement tumoral dels teixits, de caràcter maligne i pertorbador de les funcions biològiques normals', que forma part del significat lèxic del mot. Així, la selecció d'una paraula o l'altra contamina el terme que remet al domini de destinació (el seu govern) amb les connotacions associades al terme que activa un domini d'origen (problema) o un altre (càncer). 


\subsubsection{Tipus de metàfores}

Des d'un punt de vista formal, segons els mecanismes expressius utilitzats per transmetre l'analogia, es poden distingir les metàfores lingüístiques de les visuals, les olfactives o les tàctils. Recentment, alguns especialistes (Van Leeuwen, 2005; Forceville, 2009) han posat en circulació el concepte de metàfora multimodal, per referir-se a aquell tipus de metàfores que utilitzen diferents sistemes semiòtics per construir l'analogia entre els dos sistemes conceptuals. Segons el grau d'innovació, podem distingir entre metàfores convencionals (metàfores que estructuren la vida quotidiana i que ens permeten la transmissió de valors i punts de vista) i metàfores creatives (o metàfores de nova creació).

Des d'una perspectiva estructural, podem distingir quatre tipus de metàfores:

a) Les metàfores estructurals o sistemàtiques: El temps són diners; una discussió és una guerra.

b) Les metàfores orientacionals: La borsa és una entitat que puja i baixa.

c) Les metàfores ontològiques: La ment és una màquina; La inflació és el major enemic.

d) Les metàfores visuals o metàfores d'imatge: La bota d'Itàlia; la pell de brau.

Finalment, cal assenyalar les metàfores gramaticals, un tipus de metàfores que tenen un rendiment extraordinari. Es tracta d'un procediment de creació lèxica que consisteix a expressar un significat mitjançant una forma lèxica que habitualment s'utilitza per expressar un altre tipus de significats. Les nominalitzacions - que suposen l'ús d'unitats nominals per expressar processos, com si realment foren verbs - n'és la manifestació més característica.

\begin{tabular}{|c|c|c|}
\hline Tipus de metàfora & Definició & Exemples \\
\hline Orientacionals & $\begin{array}{l}\text { Un sistema global de conceptes s'or- } \\
\text { ganitzen en relació a un altre, sovint } \\
\text { d'acord amb una orientació espacial. }\end{array}$ & $\begin{array}{l}\text { Rato enfonsa les accions de Telefònica } \\
\text { en anunciar, per error, una baixada de } \\
\text { tarifes. }\end{array}$ \\
\hline Estructurals & $\begin{array}{l}\text { Un concepte està estructurat metafòri- } \\
\text { cament sobre un altre domini cognitiu } \\
\text { més concret } \mathrm{i} \text { conegut. }\end{array}$ & $\begin{array}{l}\text { Les teues posicions són indefensables. } \\
\text { Em fas perdre el temps. } \\
\text { L'amor és un viatge apassionant. }\end{array}$ \\
\hline Ontològiques & $\begin{array}{l}\text { Ens permeten entendre les experiències } \\
\text { com si foren objectes o substàncies, o } \\
\text { conceptualitzar els objectes físics com } \\
\text { si foren persones (personificació). }\end{array}$ & $\begin{array}{l}\text { El València ix de la UVI davant del Sa- } \\
\text { ragossa; el grup de Ranieri recupera } \\
\text { les constants vitals. } \\
\text { El Valladolid obre una altra via d'ai- } \\
\text { gua en un Barça que va a la deriva pel } \\
\text { Camp Nou. }\end{array}$ \\
\hline $\begin{array}{l}\text { D'imatge o } \\
\text { visuals }\end{array}$ & $\begin{array}{l}\text { Funcionen projectant una imatge men- } \\
\text { tal convencional sobre una altra. }\end{array}$ & $\begin{array}{l}\text { Esperanza Aguirre s'ha convertit en } \\
\text { l'escletxa del govern. } \\
\text { L'ombra de la guerra del Golf es pro- } \\
\text { jecta novament sobre l'Iraq. }\end{array}$ \\
\hline Gramaticals & $\begin{array}{l}\text { Expressió de significats mitjançant } \\
\text { formes lèxiques no habituals. }\end{array}$ & $\begin{array}{l}\text { El descobriment de noves proves ha } \\
\text { provocat la suspensió del judici. }\end{array}$ \\
\hline
\end{tabular}

Fig. 87. Tipus de metàfores 

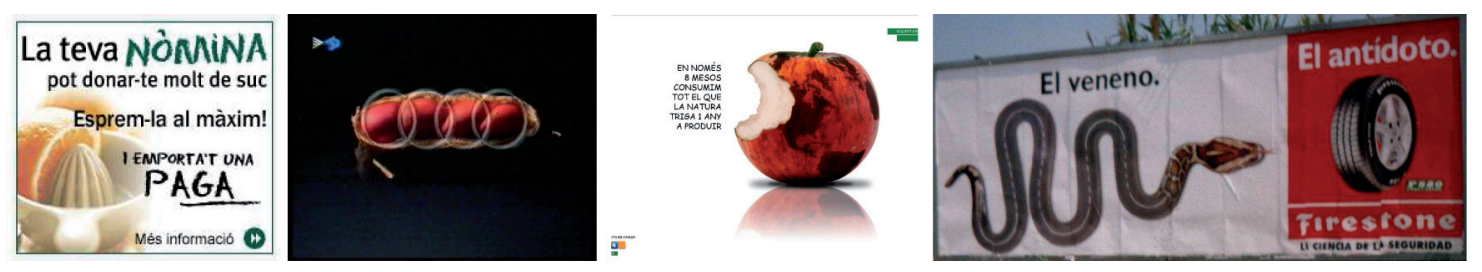

Fig. 88. Exemples de metàfores en el discurs publicitari

\subsection{Selecció lèxica i punt de vista}

\subsubsection{De l'argumentació en la llengua als blocs semàntics}

En les pàgines anteriors, hem vist algunes estratègies que permeten la introducció de determinades orientacions o punts de vista sobre la realitat en el discurs -els actes de parla, el discurs reportat, els recursos modalitzadors o les figures retòriques- $\mathrm{i}$ poden interpretar-se, per tant, com a procediments argumentatius, és a dir, com a artificis discursius programats per provocar l'adhesió dels destinataris a una tesi concreta i per transmetre determinats valors i estils de vida. Gràcies a aquestes estratègies, en el discurs dels mitjans -i també en la comunicació de la vida quotidiana-, el discurs pren una orientació argumentativa sense adoptar formalment l'estructura d'una argumentació prototípica - amb una introducció formal, la tesi, els arguments i la conclusió. Aquesta argumentació implícita, que sovint es presenta maquillada amb els recursos de la seducció, té una gran eficàcia persuasiva, atès que, en no ser formalment una argumentació, no deixa un espai per a la formulació de tesis alternatives ni per a l'enunciació d'arguments discrepants. Javier Vellón (2007) ha analitzat l'eficàcia d'alguns d'aquests mecanismes en la construcció del discurs publicitari.

Durant les últimes dècades, els estudis sobre l'argumentació -que, almenys des d'Aristòtil, havien ocupat un lloc central en l'antiga retòrica- s'han renovat profundament i s'han ocupat d'investigar com es produeix l'orientació semàntica dels enunciats a partir dels encadenaments argumentatius. Aquesta nova perspectiva -iniciada amb els treballs d'Anscombre i Ducrot, particularment en L'argumentation dans la langue (1988), que els mateixos autors situen en la perspectiva teòrica saussureana- defensa la idea que l'orientació argumentativa forma part del sentit dels enunciats i que l'argumentació se situa en el cor mateix de la llengua, en el significat de les unitats lèxiques. La teoria de l'argumentació en la llengua no s'interessa per l'estudi de les estratègies de persuasió ni per les formes d'organització del discurs i es limita a treballar sobre els connectors que permeten l'encadenament dels enunciats i sobre els mecanismes que els asseguren implícitament. De fet, el mateix Ducrot ha reafirmat posteriorment aquesta perspectiva $i$ ha insistit que l'argumentació lingüística no té cap relació amb l'argumentació retòrica i que el significat dels signes lingüístics no està constituït per coses o per idees, sinó per les relacions amb els altres signes, per relacions argumentatives (Carel-Ducrot, 2005: 11-12). 
Per explicar com es produeixen en la llengua els encadenaments argumentatius, Anscombre i Ducrot desenvoluparen, durant els anys noranta, la teoria dels topoi, que constitueix una aportació força interessant per a l'anàlisi del discurs de la publicitat i dels mitjans de comunicació de massa, i recentment el mateix Ducrot ha formulat, amb Marion Carel, l'anomenada teoria dels blocs semàntics, una ampliació que corregeix i amplia el punt de vista inicial (Carel-Ducrot, 2005).

Els topoi són creences compartides per una determinada col-lectivitat que garanteixen els encadenaments argumentatius, tenen un valor general i presenten una forma gradual, una escalaritat, que permet l'aparició de formes tòpiques. Són, per tant, un mecanisme argumentatiu amb un gran poder explicatiu que constitueix un dels pilars d'una teoria de l'argumentació basada en la pragmàtica integrada, és a dir, d'una aproximació original a l'argumentació en què la pragmàtica i la semàntica es presenten unides d'una forma indissociable.

Però allò que constituïa la principal novetat, i un dels atractius, d'aquesta aproximació a l'argumentació - la consideració dels valors argumentatius associats al llenguatge en ús- constituïa precisament un risc per als fonaments teòrics de l'argumentació en la llengua -ja que situava l'argumentació al marge de la llengua-, i el mateix Ducrot se n'ha allunyat els últims anys i ha denunciat els errors de la proposta: «Al basar, entonces, la argumentación en nociones independientes de la lengua, estábamos, en realidad, renunciando al principio saussureano según el cual la lengua sólo se estudia a partir de ella misma» (Carel-Ducrot, 2005: 12-13).

Per evitar la infidelitat i corregir les errades de la teoria dels topoi, Oswald Ducrot i Marion Carel han plantejat recentment una alternativa que encara es troba en fase de desenvolupament, la teoria dels blocs semàntics (Garcia NegroniNarvaja: 2004; Carel-Ducrot, 2005), que es presenta com una superació de la teoria dels topoi i aspira a precisar una nova concepció del sentit: «La idea central de la teoría es que el sentido mismo de una expresión está dado por los discursos argumentativos que pueden encadenarse a partir de esa expresión. La argumentación no se agrega al sentido, sino que constituye el sentido» (Carel- Ducrot, 2005: 12-13).

Malgrat que els plantejaments recents de Ducrot i Carel semblen construir un mur infranquejable entre l'argumentació en la llengua i l'argumentació en el discurs (Amossy, 2006: 27), és possible que les aplicacions que es realitzen els propers anys a l'anàlisi de l'ús lingüístic s'encarreguen de matisar d'una forma substancial aquesta oposició irreconciliable. De fet, entre el discurs i la llengua (o entre la parla i el sistema, si volem utilitzar la terminologia saussureana) es pot detectar amb facilitat un conjunt nombrós d'unitats en procés de gramaticalització que dibuixen la perifèria del sistema i constitueixen un valuós pont entre el discurs i la llengua. 


\subsubsection{Argumentació i topoi}

Una de les hipòtesis bàsiques de la teoria de l'argumentació en la llengua és que l'orientació argumentativa dels enunciats lingüístics té molt a veure amb el lèxic, amb el sentit de les paraules, i que la construcció del sentit dels enunciats depèn directament d'una sèrie de principis generals de raonament anomenats topoi, que formen part de la significació de les unitats lèxiques. Aquesta idea, que constitueix la columna vertebral de la teoria de l'argumentació en la llengua, implica que «el sentit d'una frase és el conjunt de topoi activats des del moment de l'enunciació» (Anscombre, 1995: 44). Des d'aquesta perspectiva, conèixer el sentit d'un mot és saber quins topoi du associats.

Tècnicament, en l'àmbit de la teoria de l'argumentació, el terme topoi s'utilitza per fer referència a enunciats o regles d'inferència gradual que en ser aplicats a determinats elements del discurs en provoquen l'orientació argumentativa. Es tracta d'una sèrie d'estratègies de gestió del pensament que no procedeixen de la lògica, que els locutors presenten com a generals i acceptades pel conjunt dels interlocutors, que fan de pont entre els coneixements lingüístics i els coneixements del món i formen part del bagatge cognitiu dels locutors. Aquestes regles tenen un caràcter gradual i presenten quatre formes tòpiques que funcionen en parelles simètriques:
a) Com més $\mathrm{x}$ és $\mathrm{P}$, més y és $\mathrm{Q}$
b) Com menys x és $\mathrm{P}$, menys y és $\mathrm{Q}$
c) Com més x és $P$, menys y és $Q$
d) Com menys x és $\mathrm{P}$, més y és $\mathrm{Q}$

Les dues primeres formes tòpiques tenen el mateix sentit de recorregut al llarg de les escales $\mathrm{P}$ i Q -com $+\mathrm{P}$, +Q i com -P, -Q- i constitueixen un topos concordant. Paral-lelament, les altres dues formes van associades a recorreguts oposats -un recorregut ascendent de $\mathrm{P}$ implica un recorregut descendent de $\mathrm{Q}, \mathrm{i}$ un recorregut descendent de $\mathrm{P}$ comporta un recorregut ascendent de $\mathrm{Q}-\mathrm{i}$ donen lloc a un topos discordant.

Així, per exemple, en l'enunciat [22], l'ús del mot calor provoca una sèrie d'encadenaments argumentatius a través del topos 'com més calor fa, més abelleix anar a la platja'.

[22] Avui farà molta calor.

Amb la simple pronunciació de l'enunciat, el topos esmentat orienta la interpretació envers una conclusió lògica: Per tant, podriem anar a la platja. Aquest mecanisme argumentatiu presenta, com hem apuntat, una forma gradual, i aquesta gradualitat es pot representar gràficament en dues escales que presenten, com es pot veure en la fig. 84, un recorregut concordant (+calor, +desig d'anar a la platja; -calor, -desig d'anar a la platja).

Òbviament, podem imaginar una situació comunicativa en què un ascens en l'escala de la temperatura $(\mathrm{P})$ siga un element dissuasori i no permeta, per tant, d'obtenir l'encadenament normatiu. Per exemple, imaginem una parella amb una 
criatura de pocs mesos que acostuma a anar a la platja totes les tardes de l'estiu quan el sol ja ha baixat en l'horitzó i no constitueix una agressió per al petit. Si un dia els meteoròlegs anuncien una pujada de les temperatures, un dels membres de la parella pot pronunciar l'enunciat Avui farà molta calor per suggerir una conclusió del tipus Per tant, no convé que anem a la platja. És evident, doncs, que aquest tipus d'encadenaments argumentatius depenen de factors contextuals $\mathrm{i}$ afegeixen als enunciats, com apunta Ducrot, matisos significatius extralingüístics.

\section{[1] Fa calor. Doncs, anem a la platia}

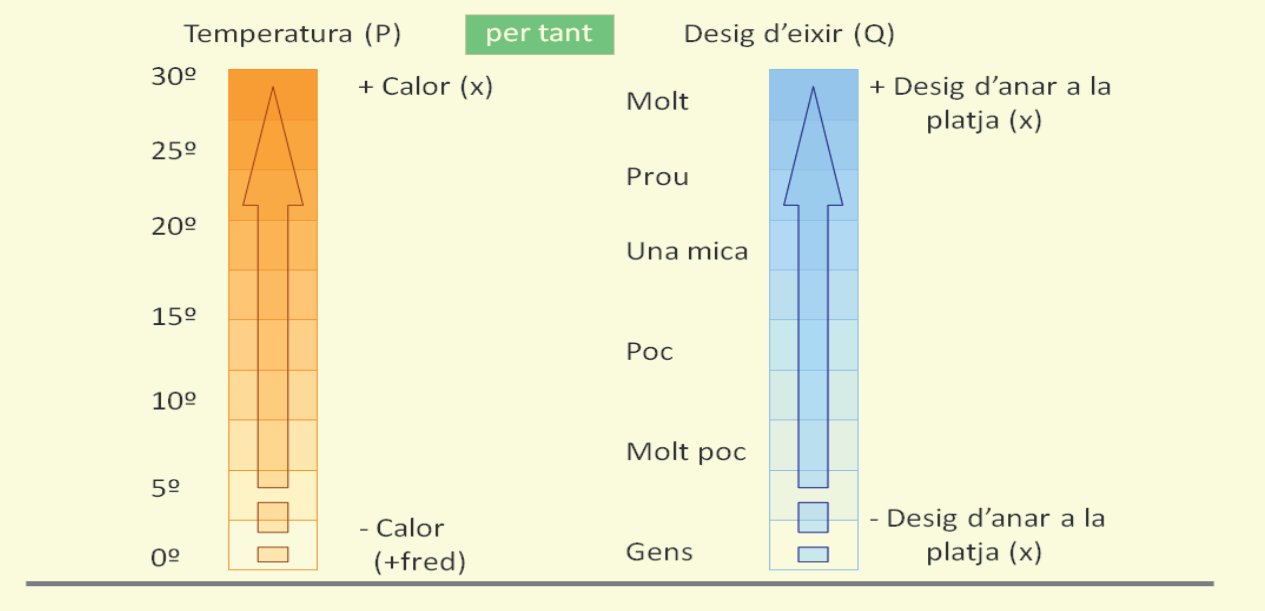

Fig. 89. Topoi i argumentació

Segons Oswald Ducrot (1995), els topoi constitueixen el punt d'articulació entre la llengua i el discurs argumentatiu, el mecanisme a través del qual es restringeixen els encadenaments discursius dels enunciats amb independència dels continguts informatius que aquests vehiculen.

En el discurs dels mitjans de comunicació, i especialment en la comunicació publicitària, els topoi demostren tota la seua capacitat persuasiva, ja que permeten activar - a partir simplement de la formulació de l'eslògan, de l'aparició d'un mot o d'una successió d'imatges- una sèrie d'encadenaments argumentatius que formen part de la doxa o del sentit comú, del «conjunt de representacions socials predominants, la veritat de les quals és incerta», d'allò que és pensa habitualment sobre les persones o sobre les coses (Charaudeau-Maingueneau, 2002: 197).

Tot i que els encadenaments propiciats pels topoi es formulen de vegades explícitament en els eslògans o en el cos textual d'un espot, com es pot comprovar en els exemples [23] i [24], el més habitual és que aquests mecanismes s'activen a partir de la selecció de determinats mots i expressions que s'inscriuen en els eslògans, com es pot comprovar en els enunciats [25] i [26].

[23] Com més el condueixes, més gust en treus (Ford Fiesta, 1995).

[24] Com més en facis servir, més sans tindràs els cabells (Pantene Pro-V, 2000).

[25] La qualitat i la salut, la nostra raó de ser (Llet Pascual, 1994).

[26] La tecnologia és un dret, no pas un privilegi (Opel Astra, 2000). 
En l'eslògan de Pascual ([25]), l'aparició dels mots qualitat i salut engega un complex mecanisme argumentatiu, articulat sobre una successió de topoi, que fa entrar en escena el concepte preu, sense esmentar-lo, i proposa al destinatari l'adhesió previsiblement compartida a un discurs, que tampoc no s'enuncia explícitament: «Vostè sap que la qualitat és fonamental, perquè la qualitat implica un major nivell de vida. Els productes de més qualitat són millors, però exigeixen més inversió i, per tant, són més cars. Però vosté també sap que, en alimentació, la qualitat és sinònim de salut -més qualitat és més salut-i que la salut de la nostra família és el més important per a nosaltres. De fet, també sabem que la salut no té preu i sabem que, quan estem malalts, no dubtem si hem de fer un esforç econòmic important. Per tant, si comprem productes de qualitat, estem invertint en salut, estem invertint en el futur de les persones que més ens estimem. Encara que, ja ho sabem, haurem de pagar una mica més. És lògic. Si compreu els nostres productes, pagareu una mica més, però fareu una inversió intel-ligent, perquè invertiu en salut».

En canvi, l'eslògan reproduït en [26] proposa una orientació argumentativa oposada, ja que aquí es promet tecnologia (+tecnologia, +qualitat de vida) a un cost assequible per a totes les butxaques (és un dret), tot formulant implícitament un moviment contraargumentatiu que lliga la tecnologia (i la qualitat) als cotxes de gamma alta $\mathrm{i}$, per tant, a un grup selecte de consumidors (no pas un privilegi). I tot plegat es presenta formalment en un acte de parla assertiu, amb l'aire de les grans veritats universals, que conserven la validesa més enllà del lloc i del moment històric en què es formulen o de les circumstàncies concretes de l'enunciació. Podríem afirmar que es tracta de filosofia per al consum quotidià.

\subsubsection{Els blocs semàntics i l'estratègia argumentativa}

Per a la teoria dels blocs semàntics, que manté aquesta idea de la teoria de l'argumentació en la llengua, el sentit de una entitat lingüística no està constituït per coses (fets o propietats de les coses) ni per idees (conceptes, creences psicològiques o representacions mentals), sinó pels discursos que evoca aquesta entitat lingüística, per les relacions entre signes. Aquestes relacions, que es troben en la base de qualsevol significat i constitueixen una mena d'àtoms de la significació, presenten la forma d'encadenaments argumentatius (Carel-Ducrot, 2008: 9). Un encadenament argumentatiu està constituït per dos segments, $\mathrm{X}$ i Y, units per un connector: $\mathrm{X}$ connector $\mathrm{Y}$.

Un d'aquests enunciats és el suport o l'antecedent (la premissa) de l'argumentació i l'altre, la tesi o el conseqüent. No és, però, la posició geogràfica de l'enunciat en l'encadenament el criteri que en defineix la funció. Així, el segment Plou és la premissa de l'encadenament dels dos enunciats següents, encara que físicament ocupe posicions diferents:

[27] Plou i, per tant, no eixiré de casa en tota la tarda.

[28] Eixiré de casa, encara que plou de valent. 
Segons Carel i Ducrot $(2005,2006)$, existeixen dos tipus d'encadenaments argumentatius:

a) els encadenaments normatius, construïts amb connectors de tipus consecutiu (per tant, doncs, perquè, ja que, si...), i

$b)$ els encadenaments transgressius, elaborats amb connectors de caràcter contrastiu (però, en canvi, això no obstant, tot i que, encara que...).

De vegades, aquesta relació es presenta explícitament en el discurs, com en els dos eslògans següents, però sovint es tracta d'encadenaments que emergeixen amb la simple enunciació d'una unitat lingüística:

[29] Penses, per tant Ka (Ford, 1997).

[30] Bon noi, però amb una mica de geni (Daewoo, 1997).

El discurs normatiu A PT B (o A $\rightarrow$ B) no té cap relació amb allò que habitualment anomenem argumentació, ja que entre tots dos segments no existeix una relació d'inferència, ni de raonament, ni de deducció. Cadascun dels dos segments encadenats només té sentit en la relació amb l'altre, de forma que existeix el que anomenen d'interdependència semàntica (Carel-Ducrot, 2005: 16-19), fins i tot en el cas que s'expresse amb connectors de tipus causal, com ara en [31], o que un d'ells no es presente explícitament en el discurs:

[31] Perquè existeix la teva pell, existeix Diadermine (Diadermine, 1996).

Els encadenaments argumentatius presenten, per tant, la forma X CON Y, on X i Y són els dos segments associats i CON el connector. Tant en els encadenaments normatius (A PT B, A $\rightarrow$ B) com en els transgressius (A PERÒ B, A « B), Carel i Ducrot anomenen aspectes argumentatius al conjunt dels encadenaments en què $X$ conté $A$ i Y conté B, sense que A ni B siguen objecte d'una negació. Així, en l'encadenament argumentatiu [32] -que presenta la forma X PT Y, X (l'hotel està prop de la universitat) conté A (prop) i Y (és fàcil arribar-hi) conté B (fàcil arribar). Si construïm expressions com [33], [34] o [35], combinant els dos segments amb la negació i mantenint el connector PT, veiem que X i Y són diferents, però A i B són idèntics:

[32] L'hotel està prop de la universitat i, per tant, és fàcil arribar-hi.

[33] *La platja està prop del poble i, per tant, no és fàcil arribar-hi.

[34] *L'estadi no està prop de la ciutat i, per tant, és fàcil arribar-hi.

[35] El poblat ibèric no està prop de la carretera i, per tant, no és fàcil arribar-hi.

És evident que els enunciats [33] i [34] són absurds -tot i que [34] pot ser acceptable en algunes condicions- i que l'ús lingüístic exigiria en aquests casos, per salvar-ne la gramaticalitat, la substitució del connector consecutiu, normatiu en la terminologia de Carel i Ducrot, per un connector contrastiu (però, encara que, no obstant això) que permet formular la idea sota un encadenament transgressiu: 
[36] La platja està prop del poble, però no és fàcil arribar-hi.

[37] L'estadi no està prop de la ciutat, tot i que és fàcil arribar-hi.

En teoria, la combinació dels elements A i B amb els dos tipus de connectors (per tant i però) i amb la negació (i la no-negació) permet obtenir vuit encadenaments diferents que constitueixen dos blocs semàntics. De fet, un bloc semàntic és el conjunt format per quatre encadenaments argumentatius provocats per la combinació de dos elements amb els connectors per tant i però i amb l'afirmació o la negació. Alguns d'aquests encadenaments són possibles o habituals en la interacció comunicativa, altres són poc habituals o una mica estranys i només resulten acceptables amb determinades restriccions contextuals, i alguns altres són agramaticals o inacceptables.

L'eslògan reproduit en [38] ens permet observar com es produeixen les relacions discursives a partir d'un dels blocs semàntics activats per l'emergència del mot protegir i de la idea de protecció.

[38] T’ajuda a protegir el que més estimes (Danone Actimel, 1997).

De fet, l'acció de protegir algú d'alguna cosa implica la interrelació de dos elements que constitueixen la base de la seua significació: perill (A) i defensa (B). Aquest significat és recollit amb lleugeres variants en el Diccionari de l'Enciclopèdia Catalana i en el de l'Institut d'Estudis Catalans [39]:

[39] Protegir 11 v. tr. [LC] Cobrir o defensar (algú o alguna cosa) contra allò que l'amenaça, contra un perill, un dany. Protegir una planta del fred amb estores. L'elm protegia el cap. Els pares protegeixen els fills. Protegir els febles (DIEC2, 2007).

La semàntica argumentativa permet una interpretació molt clarificadora de la idea de 'protecció', ja que, al mateix temps que facilita la visualització dels trets essencials del significat, associats com podem veure a determinats encadenaments argumentatius que es concreten en la representació gràfica de la imatge següent, posa en primer pla el concepte de punt de vista, que en aquest cas té uns efectes sociocognitius i ideològics molt evidents.
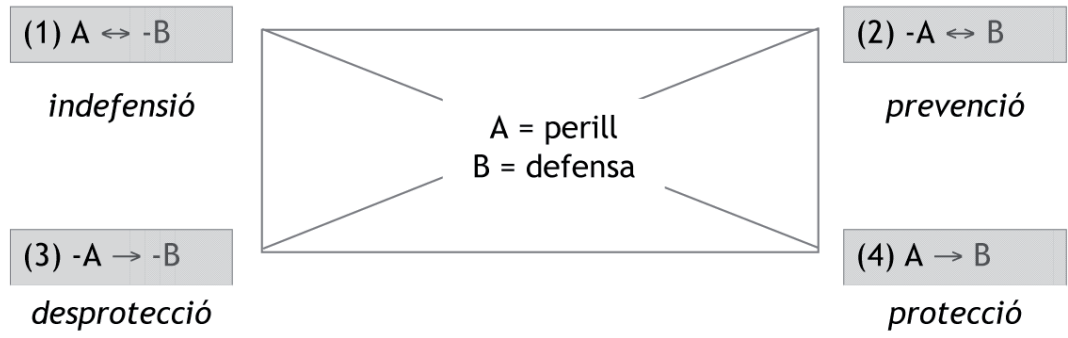

Fig. 90. Bloc semàntic dels mots protecció i protegir 
Els encadenaments que proposa aquest bloc permeten la formulació d'enunciats com els següents:

a) Tot i la imminència del perill, no havia previst la manera de defensar-se. (1)

b) No hi ha cap amenaça, però sempre està preparat per fer front als perills. (2)

c) Com que no hi ha perill, no hi ha motius per defensar-se. (3)

d) La situació és perillosa i, per tant, cal defensar-se amb eficàcia. (4)

Aquests enunciats descriuen, amb més o menys precisió, els quatre mots que hem situat en cadascun dels vèrtexs del quadrat (indefensió, prevenció, desprotecció i protecció) i ens permeten observar com es manté, en tots els casos, la idea de 'perill' i l'associació entre aquesta idea i la necessitat d'actuar (o no actuar) per cercar una defensa. Aquests encadenaments argumentatius formen part del significat del verb protegir i del substantiu protecció i expliquen la presència recurrent d'aquestes unitats lèxiques en el llenguatge publicitari.

En tots els casos que hem analitzat, la inserció de mots relacionats amb el bloc semàntic del terme protecció comporta l'adopció d'un determinat punt de vista sobre la realitat, sobre la societat i sobre les necessitats de les persones, sobre els estils de vida i sobre els sentiments i les sensacions de l'ésser humà. Aquest punt de vista, que podríem anomenar convencional o normatiu, tot i distorsionar una mica el sentit que té en la teoria de Carel i Ducrot, s'insereix en els enunciats d'una forma subtil i modela els estils de vida i les formes de pensar dels ciutadans-consumidors per ajustar-los als paràmetres de la ideologia dominant a partir de dues idees o valors fonamentals:

a) En la societat actual s'han multiplicat els perills i les amenaces a la seguretat de les persones, les agressions de tot tipus i les situacions potencialment perjudicials.

b) Per poder sobreviure en un marc tan agressiu i tan insegur és imprescindible d'invertir en mecanismes de defensa de tot tipus.

Aquest elemental esquema de pensament -que es troba inscrit, com hem vist, en el significat de mots com protecció, indefens, prevenir o desprotegit i en altres com amenaces, seguretat, agredir, defensar o precaució- permet associar aquesta idea al consum dels productes i serveis més diversos i és un dels constituents bàsics de la ideologia dominant. En aquest sentit, són ben coneguts els usos ideològics de la idea de perill i de l'amenaça exterior per tal de reforçar la cohesió nacional -només cal recordar, per exemple, les reaccions després dels atemptats de 1'11 de setembre als Estats Units- i per justificar determinades polítiques de defensa o determinades accions estratègiques en política internacional -la intervenció a l'Iraq, per posar un exemple proper.

El discurs publicitari reforça la sensació de perill i de desprotecció en què vivim -assetjats per la brutícia o l'aspror de la pell, pels accidents de trànsit, pels virus $\mathrm{i}$ les malalties, pels efectes de l'envelliment, pel dolor i per l'amenaça de la mort-i ofereix una promesa permanent de seguretat i de protecció associada al consum de 
tota mena de productes. El truc és tan evident que sembla inofensiu, però forma part d'una poderosa estratègia argumentativa que ens fa sentir vulnerables i desprotegits per vendre'ns la sensació de seguretat i de protecció associada al consum.

\section{Lectures recomanades}

Anscombre, Jean-Claude (1995): «De l'argumentation dans la langue à la théorie des topoï», en Anscombre, Jean-Claude (ed.): Théorie des topoï, París, Kimé, p. 11-47.

— i Oswald Ducrot (1983): L'argumentation dans la langue, Lieja, Mardaga [La argumentación en la lengua, Madrid, Gredos, 1994].

Hessel, Stéphane (2011): Indigneu-vos!, Barcelona, Columna Edicions / Destino.

Lakoff, George (2004): Don't Think of an Elephant! Know Your Values and Frame the Debate, Cambridge, Polity Press [No pensis en un elefant! Llenguatge $i$ debat politic, Barcelona, Viena, 2008].

Mollà, Toni (ed.) (2001): Ideologia i conflicte lingüistic, Alzira, Bromera.

Payrató, Lluís (2003): Pragmàtica, discurs i llengua oral: introducció a l'anàlisi funcional de textos, Barcelona, Editorial UOc.

Peraire, Joan (2009): «Darwin i la teoria de l'evolució en la publicitat contemporània», Ribalta, 15 , ps. 139-155.

— (2012): «L'argumentació publicitària: les paraules del desig», Articles, 58, ps. 57-70.

Pigem, Jordi (2010): Qüestió de valors. Del consumisme a la sostenibilitat, València, Tres i Quatre.

Plantin, Christian (1996): La argumentación, Barcelona, Ariel.

SÁEz, Ferran (2003): Comunicació i argumentació, Barcelona, Blanquerna.

Teruel, M. Elvira (1997): Retòrica, informació i metàfora. Anàlisi aplicada als mitjans de comunicació de massa, Castelló de la Plana, Universitat Jaume I.

Tuson, Jesús (1999): ¿Com és que ens entenem? (si és que ens entenem), Barcelona, Empúries.

- (2008): Això és (i no és) Allò, Barcelona, Ara Llibres.

VAN DiJk, Teun A. (2001): «Un estudi lingüístic de la ideologia?», en Mollà, Toni (ed.) (2001: 33-56).

- (2003): Ideología y discurso, Barcelona, Ariel.

- (2010): «Discurs, poder i elits simbòliques», en MARín, Maria Josep i altres (ed.) (2010: 79-98). 
TEMA 10

\section{Normativa ortogràfica i gramatical}

Introducció

1. Qüestions de normativa ortogràfica

2. Formes i usos dels determinants

3. Morfologia verbal

4. Adverbis i preposicions

Lectures recomanades 


\section{Introducció}

La història de la llengua catalana és la d'una contínua lluita per l'establiment de la normalitat. D'una banda, la normalitat en l'ús social i de l'altra, la normalitat de les solucions lingüístiques.

Pel que fa a l'ús social del català, no es pot dir que gaudim d'una situació que permeta la lliure expressió dels parlants en tots els àmbits d'ús i, encara menys, en l'àmbit que ens ocupa: els mitjans de comunicació. Aquesta és, però, una qüestió relacionada amb les característiques de la societat del segle Xxi i no és ara el moment de referir-nos-hi. Hem apuntat al llarg del curs algunes de les raons d'aquesta minorització i segurament ja no cal aprofundir en aquest darrer tema.

Una altra consideració mereix la lluita per l'establiment d'un estàndard lingüístic que siga equilibrat entre la normativa ortogràfica i l'ús de la llengua que fan els parlants. En els materials d'aquest curs s'ha insistit de manera sistemàtica en la defensa d'un model de llengua apte per a una societat que vol desenvolupar-se lliurement amb la seua llengua en un món caracteritzat pel fenomen de la globalització, pel mimetisme i pel canvi tecnològic. També hem subratllat la funció dels comunicadors com a transmissors d'ideologia, de valors i de pautes de comportament. I és en aquest punt que cal afegir la seua responsabilitat com a manipuladors de la llengua. Els comunicadors, de qualsevol àmbit, han de ser conscients que, com l'escola, transmeten un model de llengua que serà imitat per milers d'individus. És per això que tots han de tenir una formació lingüística que els permeta decidir en cada moment quines són les solucions que hauran d'emprar perquè l'audiència no imite usos lingüístics erronis o, en el cas dels neologismes, perquè no adopte formes estereotipades i calcs lingüístics allunyats de les recomanacions dels especialistes.

En aquest darrer tema presentem algunes de les qüestions més problemàtiques de la llengua catalana pel que fa a l'ortografia i la gramàtica. No es tracta només de problemes d'imitació de formes provinents d'altres llengües amb major ressò mediàtic (principalment el castellà i l'anglès), sinó també d'usos dispersos dels diferents dialectes de la llengua que, a causa de la manca de cohesió idiomàtica, presenten dubtes entre allò que el parlant diu cada dia i el que la normativa ortogràfica i gramatical ha fixat com a correcte.

\subsection{Qüestions de normativa ortogràfica}

\subsubsection{L'escriptura de les vocals}

La identificació entre so i grafia presenta algunes dificultats en català per la influència del castellà i també per la diversitat fònica entre els diferents parlars. De vegades el parlant dubta entre una o altra vocal per desconeixement o per l'actuació, normalment inconscient, del superstrat castellà. És per això que cal atendre a les particularitats de la llengua en l'escriptura de determinades vocals en posicions de dubte. 


\subsubsection{Confusions entre a $i$ è̀tones}

En català, l'escriptura de la $a$ i la $e$ en posició àtona segueix una distribució diferent del castellà. En el quadre 1 es presenten els mots d'ús més habitual que s'escriuen amb vocals diferents en una llengua i en l'altra. Així, paraules com afaitar, ambaixada o assassí s'escriuen amb a, mentre que monestir, javelina o resplendor s'escriuen amb $e$.

A aquestes confusions en alguns mots d'ús habitual, s'ha d'afegir la pronúncia colloquial dels grups inicials em-, en-, es- i eix-, que solen pronunciar-se amb $a$, en contrast amb les regles d'escriptura: Empar i no *Ampar, entendre i no *antendre, escola i no *ascola, eixugar i no *aixugar.

\begin{tabular}{|c|c|}
\hline \multicolumn{2}{|c|}{ Confusions entre $a$ i $e$} \\
\hline S'escriuen amb $a$ & S'escriuen amb $e$ \\
\hline $\begin{array}{l}\text { afaitar, ambaixada, arravatar, assassí, } \\
\text { atorgar, avaluar, avaria, davall, davant, } \\
\text { encomanar, escalopa, extraversió, } \\
\text { hostaleria, icona, latrina, malenconia, } \\
\text { maragda, pianista, picaporta, rancor, } \\
\text { sanefa, Sardenya, Sueca }\end{array}$ & $\begin{array}{l}\text { albercoc, Alcàsser, ametista, assemblea, bescoll, cà- } \\
\text { nem, Caterina, disfressar, ebenista, efeminat, Empar, } \\
\text { Empordà, Empúries, encarar, encendre, endavant, } \\
\text { enyorar, escola, espàrrec, estella, estendard, ester- } \\
\text { nudar, Esteve, gelea, Gramenet, javelina, llençol, } \\
\text { lleuger, meravella, monestir, orfe, punxegut, resplen- } \\
\text { dor, revenja, sergent, setí, treball, vernis, Xúquer }\end{array}$ \\
\hline
\end{tabular}

Quadre 1. Confusions entre $a$ i $e$

\subsubsection{Confusions entre o $i \mathrm{u}$}

També en el cas de la $o$ i la $u$ àtones es produeixen vacil-lacions en l'escriptura, provocades per les interferències del castellà o de la pronunciació habitual en l'oralitat espontània, que convé conèixer per evitar errades ortogràfiques.

\begin{tabular}{ll}
\hline \multicolumn{1}{c}{ Confusions entre $o$ i $u$} \\
\hline \multicolumn{1}{c}{ S'escriuen amb o } & \multicolumn{1}{c}{ S'escriuen amb u } \\
\hline aixovar, assortir, atordir, avorrir-se, bordell, & Amadeu, ateneu, barnús, bucal, bufetada, \\
Bordeus, Borriana, botifarra, brúixola, calorós, & bullit, butlletí, butxaca, cacau, camafeu, \\
capitol, cartolina, cobertor, collir, complimentar, & coliseu, correu, desmuntar, Eliseu, escrúpol, \\
cònsol, conservadorisme, cosí, cosir, croada, & escull, estiu, europeu, fetus, focus, fòrum, \\
descobrir, embotir, Empordà, engolir, escàndol, & globus, harmònium, julivert, juvenil, Ladis- \\
escodrinyar, escopir, escrúpol, esdrúixol, estoig, & lau, liceu, Màrius, muntanya, muntar, Pireu, \\
expenedoria, fonament, furóncol, govern, gropa, & Pirineus, Pius, Pompeu, porus, ritu, riu, \\
Hongria, Joan, joglar, joguina, joventut, monyó,, & sèrum, sinus, subornar, sufocar, supèrbia, \\
nodrir, obrir, ordir, pèndol, ploma, podrir, polir,, & suport, tètanus, tipus, titulació, tramuntana, \\
polsar, polvoritzar, regidoria, rètol, rigorós, & trofeu, turmell, turment, vidu, vulcanisme \\
robi, roí, Romania, rossinyol, rostir, sofrir, & \\
sorgir, sospir, sostraure, tamboret, titol, tolit, & \\
tomba, tonyina, torbar, Torí, Torís, torró, tossir, & \\
triomf & \\
\hline
\end{tabular}

Quadre 2. Confusions entre $o$ i $u$ 


\subsubsection{Altres confusions}

Finalment, convé recordar que algunes paraules presenten, en l'oralitat espontània, vacil-lacions entre la pronunciació amb e o amb $i$. Normalment, es tracta de paraules que sovint es pronuncien amb $e$, però que s'han d'escriure amb $i$. Les més habituals són les següents:

S'escriuen amb $i$ : ambigüitat, antiguitat, campió, ciment, contemporània, contenidor, còrnia, declivi, desimboltura, diabetis, eclipsi, infermera, lacti, línia, mantenidor, nucli, Ontinyent, ordinador, penis, sobirania, tinent, Tunis.

\subsubsection{El hiat i els diftongs}

Una de les definicions de vocal és la que l'associa al nucli sil·làbic. Hi ha, però, paraules amb sílllabes que contenen més d'una vocal: és el cas dels diftongs (dues vocals pronunciades en la mateixa síl-laba). Cada diftong ha de tenir una vocal $i$ o $u$ obligatòriament combinada amb una altra vocal. A les $i$ i $u$ els diem vocals dèbils, perquè en unir-se a una altra vocal per formar un diftong, mai no suporten la intensitat de la síllaba, que recau en les vocals anomenades fortes.

De la reunió de dues vocals sense pertànyer a la mateixa síllaba, en diem hiat o hiatus. Es produeix un hiat bé perquè la combinació resultant no pot pronunciar-se junta ( el cas de la reunió de dues vocals fortes, per exemple), bé perquè aquella combinació que sí que pot pronunciar-se en la mateixa síl-laba, en un cas concret, no s'hi pronuncia. En un hiat, cada vocal pertany, doncs, a una sílllaba diferent.

Segons la posició de les vocals en el diftong distingim entre diftongs creixents i decreixents.

La diferència la marca la posició de la vocal dèbil. Si és al davant, el diftong serà creixent i si és darrere, decreixent. Aquestes vocals dèbils actuen com a semivocals i reben aquesta denominació.

En català només trobem diftongs creixents amb la semivocal $u$ i en una posició específica: quan, precedida d'una consonant $q$ o $g$, és seguida d'una altra vocal $a$, $e, i, o$. Els diftongs decreixents, formats per una vocal forta $(a, e, i, o, u)$ i una altra de dèbil $(i, u)$, són molt més habituals.

\begin{tabular}{llll}
\multicolumn{2}{l}{ Diftongs creixents } & \multicolumn{2}{l}{ Diftongs decreixents } \\
\hline ua & quatre, quaranta, guatla, guarir & ai & esplai, caixera, faixa, aigüera \\
\hline ue & qüestió, freqüent, aigües, llengües & au & pau, autor, palau, clau \\
\hline uo & quota, quocient, paraiguot & ei & rei, remei, peix, freixe \\
\hline ui & obliqüitat, lingüistic, pingüi & eu & beure, teulada, meuca, feu \\
\hline
\end{tabular}




\begin{tabular}{ll}
\hline Diftongs creixents & Diftongs decreixents \\
\hline oi & almoina, boira, comboi, noi \\
\hline ou & pou, moure, nou, enrenou \\
\hline ui & cuinar, cuir, vuit, fuita \\
\hline uu & duus, lluu \\
\hline iu & estiu, ciutadà, ombriu \\
\hline
\end{tabular}

Quadre 3. Els diftongs del català

Segons aquesta distribució, en català no existeixen diftongs creixents amb la vocal $i$ ni amb la vocal $u$, excepció feta de les posicions esmentades. La reunió de tres vocals en una mateixa síl-laba s'anomena triftong. Aquesta confluència (poc habitual, per cert) es redueix als grups uai (aguaitar), іеи (déieu), иеи (стеиеи). Per tant, s'obté de la combinació de dues semivocals amb una vocal forta.

Així doncs, les combinacions que en castellà són també diftongs creixents $i u$, ie, $i o, u a$, ue i uo), no ho són en català i, per tant, s'han de pronunciar en síllabes diferents.

\subsubsection{L'accentuació}

\subsubsection{Les regles d'accentuació gràfica}

Totes les paraules tenen accent, però només algunes han de portar-ne un de gràfic (escrit) per marcar quina és la síllaba pronunciada amb més intensitat. Les regles d'accentuació pretenen reduir el nombre de paraules que en duen en un intent de facilitar l'escriptura per utilitzar-lo únicament en aquelles que presenten dificultat de pronúncia.

L'accent presenta dues formes que permeten distingir les vocals tancades i obertes: l'accent greu (') assenyala que la vocal és oberta; l'accent agut ('), que la vocal és tancada. Les vocals obertes ( $a$, $e$ oberta i $o$ oberta) sempre han de dur accent greu, mentre que les vocals tancades $(i, u, e$ tancada i $o$ tancada) s'escriuen, quan s'han d'accentuar, amb accent agut.

Ja sabem que, segons quina és la sílllaba tònica (aquella que és pronunciada amb major intensitat) d'una paraula, aquestes es classifiquen en agudes, planes o esdrúixoles. Recordem que les agudes tenen la síllaba tònica en l'última posició, les planes la tenen en la penúltima posició i finalment les esdrúixoles en l'antepenúltima.

Les regles d'accentuació gràfica són les següents:

- Agudes. S'accentuen les paraules acabades en vocal $(a, e, i, o, u)$; en vocal més $s$ (às, és, ès, ís, ós, òs i ús) i en én, èn, ín. Ex.: Dublín, avió, arròs, matalàs, comprèn, lleó, passadís, poregós, cautxú. 
- Planes. S'accentuen aquelles que no acaben en cap de les terminacions anteriors. Ex.: exàmens, encàrrec, àrab, antídot, insòlit, mític, càntir, fàcil.

- Esdrúixoles. S'accentuen totes. Ex.: hipòtesi, anàlisi, física, pólvora, València, estratègia, estàtua, ciència.

Tot i que les regles d'accentuació són senzilles, l'aplicació pràctica presenta algunes dificultats derivades, sovint, de la manca de coincidència entre l'accentuació en els registres formals i en els informals. Convé, per tant, recordar les remarques següents:

1. Les paraules agudes acabades en diftong no s'accentuen: comboi, jersei, exclou, conreu, virrei.

2. El monosílllabs no s'accentuen si no és que ho fan per diferenciar-se d'un altre mot (accent diacrític), com veurem més endavant.

3. Els derivats acabats en -ment mantenen l'accent gràfic si en portava el primitiu, però no n'afegeixen si el primitiu no en portava: ràpidament, però completament.

4. S'ha de mantenir l'accent gràfic de les paraules quan escrivim en majúscules: VALENCIA.

5. En paraules compostes unides per guionet es manté l'accent gràfic que portaven per separat: sud-americà; també si les dues en portaven: despús-demà.

6. En les paraules compostes sense guionet només ha de portar accent l'últim component: socioeconòmic.

7. Les paraules següents són agudes: iber, humit, zenit, heroi, handicap, quilogram, handbol, poliglot, futbol, fluor, timpà, celtiber, pivot, policrom, sandvitx, xiclet, avar, tiquet, miop, xassís, elit, hoquei, oboè, xandall, xofer...

8. Són planes les paraules: cardiac, leucòcit, intèrfon, demoníac, conclave, púding, rèptil, termòstat, alvèol, vertigen, fagòcit, atmosfera, mimesi, etíop, paràgraf, tèrmits, medul·la...

9. Són esdrúixoles: elèctrode, aurèola, diòptria, línier, èczema, pneumònia, rubèola, Etiòpia, Himàlaia, olimpíada...

\subsubsection{L'accent diacrític}

L'accent diacrític no respon a les normes ortogràfiques que acabem de veure. S'usa per distingir paraules homògrafes, que s'escriuen igual però tenen significats diferents. Els mots que tenen accent diacrític el mantenen també en la derivació (nét, besnét). 
Els criteris generals que regulen l'ús de l'accent diacrític són els següents:

a) L'accent diacrític apareix en monosíl·labs, i només excepcionalment en mots bisíl·labs: vénen/venen, dóna i dónes/dona i dones.

b) L'accent diacrític s'usa generalment amb les vocals $e$ i $\boldsymbol{o}$, i només excepcio-

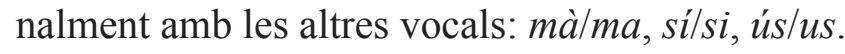

c) Si hi ha un mot tònic $\mathrm{i}$ un altre d'àton, el tònic és el que duu el diacrític: $m a ̀$ l ma, sé/se, té/te, ús/us.

d) Si els dos mots són tònics, i hi ha diferències de timbre, l'accent apareix com a norma general en el mot amb la vocal tancada: bélbe, dónaldona, fóral fora, móra/mora, sóc/soc.

En l'annex VII es reprodueix el llistat de les paraules més habituals que porten aquest tipus d'accent.

\subsubsection{La qüestió de la e tònica}

La pronúncia de la $e$ tònica presenta una dificultat afegida per a la correcta interpretació del so obert o tancat d'alguns mots, ja que pot ser oberta $(\varepsilon)$, tancada (e) o neutra ( $($ ), segons la varietat dialectal utilitzada (català central, català occidental o balear). La raó d'aquesta variació s'ha de buscar en la diferent evolució de les vocals llatines en uns territoris o uns altres.

L'única dificultat que representa en l'escriptura és l'accentuació oberta o tancada. Malgrat que generalment els escrits valencians han optat per l'accentuació tancada i els escrits catalans per l'oberta, totes dues són considerades correctes.

Aquesta dualitat afecta algunes terminacions adjectives (francès o francés, anglès o anglés), alguns temps verbals acabats en -en (comprèn o comprén), alguns mots generals (cafè o café, Mercè o Mercé, comitè o comité) i una sèrie d'infinitius (conèixer o conéixer, meréixer o merèixer, convéncer o convèncer, estrényer o estrènyer).

\subsubsection{4. Ús i estalvi de la dièresi}

La dièresi és un signe ortogràfic (") que es collloca sobre les vocals $i$ i $u$ amb diverses funcions:

1. Per indicar que la $u$ dels grups que, qui, gue i gui s'ha de pronunciar i, per tant, forma part d'un diftong creixent: llengües, pingüi, pasqües, ubiqüitat.

2. Per indicar que les vocals $i$ i $u$ no formen diftong decreixent amb la vocal anterior: jesuïta, transeünt, ensaïmada, diürn, llaüt, raïm. 
3. Per indicar que la $i$ en posició intervocàlica no és consonant $\mathrm{i}$, per tant, no forma síl·laba amb la vocal posterior: envaïa, produïen, reduïa.

Si una paraula ha de portar accent gràfic, aquest preval sobre la dièresi i té la mateixa funció per indicar l'existència d'un hiat: veí, però veïna; país, però països; Lluís, però Llü̈sa.

Tot $\mathrm{i}$ aquestes normes generals, cal recordar que no es posa dièresi en els casos següents:

a) Els sufixos -isme i -ista, encara que formen hiat amb la vocal anterior: hinduisme, egoisme, altruista, dadaista; els mots proïsme i llü̈sme no estan formats per aquests sufixos.

b) Les formes d'infinitiu, gerundi, futur i condicional dels verbs de la tercera conjugació precedits de vocal (grups -air, -eir, -oir, -uir): beneir, agraint, oiràs o conduirien.

c) Les paraules formades amb prefixos com anti-, auto-, co-, contra-, intra-, pre-, re-, semi-, bi-, macro- o micro-: antiinflamatori, autoinculpar-se, coincidència, contraindicar, intrauterí, preindustrial, reimpressió... Però no es considera prefix el formant re- en mots com reeixir, reïx, reïxia (o reeixia) o reüll.

d) En els mots que tenen la terminació llatina -us i -um, malgrat que també aquesta terminació forma un hiat: Màrius, Pius, aquàrium...

\subsubsection{Ortografia de les consonants}

\subsubsection{Els sons oclusius}

El so oclusiu bilabial sord, que es transcriu com a [p], és semblant a la pronúncia castellana de paso, a la francesa de père i a l'anglesa de Spain. S'escriu amb les grafies $p$ (plat, mapa, apte) o $b(t u b)$. El so oclusiu bilabial sonor, [b], és molt similar al que trobem en la paraula castellana bueno i en l'anglesa obey. S'escriu habitualment amb les grafies $b$ (braç, bomba) o $v$ (veure, canviar), tot i que en posició final de síl·laba es pot produir per sonorització de la lletra $p$ (hipnosi).

Aquestes grafies a principi de mot o de síl·laba no presenten cap problema, ja que es corresponen absolutament amb la pronúncia. En altres posicions, però, cal atendre un seguit de normes o regles:

a) Després de vocal o diftong tònic, escrivim $p$ encara que els derivats s'escriguen amb b: llop, cap, sap... Excepcions (cultismes o estrangerismes en consonància amb altres llengües): baobab, Carib, esnob, Jacob, Job, adob, aljub, club, cub, tub. 
b) Després de vocal àtona o consonant, s'escriu la mateixa consonant que apareix en els derivats: pòlip, verb, calb, camp, àrab, xenòfob...

c) S'escriu $p$ en els grups $c a p-,-p c-,-p t-,-p n-, p n-,-p s^{-}, p s^{-}$i $-p p-$, tot i que amb algunes excepcions:

\begin{tabular}{lll} 
GRUP & EXEMPLE & EXCEPCIONS \\
\hline cap- & captar, capgirar, capçal & cabdal, cabdell, cabdill \\
\hline -pc- & corrupció, erupció, egipci & \\
\hline -pt- & baptisme, reptar, escriptor & dissabte, dubte, sobte \\
\hline -pn-, pn- & hipnòtic, pneumàtic & \\
\hline -ps-, ps- & eclipsi, copsar, psicosi & \\
\hline -pp- & proppassat, propparent & \\
\hline
\end{tabular}

d) S'escriu $b$ en els grups $a b-, o b-, s u b$ - i -bd-, també amb alguna excepció:

\begin{tabular}{lll}
\hline GRUP & EXEMPLE & EXCEPCIONS \\
\hline ab- & abdomen, absent, abscissa & apte \\
\hline ob- & objecte, obscur & optar, òtic, òptim \\
\hline sub- & subjecte, subjuntiu & \\
\hline -bd- & molibdè & \\
\hline
\end{tabular}

El so oclusiu dental sord, representat [t], és semblant a la castellana tango, a la francesa temps, i a l'anglesa eight. En català, s'escriu habitualment amb la grafia $t$ (tall, nota o set), però en posició final de síllaba o de paraula també pot trobar-se escrit amb la lletra d (adquirir o fred). El so oclusiu dental sonor, [d], és molt similar a la pronúncia castellana de dar i similar a la francesa de dedier i a l'anglesa de thousand. En català, sempre s'escriu amb $d$ (dia, fonda) o amb dd (addicció). De la mateixa manera que en els oclusius bilabials, l'escriptura d'aquests sons està regulada per les normes següents:

1. Després de vocal o diftong tònic, escrivim $t$ encara que els derivats s'escriguen amb $d$ (pot, salut, prat, paret, nebot, buit...), amb les excepcions de mots com Bagdad, Belgrad, Conrad, Alfred, fred, David, Madrid, caid...

2. Després de vocal àtona o consonant, s'escriu la mateixa que apareix en els derivats: sort, cant, ràpid, sord, estupend... Cal anar amb compte, però, amb els gerundis, que sempre acaben en -t: anant, tenint, rebent...

3. S'escriuen amb $t$ els mots que contenen el grups -tg-, -tj-, -tl-, -tll-, -tm-, -tn-, -ts-, $t s-$, -tx- i -tz-, amb l'excepció del mot cadmi, que s'escriu amb $d$ : heretge, corretja, ametla, butlletí, setmana, cotna, potser, sotsobre, tsar, cartutxera, dotze, guitza, horitzó.

4. En canvi, s'escriuen amb - $d$ final tots els noms femenins acabats en -etud i-itud (quietud, solitud, magnitud...) i les paraules que contenen el grup ad- 
(addició, addicció, adverbi, adjacent, adjectiu...), amb algunes excepcions, com ara atlas, atlàntic, atmosfera, atzabeja, atzar, atzavara i atzur, entre d'altres.

El so oclusiu velar sord, [k], és semblant al de la pronúncia castellana de caso, a la francesa de camion o a l'anglesa de sky. En català, s'escriu amb c (cau, encara, tractar, sac), amb q (quatre, quota) o qu (qui, enquesta), amb ch (March, Pitarch), amb $x$ (taxi) o amb $g$ (càstig). El so oclusiu velar sonor, [g], s'assembla a la pronúncia castellana de gas, i s'aproxima bastant a la pronúncia francesa de garçon i a l'anglesa again. Es representa en l'escriptura amb les grafies g (gana, greu, mangosta, maragda, pingüi), gu (guerrer, guitarra), x (examen, exercici) o c (dracma, sac al coll).

L'escriptura dels sons oclusius velars segueix les regles següents:

1. Després de vocal o diftong tònic, s'escriu $c$ encara que els derivats s'escriguen amb g: bec, dic, duc, afalac, abric, poruc, feixuc... Excepcions: mag, estrateg, demagog, pedagog, Hug, tuareg, reg...

2. Després de vocal àtona o consonant, s'escriu la mateixa consonant que apareix en els derivats: arc, llarg, clàssic, fang, banc... Tanmateix, s'escriuen amb $c$ la primera persona del present d'indicatiu dels verbs velaritzats (tinc, aprenc, puc...) i mots com ànec, espàrrec, aràbic...

3. S'escriu $c$ en els grups -cc-, -cs-, -ct- i -cz-: accelerar, accent, dacsa, fúcsia, delicte, conjectura, èczema...

4. S'escriuen amb g els grups -gd-, -gg-, -gm- i -gn-: amígdala, maragda, suggerir, suggestió, augmentar, diafragma, cognom, digne, lignit; són excepcions, però, els mots anècdota, sinècdoque, dracma, aràcnid i tècnic.

\subsubsection{Els sons fricatius}

El so fricatiu labiodental sord, representat [f], és semblant a la pronúncia castellana de fondo, a la francesa de femme i a l'anglesa de face. En català, es representa sempre amb la grafia $f($ fam, infant, inflama, baf). El so fricatiu labiodental sonor, [v], es pronuncia com el francès vie o l'anglès view. Tot i que es troba en recessió en la major part del domini lingüístic, es manté encara en alguns parlars del valencià no apitxat, en balear i en alguerès (vi, canvi). En la resta del domini només es realitza com a resultat d'una assimilació de sonoritat (afgà).

La confusió en gran part del territori del so bilabial amb el labiodental obliga a conéixer algunes normes bàsiques d'escriptura dels dos sons:

1. S'escriu $b$ davant de $l$ or (moble, oblidar, braç, arbre...) i darrere de la grafia $m$ (embenar, ambiciós...; tot i que existeixen algunes excepcions, com triumvir, circumval·lació, tramvia...). 
2. En canvi, cal escriure $\boldsymbol{v}$ darrere de $n$ (canvi, conversa, minvar, envestir...) i en les desinències de l'imperfet d'indicatiu dels verbs de la primera conjugació (cantava, portaves, trituràveu...).

3. En les paraules derivades, s'escriuen amb $b$ els mots que porten $p$ en els primitius: saber (sap), lloba (llop)...; i s'escriuen amb $v$ els mots que porten la vocal $u$ en els primitius: hereva (hereu), moviment (moure), nevar (neu)... Malgrat aquesta regla, existeixen paraules amb el mateix primitiu o lexema que alternen $v$ i $b$ a causa de la naturalesa dels mots, ja siguen patrimonials o bé cultismes. Així, es pot observar que els derivats següents segueixen la regla, però no els pseudoderivats o cultismes de la columna de la dreta:

\begin{tabular}{lll}
\hline Mots primitius & Derivats & Pseudoderivats \\
\hline avortar & avortament & abortiu \\
\hline calb & calba & calvície \\
\hline corb & corbató & còrvids \\
\hline corb & corba & curvatura \\
\hline deure & devent, devia & dèbit \\
\hline escriure & escrivent & escriba \\
\hline llavi & llavifès & labial \\
\hline lliure & lliurement & llibertat \\
\hline moure & moviment & móbil, automóbil \\
\hline núvol & ennuvolat & nebulós \\
\hline provar & provador & probable \\
\hline riu & riuada & ribera, ribet \\
\hline
\end{tabular}

Finalment, cal recordar que la divergència en l'escriptura d'alguns mots en castellà i en català pot provocar també algunes vacil·lacions en l'ortografia:

\begin{tabular}{|l|l|}
\hline $\begin{array}{l}\text { S'escriuen } \\
\text { amb v }\end{array}$ & $\begin{array}{l}\text { advocat, alcova, almadrava, almívar, anvers, arravatar, arrova, avall, } \\
\text { avet, avi, avorrir, avortar, bava, bevem, canvi, caravel-la, cascavell, } \\
\text { cavalcar, cavall, cervell, civada, clivellar, Còrdova, covard, devem, endi- } \\
\text { via, envestir, espavilar, escrivim, Esteve, esvelt, fava, gavardina, gavarra, } \\
\text { gavatx, gleva, govern, gravar, l'Havana, haver, javelina, llavi, núvol, } \\
\text { pavelló, prevere, provar, raval, rave, rivet, savi, savina, Savoia, serva, } \\
\text { sivella, taverna }\end{array}$ \\
\hline $\begin{array}{l}\text { S'escriuen } \\
\text { amb b }\end{array}$ & $\begin{array}{l}\text { Alaba, baf, baró, basc, beina, bena, berruga, besllum, biga, Biscaia, } \\
\text { bivac, bolcar, calb, comboi, corb, debanar, desimbolt, mobil, oblidar, } \\
\text { rebentar, rebolcar, saba, trobador }\end{array}$ \\
\hline
\end{tabular}

El so fricatiu alveolar sord, [s], és similar al de la pronúncia castellana de seis i una mica diferent d'altres realitzacions veïnes. En català, es pot escriure amb les grafies $s$ (salat, asimètric, mestre, pas), ss (passar), c (vici, cendra, vèncer), sc (ascendir), ç (caçador, feliç) ix (taxi). 
1. S'escriu $s$ a principi de mot (savi, senyor, saber, sort...), darrere de consonant (cansat, potser, molsa, capsa, dansa...), davant de consonant (festa, mestra, costa, caspa...), a final de paraula (falses, mostres, senyes, cos, mos...) i després dels prefixos $a$ - (asimetria), ante- (antesala), anti- (antisocial), bi- (bisecció), contra- (contrasentit), entre-(entresòl), mono- (monosíllab), para-(parasíntesi), pre- (preselecció), sobre-(sobresortir), tele-(telesella), ultra- (ultrasò), uni- (unisexual) i vice- (vicesecretari).

2. S'escriu ss entre vocals (passió, interessant, abadessa, impressió...), al mot qualssevol (plural de qualsevol) i els compostos amb el prefix trans- (transsexual, transsudar, transsònic...), als superlatius acabats en -íssim i derivats (enfeinadissim, interessantíssimes...), als femenins acabats amb el sufix essa (comtessa, jutgessa, poetessa..., excepció feta de marquesa i princesa) i als compostos de -gressor, -gressió, -missor, -missió, -pressor, -pressió (agressor, agressió, transmissor, remissió, opressor, compressió).

3. S'escriu ç davant de $a, o, u$ i en posició final (caça, cançó, forçut, jaç); s'escriuen $\mathrm{amb}$ ç els sufixos -ança i -ença: esperança, benvolença...; cal anar amb compte, però, amb mots com dansa, pensa o defensa, que no són formats amb aquest sufix.

4. S'escriu $c$ davant de les vocals e i $i$ (cingle, cendra...) i en els sufixos -ància i-ència: abundància, ciència...

El so fricatiu alveolar sonor, [z], similar a l'articulació de la castellana mismo, la francesa poison o l'anglesa busy, es pot representar, en català, amb les grafies $\boldsymbol{s}$ (pesar, casa, desdir), z (zona, zero, amazona, alzina) i x (examen, exercici).

1. S'escriu $s$ entre vocals i en algunes paraules derivades dels mots fons, dins i trans: adhesió, anàlisi, anestèsia, paisatge, països, frase, lesió, nasal, tesi, residu...; enfonsar, transistor, endinsar...

2. S'escriu $z$ a començament de paraula (zero, zodiac, zoològic, Zacaries...) i després de consonant (onze, colze, quinze, alzina, utilitzar...).

3. També s'escriu $z$ entre vocals en algunes paraules d'origen grec (amazona, bizantí, ozó, azalea, àzim...), en els compostos de rizo- o esquizo- (rizotònic, esquizofrènic), en un petit grup de paraules (Ezequiel, nazisme...) i en els compostos de -zoic-, -zou-, -zoide- (protozoic, espermatozou, trapezoide).

El so fricatiu palatal sord, [ ]], és un so similar al francès chercher i a l'anglès shine. En català, es pot representar amb les grafies $\boldsymbol{x}$ (xarxa, xec, arxiu, caixa, guix) i ix (dibuix, peix).

En moltes ocasions aquest so es confon amb l'africat en bona part dels parlars valencians, en gran part del català nord-occidental i en els dialectes balears. Es comú a aquests territoris la pronúncia africada a principi de mot (xinxa, xinès, xec) 
i darrere de consonant (panxa, xinxeta, arxiu), malgrat que es manté el so fricatiu en el grup -ix- i en la majoria de posicions inicials (Xeraco, Xàtiva, Xixona ...).

1. S'escriu $x$ a principi de mot (xarop, xofer, Xixona, Xàtiva...), darrere de consonant (punxa, torxa, panxa, clenxa...), darrere de $i$ (guix, clixé, bixest...) i darrere de $u$ (rauxa, disbauxa...).

2. Escrivim $i x$ sempre darrere de vocal: calaix, baixar, encaixonar, eixam, eixir, peix...

El so fricatiu palatal sonor, [3], podem comparar-lo amb el francès Jean o l'anglès measure. En català, s'escriu amb $g$ (gener, bogeria, verge) o amb $j$ (juny, joc, rajar, majestat). La confusió entre el so africat i el fricatiu és molt generalitzada. Tanmateix, el podem trobar per fonètica sintàctica a peix insípid o a peix gelat.

1. S'escriu $j$ davant de $a, o, u$ (rajar, roja, rajoli, joventut, just, juntar...); en mots cultes amb els nexes -jecc-i -ject- (injecció, objectar, projecte, objecte, subjecte...); en alguns mots com jeroglific, jerarquia, jersei, majestat...; en noms hebreus com Jesús, Jeremies, Jerusalem..., i en l'imperfet d'indicatiu del verb jaure (jeia, jeies...).

2. S'escriu $g$ davant de les vocals $e, i$ : girar, gentilesa, règim, gener, ginesta...

\subsubsection{Els sons africats}

El so africat alveolar sord, [ts], és similar als sons del francès médecin, l'italià pazzo o l'anglès cats. En català, es representa amb les grafies ts (potser, tots, pots), tc (etcètera) i ds (adscriure).

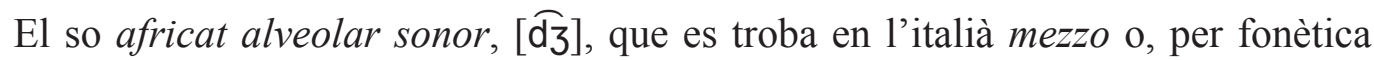
sintàctica, en l'anglès heads or tails, es representa en l'escriptura amb el dígraf $t z$ (dotze, analitzar).

El so africat palatal sord, [†]], similar al castellà coche i a l'anglès church, es pot representar per les grafies $t x$ (txec, cotxe, despatx), ig (boig) i $g$ (maig, veig, fuig). Les regles que regulen l'escriptura d'aquest so en català són les següents:

1. S'escriu $t x$ a l'interior de mot entre vocals (botxí, metxa, butxaca...), a principi de paraula en alguns gentilicis, noms propis i estrangerismes (Txèquia, txapela...) i en posició final després de vocal, quan els primitius contenen aquest mateix so (despatxar, cartutxera, escabetxar...).

2. S'escriu ig en posició final després de vocal quan els derivats canvien aquest so pel palatal africat (o fricatiu) sonor: roig (roges), passeig (passejar), rebuig (rebutjar), desig (desitjar)...

3. S'escriu g quan l'última vocal és una $i$ : desig, mig, frig... 


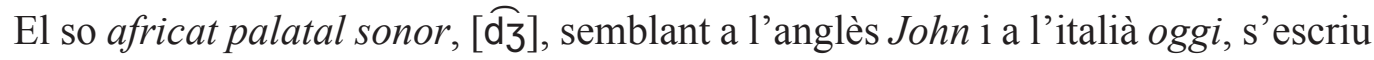
en català amb els dígrafs tg (metge, fetge), tj (platja, mitja) i gg (suggerir).

1. S'escriu tj sempre entre vocals i davant $a, o, u$ : desitjar, coratjós...

2. Escrivim tg sempre entre vocals i davant $e, i$ : massatgista, ferotge, rellotge, jutge...; també en el sufix d'origen gal -atge (damnatge, paisatge, formatge...). Cal anar amb compte amb la paraula imatge, el verb derivat de la qual és imaginar, sense l'africació.

S'han de tenir en compte els canvis ortogràfics que es produeixen amb el canvi de vocals en paraules amb el mateix lexema: trepitgem, trepitja; enutgi, enutjava...

\subsubsection{Els sons sonants}

El so bilabial nasal sonor, [m], semblant al castellà mismo, al francès madame o a l'anglès medium, es representa habitualment amb la grafia $m$ (mapa, cama, ambaixador), tot i que en alguns casos, per fonètica sintàctica, també es pot representar amb la grafia $n$ (canvi). S'escriu $m$ :

1. Davant de les lletres $p, b, m$ : embarcar, empresonar, emmalaltir... Excepcions: benparlat, enmig, tanmateix...

2. Davant f: circumferència, amfiteatre, àmfora, triomf, simfonia... Excepcions: fanfara, fanfarró; i els prefixos con-, en-, in-: confessar, enfilar, inflar...

3. En els prefixos con-, en- i in- davant d'una altra m: commemorar, emmarcar, immòbil...

4. En l'aplec $m p$, que es conserva per raons etimològiques en alguns mots: Assumpta, atemptar, compte, exempció, temptar, símptoma...

El so alveolar nasal sonor, [n], és molt semblant al castellà nuestro, el francès bonnet i l'anglès nanny. Es representa habitualment amb la grafia $n$ (nas, conill, conte, fan). S'escriu $n$ generalment davant $v$ (canvi, convent, minvar...), amb algunes excepcions, com circumval-lació, triumvirat, tramvia... Cal recordar que algunes paraules dupliquen la $n$ : Anna, connexió, innecessari, tarannà, bienni...

El so palatal nasal sonor, [n], és semblant al castellà teñir, al francès agneau i al portuguès vinho. En català es representa amb el dígraf ny (nyu, canya, puny). 


\subsubsection{Els sons laterals}

El so lateral alveolar sonor, [1], en la majoria de parlars es pronuncia molt velaritzat (semblant a bill o help de l'anglès), tot i que en altres parlars no es pronuncia tan velaritzat $\mathrm{i}$ és molt similar al castellà lente $\mathrm{o}$ al francès ville. En català es representa amb la grafia $l$ (línia, pala, alta, $f(l)$ i amb els dígrafs $l \cdot l$ i $t l$, que apareix en algunes paraules com ametla, atlas, atlàntic, atleta...

La ela geminada $(l \cdot l)$ es pronuncia habitualment com una $l$ simple, però es manté per raons etimològiques i és un dels trets característics de l'ortografia catalana. S'escriuen amb $l \cdot l$ la majoria dels contraris d'adjectius començats per $l-$ : legítim/il·legítim, lògic/il·logic, lícit/il·lícit... També s'escriuen amb $l \cdot l$ paraules cultes derivades d'altres patrimonials acabades amb $-l l \mathrm{o}-l$ : metall/metàl.lic, cristall/ cristal·lí, rebel/rebel·lió... La distribució completa dels sons laterals es pot consultar en aquest quadre:

\begin{tabular}{|c|c|c|}
\hline Context & S'escriu $l$ & S'escriu $l \cdot l$ \\
\hline En prefixos & $\begin{array}{l}\text { Després dels prefixos següents: } \\
\text { - } a \text { - (verbalitzador): alentir, alinear } \\
\text { - } a \text { - (negatiu): alàlia, alèxia, alògic }\end{array}$ & $\begin{array}{l}\text { Quan a un radical començat per } l \text { s'adjunten els } \\
\text { prefixos } \\
\text { - al-: al·literació, al·lusió } \\
\text { - col-(var. de con-): col·lateral, col·lineal } \\
\text { - il-(var. de in-): il·limitat, il·lòic } \\
\text { - sil- (var. de sin-): silllaba, sil·lepsi, sil·logisme }\end{array}$ \\
\hline $\begin{array}{l}\text { En formants } \\
\text { cultes }\end{array}$ & milè, miler, milenar & $\begin{array}{l}\text { En els formants cultes següents: } \\
\text { - al·lo- 'altre': al·lomorf, al·lòpata, al·lòtrop } \\
\text { - cal·li- 'bell': cal·ligrafia, cal·ligrama } \\
\text { - gal·lo- 'de la Gàl·lia': gal·licisme, gal·loromà } \\
\text { - fil·lo- 'fulla': fil·lòfag, fil·loxera, clorofil·la } \\
\text { - mil·li- 'mil': mil·lenari, mil·lèsim }\end{array}$ \\
\hline $\begin{array}{l}\text { En derivats } \\
\text { savis de radi- } \\
\text { cals acabats } \\
\text { en }-l l\end{array}$ & $\begin{array}{l}\text { En casos com anular (cf. anell), } \\
\text { consiliari (cf. consell), filial (cf. fill), } \\
\text { foli (cf. full) }\end{array}$ & 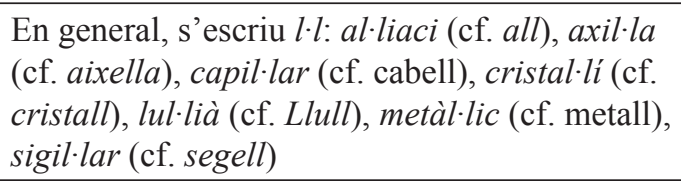 \\
\hline $\begin{array}{l}\text { Derivats de } \\
\text { radicals aca- } \\
\text { bats en }-l\end{array}$ & $\begin{array}{l}\text { En general, s'escriu l: encarrilar (cf. } \\
\text { carril), filar (cf. fil), gelat (cf. gel), } \\
\text { perfilar (cf. perfil), tela (cf. tel), vela } \\
\text { (cf. vel) }\end{array}$ & $\begin{array}{l}\text { S'escriu } l \cdot l \text { en mots com argil·lifer (cf. argila), } \\
\text { caramel·litzar (cf. caramel), constel·lació (cf. } \\
\text { estel), nul·la (cf. nul) }\end{array}$ \\
\hline $\begin{array}{l}\text { En termina- } \\
\text { cions }\end{array}$ & $\begin{array}{l}\text { - En el sufix -ela (col.): clientela, } \\
\text { parentela } \\
\text { - En mots com biela, candela, cautela, } \\
\text { esquela, estela, mistela, mostela, pa- } \\
\text { mela, seqüela, tutela; arrelar, gelar, } \\
\text { pelar, velar } \\
\text { - En el formant -fil 'amic': bibliòfila, } \\
\text { cinèfila } \\
\text { - En mots com anguila, argila, barri- } \\
\text { la, fila, lila, pila, tequila, vila 'poble' } \\
\text { (cf. vil·la 'casa'), anihilar, espavilar, } \\
\text { jubilar, mutilar, ventilar, vigilar } \\
\text { - En el mot pomelo }\end{array}$ & 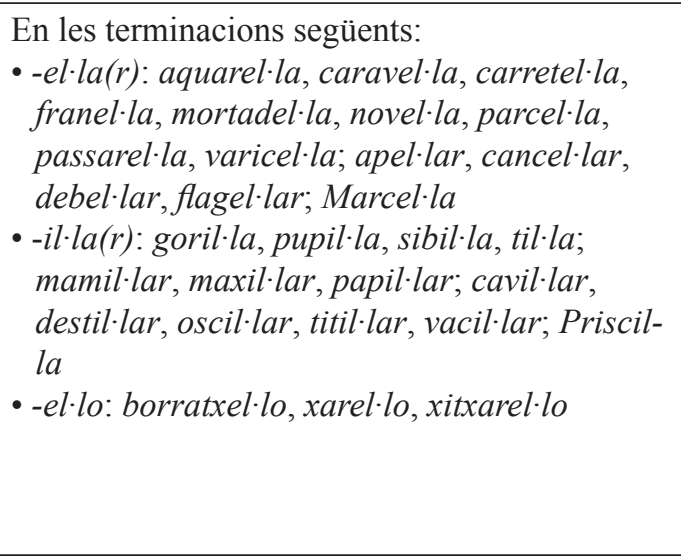 \\
\hline
\end{tabular}


El so lateral palatal sonor, $[\Lambda]$, similar a l'italià figlio, es pot representar amb els dígrafs $l l$ (lluna, palla, all) i tll (bitllet, butlletí, ratlla, rotllo, enrotllar, ratllar...). Alguns mots poden alternar el dígraf palatalitzat amb el dígraf sense palatalització: espatlla (espatla), vetlla (vetla)...

\subsubsection{Els sons ròtics}

El so ròtic bategant, [r], semblant al castellà pradera o l'anglès britànic very, es representa amb la lletra $r$ (pare, herba,per). En la majoria de dialectes (exceptuant alguns parlars valencians) s'ensordeix totalment o parcialment davant de pausa: parlar [parlár], senyor [senor].

El so ròtic vibrant, [r], similar al castellà perro o a l'italià ferro, es pot representar, en català, amb les grafies $r$ (rap, ric, roig, conreu, enrere, preromà) i rr (córrer, parra). Les normes que en regulen l'escriptura són les següents:

1. A principi i a final de paraula, en posició inicial de síl·laba i darrera de consonant, s'escriu sempre $r$ (i mai rr): Ramon, riu, roure, saber, folrar, conreu.

2. En posició intervocàlica, s'escriu normalment el dígraf $\boldsymbol{r r}$ : terra, carruatge, córrer.

3. No obstant això, s'escriu $r$ entre vocals després dels prefixos següents: $a$-: arítmia, arizòfit; anti-: antirotatori; auto-: autoregressió; bi-: birectangle; contra-: contrarestar; di-: diradical; extra-: extraradi; foto-: fotoreceptor; infra-: infraroig; micro-: microruptor; mono-: monorail; multi-: multiracial; neo-: neorealisme; poli-: poliritmia; pre-: preromà; pseudo-: pseudoràbia; quimio-: quimioreceptor; semi-: semireacció; sobre-: sobrereserva; supra-: suprarenal; tele-: telereunió; termo-: termoregulador; tri-: triradiat; vice-: vicerector.

\subsubsection{Al·lòfons}

Els al·lòfons són variants articulatòries d'un fonema producte d'assimilacions dels sons veïns. Així, per exemple, els sons aproximants són variants dels fonemes oclusius que es realitzen en posició intervocàlica o entre un so lateral o vibrant $\mathrm{i}$ una vocal.

El so aproximant bilabial sonor, $[\beta]$, semblant al castellà abrevar, es troba representat en l'escriptura amb les grafies b (lloba, obligar, albarà, herba) i v (avisar). En els parlars occidentals és bastant habitual la pronúncia aproximant del grup $b l$ (poble, estable), que en altres parlars gemina.

El so aproximant dental sonor, [ठ], similar al castellà adrede i, tot i que no tant, a l'anglès this, es representa en l'escriptura amb la lletra $d$ (cada, assedegat, didal, ordenar, esdevenir). 
El so aproximant velar sonor, [४], similar al castellà agregar, es pot trobar en l'escriptura amb les grafies $g$ (paga, castigar) i gu (orgue).

El so nasal labiodental sonor, [m], semblant al castellà infanta i a l'anglès comfortable, es troba representat en l'escriptura per les grafies $m$ (èmfasi) i $n$ (infant).

El so nasal velar sonor, [n], molt habitual en anglès, en mots com sing, i en alemany, és una variant del so [n] quan es troba en contacte amb un so velar (llengua, sang).

\subsubsection{La lletra h}

La lletra $h$ és una grafia que es conserva per raons exclusivament etimològiques i no té cap pronúncia excepte en les onomatopeies $(h a, h a, h a)$ i en mots manllevats d'altres llengües (Hong Kong, hippy, holding...). S'escriuen amb $h$ :

1. Alguns noms propis com Helena, Hanníbal o Hasdrúbal, tot i que presenten vacil·lacions i de vegades els podem trobar sense $h$.

2. Mots com hàmster, harmonia, ham, hivern, hendecasílllab, hostessa...

3. Diversos mots que contenen la $h$ en posició interior: alcohol, exhalar, subhasta, conhort, exhaurir, exhortar, alhora, aleshores, tothom, tothora...

Cal recordar que en català no s'escriuen amb $h$ diverses paraules que sí que en porten en castellà, com ara orfe, orxata, ou, os, cacauet, coet...

\subsection{Formes i usos dels determinants}

\subsubsection{Determinants indefinits}

Delimiten l'extensió quantitativa de forma imprecisa. Poden ser adjectius o bé pronoms. En el quadre següent veiem els indefinits classificats segons la flexió:

\begin{tabular}{lllll}
\hline Masculí singular & Femení singular & Masculí plural & Femení plural & Pronoms \\
\hline un & una & uns & unes & u, un \\
\hline algun & alguna & alguns & algunes & $\begin{array}{l}\text { algú, hom, quel- } \\
\text { com }\end{array}$ \\
\hline qualcun & qualcuna & qualcuns & qualcunes & $\begin{array}{l}\text { qualcú, cadascú, } \\
\text { cada } u\end{array}$ \\
\hline tot & tota & tots & totes & tothom, tot, tots \\
\hline mateix & mateixa & mateixos & mateixes & \\
\hline cert & certa & certs & certes & \\
\hline altre & altra & altres & & altri \\
\hline tal & & tals &
\end{tabular}




\begin{tabular}{|c|c|c|c|c|}
\hline Masculí singular & Femení singular & Masculí plural & Femení plural & Pronoms \\
\hline qualsevol & & qualssevol & & \\
\hline qualque & & qualques & & \\
\hline \multicolumn{5}{|l|}{ cada } \\
\hline \multirow[t]{2}{*}{ cap } & & & & cap \\
\hline & & ambdós & ambdues & \\
\hline \multicolumn{5}{|l|}{ sengles } \\
\hline & & & & ningú \\
\hline res & & & & \\
\hline
\end{tabular}

Algunes remarques sobre els indefinits:

1. Algú, cadascú, cada u i ningú només funcionen com a pronoms i són per tant, invariables: Algú sap què diu?; Cadascú va a la seua; Ningú no s'ho pensava.

2. La forma quelcom s'ha de reservar per a usos formals; és preferible en els altres usos emprar alguna cosa o res. Quelcom, però, no té valor quantificador (*quelcom nerviosa, per un poc nerviosa).

3. Cap, res i ningú només apareixen en frases condicionals, interrogatives i dubitatives, en sentit positiu i en negatives: Si tens cap queixa, comunica-li-la; Vols res?; Si no dius res, ningú no se n'assabentarà.

4. Mateix/a/os/es, mai no s'usa com a pronom (tenia un cotxe $i$ sempre se'n queixava; però no es queixava *del mateix). Concorda amb el substantiu que determina quan va davant i es manté invariable quan va darrere (si no són pronoms personals). Exemples: La mateixa Anna es va oferir; L'Anna mateix es va oferir; Ella mateixa es va oferir. No es pot usar l'adjectiu propi (i variants) per mateix (i variants). Així, per emfasitzar, direm: El mateix professor ho va recomanar (i no el *propi).

5. Tot i mig són invariables quan precedeixen topònims. Ara bé, si el topònim comença amb l'article femení, llavors s'ha de feminitzar el determinant: $L i$ van concedir un premi $i$ han pogut viatjar per tot Europa; Amb aquestes pluges hi ha hagut inundacions a mig Amèrica; Tota la Plana pateix la sequera.

\subsubsection{Determinants numerals}

Hi ha quatre tipus de numerals segons si en delimiten la quantitat exacta (cardinals), l'ordre (ordinals), una part o fracció (partitius) o bé una quantitat multiplicada (múltiples). Vegem-ho: 


\begin{tabular}{lllll}
\hline \multicolumn{5}{c}{ Cardinals } \\
\hline Un/una & Set & Tretze & Dinou/dènou & Setanta \\
\hline Dos/dues & Vuit/huit & Catorze & Vint & Vuitanta \\
\hline Tres & Nou & Quinze & Trenta & Noranta \\
\hline Quatre & Deu & Setze & Quaranta & Cent/s/es \\
\hline Cinc & Onze & Disset/dèsset & Cinquanta & Mil \\
\hline Sis & Dotze & Divuit/divuit/díhuit & Seixanta & Milió \\
\hline
\end{tabular}

Pel que respecta a l'escriptura dels nombres cardinals i ordinals, ja hem vist l'ús del guionet.

Llevat dels assenyalats, els numerals no prenen formes flexives si no és que s'usen com a substantius (la tresa, el cinquet, un deuet...), generalment en el registre colloquial.

Tampoc no prenen la forma femenina quan s'usen com a ordinals o com a noms de xifres: Heu d'arribar al quilòmetre quatre; Obriu el llibre per la pàgina vint-iquatre; Ha eixit premiat l'u; El resultat de la suma és trenta-dos.

\begin{tabular}{lllll}
\hline \multicolumn{5}{c}{ Ordinals } \\
\hline $1 r$ & Masculísg. & Femenísg. & Masculí pl. & Femení pl. \\
\hline $2 n$ & segon & primera & primers & primeres \\
\hline $3 r$ & tercer & tercera & segons & segones \\
\hline $4 t$ & quart & quarta & quarts & terceres \\
\hline $5 \grave{2}$ & cinquè & cinquena & cinquens & quartes \\
\hline $9 \grave{e}$ & novè & novena & novens & novenes \\
\hline $18 \grave{ }$ & divuitè & divuitena & divuitens & divuitenes \\
\hline $44 \grave{e}$ & quaranta-quatrè & quaranta-quatrena & quaranta-quatrens & quaranta-quatrenes \\
\hline $100 \grave{ }$ & centè & centena & centens & centenes \\
\hline
\end{tabular}

Llevat de les quatre primeres formes, els ordinals es construeixen afegint $-\grave{e}$ (o $-e ́$ ) al cardinal. Com veiem en el quadre, tenen flexió com els adjectius de quatre terminacions. La resta es formen amb la terminació - è, igual que els ordinals.

\begin{tabular}{lllll}
\hline \multicolumn{5}{c}{ Partitius } \\
\hline $1 / 2$ & Masculí sg. & Femení sg. & Masculí pl. & Femení pl. \\
\hline $1 / 3$ & mig & mitja & mitjos & mitges \\
\hline $1 / 4$ & terç & terça & terços & terces \\
\hline $1 / 10$ & quart (quarter) & quarta & quarts & quartes \\
\hline dècim & dècima & dècims & dècimes \\
\hline $1 / 100$ & centèsim & centèsima & centèsims & centèsimes \\
\hline & mil·lèsim & mil·lèsima & mil·lèsims & mil·lèsimes \\
\hline
\end{tabular}


Els múltiples són doble, triple, quàdruple, quíntuple, sèxtuple, sèptuple, òctuple, nònuple, dècuple, cèntuple. Els multiplicatius presenten flexió de gènere (llevat de doble) quan s'apliquen a quantitats més grans que unes altres (Una xifra tripla d'una altra), però són invariables quan signifiquen 'conjunt format per tants membres' (La triple aliança). En els registres informals se solen substituir els multiplicatius per considerar-los massa formals, i en el seu lloc s'utilitzen fórmules perifràstiques ( $S$ 'ha comprat una casa tres vegades més gran).

\subsubsection{Quantificadors o determinants quantitatius}

\begin{tabular}{llll}
\hline Masculí singular & Femení singular & Masculí plural & Femení plural \\
\hline quant & quanta & quants & quantes \\
\hline tant & tanta & tants & tantes \\
\hline molt & molta & molts & moltes \\
\hline poc & poca & pocs & poques \\
\hline bastant & & bastants & \\
\hline gaire & gaires & \\
\hline més (pus) & & \\
\hline menys (manco) & & & \\
\hline prou (de) & & & \\
\hline força $(d e)$ & & & \\
\hline massa (de) & & \\
\hline gens $(d e)$ & & \\
\hline que & & \\
\hline
\end{tabular}

A banda d'aquests quantitatius, existeixen moltes locucions amb valor quantitatiu: una mica (de), un grapat (de), gens ni mica (de), una colla de, una munió de, un fum de, etc.

Algunes remarques sobre l'ús:

1. Gens demana obligatòriament l'ús de la preposició de; en canvi, massa, força i que no l'admeten. I pel que fa a la resta, s'admet l'ús opcional: No fa gens de calor; Fa massa calor; Fa tant de temps o fa tant temps. En valencià s'usa la preposició en masculí: No sé quant d'oli he de posar; No sé quanta farina fa falta. En baleàric, la preposició és possible en qualsevol cas: Tinc molta de gana; Hi ha prou de convidats.

2. Molt i força s'usen en frases afirmatives, mentre que en frases condicionals, interrogatives, dubitatives i negatives és preferible emprar gaire: Tinc molt de temps per escoltar-te; No tinc gaires ganes d'escoltar-te. 
3. Prou i bastant no són sinònims. Prou representa 'en quantitat suficient', mentre que bastant significa 'en quantitat acceptable o regular': He descansat bastant però no prou.

4. No hem de confondre el quantitatiu gens amb l'indefinit res: No necessito res (cap cosa); No té gens de valor (quantitat de valor).

5. Notem algunes incorreccions per la interferència del castellà: Com més gent entre, més guanyaràs (i no *quanta més); No pots imaginar-te com t'estimava (i no *quant); Els nombrosos telegrames en confirmen el record (i no *els molts telegrames); Com abans ho acabes, millor (i no *quant abans).

\subsubsection{Determinants demostratius}

Actualitzen els substantius en relació amb l'espai i el temps i els participants de la comunicació.

Hom distingeix entre dues gradacions demostratives: la doble (prop de qui parla i lluny de qui parla) i la triple (prop de qui parla, prop de qui escolta i lluny de tots dos). El sistema ternari de la llengua clàssica té dues formes, segons que s'acosten més o menys al llatí:

\begin{tabular}{lllll}
\hline \multicolumn{5}{c}{ Demostratius gradació ternària (1) } \\
\hline Grau díctic & Masc. sing. & Fem. sing. & Masc. pl. & Fem. pl. \\
\hline $1 r$ & aquest & aquesta & aquests & aquestes \\
\hline $2 n$ & aqueix & aqueixa & aqueixos & aqueixes \\
\hline $3 r$ & aquell & aquella & aquells & aquelles \\
\hline
\end{tabular}

Aquestes formes però, tenen poca vitalitat i, de fet, només es mantenen a Tàrbena, repoblada per mallorquins el segle XVII.

\begin{tabular}{lllll}
\hline \multicolumn{5}{c}{ Demostratius gradació ternària (2) } \\
\hline Grau díctic & Masc. sing. & Fem. sing. & Masc. pl. & Fem. pl. \\
\hline $1 r$ & est $(e)$ & esta & estos & estes \\
\hline $2 n$ & eix $(e)$ & eixa & eixos & eixes \\
\hline $3 r$ & aquell & aquella & aquells & aquelles \\
\hline
\end{tabular}

Les formes més simples (i més pròximes al llatí) tenen més vitalitat que les anteriors $i$ es mantenen en valencià, ribagorçà i lliterà, malgrat que en l'actualitat es prefereixen les anteriors a nivells formals.

Finalment, tenim el paradigma binari que és molt més general als nostres parlars (Principat, la Catalunya de Nord, Andorra, l'Alguer, Balears i Pitiüses) i molt més recurrent en la llengua escrita: 


\begin{tabular}{lllll}
\hline \multicolumn{5}{c}{ Demostratius gradació binària } \\
\hline Grau díctic & Masc. sing. & Fem. sing. & Masc. pl. & Fem. pl. \\
\hline $1 r$ & aquest & aquesta & aquests & aquestes \\
\hline $2 n$ & aquell & aquella & aquells & aquelles \\
\hline
\end{tabular}

\subsubsection{Determinants possessius}

Afegeixen a la determinació una referència de possessió en sentit ampli.

Existeixen dos paradigmes que responen a diferents formes: el possessiu àton $\mathrm{i}$ el possessiu tònic. Malgrat que el primer només s'usa en l'actualitat en relacions de parentiu i davant d'algun substantiu molt propi, els oferim tots dos. L'àton va entre parèntesi:

\begin{tabular}{lllll}
\hline \multicolumn{5}{c}{ Possessius (un sol posseïdor) } \\
\hline Persona & Masc. sing. & Fem. sing. & Masc. pl. & Fem. pl. \\
\hline la & El meu (mon) & La meua (ma) & Els meus (mos) & $\begin{array}{l}\text { Les meues } \\
\text { (mes) }\end{array}$ \\
\hline $2 a$ & El teu (ton) & La teua (ta) & Els teus (tos) & Les teues (tes) \\
\hline $3 a$ & El seu (son) & La seua (sa) & Els seus (sos) & Les seues (ses) \\
\hline
\end{tabular}

\begin{tabular}{lllll}
\hline \multicolumn{5}{c}{ Possessius (més d'un posseïdor) } \\
\hline Persona & Masc. sing. & Fem. sing. & Masc. pl. & Fem. pl. \\
\hline $1 a$ & El nostre & La nostra & Els nostres & Les nostres \\
\hline $2 a$ & El vostre & La vostra & Els vostres & Les vostres \\
\hline $3 a$ & El seu (llur) & La seua (llur) & Els seus (llurs) & $\begin{array}{l}\text { Les seues } \\
\text { (llurs) }\end{array}$ \\
\hline
\end{tabular}

Com havíem dit, els possessius àtons actualment s'usen en poques ocasions. Cal remarcar que s'usen sense article: Vaig a ta casa; Ta tia viu prop de ma casa; Sa Majestat els rebrà de seguida.

Pel que respecta a llur/llurs, són possessius arcaïtzants que només tenen vitalitat en la llengua literària i en rossellonès: Aparegueren amb llurs fills $i$ volien dinar.

En l'ús general dels possessius, hom tendeix a abusar-ne. En català només són correctes si són necessaris per a la comprensió del discurs. En expressions en què coneixem la pertinença d'allò de què es parla, no cal usar-los: Avui la biblioteca comença l'horari normal (i no *el seu horari); Un dels paràmetres més significatius del rendiment d'un processador és la velocitat (i no *la seua velocitat); Està acabant els estudis de Magisteri (i no *els seus estudis); L'assassí va llançar l'arma quan fugia (i no *en la seua fugida); No coneixia aquella professora ni en sabia el nom (i no *el seu nom); Demana una pomada per als peus (i no * per als teus peus). 
Les formes femenines tòniques a què hem fet referència són les més habituals en el català occidental, tot i que les més generals són les consonantitzades (meva, teva, seva, meves, teves, seves) per pertànyer a la forma dialectal de més difusió.

\subsection{Morfologia verbal}

\subsubsection{La flexió verbal}

En l'annex VIII es reprodueixen els paradigmes verbals dels diversos models pertanyents a les tres conjugacions dels verbs catalans tal com apareixen en la introducció de la primera edició del Diccionari de l'Institut d'Estudis Catalans. Es tracta d'uns paradigmes que inclouen, a més de les formes considerades estàndards, aquelles que Fabra, en la primera edició de la Gramàtica catalana (1918), considerava variants geogràfiques vives en diversos indrets, malgrat que havien caigut en desús en el català central. Així doncs, al costat de cada forma normativa pròpia del català central, apareixen també les formes pròpies generals del valencià o del baleàric.

Tot i que és útil tenir a l'abast aquests models de conjugació regular, els aspectes més problemàtics de l'ús dels verbs estan relacionats amb les irregularitats verbals -la major part de les quals afecten els verbs de la segona conjugació i els de la tercera-, amb l'ús com a pronominals o com a transitius de verbs que no ho són (i a l'inrevés), amb les formes no personals i amb la proliferació de nombroses interferències de caràcter semàntic, procedents del castellà, sovint a través del filtre del registre col-loquial. En la major part dels casos, es tracta d'usos que entren en conflicte amb la normativa i que, per tant, cal evitar sistemàticament, tant en els registres formals com en els usos lingüístics informals; en d'altres, en canvi, es tracta d'usos inacceptables o poc recomanables en els registres formals, però perfectament vàlids per als usos informals.

Algunes irregularitats verbals són simples adaptacions ortogràfiques provocades pel contacte de l'última consonant del lexema amb una desinència començada en $e$ o en $i$ (pujo/puges, adequa/adeqües, rego/regues, etc.). Altres irregularitats són, però, de caràcter morfològic i constitueixen, com hem dit, un dels aspectes més problemàtics de l'ús dels verbs. En les pàgines següents veurem els aspectes que presenten una major dificultat.

\subsubsection{Irregularitats verbals}

\subsubsection{Els verbs de la primera conjugació}

La major part de les irregularitats dels verbs de la primera conjugació són de tipus ortogràfic. No obstant això, cal recordar que les tres persones del singular i la tercera de plural dels verbs acabats en consonant + iar (com ara estudiar, pronunciar, canviar, acariciar, anunciar...) es pronuncien amb la -i tònica: estudio, acaricies, pronuncía, canvien... 


\subsubsection{Observacions sobre la segona conjugació}

La major part dels verbs de la segona conjugació -que comprèn els acabats en -er i en -re, a més dels verbs dir i dur-són irregulars. Els verbs d'aquesta conjugació segueixen els models de perdre o témer.

L'existència d'un grup de verbs que tenen el radical acabat en consonant velar (bec, bega, begueres...) provoca, en la llengua parlada, algunes vacil·lacions pel que fa a l'ús de les formes velaritzades i no velaritzades. En la majoria dels casos, si un verb té forma velar en la primera persona del present d'indicatiu (bec), aquesta forma reapareix en el present (bega) i en l'imperfet de subjuntiu (begués/beguera), en la primera persona del plural de l'imperatiu (beguem!), en el passat simple (beguí, begueres) i en el participi (begut). No segueixen aquest model alguns verbs irregulars (com prendre), un grup de verbs que tenen imperatius irregulars en la segona persona (que adopten formes velaritzades: digues, estigues...), els verbs voler, obrir i omplir (que presenten formes com vulga, volgué, òbric o òmpliga) i els verbs escriure, saber i cabre (que en alguns contextos presenten variació entre les formes velaritzades i no velaritzades: escric, escriga, escriguélescriví, escrigués/escrivís, sàpia/sàpiga, sapiem/sapiguem, càpia/càpiga...).

En el català col-loquial s'observa una certa tendència a la generalització de les formes velaritzades en contextos diferents dels apuntats en el paràgraf anterior $i$ que no són, en cap cas, acceptables en els registres formals:

a) En molts parlars, la generalització es produeix en formes que tenen una desinència $\mathrm{amb} e$ tònica en el gerundi, en la primera i segona persona del plural del present d'indicatiu i en la segona del plural de l'imperatiu: *beguent, *beguem $\mathrm{i}$ *begueu (en lloc de les formes normatives bevent, bevem i beveu).

b) En els parlars valencians, la generalització s'ha estès també, per analogia, a una sèrie de verbs regulars (com ara perdre) i als verbs purs de la tercera conjugació (com ara dormir o cosir). Així, en el valencià col·loquial, són habituals les formes * perguem, *pergueu, *dorgues o *cusga, absolutament inacceptables en els registres formals.

En el llenguatge col·loquial alguns verbs de la segona conjugació adopten les desinències clàssiques - $a m \mathrm{i}-a u$, en comptes de les normatives -em $\mathrm{i}-e u$, per a la primera i la segona persones del plural del present de subjuntiu: *begam (beguem), *begau (begueu), *rigam (riguem), *rigau (rigueu)...

Els verbs acabats en -eure o-aure han adoptat en la major part de parlars formes amb la semivocal [j] en les persones 4a i 5a del present d'indicatiu, per evitar l'hiat entre les dues vocals iguals o pròximes: creiem, creieu, veiem, veieu, caiem, caieu... (en lloc de creem, creeu, veem...). El canvi, que s'ha produït també en el gerundi, per la mateixa raó, provoca la confluència de dues formes $(\mathrm{creiem} / \mathrm{creem})$ igualment acceptables, tot i que en els registres formals són preferibles les formes amb la semivocal. 
Alguns verbs de la segona conjugació (creure, veure, fer, caure, seure, dir i dur) adopten formes amb accent en el radical $i$ amb una $-i$ - antihiàtica en l'imperfet d'indicatiu: creia, deia, feia, reia, queia... Amb l'excepció del verb dur, es tracta de verbs que tenen un radical amb la vocal $e$ i que en la llengua clàssica tenien formes regulars amb accent en la vocal temàtica: creïa, deïa, seïa... El desplaçament de l'accent, que es va produir per evitar el hiat entre la vocal del radical i la vocal temàtica, va provocar el retrocés en l'ús de les formes clàssiques (que es mantenen vives encara, de manera vacil·lant, en alguns parlars valencians meridionals) i la proliferació de simplificacions i variants fonètiques en altres parlars valencians $\mathrm{i}$ nord-occidentals (*fea, ${ }^{*} f e e s,{ }^{*}$ desfea,${ }^{*}$ dia (per deia), vea (per veia), trauïa, crevïa...). Davant la diversitat i la irregularitat d'aquestes formes, en l'estàndard actual només són acceptables les formes amb la semivocal antihiàtica.

De vegades, es conjuguen com a verbs incoatius (amb l'increment - eix característic) alguns verbs que, en realitat, són de la segona conjugació (debatre, admetre, permetre...): *debateixes (debats), *admetesca (admeta), *permetesques (permetes)... Aquest ús afecta els verbs acabats en -batre, -córrer, -fondre, -cloure, -metre i-cebre i no és acceptable en cap context.

Cal tenir present que el verb haver-hi és impersonal i que no concerta en nombre amb el complement directe. També cal recordar que totes les formes verbals del verb haver, per a expressar existència, s'han de conjugar amb el pronom hi: *Hi han dos elements amb càrrega positiva; *Ha hagut un gran descens de natalitat; * Aquell any hagué dos moviments sísmics.

En els parlars valencians, el verb ser adopta en la segona persona del singular la forma eres, en lloc de la general ets. Totes dues són acceptables, però en els registres formals és preferible la forma genuïna ets.

\subsubsection{Remarques sobre els verbs de la tercera conjugació}

1) Participis no normatius

De vegades s'utilitzen alguns participis no normatius originats per analogia amb altres verbs o per influència d'altres llengües: *atengut (atès), *confundit (confòs), *detès (detingut), *exclü̈t (exclòs), *fundit (fos), *imprimit (imprès), *molgut (mòlt), *obrit (obert), *obtès (obtingut), *pretengut (pretès), *prometut (promès), *respongut (respost), *romangut (romàs), *tragut (tret), *vengut (venut)...

2) Formes velaritzades

No són normatives algunes formes verbals que tenen el so $/ \mathrm{k} /$ en la desinència de la primera persona del singular del present d'indicatiu, per analogia amb altres verbs on sí que són normatives: *cullc (cull), *cusc (cus), *fuigc (fuig), *perc (perd), *senc (sent), *tusc (tus), *vullc (vull)... 
Aquesta tendència a la velarització, que afecta també els verbs de la segona conjugació, apareix en alguns verbs en la primera i en la segona persones del present d'indicatiu -*diguem (diem), *escriguem (escrivim), *escrigueu (escriviu)-i en el present de subjuntiu - *dorga (dorma), *cullguen (cullen), *cusga (cusa), *fuiggues (fuges), *perga (perda).

3) Alguns verbs fantasmes

Algunes formes verbals genuïnes, de vegades, són substituïdes per verbs «fantasmes», creats per analogia amb altres llengües o per derivació a partir d'un substantiu. Són, per tant, formes que cal evitar: *atemoritzar (atemorir), *col-lisionar (col-lidir), *concretitzar (concretar), *decepcionar (decebre), *explosionar (explotar o esclatar), *fecunditzar (fecundar), *formatejar (formatar), *garantitzar (garantir), *insertar (inserir), *ofertar (oferir), *reflexar (reflectir), *telefonejar (telefonar), *trä̈cionar (trair)...

4) Verbs purs $i$ incoatius

Els verbs de la tercera conjugació són els acabats en -ir i es conjuguen seguint dos models: els dels verbs incoatius, que segueixen els models IV $\mathrm{i}$ v, $\mathrm{i}$ els dels verbs purs, que es conjuguen d'acord amb el model vi.

a) Els verbs incoatius (com servir) afegeixen l'increment -eix- (o -ix, -isc en alguns parlars) en les tres persones del singular i en la tercera del plural del present d'indicatiu, de subjuntiu i d'imperatiu: serv-eix-o (o serv-isc), serv-eix-es, serv-eix, serv-im, serv-iu, serv-eix-en.

b) Els verbs purs (com dormir) no afegeixen aquest increment: dorm-o (o dorm), dorm-s, dorm, dorm-im, dorm-iu, dorm-en.

En la llengua actual, les formes amb $e$, pròpies de la llengua clàssica, han caigut en desús i només s'admeten en registres molt formals: servesca, servesques, servesquen... En canvi, s'accepta la pronunciació popular de la $s$, característica de la major part dels parlars valencians i nord-occidentals en les formes amb-sc (o amb $-s q u)$ : [serßísk], [serßíska]. Tot i que la normativa actual accepta com a variants igualment correctes les formes amb - eix- (compleix, serveix, pateix, tradueix...) i les formes amb -ix- (complix, servix, patix, traduix...) és recomanable l'ús de les formes en -eix- en el llenguatge escrit i en l'oral formal, i restringir les formes en $-i x$ - als registres orals informals.

La majoria dels verbs de la tercera conjugació són incoatius, però sovint es produeixen algunes vacil·lacions en la conjugació. El quadre següent presenta els usos d'aquests verbs: 


\begin{tabular}{|c|c|c|c|c|}
\hline \multirow{2}{*}{\multicolumn{2}{|c|}{ Distribució dels verbs purs i incoatius }} & \multicolumn{2}{|c|}{ Verbs amb doble conjugació } & \multirow[t]{2}{*}{ Falsos incoatius } \\
\hline & & $\begin{array}{l}\text { Amb canvi de } \\
\text { significat }\end{array}$ & $\begin{array}{l}\text { Sense canvi } \\
\text { de significat }\end{array}$ & \\
\hline Purs & $\begin{array}{l}\text { ajupir, bullir, collir (escollir, } \\
\text { recollir...), convenir, cosir, cruixir, } \\
\text { dormir, eixir, escopir, esmunyir, } \\
\text { fugir, grunyir, morir, munyir, } \\
\text { obrir, oir, omplir, prevenir, pudir, } \\
\text { reeixir, sentir (consentir, pressen- } \\
\text { tir, ressentir...), sortir (sobresor- } \\
\text { tir...), tenir, tossir, venir }\end{array}$ & $\begin{array}{l}\text { acudir (venir } \\
\text { a algú una } \\
\text { idea), } \\
\text { lluir ('aparèi- } \\
\text { xer lluminós, } \\
\text { tenir reflexos } \\
\text { lluminosos') }\end{array}$ & \multirow{2}{*}{$\begin{array}{l}\text { afegir, } \\
\text { arrupir-se, } \\
\text { brunzir, } \\
\text { consumir, } \\
\text { engolir, lle- } \\
\text { gir, mentir, } \\
\text { percutir, } \\
\text { presumir, } \\
\text { renyir, resu- } \\
\text { mir, teixir, } \\
\text { vestir... }\end{array}$} & \\
\hline Incoatius & $\begin{array}{l}\text { argüir, assentir, assortir, desco- } \\
\text { brir, discutir, dissentir, engolir, } \\
\text { fugir, imprimir, patir, partir, } \\
\text { sofrir, traduir }\end{array}$ & $\begin{array}{l}\text { acudir ('anar } \\
\text { a un lloc'), } \\
\text { lluir (altres } \\
\text { sentits figu- } \\
\text { rats, 'lluir un } \\
\text { vestit') }\end{array}$ & & $\begin{array}{l}\text { *batre (abatre, deba- } \\
\text { tre, combatre...), *cór- } \\
\text { rer, *metre (admetre, } \\
\text { permetre...), *rompre } \\
\text { (irrompre, corrompre, } \\
\text { interrompre...), *per- } \\
\text { cebre, }{ }^{*} \text { rebre... }\end{array}$ \\
\hline
\end{tabular}

5) Els verbs tenir i venir

Els verbs tenir i venir tenen una forma secundària acabada en -dre (tindre $\mathrm{i}$ vindre), que és molt utilitzada en els registres informals. Cal recordar, però, que aquesta segona forma és poc recomanable en els registres formals i no és admesa en els derivats d'aquests verbs (contenir, mantenir, sostenir, intervenir, prevenir...).

6) Irregularitats ortogràfiques

Els verbs collir, cosir, escopir, sortir, tossir i els seus derivats mantenen la pronunciació de la $o$ del lexema en posició àtona, però en posició tònica aquesta $o$ es pronuncia (i s'escriu) $u$ : surto, surts, surt, sortim, sortiu, surten .

Els verbs acabats en vocal + ir (agrair, conduir, traduir, construir, trair...) porten dièresi en algunes formes (agraïm, agraïu, agraïa, agraïes, agraïda) $\mathrm{i}$ accent en altres (agraírem, agraiem, agraíeu). Cal recordar, però, que no porten mai dièresi l'infinitiu, el gerundi, el futur ni el condicional.

En els parlars valencians, els verbs obrir i omplir presenten formes amb $i$, en lloc de les generals i pròpies de la llengua clàssica amb $e$, en les persones 2a, 3a i 6a: obris, obri, obrin, omplis, ompli, omplin (en lloc d'obres, obre, obren, omples, omple i omplen). Totes dues són acceptables, però en la llengua parlada són preferibles les formes amb $i$.

Cal recordar que algunes formes verbals duen accent diacrític: té (del verb tenir), véns i vénen (del verb venir). 


\subsubsection{Verbs transitius i pronominals}

\subsubsection{Verbs transitius $i$ intransitius}

Un verb transitiu és aquell que selecciona un complement directe, és a dir, que expressa un argument mitjançant un objecte. Es tracta de verbs de predicació incompleta que necessiten el complement per completar-ne el sentit:

[1] Llegeix el diari.

[2] Menjarem amanida.

[3] Construïren un edifici.

[4] Convencerem els estudiants.

[5] Esperarem que ens revise la pràctica.

Generalment, el parlant coneix quins verbs de la seua llengua necessiten d'aquests complements sense haver de consultar el diccionari; tanmateix, en el cas del català, a causa de la situació de contacte amb diverses llengües en una posició d'inferioritat, els parlants dubten o s'equivoquen sovint.

Hi ha uns quants verbs que són transitius, tot i que sovint, en la llengua poc acurada, s'usen com a intransitius: abominar, acabar, acompanyar, anomenar, apassionar, apropiar-se, avisar, concernir, conèixer, convidar, cridar, deixar, emprenyar, encantar, entusiasmar, escoltar, insultar, molestar, preocupar, veure, visitar...

Pel contrari, un verb intransitiu no admet complement directe, perquè es tracta d'un verb de predicació completa que no necessita un altre argument. Poden, per tant, usar-se sols o amb un complement introduït per una preposició:

[6] Nevava copiosament.

[7] El camí baixa fins aquella plana.

[8] No podeu parlar dels secrets obertament.

[9] Confiava cegament en aquella dona.

[10] Sempre somie en les mateixes bajanades.

Són verbs intransitius: avortar, berenar, cessar, contactar, dinar, esmorzar, incumbir, recórrer, ressaltar, sopar, teclejar...

\subsubsection{Verbs personals (o impersonals) i pronominals (o no pronominals)}

La distinció entre els verbs personals i els verbs impersonals afecta un nombre reduït de verbs. La majoria dels verbs són personals, és a dir, tenen un subjecte; uns quants verbs, però, no en tenen, de subjecte, bé perquè són verbs referits a fenòmens atmosfèrics (ploure, nevar...), bé perquè parlen de l'existència o inexistència d'algun objecte, persona o animal (haver-hi):

[11] Com més ens hi acostàvem, més plovia.

[12] Hi ha homes que segueixen obrint-se camí. 
Distingir entre verbs pronominals i no pronominals es fa una mica més difícil a causa de la influència d'altres llengües. Un verb pronominal és aquell en què el pronom en forma part com un morfema i no representa cap funció sintàctica. No hem de tenir en compte, doncs, els verbs reflexius (pentinar-se, estirar-se, afaitar-se) ni els recíprocs (estimar-se, estomacar-se). Tanmateix, hi ha verbs que poden ser pronominals o no pronominals depenent del context en què es troben. Els verbs pronominals purs són: abstenir-se, adelitar-se, adonar-se, atrevir-se, burlar-se, aprimar-se, engreixar-se, entrenar-se... Verbs que poden ser pronominals o no pronominals segons el context: menjar, venjar, pensar, anar, témer, estar... I finalment, verbs que no són pronominals i que col·loquialment s'usen com a pronominals: baixar, callar, caure, coure, conèixer, demanar, marxar, olorar, passar, pujar, quedar, saber, saltar, trobar, venir...

[13] Si voleu solucionar aquest assumpte, passeu pel centre de suport que tingueu més a la vora.

[14] Han pujat al cotxe que els esperava i han fugit ràpidament.

[15] Mai no m'ha passat pel cap de fer-ho així.

[16] Ha quedat glaçat quan ha sabut la notícia.

[17] El nostre veí s'ha engreixat moltíssim.

\subsubsection{Les formes no personals del verb}

L'ús de les formes no personals del verb (infinitiu, gerundi i participi) presenta, en català, una sèrie de dificultats que convé conèixer per tal d'evitar usos inadequats que tenen el seu origen, principalment, en la interferència del castellà.

L'infinitiu té un sentit independent de qualsevol matís temporal i és per això que forma part de un nombre important de perífrasis verbals. Sobre l'ús de l'infinitiu, convé recordar les observacions següents:

a) La perífrasi al + infinitiu no és recomanable en els registres formals i convé, per tant, substituir-la per la perífrasi en + infinitiu: En tornar del cinema he vist que $m$ 'havies telefonat, i no *Al tornar del cinema...

b) En català tampoc no són correctes l'ús de l'infinitiu amb un valor d'obligació, o de recomanació ni l'ús, precedit de la preposició de, amb un sentit condicional. En el primer cas, cal emprar l'imperatiu o una perífrasi d'obligació, i en el segon es poden emprar les construccions $s i+$ verb, en cas de + infinitiu o en cas que + subjuntiu. Vegem-ne uns exemples: *Estirar; *De no eixir el sol, haurem d'ajornar l'excursió.

c) Normalment l'infinitiu, fora dels casos en què està nominalitzat, no admet l'anteposició de l'article: *L'haver vist el seu xicot amb la Marta la va enfonsar.

d) És impropi també del català l'ús de l'infinitiu directament, sense cap altre verb davant, per afegir una última idea a les que ja s'havien expressat, i l'ús de l'infinitiu precedit de la preposició $a$ en verbs com ara destacar o 
remarcar. Exemples: *Respecte a les causes del fenomen, recordar només que...; * A destacar el bon paper que han fet els jugadors del filial; *A remarcar la bona disposició de tots els partits.

El gerundi expressa, en general, una acció en desenvolupament i té, per tant, un valor adverbial.

a) En les oracions compostes, el gerundi expressa una acció simultània o anterior a la del verb principal (pot expressar la manera com es realitza o la causa de l'acció que expressa aquest), però és incorrecte si expressa una acció posterior o una acció que n'és la conseqüència. Per assegurar-se que un gerundi que va darrere del verb principal és correcte, podem canviar l'ordre i col-locar-lo davant del verb. Si la frase continua tenint sentit, l'ús del gerundi és correcte. Vegem-ne un parell d'exemples:

Correcte: He calculat el cost de l'operació seguint les vostres indicacions. Incorrecte: * He calculat el cost de l'operació, trobant-lo excessiu.

b) Són incorrectes el gerundi purament copulatiu (sense un matís de posterioritat) $i$ el gerundi especificatiu (equivalent a un adjectiu):

- Aqui el raïm s'ha cultivat de sempre, *essent la base de l'economia comarcal.

- Avui ha estat aprovada la llei *regulant el funcionament dels partits polítics.

c) També són incorrectes les següents perífrasis verbals de gerundi:

- Estar + gerundi + participi passat: L'acusació particular *està sent portada per un conegut advocat barceloní. La perífrasi només és correcta quan té un valor de continuïtat o de reiteració.

- Venir + gerundi quan indica continuïtat en el temps (del passat cap al present): Ho *ve dient des de fa temps.

- Venir + gerundi (sent o essent) + participi passat amb un sentit similar a venir + gerundi: El manteniment de l'edifici *ve sent fet per una empresa especialitzada.

- Portar + una expressió temporal + gerundi, quan pretén expressar un sentit duratiu i marcar-ne els límits temporals: Porta dos dies *perseguint-me per tot arreu. En català, cal substituir-la per fer + expressió temporal + que: Fa dos dies que em persegueix per tot arreu.

El participi és la forma no personal emprada en les formes verbals compostes. Pot expressar el resultat d'una acció simultània o anterior i el resultat d'un procés; també pot tenir el valor d'un adjectiu i, precedit d'una forma del verb ésser, s'usa en les oracions passives. L'ús del participi presenta les dificultats següents:

a) Tot i que, generalment, el participi té una forma invariable en les formes compostes dels verbs, és recomanable de fer-lo concordar amb el complement 
directe quan aquest és representat pels pronoms el, la, els, les i en. La concordança del participi, que és manté viva en la llengua parlada, però s'usa molt poc en el llenguatge periodístic, és especialment recomanada quan el CD és representat per la i les. Exemples:

- Vaig deixar-li les dues cintes dilluns passat i encara no me les ha tornades.

- Havíem quedat amb els teus cosins a la platja, però no els hem vistos.

- Va dir que em regalaria una pilota de bàsquet, però encara no me l'ha donada.

b) De vegades, s'utilitzen alguns participis no normatius originats per analogia amb altres verbs o per influència d'altres llengües: capigut (cabut), emitit (emès), estrengut (estret), confundit (confòs), incluït (inclòs), interrumpit (interromput), percebit (percebut), romangut (romàs), sapigut (sabut), tragut (tret), vengut (venut), comprengut (comprès), exclü̈t (exclòs), fundit (fos), imprimit (imprès), detès (detingut), mantès (mantingut), etc. El verb coure té dos participis, segons el significat: cuit, amb el significat de cuinat, i cogut, que significa picar.

\section{www}

A més de La flexió verbal, d’Enric Valor, per consultar les formes verbals normatives, es pot accedir als llocs web següents:

http://www.verbscatalans.com/

http://ca.wikipedia.org/wiki/Flexi\%C3\%B3_verbal_del_catal\%C3\%A0

http://ca.wikipedia.org/wiki/Gram\%C3\%A0tica_catalana

\subsection{Adverbis i preposicions}

\subsubsection{Aspectes generals}

Les preposicions són mots invariables que funcionen com a elements d'enllaç entre els constituents de la frase. Es poden classificar en cinc subclasses:

a) Preposicions febles o àtones: $a$, amb, de, en, per i per $a$.

b) Preposicions fortes o tòniques: contra, cap a, des de, entre, fins a, envers, malgrat, sense, vers...

c) Preposicions procedents d'adverbis:

- poden dur (opcionalment) la preposició de: davant (de), darrere (de), dins (de), davall (de), vora (de)... 
- porten sempre de (obligatòriament): abans de, arran de, després de, enfront de, enmig de, entorn de, fora de, lluny de, prop de.

d) Preposicions procedents de gerundis i participis: durant, mitjançant, no obstant, llevat (de), tocant a, dret a, salvat, etc.

e) Altres locucions preposicionals (preposició + altre element + preposició): $a$ desgrat de, a fi de, per tal de, a força de, a partir de, a través de, al cap de, al llarg de, al peu de, d'acord amb, en contra de, en lloc de, en vista de, per culpa de, per mitjà de, etc.

A causa de les discrepàncies entre l'ús oral espontani i la normativa recomanable en els registres més formals de la llengua, cal tenir especialment en compte les normes d'ús de les preposicions febles, la distribució dels usos de les preposicions per i per a i la normativa relacionada amb el canvi i caiguda de preposicions.

\subsubsection{Remarques sobre l'ús de les preposicions $a$, $a m b$, de i en}

El complement directe no s'introdueix, en català, amb la preposició $a$, tret que el complement siga un pronom fort, un complement que expresse reciprocitat o hi haja dificultat de comprensió:

[18] Això importa a tothom.

[19] S'estimaven els uns als altres.

[20] Com creieu que afectarà l'ús d'Internet a les economies familiars?

L'ús de determinades preposicions comporta molts dubtes a l'hora de decidir quina és la més apropiada i, sobretot, quina és la més genuïna, la que té tradició en l'ús estàndard de la llengua. A continuació, proposem alguns exemples que poden presentar dificultats d'elecció de la solució adequada. De tota manera, es poden consultar diversos recursos (en línia i en paper) que resoldran de manera més extensa els possibles dubtes:

[21] En l'anàlisi, heu de diferenciar causa d'efecte.

[22] Aquesta vegada, el president $s$ 'ha escapat de les preguntes incòmodes.

[23] Entre tots hem de contribuir a la millora de les infraestructures.

[24] A causa de la fàbrica, tot el poble fa olor de sabó.

[25] El departament reclama trobar una solució del problema.

[26] Volem fer una menció especial del treball dels auditors.

[27] En l'informe es considera que hi va haver quaranta-dos ferits lleus $i$ dos de greus.

[28] La reunió és a l'edifici del Rectorat.

[29] Sempre hem patit els mateixos problemes en aquestes terres.

[30] Tota la documentació la trobareu en la bibliografia.

[31] La reunió acabarà amb una dissertació de la directora.

[32] El govern vol acabar les descàrregues il·legals. 
[33] Les notes s'exposaran demà al matí.

[34] Al mes de febrer, haurem d'amanir els resultats.

[35] Sempre tenim les classes de matí.

\subsubsection{Canvi i caiguda de preposicions}

Les preposicions en (tret que tinga valor temporal) i $a m b$ s'han de canviar per $a$ o per de davant d'infinitiu i cauen davant de la conjunció que (però no davant d'un què relatiu o interrogatiu). De la mateixa forma, les preposicions $a$ i de (soles o formant part d'una locució preposicional) s'han de suprimir davant la conjunció que. De vegades, si en resulta una construcció molt forçada, es pot intercalar una altra paraula entre la preposició i la conjunció.

[36] Tinc interès en aquests informes.

[37] Tinc interès $a$ estudiar aquests informes.

[38] Tinc interès que redacteu aquests informes.

[39] Compteu amb les excepcions.

[40] Compteu $a / d$ 'escriure correctament.

[41] Compteu que se us entenga.

\subsubsection{Distribució de per i per a}

S'han de fer servir correctament les preposicions per ('lloc de pas, temps durant, causa, motiu, autor de l'acció, instrument, mitjà, manera', etc.) i per a ('destinació, objecte, finalitat, direcció, termini fix referit al futur, opinió', etc.). També davant d'infinitiu s'han de diferenciar per ('causa, finalitat i causa alhora, acció que s'espera però que encara no s'ha realitzat, circumstància de manera', etc.) i per a ('destinació, finalitat sola, condició, conseqüència, fet posterior', etc.) mentre l'autoritat acadèmica no canvie la normativa. A continuació es presenten alguns exemples i un quadre general amb la distribució dels usos de les dues preposicions:

[42] Analitzem les dades registrades per donar resposta als problemes plantejats.

[43] En aquest país es revolten per aconseguir drets democràtics.

[44] Ens posem a la vostra disposició per atendre-us des de casa.

[45] No ha pogut sortir perquè encara tenia molts exàmens per corregir.

[46] Per acabar, podem dir que encara no s'han assolit els objectius.

[47] Es redueix el nombre de clics necessaris per a arribar a llegir els missatges.

[48] Les teues aportacions són fonamentals per a aconseguir un bon desenvolupament del projecte.

[49] Li explicaran totes les eines que té a l'abast per a poder seguir bé els estudis.

[50] Aquí tenim el terme per a designar aquesta figura.

[51] Per a resoldre el problema, l'has de plantejar bé.

[52] El curs vinent serà massa aviat per a valorar el resultat d'aquest canvi. 


\begin{tabular}{|c|c|c|c|c|}
\hline \multicolumn{5}{|c|}{ Distribució dels usos de per i per $a$} \\
\hline & per & & per $a$ & \\
\hline & Expressa & Exemples & Expressa & Exemples \\
\hline $\begin{array}{l}\text { Davant de } \\
\text { noms, pronoms, } \\
\text { adjectius i } \\
\text { articles }\end{array}$ & $\begin{array}{l}\text { Qui fa l'acció, el } \\
\text { motiu o la causa } \\
\text { de l'acció }\end{array}$ & $\begin{array}{l}\text { L'acte va ser presidit } \\
\text { pel rector. } \\
\text { Van suspendre la } \\
\text { representació per la } \\
\text { pluja. }\end{array}$ & $\begin{array}{l}\text { Finalitat, destinació o } \\
\text { un termini fix referit } \\
\text { al futur }\end{array}$ & $\begin{array}{l}\text { He comprat un re- } \\
\text { gal per a la mare. } \\
\text { Han portat el ma- } \\
\text { terial per a tu. } \\
\text { Convoquem la reu- } \\
\text { nió per al dia } 27 .\end{array}$ \\
\hline $\begin{array}{l}\text { Davant } \\
\text { d'adverbis o } \\
\text { conjuncions }\end{array}$ & $\begin{array}{l}\text { Causa, circums- } \\
\text { tàncies de temps }\end{array}$ & $\begin{array}{l}\text { Ho necessito per ara } \\
\text { mateix. } \\
\text { No sé per què no } \\
\text { se'n va. }\end{array}$ & Finalitat & $\begin{array}{l}\text { No sé per a què } \\
\text { vols les tisores. }\end{array}$ \\
\hline $\begin{array}{l}\text { Davant d'infi- } \\
\text { nitiu }\end{array}$ & $\begin{array}{l}\text { El motiu de } \\
\text { l'acció del verb } \\
\text { principal o una } \\
\text { acció voluntària } \\
\text { (perquè + voler) }\end{array}$ & $\begin{array}{l}\text { Va parar la mà per } \\
\text { rebre els diners. } \\
\text { Vaig a València per } \\
\text { saludar-hi els amics. }\end{array}$ & $\begin{array}{l}\text { Destinació (a fi que, } \\
\text { per tal de) o una } \\
\text { acció amb verbs que } \\
\text { no indiquen el mòbil } \\
\text { de l'acció (bastar, } \\
\text { tenir prou, necessitar, } \\
\text { caldre, emprar, servir, } \\
\text { aprofitar, utilitzar, } \\
\text { etc.) }\end{array}$ & $\begin{array}{l}\text { La investigació ha } \\
\text { servit per a provar } \\
\text { el funcionament de } \\
\text { la vacuna. } \\
\text { Necessitareu un } \\
\text { bon diccionari per } \\
\text { a solucionar els } \\
\text { dubtes. }\end{array}$ \\
\hline
\end{tabular}

(*) En els casos ombrejats, segons la proposta de Joan Coromines i Joan Solà, l'ús de per $a$ és facultatiu. Per tant, davant d'adverbis, conjuncions i infinitius sempre es pot utilitzar la preposició per.

\subsubsection{Adverbis i locucions adverbials}

Alguns dels principals adverbis i locucions adverbials:

\begin{tabular}{|l|l|}
\hline De manera & $\begin{array}{l}\cdot \text { com, bé, així, a poc a poc, de pressa, arran, sobretot, de mica en mica. } . \\
\cdot \text { Formats per adjectiu en femení + -ment: malament, sàviament, lleument, comunament, } \\
\text { difícilment, contínuament, etc. }\end{array}$ \\
\hline De lloc & on, aquí, allà, ençà, (a) dalt, (a) prop, lluny, enllà, pertot, enlloc, avall. \\
\hline De temps & ara, quan, després, demà, ahir, avui, sovint, de tant en tant, enguany, suara. \\
\hline De quantitat & molt, poc, massa, molt, gaire, força, qui-sap-lo, prou, que, gens, tant, tan.. \\
\hline D’afirmació & sí, prou, també, àdhuc, així mateix, sens dubte, i tant, de debò, ben segur. \\
\hline De negació & no, tampoc, no $[\ldots]$ pas, i ara!, de cap manera.. \\
\hline De dubte & potser, tal vegada, tal volta, a la millor, si molt convé, qui sap, per ventura.. \\
\hline
\end{tabular}

UOC (2002): Criteris lingüistics,

http://www.uoc.edu/serveilinguistic/criteris/gramatica/adverbis.html 
Observacions :

Quan hi ha més d'un adverbi en -ment, es poden mantenir els sufixos en tots o posar-lo només en el primer:

[53] Ens vam saludar reiteradament i efusivament.

[54] Ens vam saludar reiteradament i efusiva.

Els adverbis bé i malament prenen les formes ben i mal respectivament quan precedeixen el mot que modifiquen.

[55] Tot allò que està mal plantejat, no es podrà resoldre.

[56] Les qüestions van quedar ben resoltes.

Les partícules mai, res, ningú, enlloc, tampoc, cap, gens no tenen soles sentit negatiu; per tant, en aquests casos s'ha d'afegir l'adverbi no, llevat que s'usen soles.

[57] Mai ningú no podrà oferir-nos unes condicions millors.

[58] Res no ens ha d'impedir arribar al fons de l'assumpte.

[59] T’agrada el cafè? Gens!

Amb els adverbis de dubte (potser, tal vegada, probablement, etc.) el verb ha d'anar en indicatiu i no en subjuntiu.

[60] Tal vegada s'equivoca, però, almenys, ho ha exposat.

S'han de fer servir les formes genuïnes d'adverbis o expressions adverbials (dret, a poc a poc, de mica en mica, com a màxim o a tot estirar, per força, de cara enlaire, a vegades, etc.) en comptes de les que són calcades incorrectament del castellà (de peu, poc a poc, mica en mica, com a molt, a la força, de cara per amunt, en ocasions, etc.) i s'han de distingir mentrestant de mentre, a dalt i a baix d'amunt $\mathrm{i}$ avall, massa de gaire i molt, força de molt, etc.

[61] Les descobertes anaven apareixent a poc a poc.

[62] Vulguen o no, ho hauran de fer per força.

[63] Sonava la marxa. Mentrestant, les autoritats ocupaven els seus llocs.

\section{Lectures recomanades}

ABRIL, Joan (1997): Diccionari pràctic de qüestions gramaticals, Barcelona, Edicions 62.

Alcover, Antoni M. (2006): Dietari de l'excursió filològica 1906, Barcelona, Proa.

Cuenca, Maria Josep i Manel Pérez Saldanya (2002): Guia d'usos lingüístics. 1. Aspectes gramaticals, València [en línia], Institut Interuniversitari de Filologia Valenciana, $<$ www.ua.es/institutos/inst.filovalen/Guiausos.pdf $>$. 
Pla, Albert (2010): Això del català, Barcelona, Columna.

ReIG, Eugeni (2008): Les nostres paraules, València, Acadèmia Valenciana de la Llengua.

SolÀ, Joan (2009): Planteu cara, Barcelona, La Magrana.

VALOR, Enric (2010): La flexió verbal, València, Tres i Quatre. 
ANNEXOS 


\section{Annex I: Funcions textuals dels signes de puntuació}

Les funcions textuals estan relacionades amb l'entonació i amb la sintaxi i permeten marcar els diferents elements del text i de l'oració, separar els constituents oracionals, indicar elements elidits i alteracions en l'ordre de l'oració, introduir informacions complementàries i precisar els matisos significatius d'una unitat lingüística, de la modalitat oracional i dels actes de parla.

Funció

Demarcador de text, de paràgraf i d'oració.

Demarcador de clàusules a l'interior d'una oració.

Separador dels elements d'una enumeració quan a l'interior d'un element hi ha comes.

Separador dels elements d'una enumeració.

Separar els vocatius dels verbs.

Marcador dels incisos o aposicions en qualsevol posició de la frase (interior, inicial o final).

Delimitador dels complements circumstancials i les clàusules finals, causals, condicionals, concessives i adversatives (entre d'altres), especialment quan s'han desplaçat de la seua ubicació habitual en l'oració.

Marcador d'elements elidits en l'oració (esp. verbs).

Marcador d'expressions imperatives i exclamatives que no tanquen un període.

Indicador del desplaçament dels elements del seu lloc habitual o neutre en l'oració.

Clarificador de lectures ambigües.

Introductor dels elements d'una enumeració.

Introductor d'elements que amplien la informació de l'oració (reformulacions, explicacions, exemplificacions, resums, causes, conseqüències o conclusions).

Introductor de citacions textuals i dels fragments escrits en estil directe.

Marcador d'enumeracions i sèries inacabades.

Marcador d'elements elidits en les citacions literals.

Demarcador d'unitats màximes (oració, paràgraf o text) per indicar modalitat exclamativa o interrogativa.

Indicador de dubte, sorpresa o inseguretat.

Demarcador d'incisos i informacions complementàries.

Demarcador de paraules, informacions o dades que ja estan entre parèntesis.

Delimitador de fragments opcionals o elidits en el text.

Separador de les síl·labes d'una paraula a final de línia.

Separador en l'escriptura dels numerals i en les paraules compostes.

Introductor dels diàlegs en els textos narratius.

Indicador d'una citació o transcripció literal.

Indicador d'un matís o significat especial d'un mot.

Demarcador del significat d'una paraula o expressió.

Indicador d'oposició o alternança entre els elements separats.
Signes de puntuació
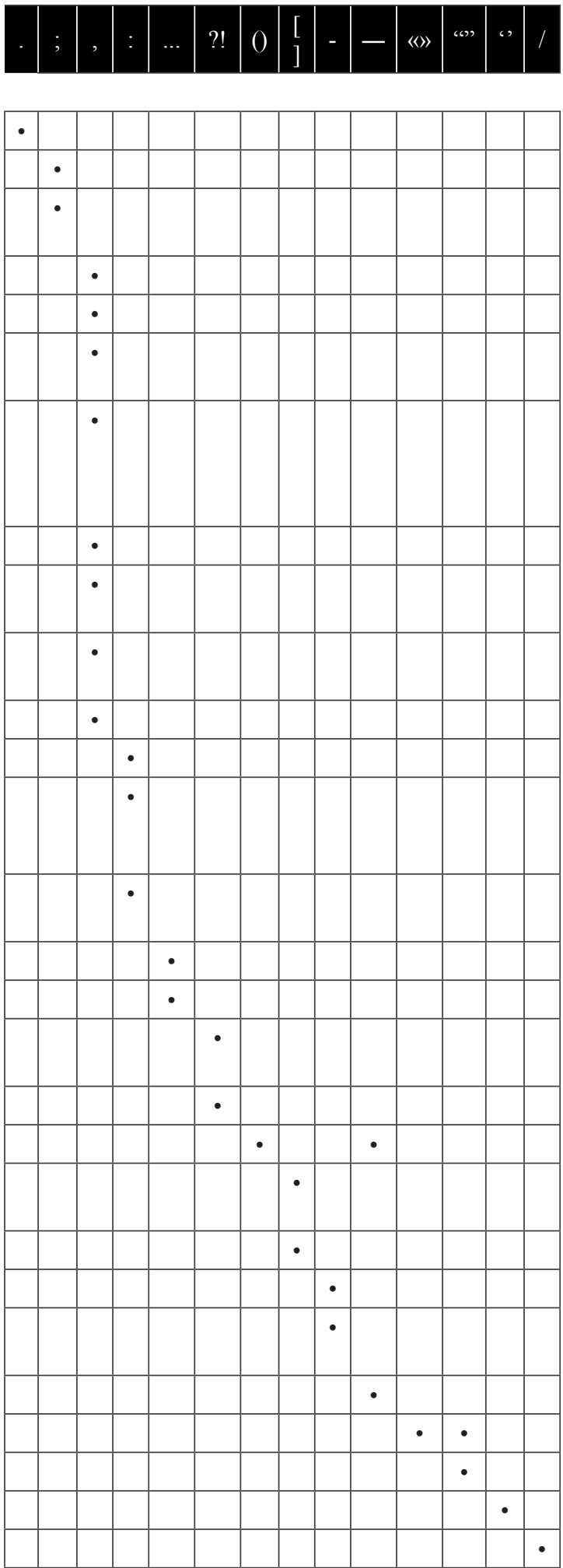


\section{Annex II: Funcions convencionals dels signes de puntuació}

Funció

Indicador de les abreviatures (no de símbols i sigles).

Delimitador entre la part numèrica i la part descriptiva dels títols d'apartats, temes i enumeracions de llibres i treballs acadèmics.

Separador entre les hores i els minuts i entre els minuts i els segons en les expressions horàries.

Marcador dels milers i milions en l'escriptura numèrica dels nombres que expressen quantitats.

Separador, en textos jurídics, de cadascun dels paràgrafs que corresponen a la descripció dels fets i als fonaments de dret.

Separador dels elements d'una enumeració quan s'escriuen en paràgrafs diferents.

Separador, en les adreces i en les dates, del nom del carrer i el número, i del lloc o població i la data.

Marcador de la inversió de l'ordre habitual Nom-Cognom en les relacions bibliogràfiques: Cognom, Nom.

Indicador d'una concreció o especificació.

Separador de la data de promulgació d'un text legal de la resta del títol.

Indicador de la separació entre la part entera i la decimal dels nombres.

Delimitador de certes fórmules (darrere de verbs com expose, demane, certifique, etc.) en alguns documents administratius.

Indicador de divisió entre dues quantitats o magnituds.

Substitutiu de paraules o expressions considerades malsonants (després de la primera lletra).

Indicador del desconeixement d'una dada, en taules i quadres.

Indicador de dubte, sorpresa o inseguretat.

Separador d'apartats i paràgrafs d'un text, després de números o lletres.

Indicador de formes dobles o diverses opcions de lectura d'un text.

Indicador d'ordre i marcador d'agrupació en fórmules matemàtiques, físiques o químiques.

Demarcador de les transcripcions fonètiques.

Marcador d'elements opcionals en una expressió.

Marcador d'agrupació en les fórmules matemàtiques quan els elements inclosos ja contenen parèntesis.

Separador dels diversos elements d'una correlació.

Separador dels elements en l'expressió de dates abreujades i en les paraules compostes.

Indicador de la lectura unitària d'una expressió.

Demarcador de malnoms i títols d'articles i d'apartats d'una revista o d'un llibre.

Indicador d'equivalències lèxiques.

Indicador d'operacions matemàtiques i marcador en el sistema internacional d'unitats.

Separador del número d'ordre dels textos legals de l'any en què s'han promulgat.

Substitutiu del punt en l'abreviatura dels carrers, places i altres genèrics en l'escriptura dels topònims.
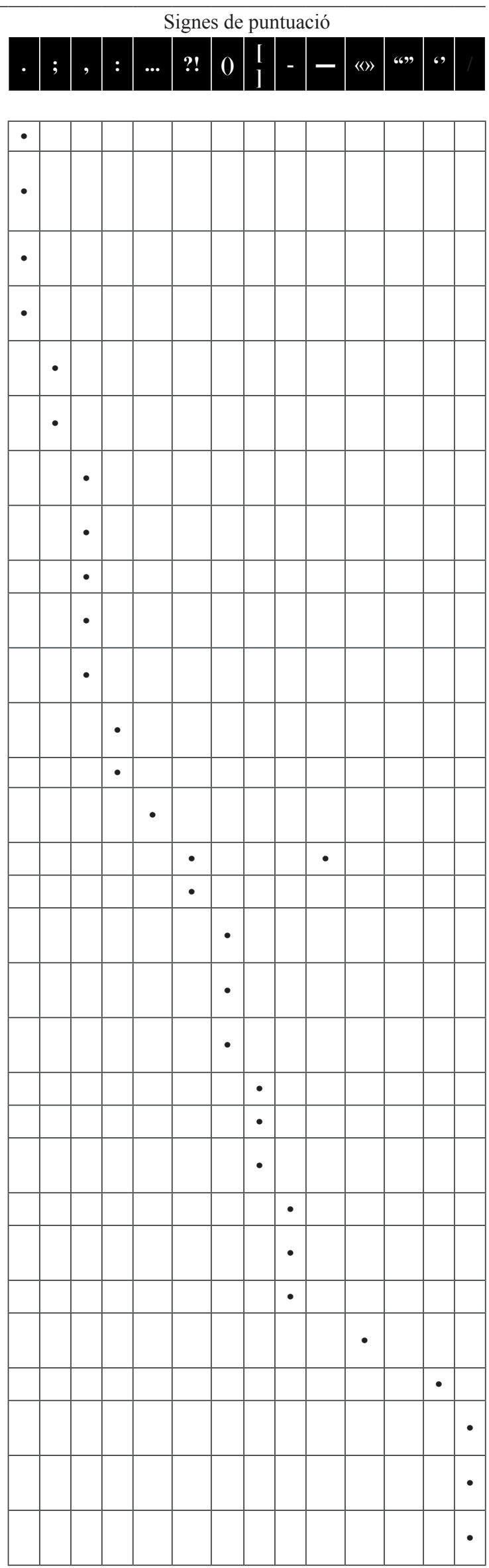

Joan Peraire / Enric Portalés - ISBN: 978-84-695-3671-1 


\section{Annex III: Tipografia}

\begin{tabular}{|c|c|c|}
\hline Categoria & Nom de la marca & Funcions \\
\hline Estil & Rodona o normal & $\begin{array}{l}\text { - Text no marcat. } \\
\text { - Noms de marques comercials. } \\
\text { - Noms d'establiments comercials o de lleure. } \\
\text { - Textos citats, en català o en una altra llengua. }\end{array}$ \\
\hline Estil & Negreta & $\begin{array}{l}\text { - Marcador d'èmfasi en manuals i textos de divulgació } \\
\text { - Marcador per destacar expressions en textos didàctics. } \\
\text { - Títols de capítols, apartats i subapartats d'un treball. } \\
\text { - Títols de taules o de figures. } \\
\text { - Encapçalament de quadres o taules. }\end{array}$ \\
\hline Estil & Cursiva o itàlica & $\begin{array}{l}\text { - Títols d'obres de creació: llibres, quadres, pel-lícules... } \\
\text { - Títols de publicacions periòdiques. } \\
\text { - Préstecs no adaptats gràficament (inclosos llatinismes). } \\
\text { - Remissions a parts del text. } \\
\text { - Acotacions d'obres de teatre. } \\
\text { - Advertiments i peus d'illlustracions. } \\
\text { - Paraules remarcades per l'autor del text. } \\
\text { - Conceptes que són definits en el mateix text. } \\
\text { - Paraules o expressions usades en sentit metalingüístic. } \\
\text { - Paraules o expressions escrites incorrectament. } \\
\text { - Exemples en els diccionaris i enciclopèdies. } \\
\text { - Sobrenoms i pseudònims, quan acompanyen el nom. }\end{array}$ \\
\hline Efecte & Versaletes & $\begin{array}{l}\text { - Numerals romans per expressar els segles. } \\
\text { - Cognoms dels autors en les relaciones bibliogràfiques. }\end{array}$ \\
\hline Efecte & MAJÚSCULES & $\begin{array}{l}\text { - Eslògans publicitaris, lemes i rètols de carrers. } \\
\text { - Títols de llibres en la portada i en el llom. } \\
\text { - Títols de capítols i parts de llibres i treballs. } \\
\text { - Textos breus: avisos, anuncis, inscripcions... }\end{array}$ \\
\hline Efecte & $\underline{\text { Subratllat }}$ & - Selecció de paraules i idees durant la lectura d'un text. \\
\hline Efecte & Superindex & $\begin{array}{l}\text { - Marcador de l'operació matemàtica de potenciació. } \\
\text { - Números introductors de les notes a peu de pàgina. }\end{array}$ \\
\hline Efecte & Ombra, coinitorith, & $\begin{array}{l}\text { - Efectes estètics en títols de treballs o dossiers. } \\
\text { - Situacions excepcionals: cartells, rètols... }\end{array}$ \\
\hline Efecte & Ratllat & - Marcador d'expressions que s'han d'eliminar. \\
\hline $\begin{array}{l}\text { Tipus de } \\
\text { lletra }\end{array}$ & Tipus o font & $\begin{array}{l}\text { - Indicador de canvi de tipus d'informació. } \\
\text { - Destacar noms de fonts en textos especialitzats. }\end{array}$ \\
\hline $\begin{array}{l}\text { Tipus de } \\
\text { lletra }\end{array}$ & Color & $\begin{array}{l}\text { - Títols o subtítols d'un treball. } \\
\text { - Correccions en una versió provisional del text. }\end{array}$ \\
\hline $\begin{array}{l}\text { Tipus de } \\
\text { lletra }\end{array}$ & Grandària & $\begin{array}{l}\text { - Títols i subtítols (cos superior al cos del text principal). } \\
\text { - Notes a peu de pàgina i citacions extenses (cos inferior). }\end{array}$ \\
\hline
\end{tabular}




\section{Annex Iv: Senyals per llegir}

\begin{tabular}{|c|c|c|}
\hline \multicolumn{3}{|c|}{ Senyals per llegir } \\
\hline \multirow{8}{*}{ Senyals d'anticipació } & Títols & - Títols i subtítols \\
\hline & Resums & - Extractes \\
\hline & & · Encapçalaments \\
\hline & & $\cdot$ Citacions \\
\hline & & $\begin{array}{l}\text { - Apartats específics del text: introducció, } \\
\text { pròleg o prefaci }\end{array}$ \\
\hline & Frases & - Frases inicials de tesi, qüestió o propòsit \\
\hline & & - Frases temàtiques de paràgraf \\
\hline & Índexs & \\
\hline \multirow{3}{*}{ Senyals de resum } & Frases finals de res & $\mathrm{m}$, cloenda o record \\
\hline & Apartats específics & resum, conclusions o epíleg \\
\hline & Recapitulacions & \\
\hline \multirow{10}{*}{ Senyals visuals } & Tipografia & - Variació tipogràiica: cos, família, color, \\
\hline & & efectes... \\
\hline & & - Estils: subratllat, negreta i cursiva \\
\hline & & · Majúscules i nombres \\
\hline & & - Numeració d'apartats i capítols \\
\hline & Disposició visual & - Espais en blanc \\
\hline & & $\cdot$ Marges \\
\hline & & - Interliniat i sagnia \\
\hline & & - Files, franges i columnes \\
\hline & & - Dibuixos, gràfics i esquemes \\
\hline \multirow{6}{*}{ Marcadors textuals } & Connectors & - Connectors oracionals \\
\hline & & - Connectors textuals \\
\hline & & - Marcadors discursius \\
\hline & Mecanismes de & - Anàfora zero o el·lipsi \\
\hline & referència & - Pronoms \\
\hline & & - Sinonímia \\
\hline
\end{tabular}




\section{Annex v: Interferències lèxiques}

\section{Barbarismes}

\begin{tabular}{|c|c|}
\hline abertura obertura & creència creença \\
\hline acàs (si) si de cas & crusar creuar, travessar \\
\hline acaudalat acabalat & cuidadós acurat, curós \\
\hline aclarar aclarir & decepcionar decebre, defraudar \\
\hline aconteixement esdeveniment, fet & demés (els) els altres, la resta \\
\hline acoplament acoblament & derribar derrocar, enderrocar, abatre \\
\hline acostumbrar acostumar & derrotxar malgastar, malbaratar \\
\hline adelantar avançar, anticipar & desarme desarmament \\
\hline ademés a més, a més a més & desarrollar desenvolupar, desplegar \\
\hline agotar esgotar, exhaurir & descuidar descurar, negligir // distraure \\
\hline agravar agreujar & desde luego sens dubte, per descomptat, és clar, i tant! \\
\hline alabar lloar, elogiar & desempenyar [un paper] exercir, fer \\
\hline albedrío arbitri, albir & desetxar rebutjar, excloure, refusar \\
\hline alcançar arribar, abastar, assolir & despedida comiat, acomiadament $m$. \\
\hline algo alguna cosa & despejar aclarir, desembarassar // aïllar [una incògnita] \\
\hline ambos ambdós, tots dos, els dos & despreci menyspreu, desdeny \\
\hline amparo empara $f$. & desprovist desproveït, mancat \\
\hline àngul angle & destino destí [sort] // destinació [Iloc] // càrrec, Iloc de treball \\
\hline aplaçar ajornar & deuda deute $m$. \\
\hline apoiar ajudar, donar suport // recolzar, descansar & disfrutar gaudir, fruir, passar-s'ho bé // tenir \\
\hline armonía harmonia & divisar entreveure, albirar \\
\hline arrepentir-se penedir-se & donar-se compte adonar-se \\
\hline assamblea assemblea & duda dubte $m$. \\
\hline atràs retard, endarreriment // subdesenvolupament & eje eix \\
\hline atravessar travessar, creuar & empenyar-se entestar-se, obstinar-se // aferrar-se, endeutar-se \\
\hline base a (en) segons, d'acord amb & enchufe endoll // amiguisme \\
\hline bisagra frontissa & enfermetat malaltia \\
\hline búsqueda recerca, cerca & ensalçar enaltir, exalçar \\
\hline calificar qualificar & enterar-se assabentar-se, saber, adonar-se \\
\hline calitat qualitat & entonces llavors, aleshores \\
\hline cantitat quantitat & en ves de en lloc de, en compte de \\
\hline carèixer mancar, faltar, freturar & equis ics, xeix \\
\hline casi quasi, gairebé & eslabó baula, anella $f$. \\
\hline caudal cabal [quantitat] & extranger estranger \\
\hline conllevar comportar & extrany estrany \\
\hline conta compte $m$. & fallo error, errada // sentència \\
\hline cotejar acarar, comparar, confrontar & fetxa data \\
\hline cotidià quotidià & fi i al cap (al) al cap i a la fi, al capdavall \\
\hline florèixer florir & prompte (de) de sobte \\
\hline front a enfront de, davant & quiebra fallida, crac \\
\hline
\end{tabular}




\author{
fronterís fronterer \\ fulla [de paper] full, foli $m$. \\ ganader ramader \\ ganància guany, lucre $m$. \\ garabato gargot \\ garantitzar garantir \\ gasto despesa $f$. \\ grave greu \\ halagar afalagar \\ hassanya proesa \\ hasta fins (a) \\ humillar humiliar \\ impar imparell, senar \\ insertar inserir \\ junt a al costat de, prop de, juntament amb \\ jusgat jutjat \\ lograr aconseguir, obtenir \\ luego després \\ medir mesurar, amidar \\ menos (por lo) almenys, si més no \\ menospreci menyspreu \\ menut (a) sovint \\ monasteri monestir \\ movilitzar mobilitzar \\ número [quantitat] nombre \\ ocurrir ocórrer, passar, tenir Iloc \\ olvidar oblidar \\ par parell \\ paradògic paradoxal \\ pareat apariat \\ pàrraf parágraf \\ permanèixer quedar-se, romandre \\ pertenèixer pertànyer \\ plaç termini \\ postrimeries acaballes, darreries \\ prevalèixer prevaler \\ promedi (o promig) mitjana $f$. \\ prompte (de) de sobte \\ quiebra fallida, crac
}

raís de (a) arran de, per motiu de

rasgo tret, detall

rato moment $m$., estona $f$.

real reial [de rei] // real [de realitat]

rebeldia rebel·lia

recaudar recaptar

recibir rebre

red xarxa

redondejar arredonir

reflejar (o reflexar) reflectir

remediar remeiar

repent (de) de sobte, de colp, tot d'una

retràs retard

retxassar rebutjar

rissa riure $m$., rialla $f$.

sacar traure

seqüestrar segrestar

ser que (a no) Ilevat que, tret que, a menys que

sério seriós

sério (en) de veres, de debò, seriosament

sospetxa sospita

supost suposat // supòsit

supost (per) per descomptat, evidentment, és clar, i tant! tamany grandària, dimensions, mida $f$.

tentació temptació

testic testimoni

títul títol

traïcionar trair

tregua treva

umbral llindar

valiós valuós

vanguàrdia avantguarda

vano (en) debades, en va, inútilment

varis (varios) alguns, diversos, diferents, uns quants

vasc basc 


\section{Expressions i frases fetes}

a bulto, a la buena de Dios a la babalà, a la bona de Déu

a carretadas, a patadas a carretades, a palades, a balquena

a chorro, en abundancia a doll, en abundància

a ciegas, a tientas, a pies juntillas a ulls clucs, a les palpentes

a ciencia cierta amb certesa, de ciència certa

a decir verdad amb franquesa, francament

a diestro y siniestro a tort $\mathrm{i}$ a dret

a escape, a toda prisa a corre-cuita, a correcorrents, de pressa

a escondidas d'amagat

a grandes rasgos a grans trets, amb poques paraules

a la vez alhora, a la vegada

a las mil maravillas, a pedir de boca a cor què vols, cor què desitges; a meravella; d'allò més bé

a lo mejor tal volta, potser; si molt convé; segons com; qui sap si

a mediados de a mitjan

a medida que a mesura que, tal com

a no ser que Ilevat que, fora que, si no és que, tret que

a oscuras a les fosques

a raíz de arran de

a rastras a rossegons, arrossegant

a regañadientes, de mala gana a contracor, de mala gana

a su vez al seu torn

acerca de sobre, pel que fa a, quant a

al fin y al cabo al cap i a la fi, fet $i$ fet, al capdavall al menos almenys, si més no

al pelo com I'anell al dit, a tomb

al por mayor a I'engròs

al por menor, a granel al detall, a la menuda al oído a cau d'orella

apenas a penes

como mínimo, por lo menos com a mínim, pel cap baix

con creces de sobra, amb escreix

con sinceridad amb sinceritat, sincerament, de cor cuanto antes mejor com més aviat millor

dado que atès que, posat que, a condició que, si, posat cas que

de antemano per endavant de arriba abajo, de pies a cabeza de cap a peus, de dalt a baix

de balde de franc, gratuïtament, gratis

de bote en bote de gom a gom

de buena gana de bon cor, de tot cor, de bona gana de cabo a cabo, de cabo a rabo de cap a cap, de cap a peus

de firme de valent, de ferm

de golpe, de pronto de colp, de colp i volta, de sobte de hinojos de genolls

de hito en hito de fit a fit

de nuevo de nou

de par en par de bat a bat

de paso de passada

de pe a pa, al dedillo amb detall, punt per punt,

de cap a peus, fil per randa

de puntillas de puntetes

de rebote, de rechazo de rebot, de retop

de reojo de reüll, de cua d'ull

de repente, de sopetón de sobte, tot d'una

de soslayo de biaix, de gairell // de reüll, de cua d'ull

de veras, de verdad, en serio de veres, de debò de vez en cuando de tant en tant

debido a per causa de, per raó de, gràcies a, per culpa de

dejarse de cuentos deixar-se de romanços desde luego evidentment, sens dubte, certament, i tant!

en ayunas en dejú

en balde debades, inútilment, en va

en cantidad suficiente a bastament, prou

en cuanto a pel que fa a, quant a

en el acto, enseguida que tot seguit, a l'acte, de seguida

en seguida de seguida, tot seguit

en todo caso, si acaso si més no, en tot cas,

potser, si de cas

en vez de, en lugar de en compte de, en comptes

de, en Iloc de

hoy por hoy ara per ara, ara com ara

más bien més aviat, més aïna

más o menos si fa no fa, més o menys

ni mucho menos ni de bon tros, ni de molt

ni siquiera ni tan sois 
por adelantado per endavant, a la bestreta [pagar] por añadidura a més a més, d'afegitó

por la tremenda a la valenta, passe el que passe

por lo menos si més no, almenys

por lo pronto de moment, d'entrada, ara com

ara, de primer

sano y salvo sa i estalvi si procede si escau, si és procedent siempre y cuando sempre que

sin embargo amb tot, no obstant això, això no obstant, tanmateix

Perujo, Joan M. (2002): Gripau, Alacant, Universitat d'Alacant 


\section{Annex vI: Ús de l'apòstrof i el guionet}

\section{Ús de l'apòstrof}

L'apòstrof és un signe gràfic (') que indica que s'ha produït l'elisió d'una vocal en alguns contextos fònics. En català, l'apòstrof s'utilitza exclusivament per indicar l'elisió de la vocal en l'article, en la preposició de i en els pronoms febles en els contextos que s'indiquen en el quadre següent:

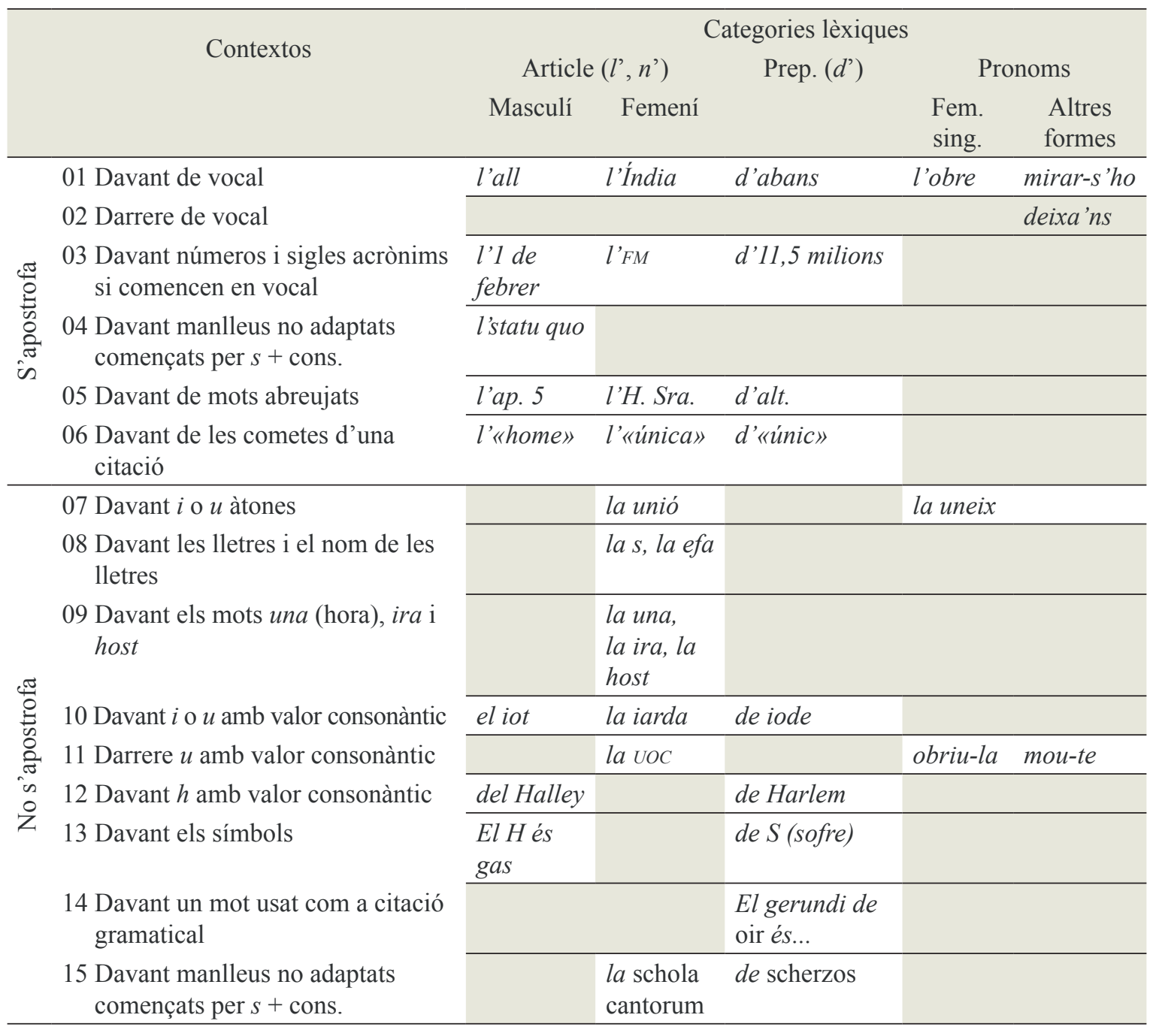




\section{Normes d'ús del guionet}

\begin{tabular}{|c|c|c|}
\hline \multirow{2}{*}{ S'escriuen amb guionet } & \multicolumn{2}{|c|}{ S'escriuen sense guionet } \\
\hline & S'escriuen junts & S'escriuen separats \\
\hline $\begin{array}{l}\text { 1. Els mots derivats amb el prefix no- si el segon } \\
\text { element és un substantiu: no-agressió. }\end{array}$ & $\begin{array}{l}\text { 1. Els derivats de qualsevol } \\
\text { prefix (excepte no-): sots- } \\
\text { director. } \\
\text { 2. Els derivats de sintagmes } \\
\text { o de paraules compostes: } \\
\text { xiuxiuejar. }\end{array}$ & $\begin{array}{l}\text { 1. Derivats amb el } \\
\text { prefix no- si el } \\
\text { segon element és } \\
\text { un adjectiu: no } \\
\text { agressiu. }\end{array}$ \\
\hline $\begin{array}{l}\text { 2. Els mots compostos si } \\
\text { · el primer element porta accent gràfic: pèl- } \\
\text { curt; } \\
\text { · el segon element comença per } r, \text { s o } x \text { : busca- } \\
\text { raons, penya-segat; } \\
\text { ·és un numeral: vint-i-tres, quaranta-vuit; } \\
\text { · hi figura un punt cardinal: sud-africà; } \\
\text { · són manlleus no adaptats: ex-libris, agnus- } \\
\text { dei; } \\
\text { - es tracta d'expressions singulars: despús- } \\
\text { anit; } \\
\text { · es poden produir problemes de lectura: ocell- } \\
\text { lira, } \\
\text { · són expressions repetitives o expressives: } \\
\text { xino-xano, flist-flast, poti-poti, corre-cuita... }\end{array}$ & $\begin{array}{l}\text { 3. Els compostos cultes amb } \\
\text { la forma prefixada acabada } \\
\text { en -o: fisicoquímic, } \\
\text { audiovisual. } \\
\text { 4. Els compostos que no es } \\
\text { troben afectats per les } \\
\text { situacions especificades } \\
\text { en la primera columna: } \\
\text { capicua, terrabastall... } \\
\text { 5. Els compostos que són } \\
\text { manlleus adaptats: exvot. }\end{array}$ & $\begin{array}{l}\text { 2. Els sintagmes } \\
\text { lexicalitzats que } \\
\text { són compostos } \\
\text { sinàptics o col- } \\
\text { locacions: guàr- } \\
\text { dia civil, eixida } \\
\text { d'emergència, } \\
\text { decret llei... }\end{array}$ \\
\hline $\begin{array}{l}\text { 3. Les formes plenes dels pronoms febles darrere } \\
\text { del verb: anem-nos-en }\end{array}$ & $\begin{array}{l}\text { 6. Les formes elidides i } \\
\text { les formes reduïdes dels } \\
\text { pronoms febles (davant o } \\
\text { darrere del verb): l'estima, } \\
\text { porta'ls. }\end{array}$ & $\begin{array}{l}\text { 3. Les formes } \\
\text { reforçades dels } \\
\text { pronoms febles } \\
\text { (davant del verb): } \\
\text { no ens escolta. }\end{array}$ \\
\hline
\end{tabular}




\section{Annex VII: L'accent diacrític}

\begin{tabular}{|c|c|c|c|c|c|}
\hline \multicolumn{3}{|c|}{ Mots amb accent diacrític } & \multicolumn{3}{|c|}{ Mots sense accent diacrític } \\
\hline Mot & Informació gram. & Significat o sentit & Mot & Informació gram. & Significat o sentit \\
\hline$b e ́$ & $\begin{array}{l}\text { m., adv., conj. o } \\
\text { interj. }\end{array}$ & $\begin{array}{l}\text { 'el que és bo o } \\
\text { beneficia' }\end{array}$ & $b e$ & $\begin{array}{l}\mathrm{m} . \\
\mathrm{f} .\end{array}$ & $\begin{array}{l}\text { 'anyell' } \\
\text { 'nom de la lletra } b \text { ' }\end{array}$ \\
\hline déu & $\mathrm{m}$. & 'ésser sobrehumà' & deu & $\begin{array}{l}\text { f. } \\
\text { num. } \\
\text { verbs dar o deure }\end{array}$ & 'font' \\
\hline $\begin{array}{l}\text { dóna } \\
\text { dónes }\end{array}$ & $\begin{array}{l}\text { formes del verb } \\
\text { donar }\end{array}$ & & $\begin{array}{l}\text { dona } \\
\text { dones }\end{array}$ & f. & 'persona femenina' \\
\hline és & $\begin{array}{l}\text { formes del verb ser } \\
\text { o ésser }\end{array}$ & & es & $\begin{array}{l}\text { pronom feble } \\
\text { art. salat masc. } \\
\text { fem. pl. de } \boldsymbol{e}\end{array}$ & $\begin{array}{l}\text { 'persona femenina' } \\
\text { es castell } \\
\text { 'nom de la lletra } \boldsymbol{e} \text { ' }\end{array}$ \\
\hline féu & $\begin{array}{l}\text { forma de passat } \\
\text { del verb fer }\end{array}$ & & feu & $\begin{array}{l}\text { m. } \\
\text { pr. d'ind., subj. i imp. } \\
\text { del verb } f e r\end{array}$ & 'domini' \\
\hline fóra & $\begin{array}{l}\text { forma del verb } \\
\text { ser o ésser }\end{array}$ & & fora & adv. & \\
\hline $\begin{array}{l}\text { mà } \\
(p l . \\
\text { mans })\end{array}$ & f. & $\begin{array}{l}\text { 'part terminal del } \\
\text { braç' }\end{array}$ & $m a$ & possessiu $\mathrm{f}$. & \\
\hline més & adv. & & mes & $\begin{array}{l}\text { m. } \\
\text { conj. } \\
\text { pos. fem. pl. } \\
\text { part de metre }\end{array}$ & $\begin{array}{l}\text { 'part de l'any' } \\
\text { 'però' }\end{array}$ \\
\hline mòlt & part. de moldre & & molt & quantitatiu & \\
\hline $\begin{array}{l}\text { món } \\
\text { (mons) }\end{array}$ & $\mathrm{m}$. & $\begin{array}{l}\text { 'conjunt de totes les } \\
\text { coses creades' }\end{array}$ & mon & possessiu m. & \\
\hline $\begin{array}{l}\text { nét } \\
\text { néta }\end{array}$ & $\begin{array}{l}\mathrm{m} . \\
\mathrm{f} .\end{array}$ & $\begin{array}{l}\text { 'fill d'un fill o d'una } \\
\text { filla' }\end{array}$ & $\begin{array}{l}\text { net } \\
\text { neta }\end{array}$ & $\begin{array}{l}\text { adj. m. } \\
\text { adj. f. }\end{array}$ & $\begin{array}{l}\text { 'impol·lut' } \\
\text { 'impol·luta' }\end{array}$ \\
\hline ós & $\mathrm{m}$. & 'mamífer carnívor' & os & $\begin{array}{l}\text { m. } \\
\text { f. }(\text { pl. de } o)\end{array}$ & $\begin{array}{l}\text { 'peça de l'esquelet' } \\
\text { 'nom de la lletra } o \text { ' }\end{array}$ \\
\hline pèl & $\mathrm{m}$. & $\begin{array}{l}\text { 'filament de matèria } \\
\text { còrnia' }\end{array}$ & pel & $\begin{array}{l}\text { contracció de } \\
\text { peri el }\end{array}$ & \\
\hline$q u e ̀$ & $\begin{array}{l}\text { pronom relatiu } \\
\text { o interrogatiu }\end{array}$ & & que & $\begin{array}{l}\text { pronom relatiu } \\
\text { adv. o conj. }\end{array}$ & \\
\hline sé & forma del verb saber & & se & pron. feble & \\
\hline$s i$ & $\begin{array}{l}\text { adv o m. (a partir de } \\
\text { l'adverbi) }\end{array}$ & & si & $\begin{array}{l}\text { m. } \\
\text { pron. conj. }\end{array}$ & 'nota mus.' o 'interior' \\
\hline sóc & forma del verb ser & & $\operatorname{soc}$ & $\mathrm{m}$ & ‘esclop’ o ‘soca’ \\
\hline sòl & $\mathrm{m}$. & $\begin{array}{l}\text { 'terreny, esp. la super- } \\
\text { fície }\end{array}$ & sol & $\begin{array}{l}\text { m. } \\
\text { adj. m. } \\
\text { verb soler }\end{array}$ & $\begin{array}{l}\text { 'astre', 'nota musical' o } \\
\text { 'sistema col·loïdal' } \\
\text { 'solitari' }\end{array}$ \\
\hline són & $\begin{array}{l}\text { forma del verb } \\
\text { ser o ésser }\end{array}$ & & son & $\begin{array}{l}\mathrm{m} . \\
\text { possessiu }\end{array}$ & 'ganes de dormir' \\
\hline té & $\begin{array}{l}\text { forma del verb } \\
\text { tenir }\end{array}$ & & te & $\begin{array}{l}\text { m. } \\
\text { f. } \\
\text { pronom feble }\end{array}$ & $\begin{array}{l}\text { 'planta' } \\
\text { 'nom de la lletra }\end{array}$ \\
\hline $\begin{array}{l}\text { ús }(p l . \\
\text { usos })\end{array}$ & $\mathrm{m}$. & 'acció de fer servir' & us & $\begin{array}{l}\text { pronom feble } \\
\text { f. (pl. de } u)\end{array}$ & 'nom de la lletra $u$ ' \\
\hline $\begin{array}{l}\text { vénen, } \\
\text { véns }\end{array}$ & $\begin{array}{l}\text { formes del verb } \\
\text { venir }\end{array}$ & & $\begin{array}{l}\text { venen, } \\
\text { vens }\end{array}$ & $\begin{array}{l}\text { formes del verb } \\
\text { vendre }\end{array}$ & \\
\hline vés & $\begin{array}{l}\text { forma del verb } \\
\text { anar }\end{array}$ & & ves & $\begin{array}{l}\text { m. } \\
\text { f. }(\mathrm{pl} . \text { de } v) \\
\text { forma del verb } \\
\text { veure }\end{array}$ & $\begin{array}{l}\text { 'tros de tela forta' } \\
\text { 'nom de la lletra } v \text { ' }\end{array}$ \\
\hline vós & pronom fort & & vos & pronom feble & \\
\hline
\end{tabular}




\section{Annex VIII: La conjugació verbal}

Model I

\begin{tabular}{|l|l|}
\hline INFINITIU & cantar \\
\hline GERUNDI & cantant \\
\hline PARTICIPI & sing. cantat, cantada; pl. cantats, cantades \\
\hline INDICATIU & $\begin{array}{l}\text { present: } 1 \text { canto/cante, cant, canti; } 2 \text { cantes; } 3 \text { canta; } 4 \text { cantem/cantam; } 5 \text { canteu/cantau; } 6 \text { canten } \\
\text { imperfet: } 1 \text { cantava, } 2 \text { cantaves, } 3 \text { cantava, } 4 \text { cantàvem, } 5 \text { cantàveu, } 6 \text { cantaven } \\
\text { perfet: } 1 \text { cantí, } 2 \text { cantares, } 3 \text { cantà, } 4 \text { cantàrem, } 5 \text { cantàreu, } 6 \text { cantaren } \\
\text { futur: } 1 \text { cantaré, } 2 \text { cantaràs, } 3 \text { cantarà, } 4 \text { cantarem, } 5 \text { cantareu, } 6 \text { cantaran } \\
\text { condicional: } 1 \text { cantaria, } 2 \text { cantaries, } 3 \text { cantaria, } 4 \text { cantaríem, } 5 \text { cantaríeu, } 6 \text { cantarien }\end{array}$ \\
\hline SUBJUNTIU & $\begin{array}{l}\text { present: } 1 \text { canti/cante; } 2 \text { cantis/cantes; } 3 \text { canti/cante; } 4 \text { cantem; } 5 \text { canteu; } 6 \text { cantin/canten } \\
\text { imperfet: } 1 \text { cantés/cantara, cantàs; } 2 \text { cantessis/cantesses, cantares, cantassis; } 3 \text { cantés/cantara, cantàs; } \\
4 \text { cantéssim/cantéssem, cantàrem, cantàssim; } 5 \text { cantéssiu/cantésseu, cantàreu, cantàssiu; } 6 \text { cantessin/ } \\
\text { cantessen, cantaren, cantassin }\end{array}$ \\
\hline IMPERATIU & 2 canta; 3 canti/cante; 4 cantem; 5 canteu/cantau; 6 cantin/canten \\
\hline
\end{tabular}

Model II

\begin{tabular}{l|l}
\hline INFINITIU & perdre \\
\hline GERUNDI & perdent \\
\hline PARTICIPI & sing. perdut, perduda; pl. perduts, perdudes \\
\hline INDICATIU & $\begin{array}{l}\text { present: } 1 \text { perdo/perd, perdi; } 2 \text { perds; } 3 \text { perd; } 4 \text { perdem; } 5 \text { perdeu; } 6 \text { perden } \\
\text { imperfet: } 1 \text { perdia, } 2 \text { perdies, } 3 \text { perdia, } 4 \text { perdíem, } 5 \text { perdíeu, } 6 \text { perdien } \\
\text { perfet: } 1 \text { perdí, } 2 \text { perderes, } 3 \text { perdé, } 4 \text { perdérem, } 5 \text { perdéreu, } 6 \text { perderen } \\
\text { futur: } 1 \text { perdré, } 2 \text { perdràs, } 3 \text { perdrà, } 4 \text { perdrem, } 5 \text { perdreu, } 6 \text { perdran } \\
\text { condicional: } 1 \text { perdria, } 2 \text { perdries, } 3 \text { perdria, } 4 \text { perdríem, } 5 \text { perdríeu, } 6 \text { perdrien }\end{array}$ \\
\hline SUBJUNTIU & $\begin{array}{l}\text { present: } 1 \text { perdi/perda; } 2 \text { perdis/perdes; } 3 \text { perdi/perda; } 4 \text { perdem; } 5 \text { perdeu; } 6 \text { perdin/perden } \\
\text { imperfet: } 1 \text { perdés/perdera; } 2 \text { perdessis/perdesses, perderes; } 3 \text { perdés/perdera; } 4 \text { perdéssim/perdés- } \\
\text { sem, perdérem; } 5 \text { perdéssiu/perdésseu, perdéreu; } 6 \text { perdessin/perdessen, perderen }\end{array}$ \\
\hline IMPERATIU & 2 perd; 3 perdi/perda; 4 perdem; 5 perdeu; 6 perdin/perden \\
\hline
\end{tabular}

Model III

\begin{tabular}{l|l}
\hline INFINITIU & témer \\
\hline GERUNDI & tement \\
\hline PARTICIPI & sing. temut, temuda; pl. temuts, temudes \\
\hline INDICATIU & $\begin{array}{l}\text { present: } 1 \text { temo/tem, temi; } 2 \text { tems; } 3 \text { tem; } 4 \text { temem; } 5 \text { temeu; } 6 \text { temen } \\
\text { imperfet: } 1 \text { temia, } 2 \text { temies, } 3 \text { temia, } 4 \text { temíem, } 5 \text { temíeu, } 6 \text { temien } \\
\text { perfet: } 1 \text { temí, } 2 \text { temeres, } 3 \text { temé, } 4 \text { temérem, } 5 \text { teméreu, } 6 \text { temeren } \\
\text { futur: } 1 \text { temeré, } 2 \text { temeràs, } 3 \text { temerà, } 4 \text { temerem, } 5 \text { temereu, } 6 \text { temeran } \\
\text { condicional: } 1 \text { temeria, } 2 \text { temeries, } 3 \text { temeria, } 4 \text { temeríem, } 5 \text { temeríeu, } 6 \text { temerien }\end{array}$ \\
\hline SUBJUNTIU & $\begin{array}{l}\text { present: } 1 \text { temi/tema; } 2 \text { temis/temes; } 3 \text { temi/tema; } 4 \text { temem; } 5 \text { temeu; } 6 \text { temin/temen } \\
\text { imperfet: } 1 \text { temés/temera; } 2 \text { temessis/temesses, temeres; } 3 \text { temés/temera; } 4 \text { teméssim/teméssem, te- } \\
\text { mérem; } 5 \text { teméssiu/temésseu, teméreu; } 6 \text { temessin/temessen, temeren }\end{array}$ \\
\hline IMPERATIU & \begin{tabular}{l}
2 tem; 3 temi/tema; 4 temem; 5 temeu; 6 temin/temen \\
\hline
\end{tabular}
\end{tabular}


Model IV

\begin{tabular}{l|l|}
\hline INFINITIU & patir \\
\hline GERUNDI & patint \\
\hline PARTICIPI & sing. patit, patida; pl. patits, patides \\
\hline INDICATIU & $\begin{array}{l}\text { present: } 1 \text { pateixo/patixo, patisc, patesc, pateixi; } 2 \text { pateixes/patixes; } 3 \text { pateix/patix; } 4 \text { patim; } 5 \text { patiu; } \\
6 \text { pateixen/patixen } \\
\text { imperfet: } 1 \text { patia, } 2 \text { paties, } 3 \text { patia, } 4 \text { patíem, } 5 \text { patíeu, } 6 \text { patien } \\
\text { perfet: } 1 \text { patí, } 2 \text { patires, } 3 \text { patí, } 4 \text { patírem, } 5 \text { patíreu, } 6 \text { patiren } \\
\text { futur: } 1 \text { patiré, } 2 \text { patiràs, } 3 \text { patirà, } 4 \text { patirem, } 5 \text { patireu, } 6 \text { patiran } \\
\text { condicional: } 1 \text { patiria, } 2 \text { patiries, } 3 \text { patiria, } 4 \text { patiríem, } 5 \text { patiríeu, } 6 \text { patirien }\end{array}$ \\
\hline SUBJUNTIU & $\begin{array}{l}\text { present: } 1 \text { pateixi/patisca, patesqui; } 2 \text { pateixis/patisques, patesquis; } 3 \text { pateixi/patisca, patesqui; } 4 \text { pa- } \\
\text { tim/patiguem; } 5 \text { patiu/patigueu; } 6 \text { pateixin/patisquen, patesquin } \\
\text { imperfet: } 1 \text { patís/patira; } 2 \text { patissis/patisses, patires; } 3 \text { patís, patira; } 4 \text { patíssim/patíssem, patírem; } \\
\text { 5 patíssiu/patísseu, patíreu; } 6 \text { patissin/patissen, patiren }\end{array}$ \\
\hline IMPERATIU & $\begin{array}{l}\text { 2 pateix/patix; } 3 \text { pateixi/patisca, patesqui; } 4 \text { patim/patiguem; } 5 \text { patiu; } 6 \text { pateixin/patisquen, patesquen, } \\
\text { patesquin }\end{array}$ \\
\hline
\end{tabular}

Model V

\begin{tabular}{l|l|}
\hline INFINITIU & trair \\
\hline GERUNDI & traint \\
\hline PARTICIPI & sing. traït, traïda; pl. traïts, traïdes \\
\hline INDICATIU & $\begin{array}{l}\text { present: } 1 \text { traeixo/traïxo, traïsc, traesc, traeixi; } 2 \text { traeixes/traïxes; } 3 \text { traeix/traïx; } 4 \text { traïm, } 5 \text { traïu; } \\
6 \text { traeixen/traïxen } \\
\text { imperfet: } 1 \text { traïa, } 2 \text { traïes, } 3 \text { traïa, } 4 \text { traíem, } 5 \text { traíeu, } 6 \text { traïen } \\
\text { perfet: } 1 \text { traí, } 2 \text { traïres, } 3 \text { traí, } 4 \text { traírem, } 5 \text { traíreu, } 6 \text { traïren } \\
\text { futur: } 1 \text { trairé, } 2 \text { trairàs, } 3 \text { trairà, } 4 \text { trairem, } 5 \text { traireu, } 6 \text { trairan } \\
\text { condicional: } 1 \text { trairia, } 2 \text { trairies, } 3 \text { trairia, } 4 \text { trairíem, } 5 \text { trairíeu, } 6 \text { trairien }\end{array}$ \\
\hline SUBJUNTIU & $\begin{array}{l}\text { present: } 1 \text { traeixi/traïsca, traesqui; } 2 \text { traeixis/traïsques, traesquis; } 3 \text { traeixi/traïsca, traesqui; } 4 \text { traïm/ } \\
\text { traïguem; } 5 \text { traïu/traïgueu; } 6 \text { traeixin/traïsquen, traesquin } \\
\text { imperfet: } 1 \text { traís/traïra; } 2 \text { traïssis/traïsses, traïres; } 3 \text { traís/traïra; } 4 \text { traíssim/traíssem, traírem; } 5 \text { traíssiu/ } \\
\text { traísseu, traíreu; } 6 \text { traïssin/traïssen, traïren }\end{array}$ \\
\hline IMPERATIU & \begin{tabular}{l}
2 traeix/traïx; 3 traeixi/traïsca, traesqui; 4 traïm/traïguem; 5 traïu; 6 traeixin/traïsquen, traesquin \\
\hline
\end{tabular}
\end{tabular}

Model VI

\begin{tabular}{l|l|}
\hline INFINITIU & dormir \\
\hline GERUNDI & dormint \\
\hline PARTICIPI & sing. dormit, dormida; pl. dormits, dormides \\
\hline INDICATIU & $\begin{array}{l}\text { present: } 1 \text { dormo/dorm, dormi; } 2 \text { dorms; } 3 \text { dorm; } 4 \text { dormim; } 5 \text { dormiu; } 6 \text { dormen } \\
\text { imperfet: } 1 \text { dormia, } 2 \text { dormies, } 3 \text { dormia, } 4 \text { dormíem, } 5 \text { dormíeu, } 6 \text { dormien } \\
\text { perfet: } 1 \text { dormí, } 2 \text { dormires, } 3 \text { dormí, } 4 \text { dormírem, } 5 \text { dormíreu, } 6 \text { dormiren } \\
\text { futur: } 1 \text { dormiré, } 2 \text { dormiràs, } 3 \text { dormirà, } 4 \text { dormirem, } 5 \text { dormireu, } 6 \text { dormiran } \\
\text { condicional: } 1 \text { dormiria, } 2 \text { dormiries, } 3 \text { dormiria, } 4 \text { dormiríem, } 5 \text { dormiríeu, } 6 \text { dormirien }\end{array}$ \\
\hline SUBJUNTIU & $\begin{array}{l}\text { present: } 1 \text { dormi/dorma; } 2 \text { dormis/dormes; } 3 \text { dormi/dorma; } 4 \text { dormim/dormiguem; } 5 \text { dormiu/dormi- } \\
\text { gueu; } 6 \text { dormin/dormen } \\
\text { imperfet: } 1 \text { dormís/dormira; } 2 \text { dormissis/dormisses, dormires; } 3 \text { dormís/dormira; } 4 \text { dormíssim/dor- } \\
\text { míssem, dormírem; } 5 \text { dormíssiu/dormísseu, dormíreu; } 6 \text { dormissin/dormissen, dormiren }\end{array}$ \\
\hline IMPERATIU & \begin{tabular}{l} 
2 dorm; 3 dormi/dorma; 4 dormim/dormiguem; 5 dormiu; 6 dormin/dormen \\
\hline
\end{tabular} \\
\hline
\end{tabular}


A més de les formes exposades en els models anteriors, per a completar la conjugació cal tenir present que els temps compostos es construeixen amb les formes simples del verb auxiliar haver seguides del participi del verb que es conjuga. Així mateix, el pretèrit perfet perifràstic presenta, seguides de l'infinitiu del verb que es conjuga, les formes auxiliars següents:

INDICATIU 1 vaig, 2 vas o vares, 3 va, 4 vam o vàrem, 5 vau o vàreu, 6 van o varen

SUBJUNTIU 1 vagi, 2 vagis, 3 vagi, 4 vàgim, 5 vàgiu, 6 vagin

\section{Algunes observacions}

\section{Primera conjugació}

Els verbs acabats en -ar (com cantar) es conjuguen segons el Model I. Cal, però, tenir en compte que en els verbs que acaben en -gar, -car, -guar, -quar, -jar i -çar, la $g, c, g u, q u, j$ i ç d'aquestes terminacions es canvien respectivament en $g u, q u, g u ̈$, $q \ddot{u}, g$ i $c$ davant d'una desinència començada en $e$ o en $i$. Les desinències $-i$, -is $\mathrm{i}$-in s'escriuen $-\ddot{i}$, - $\ddot{i}$ i $-\ddot{i n}$, respectivament, en els verbs en els quals la darrera síllaba del radical és formada per una consonant seguida de $e, i, o$ o $u$, llevat dels verbs que acaben en -guar i -quar. Així, el present de subjuntiu d'evacuar és: evacuï, evacuïs, evacuï, evacuem, evacueu, evacuïn. Si davant les terminacions - $-i$, , $-\ddot{s}$, -ïn, hi ha una $i$ precedida de vocal, aquesta $i$ desapareix. Així, desmaiar fa desmaï, etc.

\section{Segona conjugació}

Els verbs acabats en -re (com perdre) es conjuguen segons el Model II; els acabats en -er feble (com témer), segons el Model III. La $i$ de les desinències -ia, -ies i -ien de l'imperfet d'indicatiu pren una dièresi quan la precedeix una vocal àtona. Així, l'imperfet de cloure és, amb el radical clo- del gerundi (cloent): cloïa, clö̈es, cloïa, cloíem, cloíeu, cloïen.

\section{Tercera conjugació}

Els verbs acabats en -ir (com patir o trair) es conjuguen d'acord amb els Models IV i V, respectivament, segons que la darrera lletra de llur radical siga una consonant (com en patir) o una vocal (com en trair).

Hi ha un petit nombre de verbs en -ir que no admeten l'increment -eix- (com dormir, que no fa *dormeixo, *dormeixes, etc., sinó dormo, dorms, etc.). Aquests verbs es conjuguen d'acord amb el Model VI. El fet que un verb en -ir no prenga l'increment -eix- és indicat, en el diccionari, posant entre claudàtors la forma 3 del seu present d'indicatiu. Així: «dormir [ind. pr. 3 dorm]». 
BIBLIOGRAFIA 
ABril, Joan (1997): Diccionari pràctic de qüestions gramaticals, Barcelona, Edicions 62.

AdAm, Jean-Michel i Marc Bonhomme (1997): L'argumentation publicitaire. Rhétorique de l'éloge et de la persuasion, París, Nathan.

- (ed.) (2000): Analyses du discours publicitaire, Tolosa, Eus.

Agulló, Maria Alba i Oriol CAmps (dir.) (2006): És a dir, Barcelona, Servei Lingüístic CCRTV Interactiva, <http://esadir.com/> [consulta: 20 de juliol de 2011].

— (2006): «Xifres i lletres» [en línia], en És a dir, Barcelona, Servei Lingüístic CCRTV Interactiva, <http://esadir.com/> [consulta: 20 de juliol de 2011].

Alcover, Antoni M. (2006): Dietari de l'excursió filològica 1906, Barcelona, Proa.

Alturo, Núria i altres (ed.) (2002): Variació dialectal i estandardització, Barcelona, PPU.

AMAdEO, Imma i Solé, Jordi (2009): Curs pràctic de redacció, Barcelona, Educaula.

Amossy, Ruth (2006): L'argumentation dans le discours, París, Armand Colin.

- i Anne Herschberg Pierrot (1997): Stéréotypes et clichés, París, Armand Colin.

Anscombre, Jean-Claude (1995): «De l'argumentation dans la langue à la théorie des topoï», en Anscombre, Jean-Claude (ed.): Théorie des topoï, París, Kimé, p. 11-47.

- i Oswald Ducrot (1983): L'argumentation dans la langue, Lieja, Mardaga [La argumentación en la lengua, Madrid, Gredos, 1994].

ArACIL, Lluís (1984): «L'ús del català estàndard: la qüestió dels dialectes», Com ensenyar català als adults, núm. 1 .

Artigas, Rosa i altres (2003): Tipotext. Una tipologia de textos de no-ficció, Vic, Eumo / Universitat de Vic.

Avl (2006): Gramàtica normativa valenciana, València, Acadèmica Valenciana de la Llengua [disponible també en línia, <www.avl.gva.es $>$ [consulta: 21 de juliol de 2011]].

AVUI (1997): Llibre d'estil del diari Avui, Barcelona, Empúries.

Badia i Margarit, Antoni (1994): Gramàtica de la llengua catalana, Barcelona, Enciclopèdia Catalana.

BADIA, Jordi i altres (1997): El llibre de la llengua catalana, Barcelona, Castellnou.

- (1997a): «Els signes de puntuació», en Llibre de la llengua catalana, Barcelona, Castellnou, p. 557-592.

BAKHTIN, Mikhail (1982): «El problema de los géneros discursivos», Estética de la creación verbal, Mèxic, Siglo xxi, p. 248-293.

BAssols, Margarida (2010): «La construcció de la identitat transnacional a través del discurs polític: la globalització», en Marín, Maria Josep I ALtres (ed.) (2010: 19-58).

— i altres (ed.) (1997): La llengua de tv3, Barcelona, Empúries.

- i Anna M. Torrent (1996): Models textuals, Vic, Eumo.

— i Mila Segarra (ed.) (2009): El col-loquial dels mitjans de comunicació, Vic, Eumo.

Bauman, Zygmunt (2005): Liquid Life, Cambridge, Polity Press [Vida líquida, Barcelona, Paidós, 2006].

BERnÁRDEZ, Enrique (1982): Introducción a la lingüistica del texto, Madrid, Espasa-Calpe. 
- (1987): Lingüística del texto, Madrid, Arco Libros.

BiBILONI, Gabriel (1997): Llengua estàndard i variació lingüistica, València, Eliseu Climent.

Bonet, Sebastià (2002): «Les subordinades substantives», en SolÀ, Joan (dir.) (2002: 2321-2387).

BroncKart, Jean-Paul (1977): Théories du langage. Une introduction critique, Brusel-les, Dessart-Mardaga [Teorías del lenguaje: introducción crítica, Barcelona, Herder, 1985].

- (1985): Le fonctionement des discours, París-Lausanne, Delachaux et Niestlé.

- (1996): Activité langagière, textes et discours. Pour un interactionisme socio-discursif, París-Lausanne, Delachaux et Niestlé [Actividad verbal, textos y discursos: por un interacionismo socio-discursivo, San Sebastián de los Reyes, Fundación Infancia y Aprendizaje, 2004].

Brown, Gillian i George Yule (1983): Discourse Analysis, Cambridge, Cambridge University Press [Análisis del discurso, Madrid, Visor, 1993, p. 95-233 i 275-332].

Bruguera, Jordi (2000): Diccionari de dubtes i dificultats del català, Barcelona, Enciclopèdia Catalana.

CABré, Maria Teresa (2004): «Introducció: la importància de la neologia per al desenvolupament sostenible de la llengua catalana», en FreIXA-Solé (coord.) (2004: 17-45).

— i altres (2001): «Anàlisi contrastiva de la innovació lèxica en català i en caste1là», Caplletra, 30, p. 192-212.

Calaforra, Guillem (2001): «Secessionistes i unionistes», en Vallverdú, Josep (dir.) (2001: 181).

Carbonell, Jordi (1979): «Elements d'història social i política de la llengua catalana», Treballs de sociolingüística catalana, 2, p. 87-102.

CAREL, Marion i Oswald Ducrot (2005): La semántica argumentativa: una introducción a la teoría de los bloques semánticos, Buenos Aires, Colihue Universidad.

- (2008): «Descrição argumentativa e descrição polifônica: o caso da negação», Letras de Hoje, vol. 43, núm. 1 (gener-març de 2008), p. 7-18 [en línia, <http://revista seletronicas.pucrs.br/ojs/index.php/fale/article/viewFile/2865/2804> [consulta: 10 de març de 2011]].

CASALS, Daniel (2003): El català en antena, Benicarló, Onada.

CASSANY, Daniel (1993): La cuina de l'escriptura, Barcelona, Empúries.

- (2007): Esmolar l'eina, Barcelona, Empúries.

- i CARMEn López (2006): Centre de redacció [en línia], Barcelona, Universitat Pompeu Fabra, <http://mutis2.upf.es/cr/> [consulta: 5 de juliol de 2011].

- (2007): «Connectors», en Centre de redacció [en línia], Barcelona, Universitat Pompeu Fabra, <http://mutis2.upf.es/cr/catacd/visorcct.htm> [consulta: 11 de juliol de 2011].

Castellà, Josep M. (1992): De la frase al text. Teories de l'ús lingüístic, Barcelona, Empúries, p. 77-91 i 139-184.

— i altres (2007): Entendre('s) a classe: les estratègies comunicatives dels docents ben valorats, Barcelona, Graó.

- i Montserrat VILÀ (2002a): «La llengua oral formal: una fesomia gramatical pròpia», en VILÀ, Montserrat (coord.) (2002: 95-109). 
— (2002b): «La llengua oral formal: un espai intermedi entre oralitat i escriptura», dins VILÀ, Montserrat (coord.) (2002: 19-30).

Castellanos, Josep-Anton (2004): Manual de pronunciació. Criteris i exercicis d'elocució, Vic, Eumo.

Charaudeau, Patrick i Dominique Maingueneau (2002): Dictionnaire d'analyse du discours, París, Seuil.

Charolles, Michel (1978): «Introduction aux problèmes de la cohérence des textes», dins Langue française, 38, p. 7-42.

Colom, Ramon (dir.) (2001): «300 anys sense imposicions?» [vídeo], Millennium, Canal 33, Televisió de Catalunya.

Combettes, Bernard (1983): Pour une grammaire textuelle. La progression thématique, Brussel.les-París, De Boeck / Duculot, 1988 (2a ed.).

Comissió de Normalització Lingǘstica de TVC (1995): El català a TV3: llibre d'estil, Barcelona, Edicions 62 / Televisió de Catalunya.

ConcA, Maria i altres (1998): Text i gramàtica. Teoria i pràctica de la competència discursiva, Barcelona, Teide.

Coromina, Eusebi (1991): El 9 nou: manual de redacció i estil, Vic, Eumo.

Coromines, Joan (1971): Lleures i converses d'un filoleg, Barcelona, Club Editor.

Creus, Imma i altres (2000): Llengua i mitjans de comunicació, Lleida, Pagès Editors.

Cros, Ana i altres (2000): Llengua oral i llengua escrita a la televisió, Barcelona, Publicacions de l'Abadia de Montserrat.

CuencA, Maria Josep (1988): L'oració composta, València, Universitat de València. vol. 1.

- (1990a): «Els matisadors: connectors oracionals i textuals», Caplletra, 8, p. 149-167.

— (1990b): «Sobre el català als mitjans de comunicació de massa», en SALVAdOR, Vicent (coord.), Teletextos I, València, Universitat de València, p. 121-150.

- (1991a): L'oració composta, València, Universitat de València, vol. 2.

- (1991b): Les oracions adversatives, València, Universitat de València.

- (1999): «La connexió en la construcció discursiva», Articles de didàctica de la llengua i la literatura, 17, p. 77-89.

- (2000) «Estudi estilístic i contrastiu de l'arquitectura de l'oració. Estil segmentat vs. estil cohesionat», en Caplletra, 29, p. 105-120.

- (2002): «Els connectors textuals i les interjeccions», en SolÀ, JoAn (2002: 3173-3237).

- (2003): Sintaxi catalana, Barcelona, Editorial uoc.

- (2006): La connexió $i$ els connectors. Perspectiva oracional i textual, Vic, Eumo.

- (2007): La sintaxi, Barcelona, Editorial uoc.

- (2008): Gramàtica del text, Alzira, Bromera.

— i altres (2008): «La coherència textual», dins Pensar, ortanitzar, escriure, Barcelona, Editorial UOC.

— i FrancesCA Nicolau (2007): «Els signes de puntuació», en Tècniques de producció de textos especialtzats (3): puntuació $i$ aspectes formals, Barcelona, Editorial UOC [materials de l'assignatura Competència comunicativa per a professionals de les TIC]. 
- i Manel Pérez SAldanya (2002): Guia d'usos lingüistics. 1. Aspectes gramaticals, València [en línia], Institut Interuniversitari de Filologia Valenciana $<$ www.ua.es/institutos/inst.filovalen/Guiausos.pdf $>$

De Blas, Marta i Jordi Giner (2006): Fitxer lingüístic [en línia], Barcelona, Servei de Llengües i Terminologia / Universitat Politècnica de Catalunya, <http:// www2.upc.edu/slt/fl/> [consulta: 23 de maig de 2011].

Ducrot, Oswald (1972): Dire et ne pas dire, París, Hermann.

- (1984): Le dire et le dit, Paris, Minuit [El decir y lo dicho, Barcelona, Paidós, 1986].

— (1995): «Topoï et formes topiques», dins Anscombre, Jean-Claude (ed.), Théorie des topoï, París, Kimé, p. 11-47.

— i altres (1980): Les mots du discours, París, Minuit.

Eco, Umberto (1977): A theory of semiotics, Milà, Bompiani [Tratado de semiótica general, Barcelona, Lumen, 1977, p. 34-36 i 86-95].

EGGS, Ekkehard (1994): Grammaire du discours argumentatif, París, Kimé.

Enciclopèdia Catalana (1998): «Català», Enciclopèdia catalana bàsica interactiva [CD-ROM], Barcelona, Proa / El Periódico.

Espinal, Maria Teresa (1988): Significat i interpretació, Barcelona, Abadia de Montserrat.

Fabra, Pompeu (2002): Gramàtica catalana, Barcelona, Teide [1a edició, 1956].

FERrAndo, Antoni (ed.) (1990): La llengua als mitjans de comunicació, València, Institut Universitari de Filologia Valenciana / Universitat de València.

Ferré, Carme (2008): Barcelona TV. Llibre d'estil, Barcelona, Editorial uoc.

- i Anna Nogué (2010): Llibre d'estil. Agència Catalana de Notícies, Barcelona, Editorial UOC.

Ferrer, Montserrat (2004): Els pronoms febles, València, Tàndem.

ForCeVILle, Charles (1996): Pictorial Metaphor in Advertising, Londres, Routledge.

- (2008): «Metaphor in Pictures and Multimodal Representations», en RAYMOND W. GiBBS JR. (ed.), The Cambridge Handbook of Metaphor and Thought, p. 462-482.

- i Eduardo Urios-Aparici (2009): Multimodal Metaphor, Berlín / Nova York, Mouton de Gruyter.

FreIXA, Judit i E. SolÉ (ed.) (2004): Llengua catalana i neología, Barcelona, Meteora.

Fuster, Joan (1972): Babels i babilònies, en Obres completes, Barcelona, Edicions 62 , vol. 6 .

- (1990): «Per una cultura catalana majoritària», en FERrAndo, Antoni (ed.) (1990: 149-171).

Gabinet de Llengua Catalana (2000): Guia de comunicació eficaç [en línia], Bellaterra, Universitat Autònoma de Barcelona, $<$ http://antalya.uab.es/gab-llenguacatalana/www/cat/assessorament/guia/index.html $>$ [consulta: 23 de maig de 2011].

Gifreu, Josep (1987): «Cultura, comunicació i dependència», dins Segones reflexions critiques sobre la cultura catalana, Generalitat de Catalunya, p. 1-30 [reproduït en GifReu, Josep (2006)].

- (2003): «Els mitjans audiovisuals: laboratoris de la segona oralitat», en MARTíMestres (ed.) (2003: 137-147). 
- (2006): La pell de la diferència. Comunicació, llengua i cultura des de l'espai català, Barcelona, Pòrtic.

Gimeno, Montserrat (coord.) (1989): Mapes per a l'estudi de la llengua catalana, monogràfic de Com ensenyar català als adults, suplement núm. 6, Barcelona, Departament de Cultura de la Generalitat de Catalunya.

GineBRA, Jordi (2003): «Fraseologia, concurrències lèxiques i llengua estàndard», en Pradilla, Miquel Àngel (ed.) (2003): Identitat lingüística i estandardització, Valls, Cossetània-URV.

Gomis, Llorenç (1997): «Gèneres literaris i gèneres televisius», dins BuRdEUs, Maria Dolores i altres (eds.), La diversitat discursiva, Castelló de la Plana, Universitat Jaume I, p. 187-197.

- (1989): «Funció dels gèneres en el periodisme», dins Teoria dels gèneres periodistics, Barcelona, Generalitat de Catalunya, p. 78 i 98-111.

— (1989): «Gèneres literaris i gèneres periodístics», Periodística, 1, p. 129-141.

Grau, Maria (2002): «La modalització: adequació del text als paràmetres de la situació de comunicació», en VILÀ, Montserrat (coord.) (2002: 83-94).

Graves, G. i M. Short (1995): The Use and Abuse of the English Language, Nova York, Marlow \& Co.

Gregory, Michael i Suzanne CARroll (1978): Language and situation. Language Varieties and Their Social Contexts, Londres, Routledge / Kegan Paul.

Grunig, Blanche N. (1990): Les mots de la publicité : l'architecture du slogan, París, Presses du CNRS.

- (2000): «Slogan publicitaire et recherches cognitives», en AdAm-BonHomme (ed.) (2000: 75-93).

Grup Flaix (2009): Diccionari del català col·loquial, Barcelona, Enciclopèdia Catalana.

Halliday, M. A. K. i R. Hassan (1976): Cohesion in English, Londres, Longman. Hessel, Stéphane (2011): Indigneu-vos!, Barcelona, Columna Edicions / Destino. IEC (1995): Diccionari de la llengua catalana DIEC2, Barcelona, Institut d'Estudis Catalans [en línia], <http://dlc.iec.cat/>.

IeC Secció Filològica (1998): Aplicació al català dels principis de transcripció de l'Associació Fonètica Internacional, Barcelona, Institut d'Estudis Catalans.

- (1999a): Proposta per a un estàndard oral de la llengua catalana, I. Fonètica, Barcelona, Institut d'Estudis Catalans [en línia], <http://retoc.iula.upf.edu/ docs/ortol/Propostaestndard1.pdf $>$ [consulta: 27 de juliol de 2011].

- (1999b): Proposta per a un estàndard oral de la llengua catalana, II. Morfologia, Barcelona, Institut d'Estudis Catalans [en línia], <http://www.iecat.net/ institucio/seccions/Filologica/pdf/Proposta estndard 2.pdf $>$ [consulta: 27 de juliol de 2011].

- (2002): Gramàtica de la llengua catalana. Fonètica i fonologia. Les vocals, Barcelona, Institut d'Estudis Catalans <http://www.iecat.net/institucio/seccions/ Filologica/gramatica $>$ [consulta: 27 de juliol de 2011].

- (2006): «La dixi i les categories lèxiques i gramaticals», en Gramàtica de la llengua catalana [en línia], Barcelona, Institut d'Estudis Catalans $<$ http:// www2.iec.cat/institucio/seccions/Filologica/gramatica/default.asp $>$ [consulta: 27 de juliol de 2011]. 
- (2009): «Els tipus de lletra» [en línia], en Gramàtica de la llengua catalana, Barcelona, Institut d'Estudis Catalans, <http://www2.iec.cat/institucio/seccions/ Filologica/gramatica/default.asp > [consulta: 27 de juliol de 2011].

- (2009): «La grafia dels mots» [en línia], en Gramàtica de la llengua catalana, Barcelona, Institut d'Estudis Catalans, <http://www2.iec.cat/institucio/seccions/ Filologica/gramatica/default.asp > [consulta: 27 de juliol de 2011].

Julià-Muné, Joan (2004): El llenguatge de la ràdio i de la televisió, Alzira, Bromera.

- (2005): Fonètica aplicada catalana. Dels fonaments a les aplicacions de les ciències fonètiques, Barcelona, Ariel [inclou un CD].

— i altres (2004): El català nord-occidental. Descripció i orientacions ortoèpiques, Lleida, Pagès Editors.

LACReU, Josep (1990): Manual d'ús de l'estàndard oral, València, Universitat de València.

- (2001): Diccionari valencià de pronunciació, Alzira, Bromera.

LACroix, Michel (2001): Le culte à l'émotion, París, Flamarion [El culte a l'emoció, Barcelona, La Campana, 2005].

Lakoff, George (2004): Don't Think of an Elephant! Know Your Values and Frame the Debate, Cambridge, Polity Press [No pensis en un elefant! Llenguatge $i$ debat politic, Barcelona, Viena, 2008].

LEECH, Geoffrey N. (1983): Principles of Pragmatics, Londres, Longman [Principios de Pragmática, Logroño, Universidad de la Rioja, 1998].

Levinson, Stephen C. (1983): Pragmatics, Cambridge, Cambridge University Press [Pragmática, Barcelona, Teide, 1990].

LÓPeZ DEl CASTILlo, Lluís (2001): «La variació funcional», en VAlLVerdú, JoseP (dir.) (2001: 196-198).

LOUREDA, Óscar i Esperanza Acín (2010): Los estudios sobre marcadores del discurso en español, hoy, Madrid, Arco Libros.

LozAno, Jorge i altres (1989): Análisis del discurso: hacia una semiótica de la interacción textual, Madrid, Cátedra.

MaciÀ, Jaume (1992): Faci'ls fàcils, els pronoms febles, Barcelona, Teide [el mètode inclou un programa informàtic, en disquet].

Maingueneau, Dominique (1991): L'analyse du discours, París, Hachette, p. 207-250.

- (1998): Analyser les textes de communication, París, Dunod.

— i Vicent Salvador (1995): Elements de lingüistica per al discurs literari, València, Tàndem.

MARÍ, Isidor (1983): «Registres i varietats de la llengua», Com ensenyar català als adults, 3.

- i Daniel CASSANY (1990): Els perfils del català (varietats de la llengua catalana [vídeo], Barcelona, Generalitat de Catalunya. Departament d'Ensenyament.

Marín, Enric i Joan Manuel Tresserras (1994): Cultura de masses i postmodernitat, València, Tres i Quatre, p. 195-199.

MARín, Maria Josep i altres (ed.) (2010): Discurs politic i identitats (trans)nacionals, València, Universitat de València [Quaderns de filologia, annex 72].

MARINA, José Antonio (2007): Las arquitecturas del deseo, Barcelona, Anagrama.

MARTí, Joan (2003): «És espontània l'oralitat?», dins MArTí-Mestres (ed.) (2003: 197-211). 
Martí, Joan i Josep M. Mestres (ed.) (2002): Les llengües i les cultures en el procés de globalització de la societat de la informació, Barcelona, Institut d'Estudis Catalans.

— (ed.) (2003): L'oralitat als mitjans de comunicació, Barcelona, Institut d'Estudis Catalans.

- (ed.) (2004): Quin(s) model(s) de llengua escrita per als mitjans de comunicació?, Barcelona, Institut d'Estudis Catalans.

— i altres (ed.) (2003): La qualitat de la llengua oral en els mitjans de comunicació. II Seminari de Correcció de Textos, Barcelona, Institut d'Estudis Catalans.

Martínez, Quilo (1996): Aprenguem a llegir la publicitat, Vic, Eumo.

McCarthy, Michael (1991): Discourse Analysis for Language Teachers, Cambridge, Cambridge University Press.

Mestres, Josep M. (1995): Manual d'estil. La redacció i l'edició de textos, Vic, Eumo.

Micó, Josep Lluís (2006): Periodisme en xarxa: llenguatge nou d'un ofici vell, Vic, Eumo.

Mollà, Antoni (1990): La llengua dels mitjans de comunicació, Alzira, Bromera.

- (1990): «El model oral referencial: criteris d'elocució», en La llengua dels mitjans de comunicació, Alzira, Bromera, p. 83-101.

- (ed.) (1998): La política lingüistica a la societat de la informació, Alzira, Bromera.

- (ed.) (2001): Ideologia i conflicte lingüístic, Alzira, Bromera.

Nicolau, Francesca i Maria Josep Cuenca (2007): «Puntuació i aspectes formals» [material electrònic], en Tècniques de producció de textos especialitzats, III, Barcelona, Universitat Oberta de Catalunya.

NúÑez Ladevéze, Luis (1991): La construcción del texto, Madrid, Eudema.

ONG, Walter J. (1982): Orality and Literacy. The Technologizing of the Word, Londres, Methuen \& Co. [Oralidad y escritura. Tecnologías de la palabra, Mèxic, Fondo de Cultura Económica, 1987].

PAYrató, Lluís (2001): «La variació lingüística», en VALLVERdú, Josep (dir.) (2001: 170-171).

- (2003): Pragmàtica, discurs i llengua oral: introducció a l'anàlisi funcional de textos, Barcelona, Editorial uoc.

- (2003): «Factors de la variació funcional», en Pragmàtica, discurs i llengua oral, Barcelona, Editorial UOC, p. 185-186.

- (2003): «Variació funcional i llengua oral», en Pragmàtica, discurs i llengua oral, Barcelona, Editorial Uoc, p. 177-272.

- (ed.) (2004): Les fronteres del llenguatge, Barcelona, PPU.

Peraire, Joan (2005): «Unitats fraseològiques i ideologia en el discurs publicitari», Articles de didàctica de la llengua i la literatura, 36, p. 43-55.

— (2006): «Sintaxi i pragmàtica de l'eslògan», en Salvador-Climent (2006), p. 109-138.

- (2009): «Darwin i la teoria de l'evolució en la publicitat contemporània», Ribalta, 15, p. 139-155.

Perelman, C. i L. Olbrechts-Titeca (1994): Tratado de la argumentación: la nueva retórica, Madrid, Gredos.

PÉRez, Carles (pres.) (2005): «Homes i dones: Parlem idiomes diferents?» [ràdio], en La solució, Barcelona, Catalunya Ràdio, 4 d'octubre de 2005 [conversa amb Pere Font], <http://www.catradio.com/cr/solucio/> [consulta: 7 d'octubre de 2005]. 
PIgem, Jordi (2010): Qüestió de valors. Del consumisme a la sostenibilitat, València, Tres i Quatre.

PLA, Albert (2009): «El català col·loquial», Avui, 29 d'abril de 2009, p. 23, <http:// paper.avui.cat/article/dialeg/162422/catala/col\%C2\%B7loquial.html $>$ [consulta: 1 d'octubre de 2009].

- (2010): Això del català, Barcelona, Columna.

Plantin, Christian (1996): La argumentación, Barcelona, Ariel.

Polanco, Lluís B. (1990): «Reflexions sobre el model lingüístic dels mitjans de comunicació valencians», en FERRANDO, ANTONI (ed.) (1990: 25-50).

- (1990b): «Elements per a una proposta morfosintàctica», en FERRANDO, Antoni (ed.) (1990), p. 65-100.

Pons, Albert (2005): Activitats de llengua [en línia], Barcelona, Edu365.com (Activitats JClic) $<$ http://www.edu365.com/eso/muds/catala/index.htm $>$ [consulta: 10 d'octubre de 2010].

Pons, Lídia (2004): «Unitats comunicatives i llengua escrita en la publicitat», en Martí-Mestres (ed.) (2004: 85-100).

Portolés, José (2001): Marcadores del discurso, Barcelona, Ariel.

Puigdomènech, Laura i Marina Solís (2005): Proposta per a llibre d'estil per a Andorra televisió [en línia], <http://www4.uji.es/ al058181/Llibre_estil_ Andorra.pdf $>$ [consulta: 23 d'octubre de 2009].

Pujol, Josep M. i Joan Solà (1993): Tractat de puntuació, Barcelona, Columna.

- (2000): Ortotipografia. Manual de l'autor, l'autoeditor i el dissenyador gràfic, Barcelona, Columna.

REIG, Eugeni (2008): Les nostres paraules, València, Acadèmia Valenciana de la Llengua.

RibAs, Montserrat (2002): «De la explicación a la argumentación», Textos, 29, p. 11-20.

RuIz, Francesc (1996): Història social i política de la llengua catalana, València, Eliseu Climent.

— i Rosa SAnz (1990): Quaderns d'activitats 1, València, Tàndem.

SABATÉ, Joan (1999): La publicitat en català, Barcelona, Pòrtic.

SABATER, Ernest (1988): «Un model de llengua per als mitjans de comunicació», Escola catalana, 246, p. 23-24.

SÁEz, Ferran (2003): Comunicació i argumentació, Barcelona, Blanquerna.

- (2003): Què (ens) passa? Subjecte, identitat i cultura en l'era de la simulació, Barcelona, Proa.

- (2008): Mitjans de comunicació i valors, Barcelona, Fundació Lluís Carulla.

SALVAdOR, Vicent (1990): «Discurs televisiu i discurs periodístic», en Teletextos II, València, Universitat de València, p. 13-29.

- (1990a): «Els registres orals», en Ferrando, ANTONi (ed.), La llengua als mitjans de comunicació, València, Universitat de València / IFV, 205-222.

- (1990b): «Discurs televisiu i discurs periodístic», en SALVADOR, VicENT (coord.), Teletextos II, València, Universitat de València, p. 13-29.

- (1995): «De la fraseologia a la lingüística aplicada», Caplletra, 18, p. 11-30.

- (2000): «Idiomaticitat i discurs prefabricat», en SALVADOR-PiQuer (ed.) (2000: 19-31).

- (2002): «Les construccions condicionals i les concessives», en SoLÀ, Joan (dir.) (2002: 2977-3025). 
— i Adolf Piquer (ed.) (2000): El discurs prefabricat, 1. Estudis de fraseologia teòrica $i$ aplicada, Castelló de la Plana, Universitat Jaume I.

- i Laia Climent (ed.) (2006): El discurs prefabricat, 2. Fraseologia i comunicación social, Castelló de la Plana, Universitat Jaume I.

- (2010): «L'eufemisme, entre la retòrica i la política», en MARín, Maria Josep i altres (ed.) (2010: 133-159).

SAncho, Pelegrí (1999): Introducció a la fraseologia. Aplicació al valencià colloquial, Paiporta, Denes.

SARAGOSSÀ, Abelard (2002): «Les construccions comparatives i les oracions consecutives», dins SolÀ, Joan (2002: 3095-3171).

Schiffrin, Deborah (1987): Discourse markers, Cambridge, Cambridge University Press.

Secretaria de Política Lingüística (2005a): Web de la llengua catalana [en línia], Barcelona, Generalitat de Catalunya, <http://www6.gencat.net/llengcat/index. htm> [consulta: 27 de juliol de 2011].

Secretaria de Política Lingüística (2005b): El català a l'abast [en línia], Barcelona, Generalitat de Catalunya, <http://www6.gencat.net/llengcat/aprencat/ recursos.htm $>$ [consulta: 27 de juliol de 2011].

Secretariat de Promoció del Valencià (2011): Gripau, Alacant, Universitat d'Alacant, [en línia], <http://www.ua.es/spv/gripau.pdf $>$ [consulta: 27 de juliol de 2011].

Serafini, T. (1992): Come si scrive, Milà, Fabbri-Bompiani [Cómo se escribe, Barcelona, Paidós, 1994].

SERrA, Enric (2011): Aprendre llengües [en línia], Barcelona, Universitat Autònoma de Barcelona, <http://enricserrabloc.blogspot.com/2010/12/587-cortesialexpressio-oral-1.html $>$ [consulta: 25 de juliol de 2011].

Serra, Enric i Manuel Prunyonosa (2002): «La coordinació», en SolÀ, Joan (dir.) (2002: 2181-2245).

Serrano, Sebastià (1980): Signes, llengua, cultura, Barcelona, Edicions 62.

- (1999): Comprendre la comunicació, Barcelona, Proa.

- (2009): La festa dels sentits, Barcelona, Ara Llibres.

Servei de Llengües i Terminologia de la upC (1999): Guia lingüística pràctica. 1. Dubtes lingüistics més freqüents [en línia], Barcelona, Universitat Politècnica de Catalunya, <http://www.upc.edu/sft/gl/glp1.pdf $>$ [consulta: 8 de febrer de 2011].

- (2006): Els signes de puntuació [en línia], Barcelona, Universitat Politècnica de Catalunya / Universitat Autònoma de Barcelona, <http://www.upc.es/slt/ signes/> [consulta: 24 d'octubre de 2007].

- (2006): Traductors automàtics: traducció text [en línia], Barcelona, Universitat Politècnica de Catalunya, <http://www2.upc.edu/slt/serveis/traductor_automatic/ text.php> [consulta: 10 d'octubre de 2009].

Servei de Llengües Modernes (2009): Els numerals: xifres o lletres? [en línia], Girona, Universitat de Girona, <http://www3.udg.edu/sling/portal/criteris/xifres/xifres.htm> [consulta: 7 de desembre de 2009].

SolÀ, Joan (1994): Qüestions controvertides de sintaxi catalana, Barcelona, Edicions 62.

— (2002): «Les subordinades de relatiu», en SolÀ, Joan (dir.) (2002: 2455-2565). 
- (2009): Plantem cara, Barcelona, La Magrana / RBA.

- (dir.) (2002): Gramàtica del català contemporani, Barcelona, Empúries, 3 vols.

SolÉ, Eulàlia (2002): «Renecs a la televisió», Avui, 13 de juny de 2002.

Soler, Toni (2003): «La creació d'argot en televisió», en Martí-Mestres (ed.) (2003: 179-186).

Teruel, M. Elvira (1997): Retòrica, informació i metàfora. Anàlisi aplicada als mitjans de comunicació de massa, Castelló de la Plana, Universitat Jaume I.

Todolí, Júlia (1998): Els pronoms personals, València, Universitat de València.

Torrent, Anna M. (1999): El llenguatge de la publicitat, Barcelona, Publicacions de l'Abadia de Montserrat.

- (coord.) (2004): Els anuncis de la premsa, Vic, Eumo Editorial.

Torres, Marta (2001): «Els xats: entre l'oralitat i l'escriptura», Els Marges, 65 (desembre del 1999), p. 113-126.

Tubau, Ivan (1990a): Paraula viva contra llengua normativa, Barcelona, Laertes.

- 1990b: El català que ara es parla. Llengua i periodisme a la ràdio i la televisió, Barcelona, Empúries.

Tubella, Imma (ed.) (2002): El català en els mitjans de comunicació, Barcelona, Institut d'Estudis Catalans.

Tuson, Jesús (2001): Històries naturals de la paraula, Barcelona, Empúries, p. 49-59.

Universitat de les Illes Balears (2005): Llibre d'estil per als mitjans de comunicació orals $i$ escrits, Palma de Mallorca, Consell de Mallorca / UIB.

Universitat Pompeu Fabra (2005): Llibre d'estil de la Universitat Pompeu Fabra [en línia], Barcelona, uPf, <http://www.upf.edu/leupf/> [consulta: 23 d'octubre de 2009].

Uoc Servei Lingüístic (2006): Recursos lingüistics [en línia], Barcelona, Universitat Oberta de Catalunya, <http://www.uoc.edu/serveilinguistic/home/index. html $>$ [consulta: 10 d'octubre de 2009].

- (2007): «Abreviacions» [en línia], en Convencions formals, Barcelona, Universitat Oberta de Catalunya, <http://www.uoc.edu/serveilinguistic/criteris/ convencions/abreviacions.html $>$ [consulta: 8 de desembre de 2009].

- (2007): «Majúscules i minúscules» [en línia], en Convencions formals, Barcelona, Universitat Oberta de Catalunya, <http://www.uoc.edu/serveilinguistic/ criteris/convencions/majuscules_minuscules.html> [consulta: 8 de desembre de 2009].

- (2007): «Tipus de lletra» [en línia], en Convencions formals, Barcelona, Universitat Oberta de Catalunya, <http://www.uoc.edu/serveilinguistic/criteris/convencions/tipus_lletra.html> [consulta: 8 de desembre de 2009].

- (2007): Guia lingüistica (català) [en línia], Barcelona, Universitat Oberta de Catalunya, <http://www.uoc.edu/serveilinguistic/pdf/guia_catalana_febrer_2007. pdf $>$ [consulta: 10 d'octubre de 2009].

VAlle, Maria (2002): Els pronoms febles: morfologia, sintaxi i combinació de pronoms, Barcelona, Generalitat de Catalunya.

VALLVERDÚ, Francesc (2000): El català estàndard i els mitjans audiovisuals, Barcelona, Edicions 62 / Televisió de Catalunya.

- (2002): «Els mitjans audiovisuals i la contaminació lingüística», Llengua i ús, 25, p. 4-10. 
- (2003): «L'oralitat als mitjans audiovisuals: les limitacions del llenguatge colloquial», en MarTí-Mestres (ed.) (2003: 47-55).

- (dir.) (2001): Enciclopèdia de la llengua catalana, Barcelona, Edicions 62.

Vallverdú, Josep (dir.) (2001): Enciclopèdia de la llengua catalana, Barcelona, Edicions 62.

VALOR, Enric (2010): La flexió verbal, València, Tres i Quatre.

VAN DiJK, Teun A. (1983): La ciencia del texto: una aproximación interdisciplinaria, Barcelona, Paidós.

- (2001): «Un estudi lingüístic de la ideologia?», en Mollà, Toni (ed.) (2001: 33-56).

- (2003a): Ideología y discurso, Barcelona, Ariel.

- (2003b): «Las ideologías en la sociedad», en Ideología y discurso, Barcelona, Ariel, p. 42-49.

- (2010): «Discurs, poder i elits simbòliques», en Marín, Maria Josep i altres (ed.) (2010: 79-98).

Van Leeuwen, Theo (2005): Introducing Social Semiotics, Londres / Nova York, Routledge.

- (2008): Discourse and Practice: New Tools for Critical Discourse Analysis, Oxford / Nova York, Oxford University Press.

VIANA, Amadeu i Jordi SülLs (2002): «Les construccions causals i les finals», en SoLÀ, Joan (dir.) (2002: 2937-2975).

VelLÓN, JAVIER (2007): Estrategias lingüísticas de los textos publicitarios, Barcelona, Editorial UOC.

VILÀ, Montserrat (2002b): «Estratègies comunicatives de l'explicació oral», en VILÀ, Montserrat (coord.) (2002a: 31-30).

- (coord.) (2002a): Didàctica de la llengua oral formal, Barcelona, Graó.

VILAWEB (2005): Llibre d'estil 1.0, Barcelona, Vilaweb, <http://10anys.vilaweb. com/llibreestil/> [consulta: 27 de juliol de 2011].

Villalba, Xavier (2002): «La subordinació», en SolÀ, Joan (dir.) (2002), capítol 18 , p. $2247-2319$.

VIQUIPĖDIA (2009): Llibre d'estil [en línia], San Francisco, Vikimedia Foundations $<$ http://ca.wikipedia.org/wiki/Categoria:Normes_d\%27estil_de_la_Viquip\%C 3\%A8dia> [consulta: 23 de març de 2011].

Widdowson, H. G. (1978): Teaching Language as Communication, Oxford, Oxford University Press. 
ÍNDEX D'IL-LUSTRACIONS 


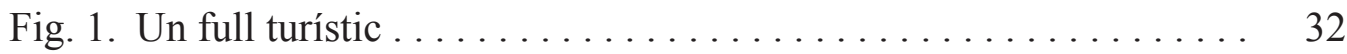

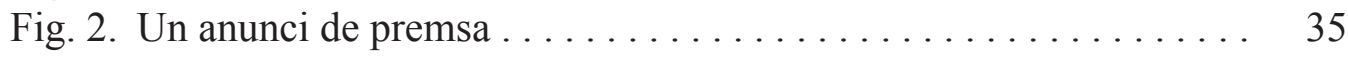

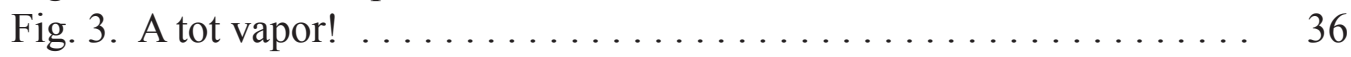

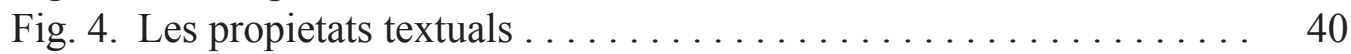

Fig. 5. Les ciències del llenguatge $1 \ldots \ldots \ldots \ldots \ldots \ldots \ldots \ldots \ldots \ldots \ldots$

Fig. 6. Les ciències del llenguatge $2 \ldots \ldots \ldots \ldots \ldots \ldots \ldots \ldots \ldots$

Fig. 7. El contacte de llengües en la retolació (font: http://bibiloni.cat/ imatge/imatges.htm) .................... 47

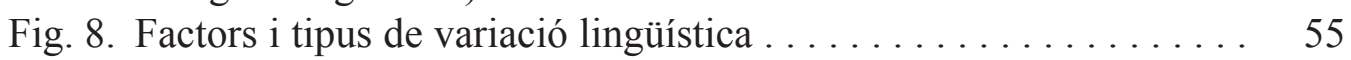

Fig. 9. Varietats geogràfiques del català . . . . . . . . . . . 57

Fig. 10. Logos de l'AVL i l'IEC, dues institucions normatives per a una

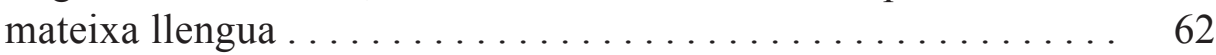

Fig. 11. Els gèneres periodístics $\ldots \ldots \ldots \ldots \ldots \ldots \ldots \ldots \ldots \ldots \ldots$

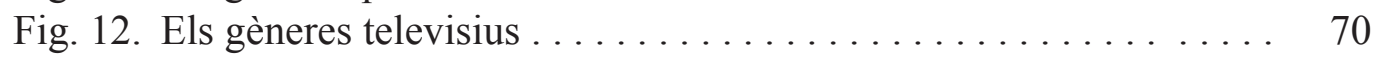

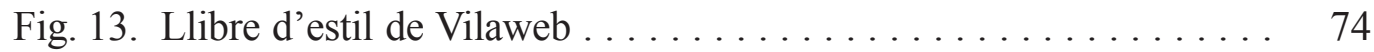

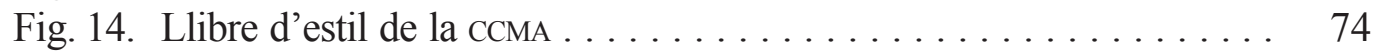

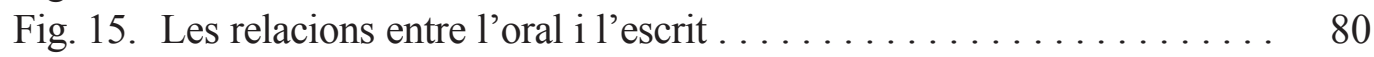

Fig. 16. La gradació oral/escrit i els paràmetres contextuals . . . . . . . . 82

Fig. 17. Característiques generals i trets gramaticals de la llengua oral formal . 84

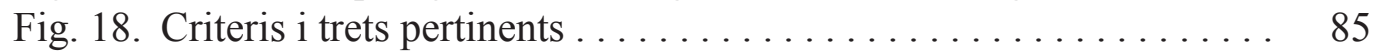

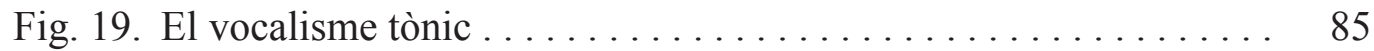

Fig. 20. Contextos en què apareix la vocal $e$ oberta . . . . . . . . . 87

Fig. 21. Els sons del català ........................ 87

Fig. 22. Contextos en què apareix la vocal $o$ oberta . . . . . . . . 88

Fig. 23. El vocalisme àton i la reducció vocàlica . . . . . . . . . . . . . 89

Fig. 24. El sistema consonàntic del català . . . . . . . . . . . . . . 91

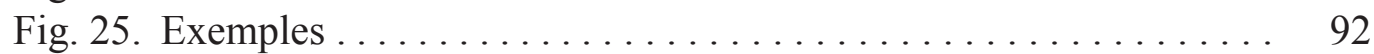

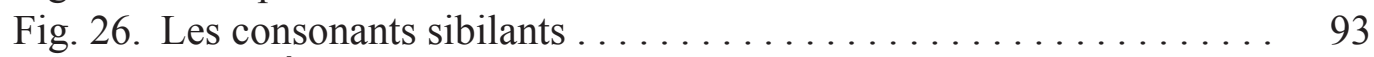

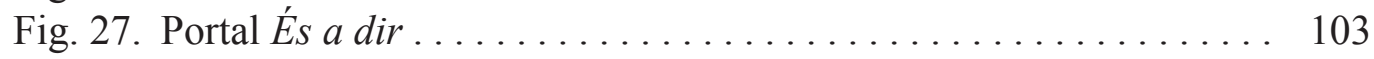

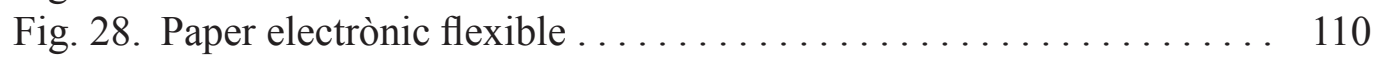

Fig. 29. Evolució de les tecnologies de la comunicació . . . . . . . . . . . . 112

Fig. 30. L'escriptura jeroglìfica egípcia . . . . . . . . . . . . . . . 112

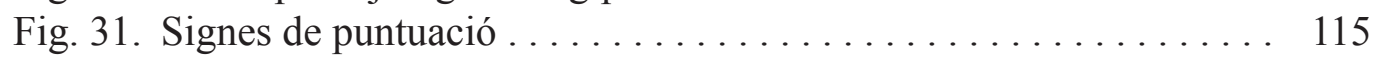

Fig. 32. Anunci de Nissan Terrano (2000) . . . . . . . . . . . . . . 123

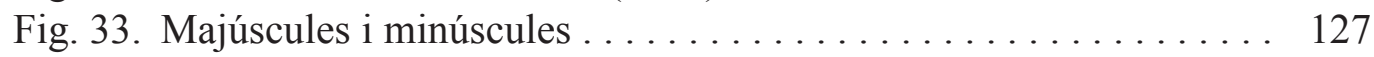

Fig. 34. Anatomia de la lletra . . . . . . . . . . . . . . . . . . . . . . . . 129

Fig. 35. Menú Tipus de lletra del Word . . . . . . . . . . . . . . . . 133

Fig. 36. Un anunci d'Audi (2010) . . . . . . . . . . . . . . . . . . 146

Fig. 37. Les regles de coherència . . . . . . . . . . . . . . . 151

Fig. 38. Procediments per ampliar, aclarir i condensar la informació . . . . 160

Fig. 39. Usos i funcions dels relatius . . . . . . . . . . . . . . . . 167

Fig. 40. El principi de cooperació i les màximes conversacionals . . . . . . 170

Fig. 41. Implicatures en Mafalda . . . . . . . . . . . . . . . . . . . . . . 172

Fig. 42. Orientacions d'ús del lèxic del portal És a dir . . . . . . . . . . 179

Fig. 43. Procediments de creació lèxica . . . . . . . . . . . . . 182

Fig. 44. Pàgina principal del Termcat . . . . . . . . . . . . . . . . . . . 189

Fig. 45. L'Observatori de Neologia (OBNEO) de la Universitat Pompeu

Fabra ............................... 
Fig. 46. Anglicismes d'ús habitual . . . . . . . . . . . . . . . . 192

Fig. 47. Paraules i expressions d'origen llatí . . . . . . . . . . . . . . 193

Fig. 48. Classificació de les unitats fraseològiques . . . . . . . . . . . 195

Fig. 49. Mecanismes de referència ................... 205

Fig. 50. Estil segmentat i estil cohesionat . . . . . . . . . . . . 207

Fig. 51. El concepte de referència . . . . . . . . . . . . . . . . . 209

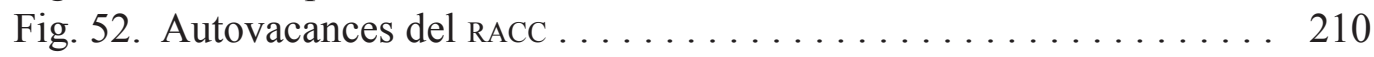

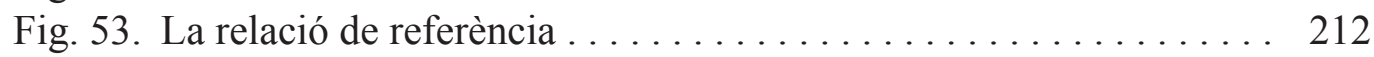

Fig. 54. L'anàfora gramatical en una notícia de premsa . . . . . . . . . 214

Fig. 55. Criteris d'escriptura dels pronoms febles . . . . . . . . . . . 217

Fig. 56. Formes i funcions dels pronoms febles . . . . . . . . . . . . 217

Fig. 57. Formes i funcions dels pronoms febles (quadre-resum) . . . . . . 218

Fig. 58. Quan parla el llop... . . . . . . . . . . . . . . . . . 224

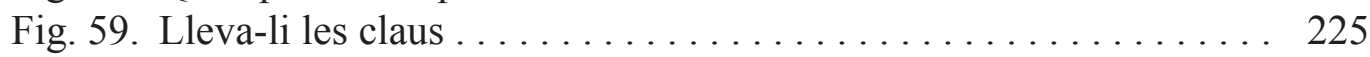

Fig. 60. Relacions de cohesió lèxica . . . . . . . . . . . . . . . 227

Fig. 61. La reiteració sinonímica en una notícia de premsa . . . . . . . . 228

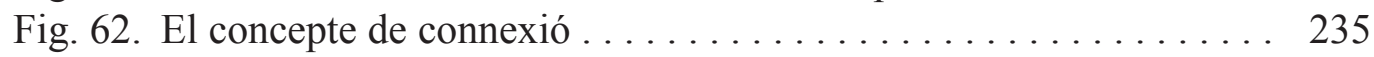

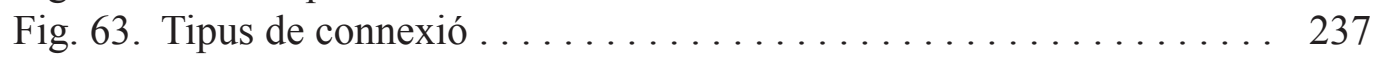

Fig. 64. Significats proposicionals bàsics i tipus de connectors . . . . . . . 240

Fig. 65. Tipus d'oracions compostes . . . . . . . . . . . . . . . 243

Fig. 66. Els connectors dialèctics i la composició oracional . . . . . . . . 244

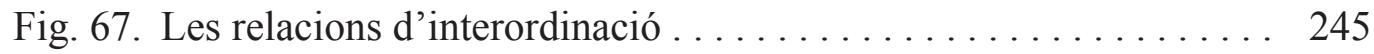

Fig. 68. Marques de la subordinació . . . . . . . . . . . . . . . 247

Fig. 69. Connexió textual i composició oracional . . . . . . . . . . 248

Fig. 70. Els connectors metadiscursius o connectors parentètics . . . . . . 250

Fig. 71. Bibliografia sobre marcadors del discurs . . . . . . . . . . . . . 253

Fig. 72. Classificació dels marcadors discursius . . . . . . . . . . . . . . 254

Fig. 73. Pantalla d'entrada del lloc web Argumenta . . . . . . . . . . . . . . 259

Fig. 74. Consells per escriure frases eficients (font: Cassany, 1993). . . . . 261

Fig. 75. Regles per millorar l'escriptura . . . . . . . . . . . . . 262

Fig. 76. Funció social de les ideologies dels valors a les pràctiques socials. . . . . . . . . . . . . . . . . . . . . . . . . 268

Fig. 77. Manifestació de la ideologia en un graffiti . . . . . . . . . . . . 269

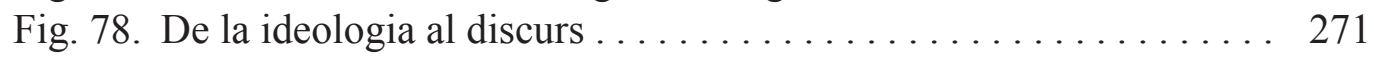

Fig. 79. Llocs d'inserció de la ideologia en el discurs . . . . . . . . . . 273

Fig. 80. Tipus de dixi . . . . . . . . . . . . . . . . . . . . 275

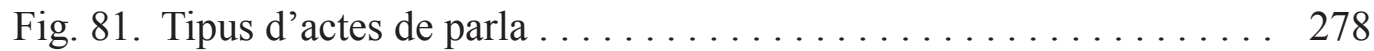

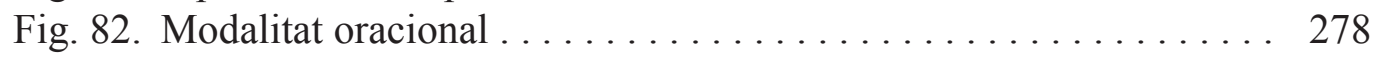

Fig. 83. Verbs de locució . ....................... 284

Fig. 84. Recursos per expressar els diferents graus de certesa . . . . . . . 288

Fig. 85. Espot d'Aquarius . . . . . . . . . . . . . . . . . . 291

Fig. 86. Funcionament de la metonímia . . . . . . . . . . . . . . 292

Fig. 87. Tipus de metàfores . . . . . . . . . . . . . . . . . . 293

Fig. 88. Exemples de metàfores en el discurs publicitari . . . . . . . . . . . 294

Fig. 89. Topoi i argumentació. . . . . . . . . . . . . . . . . . . . . . . 297

Fig. 90. Bloc semàntic dels mots protecció i protegir . . . . . . . . . 300 
ÍNDEX TEMȦTIC 
abreviació, 135, 136

abreviatura, 135, 136

accent diacrític, 308, 309

accentuació, 307, 308

acronímia, 185

acrònim, 138

acte il $\cdot$ locutiu, 277

acte locutiu, 277

acte perlocutiu, 277

actes de parla, 277

actes de parla indirectes, 278

actituds, 270

actituds lingüístiques, 45

activitat discursiva, 27

adequació, 34

adverbis i locucions adverbials, 336

al·lòfons, 318

àmbits d'ús, 30

anacolut, 263

anàfora, 203, 205, 209

anàfora gramatical, 213

anàfora lèxica, 212, 226

anàfora zero, 224

anàlisi crítica del discurs, 43

anàlisi del discurs, 42

anglicisme, 192

antecedent, 209

anuncis descriptius, 73

anuncis narratius, 73

anuncis testimonials, 73

apocalíptic, 52

aposició, 160

arcaisme, 102, 177

àrees de transició, 57

argot, 58

argumentació en el discurs, 294

argumentació i topoi, 296

aspectes gràfics, 124

associació, 229

associació lèxica, 229

autor, 279 barbarisme, 180

bilingüisme, 46

bloc semàntic, 298

calc, 187

calc lingüístic, 177

camp, 59

canal, 60

canvi i caiguda de preposicions, 335

canvi semàntic, 186

castellanisme, 191

catàfora, 209

català heavy, 61

català light, 61

categoria, 268, 274

categoria gramatical, 234, 236

ciències del llenguatge, 40

citació, 139

claudàtors, 121

coherència, 37, 147

coherència discursiva, 203

cohesió, 39

cohesió textual, 148

col·locació, 195

color i grandària de la lletra, 129

coma, 115

cometes dobles, 122

cometes simples, 122

competència comunicativa, 30

competència discursiva, 31

competència estratègica, 31

competència gramatical, 31

competència lingüística, 30

competència sociolingüística, 31

composició, 184

composició culta, 184

composició oracional, 208

composició patrimonial, 184

comunicació, 108, 25

comunicació inferencial, 28

comunicació no verbal, 28

concisió, 260 
conclusió, 161

concordança, 262

concurrència, 195

conflicte lingüístic, 46

confusions entre $a$ i $e$ àtones, 305

confusions entre $o$ i $u, 305$

conjugació regular, 325

conjunció que, 256

conjuncions d'interordinació, 238

conjuncions de coordinació, 238

conjuncions de subordinació, 238

connectors causals i consecutius, 254

connectors comparatius i condicionals, 256

connectors de contrast, 255

connectors gràfics, 239

connectors lèxics, 239

connectors oracionals, 244

connectors parentètics, 239, 249

connexió, 235

connexió oracional, 240

connexió pragmàtica, 250

connexió textual, 248

consumisme, 109

contacte lingüístic, 46

conversa espontània, 80

conversió sintàctica, 187

coordinació, 243

creences, 268

cronolecte, 55

culte a l'emoció, 24

cultura, 25, 52

cultura de masses, 52

cursiva, 130

definició, 161

derivació, 183

desenvolupament tecnològic, 109

destinatari, 281

determinants, 319

determinants demostratius, 323

determinants indefinits, 319

determinants numerals, 320 determinants possessius, 324

determinants quantitatius, 322

dialectalismes, 102

dialectes geogràfics, 54

díctic, 274

dièresi, 309

diftong, 306

digitalització, 23

diglòssia, 47

dimensió il·locutiva, 277

dimensió lingüística del discurs, 27

dimensió locutiva, 277

dimensió paralingüística, 277

dimensió perlocutiva, 277

discriminació tecnològica, 23

discurs, 27

discurs directe, 281

discurs directe lliure, 282

discurs indirecte, 282

discurs indirecte lliure, 282

discurs multimodal, 70

discurs narrativitzat, 281

discurs polític, 231

discurs publicitari, 72

discurs reportat, 281

discursos audiovisuals, 24, 109

disfemisme, 59, 64

disposició convencional del text, 134

distribució de per i per $a, 335$

dixi, 209, 274

dixi discursiva, 276

dixi espacial, 276

dixi personal, 275

dixi social, 276

dixi temporal, 276

dixi textual, 276

domini d'origen, 290

domini de destinació, 290

dos punts, 118

doxa, 297

$e$ tònica, 309 
efectes tipogràfics, 131

el·lipsi, 224

elements paralingüístics de l'escriptura, 125

emissor, 279

encadenaments argumentatius, 297

encadenaments normatius, 299

encadenaments transgressius, 299

enunciació, 29

enunciadors, 280

enunciat, 29

enunciats fraseològics, 196

escriptura, 79, 110

escriptura dels nombres: xifres i lletres, 128

eslògan, 197

espais en blanc, 133

espais televisius, 69

esquemes, 268

estils, 130

estrangerisme, 188, 191

estructura comparativa, 154

estructura de causa-conseqüència, 155

estructura de problema-solució, 155

estructura del text, 153

estructura dels gèneres expositius, 154

estructura descriptiva o enumerativa, 154

estructura interna del paràgraf, 158

estructura seqüencial o temporal, 155

estructura textual, 154

estructures narratives i argumentatives, 155

estudis sobre el llenguatge, 40

eufemisme, 59, 63, 102

exemplificació, 160

expressions fraseològiques genuïnes, 102,178

expressions idiomàtiques, 193

figures retòriques, 289

flexió verbal, 325

focalització, 98

font, 132

fonts externes, 139 formes admissibles, 95

formes no personals del verb, 331

formes no recomanables o inadmissi-

bles, 95

formes pròpies, 95

formes tòpiques, 296

formes velaritzades, 327

fórmules rutinàries, 196

fragmentació, 62

frame, 209, 230

fraseologia, 193

frases fetes, 196

funció díctica, 274

funció social de les ideologies, 269

galàxia Gutenberg, 110

gènere, $30,67,154$

gèneres d'entreteniment, 68

gèneres d'opinió, 68

gèneres dialogats, 83

gèneres discursius primaris, 82

gèneres discursius secundaris, 82

gèneres informatius, 68

gèneres intermedis, 82

gèneres literaris, 67

gèneres monologats, 83

gèneres multimèdia, 71

gèneres periodístics, 68

gèneres prototípics, 82

gèneres publicitaris, 68

gèneres televisius, 69

gerundi, 332

globalització, 24

grafosfera, 110

gramàtica, 42

gramaticalització, 194, 248

grau de certesa d'un enunciat, 288

guionet, 120

guions, 120

hiat, 306

hipertema, 153

hipertextualitat, 70

ideologia, 270 
ideologia dominant, 301

implicatures conversacionals, 170

implícit, 170

índex, 156

inferència, 26

infinitiu, 331

informació implícita, 170

integrats, 52

interactivitat, 70, 109

interferència lingüística, 179

interferències assimilades, 180

interferències de construcció, 180

interferències híbrides, 180

interferències lèxiques, 102, 180

interferències no assimilades, 180

interjeccions, 239

interliniat, 134

interordinació, 243

introducció, 161

irregularitats ortogràfiques, 329

irregularitats verbals, 325

isoglossa, 57

lexicalització, 188

lingüística, 40

lingüística textual, 42

llengua dominant, 32

llengua majoritària, 46

llenga minoritzada, 46

lletra $h, 319$

lletra rodona o normal, 130

llibres d'estil, 73

locucions, 196

locutor, 280

logosfera, 110

macroestructura, 30, 39

macroregles, 151

magazines, 74

majúscula, 131

majúscules i minúscules, 125

malapropisme, 59

manlleu, 187 marc, 209, 230, 270

marcadors discursius, 250

marges, 133

marques formals de la nominalització, 165

màximes de cortesia, 289

mecanismes d'integració sintàctica, 202

memòria a curt termini, 259

memòria de treball, 259

metàfora, 289

metàfora multimodal, 293

metàfores convencionals, 293

metàfores creatives, 293

metàfores d'imatge, 293

metàfores estructurals, 293

metàfores ontològiques, 293

metàfores orientacionals, 293

metàfores visuals, 293

metonímia, 291

mitjans de comunicació de massa, 52

modalitat oracional, 278

modalitats territorials, 61

modalització, 285

mode, 59

model de llengua, 75

model narratiu, 155

models de creació, 73

models mentals, 268

models textuals, 156

modisme, 193

morfologia verbal, 325

multimèdia, 70

multimodalitat, 70

narrativa audiovisual, 70

negreta, 130

neologia, 181

neologia especialitzada, 181

neologia general, 181

neologisme, 181

neologismes espontanis, 181

neologismes interns, 181

neologismes planificats, 181 
neologismes pseudosemàntics, 186

nominalització, 160, 164

normalització lingüística, 47

normes d'ús convencional, 45

normes d'ús dels signes de puntuació, 73

normes d'ús intencional, 45

normes d'ús lingüístic, 45

nota a peu de pàgina, 141

noves fronteres de la imatge, 111

noves tecnologies, 22

observatori de Neologia, 190

ofimàtica, 114

operadors discursius, 251

oració composta, 240

oracions de relatiu, 166, 246

oracions subordinades adjectives, 246

oracions subordinades adverbials, 246

oracions subordinades substantives, 245

oralitat, 79,110

organització de la pàgina, 134

orientació argumentativa, 298

ortografia de les consonants, 310

paradigma digital, 23

paradigmes verbals, 325

paraestàndards, 61

paràfrasi, 160, 163

paràgraf, 156

paràgraf d'efecte/causa, 157

paràgraf $d$ 'enumeració, 157

paràgraf de comparació/contrast, 157

paràgraf de desenvolupament, 157

paràgraf problema/solució, 157

parèmia, 196

parèntesi, 121

parlars, 55, 56

participi, 332

participi concordat, 100

participis no normatius, 333

perspectiva pragmàtica de la comunica-

ció, 26

polifonia, 279 pragmàtica, 26, 42, 273

precisió lèxica, 181

precisió i genuïnitat, 102

prefixació, 183

prejudici, 45, 270

preposicions, 333

presència de l'emissor i del destinatari,

286

presentació de l'escrit, 133

presentació del text, 133

preservació de la pròpia imatge, 289

pressuposició, 171

préstec, 187

pretèrit perfet, 99

principi de manteniment de la referència, 205

procediments explicatius, 159

producte multimèdia, 70

programa, 69

progressió amb tema constant, 152

progressió de tema derivat, 153

progressió de tema i rema expandit, 153

progressió lineal, 152

progressió temàtica, 152

pronom zero, 211

pronominalització, 215

pronoms febles, 216

pronoms personals, 216

pronoms relatius, 215

propietats textuals, 33

propòsit, 60

publicitat, 72

punt, 117

punt de vista, 294

punt i coma, 117

punts suspensius, 117

quantificadors, 97

recursivitat, 242

referència, 209

referència endofòrica, 213

referència exofòrica, 213 
referència fòrica, 211

referència lèxica, 226

referències bibliogràfiques, 139

reformulació, 163

registre col-loquial, 60

registre, 59

registres formals, 60

registres informals, 60

registres lingüístics, 59

regles d'accentuació gràfica, 307

regles de coherència, 150

reiteració sinonímica, 228

relació personal, 60

rema, 152

repetició, 151, 227

resum, 164

retransmissions en directe, 70

reversibilitat, 242

sagnies, 239

saturació informativa, 23

secessionisme lingüístic, 62

selecció lèxica, 176

semiòtica, 43, 144

sentit, 144, 145

seqüències, 27

sexisme lingüístic, 65

siglació, 138, 186

sigles, 138, 186

signe d'admiració, 120

signe d'interrogació, 120

signes de puntuació, 114

signes lingüístics, 28

significació, 144

significat, 144, 145

símbols, 137

simetria, 242

sinonímia, 227

sintagmació, 185

sobreentesos, 170

societat de consum, 22

societat de la informació, 21 sociolecte, 55

sociolingüística, 42, 43, 44

sons africats, 315

sons fricatius, 312

sons laterals, 317

sons oclusius, 310

sons ròtics o vibrants, 318

sons sonants, 316

subdialecte, 56

subíndex, 132

subordinació, 243, 245

subratllat, 132

substitució lingüística, 47

sufixació, 183

superestructura, 30, 38, 156

superíndex, 132

suport de transmissió, 73

tabú, 59, 63

tecnicisme, 102

tecnologia multimèdia, 110

tecnologies de la paraula, 109

tema, 37, 59, 152

tematització, 98, 288

teoria clàssica de la comunicació, 25

teoria de l'argumentació, 294

teoria de l'argumentació en la llengua, 294

teoria dels blocs semàntics, 298

teoria dels topoi, 296

text, 28, 29

textos argumentatius, 155

tipografia, 129

tipus de connexió, 236

tipus de lletra, 129

tipus de paràgrafs, 157

títols, 134

to, 60

tòpics, 209

topoi, 296, 297

topos concordant, 297

topos discordant, 297

transmissió de judicis de valor, 288 
transmissió de les ideologies, 272

trets d'àmbit restringit, 95

trets lingüístics d'àmbit general, 95

truncació, 185

unitats fraseològiques, 193

ús lingüístic, 44

usos abusius, 177

usos de perquè, per què i per a què, 257

usos impropis, 178

usos inadequats, 177

variació funcional, 55, 59

variació lingüística, 53

varietat estàndard, 61

varietats diafàsiques, 59

varietats diatòpiques, 54

varietats funcionals, 59

varietats generacionals, 57

varietats històriques, 57

varietats professionals, 55 varietats socials, 58

verb de locució, 283

verb intransitiu, 330

verb pronominal, 330

verb transitiu, 330

verb de predicació completa, 102, 178

verb fantasma, 328

verb feble, 102, 178

verb impersonal, 330

verb incoatiu, 328

verb personal, 330

verb pronominal, 330

verb pur, 328

verbs tenir i venir, 329

versal, 131

versaleta, 131

veu passiva, 101

vida líquida, 22, 23

videosfera, 111 
INDEX D'AUTORS 
Agulló-Camps, 73

Amossy, 295, 351

Anscombre, 294, 296, 302, 355, 358

Aristòtil, 67, 162, 294
Graves \& Short, 207

Gregory, 80, 359, 367

Grunig, 198, 359

Halliday, 80, 359

AVL, 4, 62, 94, 95, 96, 113, 337, 355, 367 Hymes, 31

Avui, 32, 40, 73, 105, 126, 148, 177, IEC, 4, 62, 87, 88, 91, 92, 93, 94, 95, 96,

$226,227,228,230,236,258,355,362,97,113,181,186,274,302,359,360,367$

364

Bakhtin, 67, 82, 355

Bauman, 22, 49, 355

Bernárdez, 28, 355

Bibiloni, 47, 58, 63, 75, 356, 367

Bronckart, 144, 356

Brown-Yule, 145

Cabré, 139, 181, 182, 190, 200, 356

Carroll, 80, 359, 367

Casals, 73, 75, 356

Cassany, 134, 135, 158, 159, 174, 232,

$259,261,356,360,368$

Castellà, 28, 34, 83, 144, 356

Castellà i altres, 171

Castellà-Vilà, 81, 82, 84

Charolles, 147, 150, 357

Chomsky, 30

Conca, 37, 357

Coromina, 73, 357

Cuenca, 97, 127, 128, 148, 150, 174, Secció Filològica de 1'IEC, 97

207, 224, 227, 229, 230, 232, 238, 239, Serafini, 206

240, 241, 242, 243, 245, 248, 249, 251, Serrano, 27

$252,264,357,361,338$

Cuenca i altres, 162, 164

Ducrot, 169, 174, 279, 285, 294, 295,

297, 298, 299, 301, 302, 355, 356, 358

Ducrot-Carel, 294, 295, 298

Forceville, 293, 358

Fuster, 27, 49, 123, 140, 235, 241, 252, 358

Garcia Negroni-Narvaja, 295

Gifreu, 27, 49, 104, 358

Gomis, 67, 68, 69, 75, 359
Lacroix, 24, 49, 360

Lakoff, 230

López, 61

Lozano, 28, 360

Maingueneau, 152, 297, 357, 360

Maingueneau-Salvador, 251

Marina, 24, 360, 362

Marín-Tresserras, 53

Martí, 48, 50, 75, 104, 105, 126, 141, $358,360,362,364,365$

Peraire, 11, 198, 200, 232, 361

Pérez Saldanya, 97, 338, 358

Pla, 104, 105, 167, 338, 362

Polanco, 103, 105, 362

Rigau, 28

Salvador, 197

Sancho, 198

Schiffrin, 251

Terricabras, 252

Vallverdú, 61, 97

Van Dijk, 29, 30, 38, 39, 268

Van Leenwen, 294

Vellón, 294

Vilà, 83

Vilaweb, 73, 74

Viquipèdia, 73

Widdowson, 147 